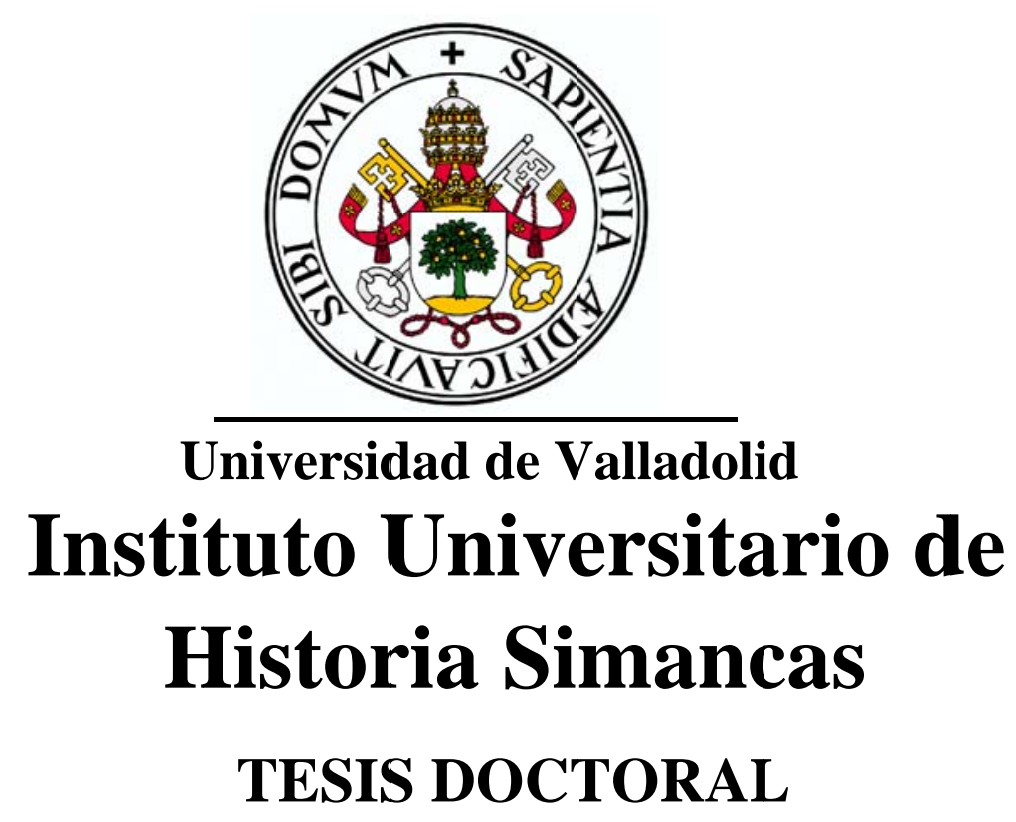

\title{
LA DIPUTACIÓN PROVINCIAL DE PALENCIA, 1875-1931. UN EJEMPLO DE ADMINISTRACIÓN LOCAL EN LA ESPAÑA DE LA RESTAURACIÓN
}

\author{
Presentada por José Antonio Lorenzo Cuesta \\ para optar al Grado de \\ doctor por la Universidad de Valladolid
}

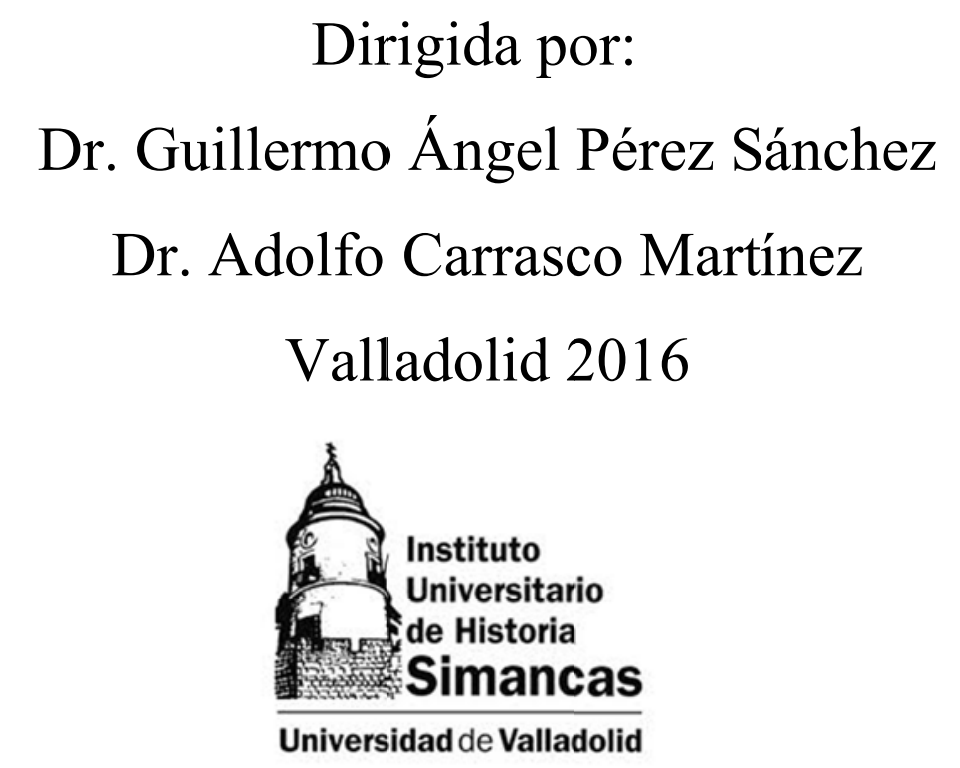


Carta Itineraria de la provincia de Palencia en 1883.

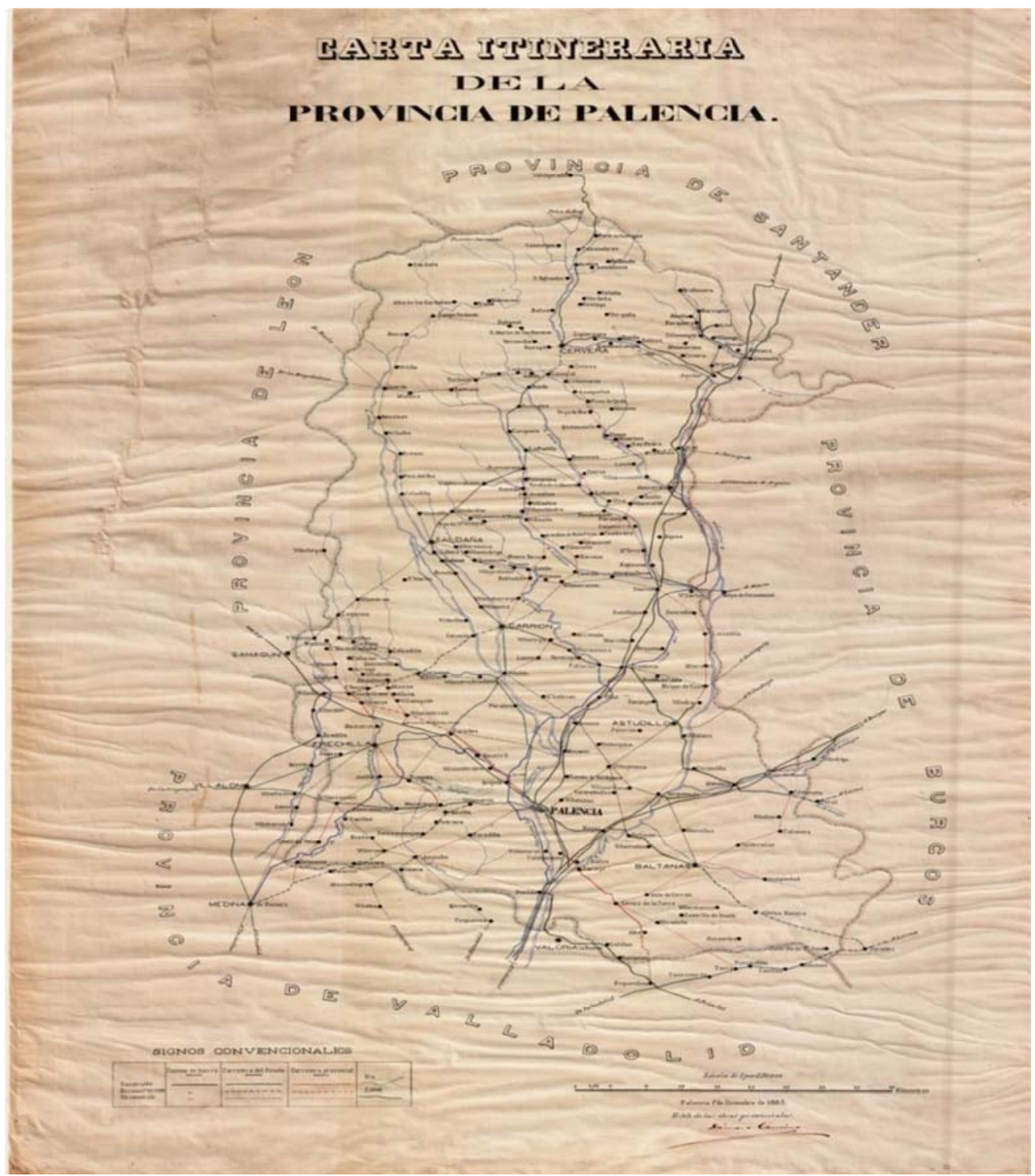

Fuente: Archivo de la Diputación Provincial de Palencia. A.D.P.P. 


\section{Agradecimientos}

Debo comenzar este trabajo mostrando mi profundo agradecimiento a las personas e instituciones sin cuya ayuda y colaboración no hubiese sido posible su realización. En primer lugar, quiero agradecer su ayuda a mis directores de tesis, los profesores Guillermo Ángel Pérez Sánchez y Adolfo Carrasco Martínez, docentes de la Universidad de Valladolid, quienes, con sus conocimientos y paciencia, han logrado la culminación de esta investigación. Mi agradecimiento al profesor emérito de la Universidad de Valladolid, Jesús María Palomares, que siempre se mostró solícito ante cualquier petición de ayuda por mi parte y que, con su reconocido magisterio en todo lo concerniente a la Historia local, contribuyó a facilitar mi labor investigadora. Mi agradecimiento al profesor de la Universidad de Valladolid, Juan Antonio Cano, quien accedió con gran interés a prestarme ayuda siempre que la solicité, y a los profesores de la Universidad de Valladolid, Pablo García Colmenares y Pilar Calvo Caballero, pues su ayuda y consejos resultaron imprescindibles para el buen término de esta investigación. Agradecer también la atención, siempre amable, del personal del Instituto Universitario Simancas de la Universidad de Valladolid, especialmente a Mercedes. No quiero olvidarme en este apartado de Enrique Orduña Rebollo, de obligada mención en el estudio de la Administración Local, quien al comienzo de mi trabajo accedió a reunirse conmigo y a dirigir mis primeros pasos en la búsqueda de fuentes documentales.

Quiero dejar constancia de la ayuda inestimable que me prestaron los profesionales del Archivo de la Diputación Provincial de Palencia, Pilar, Areños, Juan y Carlos, siempre dispuestos a facilitar mi labor de investigación en el Archivo, quienes posibilitaron que la ardua tarea de regresar al pasado, a través de los documentos, fuera más liviana y productiva para un investigador novel. También resulta de obligada mención la ayuda prestada por la archivera del Archivo Municipal del Ayuntamiento de Palencia, María José Carpintero Solla. 
Por último, aunque no por eso menos importante, mi agradecimiento a mis familiares y amigos. Gracias a Elena, su cariño, ayuda y apoyo me acompañaron en el transcurso de este trabajo; gracias a mi amigo Javier, sin sus conocimientos de informática mi labor habría resultado más ardua y áspera; gracias a Dolores, mi amiga y compañera del Centro de la Universidad Nacional de Educación a Distancia (UNED) en Palencia, que nunca permitió que cayese en el desánimo; gracias a mi familia y gracias, en fin, a todos aquellos que permitieron que mi objetivo se cumpliese.

Para finalizar, destacar la sensación especial experimentada al contemplar documentos olvidados durante un siglo y rescatados al presente. A lo largo de muchos meses, los libros dejaron de ser documentos para convertirse en una ventana a la vida de las generaciones precedentes. Después de la lectura detenida de miles de documentos, pude concluir que la institución provincial constituía, en no pocas ocasiones, la última esperanza para aquellas personas a las que la suerte les volvió la espalda, como los niños abandonados, los pobres, los enfermos, los ancianos sin recursos o los pueblos que sufrían las inclemencias de la meteorología. Las páginas de los legajos escondían las penalidades de muchos paisanos que nos precedieron en el tiempo. Sirva este trabajo como reconocimiento a la labor de la Diputación Provincial de Palencia en la Restauración a favor del desarrollo socioeconómico de los pueblos de la provincia de Palencia y de sus gentes. 


\section{Índice}

Agradecimientos ........................................................... 5

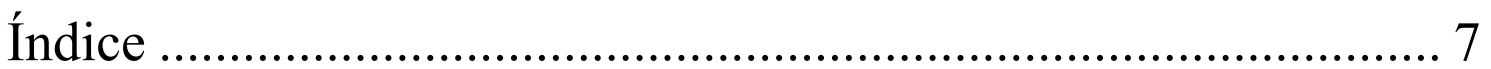

Índice de documentos, imágenes y representaciones gráficas .... 11

Introducción ...................................................................... 13

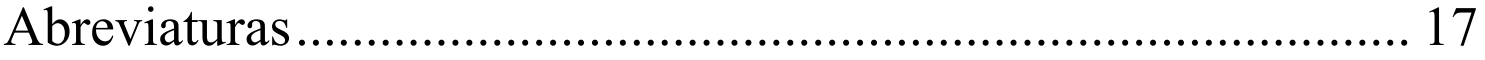

Hipótesis de partida-Aproximación metodológica e

historiográfica ................................................................. 19

Estado de la cuestión.......................................................... 23

Marco histórico y socio-político ............................................ 35

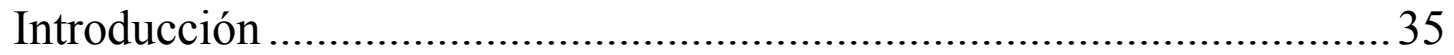

El reinado de Alfonso XII (1874-1885) ................................................. 37

1874-1881, el Partido Conservador en el Gobierno............................................... 37

1881-1884, Sagasta y el Partido Liberal en el poder .............................................. 39

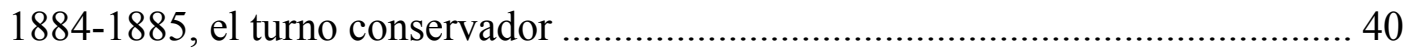

La Regencia de María Cristina (1885-1902) ........................................... 41

1885-1890, el liberalismo de nuevo en el Gobierno ........................................... 43

La década de los noventa, los gobiernos efímeros.............................................. 43

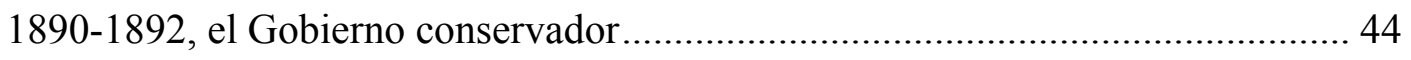

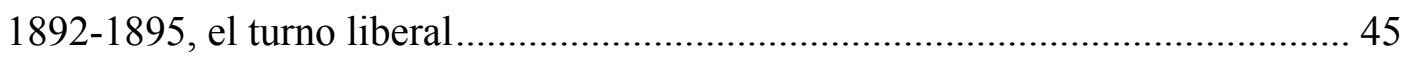

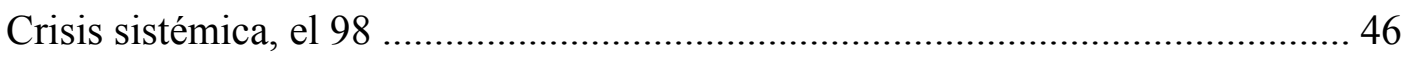

1899-1902, los gobiernos conservadores y liberales .......................................... 50

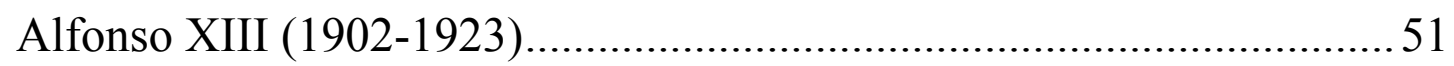

«La revolución desde arriba» de Maura................................................................... 51

José Canalejas y el liberalismo democrático......................................................... 52

1907-1909, Maura regresa al Gobierno ……...................................................... 54

1910-1912, Canalejas al frente del Gobierno .................................................... 58

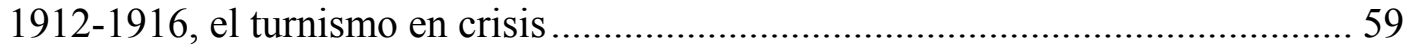

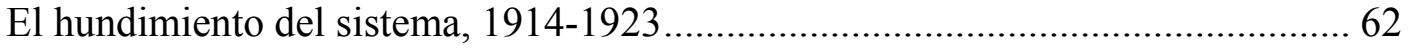

Las consecuencias de la Primera Guerra Mundial .............................................................62

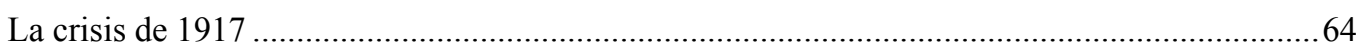

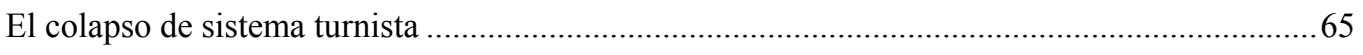

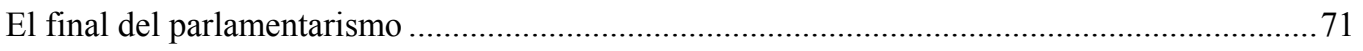


La Dictadura de Primo de Rivera (1923-1930) ...................................... 74

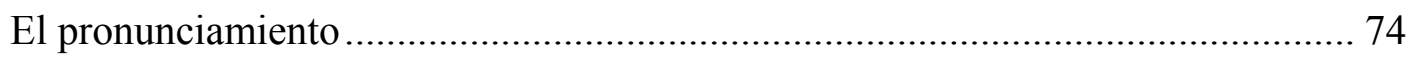

Orden público y nacionalismos......................................................................... 76

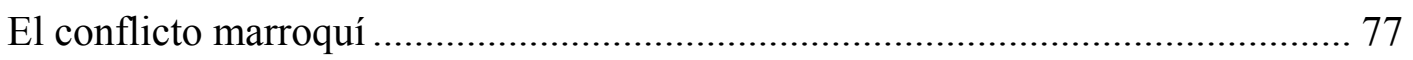

Institucionalización del régimen: El Directorio civil.............................................. 79

Política económica y social ...................................................................................................... 80

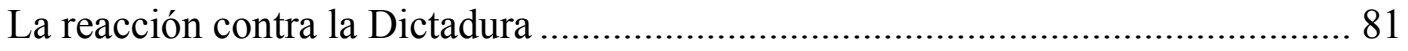

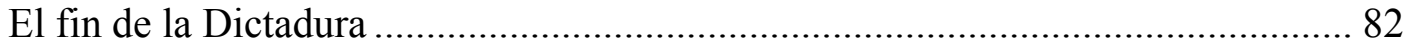

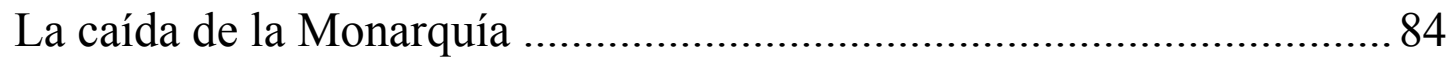

El fracaso del gobierno Berenguer......................................................................... 85

La oportunidad del republicanismo .................................................................. 86

Marco Legislativo ............................................................... 91

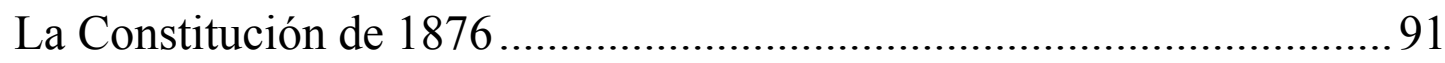

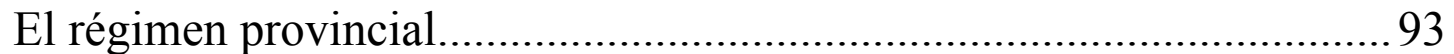

Legislación canovista. Ley de Bases de 16 de diciembre de 1876 .......................... 93

Ley Provincial de 2 de octubre de 1877 ............................................................. 95

Ley Provincial de 29 agosto de 1882 ................................................................... 96

Proyectos de reforma provincial ............................................................. 101

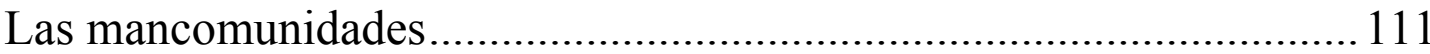

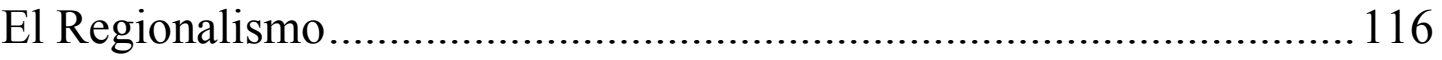

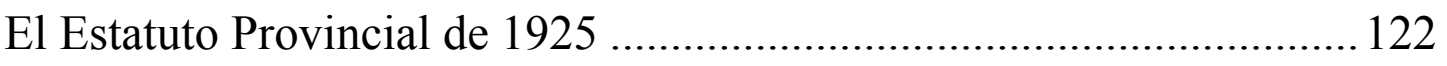

La Diputación Provincial palentina en la Restauración ............ 133

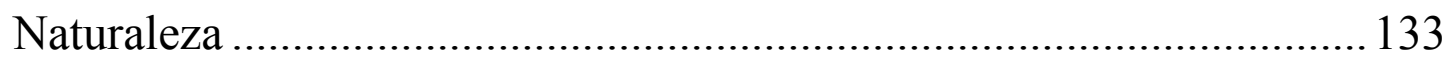

La Diputación y el gobernador provincial .............................................. 134

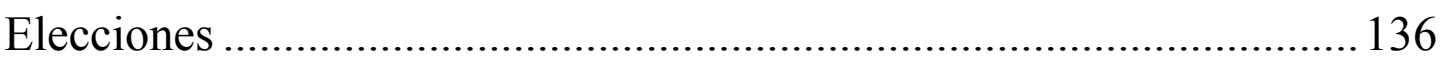

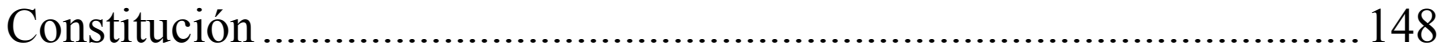

Las Comisiones de la Diputación Provincial......................................... 158

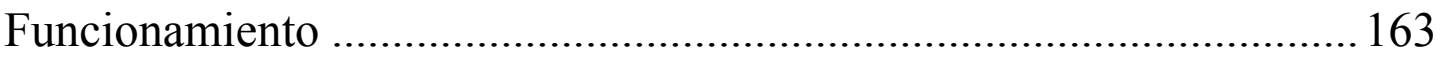

El presidente y el vicepresidente ….................................................... 171

Los diputados provinciales ................................................................ 173

Empleados de la Administración Provincial .......................................... 180

Previsión social de los trabajadores de la Diputación............................................... 191 


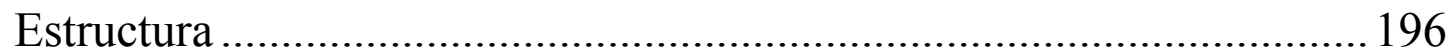

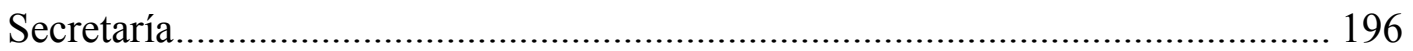

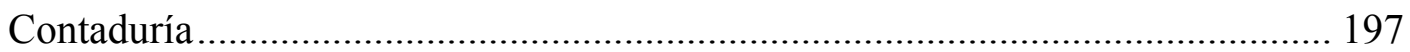

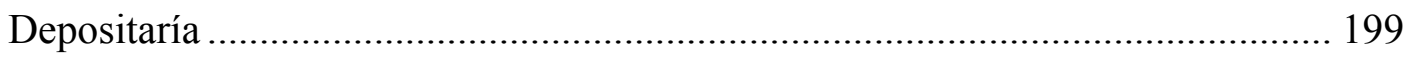

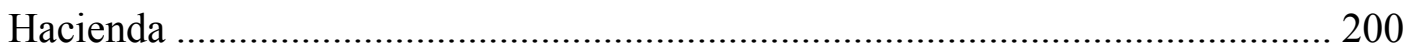

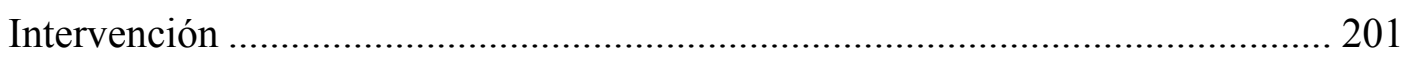

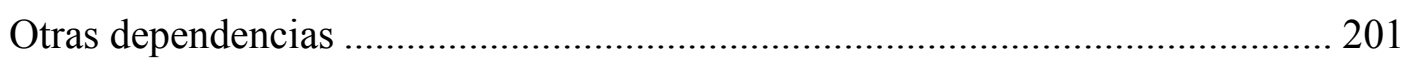

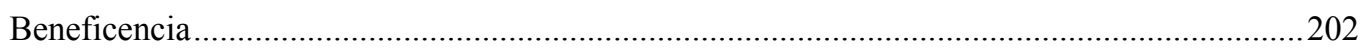

Fomento, Instrucción Pública y Obras Provinciales..............................................................202

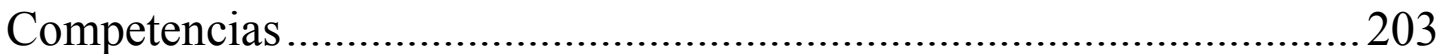

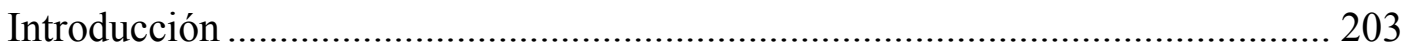

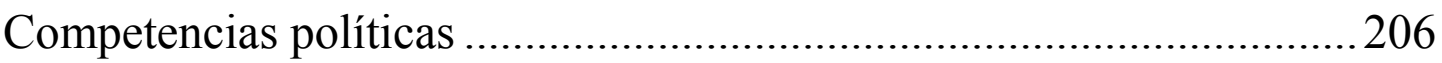

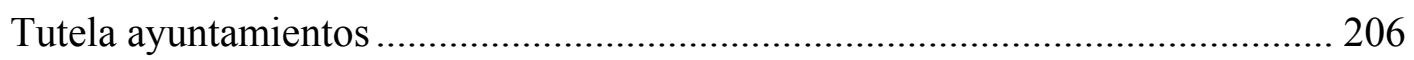

Competencias económicas y administrativas ........................................209

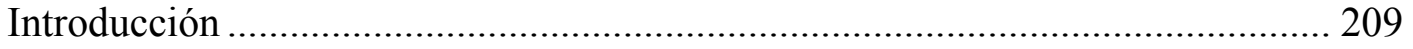

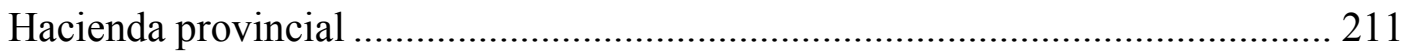

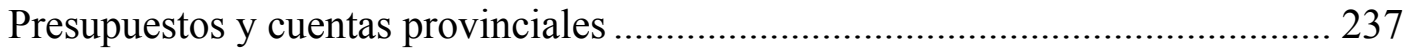

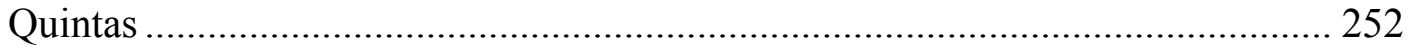

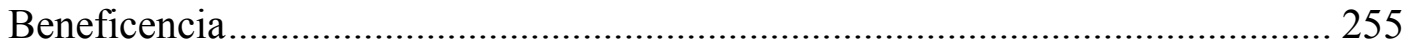

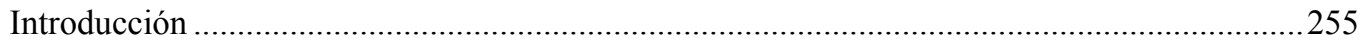

La asistencia benéfica de la Diputación Provincial ..............................................................259

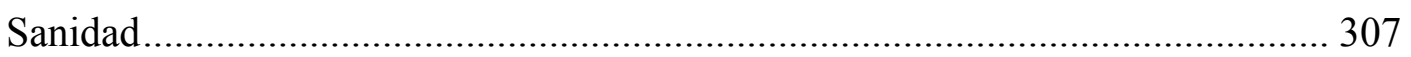

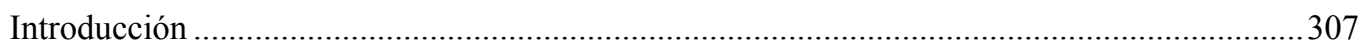

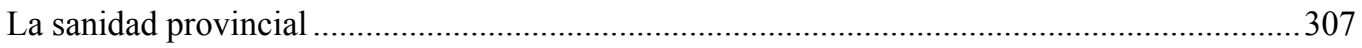

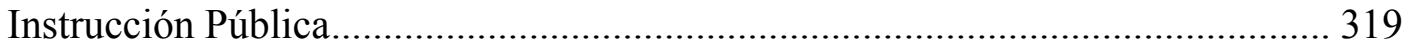

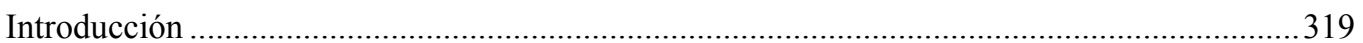

La Diputación Provincial de Palencia y la Instrucción Pública....................................................323

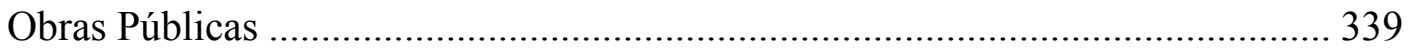

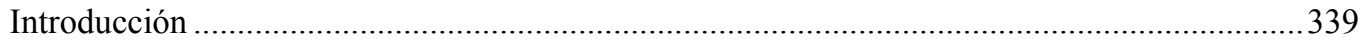

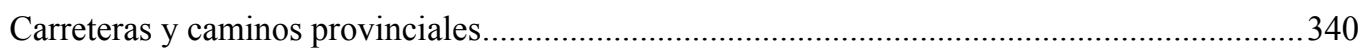

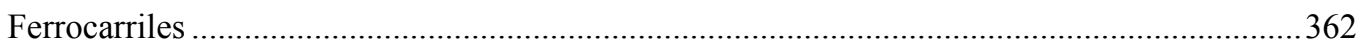

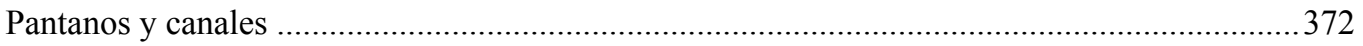

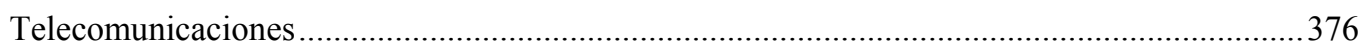

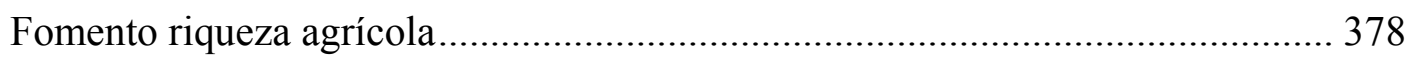

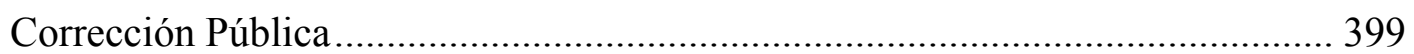

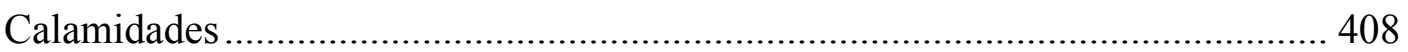




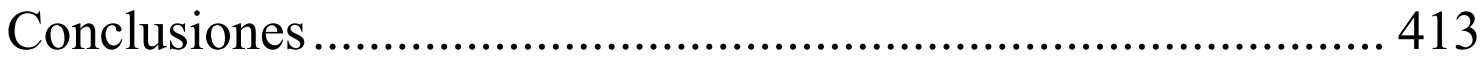

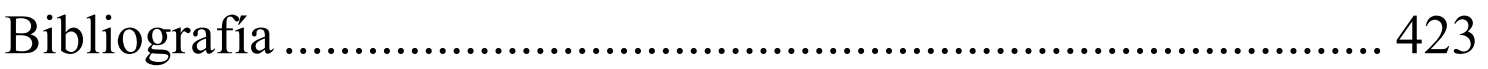

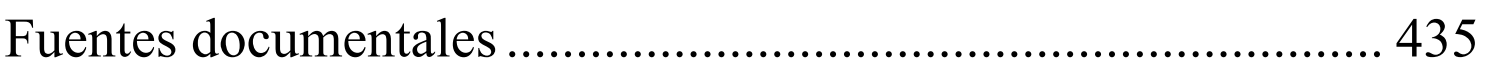

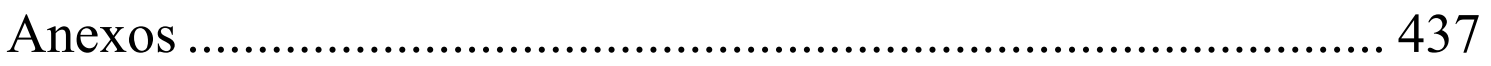

Anexo-I Modelo Presupuesto Provincial General de Gastos e Ingresos 438

Anexo II-Presupuesto provincial en pts. por capítulos 1878-1899 .......470

Anexo III-Porcentaje del Contingente Provincial en la etapa

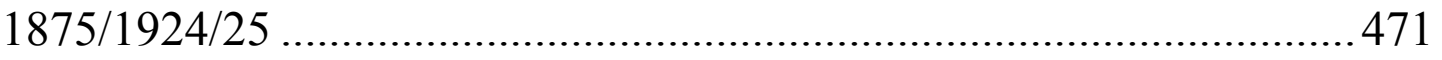

Anexo IV-Presupuesto Provincial en pts. 1875-1931 ............................. 473

Anexo V-Presupuesto Provincial en pts. Beneficencia, Instrucción Pública, Corrección Pública y carreteras 1875-1931............................. 485

Anexo VI-Tarifas Impuesto Cédulas Personales..................................... 497

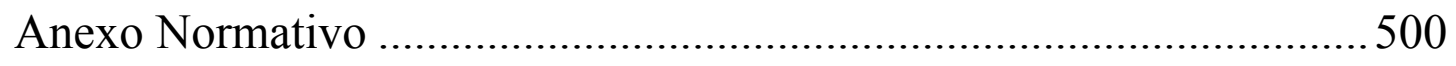




\section{Índice de documentos, imágenes y representaciones gráficas}

Documento 01. Oficio comprobación de firmas para nombramientos de

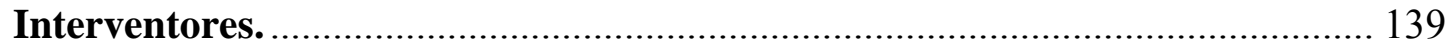

Documento 02. Repartimiento o Contingente Provincial entre los ayuntamientos de la provincia de Palencia. ............................................................................. 211

Documento 03. Cubierta del Libro de Actas de la Comisión Mixta de

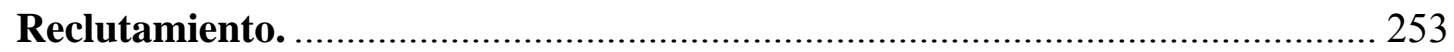

Figura 01. Estado comparativo del superávit con que se habían liquidado los presupuestos de 1923/24 y de 1927 por Presupuesto Corriente en pts. .......... 232

Figura 02. Estado comparativo del superávit con que se habían liquidado los presupuestos de 1923/24 y de 1927 por Presupuesto Refundido (Ordinario más

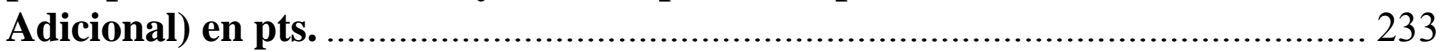

Figura 03. Estado comparativo de la recaudación de ingresos en los ejercicios 1923/24 y 1927 por Presupuesto Corriente en pts. 233

Figura 04. Estado comparativo de la recaudación de ingresos en los ejercicios 1923/24 y 1927 por resultas en pts................................................................. 234

Figura 05. Total de lo recaudado por Presupuesto Corriente y resultas en los ejercicios 1923/24 y 1927 en pts............................................................. 234

Figura 06. Situación de la Hacienda Provincial por valores del Presupuesto en fin de los siguientes ejercicios 1923/24,24/25,25/26, y 1927. 235

Figura 07. Porcentaje de gastos e ingresos de la Diputación Provincial de Palencia

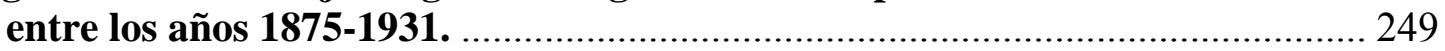

Figura 08. Evolución anual del gasto e ingreso totales de la Diputación Provincial de Palencia en el periodo 1875-1931. 250

Figura 09. Porcentaje de Gasto en Beneficencia Pública sobre el total del Presupuesto de Gasto de la Diputación Provincial de Palencia en el periodo 1875-1931.

Figura 10. Gasto en pts. en Beneficencia Pública en los ejercicios económicos del periodo 1875-1931. 260

Figura 11. Porcentaje de gasto en pts. en Instrucción Pública sobre el total del Presupuesto Provincial de Gastos entre 1875-1931. 324

Figura 12. Gasto anual en pts. en Instrucción Pública entre los años 1875-1931. 325

Figura 13. Porcentaje de gasto en carreteras provinciales sobre el total del Presupuesto de Gastos.

Figura 14. Gasto anual en pts. en construcción de carreteras provinciales en el periodo 1887-1925.

341

Figura 15. Porcentaje de gasto en Corrección Pública sobre el total del gasto en la etapa $1886 / 1924$.

Figura 16. Gasto anual en pts. en Corrección Pública entre los años 1884-1924. 403

Imagen 01. Edificio de los Establecimientos Provinciales de Beneficencia en la plaza de la Maternidad (actual plaza de Abilio Calderón. 261

Imagen 02. Ancianos acogidos en la Casa de Misericordia de la Beneficencia

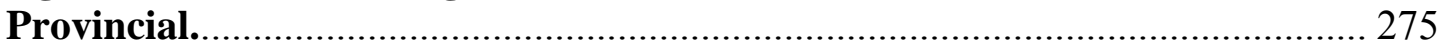

Imagen 03. Departamento de Cuna de la Beneficencia Provincial....................... 278

Imagen 04. Grupos de niños y amas de cría de la Casa de Maternidad................ 282

Imagen 05. Talleres de la imprenta de los Establecimientos de Beneficencia de la Diputación Provincial. 286 
Imagen 06. Pabellón destinado a residencia veraniega de los asilados de

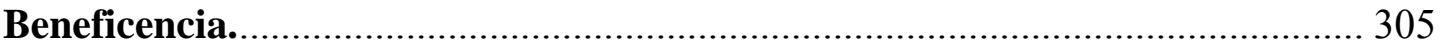

Imagen 07. Escuela de niñas de los Establecimientos de Beneficencia Provincial. 319

Imagen 08. Proyecto del ferrocarril entre Guardo y Palencia. Plano General (topográfico): “Trozo $5^{\circ}$ ”. 366

Imagen 09. Abilio Calderón Rojo en el acto de inauguración de las obras del pantano del Príncipe Alfonso (1914)............................................................ 374

Imagen 10. Cartilla filoxérica. Imprenta de la Casa de Expósitos y Hospicio

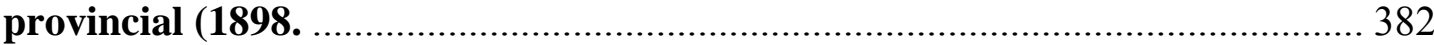

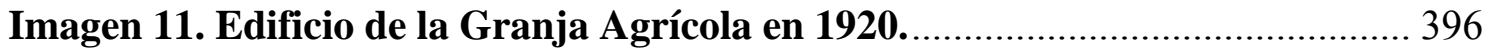

Imagen 12. Proyecto de edificación de la Cárcel Correccional de Palencia (1891).

400

Tabla 01. Número de mozos de la provincia de Palencia incorporados a filas con motivo de los sucesos de Melilla entre 1901 y 1908. ............................................ 56

Tabla 02. Elecciones provinciales de 1880, 1882 y 1884 en Palencia. ..................... 144

Tabla 03. Salarios del personal de la Diputación Provincial en 1903.................... 184

Tabla 04. Personal de la Diputación Provincial de Palencia en 1924................... 188

Tabla 05. Estado comparativo de lo recaudado en pts. en los ejercicios 1923/24 y

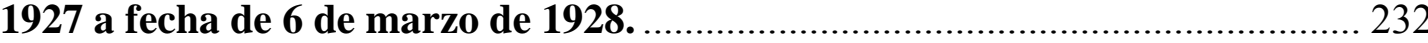

Tabla 06. Situación de la Hacienda Provincial por valores del Presupuesto en el fin de los siguientes ejercicios 1923/24, 24/25, 25/26, y 1927................................ 235

Tabla 07. Presupuesto de Gastos en pts. de la Diputación Provincial de Palencia entre los años 1918 y 1924 y porcentaje de participación en el mismo de los

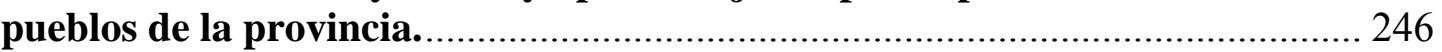

Tabla 08. Gasto en pts. asignado a los diferentes conceptos de la Beneficencia Provincial por la Diputación de Palencia el año 1884...................................... 272

Tabla 09. Pago en pts. por estancias de enfermos mentales en el Manicomio Provincial de Valladolid................................................................................. 289

Tabla 10. Acogidos en los Establecimientos de Beneficencia el año 1911. ............ 290

Tabla 11. Cuadro estadístico de enfermos mentales sostenidos por la Diputación palentina durante el periodo 1919-1923. ...................................................... 303

Tabla 12. Estado comparativo de lo invertido en pts. en Beneficencia en los

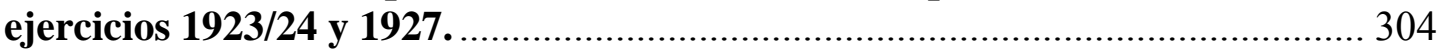

Tabla 13. Gasto en pts. para la conservación de carreteras provinciales en el

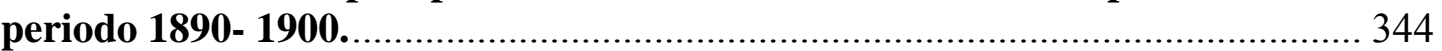

Tabla 14. Cantidades en pts. consignadas en el Capítulo $X$ del Presupuesto Provincial (Carreteras) en el periodo 1915/1924............................................ 355

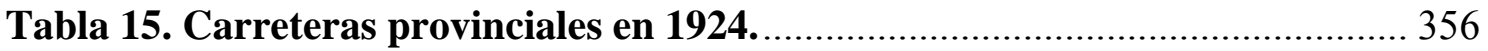

Tabla 16. Gasto anual por $\mathbf{k m}$ en carretas provinciales entre los años 1914/1923.

Tabla 17. Gasto total en pts. en carreteras provinciales en el periodo 1914/1923.358

Tabla 18. Viveros forestales de la Diputación Provincial de Palencia en 1927.... 398

Tabla 19. Cantidades invertidas por ejercicios en la construcción de la Cárcel de Audiencia de Palencia. 


\section{Introducción}

«Señor: El Municipio $y$ el Estado son dos entidades territoriales políticoadministrativas que se encuentran en el inicio $y$ en la meta de toda organización nacional. Son el punto de partida $y$ el punto final de la línea que une entre sí las diversas actividades públicas de una sociedad política estatal. En el tipo de Ciudad-Estado, que ya no existe, era innecesario pensar en círculos intermedios de vida pública. En el tipo de Estado nacional que hoy impera, no cabe prescindir de entidades territoriales intermedias entre el mismo Estado, todo $y$ cumbre, $y$ los Municipios, célula $y$ base..» ${ }^{1}$

Esta cita, procedente de la Exposición de motivos del Estatuto Provincial de 1925, puede muy bien definir la naturaleza jurídica y la razón de ser de las diputaciones provinciales, concebidas desde su nacimiento, en el año 1812, como el ente administrativo que habría de servir de vínculo entre los gobiernos central y municipal respectivamente ${ }^{2}$.

En el año 2012 se cumplió el bicentenario de la creación de las diputaciones provinciales por las Cortes de Cádiz, pensadas como instrumento del liberalismo en contra de las tentaciones involucionistas de los nostálgicos del Antiguo Régimen, que encontraban sus últimos reservorios ideológicos en los municipios del país. Las diputaciones sirvieron al poder central como una perfecta herramienta de control de la vida sociopolítica del ámbito provincial, escenario de frecuentes actividades revolucionarias a lo largo de buena parte del siglo XIX. En una época en la que las comunicaciones eran deficitarias, la mejor forma de asegurarse de que los municipios fuesen receptivos a los intereses de las élites políticas liberales era crear una institución que ejerciese la tutela de los mismos como su superior jerárquico, pero con un poder delegado del Gobierno central.

A pesar de que, como se ha dicho, las diputaciones provinciales representaron un papel fundamental en la configuración del Estado centralista liberal en España, hasta la década de los ochenta del siglo XX escasearon los trabajos de carácter científico sobre estas instituciones. Sin embargo, desde entonces y hasta la actualidad, algunos investigadores se han acercado desde la ciencia histórica a esta parcela de la vida nacional, casi siempre desde la perspectiva de la Historia administrativa y del Derecho.

\footnotetext{
${ }^{1}$ Estatuto Provincial de 1925, p. 5.

${ }^{2}$ Vid. GAY ARMENTEROS, Juan Cristóbal, De Burgos. El reformista ilustrado, Madrid, Gota a Gota, 2014.
} 
En el caso particular que nos ocupa, la provincia de Palencia, han sido varios los trabajos que se han aproximado al estudio de la Diputación Provincial desde diversas perspectivas, especialmente desde la Educación y la Beneficencia, y en diferentes etapas a lo largo de estos doscientos años. Sin embargo, hasta la fecha, existe un vacío bibliográfico de publicaciones que aborden desde una perspectiva global el estudio de la actividad administrativa de la Corporación Provincial de Palencia, desde su creación hasta la actualidad.

Este trabajo pretende contribuir a dotar de contenido ese espacio no abordado de la historia de la Diputación palentina, puesto que en ninguna de las etapas en que la historiografía suele dividir la historia española del siglo XIX y primer tercio del siglo XX, ha sido objeto de un análisis de conjunto. Se ha decidido que la Restauración, concebida como un todo temporal desde 1875, fecha del retorno a la Corona de la dinastía borbónica en la persona de Alfonso XII, hasta 1931, fecha de la caída de la Monarquía, ofrecía una magnífica oportunidad para comprender la enorme influencia que esta institución tuvo en el desarrollo de la vida provincial palentina. Como Administración subordinada, la Diputación decimonónica se vio afectada, en su organización y atribuciones, por los avatares de la política nacional, por lo que, en función del signo político del Gobierno de turno, se ampliaron sus funciones e independencia en las etapas progresistas y se restringió su actividad y facultades en las épocas moderadas. Conocer el marco histórico nacional en el que se desenvolvió la Diputación Provincial palentina resulta fundamental para juzgar la labor de esta institución en la gestión de las funciones que tenía encomendadas y en esta tesitura se justifica el epígrafe de esta tesis titulado «Marco Histórico». Asimismo, el análisis de la legislación, referida al ámbito provincial, ofrece una magnífica fuente documental que permite conocer de primera mano, a través de su articulado, la capacidad de actuación administrativa de las diputaciones provinciales y sus atribuciones, por este motivo se dedica un apartado a esta cuestión bajo el título de «Marco Legislativo». 
Durante la etapa estudiada en el presente trabajo de investigación, la Restauración, el poder central asumió la necesidad de dotar a la institución provincial de cierta estabilidad normativa que otorgase más independencia a las diputaciones a fin de que pudiesen ejercer de revulsivo de la vida provincial y local. Fruto de esta reflexión, en este periodo nacieron los innumerables proyectos de reforma de la Administración Local que perseguían dotar a las diputaciones provinciales de mayores atribuciones y liberarlas del peso centralista de etapas pretéritas. Esta cuestión no resultó un objetivo fácil de lograr, como demuestra el hecho de que ninguno de estos proyectos llegara a aprobarse. En la etapa de la Dictadura primorriverista fue aprobado el Estatuto Provincial que a pesar de que en el marco político no introdujo grandes novedades respecto de leyes anteriores, sí lo hizo en un campo de actuación fundamental para el desarrollo de las diputaciones, la Hacienda y la economía provincial. A pesar de las buenas intenciones reformistas de los diferentes gobiernos de la Restauración, especialmente de conservadores y no tanto de liberales, las diputaciones provinciales no consiguieron nunca liberarse del control del Gobierno, siempre presente a través la figura del gobernador de la provincia o gobernador civil que ejercía como jefe de la Administración Provincial y representante del poder central en el ámbito local.

Se ha considerado necesario realizar un estudio previo, en el apartado «La Diputación Provincial de Palencia en la Restauración», de la naturaleza, estructura y competencias de la Corporación Provincial en esta etapa histórica, antes de analizar el desarrollo institucional de la Diputación palentina en el terreno de la actividad gestora, en campos tan diversos como la Beneficencia, la Instrucción Pública, las Obras Públicas, la Corrección Pública o la Sanidad. Finaliza esta investigación con una necesaria reflexión sobre las principales cuestiones abordadas a lo largo de su realización, en el apartado de «Conclusiones», además de llevar a cabo esta labor de síntesis, se intenta dar respuesta a la hipótesis de partida de la tesis. 
Como en toda labor investigadora de rigor académico, resulta imprescindible la mención de las fuentes documentales y bibliográficas consultadas que han servido de basamento para levantar el edificio intelectual de este trabajo, elementos señalados en los apartados «Bibliografía» y «Fuentes documentales». Por último, en el epígrafe «Anexos» se muestran datos que ayudan a una mejor comprensión de las cuestiones tratadas en el cuerpo principal del trabajo de investigación.

En definitiva, este trabajo precisaba para una adecuada comprensión de la labor gestora de las diputaciones provinciales, del conocimiento del marco histórico nacional, de la legislación vigente, de la organización y competencias de la institución provincial y del conocimiento del conjunto de factores que pudieran dar respuesta a las cuestiones fundamentales que plantea cualquier proyecto de investigación histórica: dónde, cuándo, cómo, qué y porqué. Solo las respuestas a estos interrogantes nos permitirán juzgar de forma objetiva la labor de la Diputación Provincial de Palencia en la Restauración. 


\section{Abreviaturas}

A.D.P.P., L.A.C.P., Archivo de la Diputación Provincial de Palencia, Libro de Actas de la Comisión Provincial.

A.D.P.P., L.A.P.D., Archivo de la Diputación Provincial de Palencia, Libro de Actas del Pleno de la Diputación Provincial.

AHN, Archivo Histórico Nacional.

A.M.A.P., L.A.P.A., Archivo Municipal del Ayuntamiento de Palencia, Libro de Actas del Pleno del Ayuntamiento. 


\section{Hipótesis de partida-Aproximación metodológica e historiográfica}

Esta investigación plantea como hipótesis de partida que más allá de la pugna por el poder en el ámbito provincial, mediatizada por el juego político característico de la Restauración, los políticos comprendieron que la existencia de la Asamblea Provincial como institución se justificaba en la búsqueda de la «felicidad», en el sentido ilustrado del término ${ }^{3}$. Felicidad que solo podía conseguirse con el aumento de la riqueza provincial, único camino para elevar el nivel de vida de la población de la provincia. La actuación en el fomento de la agricultura, la defensa de la producción agrícola castellana en general y palentina en particular, y la lucha constante por la mejora de las infraestructuras, reflejada en las partidas presupuestarias, que permitiesen hacer competitivos a los productos palentinos, bien fuera el trigo, el vino o el carbón, fueron algunos de los ámbitos en los que la Diputación de Palencia actuó con premura y contundencia, a sabiendas de que en ellos la provincia se jugaba su futuro. La institución provincial tomó conciencia de que el sistema económico generaba desigualdades y de que apremiaba atender a las personas más desfavorecidas, menos afortunadas. En este ámbito, el de la Beneficencia, se centraron una buena parte de las atenciones presupuestarias provinciales. Incluso aquellas atribuciones que la Diputación Provincial consideraba como propias del Estado, y no de su gestión, como Instrucción Pública y Corrección Pública, no se vieron nunca desatendidas, lo que demuestra la validez de la hipótesis inicial. Con indiferencia hacia el color político del Gobierno central y la filiación ideológica de las diversas diputaciones formadas en esta etapa, y siempre que el presupuesto lo permitía, se atendieron todas y cada una de las funciones y competencias de la Diputación palentina. Los presupuestos provinciales constituyen una excelente fuente de confirmación de la hipótesis de esta investigación, puesto que reflejan cuáles eran las prioridades en la actividad gestora de la institución provincial en el ámbito de sus competencias.

\footnotetext{
${ }^{3}$ La Declaración de Independencia de Estados Unidos (1776) y la Declaración de los Derechos del Hombre (Francia, 1789) establecían el derecho a la felicidad de todos. En la Ilustración, filósofos como Voltaire y Rousseau afirmaban que la felicidad no era un capricho del destino, ni tampoco un don divino que uno recibía como premio a una buena conducta en vida, sino algo que todos deberíamos alcanzar en la Tierra, aquí y ahora, ya que el ser humano tenía derecho a ser feliz y era misión del gobernante conseguirlo.
} 
Para corroborar cualquier hipótesis de partida resulta necesario indagar en las fuentes documentales primarias, secundarias y bibliográficas existentes, pues solo se escribe historia de los sucesos, personas e instituciones de las que se conservan vestigios en el tiempo en el que el historiador realiza su investigación ${ }^{4}$, en otras palabras: Quod non est in actis, non est in mundo (de lo que no quedan pruebas, no se puede hablar con rigor). La tarea fundamental del historiador consiste en descubrir, identificar y clasificar esas pruebas, para proceder, a continuación, a elaborar una construcción narrativa del pasado histórico. Esta etapa de búsqueda e identificación se

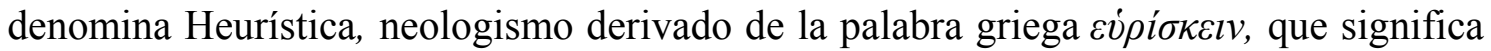
hallar, encontrar. Pero además de buscar las reliquias del pasado, el trabajo del historiador consiste en interpretar la información que las reliquias contienen, a esta

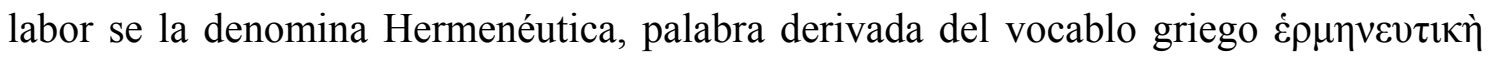
$\tau \dot{\varepsilon} \chi \vee \eta$, o el arte de explicar, traducir o interpretar. Conforme a estas premisas, la presente investigación se ha servido de varios métodos de investigación histórica, aunque de entre ellos destacan el método analítico-sintético y el método deductivoinductivo.

Esta investigación se inició con la búsqueda de la información sobre el tema a estudiar, para proceder después al análisis que nos permitiera descomponer el todo en sus partes y, de esta manera, llegar a la elaboración de un relato que, apoyado en los diversos aspectos del fenómeno estudiado, generase un todo con carácter propio capaz de singularizar la cuestión objeto de análisis respecto de otras de su misma categoría histórica. Además, el estudio se ha servido de la metodología deductiva-inductiva, imprescindible para la investigación de la realidad histórica de una institución como la Diputación de Palencia y para conocer el marco socio-político general de la nación en esa época, en otras palabras, partir del conocimiento de lo general para llegar al conocimiento de lo particular.

\footnotetext{
${ }^{4}$ Vid. MORADIELLOS GARCÍA, Enrique, El oficio de historiador. Madrid, Siglo XXI, 1994.
} 
Esta metodología se presenta como un camino bidireccional, al considerarse que solo con el análisis de lo particular se puede entender el proceso histórico a nivel general; pensemos, por ejemplo, en la dificultad de comprender el juego político de la Restauración a nivel nacional sin comprender la compleja red de intereses que unía a ayuntamientos, diputaciones y Gobierno de la nación y, como consecuencia, entender la política provincial sin medir la influencia que en la conformación y desarrollo institucional de las diputaciones provinciales tenían las decisiones que se tomaban desde el Gobierno.

Más allá del marco histórico, la propia estructura de la investigación obedece a esta metodología deductiva-inductiva, puesto que los apartados de los que se compone se organizan partiendo del conocimiento del escenario general de España, para llegar al análisis y estudio de la Corporación Provincial palentina, corpus principal de este trabajo. Además de los referidos métodos, esta investigación también se ha servido del método cronológico, al considerar que la secuencia temporal de la actividad política y de gestión de la Diputación palentina, organiza, de forma lógica y sencilla, el material documental que permite lograr una adecuada interpretación de la evolución económica, normativa, política y competencial de esta institución.

La interpretación de los hechos históricos presentes en las fuentes documentales entra en contradicción con la máxima positivista de que el historiador debería limitarse a describir hechos del pasado, como si se tratase de un notario del pasado que diera fe de lo ocurrido. En una investigación como la presente, que relata la historia de una institución, el trabajo de interpretación se antoja complicado, la actuación de las administraciones suele dejar un rastro de información rodeada de formalismos, legalismos y fríos datos estadísticos que en la mayoría de las ocasiones previenen al investigador de elaborar teorías que pudieran distar de la verdad histórica. Para evitar caer en este error, este trabajo, haciendo suyo el método empleado por la Escuela de Annales, se ha servido de la metodología propia de otras ciencias y así se ha realizado un trabajo heurístico sobre las fuentes estadísticas y demográficas que permitiera obtener una perspectiva completa de la actuación de la Diputación Provincial de Palencia en la Restauración. 
La investigación ha recorrido un largo periodo de años, desde 1875 hasta 1931, a través del análisis de los procesos sociales, económicos y políticos, la Historia episódica y el análisis de lapsus temporal, sin olvidar al protagonista de todo hecho histórico, el individuo, desde una concepción braudeliana del tiempo histórico, el tiempo estructural, el tiempo coyuntural y el tiempo episódico. No han faltado, tampoco, ciertos matices propios del materialismo histórico a la hora de abordar cuestiones como la pobreza, la desigualdad social y el problema del desempleo, en tanto que la presión de los obreros sobre el Ayuntamiento de Palencia y la Diputación Provincial ponen de relieve la preocupación de estas instituciones y también del Gobierno central porque el proletariado acabase convirtiéndose en sujeto histórico de una revolución que diese al traste con el sistema capitalista y burgués de la Restauración. Por último, señalar que cuando la investigación se ocupa de ciertos aspectos de la vida cotidiana de las personas beneficiarias de la Diputación Provincial, se acerca a los procedimientos utilizados en las últimas tendencias historiográficas, tales como la Microhistoria y la Historia cultural. Dentro de las diversas especialidades de la Historia, el presente trabajo constituye un ejemplo de eclecticismo pues si bien la base principal del mismo descansa sobre los preceptos de la Historia de las Instituciones y del Derecho, no se circunscribe a la tipología propia de estas ya que, por su propia esencia, resulta necesario e imprescindible el concurso de otras especialidades como la Historia económica, la Historia política, la Historia de la pobreza, la Historia de la mujer, la Historia de la infancia, etc.

Al abordar el estudio de la etapa de la Restauración, los historiadores discrepan sobre el periodo cronológico que este periodo comprende. A pesar de la diversidad de opiniones, la mayoría de los autores circunscriben esta etapa a los años 1875-1923. En este estudio se ha considerado que la Restauración concluyó en 1931, por dos motivos esenciales que dan continuidad histórica a la citada etapa, la Constitución de 1876 y la Monarquía borbónica. En el periodo dictatorial, la Constitución de 1876 quedó en suspenso hasta 1930, pero no fue derogada ni sustituida por otra norma de rango superior, ya que la actividad legislativa se limitó a la aprobación de leyes de ámbito local, y volvió a entrar en vigor en 1930. Respecto de la Monarquía, el rey Alfonso XIII continuó como jefe de Estado durante la Dictadura de Primo de Rivera hasta abril de 1931, fecha en la que se proclama la República. En diciembre de ese mismo año se aprobó la Constitución republicana. 


\section{Estado de la cuestión}

Los trabajos de investigación sobre la Administración Local en la España contemporánea no son muy abundantes y, si nos centramos en la Historia de las diputaciones provinciales, pocos son los autores que han dedicado sus investigaciones a indagar sobre el funcionamiento de esta institución. Entre la producción investigadora sobre la Diputación Provincial, sobresalen los trabajos que han abordado el estudio desde una perspectiva histórico jurídica. De entre ellos, cabe destacar la obra de Adolfo González-Posada ${ }^{5}$, en la que analiza la evolución de la institución provincial dentro del Régimen Local del Estado liberal español en el siglo XIX y parte del XX. Del mismo modo, Martín Retortillo ${ }^{6}$ ofrece, en el primer volumen de su obra, un completo estudio del Régimen Local español, tratando en consecuencia el tema de las diputaciones provinciales.

La tesis doctoral de Manuel Santana Molina ${ }^{7}$, proyecto desarrollado dentro del Departamento de Historia del Derecho español de la Facultad de Derecho de la Universidad de Alicante, constituye otra obra de referencia desde la óptica jurídica. Santana Molina, realiza un estudio de la evolución de la Diputación Provincial a lo largo del siglo XIX en España, apoyándose en bibliografía de carácter mayoritariamente legislativo, con alguna pincelada histórica, y en fuentes primarias compuestas por Leyes, Reales Decretos, Órdenes Reales, etc. En este trabajo de investigación se describe el organigrama institucional de la Diputación española decimonónica, su naturaleza jurídica, ámbito territorial de actuación y funcionamiento institucional.

\footnotetext{
${ }^{5}$ GONZÁLEZ-POSADA y BIESCA, Adolfo, Evolución legislativa del régimen local español 1812-1909, Madrid, Instituto de Estudios de Administración Local, 1982.

${ }^{6}$ MARTÍN-RETORTILLO BAQUER, Sebastián, La provincia: pasado, presente y futuro, Madrid, Civitas, 1991.

${ }^{7}$ SANTANA MOLINA, Manuel, La Diputación Provincial en la España decimonónica, Instituto Nacional de Administración Pública, Madrid, 1989.
} 
Desde una visión más cercana a la investigación histórica, destaca el trabajo de José Antonio González Casanova ${ }^{8}$, en el que se realiza un recorrido por las diferentes etapas por las que ha discurrido la vida institucional de la Diputación provincial, desde su nacimiento, contradictorio y polémico en Cádiz en 1812, hasta su consolidación. González Casanova muestra cómo la Diputación Provincial ha representado el papel de punto de encuentro entre la vida local y sus «fuerzas vivas» en la provincia, y el frágil Estado burocrático, a través de un esquema que centra su atención en la estructura básica, organización y funcionamiento, y no tanto en cuestiones de carácter histórico.

La publicación de trabajos sobre la Historia local se ha intensificado recientemente. Se trata de investigaciones dirigidas por una metodología propia de la ciencia histórica que han renovado la producción historiográfica sobre las instituciones locales y provinciales. Aunque de forma breve, parece obligado mencionar las obras que estudian los primeros pasos de las diputaciones provinciales como ente jurídico en la España liberal. Las funciones y el encaje institucional de las diputaciones provinciales constituyen los dos principales aspectos estudiados en los distintos ámbitos geográficos nacionales.

\footnotetext{
${ }^{8}$ GONZÁLEZ CASANOVA, José Antonio, Las Diputaciones provinciales en España. Historia politica de las Diputaciones en España desde 1812 hasta 1985, Madrid, Mancomunidad General de Diputaciones de Régimen Común, 1986.
} 
Las obras sobre las diputaciones gallegas y catalanas son pioneras en este campo. Autores como Pablo González Mariñas', y su obra sobre las primeras diputaciones provinciales en Galicia, y Fariña Jamardo y Pereira Figueroa ${ }^{10}$, y su trabajo sobre la Diputación Provincial de Pontevedra, abrieron el camino a investigaciones posteriores. También las diputaciones catalanas han sido objeto de estudio por parte de autores como Lladonosa Pujol ${ }^{11}$, con su obra sobre la Diputación Provincial de Lérida, Pedro Voltes Bou ${ }^{12}$, sobre la Diputación Provincial de Barcelona, y Antonio Jordá Fernández, ${ }^{13}$ acerca de la Diputación Provincial de Tarragona, de más reciente publicación. Deben citarse, además, trabajos como la obra dirigida por Borja de Riquer $^{14}$, alejada del esquema habitual de este tipo de aportaciones puesto que se centra casi exclusivamente en el estudio de cuestiones políticas, y solo de manera marginal aborda la labor gestora de la Diputación en la provincia de Barcelona.

A partir de los años noventa del pasado siglo, otros autores siguen el camino abierto por estos primeros trabajos. En algunas ocasiones, son los cronistas de la vida local, más que profesionales de la ciencia histórica, los que nos acercan a la historia de las diputaciones provinciales, por lo que su enfoque va dirigido a un análisis de la vida cotidiana más que a un estudio de su desarrollo institucional. En el territorio levantino, destaca la obra dirigida por Manuel Chust Calero ${ }^{15}$, sobre la Diputación Provincial de Valencia, o el trabajo de Vicente Ramos ${ }^{16}$, sobre la Diputación Provincial de Alicante, en el que, a lo largo de cuatro tomos, va desgranado la historia política de la Diputación y su labor en la gestión de la Educación y la Beneficencia, desde 1822 hasta 1929.

\footnotetext{
${ }^{9}$ GONZÁLEZ MARIÑAS, Pablo, Las Diputaciones Provinciales en Galicia: del Antiguo Régimen al Constitucionalismo, La Coruña, Diputación Provincial de la Coruña, 1978.

${ }^{10}$ FARIÑA JAMARDO, José y PEREIRA FIGUEROA, Miguel, La Diputación de Pontevedra (18361986), Pontevedra, Diputación Provincial de Pontevedra, 1986.

${ }^{11}$ LLADONOSA PUJOL, José, Historia de la Diputación de Lérida, Lérida, Diputación Provincial de Lérida, 1974.

${ }^{12}$ BOLTES BOU, Pedro, «Orígenes de la Diputación Provincial barcelonesa», en Instituto de Ciencias Sociales, La provincia. Dimensiones histórica y política, Barcelona, Diputación Provincial de Barcelona, 1966, pp. 63-70.

${ }^{13}$ JORDÁ FERNÁNDEZ, Antonio, Las Diputaciones provinciales en sus inicios. Tarragona 1836-1840. La guerra como alteración en la aplicación de la norma jurídica, Tarragona, Diputación Provincial de Tarragona, 2002.

${ }^{14}$ RIQUER y PERMANYER, Borja de (Dirección), Historia de la Diputación de Barcelona, Barcelona, Diputación Provincial de Barcelona, 2007.

${ }^{15}$ CHUST CALERO, Manuel (Dirección.), Historia de la Diputación de Valencia, Valencia, Diputación Provincial de Valencia, 1995.

${ }^{16}$ RAMOS PÉREZ, Vicente, Historia de la Diputación Provincial de Alicante, Vol. I (1822-1870), Alicante, Diputación Provincial de Alicante, 2002.
} 
En este repaso no puede olvidarse el trabajo de Manuel Martí ${ }^{17}$, sobre el caciquismo y las diputaciones provinciales en la Restauración. Las diputaciones de Castilla-La Mancha también han sido estudiadas por los investigadores de la Historia local. Luis Moreno Nieto ${ }^{18}$, diputado provincial y cronista de la vida provincial, realiza un repaso de la historia de la Diputación Provincial de Toledo, centrando su obra en la labor de la Diputación como entidad gestora de funciones tan fundamentales para la vida provincial como la asistencia benéfica. La obra de Pedro Ortego Gil ${ }^{19}$, sobre la Diputación Provincial de Guadalajara en sus primeros años de funcionamiento, puede encuadrarse en el modelo jurídico de estudio de esta institución.

Dentro del ámbito manchego, no puede obviarse la obra sobre la Diputación Provincial de Albacete ${ }^{20}$, con Manuel Requena como coordinador de la misma. Este trabajo, al contrario que el trabajo precedente, se centra en el mundo político y social de la Corporación Provincial y aborda, solo de forma marginal, aspectos jurídicos. El periodo comprendido entre 1835-1999 constituye el espacio temporal al que se circunscribe la obra coordinada por Isidro Sánchez Sánchez ${ }^{21}$, sobre la historia de la Diputación Provincial de Ciudad Real, en la que se realiza un estudio pormenorizado de la actuación de la Diputación en el campo hacendístico y se analiza la formación y evolución de los presupuestos provinciales. Este autor estudia como un todo el periodo de la Restauración y la Dictadura de Primo de Rivera y profundiza en dos aspectos fundamentales de la historia de la Diputación Provincial, la sociedad y la política. A través del análisis de la gestión de la Diputación en diversos ámbitos, realiza una semblanza de la sociedad de la Ciudad Real de la época, completando esta visión con el tradicional estudio de este tipo de trabajos sobre las tendencias políticas de los diputados provinciales. La bibliografía y las fuentes primarias, como el Boletín Oficial de la Provincia (BOP) y las Actas de la Diputación, constituyen la base sobre la que se sustenta esta interesante obra.

\footnotetext{
${ }^{17}$ MARTÍ MARTÍNEZ, Manuel, «Las Diputaciones provinciales en la trama caciquil: un ejemplo castellonense durante los primeros años de la Restauración», Hispania: Revista española de historia, Vol. 51, No 179 (1991), pp. 993-1041.

${ }^{18}$ MORENO NIETO, Luis, Historia de la Diputación Provincial de Toledo, Toledo, Diputación Provincial de Toledo, 1986.

${ }^{19}$ ORTEGO GIL, Pedro, Historia de la Diputación Provincial de Guadalajara (1813-1845), Guadalajara, Digibis Publicaciones Digitale, 2002.

${ }^{20}$ REQUENA GALlEGO, Manuel (Coordinación.), Historia de la Diputación de Albacete, 2 vols., Albacete, Diputación Provincial de Albacete, 1993.

${ }^{21}$ SÁNCHEZ SÁNCHEZ, Isidro (Coordinación.), Historia de la Diputación Provincial de Ciudad Real: (1835-1999), Ciudad Real, Diputación de Ciudad Real, 1999.
} 
En muchas ocasiones, se olvida que Madrid, además de capital del Estado, engloba un territorio que debe ser administrado. Loreto Maluenda Abadía ${ }^{22}$, inicia su obra sobre la Diputación de Madrid con esta misma crítica. La autora realiza un estudio sobre los treinta primeros años de andadura histórica de la Diputación Provincial madrileña. La Administración Provincial en el territorio aragonés también ha sido estudiada por parte de los investigadores. Alicia Sánchez Lecha ${ }^{23}$, en su Tesis doctoral, realiza un estudio sobre la función de la Diputación Provincial como institución de ámbito local en los inicios del liberalismo español y su acoplamiento dentro de la estructura institucional del Estado liberal.

Las diputaciones provinciales andaluzas han merecido, asimismo, varios trabajos de investigación. Destaca, entre estos estudios, la obra de Miguel Ángel Chamocho Cantudo $^{24}$ sobre la Diputación Provincial de Jaén. El autor establece una interesante relación entre la evolución histórico-política de la institución provincial y la aprobación de la normativa estatal que regulaba su funcionamiento. No debe obviarse la obra de Julio Ponce Alberca, dentro del trabajo coordinado por Rafael Sánchez Mantero ${ }^{25}$, sobre la Diputación Provincial de Sevilla en la época de la Dictadura de Primo de Rivera. El autor se centra en las medidas adoptadas por el Directorio que afectaron al funcionamiento institucional de la diputación sevillana. Asimismo, Ponce Alberca examina la influencia que tuvo la proclamación del Estatuto Provincial de 1925 en el desarrollo funcional de la institución provincial. La obra de Carmen Martínez Hernández $^{26}$, sobre la Diputación Provincial de Córdoba en el periodo comprendido entre 1925 y 1991, centra su investigación en los aspectos políticos de la vida provincial, sin olvidar la labor asistencial, estructura típica en este tipo de investigaciones.

\footnotetext{
${ }^{22}$ MALUENDA ABADÍA, Loreto, Orígenes de la Diputación provincial de Madrid (1813-1843), Madrid, Universidad Complutense de Madrid, 1997.

${ }^{23}$ SÁNCHEZ LECHA, Alicia, Estado liberal y provincia: los orígenes de la Diputación de Zaragoza, Zaragoza, Diputación Provincial de Zaragoza, 1998.

${ }^{24}$ CHAMOCHO CANTUDO, Miguel Ángel, La Diputación Provincial de Jaén en el primer Estado constitucional, Jaén, Instituto de Estudios Giennenses, 2004.

${ }^{25}$ PONCE ALBERCA, Julio, «Un modelo de estudio de la administración provincial: la Diputación de Sevilla durante la Dictadura de Primo de Rivera y la Segunda República (1923-1936)», en SÁNCHEZ MANTERO, Rafael, (Coordinación.), En torno al 98: España en el tránsito del siglo XIX y XX: Actas del IV Congreso de la Asociación de Historia Contemporánea, Huelva, Universidad de Huelva, Servicio de Publicaciones, 2000, pp. 435-452.

${ }^{26}$ MARTÍNEZ HERNÁNDEZ, María del Carmen, Política y administración provincial:: La Diputación de Córdoba: 1925-1991, Córdoba, Diputación Provincial de Córdoba, 2004.
} 
También las diputaciones provinciales de los territorios insulares han estado en el punto de mira de los estudiosos de la Administración Local liberal. Ramón Piña $\mathrm{Homs}^{27}$, en el caso de las Islas Baleares, es pionero del estudio de la historia de las diputaciones provinciales desde el punto de vista histórico, desde el inicio de la andadura institucional de la Diputación como ente administrativo en 1812 hasta 1979, fecha de publicación de su obra. No menos interesante es la obra de Eduardo Galván Rodríguez $^{28}$, que como Piña Homs, se remonta a los orígenes de la Diputación Provincial canaria en el año 1813. La historia de la Diputación sirve al autor para tratar el tema de la descentralización en el Estado liberal. El Estatuto Provincial de 1925 fija la fecha de cierre del periodo de investigación del trabajo.

En este breve repaso geográfico, no deben ignorarse las obras referidas a los territorios uniprovinciales. Francisco Bermejo Martín y José Miguel Delgado Idarreta ${ }^{29}$, son coautores de un libro sobre la Diputación Provincial de La Rioja desde su creación en 1822 hasta su desaparición en 1982, cuando se constituyó la Comunidad Autónoma de La Rioja. La obra comprende un estudio político de la institución, así como de su labor en diversos aspectos de la vida de la provincia, tales como Obras Públicas, Beneficencia, Instrucción Pública, etc. En Cantabria, Manuel Estrada Sánchez ${ }^{30}$, profesor de Historia del Derecho y de las Instituciones, realiza un estudio desde la óptica de la historia jurídica de la Diputación Provincial santanderina en el inicio de la andadura histórica del Estado liberal.

\footnotetext{
${ }^{27}$ PIÑA HOMS, Ramón, La Diputación Provincial de Baleares, Mallorca, Diputación Provincial de Baleares, 1979.

${ }^{28}$ GALVÁN RODRÍGUEZ, Eduardo, El origen de la autonomía canaria. Historia de una Diputación Provincial (1831-1925), Madrid, Ministerio de Administraciones Públicas, 1995.

${ }^{29}$ BERMEJO MARTÍN, Francisco y DELGADO IDARRETA, José Miguel, La administración provincial española en la Diputación Provincial de La Rioja, Logroño, Universidad de la Rioja, 1989.

${ }^{30}$ ESTRADA SÁNCHEZ, Manuel, «Delimitación territorial y poder político: La Diputación Provincial de Santander durante la configuración del Estado liberal», I Encuentro de Historia de Cantabria, Vol. 2, Santander, Universidad de Cantabria, 1996, pp. 997-1010.
} 
Antes de centrarnos en el espacio castellano y leonés, conviene mencionar los trabajos sobre las diputaciones provinciales de régimen foral. Javier Pérez Núñez ${ }^{31}$ es autor de una obra sobre el encaje del foralismo en el entramado administrativo del liberalismo español. La Diputación Foral de Vizcaya sirve de ejemplo al autor para este estudio. En el mismo sentido puede entenderse la obra de Consuelo Juanto Jiménez ${ }^{32}$, que realiza un recorrido histórico sobre la evolución institucional de la Diputación Foral de Navarra en el siglo XIX.

Este trabajo de investigación se centra en la historia de la Diputación Provincial de Palencia entre los años 1875 y 1931, por tanto, las obras referidas a las diputaciones provinciales de Castilla y León cierran este estado de la cuestión. La obra de Enrique Orduña Rebollo ${ }^{33}$ constituye una referencia obligada por sus trabajos sobre la Diputación Provincial de Segovia y la Administración Local. En ellos realiza un estudio del recorrido de la institución provincial desde el año 1883 hasta el año 1990. El autor introduce al lector en la época de la Restauración mediante tres conceptos fundamentales que sirven para definirla, «Turnismo», «Caciquismo» $\mathrm{y}$ «Regeneracionismo». Tras un detenido estudio del marco legislativo, en el que desarrollaba sus funciones la institución provincial, Orduña muestra su organización y funcionamiento, destacando su labor en la asistencia social a través de la gestión en el campo de la Beneficencia y la Sanidad, la Instrucción Pública, las Obras Provinciales, Cultura y Fomento de la Agricultura, y la lucha por el establecimiento del ferrocarril en el territorio provincial. El autor se basa en la bibliografía específica sobre el periodo y en las fuentes primarias de documentación generadas por la propia institución, como las Actas de la Comisión Provincial de la Diputación.

\footnotetext{
${ }^{31}$ PÉREZ NÚÑEZ, Javier, La Diputación foral de Vizcaya. El régimen foral en la construcción del Estado liberal (1808-1868), Bilbao, Centro de Estudios Constitucionales, 1996.

${ }^{32}$ JUANTO JIMÉNEZ, Consuelo, «Navarra en la Administración provincial de España del siglo XIX. La Diputación Foral», Rudimentos Legales: Revista de historia del derecho, № 4 (2002), pp. 197-215.

${ }^{33}$ ORDUÑ̃ REBOLLO, Enrique, Evolución histórica de la Diputación Provincial de Segovia. 18831990, Valladolid, Ámbito, 1986.
} 
No menos interesantes son los trabajos sobre las Diputaciones de León, de Soria y de Valladolid, porque las relaciones institucionales entre las diputaciones provinciales de Castilla y León fueron numerosas al defenderse intereses comunes, como la política proteccionista acordada con respecto a la importación de grano. La obra dirigida por Francisco Carantoña Álvarez y Gustavo Puente Feliz ${ }^{34}$ sobre la Diputación Provincial de León, compuesta de dos volúmenes, realiza un análisis diferencial de la actividad política y de la gestión la Diputación leonesa en la Restauración, al abordar estos dos aspectos en el tiempo del Reinado y Regencia, y de la Dictadura de Primo de Rivera. El estudio de la labor de gestión de la Diputación en Instrucción Pública, Beneficencia, Obras Públicas, etc., se completa con un repaso sobre la ejecución presupuestaria que aclara muchas de las actuaciones en los citados campos. Las Actas de la Diputación Provincial de León, la prensa local y nacional, la Gaceta de Madrid, el Archivo Histórico Nacional, el Boletín Oficial de la Provincia y la legislación de la época, junto con la bibliografía, sirven a los autores para lograr una completa visión de la vida provincial de León en esta etapa.

María Concepción García Segura ${ }^{35}$ es la autora del libro dedicado a la historia de la Diputación Provincial de Soria. Desde un triple enfoque, histórico, administrativo e institucional y tomando como hilo conductor de la obra, el desarrollo del movimiento liberal, enmarca su estudio, desde el ámbito provincial de Soria, en el contexto nacional de las diputaciones provinciales. García Segura diferencia entre Restauración y Regencia, a la vez que emprende un seguimiento de la actividad política de la Diputación en estos dos periodos, excluyendo, de modo único en la bibliografía consultada, el reinado de Alfonso XIII y la Dictadura de Primo de Rivera.

\footnotetext{
${ }^{34}$ CARANTOÑA ÁlVAREZ, Francisco y PUENTE FELIZ, Gustavo, (Dirección.), Historia de la Diputación de León, León, Instituto Leonés de Cultura, 1995.

${ }^{35}$ GARCÍA SEGURA, María Concepción, Historia de la Diputación Provincial de Soria. Siglo XIX: años 1843-1902, 2 vols., Soria, Diputación Provincial de Soria, 2003.
} 
La obra de Heliodoro Pastrana Morilla ${ }^{36}$ sobre la Diputación Provincial de Valladolid, Tesis doctoral dirigida por el profesor Jesús María Palomares Ibáñez, resulta especialmente interesante para este trabajo de investigación ya que, por cercanía geográfica e histórica, la Diputación de Valladolid fue, en muchas ocasiones, el espejo en el que se miró la Diputación Provincial de Palencia a la hora de llevar a cabo sus atribuciones. Pastrana Morilla realiza el estudio de la Diputación de Valladolid sobre dos terrenos muy bien diferenciados, el de la política y el de la gestión, algo que no resulta nuevo en la mayoría de las obras mencionadas. La existencia de personajes de la talla política de Germán Gamazo o Santiago $\mathrm{Alba}^{37}$ vinculados a Valladolid, permite al autor realizar un estudio pormenorizado del campo de batalla entre conservadores y liberales en el que se convirtió la Diputación de la provincia, reflejo fiel de lo que sucedía en España. En la obra citada, destaca el minucioso estudio de la labor de la Diputación en los diversos campos de su actuación como entidad gestora de la Beneficencia, la Instrucción Pública, los intereses agrarios, la economía provincial y los funcionarios provinciales. Pastrana relaciona la evolución histórica de la Diputación Provincial con lo acontecido en la época a nivel provincial y regional, incluyendo en la obra el típico nomenclátor de los diputados provinciales. La prensa constituye una fuente histórica de primer orden en la elaboración de este trabajo, además de la documentación generada por la propia Diputación Provincial y una cuidada selección bibliográfica. Pablo Martín Bobillo ${ }^{38}$, en su trabajo sobre la Diputación de Zamora, investiga sobre los primeros años de evolución histórica de la Corporación Provincial, desde la creación de la institución hasta el inicio de la Década Ominosa y la restauración del absolutismo fernandino.

\footnotetext{
${ }^{36}$ PASTRANA MORILLA, Helidoro, La Diputación Provincial de Valladolid: 1875-1930: política y gestión, Valladolid, Diputación Provincial de Valladolid, 1997.

${ }^{37}$ Su hermano, Enrique Alba, fue senador por Palencia. En 1918, la Diputación Provincial de Palencia enviaba su pésame al entonces ministro de Instrucción Pública, Santiago Alba, por la prematura muerte de su hermano. Archivo de la Diputación Provincial de Palencia (A.D.P.P.), Libro de Actas de la Comisión Provincial (L.A.C.P.), 126, 5-VII-1918. Vid. CANO GARCÍA, Juan Antonio, Gamacistas y albistas. La vida política en Valladolid durante la Restauración, Valladolid, Secretariado de Publicaciones, 2008.

${ }^{38}$ MARTín BOBILLO, Pablo, Orígenes de la Diputación Provincial de Zamora (1813-1823), Zamora, Diputación Provincial de Zamora, 1988.
} 
Los trabajos de investigación sobre la Diputación de Palencia en la Restauración cierran este recorrido. Hasta la fecha de escritura de este trabajo, no existe ninguna investigación que reúna en una sola obra el estudio de la Diputación Provincial de Palencia en la Restauración, entendida como el lapso temporal comprendido entre los años 1875 y 1931. Los diversos Congresos de Historia de Palencia han servido como marco de presentación de diversas ponencias sobre variados aspectos de la Historia Contemporánea de Palencia. Enrique Orduña ${ }^{39}$, en su obra sobre la Diputación palentina en la etapa primorriverista, aporta luz sobre la actividad institucional de la Corporación Provincial en la Dictadura. El autor basa su estudio en los Libros de Actas del Pleno de la Diputación y de la Comisión Provincial, en la Memorias de la Comisión Permanente, en el Anuario de la Vida Local y la prensa local, sin olvidar el aporte bibliográfico. El objetivo de su investigación se centra en el estudio de los aspectos relacionados con la labor que, como gestora, desarrolló la institución provincial en ese periodo. Como es habitual, Beneficencia, Obras Públicas, Instrucción Pública, Agricultura y un detallado estudio sobre la Hacienda local, constituyen los aspectos que desvelan cómo transcurría la vida en la provincia de Palencia durante la segunda década del siglo XX.

Del mismo modo, el trabajo de José Daniel Reboredo Olivenza ${ }^{40}$ se centra en el papel desempeñado por la Diputación Provincial palentina en las reivindicaciones castellanas, causadas por la grave crisis que presentaba el sector primario en la etapa estudiada. Da cuenta, Reboredo Olivenza, de la participación de la institución palentina en las Asambleas de diputaciones provinciales celebradas en el periodo para consensuar propuestas que luego serían formuladas ante el Gobierno de la nación. Las Actas del Pleno de la Diputación y de la Comisión Provincial constituyen las principales fuentes de información de las que se sirve este autor en su investigación.

\footnotetext{
${ }^{39}$ ORDUÑA REBOLLO, Enrique, «La gestión de la Diputación de Palencia durante la Dictadura de Primo de Rivera», en ACTAS DEL II CONGRESO DE HISTORIA DE PALENCIA, Edad Contemporánea, Tomo III, Volumen II, Palencia, Diputación Provincial de Palencia, 1990, pp. 725-748. ${ }^{40}$ REBOREDO OLIVENZA, José Daniel, «La crisis agrícola de finales del siglo XIX y la Diputación de Palencia», en ACTAS DEL II CONGRESO DE HISTORIA DE PALENCIA, Edad Contemporánea, Tomo III, Volumen II, Palencia, Diputación Provincial de Palencia, 1990, pp. 769-783.
} 
Por último, señalar trabajos que, aunque no muestren la totalidad de la realidad de la Diputación Provincial de Palencia en la Restauración, abarcan aspectos en los que esta institución desempeñó un papel de protagonista, como la Beneficencia o la Instrucción Pública. Autores como María Paz Corredera García ${ }^{41}$, Pedro Carasa Soto ${ }^{42}$, Delfina Herreras Vidal ${ }^{43}$ y Abilio Sierra Jorrín ${ }^{44}$ han investigado sobre la Beneficencia y Sanidad en Castilla y León y en Palencia, durante los siglos XIX y XX. Con una metodología diferente, las fuentes empleadas para la elaboración de sus investigaciones han sido, en numerosas ocasiones, las Actas de la Diputación Provincial, además del imprescindible apoyo bibliográfico. El trabajo de Abilio Sierra Jorrín, ya citado, constituye un ejemplo claro de lo dicho, al describir en su obra cien años de historia de los Establecimientos Provinciales de la Beneficencia Provincial. Respecto a los estudios sobre la Instrucción Pública, Rafael del Valle Curieses ${ }^{45}$, María Concepción Álvarez García $^{46}$, Carmen Labrador Herraíz ${ }^{47}$, Pablo García Colmenares ${ }^{48}$ o Carmen García Colmenares $^{49}$, han tratado el tema de la Educación en Palencia en el siglo XIX y, en menor medida, en el siglo XX.

\footnotetext{
${ }^{41}$ CORREDERA GARCÍA, María Paz., «La Beneficencia en Palencia en el primer tercio del siglo XX: la sociedad de la pobreza», en ACTAS DEL II CONGRESO DE HISTORIA DE PALENCIA, Edad Contemporánea, Tomo III, Volumen II, Palencia, Diputación Provincial de Palencia, 1990, pp. 833-848. ${ }^{42}$ CARASA SOTO, Pedro, «Beneficencia en Castilla y León: trasformaciones del sistema hospitalario (1750-1909)», en ACTAS DEL I CONGRESO DE HISTORIA DE CASTILLA Y LEÓN, Edad Contemporánea, Volumen III, Valladolid, Diputación Provincial de Valladolid, 1982, pp. 299-326.

${ }^{43}$ HERRERAS VIDAL, Delfina, «Beneficencia y Sanidad», en VV.AA., Historia de Palencia: siglos XIX-XX, Valladolid, El Norte de Castilla, 1996, pp. 277-288.

${ }^{44}$ SIERRA JORRÍN, Abilio, Primer centenario de las Hijas de la Caridad al servicio de una buena obra: 25- enero-1879, 25-enero-1979, Palencia, Diputación Provincial de Palencia, 1979.

${ }^{45}$ VALLE CURIESES, Rafael del, «El Instituto viejo»: comienzos de la segunda enseñanza en Palencia: 1845-1915, Palencia, Caja España, 1992.

${ }^{46}$ ÁLVAREZ GARCÍA, María Concepción, La enseñanza secundaria en Palencia durante el siglo XIX (1845-1901), Palencia, Diputación Provincial de Palencia, 1997.

${ }^{47}$ LABRADOR HERRAÍZ, Carmen, «La escuela en el antiguo régimen. Acciones benéfico-sociales y enseñanza en la provincia de Palencia», en ACTAS DEL II CONGRESO DE HISTORIA DE PALENCIA, Edad Contemporánea, Tomo III, Volumen II, Palencia, Diputación Provincial de Palencia, 1990, pp. 657-671.

${ }^{48}$ GARCÍA COLMENARES, Pablo, «El Instituto Provincial de Palencia (1845-1915). Historia de la Segunda Enseñanza Provincia», en VV.AA., I.B. Jorge Manrique: LXXV aniversario, Palencia, 1992, pp. 15-25.

${ }^{49}$ GARCÍA COLMENARES, Carmen, «La Escuela Normal de Palencia: apuntes histórico-pedagógicos (1861-1940)», ACTAS DEL I CONGRESO DE HISTORIA DE PALENCIA, Edad Moderna y Contemporánea, Volumen III, Palencia, Diputación Provincial de Palencia, 1987, pp. 523-537.
} 
En resumen, de forma general, los primeros trabajos sobre las diputaciones provinciales se centraron, en su mayor parte, en el estudio de la institución desde el punto de vista jurídico y administrativo. A partir de la década de los años noventa del siglo XX, la metodología empleada por varios autores ha vuelto su mirada hacia el estudio de las diputaciones provinciales desde la perspectiva de la Historia, y no tanto del Derecho. Todas las líneas de investigación presentan una uniformidad en su metodología de trabajo, estudio del entorno político de la Diputación, por un lado, y de la labor como gestora por otro, permitiendo conocer el desarrollo del sistema de la Restauración a nivel local y las principales características de la sociedad en la provincia.

Esta investigación pretende ocupar el espacio vacío del estudio simultáneo de la Historia de la Diputación palentina en la Restauración, en su doble vertiente, tanto en su aspecto administrativo, como en lo referido a su labor gestora de atenciones a las necesidades fundamentales para la sociedad de la época. 


\section{Marco histórico y socio-político}

\section{Introducción}

El periodo de la Restauración podría resumirse en un concepto, estabilidad institucional, meta que Antonio Cánovas del Castillo ${ }^{50}$ creyó haber alcanzado con el establecimiento del turno pactado entre los dos partidos dinásticos del liberalismo español, el Conservador ${ }^{51}$ y el Liberal ${ }^{52}$. Ambos partidos fijaron en la dependencia clientelar y en las relaciones privadas de amistad y familia sus principales factores de cohesión, además de contar con el respaldo del poder social y económico del país. La estabilidad política fue posible gracias a que los partidos políticos y la mayoría de las fuerzas sociales de la nación aceptaron el nuevo sistema, con la Monarquía como cabeza visible del mismo y el turnismo como garantía del ejercicio del poder para los partidos mayoritarios, lo que supuso el final del pronunciamiento militar como medio para alcanzar el Gobierno del Estado. Esta esperada tranquilidad en la esfera política supuso una evolución económica sostenida a lo largo del tiempo, sin superar el ritmo europeo marcado por la irrupción de la Segunda Revolución Industrial, gracias a la Constitución de 1876, la más longeva del constitucionalismo histórico español hasta entonces, que sirvió de soporte institucional. El sistema del turnismo se basaba en el acceso al Gobierno de liberales y conservadores de forma periódica, pactando con anterioridad el resultado de las elecciones, negociando el «encasillado» ${ }^{53}$. La determinación previa del resultado electoral parecía posible en un escenario social en el que el Gobierno ejercía un supuesto control político y social total sobre el electorado, al votar de acuerdo con los deseos de «los notables».

\footnotetext{
${ }^{50}$ Líder del Partido Conservador, el político malagueño fue el inspirador del régimen político de la Restauración. Víctima de la violencia anarquista, fue asesinado el día 8 de agosto de 1897 por el anarquista italiano Michele Angiolillo en el balneario de Santa Águeda, en Mondragón.

${ }^{51}$ Vid. SECO SERRANO, Carlos, Historia del conservadurismo español: Una línea politica integradora en el siglo XIX, Madrid, Temas de Hoy, 2000.

${ }^{52}$ Vid. SUÁREZ CORTINA, Manuel, Las máscaras de la libertad: el liberalismo español 1808-1950, Madrid, Marcial Pons, 2003.

${ }^{53}$ Término que hacía referencia a las casillas correspondientes a los Distritos Electorales que formaban la estructura electoral elaborada por el Ministerio de la Gobernación y se publicaban en la prensa sin ningún tipo de reparo.
} 
En 1876, en una sociedad mayoritariamente rural como la española, con una tasa de analfabetismo elevadísima, resultaba muy difícil que los electores votaran en contra de lo que sus señores deseaban. No obstante, durante el reinado de Alfonso XIII las relaciones de «sumisión» ${ }^{54}$ dieron paso a las relaciones «clientelares» ${ }^{55}$. Las relaciones de favor ${ }^{56}$ solo se ejercían si se controlaba la Administración, ya que solo desde el poder podían dispensarse dádivas, como empleos públicos en ayuntamientos y diputaciones, recomendaciones de opositores y exclusiones del servicio militar o socorros de lactancia, estos últimos competencia de las diputaciones provinciales. El sistema funcionó durante la primera etapa de la Restauración hasta la subida al trono de Alfonso XIII, gracias a la conjunción de intereses entre el poder central, provincial y local, armonizando las aspiraciones del partido en el poder, el partido en la oposición, las diversas tendencias dentro de los partidos y las de los poderes locales. Esta realidad, que comportaba manipulación y fraude electoral por parte de los notables locales de los partidos dinásticos, no pasó desapercibida para los hombres de la Generación del 98 y su ideal regeneracionista, en especial para Joaquín $\operatorname{Costa}^{57}$, quien tildó al sistema de la Restauración de «caciquil y oligárquico», calificativos que han servido a la historiografía para estudiar este periodo.

\footnotetext{
${ }^{54}$ Los lectores votaban de acuerdo con los deseos de sus señores por respeto ancestral a una autoridad que se consideraba natural.

${ }^{55}$ Como cliente de un patrón, los electores, a cambio de sus votos, obtenían algún favor o beneficio. Vid.CANO GARCÍA, Juan Antonio, El poder político en Valladolid durante la Restauración. La figura de César Silio, Valladolid, Universidad de Valladolid, 1997.

${ }^{56}$ El favoritismo y el nepotismo se consideraban una obligación moral de los patronos políticos con sus clientes. Los sistemas políticos basados en el clientelismo y patronazgo no eran exclusivos de España y eran comunes también en Europa. El 23 de febrero de 1917, Lorenza Gutiérrez, vecina de Palencia, escribía una carta a Constancia Gamazo y Calvo, hermana de Germán Gamazo y esposa de Antonio Maura. En esta carta, Lorenza pedía ayuda a Constancia para «agilizar» en lo posible la concesión de un estanco a su yerno: «(...) me atrevo a molestar a $\mathrm{V}$, guardándola la mayor consideración, si es posible influya cuanto la sea posible, y para el efecto le remito copia de una solicitud satisfecha y elevada a el Sr. Director de la compañía arrendataria de Tabacos, gracia que no duda se conseguirá, se despide.» Archivo de la Fundación Antonio Maura. Caja 182/11.

${ }^{57}$ Vid. COSTA MARTíNEZ, Joaquín, Oligarquía y caciquismo como forma actual de gobierno en España: urgencia y modo de cambiarla, Madrid, Establecimiento Tipográfico de Fortanet, 1901.
} 
Los estudiosos de Ciencia Política consideran que, en las sociedades tradicionales, el fraude y la manipulación electoral constituyen un paso habitual en el camino hacia la consolidación de los Estados plenamente democráticos. Sin embargo, no puede extrapolarse la idea de partido político existente en la Restauración al significado actual del término. Los partidos políticos, en la práctica, se constituían como reuniones de amigos con objetivos e ideales políticos propios que esperaban obtener una respuesta favorable en el ámbito nacional, provincial y local ${ }^{58}$.

\section{El reinado de Alfonso XII (1874-1885)}

\section{4-1881, el Partido Conservador en el Gobierno}

El principio monárquico, esencial en el sistema político diseñado por Cánovas, se concretó en la figura de Alfonso XII ${ }^{59}$, figura central del entramado institucional de la Restauración que además de conceder legitimidad a la continuidad dinástica, a diferencia de su madre, podía concitar a su alrededor todo tipo de ideales políticos. La figura del joven monarca suscitaba grandes esperanzas en la sociedad española de la época. Los actos de celebración que con motivo del enlace matrimonial de Alfonso XII y María de las Mercedes de Orleans se programaron a lo largo de toda la nación, dan muestra de la aprobación al monarca.

${ }^{58}$ Cfr. CARR, Raymond, España: de la Restauración a la democracia, 1875-1980, Madrid, Ariel, 1983, p. 29.

${ }^{59}$ Hijo de Isabel II, siempre respetó el pacto de partidos y nunca nombró a un jefe de Gobierno según sus preferencias personales. Alfonso XII se ganó el respeto de amplios sectores de la sociedad como símbolo de la estabilidad del Régimen restauracionista. Murió el 25 de noviembre de 1885. 
La Diputación Provincial de Palencia por ejemplo, acordó un programa de actuaciones que incluía ${ }^{60}$ :

1. Reforma de la verja de entrada de las oficinas provinciales y del Estado para que pudiesen ser iluminadas.

2. Comida extraordinaria a los acogidos de los Establecimientos de Beneficencia.

3. Pagos con fondos provinciales de seis títulos de Bachiller en Artes a seis alumnos pobres de la provincia que obtuviesen en los ejercicios de reválida sobresaliente en el curso académico.

4. Pago de seis títulos de maestro superior y tres de maestro elemental, a alumnos pobres de la provincia que terminasen su carrera en el curso académico en la Escuela Normal y hubiesen obtenido la nota de sobresaliente en la reválida.

5. Igual para maestras que estudiasen en la Normal de Maestras en Valladolid.

6. Redimir la suerte de soldado a siete mozos, uno por cada Partido Judicial, que fuesen pobres y que hubiesen nacido el 23 de enero de 1878, fecha de la boda real.

Cánovas fue consciente de la necesidad de dotar al país de una Constitución que, a diferencia de las precedentes, contara con la mayor aceptación posible. La Constitución de 1876 sería la norma reguladora de la convivencia en la Restauración y permanecerá vigente, salvo en la etapa dictatorial de Primo de Rivera, hasta la proclamación de la II República, en el año 1931. Durante la redacción de las bases de la Constitución, en 1875, se puso de manifiesto esta preocupación por lograr el consenso, cuando Cánovas reunió a destacados personajes políticos de etapas anteriores y procedentes de diferentes tendencias ideológicas. El texto constitucional que se pactó mantenía la inviolabilidad y el carácter sagrado de la persona del rey (art.48), consagraba la existencia de unas Cortes bicamerales, formadas por Congreso y Senado y proclamaba un poder Legislativo compartido entre las Cortes y el rey (art.18). El poder Ejecutivo lo conformaban los ministros y el rey. Si en principio, Cánovas habló sólo de «grandes partidos políticos», sin determinar cuál sería su número ideal, acabará por establecer un modelo bipartidista, al más puro estilo británico. La aceptación de la Constitución de 1876 y del régimen monárquico por las fuerzas políticas del país, salvo los republicanos radicales de Ruiz Zorrilla de la izquierda, y de algún sector del carlismo de la derecha, supuso el comienzo de una etapa de tranquila convivencia entre los partidos.

\footnotetext{
${ }^{60}$ A.D.P.P., L.A.C.P. 46, 23-XII-1877.
} 


\section{1-1884, Sagasta y el Partido Liberal en el poder}

En el año 1881, se cumplían cinco años de la llegada de Cánovas a la presidencia de un Gobierno legitimado por medio de un proceso electoral. En el año 1881, Sagasta ${ }^{61}$, líder de los denominados fusionistas ${ }^{62}$, consideró conveniente el relevo en el Gobierno del Partido Conservador y solicitó la puesta en práctica del sistema turnista. Este hecho, además del desgaste padecido por los conservadores en el ejercicio del poder durante casi seis años, propició que el rey accediera a llamar a Sagasta para la formación de Gobierno. El traspaso de poder que se produjo puede ser considerado paradigmático, pues la victoria obtenida tras la celebración de unas elecciones democráticas no facilitaba el acceso al poder, más bien al contrario, ya que, conseguido el poder a través del pacto entre partidos, las Cortes fueron disueltas y se convocaron elecciones. En estos casos, la victoria quedaba garantizada y de este modo, el Gobierno de la nación quedaba legitimado. El Gobierno fusionista, en coherencia con su ideología liberal, comenzó a implementar una serie de actuaciones encaminadas a democratizar la vida pública, como el reconocimiento de derecho de reunión y opinión o la reforma legislativa en materia de libertad de expresión, que culminarían en julio de 1883 con la publicación de la Ley Española de Policía de Imprenta, dotada de un carácter mucho más abierto que la normativa anterior, que permitía una mayor libertad en el ejercicio de la docencia universitaria.

\footnotetext{
${ }^{61}$ El político riojano había evolucionado ideológicamente partiendo de posturas revolucionarias de juventud hacia un posibilismo político, lo que le permitía la admisión de un sistema en el que las elecciones eran sistemáticamente manipuladas. Falleció el día 5 de enero de 1903, en su residencia de Madrid.

${ }^{62}$ El Partido Fusionista surgió en mayo de 1880 de la fusión, de ahí su nombre, de los centralistas de Alonso Martínez con el Partido Constitucionalista de Sagasta.
} 
En el ámbito social, Moret ${ }^{63}$, ministro del gobierno de José Posada Herrera sucesor de Sagasta en la presidencia el Gobierno desde octubre de 1883, constituyó en diciembre de ese mismo año la Comisión de Reformas Sociales ${ }^{64}$, antecedente del Instituto de Reformas Sociales ${ }^{65}$, primer indicio del interés del Gobierno por la llamada cuestión social del mundo obrero.

Sagasta fue impulsor de una política exterior más activa que la emprendida por Cánovas, ${ }^{66}$ al defender la implicación del monarca en el desarrollo de las relaciones con las principales potencias europeas, no siempre con resultados satisfactorios como demuestra el telegrama de la Comisión Provincial dirigido al ministro de la Gobernación para manifestar al rey los sentimientos de adhesión de la provincia a la vista de lo sucedido en la capital francesa ${ }^{67}$.

\section{4-1885, el turno conservador}

Cánovas, de nuevo, formó Gobierno en enero de 1884 y se mantuvo en el poder hasta noviembre de 1885. Tras las elecciones municipales, celebradas en abril de 1885 , la coalición formada por liberales y republicanos, con el apoyo del Círculo de la Unión Mercantil y de los gremios, consiguió la victoria en ciudades como Barcelona, Madrid, Valencia y Valladolid. El resultado electoral supuso para el Partido Conservador y para el ministro de la Gobernación, Romero Robledo, un duro trance. Sin embargo, la forma de afrontar la epidemia de cólera de 1885, provocó una gran crisis en el Gobierno, además del distanciamiento personal entre Cánovas y Robledo ${ }^{68}$.

\footnotetext{
${ }^{63} \mathrm{Su}$ tesis doctoral había tratado sobre la armonía del capital y el trabajo.

${ }^{64}$ El Real Decreto de 5 de diciembre de 1883 contemplaba la creación de una Comisión con el fin de estudiar las cuestiones relacionadas con la mejora de las condiciones de vida de la clase obrera, obreros agrícolas e industriales. La iniciativa partió del ministro de la Gobernación de Posada Herrera, Segismundo Moret. Los diputados provinciales Marcelo Barrios y Manuel Rizo formaron parte de la Comisión Provincial de Reformas Sociales de Palencia. Vid. HERRERO PUYUELO, María Blanca, La Comisión de Reformas Sociales en Palencia (1884-1903), Ayuntamiento de Palencia, 1990.

${ }^{65}$ Organismo creado en 1903 por el Gobierno conservador de Francisco Silvela.

${ }^{66} \mathrm{La}$ acción exterior de Cánovas se había caracterizado por el recogimiento, colocando a España en una posición de neutralidad respecto de los principales asuntos que se ventilaban a nivel europeo.

${ }^{67}$ El 29 de septiembre de 1883, Alfonso XII llegó a París procedente del Imperio alemán, en medio de una gran hostilidad debido a los errores cometidos en su viaje a tierras germanas, donde había presidido desfiles y maniobras del Ejército prusiano, además de aceptar el grado de coronel del Regimiento 15 de los Ulanos, acuartelado en Estrasburgo, capital del recién constituido Reichsland de Alsacia-Lorena, territorio que había pasado a formar parte del Imperio alemán tras el enfrentamiento franco-prusiano de 1870, (Tratado de Fráncfort de 1871). A.D.P.P., L.A.C.P. 59, 2-X-1883.

${ }^{68}$ Vid. FERNÁNDEZ SANZ, Juan José, 1885: el año de la vacunación Ferrán. Trasfondo político, médico, sociodemográfico y económico de una epidemia, Madrid, Fundación Ramón Areces, 1990.
} 
La Dirección General de Beneficencia y Sanidad formaba parte de la estructura administrativa del Ministerio de la Gobernación y por tanto el Ministerio, dirigido por Romero Robledo, era competente para aplicar las medidas que fueran necesarias para atajar el avance imparable de la epidemia. La cuarentena, como medio principal para evitar la propagación del cólera, se mostró claramente ineficaz e insuficiente. Tal medida fue criticada desde diversos sectores sociales, desde los propios partidos políticos hasta la prensa, puesto que en Barcelona, el doctor español Ferrán creía haber descubierto la vacuna contra la enfermedad. La mala gestión de Romero Robledo contra la epidemia acabó con su cargo en el ministerio, provocando un duro enfrentamiento en el Partido Conservador, entre los partidarios del antequerano, que representaban un número no desdeñable dentro del conservadurismo español, y los partidarios de Cánovas ${ }^{69}$. Dadas las circunstancias, los conservadores fueron tomando conciencia de la imposibilidad de mantener en su poder la jefatura del Gobierno. La muerte de Alfonso XII, el 25 de noviembre de 1885, precipitó los acontecimientos y Cánovas, dando muestras de un gran sentido de responsabilidad y en su condición de hombre de Estado, llevó a cabo el traspaso de poderes a Sagasta, (Pacto de El Pardo), dando lugar al turnismo que el propio político ideara.

\section{La Regencia de María Cristina (1885-1902)}

Tras el fallecimiento del rey Alfonso XII, María Cristina de HabsburgoLorena $^{70}$, su viuda, accedió a la Regencia del Estado hasta la coronación de su hijo Alfonso XIII, el 17 de mayo de 1902. Durante los diecisiete años que permaneció en la Regencia, las condiciones resultantes del pacto de la Restauración de 1876, determinaron la existencia de una etapa de continuidad, Sin embargo, los problemas derivados de la crisis económica, la conflictividad social derivada, la aparición del nacionalismo, la inestabilidad política creciente y la pérdida del potencial colonial de España, provocarán el sentimiento de necesidad de una profunda regeneración de la vida nacional.

\footnotetext{
${ }^{69}$ Vid. PAREDES ALONSO, Javier (Coordinación), Historia Contemporánea de España. Siglo XIX, Madrid, Ariel, 2009.

${ }^{70}$ La joven regente austriaca, cargó con el peso del recuerdo de la primera esposa de Alfonso XII, María de las Mercedes, muy querida por el pueblo. Sin experiencia política, fue una excelente regente y mantuvo con respeto el orden constitucional. Estableció buena relación con Sagasta, lo que contribuyó a la consolidación del régimen político en una etapa delicada.
} 
Durante este periodo no se produjeron cambios en el sistema turnista y Cánovas y Sagasta continuaron liderando a conservadores y liberales, respectivamente. A partir de 1890, y como consecuencia de la evidente inestabilidad política, los turnos de Gobierno se redujeron, sin permanencia superior a los tres años. Algunos sectores sociales vieron con inquietud el nacimiento de un movimiento obrero de signo socialista y anarquista, que fruto del desarrollo del capitalismo, surgió tanto en el mundo urbano como en el campo.

La pérdida de las últimas posesiones ultramarinas provocó en los políticos dinásticos la incapacidad para elaborar un discurso de unidad basado en una identidad histórica común y, como consecuencia, surgieron los nacionalismos en Cataluña y en el País Vasco. Esta realidad precipitó la inestabilidad de la sociedad española de comienzos del siglo XX. A finales del siglo XIX, los nacionalismos habían nacido como respuesta al afán uniformador del Estado liberal, especialmente en Cataluña y en el País Vasco. Los movimientos regionalistas, defensores de los particularismos regionales con cierto cariz folklórico, fueron transformándose en partidos políticos que ponían en duda la estructura de un Estado liberal centralista. Los problemas comenzaron a exceder al ámbito de la política doméstica y en el ámbito de las relaciones internacionales, la derrota sufrida ante Estados Unidos en el año 1898, hizo que se tambalearan los fundamentos culturales e intelectuales imperantes en la sociedad. El revisionismo histórico abogaba por encontrar soluciones al atraso y a la crisis de la España finisecular. Los intelectuales de la Generación del 98 acertaron en el diagnóstico de la enfermedad de España, aunque no aportaron las soluciones que necesitaba una España en decadencia política, militar, social y económica. 


\section{5-1890, el liberalismo de nuevo en el Gobierno}

La templanza de la regente, la moderación de Sagasta y la acertada actuación de Cánovas, contribuyeron a que la transición, desde el reinado de Alfonso XII hasta la Regencia de María Cristina, se llevara a cabo de modo tranquilo con el único temor del regreso de la reina Isabel II. La regente intervino poco en política, prefiriendo que fueran los políticos quienes ejercieran sus funciones, respetando el papel que la Constitución de 1876 le había reservado. Esta pacífica transición permitió que el sistema turnista de la Restauración confirmase su validez, ya que a partir de la crisis del 98 se cuestionó todo aquello que, durante casi veinticinco años, había regido la vida de la sociedad española. Los liberales llegaron al poder en junio de 1885, las facciones del partido se habían puesto de acuerdo, lo cual les proporcionaba una imagen de fortaleza frente a los conservadores. Con el nombre de Partido Liberal, reconocieron la jefatura de Sagasta.

\section{La década de los noventa, los gobiernos efímeros}

La unión interna del Partido Liberal, que había logrado Sagasta, se desvaneció al inicio de la década de los años noventa y el líder liberal, como había ocurrido con Cánovas, se vio obligado al abandono del poder en julio de 1890. Los cambios rápidos y continuos de Gobierno, fueron característicos de esta época. Cada dos años, los dos principales partidos se sucedieron en el poder, Cánovas en julio de 1890, Sagasta en diciembre de 1892, de nuevo Cánovas en marzo de 1895 y, como consecuencia del asesinato del político malagueño en agosto de 1897, el general Azcárraga, quien cedió el poder al nuevo Gobierno de Sagasta en octubre de 1897, tras un breve paréntesis en la presidencia del Consejo de Ministros. Tras el desastre del 98, en marzo de 1899, los conservadores, de nuevo, llegaron con Silvela al Gobierno. En el año 1900 Azcárraga volvió a la Presidencia del Consejo, hasta marzo de 1901, cediendo el paso al último Gobierno de la Regencia, presidido por Sagasta. 


\section{0-1892, el Gobierno conservador}

Tras la etapa liberal, en 1890 los conservadores regresaron al poder y, contra todo pronóstico, respetaron todo lo que los liberales habían adoptado en materia de reformas políticas, lo que permitió la consolidación de la Restauración como sistema político, además de la modernización de la nación. Cánovas siempre fue consciente de la urgente necesidad de resolver el problema obrero mediante la intervención estatal en cuestiones de orden social. En coherencia con su pensamiento político, se intentaron regular las condiciones laborales, mejorando las condiciones de vida y protegiendo los derechos de los trabajadores. Esta nueva tendencia del liberalismo no era exclusiva de España, pues otros gobiernos de diferente signo político habían implementado políticas semejantes en los países europeos de nuestro entorno.

En materia económica, Cánovas puso en práctica una política proteccionista, consistente en la aprobación de un arancel que primaba la producción nacional en 1891, y que dio al traste con las franquicias de la Ley de 1882. La medida fue acogida de buen grado por los agricultores y también por los industriales por lo que, al final de la década de los años 80 y fruto de la crisis de 1887-1888, Europa implementó medidas de carácter proteccionista a fin de defender las economías nacionales de la competencia exterior. Cánovas pretendió proteger así la débil economía española de la competencia exterior. La Diputación Provincial palentina fue una firme partidaria del proteccionismo en materia económica y en la defensa del sector agrario castellano y figuró siempre a la cabeza de las reivindicaciones sobre el establecimiento de barreras arancelarias para el cereal extranjero.

En noviembre de 1891, Romero Robledo, apoyado por Cánovas, entró a formar parte del Gobierno como ministro de Ultramar. Este hecho provocó una crisis interna en el Partido Conservador ${ }^{71}$ y Francisco Silvela, comprobando el apoyo de Cánovas a su antiguo amigo, abandonó el Ministerio de Gobernación y, más tarde, la formación conservadora $^{72}$.

\footnotetext{
${ }^{71}$ Silvela y Romero Robledo mantenían una concepción de la ética política tan opuesta que la presencia de ambos en el mismo gobierno era impensable. Silvela defendía la legalidad y la educación de los españoles como camino hacia el desarrollo de la nación. Romero Robledo, político eminentemente pragmático, fue partidario de todo lo que le permitiese alcanzar sus objetivos electorales, intentando favorecer a sus partidarios para mantener los apoyos necesarios y lograr sus objetivos.

${ }^{72}$ En diciembre de 1892, tras una encendida discusión parlamentaria con Cánovas, Silvela abandonó el Partido Conservador.
} 


\section{2-1895, el turno liberal}

El Partido Liberal regresó al poder en el año 1892. Sagasta, durante esta etapa, intentó llevar a buen fin una serie de reformas ${ }^{73}$ con la intención de lograr la ansiada modernización de España y su incorporación a los países más avanzados de Europa. Este espíritu reformador encontró una fuerte resistencia en los sectores más conservadores de la sociedad finisecular española y, como consecuencia, las reformas emprendidas no vieron satisfechos sus objetivos. Este fracaso provocó la caída del Ejecutivo en marzo de 1895 y el final de la etapa liberal de Gobierno.

Sagasta intentó unificar las distintas facciones existentes en el seno del Partido Liberal otorgándolas representación en sus gobiernos. Tras el fracaso del intento reformista de esta etapa, nacieron voces disidentes de diferente signo ideológico. Antonio Maura, intentó un acercamiento al Partido Conservador y después de su fracaso reformista en Ultramar, José Canalejas tomó el relevo en el liderazgo del Partido. En esa época, la situación socioeconómica de la provincia de Palencia era calamitosa. En abril de 1896, una Comisión ${ }^{74}$ del Ayuntamiento de Palencia se presentó en la sede de la Diputación Provincial palentina con el objetivo de solicitar el apoyo de la institución provincial para afrontar la crisis obrera provocada por la sequía que venía afectando a la provincia.

Varios diputados provinciales, Calderón Rojo, Medina Cuadros y Pastor Ovejero, propusieron que se concediese por la Diputación Provincial 1.000 pts. en bonos de la tienda asilo a las familias más desfavorecidas. Se decidió elegir una Comisión Especial para que determinase sobre dicha proposición y esta Comisión dictaminó que no era posible conceder la ayuda porque los efectos de la sequía afectaban a todos los pueblos de la provincia. ${ }^{75}$

\footnotetext{
${ }^{73}$ Germán Gamazo ocupó la cartera de Hacienda y adoptó una nueva política arancelaria, Antonio Maura desde el Ministerio de Ultramar impulsó importantes reformas en las Colonias y Segismundo Moret apoyó una serie de reformas sociales desde el Ministerio de Fomento.

${ }^{74}$ Comisión formada por el alcalde, los tenientes de alcalde y varios concejales, que presentaron su petición de auxilio ante la inexistencia en las arcas municipales de fondos para hacer frente a las peticiones de los jornaleros faltos de trabajo. No solo se solicitó ayuda a la Diputación Provincial, también al Obispado de la Diócesis de Palencia, al delegado de Hacienda y a los diputados en Cortes y senadores por la provincia. Archivo Municipal del Ayuntamiento de Palencia (A.M.A.P.), Libro de Actas de Pleno del Ayuntamiento (L.A.P.A), A-21-106, 23-IV-1889.

${ }^{75}$ A.D.P.P., Libro de Actas del Pleno de la Diputación (L.A.P.D.) 70, 24-IV-1896.
} 


\section{Crisis sistémica, el 98}

En 1898, durante el transcurso de la guerra con los Estados Unidos, España perdió sus últimas posesiones en el Caribe y en el Océano Pacífico ${ }^{76}$. La maquinaria bélica de una potencia como Estados Unidos no podía ser contrarrestada con el Ejército de un país tan poco industrializado como España. La equivocada política adoptada por los diferentes gobiernos españoles en relación a sus posesiones ultramarinas, incapaces de dar solución a las tensiones nacionalistas, junto con el afán expansionista de los Estados Unidos, en un contexto internacional caracterizado por la competencia por los territorios coloniales, fueron las razones que condujeron a España a una guerra imposible de ganar.

Los partidos dinásticos, conscientes de la superioridad bélica de los Estados Unidos, consideraban que la guerra ${ }^{77}$ era la única solución digna para España y optaron por perder las colonias en un enfrentamiento bélico antes que ceder de forma pactada poniendo en entredicho al sistema político y a la propia institución monárquica. La Diputación Provincial de Palencia apoyó la participación de los soldados palentinos en el conflicto cubano de diversas formas, desde el respaldo económico a los soldados y sus familias, hasta el reconocimiento público.

En noviembre de 1895, la Diputación Provincial recibía el agradecimiento del comandante en jefe de la Región Militar ${ }^{78}$ por las atenciones dispensadas al batallón expedicionario de Toledo ${ }^{79}$ en su tránsito hacia Cuba. Ese mismo año, el vicepresidente de la institución provincial anticipaba de su sueldo, posteriormente se le reintegraría por la Diputación, 180 pts. para los soldados palentinos del Regimiento Farnesio que «(...) marchaban a Cuba a defender la integridad de la patria.» ${ }^{80}$

\footnotetext{
${ }^{76}$ Vid. GIRÓN GARROTE, José, (Coordinación.), Un cambio de siglo 1898. España, Cuba, Puerto Rico, Filipinas y Estado Unidos, Oviedo, Universidad de Oviedo, 2008.

${ }^{77} \mathrm{La}$ guerra con Estados Unidos por el problema cubano constituía una cuestión candente en la sociedad española de 1898 y tal era la certeza de que era inevitable, que poco antes del estallido del conflicto, la Diputación Provincial donaba 25.000 pts. al Gobierno para atender el fomento de la Marina de Guerra. El dinero provenía de la cesión de un día de haberes de los empleados de Secretaría, Contaduría, Depositaría y Construcciones Civiles y Carreteras. A.D.P.P., L.A.C.P. 86, 15-IV-1898.

${ }_{78}^{78}$ A.D.P.P., L.A.C.P. 83, 29-XI-1895.

${ }^{79}$ Este batallón quedó aislado en Guantánamo y resistió varios días después de haberse firmado las capitulaciones en la Habana.

${ }^{80}$ A.D.P.P., L.A.C.P. 83, 29-XI-1895.
} 
En 1897, el diputado provincial García Crespo, conservador, presentaba una moción $^{81}$ para que se felicitase a la reina por la paz de Filipinas. Su compañero de Corporación, Jubete Tejerina, gamacista, no aceptaba la moción en los términos en los que se hallaba redactada y precisaba que lo mejor sería abstenerse de felicitaciones y que, en el caso de existir, estas debían referirse a la patria, «(...) que es la que da la sangre y el dinero, y en nombre de ella al jefe del Gobierno». El vicepresidente de la Comisión Provincial mostró su acuerdo con Jubete Tejerina, sin embargo, García Crespo insistía en que no debía «(...) suprimirse un solo concepto de su moción», y se aceptaba esta moción por mayoría, discrepando el vicepresidente y Jubete Tejerina ${ }^{82}$.

La derrota sirvió para revisar la situación política, social y económica de España. Ese año se manifestaron las mujeres de los obreros de Palencia pidiendo pan y trabajo, mientras el gobernador de la provincia señalaba que estas protestas no estaban incitadas por las ideas comunistas, dado que en Castilla imperaban los principios del cristianismo sobre cualquier otra ideología y el pueblo castellano sabía que el problema social lo había resuelto León XIII con su encíclica Rerum Novarum. Los diputados provinciales Abilio Calderón Rojo, Jubete Tejerina y Junco Rodríguez proponían que la Diputación Provincial levantase la prohibición establecida en la Base $14^{83}$ para la subvención de obras municipales. La propuesta fue aprobada por catorce votos a favor y dos en contra $^{84}$. Votaron a favor: Calderón Rojo, Rodríguez Blanco, Herrero Abia, Polanco Aguado, Herreros Harlucea, Alonso Villazán, Junco Rodríguez, Gutiérrez Comillas, Varona Gutiérrez, Polanco y Polanco, Jubete Tejerina, Pérez Juárez, Velasco y Quintana, y el presidente Guijelmo Aguado, gamacistas, en contra: Gómez Inguanzo y García Crespo, conservadores.

\footnotetext{
${ }^{81}$ A.D.P.P, L.A.C.P. $85,23-X I I-1897$.

${ }^{82}$ A.D.P.P, L.A.C.P. 85,23 -XII-1897.

${ }^{83}$ Bases aprobadas el 14 de noviembre de 1896. La Base 14 subvencionaba con un $4 \%$ las expropiaciones para realizar obras públicas. Tras la reforma de la Base 14, se concedía el $30 \%$ de subvención del valor de las expropiaciones, en ningún caso podía exceder de 10.000 pts. en cada ejercicio económico. A.D.P.P., L.A.P.D. 86, 10-II-1898.

${ }^{84}$ A.D.P.P., L.A.P.D. 86, 11-II-1898.
} 
La situación del momento sirvió para plantearse el papel del Ejército, la organización del Estado, la política exterior, la solución a la complicada situación económica, etc. Todos estos planteamientos provocaron el surgimiento de un movimiento regeneracionista que pretendía dar un impulso renovador a la sociedad española de finales del siglo XIX, mediante la puesta de manifiesto de los problemas y sus posibles soluciones para convertir a España en un país avanzado y moderno. Incluso, llegó a plantearse la existencia misma de las diputaciones provinciales, a las que se acusaba de formar parte del entramado institucional que había arrastrado a la nación a la situación en la que se encontraba.

Ante la amenaza de la eliminación de las diputaciones provinciales como entidad de la Administración Local, la Comisión Provincial de la Diputación palentina publicaba los presupuestos provinciales desde el año económico de 1878-79 al corriente de 1898-99, «(...) para que el Poder Central, el público y los que han elegido a las diferentes diputaciones que desde 1878 han venido administrando los intereses provinciales, pronuncien el veredicto que estimen pertinente. ${ }^{85}{ }^{85} \mathrm{La}$ Comisión Provincial defendía el papel institucional de las diputaciones ante las críticas vertidas contra ellas y su gestión. Justificaba su validez desde varias posiciones, como la existencia de estas instituciones en otros países, desde Prusia hasta Uruguay, pero, en opinión de la Comisión Provincial, a diferencia de otros países, en España se culpaba de los males de la Administración a las diputaciones ${ }^{86}$. En España, decía la Diputación palentina,

«(...) se piensa y discurre de otra manera, y por todas partes saltan leguleyos y rágulas, especialistas y curanderos que atribuyendo los desastres sufridos y cuantos males aflijan a la Nación, a los mentados organismos, piden a voz en grito al Poder Central, la desaparición inmediata de las envejecidas y herrumbrosas diputaciones.» ${ }^{87}$

La Comisión Provincial justificaba la existencia de las diputaciones,

«(...) que no paguen justos por pecadores, (...) empezaríamos por sentar el principio cierto y evidente de que la existencia de abusos en las diferentes entidades y personas jurídicas no entraña la desaparición de todo lo existente, principio a todas luces anárquico, subversivo y destructor, porque en el orden legal, como en el físico, todo lo que existe es necesariamente limitado.. ${ }^{88}$

\footnotetext{
${ }^{85}$ A.D.P.P., Memoria Año Económico Primer Semestre 1898-1899, C-R / 1,15, p. 38. Véase Anexo II. Presupuesto Provincial en pts. por capítulos 1878-1899, p. 470.

${ }^{86}$ A.D.P.P., Memoria Año Económico Primer Semestre 1898-1899, C-R / 1,15.

${ }^{87}$ A.D.P.P., Memoria Año Económico Primer Semestre 1898-1899, C-R / 1,15, p. 35.

${ }^{88}$ A.D.P.P., Memoria Año Económico Primer Semestre 1898-1899, C-R / 1,15, p. 36.
} 
Como ejemplos de mal funcionamiento de otras instituciones, se ponía de manifiesto la situación en el campo judicial, con la existencia de magistrados y jueces prevaricadores, $«(\ldots)$ dispuestos a colocar la toga a los pies de los que mandan, para llegar en doce años desde un juzgado de entrada al Tribunal Supremo», en el ámbito parlamentario «(...) ni las Cortes, por los abusos del parlamentarismo y porque haya diputados serviles que vendan el voto por un empleo.» ${ }^{89}$, e incluso en el ámbito privado, «(...) ni las empresas, porque nombren consejeros con grandes sueldos a los ministros y políticos importantes.» ${ }^{90}$

Sin embargo, esta esperanza renovadora no introdujo cambios en el sistema político instaurado desde la coronación de Alfonso XII. La Constitución de 1876 se mantenía vigente, los partidos políticos continuaron turnándose en el poder y la Monarquía contaba con la aceptación de la mayor parte de la sociedad. Esta situación inamovible fortalecía la idea de los partidos dinásticos de considerar que una derrota en la guerra no ocasionaría consecuencias demasiado graves para el sistema de la Restauración. Ni siquiera la economía se vio muy quebrantada, pues para los intereses de los sectores más afectados ${ }^{91}$, resultaba más conveniente una solución rápida del conflicto que un enfrentamiento que se prolongase en el tiempo. Estos sectores aspiraban a la negociación del Gobierno de los derechos de entrada de los productos españoles, sin pensar en quién fuera el administrador político.

\footnotetext{
${ }^{89}$ A.D.P.P., Memoria Año Económico Primer Semestre 1898-1899, C-R / 1,15, p. 36.

${ }^{90}$ A.D.P.P., Memoria Año Económico Primer Semestre 1898-1899, C-R / 1,15, p. 37.

${ }^{91}$ Textiles catalanes, cerealistas castellanos y siderúrgicos vascos.
} 


\section{9-1902, los gobiernos conservadores y liberales}

En 1899, al desgaste producido tras la pérdida de las últimas colonias se sumó la disidencia de Germán Gamazo, lo que conllevó la renuncia de Sagasta ${ }^{92}$ a continuar en el Gobierno. Silvela ${ }^{93}$ de nuevo al frente de los conservadores y les condujo al poder en 1899, proponiéndose dotar a la vida pública de una moral nueva, suprimir el peligro de un posible pronunciamiento militar, reformar la economía y lograr la implicación de los partidos nacionalistas en la política estatal. Para afrontar el reto que suponía dotar a España de una administración moderna, el Gobierno Silvela se vio obligado a implantar un nuevo impuesto, el Impuesto de Utilidades, que gravaba, sobre las demás, a las clases medias y a la burguesía. La oposición de la Unión Nacional de Productores a las medidas adoptadas por Silvela dejó muy tocado al Gobierno, pero la razón que acabó por desalojar al Partido Conservador del poder fue el nombramiento del general Weyler como capitán general de Madrid. En octubre de 1900, Silvela dimitió y el general Azcárraga $^{94}$ le sucedió por un breve espacio de tiempo. En marzo de 1901, Sagasta regresó por última vez al Gobierno, fue este, también, el último Gobierno de la Regencia.

Durante esta etapa, se vivieron momentos de gran convulsión social, con numerosas huelgas ${ }^{95}$ y enfrentamientos, que llegaron a su culmen con la huelga general de febrero de 1902. El día 7 de mayo de 1902, Alfonso XIII ${ }^{96}$ cumplió 16 años, desde ese día, y tras jurar la Constitución de 1876, asumió la totalidad de las funciones que la Carta Magna le asignaba. Comenzaba, así, una nueva etapa de la Restauración, que tras el interludio de la Dictadura primorriverista, se cerraría en abril de 1931 con la caída de la Monarquía y el final de la Restauración como sistema político.

\footnotetext{
${ }^{92}$ Sagasta regresó al Gobierno tras la derrota contra Estados Unidos, dos años después.

${ }^{93}$ Vid. TUSELL GÓMEZ, Javier, MONTERO GRACÍA, Feliciano y MARÍN ARCE, José María (Coordinación.), Las derechas en la España contemporánea, Madrid, UNED, 1997, pp. 45-58.

${ }^{94}$ Azcárraga había participado en la expedición de Prim en Méjico en 1862. Fue un convencido defensor de la restauración borbónica, por lo que apoyó sin reservas a Alfonso XII alcanzando el grado de teniente general en la coronación del monarca.

${ }^{95}$ El 29 de julio de 1902, los obreros de la fábrica palentina Cemento Hidráulico fueron a la huelga en protesta por el excesivo número de horas de trabajo y los trabajadores, que pertenecían a la Agrupación Socialista de Albañiles, reclamaban una jornada laboral de 10 horas. El Día de Palencia, 30-VII-1902. Por el mismo motivo se declararon en huelga los trabajadores de la Tejería Mecánica el 14 de mayo de 1906. El Día de Palencia, 15-V-1906.

${ }^{96}$ Vid. TUSELL GÓMEZ, Javier, GARCÍA QUEIPO DE LLANO, Genoveva, Alfonso XIII: el rey polémico, Madrid, Taurus Ediciones, 2001.
} 


\section{Alfonso XIII (1902-1923)}

Hasta que en 1923 se instaurara la Dictadura de Primo de Rivera, el sistema político que en 1876 introdujo Cánovas se mantuvo estable en lo fundamental. No obstante, durante esos cuarenta y siete años se produjeron desarreglos en su funcionamiento que provocaron una profunda crisis sistémica que buscó la solución en el autoritarismo de Primo de Rivera ${ }^{97}$. La fragmentación de los partidos dinásticos en diversas facciones persiguiendo el poder en la jefatura del partido, la merma de poder del Estado frente al poder provincial y local, la injerencia del rey en la política ${ }^{98}$ y la concienciación política del electorado, fueron factores de las causas que contribuyeron a debilitar los cimientos de este sistema hasta dañarlo de tal forma que resultó imposible su funcionamiento.

\section{«La revolución desde arriba» de Maura}

En 1902, Antonio Maura ${ }^{99}$ abandonó el Partido Liberal y se unió al Partido Conservador, en el que no tardó en imponer su autoridad. En el año 1903, Maura se había convertido en el jefe del Partido y del Gobierno. Maura defendía la vigencia del sistema canovista, pero estaba convencido de la necesidad de aplicar reformas para corregir los graves defectos que, en su opinión, aquejaban su funcionamiento. El político mallorquín creía que el defecto más grave que afectaba a la sociedad era la desafección política, consecuencia del elevado grado de pasividad ciudadana. La perversión del sistema electoral era tan considerable que desincentivaba la iniciativa ciudadana en favor de un voto predecible. Maura consideraba que desde el poder podría promover la movilización social que legitimaría el sistema y activaría la participación ciudadana. Para conseguir este objetivo, bastaría con moralizar la vida pública y lograr que las instituciones fueran para la ciudadanía ejemplo de honestidad.

\footnotetext{
${ }^{97}$ Vid. AVILÉS FARRÉ, Juan, ELIZALDE PÉREZ GRUESO, María Dolores, y SUEIRO SEOANE, Susana, Historia política. 1875-1939., Madrid, ISTMO, 2002.

${ }^{98} \mathrm{La}$ fragmentación de los partidos dinásticos en facciones rivales dificultó la labor de Gobierno y el rey fue adquiriendo protagonismo político amparado por la Constitución de 1876 que contemplaba la soberanía compartida con las Cortes.

${ }^{99}$ Vid. TUSELL GÓMEZ, Javier, Antonio Maura: Una biografia política, Madrid, Alianza Editorial, 1994. Presidente del Consejo de Ministros en cinco ocasiones durante el reinado de Alfonso XIII.
} 
Estas medidas devolverían al ciudadano su confianza en el juego político. Maura, denunciaba la práctica del caciquismo tanto como Costa, aunque no fue nunca partidario de adoptar medidas extraordinarias ${ }^{100}$ para su eliminación. En las elecciones generales que se celebraron en 1903, las primeras del reinado de Alfonso XIII, Maura se negó a la utilización del Ministerio de la Gobernación para conseguir influir sobre el resultado. Esta circunstancia favoreció el que los republicanos obtuviesen resultados muy positivos en un buen número de las ciudades con mayor población, incluidas Madrid y Barcelona. A tenor de lo sucedido en estas elecciones podría concluirse que la democracia y el sistema de la Restauración resultaban incompatibles.

La evolución que Maura proponía pasaba desde un régimen de notables hacia uno más democrático, lo que parecía imposible sin acabar con el propio sistema. Sin embargo, con los ajustes y medidas necesarias, sería suficiente. Maura partía del convencimiento de que solo con el estricto cumplimiento de las leyes y el respeto institucional podría salvarse el marco político de la Restauración, por lo que en diciembre de 1904, cuando el rey Alfonso XIII impuso su candidato para la Jefatura del Estado Mayor Central del Ejército, en contra del propuesto por el ministro de la Guerra, Maura dimitió ${ }^{101}$ como jefe del Gobierno.

\section{José Canalejas y el liberalismo democrático}

Tras la muerte de Sagasta en 1903, el Partido Liberal inauguró una serie de luchas internas por el liderazgo. Las diferentes facciones enfrentadas pretendían la imposición de su ideario y la cohesión del Partido bajo su jefatura. Transcurridos tres años de Gobierno conservador, entre los años 1902 y 1905, cuando los liberales accedieron al poder, los cambios de Gobierno se multiplicaron. En dos años, desde 1905 a 1907, se sucedieron seis gabinetes y esta inestabilidad provocó que la acción de Gobierno fuera ineficaz. En este ambiente de enfrentamiento e inestabilidad dentro del Partido Liberal, surgió la figura política de José Canalejas ${ }^{102}$.

\footnotetext{
${ }^{100}$ Costa apelaba a un «cirujano de hierro» para transformar el corrupto sistema político en el que había degenerado el sistema turnista.

${ }^{101}$ Maura reprochaba al monarca sus continuas injerencias en política, a pesar de que la Constitución confería al rey la potestad de nombrar a los altos cargos militares. Maura pretendía reducir el poder del rey, convirtiendo su figura en la de un monarca parlamentario al estilo de la Monarquía británica.

${ }^{102}$ Vid. FORNER MUÑOZ, Salvador, Canalejas y el Partido Liberal Democrático (1900-1910), Madrid, Cátedra, 1993. Entre los años 1900 y 1910, el político liberal fue consolidando sus propuestas programáticas e ideológicas acerca del nuevo modelo de liberalismo que con un marcado carácter democrático y social se estaba fraguando en Europa.
} 
El político gallego creía necesario aumentar el poder y las prerrogativas del rey, al que consideraba elemento imprescindible para conseguir el impulso y la regeneración de la vida pública española, justo al contrario que Maura. Canalejas consideraba imposible la regeneración política defendida por Maura sin contar con una previa regeneración social y cultural. Defensor del liberalismo social que se imponía en el entorno europeo, proponía la intervención social del Estado como modo de compensar los desequilibrios causados por el sistema político económico, mediante una legislación que defendiera los derechos de las clases sociales más pobres, la clase obrera ${ }^{103}$.

Esta política social perseguía la protección de un sistema político que podía ponerse en riesgo por la exclusión de importantes sectores sociales, sobre todo el obrero. En materia económica, los liberales abandonaron su clásica política librecambista ${ }^{104}$ y en 1906, el Gobierno Moret ${ }^{105}$ aprobó el Arancel Industrializador Salvador ${ }^{106}$, un arancel proteccionista que beneficiaba a la industria catalana. Los continuos conflictos surgidos entre las facciones existentes en el Partido Liberal, canalejistas, moretistas y monteristas, impidieron a los liberales imponer su poder a la Iglesia y el Ejército ${ }^{107}$, asuntos de máximo interés en la etapa liberal de Gobierno entre los años 1905-1907. Este debilitamiento del poder civil con respecto al militar trajo como consecuencia la aprobación de la controvertida Ley de Jurisdicciones por el Gobierno Moret, que incluía en su articulado el enjuiciamiento de las ofensas cometidas por medio de la imprenta contra el Ejército por la jurisdicción militar. El catalanismo, fue afianzando su poder sobre los partidos dinásticos en Cataluña a consecuencia del desprestigio del turnismo e incluso de la figura del rey.

\footnotetext{
${ }^{103}$ Eduardo Dato, representante del reformismo social católico en el Partido Conservador, durante el Gobierno de Silvela, en el tránsito de un siglo a otro, había elaborado leyes laborales que de manera tímida trataban de salvaguardar los derechos de los más débiles, como la Ley de Accidentes de Trabajo (1900).

${ }^{104}$ Las protestas de importantes sectores de la estructura económica nacional, como el cerealista castellano y el textil catalán, contra la política de aranceles del Gobierno provocaron que conservadores y liberales adoptaran políticas proteccionistas a favor de la producción nacional.

${ }^{105}$ Vid. FERRERA CUESTA, José Carlos, La frontera democrática del liberalismo: Segismundo Moret (1838-1913), Madrid, Biblioteca Nueva, 2002. Tras Sagasta, Moret no tuvo éxito en su lucha con Montero Ríos por el liderazgo del Partido Liberal. Decretó la autonomía de Cuba y Puerto Rico mientras fue ministro de Ultramar y colaboró en la creación del Instituto de Reformas Sociales en 1902. Presidió el Consejo de Ministros en tres ocasiones bajo el reinado de Alfonso XIII.

${ }^{106}$ Cfr. VELARDE FUERTES, Juan, Cien años de economía española, Madrid, Encuentro, 2009, p. 67.

${ }^{107} \mathrm{El}$ incidente del $\mathrm{Cu}$-Cut! constituía una señal inequívoca de la intromisión del Ejército en el campo de la política y del sometimiento del poder civil al militar. El incidente tuvo lugar cuando algunos oficiales del Ejército asaltaron la redacción del periódico satírico catalán como reacción a la publicación de una viñeta injuriosa, en su opinión, para el estamento militar.
} 


\section{7-1909, Maura regresa al Gobierno}

El 1lamado «gobierno largo de Maura» representó un paréntesis de estabilidad en el reinado de Alfonso XIII. Maura llegó a la presidencia del Gobierno dispuesto a poner en práctica su programa regeneracionista, la famosa «revolución desde arriba». La reforma de la Administración Local ${ }^{108}$ fue su proyecto político más destacado. El político conservador, convencido de la necesidad de eliminar el caciquismo, al que consideraba causa del desprestigio del sistema turnista de Cánovas, consideró que la descentralización constituía la mejor vía para alcanzar su objetivo.

El centralismo podía ser considerado como el mejor soporte para el sistema caciquil por lo que urgía sustituir el modelo de organización administrativa y redireccionar el sistema de la Restauración que defendía. Después de tres años de discusiones parlamentarias, el proyecto estrella del maurismo encontró el rechazo de los liberales, e incluso de un sector del Partido Conservador. Maura logró, sin embargo, que en 1907 fuera aprobada la Ley de Reforma Electoral ${ }^{109}$ con la pretensión de erradicar las prácticas fraudulentas ${ }^{110}$ de los procesos electorales. La Ley, aunque intentó eliminar cualquier posibilidad de influencia caciquil en las elecciones, no consiguió su objetivo, e incluso puede afirmarse que el poder de los caciques sobre los electores aumentó ${ }^{111}$. A pesar de su aire renovador, la Ley Electoral de 1907 no ponía en peligro el predominio de los partidos dinásticos y entorpecía la posibilidad de triunfo de los partidos que se encontraban al margen del sistema turnista, sobre todo de republicanos ${ }^{112}$ y socialistas.

\footnotetext{
${ }^{108}$ Incluía medidas modernizadoras de la Administración Local, como la elección de las diputaciones provinciales por los ayuntamientos o la posibilidad de crear Mancomunidades locales y provinciales.

${ }^{109}$ Dotaba de configuración automática a las mesas electorales y a las Juntas del Censo, y declaraba obligatorio el voto.

${ }^{110}$ En las elecciones municipales del Ayuntamiento de Dueñas del año 1911, varios candidatos protestaron ante la Comisión Provincial por la compra de votos, por los que se llegaban a pagar ente cuatro y ocho duros, y por la coacciones y amenazas a los electores por parte de la autoridad local para que votasen a favor de una determinada candidatura. A.D.P.P., L.A.C.P. 115, 6-XII-1911.

${ }^{111}$ El art. 29 de la Ley de Reforma Electoral de 1907 disponía que los escaños electorales que solo contasen con un candidato serían adjudicados directamente, pues se pretendía evitar una lucha inexistente por la elección. El resultado fue que la presión caciquil se trasladó del acto de la elección al de proclamación de los candidatos.

${ }^{112}$ La oligarquía política alarmada ante el éxito electoral de los republicanos en las elecciones de 1903, logrado gracias al propósito de Maura de conseguir la celebración de unas elecciones «limpias», se negaba a ceder más poder a los republicanos.
} 
Como político conservador social, Maura partía del convencimiento de que la celebración de unas elecciones limpias en una sociedad conservadora, como la española, asegurarían una mayoría conservadora permanente, dando fin al sistema turnista e impidiendo que el Partido Liberal accediera al poder. A su juicio, el Partido Liberal carecía de respaldo social y solo mediante el fraude y la corrupción podía mantener las cotas de poder. En el ámbito económico, Maura puso en marcha una política basada en el fomento de las exportaciones, ayudando a importantes sectores de la economía mediante la adopción de medidas regulatorias en el sector del vino o en el azucarero. No menos importante fue su política social, en la que se propuso la modernización de la legislación social mediante la creación de una serie de organismos administrativos encargados de velar por su cumplimiento, como la Inspección de Trabajo, los Tribunales Industriales y el Instituto Nacional de Previsión, y se fomentó la creación de sindicatos agrarios. Al contrario que en gobiernos anteriores, Maura dio muestras de una clara disposición al diálogo con los regionalistas catalanes. Consciente de la importancia de atraer hacia el sistema al catalanismo, consideraba a Cataluña pieza clave de su política regeneracionista. El dirigente de la Lliga, Cambó ${ }^{113}$, prestó su apoyo a Maura y fruto de esta colaboración nació el Proyecto de Ley de Descentralización Administrativa. Los catalanistas se negaron a abandonar la posición marginal que ocupaban en el régimen, debido a los resultados electorales que podía proporcionarles, por lo que Maura fracasó en su intento de integrar a los catalanistas. En el Partido Liberal, las facciones moretista y monterista acordaron unirse bajo la jefatura de Moret. Los liberales temían que la reforma de la Administración Local terminara con el sistema caciquil y con ello sus posibilidades de acceder al poder. Alarmados por las reformas que Maura pretendía, intentaban buscar una excusa para debilitar al Gobierno que había mantenido una legislatura tranquila hasta el año 1908. El propio Maura hizo posible la ocasión, pues tras la aprobación del Proyecto de Ley de Represión del Terrorismo ${ }^{114}$, posibilitaba al Gobierno el cierre de centros y prensa anarquistas sin autorización judicial previa.

\footnotetext{
${ }^{113}$ Cofundador y líder de la Liga Regionalista, fue ministro de Fomento y Hacienda en el reinado de Alfonso XIII.

${ }^{114} \mathrm{El}$ aumento del fenómeno terrorista fue muy preocupante en Cataluña, donde el Gobierno se vio obligado a suspender en algunas ocasiones las garantías constitucionales en Barcelona y Gerona.
} 
Los liberales buscaron el apoyo de los republicanos moderados de Melquiades Álvarez $^{115}$ con el objetivo de impedir a Maura llevar a término su programa regeneracionista, configurando lo que se denominó el Bloque Liberal o Bloque de Izquierdas $^{116}$. De nuevo, en junio de 1909, la cuestión marroquí irrumpió en la vida política, especialmente en una zona tan sensible como Cataluña, con los sucesos acontecidos en Barcelona durante la llamada Semana Trágica ${ }^{117}$. Maura consideraba la presencia española en Marruecos una cuestión de prestigio. Los altercados entre rifeños y tropas españolas se sucedían desde hacía tiempo pero el asesinato de cuatro trabajadores españoles del ferrocarril fue el incidente que acabó de convencer a Maura de la necesidad de enviar tropas de refuerzo a la zona. La relación de los mozos de la provincia de Palencia incorporados a filas con motivo de los sucesos de Melilla, constituía un fiel reflejo de la creciente conflictividad que se produjo en el escenario marroquí desde comienzos del siglo XX.

Tabla 01. Número de mozos de la provincia de Palencia incorporados a filas con motivo de los sucesos de Melilla entre 1901 y 1908.

\begin{tabular}{|c|c|}
\hline Año & Número de mozos \\
\hline 1901 & 1 \\
\hline 1902 & 7 \\
\hline 1903 & 47 \\
\hline 1904 & 41 \\
\hline 1905 & 247 \\
\hline 1906 & 24 \\
\hline 1907 & 183 \\
\hline 1908 & 39 \\
\hline
\end{tabular}

\footnotetext{
${ }^{115}$ Vid. SUÁREZ GONZÁLEZ, Fernando, Melquiades Álvarez. El drama del reformismo español, Madrid, Marcial Pons, 2014. En 1912, Melquiades Álvarez fundó el Partido Reformista, de ideas republicanas, aunque aceptaba la Monarquía democrática como forma de Gobierno.

${ }^{116} \mathrm{La}$ facción monterista cuestionaba esta alianza con los republicanos y discrepaba con los moretistas a propósito de la cuestión catalana. Monteros Ríos mostraba una intransigencia absoluta a este respecto.

${ }^{117}$ Vid. ROMERO MAURA, Joaquín, La rosa de fuego: el obrerismo barcelonés de 1899 a 1909, Madrid, Alianza Editorial, 1989.
} 
El reclutamiento de reservistas en Barcelona fue causa de fuertes protestas que culminaron el día 26 de junio con una huelga general que en Barcelona derivó en una sublevación urbana. El conflicto, que en principio obedecía a motivaciones de carácter sociopolítico, adquirió después connotaciones religiosas, lo que provocó el estallido de una revuelta anticlerical. El Gobierno adoptó fuertes medidas represivas para sofocar la rebelión. Los liberales, deseosos de acceder al poder, no dejaron pasar la oportunidad para lanzar ataques al Ejecutivo.

Al reabrir las Cortes después de las vacaciones parlamentarias, el día 15 de octubre de 1909, dos días después de la ejecución de Ferrer Guardia ${ }^{118}$ y en el momento en el que la repulsa internacional contra el Gobierno adquirió mayores dimensiones, Maura facilitó el propósito de los liberales. La totalidad de las fuerzas políticas se unieron en su contra acusándole de dañar la imagen de España en el exterior. El presidente nunca asimiló la fuerte oposición a su actuación en los sucesos de Barcelona y consideró que la posición del Partido Liberal constituía una traición a los principios de lealtad del turnismo que había regido la política española desde 1876. Como consecuencia, los partidos dinásticos, o parte de sus facciones, siendo sus máximos beneficiarios, pusieron en cuestión el sistema canovista y ocasionando un daño irreparable al régimen, provocaron la crisis del Gobierno de Maura. La oposición dinástica, por primera vez, se había unido a la oposición revolucionaria en su propósito de derribar al Gobierno. A la vista de las dimensiones del enfrentamiento entre liberales y conservadores, el rey retiró la confianza a Maura y este abandonó el poder sintiéndose traicionado por los liberales.

\footnotetext{
${ }^{118}$ Pedagogo y fundador de la Escuela Moderna, no existen pruebas de su participación en los sucesos acaecidos en Barcelona durante la llamada «Semana Trágica». Sin embargo, parece probada la implicación en el atentado del anarquista Mateo Morral contra Alfonso XIII el día de la boda real.
} 


\section{0-1912, Canalejas al frente del Gobierno}

El 21 de octubre de 1909, Alfonso XIII encargó a Moret la formación del Gobierno. El líder liberal sufrió la oposición continua de Maura por su actitud durante los sucesos de Barcelona, considerando roto el pacto tácito de lealtad al partido gobernante. Además, tampoco contaba con el apoyo los republicanos ${ }^{119}$, que le ayudaron en su campaña de derribo de Maura, e incluso de parte de su propio Partido ${ }^{120}$. El sistema turnista comenzaba a mostrar graves síntomas de agotamiento después de casi treinta años de vigencia. Moret podía sumar, además, la oposición del Ejército por la reimplantación de los ascensos por mérito de guerra ${ }^{121}$ y por su posicionamiento cercano a los partidos de izquierdas.

Alfonso XIII, consciente de la precariedad del Gobierno de Moret, consideró que llamar de nuevo al poder a Maura significaría reavivar las protestas y enfrentamientos que condujeron al cambio de Gobierno en 1909. El Partido Liberal debía mantenerse en el Gobierno pero Moret no podía continuar al frente del mismo, por lo que resultaba urgente buscar un líder que pudiera aglutinar en su persona a las diferentes sensibilidades que convivían en el Partido Liberal, que llevara a cabo las reformas iniciadas por Maura y que no se sintiera mediatizado por los intereses de los partidos republicanos. José Canalejas reunía estas condiciones, por lo que el rey le eligió para formar Gobierno el 9 de febrero de 1910. La etapa de Gobierno de Canalejas fue la más larga del Gobierno de los liberales durante el reinado de Alfonso XIII y puede ser considerada como el último intento reformista para la transformación del régimen de la Restauración ${ }^{122}$.

\footnotetext{
${ }^{119}$ Los republicanos se aliaron con los socialistas en la llamada Conjunción Republicano-Socialista, formada por los líderes republicanos más destacados en el frontón Jai-Alai de Madrid, tras un mitin de Pablo Iglesias. En las elecciones de mayo de 1910, la Conjunción obtuvo un gran resultado electoral, en Madrid. Vid. ROBLES EGEA, Antonio, «Formación de la conjunción republicano-socialista de 1909», Revista de estudios políticos, $\mathrm{N}^{\circ} 29$ (1982), pp. 145-162.

${ }^{120} \mathrm{El}$ sector liderado por el Conde de Romanones se mostró en desacuerdo con Moret por su exclusión del nuevo Gobierno.

${ }^{121}$ Los ascensos por méritos de guerra habían sido suprimidos en 1899 porque esta medida causaba rechazo entre la oficialidad.

${ }^{122}$ Canalejas era partidario, al igual que Maura, de la «revolución desde arriba», aunque al contrario que el político conservador, que se apoyó en la oligarquía más conservadora para lograrlo, Canalejas intentó involucrar a los sectores más populares de la sociedad en el sistema, mostrando una marcada tendencia anticlerical y un profundo convencimiento democrático. Albergaba la esperanza de que la educación de los ciudadanos propiciaría el nacimiento de una sociedad más justa y democrática.
} 
El programa de Gobierno de Canalejas daba por supuesta la reedición del Pacto de El Pardo ${ }^{123}$. Consciente de la delicada situación por la que atravesaba el sistema de la Restauración en el ámbito de la práctica política, José Canalejas pretendió resolver de forma definitiva los principales problemas que afectaban en el tiempo a la sociedad española, el problema religioso, con la Ley de Asociaciones Religiosas ${ }^{124}$, el problema social, con la regulación de las relaciones laborales y la mejora de las condiciones de vida y trabajo de la clase obrera ${ }^{125}$, la organización del Estado, con la creación de mancomunidades y la cuestión marroquí, con la intervención militar en Marruecos ${ }^{126}$.

\section{2-1916, el turnismo en crisis}

El asesinato de Canalejas ${ }^{127}$ significó, no solo la desaparición del político sino también la pérdida de la última oportunidad para renovar el sistema turnista que como demostraría el tiempo, quedaba herido de muerte con el magnicidio. Tras la muerte de Canalejas, se reactivó la lucha interna por el liderazgo del Partido Liberal, como muestra el enfrentamiento entre Romanones ${ }^{128}$, favorecido por el rey al ser llamado para formar Gobierno, y García Prieto que fracturó al Partido. En el grupo romanonista destacaban los moretistas que consideraban como su líder natural a Santiago Alba ${ }^{129}$ al comenzar a despuntar como hombre fuerte del liberalismo.

\footnotetext{
${ }^{123}$ Supuesto acuerdo entre Cánovas y Sagasta en 1885 para, tras la muerte de Alfonso XII, alternarse en el poder y preservar el sistema de la Restauración.

${ }^{124} \mathrm{La}$ llamada «Ley del candado», que frenaba la expansión de las órdenes religiosas durante un periodo de dos años, fue aprobada en 1910, mientras se preparaba la Ley de Asociaciones Religiosas. El plazo marcado transcurrió sin que se hubiese aprobado la Ley de Asociaciones Religiosas por lo que la medida quedó sin efecto.

${ }^{125}$ Reducción de la duración de la jornada laboral (en 1910, en las minas se estableció la jornada de nueve horas), protección del trabajo infantil y femenino e implantación de una Seguridad Social obligatoria con participación del Estado.

${ }^{126}$ La política expansiva francesa en Marruecos (ocupación en 1911 de Fez, capital del sultanato), «obligó» a Canalejas a intervenir militarmente y ocupar Larache, Arcila y Alcazarquivir. Esta intervención militar le granjeó a Canalejas la oposición de la Conjunción Republicano-Socialista.

${ }^{127}$ Asesinado por un anarquista en la madrileña Puerta del Sol, el 12 de noviembre de 1912. El anarquismo llamaba a la confrontación directa entre trabajadores y patronos mediante acciones de agitación propagandística, huelgas, sabotajes y acciones terroristas.

${ }^{128}$ Fue elegido diputado a Cortes de manera consecutiva desde 1886 hasta 1936. Su cacicazgo dominó el panorama electoral en la provincia de Guadalajara y fue considerado como el paradigma del cacique restauracionista.

${ }^{129}$ Ejemplo del político regenerador, su carrera política se inició siendo concejal, llegando a ser presidente de las Cortes tras su paso por varios ministerios durante el reinado de Alfonso XIII.
} 
La Ley de Mancomunidades del Gobierno Romanones supuso el detonante final en la escisión en el Partido Liberal pues el grupo de los demócratas, poseedor de una concepción centralista de la organización del Estado, se oponía frontalmente a esta Ley. A causa de esta cuestión, en el otoño de 1913, los demócratas decidieron formar un grupo parlamentario propio bajo el liderazgo de García Prieto. La situación en el Partido Conservador tampoco era más tranquila ya que notables miembros del Partido veían en la figura de Maura un peligro para la situación de privilegio que les proporcionaba el sistema de turno. La gran esperanza para el importante sector del conservadurismo español tenía un nombre, Eduardo Dato ${ }^{130}$. Tras la caída del Ejecutivo Romanones, las continuas luchas por el liderazgo en el Partido Liberal dificultaban la formación de un Gobierno de consenso. Ante esta situación, y conforme a la tradición de alternancia en el poder, el rey decidió encargar la formación del Gobierno a los conservadores. Las condiciones impuestas por Maura para gobernar fueron tan duras que los mismos conservadores optaron por encargar a Dato la formación de Gobierno. La mayor parte de los notables del partido conservador preferían restaurar el entendimiento con los liberales para turnarse en el poder y Dato, a diferencia de Maura, estaba dispuesto a ello.

El rey ${ }^{131}$ encargó la formación de Gobierno a Dato y Maura quien profundamente decepcionado con la actitud del monarca decidió renunciar a la actividad política y a la jefatura del Partido. El Partido Conservador, quedó dividido en dos tendencias ideológicas, los datistas y los mauristas. En 1914, Juan de la Cierva formó un grupo propio con un corpus ideológico de derecha reaccionaria. La división de los partidos dinásticos constituía un síntoma más de la agonía del sistema restauracionista, pero hechos tan destacados como la declaración de Melquiades Álvarez sobre la postura posibilista de su partido, el Partido Reformista, parecían indicar que la evolución del sistema aún era posible. El Gobierno Dato (1913-1915) logró superar algunos de los problemas que el país arrastraba desde hacía tiempo.

\footnotetext{
${ }^{130}$ Vid. GARCÍA-MONCÓ MARTÍNEZ, Alfonso Carlos, Eduardo Dato Iradier. Presidente del consejo de ministros de España, Madrid, Cinca, 2014.

${ }^{131}$ Alfonso XIII no consideraba a Maura la persona más idónea para gobernar por su enfrentamiento con los liberales y su posición contraria a cualquier posibilidad de acercamiento a los partidos de izquierda, cuestión en la que el monarca estaba interesado.
} 
La aprobación de la Ley de Mancomunidades ${ }^{132}$, pendiente desde la etapa de Gobierno de Canalejas, parecía orientar el problema catalán hacia una solución definitiva. El problema marroquí ${ }^{133}$ también entraba en vías de solución tras la consolidación de la posición española en el Protectorado gracias a los acuerdos firmados entre Francia y España. La política parecía capaz de resolver los problemas de la nación, aunque un acontecimiento exterior, la Primera Guerra Mundial, trastocaría la situación de tal modo que el devenir de la historia española cambiaría dando paso a un nuevo escenario político social.

A pesar de que la posición del rey se veía cada vez más comprometida por la inestabilidad interna de los partidos dinásticos, el prestigio de la institución monárquica en Palencia no había sufrido el menor menoscabo, como demuestran las fuentes documentales consultadas ${ }^{134}$. En la sesión de la Comisión Provincial de mayo de 1913, la Presidencia de Edad « (...) haciéndose fiel intérprete de los sentimientos monárquicos de los representantes de la provincia que integran la corporación», acordó que todos los diputados provinciales se personasen en Venta de Baños con motivo del paso del rey y la reina por la estación de ferrocarril de esa población a las quince horas y veintidós minutos para tributarle el legítimo homenaje que se merecía ${ }^{135}$.

\footnotetext{
${ }^{132}$ Esta ley contemplaba la posibilidad de que las provincias pudieran mancomunarse con fines únicamente administrativos. Los catalanes habían solicitado con insistencia esta posibilidad. El 6 de abril de 1914 se constituyó la Mancomunidad de Cataluña, que mancomunaba a las cuatro diputaciones provinciales catalanas, presidida por Prat de la Riba. El político catalán logró llevar a cabo una política nacionalista basada en el desarrollo de la identidad catalanista.

${ }^{133} \mathrm{Al}$ igual que había sucedido en el conflicto cubano de 1898, la Diputación Provincial palentina apoyó siempre al Ejercito en sus operaciones en Marruecos. En octubre de 1909, el Regimiento Guipúzcoa, compuesto en su mayoría por soldados de la provincia de Palencia, pasó por la estación de Venta de Baños en dirección a Melilla y la Junta provincial de Socorros, en nombre de la Comisión Provincial y el Ayuntamiento de Palencia, entregaron al coronel del Regimiento, Joaquín Martínez, 500 pts. cada institución, para que los repartiese entre los soldados de la provincia. A.D.P.P., L.A.P.D. 107, 2-X-1909. En julio de 1913, el vicepresidente de la Comisión Provincial hacía entrega de 300 pts. al capitán jefe del Tercer Escuadrón del Regimiento de Cazadores de Talavera, acuartelado en Palencia, destinado en el Cuerpo de Operaciones de África, para que las repartiese como socorro entre los soldados de tropa. A.D.P.P., L.A.C.P. 117, 22-VII-1913. En 1916, se acordó por la Comisión Provincial sufragar los gastos del rancho extraordinario con que fueron obsequiados las tropas expedicionarias del escuadrón mencionado, que regresaba de África. A.D.P.P., L.A.C.P. 124, 24-I-1916.

${ }^{134}$ Aun en 1902, cuando el diputado provincial Rodríguez Blanco solicitaba que se contribuyese a la construcción de un monumento a Emilio Castelar, presidente de la I República, con 250 pts., varios diputados provinciales se manifestaban en contra, justificando su postura, no porque se tratase de Castelar sino por la inoportunidad de la discusión en ese momento. Rodríguez Blanco solicitaba que se contribuyese con la misma suma que se donó para el monumento a Cánovas. Finalmente, tras largas discusiones, se libraron 250 pts. para erigir un monumento a Castelar. A.D.P.P., L.A.P.D., 94, 25-IV1902.

${ }^{135}$ A.D.P.P., L.A.C.P., 112, 6-V-1913.
} 


\section{El hundimiento del sistema, 1914-1923}

\section{Las consecuencias de la Primera Guerra Mundial}

El Gobierno declaró la neutralidad ${ }^{136}$ de España en el conflicto, lo que situó a la nación ${ }^{137}$ en una posición ventajosa desde el punto de vista económico. La industria se dispuso a abastecer de todo tipo de bienes a los países beligerantes, por lo que este sector pudo alcanzar un grado de desarrollo ${ }^{138}$ desconocido hasta entonces. Esta situación, sin embargo, no benefició por igual a todas las capas sociales ya que mientras la élite empresarial y financiera se enriqueció de manera espectacular, la clase obrera padecía impotente el alza de los precios de los productos básicos ${ }^{139}$ que superaban a la subida de los salarios.

La carestía de la vida provocó el descenso del nivel de vida del proletariado rural y urbano, lo que derivó en el aumento de la agitación social ${ }^{140}$. El empobrecimiento del mundo obrero se convirtió en un efecto dinamizador sobre la clase trabajadora cuyo punto más álgido se alcanzó en la huelga del año 1917. En diciembre de 1915, los liberales llegaron por su turno al Gobierno; Romanones logró formar un Ejecutivo en el que todas las tendencias del partido tenían representación, pero el aumento desproporcionado de los precios de los productos básicos constituía el principal problema al que se enfrentaba el Ejecutivo. Santiago Alba, desde su puesto ministerial de Hacienda, emprendió una reforma fiscal ${ }^{141}$ que perseguía como objetivo el aumento de la recaudación con la intención de paliar, en la medida de lo posible, la grave situación social que la creciente inflación había generado.

\footnotetext{
${ }^{136}$ La Comisión Provincial de la Diputación de Palencia envió un telegrama al presidente el Consejo de Ministros felicitando al Gobierno por la actitud de neutralidad ante la guerra europea. A.D.P.P., L.A.C.P. 118, 1-IX-1914.

${ }^{137}$ Vid. GARCÍA SANZ, Fernando, España en la Gran Guerra. Espías, diplomáticos y traficantes. Madrid, Galaxia Gutenberg, 2014.

${ }^{138}$ Cataluña, Asturias, y País Vasco, fueron las zonas que más se beneficiaron de la neutralidad española en la Primera Guerra Mundial. Vid. LÓPEZ IGLESIAS, Víctor, El papel de España en la I Guerra Mundial, Letra Internacional, № 119 (2014), pp. 81-86.

${ }^{139}$ Entre los años 1914 y 1918, el precio de muchos de los productos básicos se elevó entre un $70 \%$ y un 90\%. Vid. GARCÍA DELGADO, Santiago, MUÑOZ, José Luis y ROLDÁN, Juan, La formación de la sociedad capitalista en España, 1914-1920, Madrid, CECA, 1973.

${ }^{140}$ El número de huelgas ascendió desde 169, en el año 1915, hasta 237, solo un año después, casi todas reivindicaban demandas económicas.

${ }^{141}$ La reforma pretendía imponer una carga sobre los beneficios extraordinarios de la guerra. El sector empresarial mostró su rechazo a esta medida, especialmente el capital catalán y vasco, quienes apoyados en el sentimiento nacionalista atacaron al Gobierno para impedir que la reforma llegara a tener éxito. $C f r$. MARTORELL LINARES, Miguel Ángel, «El fracaso del proyecto de ley de beneficios extraordinarios de Santiago Alba en 1916: Una lectura política», Revista de Historia Económica, No 2 (primavera-verano 1998), pp. 521-555.
} 
Palencia no era ajena a la situación de crisis económica que se vivía a nivel nacional. En febrero de 1915, una comisión de obreros de la ciudad de Palencia se presentó en el Palacio provincial suplicando algún donativo, con cargo al Presupuesto de la Diputación Provincial, para remediar la crisis existente en la capital derivada de la paralización de todo tipo de obras. La Corporación provincial no disponía de dinero para atender esa súplica, ya que la situación se repetía en cada pueblo de la provincia, y se justificaba alegando que debían ser los ayuntamientos quienes atendiesen esas necesidades. El diputado provincial Calderón Martínez de Azcoitia, mostraba su desacuerdo con esa decisión y defendía que la Diputación, con cargo al Capítulo de Imprevistos y Calamidades, debía atender las reclamaciones de los obreros ${ }^{142}$.

El Gobierno Romanones, incapaz de solventar la grave situación social que vivía España, cayó acosado desde diversos sectores. En abril de 1917, fue sustituido por el Gobierno liberal que presidía García Prieto. Al problema social existente vino a sumarse el descontento militar, surgido del enfrentamiento en el seno del Ejército entre oficiales de las unidades peninsulares y las destacadas en Marruecos ${ }^{143}$. La petición de mejoras salariales para atenuar la inflación y la desconfianza en la clase política para resolver las tensiones nacionalistas que amenazaban la integridad territorial de la nación, fueron algunos de los motivos que condujeron a los militares a la creación de las Juntas Militares. En 1916, ya existía una Junta de Defensa del Arma de Infantería y solo un año más tarde el movimiento juntista se había extendido por todas las unidades militares del territorio nacional.

\footnotetext{
${ }^{142}$ A.D.P.P., L.A.C.P. $111,6-\mathrm{II}-1915$.

${ }^{143}$ Los oficiales destinados en la Península criticaban como sus colegas «africanistas» podían ascender en el escalafón por méritos de guerra con gran facilidad. Una de las principales reivindicaciones del movimiento juntista era la instauración de la «escala cerrada», es decir, el ascenso por antigüedad y no por méritos de guerra.
} 
La grave crisis inflacionaria padecida en España afectaba también a los funcionarios de diversos cuerpos de la Administración, lo que provocó que a mediados del año 1917 y siguiendo el ejemplo de los militares, se creasen las Juntas de Defensa en varios Ministerios. Las fuerzas situadas al margen del sistema canovista vieron en esta convulsa situación una oportunidad única para cambiar su situación política. Ante la posición de Eduardo Dato, de nuevo al frente del Gobierno en junio de 1917, de no abrir las Cortes después del verano, Cambó convocó una Asamblea de parlamentarios en Barcelona para exigir una serie de reformas ${ }^{144}$ que lograran la regeneración del caduco sistema turnista. El movimiento obrero, de carácter socialista y anarquista, las

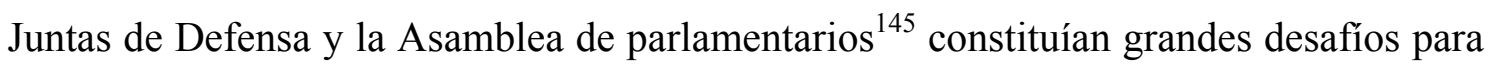
poner en riesgo no solo al Gobierno, sino al mismo sistema. La estrategia seguida por Dato fue la clásica de «divide y vencerás» y así, su actuación pasó por ceder ante las reivindicaciones más perentorias de las Juntas de Defensa, granjeándose el apoyo de los militares y utilizándoles para reprimir al movimiento obrero. No quiso escuchar las demandas de Cambó, quien abandonó su postura reivindicativa ante la falta de apoyo gubernamental temiendo que los partidos de izquierdas pudieran capitalizar en su provecho las reivindicaciones de la Asamblea de parlamentarios ${ }^{146}$.

\footnotetext{
${ }^{144}$ Las principales reformas que solicitaba la Asamblea de parlamentarios eran la limitación de las prerrogativas regias, la democratización del Senado y la descentralización del Estado, considerando a la región como unidad administrativa dentro del texto constitucional.

${ }^{145}$ Vid. ALÓS MARTÍN, Ignacio de, «El Regionalismo en el proyecto de reforma constitucional elaborado por la Asamblea de Parlamentarios de 1917», Estudios de historia social, № 28-29 (1984), pp. 347-352.

${ }^{146}$ Cambó no pretendía el cambio de sistema, por lo que ante la posibilidad de desestabilizar al régimen político de una manera irreversible, el líder catalanista asumió el apoyo a un Gobierno de concentración en el que a cambio, se le ofrecieron dos carteras ministeriales.
} 


\section{El colapso de sistema turnista}

La crisis de 1917 parecía resuelta gracias a la habilidad política de Dato, pero los problemas que la originaron se mantuvieron, causando una grave inestabilidad para la supervivencia del sistema que Cánovas había creado. La persistencia de los problemas sociales, militares, económicos y territoriales que padecía la sociedad puso de relieve la incapacidad de los partidos dinásticos para resolverlos. Esta realidad, con ser muy preocupante, no era lo peor de la situación, pues más grave parecía que ni siquiera los partidos antidinásticos se sintieran capaces de elaborar una alternativa democrática al sistema turnista.

En octubre de 1917, la presión de las Juntas de Defensa, con una posición política más fuerte tras la intervención del Ejército en la huelga revolucionaria de $1917^{147}$, junto con la campaña renovada de Cambó contra el turnismo forzaron la dimisión de Dato. En noviembre de 1917, García Prieto ${ }^{148}$ formó un Gobierno de composición heterogénea con la colaboración de demócratas, mauristas, ciervistas, catalanistas y romanonistas que constituía la expresión más evidente de la agonía política del sistema de turno de partidos. El Ejecutivo ${ }^{149}$ de García Prieto abrió una nueva etapa política en la que los partidos dinásticos dejaron de turnarse en el poder. A partir de 1917, y hasta 1922, se formaron gobiernos de coalición con la participación de las facciones de los partidos liberales y conservadores, que contaron con la colaboración ocasional de los catalanistas de la Lliga.

\footnotetext{
${ }^{147}$ La huelga general de agosto de 1917, anunciada como revolucionaria, fracasó principalmente a causa de la intervención del Ejército, incluidas las Juntas de Defensa, a favor del Gobierno. La declaración del Estado de Guerra, por parte del Gobierno de Dato, amparaba la intervención de los militares en el problema obrero, lo que fue determinante para terminar con la movilización de los trabajadores. El 14 de agosto de 1917, el gobernador militar de la provincia de Palencia remitió a la Diputación Provincial el bando de declaración de guerra en todas las provincias de la VII Región Militar que había emitido la Capitanía General.

${ }^{148}$ Presidente del Consejo de Ministros en cuatro ocasiones durante el reinado de Alfonso XIII. Mientras fue ministro de Estado del Gobierno Canalejas, en 1910, preparó los tratados para la creación del Protectorado español sobre Marruecos, lo que le valió el título de marqués de Alhucemas.

${ }^{149}$ Vid. GARCÍA PRIETO, Manuel, SAINZ DE VICUÑA y GARCÍA PRIETO, Manuel, Manuel García Prieto, Marqués de Alhucemas, 1859-1938. Actuación política e intervenciones parlamentarias, Madrid, Secretaría General del Senado, 2004.
} 
En las elecciones celebradas en febrero de 1918, no existió encasillado oficial, ni los gobernadores civiles intervinieron para alterar el proceso electoral. Socialistas, catalanistas y nacionalistas vascos fueron beneficiarios de la limpieza electoral y consiguieron buenos resultados, mientras que republicanos y reformistas sufrieron una gran derrota ${ }^{150}$. La existencia de unas Cortes muy fraccionadas y la pluralidad del nuevo Gobierno hicieron imposible gobernar ${ }^{151}$, por lo que en marzo de 1918, García Prieto dimitía como Presidente del Gobierno. La situación del país resultaba tan crítica que la amenaza de la abdicación por parte de Alfonso XIII sirvió para que se constituyera un «Gobierno Nacional» ${ }^{152}$, presidido por Antonio Maura, que regresaba al poder después de su abandono en 1909. Aunque este Gobierno alentó las esperanzas de gran parte de la sociedad, pronto los enfrentamientos de carácter personal y sobre todo, las diferentes soluciones aportadas para la resolución de los problemas más graves acabaron con el Ejecutivo $^{153}$. El 6 de noviembre, Maura presentaba su dimisión y con su marcha se desvanecía cualquier atisbo de esperanza en una solución democrática a la crisis social de 1918 y en la renovación del sistema político. El intento había fracasado por lo que se recurrió al ya conocido sistema de turno en el poder, el clásico turnismo. El viejo sistema canovista no había sido capaz de solventar los principales problemas de España y las continuas luchas entre las diferentes facciones que componían los partidos no hacían sino sembrar el descrédito en los partidos dinásticos, que eran capaces de unirse para defender su posición privilegiada en el escenario político de la Restauración.

\footnotetext{
${ }^{150}$ Vid. ÁLVAREZ JUNCO, José, El emperador del paralelo: Lerroux y la demagogia, Madrid, Alianza Editorial, 1994. Lerroux y Melquiades Álvarez, no obtuvieron escaño.

${ }^{151}$ De la Cierva, Ministro de Defensa, impuso por Decreto su reforma militar, sin esperar, tras las elecciones de febrero de 1918, a la constitución del Parlamento. Su reforma contemplaba entre otras medidas el ascenso por antigüedad tanto en tiempo de paz como de guerra. Esta medida constituía la demanda principal del programa de reformas de las Juntas de Defensa.

${ }^{152}$ Políticos de la talla de Dato, García Prieto, Romanones, Alba o Cambó, integraron el Gobierno de «salvación nacional» que presidió Maura. Vid. MAURA GAMAZO, Miguel y ROMERO MAURA, Joaquín, Así cayó Alfonso XIII. De una dictadura a otra, Madrid, Marcial Pons Historia, 2007.

${ }^{153} \mathrm{El}$ enfrentamiento entre Alba y Cambó, a cuenta del aumento del sueldo de los maestros, constituyó el último de los desencuentros entre los líderes de las posiciones políticas representadas en el Gobierno.
} 
De esta confluencia de intereses entre los partidos dinásticos constituye un ejemplo claro lo sucedido en Palencia, cuando la Comisión Permanente de Actas proponía, en 1917, la gravedad del Acta $^{154}$ del candidato a diputado provincial García Muñoz Jalón, maurista, elegido por el distrito de Astudillo-Baltanás, a causa de las protestas consignadas en el Acta de escrutinio general que afectaban a las secciones de Alba de Cerrato, Antigüedad, Amusco, Astudillo, Baltanás, Hontoria, Husillos, Palenzuela, Piña, Cevico de la Torre y Torquemada. Las protestas se justificaban por la compra de votos y coacciones ejercidas por los personados de la Fundación Monedero, germen del Partido Maurista en Palencia, cuyo representante era Muñoz Jalón ${ }^{155}$, otrora político del Partido Conservador. En este ambiente enrarecido comenzaban a escucharse voces que reclamaban un Gobierno fuerte, no mediatizado por los intereses de los caciques y de los líderes de los partidos tradicionales.

En noviembre de 1918, continuando la alternancia en el poder de los partidos dinásticos ${ }^{156}$, se formó un Gobierno de signo liberal, con el apoyo de demócratas y albistas, presidido por García Prieto. Los problemas de corte nacionalista $^{157}$ y las desavenencias internas en el propio Partido Liberal terminaron con el Gobierno de García Prieto en poco más de un mes. En diciembre de 1918, se formó un nuevo Gobierno liberal, presidido por Romanones, que afrontó en la ciudad de Barcelona la mayor huelga general ${ }^{158}$ de la Restauración.

\footnotetext{
${ }^{154}$ Liberales y conservadores votaron juntos a favor de la declaración de gravedad, que fue aprobada por 6 votos a favor y la abstención, por no poder votar en contra de Muñoz Jalón. A.D.P.P, L.A.P.D. 122, 4-V1917.

${ }^{155}$ A.D.P.P, L.A.P.D., 122, 4-V-1917. Muñoz Jalón, del Partido Maurista, escribía en octubre de 1917 a su jefe, Antonio Maura, expresándole sus temores sobre la posibilidad de que su Acta fuese declarada nula, toda vez que conservadores y liberales se habían puesto de acuerdo para declarar la gravedad de la misma en la sesión del pleno del 4 de abril de 1917: «Mi distinguido amigo e ilustre jefe: En esta desgraciada provincia seguimos dominados por la tiranía caciquil con más fuerza que nunca, (...) la Diputación Provincial se reúne ahora, no sé qué suerte correrá mi acta, me figuro la anularán consumando así el atropello de haberla declarado grave sin motivo y no haberme dejado tomar posesión del cargo». Archivo Fundación Antonio Maura. Caja 182/11. El 4 de octubre de 1917, en la sesión del Pleno de la Diputación Provincial, quedó aprobada el Acta de Muñoz Jalón, por unanimidad.

${ }^{156} \mathrm{El}$ Partido Conservador había formado Gobierno en 1917 bajo la presidencia de Dato.

${ }^{157}$ Vid. RIQUER PERMANYER, Borja de, Alfonso XIII y Cambó. La monarquía y el catalanismo político, Barcelona, RBA, 1994. Los parlamentarios catalanes de diversas ideologías se pusieron de acuerdo para pedir al gobierno de García Prieto la creación de un Gobierno regional autónomo para Cataluña.

${ }^{158}$ Conocida como la «huelga canadiense», por comenzar el movimiento de protesta en esta compañía que suministraba electricidad a la Ciudad Condal, extendiéndose a todos los sectores productivos de la misma. Vid. COMÍN COLOMER, Eduardo, El Anarquismo contra España: de "La Mano Negra" a la huelga de "La Canadiense", Madrid, Publicaciones Españolas, 1959.
} 
La represión de la huelga supuso el fortalecimiento de las dos posturas extremas enfrentadas en este tipo de conflictos, el Ejército, como elemento fundamental de la vida política española, y el movimiento anarquista, que incrementó su actividad subversiva con nuevas acciones de pistolerismo y terrorismo. A consecuencia de los sucesos de la huelga de Barcelona, el Gobierno Romanones se vio abocado a la dimisión y en abril de 1919, el Partido Conservador regresaba al poder de la mano de Maura. A la vista de su situación de minoría en las Cortes, Maura solicitó al rey la convocatoria de nuevas elecciones con el objetivo de conseguir unos resultados que le legitimasen en su propósito regeneracionista. Para Maura, dado el ambiente prerrevolucionario y la alta conflictividad social presente en la nación, la regeneración resultaba ser ahora más necesaria que nunca. Por primera vez desde 1876, el Gobierno perdió las elecciones ${ }^{159}$ y Maura no pudo intentar unificar al Partido Conservador bajo su liderazgo. Ante la falta de apoyo de los conservadores y la oposición de los liberales albistas y la izquierda antidinástica, Maura presentó la dimisión.

En Palencia, la crisis socio-económica gestó un clima de hostilidad y de inestabilidad política que la Comisión Especial de Obras Públicas de la Diputación palentina $^{160}$ intentaba resolver. Creía que la paz social vendría de la mano del trabajo, por lo que proponía al Ministerio de Fomento la terminación y construcción de las siguientes obras:

1. Construcción del ferrocarril de Palencia a Guardo.

2. Construcción acequia de Requena de Campos a Astudillo.

3. Construcción acequia de Requena de Osorno a Astudillo.

4. Ferrocarril Palencia a Aranda,

5. Construcción de la carretera desde Sotobañado hasta la estación de Espinosa de Villagonzalo.

6. Encauzamiento de los ríos Retortillo y Valdeginete.

7. Terminación del encauzamiento del río Ucieza.

8. Construcción de la carretera Saldaña-Almanza.

9. Terminación del canal de Alfonso XIII.

10. Canalización del rio Arlanza.

\footnotetext{
${ }^{159}$ A pesar de su espíritu regeneracionista, Maura permitió que De la Cierva, desde el Ministerio de Gobernación, emplease medios poco democráticos para asegurar un resultado favorable a los intereses de su Partido. A pesar de ello, no pudo ganar las elecciones.

${ }^{160}$ A.D.P.P., L.A.P.D. 123, 3-X-1918.
} 
En julio de 1919, el conservador Joaquín Sánchez Toca ${ }^{161}$ fue nombrado jefe de Gobierno. Con mayoría parlamentaria y dando muestras de un espíritu conciliador, creía que el diálogo podía encauzar la situación de conflictividad hacia su solución pero la realidad mostraba que todo intento de acercamiento entre las posturas enfrentadas se veía frustrado por la actuación de los elementos extremistas de ambos bandos ${ }^{162}$. El gobierno de Sánchez Toca, al igual que los precedentes, cayó sin haber transcurrido seis meses desde su formación y en diciembre de 1919, fue sustituido por un Ejecutivo de coalición presidido por Manuel Allendesalazar ${ }^{163}$, quien dimitió tras la aprobación del Presupuesto, algo que no sucedía desde hacía cinco años. En mayo de 1920, Eduardo Dato aceptó formar Gobierno y permaneció, de manera insólita, en el poder hasta marzo de 1921. Durante su etapa de Gobierno se creó el Ministerio de Trabajo, prueba evidente de la preocupación gubernamental por la cuestión social y la conflictividad obrera generada. Sin embargo, al igual que anteriores gobiernos, Dato optó por la línea dura ${ }^{164}$ y no logró que la problemática del mundo laboral desapareciera de la escena política española.

Tras el asesinato de Dato, por los anarquistas Cusidó, Fort y Casanellas Lluch, Maura intentó la formación de un Gobierno de coalición a semejanza del que fracasó en el año 1918, aunque la negativa de aquellos llamados a formar parte del mismo impidió su constitución. Ni Ossorio, dentro del Partido Conservador, ni Cambó, ni Romanones estaban dispuestos a repetir el fracaso de 1918 por lo que Maura desistió de su propósito. Tras este intento fallido, se constituyó un Gobierno de corte conservador presidido por Allendesalazar, que hizo frente al recrudecimiento del conflicto en Marruecos.

\footnotetext{
${ }^{161}$ Había formado parte del Gobierno de Silvela como ministro de Marina entre los años 1902-1903.

${ }^{162}$ Patronos y Ejército por un lado, y la Confederación Nacional del Trabajo (CNT) por otro, no estaban dispuestos a ceder en sus posiciones por lo que se desencadenó una «guerra social» que pretendía la eliminación del contrincante.

${ }^{163}$ Entre otros cargos, ocupó el de ministro de Estado en el «Gobierno largo» de Maura.

${ }^{164}$ Buena prueba de este modo de actuación fue el nombramiento del general Martínez Anido como gobernador civil de Barcelona. Dato fue asesinado por un anarquista el 8 de marzo de 1921, en La Puerta de Alcalá de Madrid.
} 
El desastre de Annual ${ }^{165}$ en Marruecos ocasionó entre la opinión pública española una conmoción comparable al desastre del 98. La cuestión marroquí, generadora de inestabilidad durante el régimen de la Restauración en 1909, constituyó, hasta el Golpe de Estado de Primo de Rivera de 1923, una constante fuente de conflictos para los gobiernos de turno. La fórmula ensayada con «el Gobierno Nacional» en 1918 se consideró, de nuevo, el mejor remedio para los males que afectaban a la delicada salud del sistema turnista y en agosto de 1921, una vez más, Maura, inasequible al desaliento, fue elegido para dirigir el Gobierno. La gravedad de la situación ayudó a que todas las fuerzas dinásticas acordasen formar parte del Gobierno $^{166}$, aunque el acuerdo se mantuvo soló durante el tiempo en que se tardó en restablecer la situación en Marruecos. Atajado el peligro inmediato que suponían las huestes de Abd-el-Krim, se planteaba de qué modo actuar en la zona de Protectorado español en Marruecos y si la crisis del Rif había fomentado el consenso, la acción futura a desarrollar ${ }^{167}$ en la zona fue causa del desencuentro acabando con el «Gobierno Nacional» de Maura, cinco meses después de su formación.

En marzo de 1922, José Sánchez Guerra ${ }^{168}$, presidió un nuevo Gobierno conservador. El Ejecutivo se sintió mediatizado por las secuelas del desastre de Annual en lo que se refería a la depuración de responsabilidades por lo que Sánchez Guerra relevó de su cargo al general Martínez Anido, disolvió las Juntas de Defensa y restableció las garantías constitucionales que fueron suspendidas tras los acontecimientos en el Rif. El «error» del Presidente del Gobierno fue emprender la depuración de las responsabilidades militares originadas en la catástrofe africana.

\footnotetext{
${ }^{165}$ Vid. PRIETO TUERO, Indalecio, Crónicas de guerra: Melilla 1921, Málaga, UNED, 2001. En julio de 1921, comenzó una rebelión de las cabilas rifeñas bajo el mando Abd-el-Krim en el sector oriental del Protectorado español en Marruecos, que ocasionó la pérdida de todas las posiciones del sector excepto Melilla. La cifra de muertos en las filas españolas se ha estimado en un número cercana a los 10.000. En agosto del mismo año, el diputado provincial, César Gusano proponía a la Diputación Provincial el envío de un telegrama al Gobierno y otro al Alto Comisario de Marruecos, alentándoles a continuar la campaña emprendida a fin de castigar a las cabilas por los desmanes cometidos que consideraba un ultraje nacional. A.D.P.P., L.A.P.D. 129, 3-VIII-1921.

${ }^{166} \mathrm{El}$ grupo de Alba, Izquierda Liberal, no quiso formar parte del «Gobierno Nacional».

${ }^{167} \mathrm{Se}$ barajaban dos opciones con respecto a la política en Marruecos: restringir sustancialmente la presencia española, opción de la que el propio Maura era partidario, y la ocupación de la zona española.

${ }^{168}$ Tras el asesinato de Dato, Sánchez Guerra se había erigido como líder de los datistas o «idóneos».
} 
El «expediente Picasso» ${ }^{169}$ se presentó a debate en el Parlamento y el Consejo Supremo de Guerra y Marina, a la vista de las conclusiones y de su gravedad, procesó a un total de 39 oficiales, incluyendo al general Berenguer, máxima autoridad del Protectorado. Además del descontento originado dentro del estamento militar, con las graves implicaciones que supondría para el futuro, vino a sumarse el oportunismo político de los partidos de la izquierda antidinástica que lejos de conformarse con el castigo a los responsables militares del desastre, exigía que se aclarase la responsabilidad política de Annual, apuntando en sus ataques hacia la Corona, cabeza visible del sistema de la Restauración. Los liberales se sumaron a la ofensiva contra el Gobierno, pues después de tres años creían llegada la hora de desalojar a los conservadores del poder y lo acontecido en Marruecos servía al liberalismo como una magnífica excusa para menoscabar la legitimidad del Ejecutivo conservador y acceder de nuevo al Gobierno. A pesar de lo ocurrido, la lucha política entre partidos no constituía el principal problema derivado de la cuestión marroquí por lo que el Ejército se sintió menospreciado por los políticos, a los que acusaba de debilidad, y adoptó una posición de clara hostilidad hacia el sistema restauracionista.

\section{El final del parlamentarismo}

El enfrentamiento ocasionado por el debate parlamentario del informe Picasso dio al traste con el Gobierno de Sánchez Guerra y puso fin a tres años de gobiernos conservadores. En diciembre de 1922, se formó un Gobierno con representación de las principales facciones del liberalismo presidido por García Prieto, con Santiago Alba como principal figura política del Ejecutivo. Las elecciones de 1923 se desarrollaron conforme al clásico método de reparto previo de escaños, prueba evidente de que el sistema no había sido capaz de evolucionar hacia prácticas más participativas y democráticas.

\footnotetext{
${ }^{169}$ Allendesalazar constituyó una Comisión de investigación presidida por el General Picasso con la finalidad de dirimir las responsabilidades derivadas del desastre militar ocurrido en el sector oriental del Protectorado español. Hasta la proclamación de la II República, el citado informe no fue conocido por la opinión pública. Vid. PICASSO GONZÁLEZ, Juan, El expediente Picasso, Madrid, Ediciones Morata, 1931.
} 
El funcionamiento del sistema turnista, basado en la obtención de mayorías parlamentarias que permitiesen acometer programas reformistas, exigía el «amaño» de los procesos electorales. La experiencia había demostrado que unas elecciones sin fraude derivaban en unas Cortes fraccionadas que hacían poco menos que imposible gobernar, y mucho menos llevar a término cualquier intento reformista. Esta realidad pesaba como una losa en el pensamiento de los políticos dinásticos. A esta circunstancia contribuían hechos como los sucedidos en Palencia con motivo de un presunto fraude electoral. El 21 de octubre de 1921, la Audiencia Territorial de Valladolid dictaba sentencia, desestimando los recursos interpuestos por los candidatos Teodoro García Crespo y Pedro Carrancio, contra el acuerdo adoptado por la Diputación Provincial de 12 de septiembre que aprobaba las Actas de los diputados provinciales electos por el distrito de Carrión -Frechilla, Luis Nájera de la Guerra, Manuel Arija García y Cesáreo de la Guerra Castellanos ${ }^{170}$. El acuerdo se basaba en dictamen de la Comisión Permanente de Actas, referente a la elección verificada en el distrito de CarriónFrechilla, donde fueron proclamados diputados provinciales por la Junta Provincial del Censo, en el Acta del escrutinio general celebrado el 16 de mayo de 1921, Manuel Betegón Pérez, Luis Nájera de la Guerra, Manuel Arija García y Cesáreo de la Guerra Castellanos. En este dictamen se proponía la aprobación de las Actas y proclamación de los electos, ya que si bien de los datos de la Comisión Auxiliar de Actas, referentes a 20 secciones del citado distrito, y la protesta formulada por Pedro Carrancio, parecía haberse cometido alguna irregularidad, esta no afectaba al resultado de la votación. A juicio de la Comisión, aun cuando hubiesen emitido sufragio algunos ausentes y fallecidos, no podía ser causa de nulidad por haber quedado en todas las secciones bastantes electores que no votaron, «(...) amparándose en el criterio de benevolencia que siempre ha prevalecido en esta Asamblea, se estima la validez de dichas elecciones.» ${ }^{171}$

\footnotetext{
${ }^{170}$ A.D.P.P., L.A.C.P. 133, 5-XI-1921

${ }^{171}$ A.D.P.P., L.A.P.D. 130, 12-IX-1921.
} 
Betegón Pérez protestaba por haberse declarado grave su Acta, dando lectura de la sentencia dictada por la Audiencia Territorial de Valladolid de 4 de junio de 1921. La doctrina en la que esta sentencia se fundaba determinaba la anulación de las Actas de aquellos diputados a quienes afectasen las protestas por lo que el diputado provincial no comprendía porque se declaraba la gravedad de la suya, «(..) a no ser que obedezca a ser adverso a la política de la mayoría y haber obtenido mayor número de votos que los adictos de aquella.» ${ }^{172}$ El dictamen sobre la gravedad el Acta de Betegón, se votó, absteniéndose como afectado por la resolución, siendo aprobada con catorce votos a favor y uno voto en contra, formulado por Ortega Arredondo.

García Prieto intentó, como sus predecesores en el cargo, llevar adelante un programa de modernización del país, consciente de la necesidad de acometer las reformas necesarias para que el sistema no quebrara. Su programa contemplaba terminar con la farsa de las elecciones democratizando los procesos electorales, reformar el Senado, limitar la potestad gubernamental para suspender las garantías constitucionales, abrir las Cortes al menos cuatro meses al año, revisar la cuestión religiosa, llevar a cabo un control civil sobre el Protectorado de Marruecos ${ }^{173}$ e incluso una reforma agraria. La política de Santiago Alba con respecto a Marruecos, fue recibida por el Ejército como un ataque a su honor y el político, contra su concepción civilista de la cuestión marroquí, dio marcha atrás aceptando una solución bélica ${ }^{174}$ para esta cuestión. Este cambio de postura de Alba provocó una crisis en el seno del Gobierno liberal que se saldó con la dimisión de varios ministros contrarios a ceder ante la presión militar.

\footnotetext{
${ }^{172}$ A.D.P.P, L.A.P.D., 130, 5-VIII-1921.

${ }^{173}$ Alba, por primera vez en la historia del Protectorado, impuso a un funcionario civil como Alto Comisario, Miguel Villanueva Gómez. Aceptó, además, el pago del rescate de los prisioneros españoles que retenía Abd-el -Krim desde la caída de Monte Arruit, unos 700, de los cuales solo sobrevivieron en 1923 unos 326.

${ }^{174}$ La ineficacia de la política pacifista en el Protectorado quedó demostrada, debido sobre todo a la postura de las cabilas rifeñas, que no estaban dispuestas a cesar en sus ataques a las posiciones españolas. Esta actitud provocó un continuo goteo de muertes en las filas españolas que contribuyeron a crispar la vida política del país y a afianzar en sus posiciones a los militares y partidarios de la mano dura en Marruecos.
} 
La desintegración de los partidos dinásticos, la inestabilidad paulatina de los gobiernos ${ }^{175}$, la incapacidad de los ejecutivos para dar respuesta a las reivindicaciones populares, la imposibilidad de vertebrar un modelo territorial acorde con las expectativas regionalistas de Cataluña, la dificultad de integración en el sistema de las fuerzas políticas de la derecha e izquierda no dinástica, la débil estructura del Estado, que permitía crecer al clientelismo caciquil, la errónea y vacilante política exterior en Marruecos y la cesión de poder ante el estamento militar, fueron algunas de las razones que motivaron el colapso al sistema de la Restauración en septiembre de 1923.

\section{La Dictadura de Primo de Rivera (1923-1930)}

\section{El pronunciamiento}

En septiembre de 1923, la inestabilidad de la situación sociopolítica podía anunciar una actitud claramente favorable a una intervención militar que pusiese orden en la convulsa situación de país ${ }^{176}$. El propio monarca, desencantado con la acción de los partidos dinásticos, incluso llegó a consultar a Maura sobre la posibilidad de auspiciar una solución autoritaria ${ }^{177}$ a la crisis padecida en la sociedad. Durante los meses de agosto y de septiembre se vivieron una serie de incidentes ${ }^{178}$ que allanaron el camino hacia el levantamiento militar del 13 de septiembre. Ese día, Primo de Rivera ${ }^{179}$, capitán general de Cataluña, proclamó el Estado de Guerra y difundió un manifiesto en tono regeneracionista lleno de reproches hacia la clase política. En un primer momento, el Gobierno adoptó una postura de pasividad y solo algunos ministros se mostraron partidarios de oponerse al Golpe. La mayoría del Gobierno no se mostraba dispuesta a enfrentarse a Primo de Rivera, sobre todo por la percepción del apoyo del monarca al general golpista. Republicanos, socialistas y la inmensa mayoría de la población aceptaron el pronunciamiento militar con indiferencia e incluso esperanza.

\footnotetext{
${ }^{175}$ Entre los años 1917 y 1922 , se formaron 14 gobiernos.

${ }^{176}$ El Día de Palencia informaba con estas palabras del levantamiento militar de Primo de Rivera: «Se ha cargado tanto el ambiente, se ha saturado el aire con tantos graves desaciertos y con tan peligrosos yerros, que, al fin, ha surgido lo inevitable». El Día de Palencia, 13-IX-1923.

${ }^{177}$ Maura convenció a Alfonso XIII de la conveniencia de esperar a la realidad de que se produjera un golpe militar que concediera el poder a los militares antes de que el rey apareciera ante la sociedad como patrocinador del golpe.

${ }^{178}$ Incidentes en Málaga a finales de agosto con motivo del embarque de tropas hacia Marruecos y el más grave, el día 11 de septiembre, en Barcelona con enfrentamientos entre jóvenes nacionalistas y la policía durante la celebración de la Diada.

${ }^{179}$ Cfr. NAVAJAS ZUBELDÍA, Carlos, «La ideología corporativa de Miguel Primo de Rivera (19051919), Hispania: Revista española de historia, Vol. 53, Nº184 (1993), pp. 617-649.
} 
Solo la CNT y el Partido Comunista de España (PCE) 1lamaron, sin éxito, a oponerse al Golpe. Ante el desprestigio del sistema turnista, cualquier situación que supusiera renovación ${ }^{180}$ concitaba esperanzas de mejora y por tanto de apoyo tácito al cambio. Primo de Rivera presentaba el pronunciamiento como una situación temporal $^{181}$, en la que tras renovar el sistema y superar la crisis que lo atenazaba se volvería a la normalidad constitucional, como prueba que la Constitución de 1876 no fuera derogada. El dictador no pretendía la instauración de un nuevo Régimen, sino la formación de un Gobierno fuerte sin las divisiones que habían caracterizado a los ejecutivos de los partidos dinásticos, que imposibilitaban cualquier acción de Gobierno eficaz para resolver los problemas principales del país: Caciquismo, nacionalismo, Marruecos y orden público. El día 15 de septiembre de 1923, el general Primo de Rivera juraba como presidente y ministro universal, asistido por un Directorio Militar del que formaban parte generales de brigada de cada Región Militar. El dictador pretendía desmantelar el sistema clientelar, motor de la Restauración, y pensaba que liberada la sociedad de la presión caciquil, podría emprender con garantías la regeneración del entramado institucional y del país. Desde este posicionamiento, adoptó medidas en coherencia con su programa político, comenzando por la suspensión de los $\operatorname{ayuntamientos}^{182}$ y diputaciones provinciales, puesto que en el ámbito de la Administración Local, el caciquismo alcanzaba su mayor grado de influencia. La figura del cacique y sus redes clientelares formaban parte del paisaje local y provincial y, además, constituían una parte sustancial del sistema de la Restauración, por lo que después de casi cincuenta años de funcionamiento, no iba a resultar fácil llevar a cabo su propósito.

\footnotetext{
${ }^{180}$ Primo de Rivera se presentaba como el «cirujano de hierro» imaginado por Costa para salvar a la nación en su obra, publicada en 1901, Oligarquía y caciquismo como la forma actual de Gobierno en España: Urgencia y modo de cambiarla. Ortega y Gasset, regeneracionista como Costa, creía que la solución para el atraso español no estaba en manos de un dictador sino que consistía en estrechar lazos con Europa y lograr dejar atrás el provincianismo español.

${ }^{181} \ll(\ldots)$ nuestro propósito es constituir un breve paréntesis en la marcha constitucional de España para restablecerla tan pronto como, ofreciéndonos el país hombres no contagiados de los vicios que a las organizaciones políticas imputamos, podamos nosotros ofrecerlos a Vuestra Majestad para que restablezca pronto la normalidad.» Real Decreto 15 de septiembre de 1923.

${ }^{182}$ Se pretendía sustituir los ayuntamientos por juntas de vocales asociadas, constituidas por los mayores contribuyentes de cada municipio. Este sistema lograba perpetuar el caciquismo, mientras que el objetivo pretendido con las reformas era el contrario, ya que los integrantes de las juntas de vocales eran los mismos que habían apoyado el sistema caciquil.
} 
Varias disposiciones legales fueron aprobadas para lograr este objetivo, pero ni el Estatuto Municipal de $1924^{183}$, ni el Estatuto Provincial de 1925 consiguieron erradicar esta práctica, mientras los «caciques» lograron adaptarse a los nuevos tiempos y pasaron a formar parte integrante de la organización territorial de la Dictadura en el ámbito local. La pretensión de dotar de más poder a las entidades locales en detrimento del centralismo estatal no se consiguió y, a través de la figura del gobernador civil, se ejerció un control total sobre las instituciones locales y provinciales. Durante la etapa de la Dictadura ni siquiera se convocaron elecciones municipales.

\section{Orden público y nacionalismos}

Primo de Rivera se había comprometido a resolver los problemas de orden público, mediante una serie de medidas represoras que tuvieron un efecto disuasorio entre los anarquistas de la CNT, sin olvidar que la organización atravesaba una grave crisis que influyó para que el número de actividades terroristas ${ }^{184}$ descendiera de forma notable en la etapa de la Dictadura.

En el tema de los nacionalismos, la respuesta adoptada por el régimen fue la promulgación del Estatuto Provincial de 1925, que fortalecía el papel de las diputaciones provinciales frente a las mancomunidades provinciales. El catalanismo conservador sufrió una grave decepción y como consecuencia, fue más perceptible su oposición al Régimen de Primo de Rivera.

\footnotetext{
${ }^{183}$ Impulsado por José Calvo Sotelo, Director General de la Administración, pretendía la sustitución del centralismo administrativo por un régimen de autonomía local. Calvo Sotelo, desde 1921, había desempeñado varios cargos de responsabilidad política en la etapa de Gobierno de Maura.

${ }^{184}$ Vid. AVILÉS FARRÉ, Juan y HERRERÍN LOPEZ, Ángel, (Edición.), El nacimiento del terrorismo en Occidente. Anarquía, nihilismo y violencia revolucionaria, Madrid, Siglo XXI, 2008.
} 


\section{El conflicto marroquí}

La cuestión marroquí, a pesar de los problemas que generó a los partidos dinásticos, se resolvió de manera favorable para los intereses del dictador. Primo de Rivera, consciente de la costosa carga que suponía para la Hacienda estatal, fue partidario de abandonar o reducir a la mínima expresión la presencia de España en Marruecos ${ }^{185}$. Sin embargo, esta posición abandonista chocaba frontalmente con el pensamiento de los militares «africanistas», que consideraban un deshonor dejar el territorio en manos de Abd-el Krim ${ }^{186}$. El caudillo rifeño había alcanzado el cénit de su poder en $1923^{187}$ y partía de la consideración de que los españoles acabarían por abandonar sus posiciones en el Rif, pero este convencimiento sería la causa de su derrota. Animado por sus éxitos, en 1925, atacó el territorio del Protectorado de Francia. Este ataque cambió la postura de Francia con respecto a la presencia española en Marruecos y ambas naciones llegaron a un acuerdo para acabar de forma definitiva con el peligro que representaban las cabilas. El día 8 de septiembre de 1925, fruto de la colaboración hispano francesa, se produjo el desembarco en Alhucemas ${ }^{188}$, en el Rif central, resultando esta operación un rotundo éxito para las armas españolas y para el prestigio de Primo de Rivera ${ }^{189}$, tanto ante la sociedad ${ }^{190}$ en general, como entre sus compañeros de armas. Sin embargo, la derrota de Abd-el-Krim no supuso el abandono de la lucha, lo que obligó a Primo de Rivera, en contra de su propio criterio, a proseguir los combates.

\footnotetext{
${ }^{185}$ En 1924, cerca de 120.000 soldados españoles se encontraban destacados en el Protectorado español en Marruecos.

${ }^{186}$ Vid. MADARIAGA ÁLVAREZ-PRIDA, María Rosa, Abd-el-Krim el Jatabi: la lucha por la independencia, Madrid, Alianza Editorial, 2009. Abd-el-Krim encabezó la resistencia contra la dominación colonial española y francesa en Marruecos. El caudillo rifeño, desde el exilio, mantuvo su lucha por la independencia hasta 1952, convirtiéndose en un símbolo del nacionalismo árabe.

${ }^{187}$ En ese año se había proclamado la República del Rif, controlando un territorio que no solo comprendía el Rif, sino también Yeballa y Gomara.

${ }^{188} C f r$. MARTÍN TORNERO, Antonio, «El desembarco en Alhucemas. Organización, ejecución y consecuencias», Revista de historia militar, $\mathrm{N}^{\circ} 70$ (1991), pp. 199-264.

${ }^{189}$ Felicitación de la Diputación de Palencia al jefe de las Fuerzas en Marruecos y presidente interino del Directorio Militar por los éxitos militares conseguidos en Kudia-Tahar. A.D.P.P., L.A.C.P. 141, 14-IX1925.

${ }^{190}$ El gobernador civil de Palencia elogiaba la figura de Primo de Rivera en la sesión del Pleno de la Diputación: «(...) que salvó a España de una hecatombe, (...) que, con su actuación en Marruecos, ha llevado la tranquilidad a los hogares españoles y cuyo talento envidiable y honradez acrisolada, debemos todos imitar». A.D.P.P., L.A.P.D. 138, 25-XI-1925.
} 
En la campaña de Marruecos desempeñó un destacado papel el general palentino Alberto Castro Girona ${ }^{191}$, y así se lo reconoció la Diputación Provincial que en sesión de la Comisión Provincial ${ }^{192}$, concedió una subvención de 250 pts. a la Comisión organizadora del homenaje al general para costearle las insignias de la Gran Cruz de San Hermenegildo, concedida por el Gobierno en atención a sus méritos de guerra en Marruecos. El curso de los acontecimientos llevó a Primo de Rivera a adoptar una política expansiva como la pretendida por el mariscal Pétain, máximo responsable militar francés en la zona, al considerar que solo la actuación decidida de los españoles en su zona de Protectorado resolvería el conflicto con los rifeños de Abd-el-Krim. La colaboración entre España y Francia consiguió vencer al caudillo rifeño y así, en mayo de 1926, Abd-el-Krim se rindió a los franceses. La paz en Marruecos supuso el mayor logro de la Dictadura primorriverista, aunque el Protectorado seguía constituyendo un lastre para las finanzas del Estado ${ }^{193}$. Finalizado el conflicto en Marruecos, Primo de Rivera consideró llegado el momento de institucionalizar el régimen dictatorial. El 2 de diciembre de 1925, el Directorio militar fue sustituido por un Gobierno civil ${ }^{194}$.

\footnotetext{
${ }^{191}$ Durante la campaña del Rif, en el asedio de Xauen, Castro Girona se disfrazó de carbonero para lograr entrar en la ciudad y negociar su rendición. Esta acción le valió el ascenso al generalato.

${ }^{192}$ A.D.P.P., L.A.C.P.P. 141, 14-IX-1925.

${ }^{193}$ En 1930, la permanencia en Marruecos suponía al Estado un gasto aproximado de unos 300 millones de pts., casi el triple de lo que se había previsto. Cfr. SUEIRO SEOANE, Susana, «El mito del estratega. Primo de Rivera y la resolución del problema de Marruecos», Cuadernos de Historia Contemporánea, $\mathrm{N}^{\mathrm{o}}$ 16(1994), pp. 122-128.

${ }^{194}$ Destacaban como miembros del gobierno José Calvo Sotelo, en el Ministerio de Hacienda, y el general Martínez Anido, como Vicepresidente del Gobierno y ministro de la Gobernación.
} 


\section{Institucionalización del régimen: El Directorio civil}

Primo de Rivera pretendía dotar al régimen de los instrumentos legales que le permitiesen perdurar en el poder, lo que entraba en contradicción con la idea de solución provisional con la que, en el año 1923, se había presentado en sociedad. Ante la necesidad de crear un partido del que saliesen los cuadros dirigentes del país, en el año 1924, creó La Unión Patriótica ${ }^{195}$, creada con esta finalidad y también, como un órgano de representación de la sociedad. En 1927, se reunió la Asamblea Nacional Consultiva $^{196}$, considerada como la primera institución de representación política corporativa del constitucionalismo español. Esta, con carácter meramente consultivo y controlada por el Gobierno, respondía a la intención de Primo de Rivera de modificar el sistema que había funcionado desde 1876. La institución debe incluirse en el descrédito del parlamentarismo europeo, en que se ensayaban nuevos sistemas de organización política con concepciones corporativistas, organicistas e intervencionistas ${ }^{197}$.

\footnotetext{
${ }^{195}$ Vid. GIL PECHARROMÁN, Julio, «La Unión Patriótica», Historia 16, № 96 (1986), pp. 28-37.

${ }^{196} 400$ asambleístas designados por el Gobierno, procedentes de la Unión Patriótica y de las diversas actividades socioeconómicas del país: enseñanza, industria, banca, sindicatos, patronal, prensa, etc.

${ }^{197}$ En octubre de 1922, Benito Mussolini formó Gobierno en Italia por encargo del rey Víctor Manuel III.
} 


\section{Política económica y social}

El Directorio Civil, en contra de la política de los gobiernos liberales que practicaron un librecambismo atenuado, adoptó una política intervencionista y de protección de la producción nacional en materia económica ${ }^{198}$. Las obras públicas constituyeron el proyecto central de la política económica de la Dictadura, al destacar la política de fomento de los regadíos mediante la construcción de pantanos en las cuencas hidrográficas a la vez que se aprovechaban para generar energía eléctrica, sin olvidar la construcción de carreteras ${ }^{199}$ y vías férreas, y un extenso programa de reforestación.

La reforma agraria pendiente no se abordó por lo que debido al desigual reparto de la tierra, que condenaba a muchos jornaleros y a sus familias a subsistir en condiciones de vida miserables, la situación en el sur fue especialmente grave, constituyendo un persistente foco de tensión. En el terreno de la seguridad, el dictador se había comprometido a restablecer el orden público. Consciente de que para lograr este objetivo necesitaba antes alcanzar la paz social, centró todos sus esfuerzos en lograr atraer a la clase obrera hacia el régimen, mediante la adopción de medidas que mejorasen la calidad de vida de los obreros. En este periodo, y tratando de mermar la conflictividad social, se produjo un incremento significativo del gasto en viviendas para los trabajadores, en Sanidad y en Educación.

\footnotetext{
${ }^{198}$ Se subsidió a las grandes empresas, se nacionalizaron industrias estratégicas (en la industria petrolífera se creó la Compañía Arrendataria del Monopolio del Petróleo (CAMPSA). Cfr. TORTELLA CASARES, Gabriel, «El monopolio de petróleos y Campsa, 1927-1947», en GARCÍA RUIZ, José Luis, HERNÁNDEZ ANDREU, Juan, (Coordinación.) Lecturas de historia empresarial, Madrid, Civitas, 1994, pp. 265-302. Además, se concedieron monopolios como a la compañía norteamericana International Telephone \& Telegraph. (ITT), con la creación de la Compañía Telefónica Nacional de España (CTNE) y se establecieron aranceles para proteger a los productores nacionales de la competencia de los productos extranjeros.

${ }^{199}$ Entre 1923 y el final del Régimen se construyeron casi $10.000 \mathrm{Km}$. nuevos de carreteras. Además, se mejoró el estado de las carreteras ya existentes. En 1926, se creó el Patronato del Circuito Nacional de Firmes Especiales, con el objetivo de reparar la red radial de carreteras, unos $7.000 \mathrm{Km}$. Hasta el año 1930 se destinaron cerca de 450 millones de pts. para mejorar el estado de unos $2.800 \mathrm{Km}$. de carreteras. El gasto derivado de las obras de mejora se sufragaba mediante la contratación de empréstitos con cargo a los presupuestos del Estado. Cfr. GARCÍA QUEIPO DE LLANO, Genoveva, Alfonso XIII: la modernización fallida, Madrid, Temas de hoy, 1996, pp.116-117.
} 
En noviembre de 1926, para emprender una reforma laboral, quiso dotar de todo un entramado institucional a las relaciones entre patronos y trabajadores y constituyó la Organización Corporativa Nacional ${ }^{200}$, cuya base la componían los comités paritarios, comités mixtos de obreros y patronos. Con esta medida, pretendía que las relaciones obrero-patrono siguieran un cauce pacifico de negociación. En la puesta en práctica de la organización corporativa de las relaciones laborales, el ministro de Trabajo pudo contar con el apoyo de los socialistas y la Unión General de Trabajadores (UGT), sindicato dominante en los comités mixtos. Este apoyo, junto con la represión del anarquismo, fueron las principales causas del logro de un periodo de cierta tranquilidad social, la ansiada paz social.

\section{La reacción contra la Dictadura}

Anarquistas y nacionalistas destacaron por ser los grupos políticos más reprimidos por la Dictadura, aunque, a decir verdad, también fueron los que menos hicieron peligrar el régimen. El verdadero riesgo procedía de las filas de los políticos dinásticos que solicitaron al rey el regreso a la normalidad constitucional aunque su pretensión no obtuvo el éxito debido a la actitud prodictadura del rey Alfonso XIII ${ }^{201}$. El rey no pretendía presionar a Primo de Rivera para que abandonase el poder y los políticos dinásticos consideraron necesario un pronunciamiento civil que con el apoyo militar, devolviera la normalidad constitucional al país. Melquiades Álvarez y Romanones, apoyados por los generales Aguilera y Weyler, llevaron a cabo un pronunciamiento pacífico conocido como la «Sanjuanada» ${ }^{202}$. Este pronunciamiento, aunque no significó un peligro real para la existencia del régimen dictatorial, demostraba la negativa de algunos sectores sociales de la sociedad a conformarse con la situación creada tras el Golpe de 1923.

\footnotetext{
${ }^{200}$ Todos los sectores industriales y comerciales se incluían en una corporación y quedaban sometidos a la jurisdicción laboral. Vid. ORTIZ DE ORRUÑO LEGARDA, José María, RIVERA BLANCO, Antonio y UGARTE TELLERÍA, Javier, Movimientos sociales en la España contemporánea, Vitoria, Abada, 2008, pp. 323-324.

${ }^{201}$ En noviembre de 1923, Melquiades Álvarez y Romanones, presidentes del Congreso y Senado respectivamente, recordaron al rey su obligación de convocar las Cortes y en respuesta, el Directorio Militar destituyó a ambos de sus cargos en las Cámaras.

${ }^{202}$ Conocido con el nombre de «Sanjuanada» porque tuvo lugar en la noche de San Juan, el 24 de junio de 1926. Vid. MORENO LUZÓN, Javier, (Edición.), Alfonso XIII: un político en el trono, Madrid, Marcial Pons Historia, 2003, p. 386.
} 
Cobra significancia que por primera vez desde 1923, el Ejército no apareciera como un sólido bloque detrás de su jefe. Además, la actitud del rey en relación a la restauración del parlamentarismo provocó un alejamiento con respecto a la Monarquía de los antiguos políticos dinásticos, circunstancia que en 1931 acabaría con la institución monárquica. El descontento se percibía entre las filas de los políticos y también los militares, en 1926, se sumaron a las filas de agraviados del Régimen. Primo de Rivera llevó a cabo la reforma del Ejército sin atacar el verdadero problema del estamento militar, el número exagerado de oficiales y la escasa modernización del mismo. Sin embargo, aprobó la abolición de la escala cerrada de ascensos, lo que granjeó al dictador la enemistad de elementos militares importantes.

\section{EI fin de la Dictadura}

El 5 de julio de 1929, se presentaba en la Asamblea Nacional Consultiva el anteproyecto de una nueva Constitución que aprobaba la creación de un régimen de carácter autoritario, corporativo y antidemocrático. Este anteproyecto constitucional causó rechazo entre los dirigentes de la Dictadura, incluso al propio dictador. Entre los planes de Primo de Rivera no se encontraba la restitución del sistema parlamentario liberal, pero no existía una concepción clara de cuál debería ser el tipo de sistema político que lo sustituyera. La falta de un proyecto político claro fue una de las principales razones del fracaso de la Dictadura en su intento de perpetuarse en el poder. La Dictadura había sido tolerada por la sociedad en base a su política económica, que a pesar de sus carencias había generado crecimiento y cierta sensación de bienestar social. 
En el año 1929, el mundo conoció una de las más graves crisis económicas de la historia del capitalismo a nivel mundial y una economía frágil como la española no podía quedar al margen. Fue un año de mala cosecha, la situación internacional influyó negativamente en la balanza comercial española y, por si fuera poco, la peseta se depreció. La depresión económica ${ }^{203}$ terminaba con un periodo de prosperidad y la economía, legitimadora de la existencia del régimen dictatorial, se volvía contra el $\operatorname{mismo}^{204}$.

Ante la creciente agitación social, el dictador respondió con mayor represión ${ }^{205}$, militares, políticos, obreros e incluso estudiantes ${ }^{206}$ mostraban su oposición a la continuidad de la Dictadura y al dictador que, el día 28 de enero de 1930, enfermo, solo y decepcionado presentó su dimisión al rey. El final de la Dictadura llegó como lo hiciera en sus inicios, casi desapercibido para el conjunto de la población. En la Diputación Provincial de Palencia, el gobernador civil, Joaquín Sarmiento Rivera, en la sesión plenaria extraordinaria de 20 de marzo de 1930 parafraseando a Fray Luis de León, cuando en 1576 tras cinco años de presidio pronunció la famosa frase, Dicebamus hesterna die, manifestaba que la Dictadura había sido un suspiro en el acontecer institucional de la Asamblea Provincial palentina:

«Aquí estamos otra vez constituyéndola, con ligeras modificaciones, los que antes la integramos. Otra vez nos disponemos a actuar, nosotros, a los que se había condenado a inhabilitación perpetua. Un hecho desgraciado, recientemente ocurrido le impide dar la merecida réplica a la persona que creyó haber pronunciado esa sentencia inapelable, al inaugurar el periodo dictatorial felizmente fenecido, pero ante los restos de la persona, como caballero se descubre y reza como cristiano. ${ }^{207}$

\footnotetext{
${ }^{203}$ Vid. PALAFOX GAMIR, Jorge, «El capitalismo español en la depresión de los años treinta», Información Comercial Española, ICE. Revista de economía, № 514 (1976), pp. 110-118.

${ }^{204}$ En Palencia y en esas fechas, se produjeron tal cantidad de robos que el depositario de Fondos Provinciales de la Diputación Provincial recomendaba que el ordenanza-auxiliar vigilase por la noche la Caja de Fondos Provinciales, que contaba con una existencia de 200.000 pts. por día (depósitos definitivos de contratistas y sumas en metálico necesarias para los pagos ordinarios que no realizaban en el día por no presentarse los acreedores a cobrar), y señalaba la conveniencia de trasladar los depósitos definitivos constituidos en valores a la sucursal del Banco de España en la capital.

${ }^{205}$ Real Orden C. de la Presidencia del Consejo de Ministros en la que se disponía que en los Centros de la Administración Provincial se abriesen cuadernos en los que figurasen los nombres de todos los funcionarios y en los que hiciese el concepto de capacidad, laboriosidad, aptitud física y discreción política, «(...) interesando conocer este último aspecto únicamente de aquellos que, con publicidad y escándalo, se manifiesten enemigos del régimen y procuren su desprestigio y quebranto». A.D.P.P, L.A.C.P. 145, 14-II-1929.

${ }^{206}$ Las protestas universitarias causaron graves daños a la imagen de la Dictadura, que vio cómo su prestigio menguaba con rapidez en todos los ámbitos de la sociedad.

${ }^{207}$ A.D.P.P, L.A.P.D. 148, 20-III-1930.
} 
La Dictadura fue concebida como una especie de remedio milagroso para los males que aquejaban al sistema de la Restauración, un tratamiento curativo que devolvería la salud al sistema turnista. Primo de Rivera, durante seis años de dictadura, no pudo sino constatar la imposibilidad de reformar y de crear una alternativa viable al sistema. En 1930, parecía imposible volver a la situación política de 1923 y en el ambiente se respiraba una sensación de cambio irreversible. La Dictadura fue incapaz de establecer una alternativa viable al parlamentarismo, también en entredicho y con él la institución eje sobre la que desde 1876 había girado el sistema canovista: la Monarquía. Alfonso XIII pagaría caro su apoyo al experimento fallido del dictador.

\section{La caída de la Monarquía}

Alfonso XIII fue consciente de que su papel en la Dictadura había dañado su imagen pública y de que, tras la caída de Primo de Rivera y a falta de un sistema político mejor que el parlamentarismo, debía apoyarse en la Constitución de 1876 para recuperar su posición política. Tras la actitud de desprecio del monarca hacia los viejos políticos dinásticos, estos se mostraron poco partidarios de acceder a sus deseos recurriendo a un militar para formar Gobierno, el general Dámaso Berenguer ${ }^{208}$, jefe de su casa militar. Berenguer, en los siguientes meses y de acuerdo con el rey, adoptó una serie de medidas ${ }^{209}$ que intentaban borrar toda señal de anterior connivencia entre el dictador y el rey. En 1930, la sociedad no era un cuerpo social desmovilizado y apático, la sociedad se había industrializado y la población contaba con una mayor cultura y conciencia política. La ciudadanía no olvidaba lo sucedido en 1923, ni tampoco estaba dispuesta a permitir el regreso de un sistema no participativo, del que tan sólo podía ser espectador pasivo. Sánchez Guerra y Melquiades Álvarez no olvidaban la actitud del rey hacia ellos y, junto con otros políticos, exigieron al Gobierno Berenguer la convocatoria de Cortes constituyentes. La animadversión hacia el rey fue tal que varios políticos monárquicos optaron por pasar al bando republicano ${ }^{210}$.

\footnotetext{
${ }^{208}$ Ministro de la Guerra en el Gobierno de García Prieto, en 1918, se mantuvo al frente del Ejecutivo hasta el 14 de febrero de 1931, fecha de su dimisión.

${ }^{209}$ Disolución de la Asamblea Nacional, restitución de los profesores universitarios sancionados a sus plazas, abandono del proteccionismo económico, etc.

${ }^{210}$ Entre los monárquicos que «desertaron»a las filas republicanas se encontraba el ex ministro liberal Niceto Alcalá Zamora y Miguel Maura, hijo de Antonio Maura.
} 


\section{El fracaso del gobierno Berenguer}

Alfonso XII, conocedor del deseo de cambio en la sociedad y de su delicada posición, contactó, en junio de 1930, con el líder liberal Santiago Alba, exiliado en París. Alba recomendó al monarca la reforma de la Constitución con la intención de dotar a la Monarquía de un carácter democrático semejante al de la Monarquía británica. La reforma constitucional pudo asegurar la continuidad de la institución monárquica en España pero el proyecto no se llevó a cabo ${ }^{211}$. Ante la desorganización de los liberales, el rey contaba con los conservadores, como única opción válida para formar Gobierno. García Prieto y Romanones, ante el temor de que Berenguer volviera a las viejas prácticas en las elecciones a Cortes, exigieron que se celebrasen elecciones municipales y provinciales, ya que consideraban que era más difícil el control del Gobierno en el ámbito local ${ }^{212}$. El Gobierno Berenguer hizo caso omiso de las peticiones liberales y, el día 8 de febrero de 1931, se convocaron de forma oficial las elecciones parlamentarias. Liberales, republicanos y socialistas anunciaron que no participarían en las elecciones, para negar legitimidad a las Cortes y al Gobierno que resultara de estas. Berenguer solo contaba con el apoyo de los conservadores y el rey Alfonso XIII consideró peligrosa para la continuidad de la Monarquía la falta de respaldo al proyecto conservador.

Hasta 1923, el rey confiaba en que el partido en la oposición actuaría con lealtad institucional hacia el Gobierno, pero en 1931 esta idea de gobierno había desparecido del corpus ideológico de los liberales. El 14 de febrero de 1931, el general Berenguer presentó su dimisión al rey, y este la aceptó. Alfonso XIII encargó la formación de Gobierno a los constitucionalistas liderados por Sánchez Guerra, declarado «monárquico sin rey» y descontento con la actitud de Alfonso XIII durante la Dictadura de Primo de Rivera. La falta de apoyo de la izquierda a Sánchez Guerra le dejaba en una situación de soledad política semejante a la que había llevado a Berenguer a la dimisión, por lo que el político constitucionalista renunció a formar Gobierno.

\footnotetext{
${ }^{211}$ Santiago Alba era partidario de celebrar unas elecciones limpias a Cortes para reformar la Constitución con posterioridad. Ni siquiera sus propios correligionarios querían renunciar a su parcela de poder en unas elecciones sin fraude, conscientes del éxito de socialistas y republicanos, especialmente en el ámbito urbano.

${ }^{212}$ En 1910, en las elecciones de diputado provincial en el Distrito de Astudillo-Baltanás, el candidato ministerial del Partido Liberal fue derrotado por el candidato del Partido Conservador, Manrique Pozo y de ello se vanagloriaban sus compañeros conservadores. El diputado provincial Santander Gallardo señalaba que: «(...) felicitando por ello a los que con una gran valentía han venido a demostrar lo arraigados que se hallan los principios del Partido Conservador en dicho Distrito, a pesar de los medios puestos en juego para el triunfo del candidato ministerial». A.D.P.P., L.AP.D. 110, 5-X-1910.
} 
La situación de inestabilidad resultaba cada vez más angustiosa para el monarca $\mathrm{y}$, como ocurriera en el pasado, se eligió la fórmula del Gobierno de concentración como única opción para salvar la situación política. El almirante Aznar $^{213}$ fue la persona elegida para presidir el nuevo Gobierno, contaba para ello con la colaboración de políticos liberales como Romanones y García Prieto, conservadores destacados como De la Cierva y también un ministro de la Lliga. El Gobierno Aznar aceptó la petición de los liberales de celebrar las elecciones municipales y provinciales antes que las legislativas y fijó como principal objetivo el regreso a la normalidad constitucional. Las elecciones constituían la mejor vía para poner en funcionamiento el sistema parlamentario y con las municipales comenzaría el proceso.

\section{La oportunidad del republicanismo}

En 1926, en pleno auge de la Dictadura primorriverista, la mayor parte de los partidos republicanos habían limado sus diferencias y se habían integrado en la Alianza Republicana $^{214}$. Los republicanos no protagonizaron las intrigas contra la Dictadura, ese papel lo desempeñaron los políticos monárquicos aunque, con la poca ilusión que la vuelta a la Monarquía parlamentaria generaba en la sociedad, el sistema republicano ofrecía una alternativa que para muchos políticos y ciudadanos aparecía como la promesa de un futuro prometedor.

El 17 de agosto de 1930, ante la situación de la política española, Alianza Republicana, el Partido Radical Socialista, Derecha Liberal Republicana, partidos republicanos de ámbito regional ${ }^{215}$ y republicanos catalanes, firmaron el llamado «Pacto de San Sebastián» ${ }^{216}$, que recogía, entre otras, las aspiraciones autonomistas de Cataluña. El objetivo principal del pacto era terminar con la Monarquía y proclamar la República.

\footnotetext{
${ }^{213}$ Ministro de Marina en 1923, con el Gobierno de García Prieto.

${ }^{214}$ El Partido Radical de Lerroux y Acción Republicana, liderada por Manuel Azaña, eran dos de los principales grupos integrados en la Alianza Republicana. Cfr. ALTED VIGIL, Alicia, «La oposición republicana», en TOWNSON, Nigel, (Edición.), El republicanismo en España (1830-1977), Madrid, Alianza Editorial, 1994, pp. 223-264. Manuel Azaña, tras abandonar el Partido Reformista de Melquiades Álvarez, se había incorporado al denominado Grupo de Acción Republicana.

${ }^{215}$ Entre ellos destacaba la Organización Republicana Gallega Autónoma, que lideraba Santiago Casares Quiroga, delegado por el Comité Revolucionario Nacional (CNR) para coordinar con el capitán Fermín Galán Rodríguez la sublevación de la guarnición de Jaca. Tras el fracaso del pronunciamiento, fue encarcelado.

${ }^{216} C f r$. GIL PECHARROMÁN, Julio, «Vísperas republicanas. El pacto de San Sebastián», La aventura de la historia, $\mathrm{N}^{\circ} 82$ (2005), pp. 54-59.
} 
Durante el mes de octubre de 1930, los socialistas, que habían apoyado a Primo de Rivera, y la UGT decidieron sumarse al movimiento republicano en su afán por derribar la Monarquía. Los políticos republicanos necesitaban de la influencia socialista sobre la clase obrera para, a semejanza de los pronunciamientos decimonónicos en España, iniciar un golpe militar con el apoyo del pueblo. Para proclamar la República se decidiría entre dos opciones, la vía electoral y la insurreccional, y ninguna de las dos opciones se descartó en San Sebastián. Los acontecimientos posteriores dieron cuenta de que los republicanos, al igual que los monárquicos en 1876 y Primo de Rivera en 1923, optaron por la opción subversiva y el día 12 de diciembre de $1930^{217}$ la guarnición de Jaca se sublevó contra el Gobierno. La intentona fracasó y su protagonista, el capitán Fermín Galán, fue condenado y fusilado. El 12 de abril de 1931, cuatro meses después del intento golpista, se celebraron las elecciones municipales que permitieron el comienzo de la II República en España. Los republicanos, conscientes de la oportunidad que la celebración de unas elecciones suponía, realizaron una campaña en la que quedaría claro no solo quiénes serían los próximos alcaldes, sino también si el resultado era favorable a los intereses republicanos. Las elecciones municipales ${ }^{218}$ podrían convertirse, como sucedió, en una especie de plebiscito sobre la forma de Gobierno más deseada por el pueblo español. Los resultados de las elecciones municipales no suponían de forma irremediable la caída de la Monarquía, pues aún no se habían celebrado las elecciones a Cortes y el resultado podía resultar más favorable a los intereses de los partidos dinásticos. Pero el rechazo mostrado por el Gobierno ${ }^{219}$ del almirante Aznar, apoyado por el rey, fue tan grande que también la Monarquía quedaba desautorizada para seguir al frente de la nación. El propio Alfonso XIII lo entendió así y el día 14 de abril, comunicó al Gobierno su intención de exiliarse y ceder su autoridad a un Gobierno para la convocatoria de Cortes constituyentes. Ese mismo día se proclamó la II República ${ }^{220}$, que fue recibida con esperanza por amplios sectores de la población, provocando un cambio de Régimen de forma pacífica.

\footnotetext{
${ }^{217}$ El Gobierno provisional de la República había fijado como fecha de la insurrección el día 15 de diciembre. $C f r$ r. BERTRAND FAUQUENOT, Luis, «Mito y verdad de Fermín Galán: la sublevación de Jaca, 12 de diciembre de 1930», Historia 16, No 109 (1985), pp. 11-32.

${ }^{218} C f r$. REQUENA GALLEGO, Manuel, «El triunfo monárquico en las elecciones municipales de 1931 en Castilla-La Mancha», Hispania: Revista española de historia, $\mathrm{N}^{\circ} 190$ (1995), pp. 673-691. Vid. VILLALAÍN GARCÍA, Pablo, Las elecciones municipales de 1931 en Madrid, Madrid, El Avapiés, 1987.

${ }^{219}$ Las candidaturas republicanas y socialistas vencieron en 41 de las 50 capitales de provincia.

${ }^{220}$ Vid. GIL PECHARROMÁN, Julio, La Segunda República española (1931-1936), Madrid, UNED, 1995.
} 
En la sesión de la Comisión Provincial, celebrada el día 10 de abril de 1931, última antes de la proclamación de la II República, el secretario hacía constar que se había anulado la sesión señalada para el 27 de abril por falta de asistencia de un número suficiente de diputados provinciales, al presentar la renuncia de sus cargos al Gobierno de la provincia con motivo del establecimiento del nuevo régimen republicano. Dichas renuncias se admitieron y se designó la Comisión Gestora que habría de encargarse interinamente de la Administración Provincial, conforme con lo dispuesto en el Decreto de la Presidencia del Gobierno provisional de 21 de abril de 1931. Las Actas de las sesiones celebradas por la Comisión gestora se extendieron en el Libro destinado a las del Pleno de la Diputación.

Así se ponía fin a medio siglo de Régimen monárquico, un sistema concebido en el siglo XIX para acabar con la inestabilidad institucional propia del constitucionalismo español y que se mostró demasiado rígido para adaptarse a los cambios que fueron sucediéndose a lo largo de su prolongada vigencia. España, desde 1875, había evolucionado y el sistema turnista no fue capaz de adaptarse al ritmo del progreso de la sociedad. Los políticos dinásticos no supieron, o no quisieron incorporar al régimen de la Restauración a nuevos partidos y convirtieron al sistema en un organismo endogámico incapaz de regenerarse. Todos los intentos que se realizaron en este sentido fallaron y el último de ellos, la Dictadura de Primo de Rivera, incluso aceleró el proceso de descomposición del sistema. Cánovas concibió la Restauración como una especie de seguro de estabilidad política tras los convulsos decenios de existencia del sistema liberal en España. La Restauración desarrolló de forma definitiva las estructuras de un Estado liberal en el que durante mucho tiempo fueron los políticos, y no los militares, los protagonistas de la vida política española. En la Restauración, pudo desarrollarse la legislación básica de todo Estado de Derecho y la economía, a pesar de las crisis cíclicas típicas del Capitalismo, vivió momentos de crecimiento que impulsaron a la nación por el camino de la industrialización y la modernización. La sociedad, especialmente en el ámbito urbano, alcanzó un nivel cultural hasta entonces desconocido, por lo que puede afirmarse que en este periodo comenzó a formarse la sociedad civil en España. Todas estas circunstancias contribuyeron a equiparar al país a las naciones de su entorno, salvaguardando las peculiaridades propias de su historia. A lo largo del espacio temporal ocupado por esta etapa política, España pasó a convertirse en un Estado moderno. 
Las dificultades superadas por los políticos liberales que forjaron el sistema canovista fueron muy numerosas; el problema de las Colonias, factor desestabilizador hasta el año 1898, o el conflicto marroquí constituyeron, en el campo de la política exterior, interferencias decisivas en la política interna española. La crisis socioeconómica, que a partir 1917 se instaló en el país, tampoco favoreció una apertura del sistema a otros sectores sociales ajenos a los partidos dinásticos. Además, el problema de los nacionalismos, especialmente el nacionalismo catalán, había evolucionado desde el regionalismo hasta posiciones de un nacionalismo rupturista con el sistema turnista. Todos estos problemas podrían haber puesto en riesgo a cualquier sistema político no solo en España, sino también en Europa. Sin embargo, el principal motivo del desprestigio del sistema y de la caída de la Monarquía se encontraba en la esencia misma del funcionamiento del régimen de la Restauración, concebido como un sistema cerrado en el que solo los partidos dinásticos podían participar. La imposibilidad de incorporar al sistema al resto de fuerzas políticas, republicanos y socialistas, provocó que estas buscasen la oportunidad de participar en el juego político en el cambio de sistema. En 1876, dados los antecedentes históricos del siglo XIX en España, la idea de turnarse pacíficamente en el poder pudo parecerle a Cánovas la solución perfecta para un país atrasado en lo económico y lo social, pero a comienzos del siglo XX la sociedad había evolucionado más deprisa que el propio sistema político. La mayor parte de los problemas que aquejaban al régimen podrían haberse resuelto mediante el desarrollo de un sistema parlamentario verdaderamente democrático, que hubiese facilitado la integración de todas las sensibilidades políticas y no solo de un grupo de privilegiados. En resumen, los políticos dinásticos no quisieron, o no pudieron, sentar las bases de un sistema democrático partiendo del régimen de notables que habían conformado y esta realidad constituyó la principal causa de la desaparición del sistema de la Restauración, que dio lugar al advenimiento de la II República, un régimen democrático abierto a la participación de todos los actores políticos y sociales del momento. Desde el año 1898 hasta el final de la Restauración, el «Santo Grial» del sistema fue el concepto del regeneracionismo; la sociedad, los políticos e incluso el monarca fueron conscientes de la necesidad de reformar el sistema. Sin embargo, esta renovación fue imposible y las circunstancias históricas se llevaron por delante el primer experimento serio de lo que debería ser una Monarquía parlamentaria de estructura plenamente moderna. 


\section{Marco Legislativo}

Durante la etapa de la Restauración continuó la pugna secular entre las fuerzas centralizadoras representadas por los partidos políticos a nivel nacional, tanto conservadores como liberales, y aquellas que defendían una mayor independencia administrativa de las entidades locales, ayuntamientos y diputaciones provinciales, fundamentalmente ${ }^{221}$. En este escenario hemos de enmarcar las sucesivas disposiciones legislativas que intentaron establecer la forma de organización y funciones de los municipios y las corporaciones provinciales, puesto que la Constitución de 1876, al no contemplar de forma explícita la normativa que les afectaba, planteaba que fuesen las leyes específicas las que regulasen todos los aspectos concernientes a su regulación.

\section{La Constitución de 1876}

Una vez restaurada la Monarquía borbónica, Cánovas debía dotar al nuevo sistema de un marco institucional y jurídico que regulase la convivencia política de la nación. El Estado liberal español había generado una sucesión de constituciones a lo largo de su trayectoria histórica, textos que reflejaban la ideología de las fuerzas en el poder. Las más próximas en el tiempo de la Restauración eran la moderada de 1845 y la progresista de 1869. Eran estas las dos opciones que se presentaban al líder conservador que, en contra de la opinión de algunos sectores de su propio Partido, se decidió por elaborar un nuevo texto constitucional. Consciente de la necesidad de que la nueva norma contase con el máximo consenso posible, reunió a la hora de su aprobación ${ }^{222}$ a antiguos senadores y diputados en una Asamblea de la que salió una Comisión de «notables»y, de esta, se seleccionó una subcomisión que bajo la dirección de Alonso Martínez y la supervisión del propio Cánovas, fue la encargada de conformar el texto que más larga vigencia ha tenido en nuestra historia constitucional.

\footnotetext{
${ }^{221}$ Cfr. TUSELL GÓMEZ, Javier, El problema político en la reforma de la administración local (19001936), Madrid, Instituto de Estudios administrativos, 1973, pp. 29 y ss.

${ }^{222} \mathrm{Cfr}$. SÁNCHEZ-ARCILLA BERNAL, José, Historia de las instituciones político-administrativas contemporáneas (1808-1975), Madrid, Dykinson, 1994, p. 93.
} 
La Constitución de 1876 establecía como forma de Gobierno una Monarquía parlamentaria, en la que el poder efectivo, en manos de los ministros del Gobierno, los hacía responsables ante las Cortes. Por lo que respecta a la Administración Local, diputaciones y ayuntamientos, la Constitución no recogía de forma explícita las normas que regulaban su formación y funcionamiento y establecía que fueran leyes particulares las encargadas de regular estos aspectos. Los principios rectores del Régimen Municipal y Provincial quedaban reflejados en el Título 10, en sus arts. 82 y $83^{223}$. El texto constitucional dejaba claro que estas leyes nunca podrían atribuir a los organismos locales funciones que entrasen en conflicto competencial con el Estado. El art. 84 contemplaba los siguientes principios ${ }^{224}$ :

«Primero. Gobierno y dirección de los intereses peculiares de la provincia o del pueblo por las respectivas corporaciones.

Segundo. Publicación de los presupuestos, cuentas y acuerdos de las mismas.

Tercero. Intervención del rey, y, en su caso, de las Cortes, para impedir que las diputaciones provinciales y los ayuntamientos se extralimiten de sus atribuciones en perjuicio de los intereses generales y permanentes.

Cuarto. Determinación de sus facultades en materia de impuestos, a fin de que los provinciales y municipales no se hallen nunca en oposición con el sistema tributario del Estado.»

La Constitución pretendía ser una norma flexible que contemplaba los principios básicos de regulación de la convivencia y dejaba un amplio margen al legislador para el posterior desarrollo de estos pilares normativos, que, de esta forma, dispondría de libertad suficiente para adecuar la legislación a las circunstancias políticas del momento. Esta faceta se aprecia también en el terreno del Gobierno local, puesto que si bien se establecían unos límites generales sobre el funcionamiento de los entes administrativos locales, no se señalaban normas específicas al respecto, de las que se ocuparía una futura legislación.

\footnotetext{
${ }^{223}$ Art. 82. «En cada provincia habrá una Diputación Provincial elegida en la forma que determine la ley y compuesta del número de individuos que se señale. Art. 83. Habrá en los pueblos alcaldes y ayuntamientos. Los ayuntamientos serán nombrados por los vecinos a quienes la ley confiere este derecho».

${ }^{224} C f r$. ORDUÑA REBOLLO, Enrique y COSCULlUELA MONTANER, Luis, Historia de la Legislación de Régimen Local, Madrid, Portal Derecho, S.A., 2008, p. 143.
} 
La Constitución de 1876 introducía dos matices importantes en la consideración jurídica de la institución provincial con respecto a las Constituciones precedentes. En primer lugar, reconocía a las diputaciones provinciales la categoría de Administración Local, abandonando la consideración de Administración periférica del Gobierno anterior. Sin embargo, y en contradicción o en compensación, «en el aspecto negativo se consagraba el intervencionismo gubernamental, con su relación de suspensiones de acuerdos, concejales y hasta ayuntamientos enteros.» 225

\section{El régimen provincial}

\section{Legislación canovista. Ley de Bases de 16 de diciembre de 1876}

El 23 de mayo de 1876, el ministro de la Gobernación, Romero Robledo, presentó a las Cortes un Proyecto de Ley de Reforma de la Administración Provincial. Este Proyecto fue concebido como el instrumento legal que devolvería al Gobierno central parte del poder cedido a las instituciones locales en el tránsito revolucionario de 1868. La Ley era reflejo de la concepción centralista que albergaba el liberalismo moderado sobre el Estado. El Proyecto se concretó en la Ley de Bases de 16 de diciembre de 1876, que reformaba las Leyes Municipal y Provincial de 20 de agosto de 1870 y que, sin aspirar a reformar la estructura de las diputaciones provinciales, pretendía reformar la Ley Provincial de 1870 con un sentido más centralizador. El espíritu de la norma era restrictivo, lo que suponía un retroceso con respecto a la legislación local anterior. Esta ley corregía la Ley Electoral de 20 de agosto de 1870 al establecer que se elegirían tres diputados provinciales por cada Partido Judicial, con un mínimo de 20 y un máximo de 30, sirviendo de referencia el número de habitantes. El sufragio universal que establecía la Ley Electoral de 20 de agosto de 1870 fue sustituido por el sufragio censitario. El Gobierno se reservaba la facultad de nombrar subgobernadores, potestad que nunca llegó a utilizar, de acuerdo con lo previsto en el Real Decreto de 31 de agosto de 1875. La Diputación Provincial presentaba una terna al rey, que nombraba a los vocales de la Comisión Provincial y a su vicepresidente, reservándose al monarca las facultades de suspensión y separación de los miembros de la Comisión Provincial.

\footnotetext{
${ }^{225}$ Ibidem, p. 144.
} 
La Ley atribuía a la Comisión Provincial (Diputación restringida, permanente y ejecutiva) funciones de cuerpo consultivo, siempre que el gobernador estimase oportuno pedirle su dictamen; además, le otorgaba la consideración de Tribunal ContenciosoAdministrativo en los asuntos que determinaban los arts. 83 y 84 de la Ley de 25 de septiembre de 1863, por lo que eran competentes en «las cuestiones referentes al cumplimiento, inteligencia, rescisión y efectos de los contratos y remates celebrados con los ayuntamientos para toda especie de servicios y Obras Públicas» ${ }^{226}$. No menos importante fue la capacidad de resolución en los incidentes de Quintas que la ley atribuía a la Comisión Provincial.

La Ley recortaba el poder de las corporaciones provinciales y aseguraba el control gubernamental de las mismas a través de la figura del gobernador, al que atribuía la facultad de presidir la Diputación Provincial y la Comisión Provincial con derecho de voto, a diferencia de lo que marcaba la Ley Provincial de 1870 en su Capítulo III $^{227}$. El Gobierno se reservaba el derecho de nombrar sustituto en caso de enfermedad o ausencia del gobernador. El control se hacía extensivo al terreno más sensible para cualquier Administración, el económico. El art. 80 de la Ley Provincial de 2 de octubre de 1870, marcaba como condición indispensable para la aprobación del Presupuesto el voto de la mayoría absoluta del total de los diputados provinciales. Esa «autonomía presupuestaria», desaparecía en la Ley de Bases de 16 de diciembre de 1876. La Modificación segunda de la décima Disposición del art. 2, determinaba que en el mes de abril, las diputaciones remitirían, por medio del gobernador, el Presupuesto aprobado al Ministerio de la Gobernación «para el doble efecto corregir las extralimitaciones legales, si las hubiere, e impedir que se perjudiquen los intereses generales de los pueblos.» ${ }^{228}$ La Diputación solo podía disponer sin el acuerdo del gobernador de la partida de imprevistos.

\footnotetext{
${ }^{226}$ Art. 2, 4a, $2^{\text {a }}$. Ley de Bases 16-XII-1876.

${ }^{227}$ Art. 9. Ley Provincial 20-VIII-1870.

${ }^{228}$ Art. 2, $10^{\mathrm{a}}, 2^{\mathrm{a}}$. Ley de Bases 16-XII-1876.
} 
Esta Ley daba al traste con la descentralización que se apuntaba en la Ley Provincial de 1870 pues la Disposición séptima del art. 2, dejaba claro que las diputaciones provinciales ejercerían las competencias exclusivas contempladas en la Ley Provincial de 1870 pero con una reserva fundamental, con «sujeción a las leyes especiales y reglamentos de los diversos ramos de la Administración pública.» ${ }^{229}$ La Constitución de 1876 ya contemplaba, en su art. 84, la posibilidad de confrontación entre las competencias estatales y provinciales. Además, la Ley Provincial de Bases de 16 de diciembre de 1876 regulaba en su art. 2, Disposición quinta, la necesidad de que, en previsión de conflictos competenciales entre Estado y diputaciones provinciales, representadas por la Comisión Provincial, esta estuviese formada por dos diputados provinciales que fuesen letrados y ante la imposibilidad de que esto fuese así, que fueran ingenieros jefes o jefes de la Administración. Bajo la denominación de abogado consultor y representante, la Diputación Provincial de Palencia siempre contó, como por ejemplo en $1880^{230}$, con diputados licenciados en derecho.

\section{Ley Provincial de 2 de octubre de 1877}

La Ley Provincial de 2 de octubre de 1877 desarrolló las Bases de la Ley de 16 de diciembre de 1876. Esta Ley solo estuvo en vigor durante cinco años, siendo sustituida por la Ley de 29 de agosto de 1882. El gobernador seguía jugando un papel fundamental en la vida de la institución provincial y no solo se mantenían las atribuciones que contemplaba la Ley de Bases de 16 de diciembre de 1876, incluida la presidencia de la Diputación y Comisión Provincial con derecho a voto, sino que la ley las ampliaba a los aspectos más nimios del funcionamiento de las diputaciones provinciales $^{231}$. En lo que afectaba a la cuestión electoral no hubo cambios significativos respecto a la Ley de 16 de diciembre de 1876.

\footnotetext{
${ }^{229}$ Art. 2, 7 a . Ley de Bases 16-XII-1876.

${ }^{230}$ A.D.P.P., L.A.P.D. 50, 5-XI-1880. El Diputado letrado Juan Martínez Merino, fue elegido para defender «(...) en los negocios contenciosos en que se hallen en oposición los intereses del Estado y de la Provincia».

${ }^{231}$ Art. 9, $5^{\circ}$. Ley Provincial 2-X-1877.
} 


\section{Ley Provincial de 29 agosto de 1882}

La ley que sustituyó a la efímera de 1877 fue la Ley Orgánica Provincial de 29 de agosto de 1882. Elaborada por el ministro de la Gobernación del Gobierno liberal de Sagasta, Venancio González y Fernández, al contrario que la Ley precedente, mantendría su vigencia hasta la aprobación del Estatuto provincial de 1925, en plena Dictadura primorriverista. Esta Ley introducía como principales novedades ${ }^{232}$ la ampliación del sufragio y la participación de las minorías mediante la elección por circunscripciones. Consideraba a la provincia como un ente administrativo subordinado del Estado y en una posición jerárquica por encima de los ayuntamientos ${ }^{233}$. El art. 1 dejaba claro qué lugar ocupaba la provincia en el entramado institucional surgido de esta Constitución, «El territorio de la Nación española en la Península e islas adyacentes, se divide para su administración y régimen en provincias». Como señalaba Adolfo Posada en su obra sobre el Régimen Local español, en la provincia «se encuentra una administración de los intereses del Estado y una derivación subordinada del poder central ${ }^{234}$. En este ámbito, resultaban ser los órganos administrativos encargados de ordenar y supervisar el buen funcionamiento de los servicios del Estado en el ámbito territorial de la provincia. Además, gestionaban los intereses supramunicipales aunque, dada su constante carencia hacendística, su labor en este terreno fue insuficiente. El Estado acabó por asumir los servicios que las diputaciones provinciales no podían gestionar por falta de medios económicos y de esta forma se contribuyó a perpetuar la subordinación de la institución provincial a los intereses del poder central. La ley, al igual que sucedía con la legislación provincial precedente, otorgaba un papel protagonista a la figura del gobernador en la Administración de la provincia. El Capítulo III, establecía las condiciones que debían reunir los candidatos al nombramiento y en el Capítulo IV, art. 1, se desarrollaban las atribuciones del cargo de gobernador, máximo representante del Gobierno en la provincia en los ámbitos del orden público y del administrativo.

\footnotetext{
${ }^{232}$ Cfr. SÁNCHEZ- ARCILLA BERNAL, José, Historia de las instituciones político administrativas contemporáneas (1808-1975), op. cit., p. 284.

${ }^{233}$ Ibidem, p. 284

${ }^{234} C f r$. GONZÁLEZ-POSADA y BIESCA, Adolfo, Evolución legislativa del régimen local en España: 1812-1909, op. cit., p. 272.
} 
El gobernador, además de representante del Estado en la provincia, era el garante del funcionamiento adecuado de los servicios de la Administración Central en la misma, de forma que, al finalizar el año, presentaba una especie de «rendición de cuentas». El art. 26 del Capítulo IV, recogía la obligación del gobernador de elevar a la Presidencia del Consejo de Ministros una Memoria en la que quedase constancia del «(...) estado de la provincia en los diferentes ramos de la Administración sometidos a su autoridad, y proponga cuanto pueda contribuir al adelanto y desarrollo intelectual y moral del país y al fomento de sus intereses materiales. ${ }^{235}$ Los ramos referidos eran Gobernación, Hacienda y Fomento. También, como en la Ley de 2 de octubre de 1877, el gobernador presidía la Diputación y la Comisión Provincial con voto. La Ley Provincial de 1882 se articulaba sobre las figuras del gobernador civil, la Diputación Provincial y la Comisión Provincial. Sin embargo, el Capítulo IV, en su art. 28, ya no señalaba entre las funciones del gobernador la representación de la provincia, como el art. 9 de la Ley de 2 de octubre de 1877. No obstante, el poder que la Ley concedía a esta figura política seguía siendo grande, pues, conforme al art. 79, el gobernador tenía la potestad de suspender los acuerdos de la Diputación y de la Comisión Provincial en el supuesto de que se infringiesen leyes y siempre que esta infracción perjudicase a los intereses del Estado o a los de otra provincia.

En lo referido al sistema de elección, la Ley establecía el sufragio universal masculino calificado. El art. 33 recogía el derecho de todos los varones mayores de edad, que no fuesen analfabetos, a elegir a los diputados provinciales e incluso, el art. 34, contemplaba excepciones que permitían el voto a aquellos que no supiesen ni escribir ni leer. Para ser elegibles como diputados provinciales se exigía que se fuera natural de la provincia por la que se presentaba o que hubieran transcurrido cuatro años consecutivos de vecindad dentro de la misma ${ }^{236}$.

\footnotetext{
${ }^{235}$ Art. 26. Ley Provincial 29-VIII-1882.

${ }^{236}$ En 1899 , tres electores presentaban denuncia contra la capacidad del diputado provincial, electo por el distrito de Saldaña, Eliseo Delgado González. El diputado no aparecía como inscrito en los padrones de habitantes de Saldaña de los años 1895-96-97 y 98, y en la partida bautismal constaba su nacimiento en la provincia de Guadalajara. Puesto que la Ley señalaba que era indispensable ser natural de la provincia o llevar cuatro años consecutivos de vecindad en la misma para ser elegido diputado provincial, el diputado citado carecía de las condiciones exigidas para el desempeño del cargo. En consecuencia, se declaró vacante el cargo de diputado provincial por Saldaña. A.D.P.P., L.A.P.D. 87, 4-IV-1899.
} 
El requisito añadido de cuatro años de vecindad suponía una novedad con respecto a las dos leyes citadas, la Ley de 16 de diciembre de 1876 y la Ley de 2 de octubre de 1877 , que únicamente requerían la vecindad dentro de la provincia ${ }^{237}$. Por tanto, fue esta Ley Provincial la primera de la Restauración que exigía la vecindad en la provincia por la que se optaba al cargo como requisito para ser elegido diputado provincial. Como se verá, esta circunstancia será fuente de frecuentes disputas a la hora de aprobar el Acta de diputado provincial. Se elegían cuatro diputados por cada Distrito, formado por dos Partidos Judiciales limítrofes.

Esta Ley pretendía dotar a las diputaciones provinciales de más independencia administrativa con respecto al poder central de lo que hiciera su antecedente legal, la Ley de 2 de octubre de 1877. Varios artículos comentados parecían ir en esa dirección, aunque el art. $73^{238}$ no dejaba dudas de que esa pretendida autonomía era solo aparente. El art. 130 de la misma Ley no admitía duda alguna sobre el quebranto del principio de autonomía administrativa en este texto legal, al especificar que tanto las diputaciones provinciales como las comisiones provinciales dependían del Gobierno en los asuntos que no eran de su exclusiva competencia. También debe destacarse que en el ejercicio de las atribuciones que les eran propias, el artículo confería «absoluta independencia»a las corporaciones provinciales.

La Diputación Provincial desarrollaba sus funciones en «régimen de exclusividad» en los campos regulados por el art. 74 de esta ley: Los Establecimientos de Beneficencia, la Instrucción Pública, los caminos, canales de navegación y riego, y toda clase de Obras Públicas de interés provincial, así como concursos, exposiciones y otras instituciones de Fomento. Asimismo, la Asamblea Provincial administraba los fondos de la provincia e invertía los mismos conforme al Presupuesto que elaboraba para tal fin. Los funcionarios provinciales eran nombrados, y en su caso separados del servicio, por la Diputación Provincial.

\footnotetext{
${ }^{237}$ La Constitución de 1812 (art. 330) establecía el requisito para ser elegido diputado provincial de ser natural de la provincia, o la residencia en ella de al menos siete años. En el Real Decreto de 21 de septiembre de 1835, se exigía haber residido cuatro años en la provincia y dos en el Partido Judicial por el que fuese elegido el diputado. En la Ley de 8 de enero de 1845, se establecía la condición de residir y llevar dos años de vecindad en la provincia para poder optar a ser elegido diputado provincial o tener en ella propiedades por las cuales se pagasen 1.000 reales de contribuciones directas.

${ }^{238} \mathrm{El}$ art. 73 de la Ley Provincial de 29 de agosto de 1882 rezaba así: «Las diputaciones provinciales no pueden ejercer otras funciones que aquellas que por las leyes se les señales».
} 
El art. 75 determinaba que la Diputación Provincial ejercía de «superior jerárquico» de los ayuntamientos $\mathrm{y}$, con arreglo a esa atribución, desarrollaba las siguientes funciones: Revisar los acuerdos de los ayuntamientos, realizar visitas de inspección y, si lo consideraba oportuno, adoptar las disposiciones que estuviesen encaminadas a mejorar la Administración Municipal. No obstante, las diputaciones aún dentro del ejercicio de sus competencias exclusivas, debían adaptar su labor a las leyes generales del Estado. El art. 76 establecía que: «Los Establecimientos de Beneficencia y los de enseñanza creados o sostenidos por las diputaciones provinciales, se acomodarán a lo que disponga la Ley de Beneficencia y de Instrucción Pública. La Diputación no podrá suprimir ninguno de estos establecimientos sin la aprobación del Gobierno». La Comisión provincial, como órgano ejecutivo de la Diputación, dentro de sus atribuciones y competencias, decidía sobre las incidencias de Quintas, sobre las reclamaciones y protestas en las elecciones municipales, así como sobre las incapacidades, incompatibilidades y excusas de los concejales conforme a la Ley Municipal y Ley Electoral vigentes. A partir de la entrada en vigor de esta Ley, la Comisión Provincial dejó de disponer de la consideración de Tribunal ContenciosoAdministrativo que le confería la Ley de 2 de octubre de 1877, en su art. 66. Esta circunstancia no era baladí ${ }^{239}$, puesto que los recursos de los ayuntamientos contra las disposiciones de la Diputación caerían dentro de la competencia de los tribunales con lo que esto conllevaba, pues ya no serían las propias autoridades que dictaban las disposiciones quienes juzgasen los recursos contra esas mismas resoluciones.

En opinión de Sánchez-Arcilla Bernal, esta Ley consagraba el control de la Administración Provincial sobre la Municipal contribuyendo de forma indirecta a perpetuar la dependencia de los ayuntamientos con respecto al poder central, en una época en la que el caciquismo basaba su existencia en las complejas redes de amiguismo tejidas entre el poder central, provincial y municipal. González Casanova concluye que la Ley Provincial de 1882 fue desde un principio concebida para dar respaldo legal al sistema caciquil que disponía de sus propias leyes consuetudinarias ${ }^{240}$.

\footnotetext{
${ }^{239}$ Cfr. MARTÍN-RETORTILLO, Sebastián y ARGULLOL MURGADAS, Enric, Descentralización Administrativa y Organización Politica. Aproximación histórica (1812-1939), Madrid, Alfaguara, 1973, vol. I, p. 209.

${ }^{240} C f r$. GONZÁLEZ CASANOVA, José Antonio, Las Diputaciones provinciales en España. Historia política de las Diputaciones en España desde 1812 hasta 1985, Madrid, Mancomunidad General de Diputaciones de Régimen Común, 1986. p. 50.
} 
Fue precisamente la práctica caciquil la que mayor daño ocasionó a la imagen pública de las diputaciones provinciales, por ser estas consideradas «la sala de reunión del cacicazgo» ${ }^{241}$. La Diputación Provincial en la etapa canovista de la Restauración fue concebida como una institución cuya principal función era velar por el buen gobierno y bienestar de la provincia, en la que política y administración no fuesen de la mano. Pero la realidad fue que la institución provincial no pudo mantenerse al margen de las luchas por el poder y las diputaciones provinciales fueron un instrumento más que utilizó la oligarquía central para asegurar y perpetuar su poder en las provincias. En este sentido, González Casanova llega la conclusión de que, por buenas que fueran las intenciones del legislador, «con los supuestos doctrinales y organizativos del Estado liberal español» ${ }^{242}$, se antojaba imposible lograr la pretendida diferencia entre política y administración económica, concepción ideal en la que la Diputación fuese una institución ajena a los enfrentamientos por el poder, centrada solo en una administración eficiente en aras del bienestar provincial.

Los diputados provinciales eran conscientes de la necesidad de concentrar los esfuerzos y escasos recursos de las diputaciones en procurar una gestión eficiente, dejando de un lado las luchas políticas, y así lo expresaba el diputado provincial del Partido Conservador, Juan Monedero y Monedero, en la sesión del Pleno de la Diputación de 3 de noviembre de 1886:

« Por segunda vez habla por alusiones el Sr. Monedero y explica el carácter de las diputaciones donde no debe haber hombres políticos, sino representantes de los intereses de los pueblos que a una desean la terminación de las luchas de los partidos; que se haga administración y que cese el caciquismo que les consume y aniquila, para lo cual es preciso cumplir con las leyes, no consentir las sofisticaciones del sufragio y mandar a los tribunales a cuantos hayan cometido coacciones.» ${ }^{243}$

El resultado de este centralismo «subyacente» fue una gran insatisfacción entre las diputaciones provinciales, descontentas con la dependencia del poder central en el desarrollo de sus atribuciones. Fue esta circunstancia la que llevó a los sucesivos gobiernos a intentar introducir reformas en la Ley Provincial que acallaran las protestas y proporcionaran algo más de autonomía funcional a las corporaciones provinciales.

\footnotetext{
${ }^{241}$ Ibidem, p. 50.

${ }^{242}$ Ibidem, p. 50.

${ }^{243}$ A.D.P.P., L.A.P.D. $62,3-\mathrm{XI}-1886$.
} 


\section{Proyectos de reforma provincial}

El primero de estos intentos fue llevado a cabo desde el pensamiento liberal y así, el Real Decreto de 6 de enero de 1884 autorizaba al ministro de la Gobernación, Segismundo Moret, a someter a la deliberación de las Cortes un Proyecto de Ley sobre la reforma de la Ley Provincial vigente ${ }^{244}$. En opinión de González Casanova ${ }^{245}$, el mayor interés de este Proyecto residía en que preveía una reforma del Régimen Provincial mediante lo que más adelante se conocería como «regionalismo funcional» ${ }^{246}$. El Real Decreto contemplaba la reducción del número de gobernadores y proponía que del número de 49 Jefes de provincia se pasase a quince grandes gobiernos, correspondientes a las regiones geográficas y económicas de España. Palencia quedaba englobada en la región de Castilla la Vieja, junto a Burgos, Santander y Soria. En el prólogo del Real Decreto dirigido a las Cortes quedaba claro cuáles eran las motivaciones del Gobierno para introducir reformas en la novísima Ley Provincial de 1882, otorgar al cargo de gobernador el prestigio que necesitaba para dirigir la vida de la provincia «por lo relativo a sus atribuciones, a la posición social que representa y a la misión que se le confía», fueron las tres razones que el Real Decreto esgrimía a tal fin, reformando los Capítulos III y IV de la Ley Provincial de 29 de agosto de 1882.

Para Enrique Orduña ${ }^{247}$, la aparición del concepto de región no conllevaba una mayor autonomía para las diputaciones provinciales, por el contrario, significaba una mayor injerencia del Gobierno central en la Administración Local. En opinión de González Casanova ${ }^{248}$, el Proyecto era de una incoherencia absoluta, ya que pretendía una organización provincial más eficiente y económica y, sin embargo, aumentaba el gasto con la creación del cargo de gobernador y la burocracia aneja de las nuevas quince provincias. Además, se añadía la figura administrativa del delegado, uno por cada provincia, que formaba parte de las quince regiones.

\footnotetext{
${ }^{244}$ Capítulos III y IV.

${ }^{245}$ Vid. GONZÁLEZ CASANOVA, José Antonio, Las Diputaciones provinciales en España. Historia política de las Diputaciones en España desde 1812 hasta 1985, op. cit., p. 63.

${ }^{246}$ Concepto que definía una estructura administrativa supuestamente más ágil y versátil, sin necesidad de variar sustancialmente el Régimen Local existente.

${ }^{247} \mathrm{Cfr}$. ORDUÑA REBOLLO, Enrique y COSCULLUELA MONTANER, Luis, Historia de la Legislación de Régimen Local, op. cit., p. 161.

${ }^{248}$ Cfr. GONZÁLEZ CASANOVA, José Antonio, Las Diputaciones provinciales en España. Historia política de las Diputaciones en España desde 1812 hasta 1985, op. cit., p. 9.
} 
En el prólogo se continuaba aludiendo al malestar de las provincias con el poder central a causa del poco interés del Gobierno en los asuntos relativos a la Administración Provincial. El Consejo de Ministros, consciente de este descontento, justificaba la reforma de la Ley porque parecía de justicia hacerlo: «Si la misión del Gobierno no exigiese esta reforma, aun habría que acometerla en obsequio de las provincias, con harta razón quejosas de que las cuestiones que afectan al Poder central se lleven casi íntegra la atención de los partidos.» Ese mismo año, el ministro de Gobernación por el Partido Conservador, Romero Robledo presentaba al Congreso el Proyecto de Ley de 27 de diciembre de 1884, sobre el Gobierno y la Administración Local, que pretendía refundir en un solo texto las dos Leyes Orgánicas de 1877 y 1882.

En palabras del propio ministro de la Gobernación, dos ideas básicas estructuraban este Proyecto de Ley, la primera era afianzar el carácter meramente administrativo de las corporaciones provinciales, separando las facultades propias de las mismas de aquellas que correspondían al Gobierno que hasta entonces ejercían las diputaciones provinciales por mandato legal. La segunda idea básica del Proyecto de Ley giraba en torno a la necesidad del planteamiento conjunto de la distribución de competencias entra las administraciones locales, lo que evitaría, a juicio del legislador, la competencia estéril entre las corporaciones en favor de la cooperación y la ayuda mutua. Para hacer de la institución provincial punto de encuentro de las diversas sensibilidades sociales, la composición de la Diputación Provincial se modificaba en este Proyecto de Ley. De este modo, la Diputación Provincial estaría constituida por diputados provinciales elegidos directamente por cada región, en la forma dispuesta por la Ley Electoral, y por los vocales natos: Senadores y diputados a Cortes por la provincia, incluyendo entre los primeros a los de derecho propio y a los vitalicios que hubiesen nacido o tuviesen bienes en la misma, presidentes de las Juntas Regionales y a aquellas personas que, por méritos contraídos en favor de la provincia, fuesen nombrados hijos predilectos de la misma. 
En el terreno económico, las diputaciones provinciales quedaban liberadas de muchas de sus obligaciones en favor de las Juntas Regionales, reservándose a la institución provincial la deliberación sobre asuntos que eran de su exclusiva competencia. Esta «liberación» de responsabilidades de las diputaciones permitía reducir a una las ocasiones en que debía reunirse la Asamblea Provincial, dividida en varias secciones, Fomento, Hacienda, Beneficencia e Instrucción Pública, y hacía prescindible la figura administrativa de la Comisión Permanente, que desaparecía como órgano administrativo de la Diputación Provincial. Este Proyecto de Ley incorporaba una novedad importante, la exigencia de determinadas condiciones para formar parte de la Comisión provincial, requerimientos que eran explicitados en su art. 227. Esta exigencia se justificaba en el preámbulo por las competencias de la Comisión Provincial como cuerpo consultivo y Tribunal Contencioso-Administrativo que, a juicio del legislador, no quedaban bien determinadas y requerían que el órgano que las ejercía estuviese compuesto por personas de determinadas características, dada la naturaleza sensible de los intereses que se les confiaban. La reforma de la Administración Local, en conclusión, fue una promesa no satisfecha por el régimen de la Restauración y buena muestra de ello fueron los sucesivos proyectos de reforma de las leyes que intentaban racionalizar un sistema intrínsecamente centralista.

En 1891, Silvela, ministro de Gobernación del Gobierno conservador de Cánovas, dispuso por Real Orden la elaboración de un informe sobre reforma de la Administración Local. La realización del informe fue encargada al subsecretario de Gobernación, Sánchez Toca, que elaboró dos proyectos: uno, Ley de Gobierno y Administración Local, y dos, Bases para la Reforma de la Ley Municipal. Con esta reforma se pretendía la refundición de las leyes vigentes y, a juicio de investigadores como González Casanova, se presentaba como «una respuesta doctrinal al proyecto de Moret» ${ }^{249}$. En esta reforma se contemplaba la división del país en regiones, trece en vez de las quince del proyecto de Moret.

\footnotetext{
${ }^{249}$ Cfr. GONZÁLEZ CASANOVA, José Antonio, Las Diputaciones provinciales en España. Historia política de las Diputaciones en España desde 1812 hasta 1985, op. cit., p. 64.
} 
A diferencia de este, el proyecto de Silvela-Sánchez Toca albergaba verdaderas intenciones descentralizadoras, por lo que no era solo «funcional» y aspiraba a que las regiones funcionasen sin la influencia interesada del caciquismo local $\mathrm{y}$, en consecuencia, con una administración eficaz y eficiente en un ámbito de mayor extensión territorial que la provincia, en el marco de un cada vez mayor complejo escenario económico y social que habría de aumentar los servicios públicos de tal forma, que dificultaría la acción eficiente de la Administración Estatal en todo el territorio nacional. Tampoco puede olvidarse que la institucionalización del espacio regional, que se contemplaba en la reforma, intentaba responder al creciente problema de los nacionalismos, especialmente el catalán y el vasco. La Constitución de 1876 solo contemplaba el municipio y la provincia como entes administrativos, por tanto, las aspiraciones de reconocimiento regional planteadas especialmente por Cataluña, tenían difícil encaje en el sistema de la Restauración. La imposibilidad de reformar la Constitución en este tema, especialmente debido al nulo consenso entre los partidos dinásticos, fue causa de enfrentamientos con los catalanistas y nacionalistas vascos y de desgaste del propio sistema canovista

En la nueva estructura administrativa que contemplaba la reforma, la cabeza visible del Estado era el gobernador regional, superior de los gobernadores civiles de las provincias que componían cada circunscripción regional. Los gobernadores civiles perdían poder ejecutivo en esta reforma pues, solo a modo de ejemplo, el art. 24 dictaminaba que solo con la autorización previa del gobernador regional podrían los gobernadores civiles suspender los acuerdos de las diputaciones y comisiones provinciales. El gobernador regional estaba asistido en el desempeño de sus funciones por el Consejo Regional, formado por representación orgánica y corporativa procedentes de la elección de las diputaciones provinciales, del Ayuntamiento de la capitalidad de la región y de las corporaciones, y a quienes la Ley Electoral de diputados a Cortes o a senadores concediese derecho electoral con domicilio en la región. Además, formaban parte del Consejo Regional los vocales nombrados por las Juntas de Beneficencia e Instrucción Pública y eran miembros natos el presidente de la Audiencia Territorial y el decano del Colegio de Abogados de la capital, el rector de la Universidad, el ingeniero jefe de Obras públicas y el de Montes y el inspector de Instrucción Pública de mayor categoría. 
La reforma depositaba sus esperanzas descentralizadoras y anticaciquiles en el Consejo Regional, al que confiaba la salvaguarda de los intereses de los ayuntamientos en contra de la burocracia y el poder de los caciques. Como superior jerárquico de las diputaciones provinciales, correspondía al Consejo Regional revisar, en caso de reclamación, los acuerdos de las diputaciones y comisiones provinciales, por lo que parecía evidente la pérdida de poder de las diputaciones como órgano administrativo territorial. Este Proyecto de Ley no contemplaba la desaparición de las diputaciones provinciales sino solo un transvase de funciones entre la Diputación y la región, ya que las competencias que se asignaban a la región eran casi idénticas a las que contemplaba la Ley de 29 de agosto de 1882 para la Corporación Provincial ${ }^{250}$.

La Diputación mantenía las competencias sobre la creación y conservación de servicios provinciales, la administración de los fondos provinciales, la custodia y conservación de los bienes, acciones y derecho provinciales y el nombramiento y la separación de los funcionarios provinciales. Si bien la Diputación continuaba su ejercicio como superior jerárquico de los ayuntamientos, resultaba evidente su pérdida de representatividad, pues los diputados eran elegidos de forma indirecta por compromisarios designados por los ayuntamientos y no por sufragio universal y directo $^{251}$. El proyecto repetía la estructura administrativa liberal de Estado, provincia y municipio, con la innovación de la región, que en el corpus ideológico doctrinario español se consideraba como una entidad natural enfrentada a la «artificialidad» de la provincia que, según esta misma concepción, se veía desbordada por la amplitud de servicios a prestar en una sociedad desarrollada por lo que necesitaba de una entidad superior que asumiese parte de las competencias provinciales. El proyecto nunca llegó a presentarse en las Cortes, al igual que el segundo proyecto «Bases para la Reforma Municipal», que pretendía racionalizar el Régimen Municipal.

\footnotetext{
${ }^{250} C f r$. ORDUÑA REBOLLO, Enrique, Municipios y Provincias, Madrid, INAP, 2003, p. 498.

${ }^{251}$ Vid. SÁNCHEZ DE TOCA, Joaquín, Regionalismo, municipalismo y centralismo, Imp. E. Velasco, Madrid, 1907.
} 
Antes de que acabase el siglo XIX, nació un nuevo intento de reforma del Régimen provincial, en octubre de 1899, Silvela presentó en el Senado un nuevo proyecto de descentralización administrativa que no llegó a finalizar el trámite parlamentario para convertirse en ley. El interés de este proyecto residía en que tanto las diputaciones como los ayuntamientos eran considerados, a todos los efectos del Capítulo II del Código Civil, personas jurídicas y por lo tanto capacitados para adquirir, poseer y enajenar bienes de todas clases ${ }^{252}$. Este avance significaba que las diputaciones provinciales y los ayuntamientos podían establecer establecimientos de Beneficencia, Cajas de Ahorro, Montes de Piedad o instituciones de Instrucción Pública, con los recursos propios, sin necesidad de autorización por parte de autoridades superiores y con la única obligación de informar al gobernador civil de los estatutos, bases y recursos de las instituciones creadas. Con respecto al proyecto de 1891, las medidas descentralizadoras eran menos ambiciosas, lo que parecía entrar en contradicción con la tendencia regeneracionista y regionalista de destacados miembros del gobierno Silvela, como el general Polavieja. Para González Casanova ${ }^{253}$, las escasas concesiones del regeneracionismo conservador al catalanismo habían sido utilizadas por Romero Robledo para atacar a Silvela ${ }^{254}$, su rival por el liderazgo del Partido Conservador tras el asesinato de Cánovas, lo que pudiera explicar la timidez del proyecto descentralizador.

También en 1899 presentaba su proyecto el ministro de Gobernación Eduardo Dato, en este caso se trataba de una reforma de contenido muy limitado que solo introducía algunas modificaciones en la estructura municipal y provincial, con dos medidas importantes, la supresión de los presupuestos adicionales y de las Juntas municipales, así los ayuntamientos serían los encargados de asumir sus atribuciones y se posibilitaba a los ayuntamientos recurrir las resoluciones del gobernador civil ante el Tribunal de lo Contencioso-Administrativo.

\footnotetext{
${ }^{252} C f r$. TUSELL GÓMEZ, Javier, CHACÓN ORTIZ, Diego, La reforma de la Administración Local en España, 1900-1936, Madrid, Instituto de Estudios y Publicaciones, 1973, pp. 69-71.

${ }^{253}$ Cfr. GONZÁLEZ CASANOVA, José Antonio, Las Diputaciones provinciales en España. Historia política de las Diputaciones en España desde 1812 hasta 1985, op. cit., p. 67.

${ }^{254} \mathrm{Vid}$. TUSELL GÓMEZ, Javier, La reforma de la administración Local en España (fines el siglo XIX a 1936), Madrid, INAP, 1988.
} 
Sin ninguna duda el Proyecto de Maura de 1903 fue el intento más serio de solucionar el siempre latente problema de la organización territorial del país, de acabar con los seculares problemas que lastraban a las administraciones locales, impidiendo un funcionamiento eficaz de las mismas. Maura quería eliminar de la vida política el nexo de unión entre caciquismo y Administración Local ${ }^{255}$, la burocracia y el intervencionismo estatal, para devolver a los ciudadanos el interés por la política, en definitiva, para realizar su ansiada «revolución desde arriba». El proyecto de Maura contó con el apoyo de los regionalistas catalanes, de carlistas y republicanos federalistas. Aunque el político mallorquín era más conservador en sus planteamientos descentralizadores que su compañero de partido Silvela, en su haber tuvo la habilidad de dar salida a las aspiraciones de más autonomía en el Gobierno local con la posibilidad de crear una nueva entidad política: la Mancomunidad de diputaciones provinciales. El 6 de mayo de 1907, poco antes de presentar su proyecto Maura, el presidente de la Diputación de Barcelona, Prat de la Riba, convocó a una Asamblea a todos los alcaldes de los ayuntamientos de la provincia, en la que se aprobaron 27 Bases para la reforma de la Administración Local.

Por lo que respecta a las diputaciones provinciales, se pretendía que estas poseyeran capacidad jurídica plena e independencia administrativa en todos aquellos aspectos propios de su gestión, tales como plantillas y salarios de sus empleados, presupuestos, así como la resolución ejecutiva de sus acuerdos, sin necesidad del posterior refrendo del Gobierno a través de la figura del delegado. Para que todo esto fuera posible, los regionalistas catalanes eran conscientes de la trascendencia de disponer de independencia financiera, tanto a la hora de recaudar, como en la forma de distribuir el gasto. Dentro del espíritu regionalista que animaba este documento, no podía faltar la alusión a la región, concebida como entidad supraprovincial, con una institución ejecutiva, la Diputación Regional, constituida por los senadores de carácter electivo de la región, los diputados a Cortes y los diputados de las provincias que formaban parte de la región. La Administración Regional aunaba las competencias propias de las diputaciones provinciales, más las que ejercía el Estado en el ámbito provincial.

\footnotetext{
${ }^{255}$ Vid. VARELA ORTEGA, José, Los amigos politicos. Partidos, elecciones y caciquismo en la Restauración (1875-1900). Madrid, Alianza Editorial, 1977.
} 
En el proyecto de Maura no se apreciaba una gran originalidad en lo referido a la configuración de la Administración Provincial, puesto que gran parte de sus postulados ya se contemplaban en la Ley Provincial de 29 de agosto de 1882. La esencia del proyecto se basaba en la concepción de Maura sobre la Diputación Provincial como institución que debía velar por los intereses socioeconómicos de la provincia, ajena a toda influencia de las confrontaciones de la política local y, en lo posible, independiente de las injerencias del Estado a través de su representante en la provincia, el gobernador. En resumen, Maura continuaba con su pensamiento político en este Proyecto, solo terminando con el caciquismo se prestigiaría la política y, de esta forma, se regeneraría el cuerpo enfermo que constituía el sistema de la Restauración. Desde este apriorismo ideológico, toda reforma de la Administración local perseguía como fin último acabar con la influencia del cacique en municipios y provincias. A semejanza del proyecto de Silvela de 1899, Maura pretendía dotar a la Diputación de plena personalidad jurídica, con independencia económica y administrativa, solo limitada en su gestión por las disposiciones legales vigentes ${ }^{256}$. En coherencia con esta concepción de la institución provincial, el proyecto maurista ya no otorgaba la máxima representación de la provincia al gobernador, sino que esa función debía ejercerla el presidente de la Diputación. A pesar de todo, el gobernador, en este proyecto, conservaba ciertas prerrogativas ya contempladas en la Ley Provincial de 1882, como la capacidad de suspender acuerdos, con la posibilidad de interponer Recurso de Alzada ante el Gobierno. No obstante, lo más destacado del proyecto de Maura se concretaba en la Disposición Adicional tercera del Proyecto, sobre las mancomunidades provinciales. Dicha disposición contemplaba la posibilidad de que las diputaciones provinciales pudiesen mancomunarse y que, previa autorización del Gobierno, obtuviesen servicios y obras públicas de interés para su ámbito territorial de administración, aun cuando estos servicios no se contemplaran como atribuciones exclusivas de estas entidades. Aunque tímido, suponía un paso en el camino hacia la descentralización administrativa, sin embargo, el regionalismo catalán, encabezado por Cambó y Prat de la Riba, consideró del todo insuficiente este Proyecto para colmar sus aspiraciones regionalistas y se eternizó en el trámite parlamentario, entre otras razones por las objeciones que desde la oposición se enfrentaban a aspectos fundamentales del mismo.

\footnotetext{
${ }^{256} C f r$. MARTÍN RETORTILlO, Sebastián y ARGULLOL MURGADAS, Enric, Descentralización administrativa y organización politica, Madrid, ED. Alfaguara, 1973, p. 236.
} 
Además de los catalanistas, las propias diputaciones provinciales reunidas en la III Asamblea de diputaciones provinciales de España, celebrada en Barcelona el 17 de mayo de 1909, criticaban que las corporaciones provinciales se vieran forzadas a asumir funciones estatales, tales como el sostenimiento de las prisiones correccionales y la conservación de edificios de la Administración Central, cuando se trataba de competencias estatales. Asimismo, se criticaba la insuficiente dotación económica para hacer frente a los gastos que debían abordar con las nuevas atribuciones que les asignaba el proyecto de Maura, al disponer como único ingreso del llamado Contingente Provincial $^{257}$, un gravamen que debían pagar los ayuntamientos, que tenían grandes dificultades económicas para hacer frente a dicho impuesto. En este sentido, también se criticaba, por parte de los ponentes en la Asamblea, lo ilusorio del Proyecto en lo relativo a la constitución de mancomunidades sin dotación presupuestaria con la que asegurar su existencia y se solicitaba que fuera el Estado quien contribuyese a su dotación económica al ceder a esta nueva entidad administrativa alguna de sus contribuciones de forma permanente.

Una vez más el proyecto reformista de Maura no logró plasmarse en una ley que pusiese las bases para la tan ansiada renovación ética de la vida pública a la que aspiraba el político conservador. Los sucesos ocurridos en la Semana Trágica de Barcelona, a finales de julio de 1909, provocaron la salida del Gobierno de Maura y, como consecuencia, el final de su Proyecto de Reforma de la Administración Local. El caciquismo había salido una vez más indemne de los intentos regeneracionistas de Antonio Maura. Sin embargo, el esfuerzo del mallorquín no fue estéril, pues su proyecto inspiró futuras reformas, especialmente en lo referido al espíritu regionalista ${ }^{258}$. Este nuevo revés suponía el final de los proyectos de reforma de la Administración Local pero, a partir de 1909 y hasta la promulgación de los estatutos municipal y provincial en la Dictadura primorriverista, el interés de la política local de la Restauración varió desde los municipios y provincias hacia las mancomunidades.

\footnotetext{
${ }^{257} \mathrm{El}$ llamado Repartimiento, se realizaba tomando como referencia las contribuciones directas (Territorial e Industrial) e indirectas (Consumos) que los pueblos satisfacían al Tesoro. La Delegación de Hacienda facilitaba una copia a la Diputación de los repartimientos girados por el Tesoro sobre las contribuciones citadas.

${ }^{258}$ En diciembre de 1911, el presidente de la Diputación de Barcelona, Prat de la Riba, entregaba al Gobierno Canalejas la Bases de la Mancomunidad de Cataluña.
} 
No obstante, todos estos intentos reformistas sirvieron para poner en evidencia la necesidad de descentralizar la Administración Local, y en esto coincidían tanto conservadores como liberales ${ }^{259}$. Sin embargo, existía un matiz importante que separaba a ambos partidos, los conservadores eran partidarios de restar competencias a las diputaciones en favor de la región y los liberales defendían la necesidad de dotar de mayor autonomía fiscal y administrativa a diputaciones y municipios. La Diputación Provincial de Palencia se mostró siempre partidaria de dotar con nuevas facultades a las diputaciones y de alcanzar mayor autonomía en la gestión de las atribuciones que la legislación les reconocía, lo que redundaría en una mejor aceptación de estas instituciones entre la población y a la vez conllevaría una mayor exigencia y rigor en su labor gestora. Ya en 1893, la Comisión Provincial de la Diputación de Palencia se mostraba «(...) íntimamente persuadidos que cuanta mayor descentralización y autonomía se conceda a las corporaciones populares, más justificación y más publicidad debe darse a sus actos, hemos sometido los nuestros a ese principio, (...) porque no basta con obrar bien y cumplir las leyes, sino que es preciso demostrarlo.» ${ }^{260}$ Por esta razón, a partir de 1893 fue obligatorio publicar en el BOP los extractos de las cuentas generales y semestrales de cada ejercicio.

\footnotetext{
${ }^{259}$ Cfr. SANTANA MOLINA, Manuel, La diputación provincial en la España decimonónica, Madrid, Instituto de Estudios de Administración Local, 1989, p. 298.

${ }^{260}$ A.D.P.P., Memoria Año Económico Primer Semestre 1893-1894, C-R / 1,11, p. 38.
} 


\section{Las mancomunidades}

En el proyecto de reforma de Moret de 1884 ya aparecía el concepto de «regionalismo funcional», y en el proyecto de Sánchez Toca de 1890 se contemplaba también la división territorial del país en regiones. Por tanto, el regionalismo constituía un sentimiento presente en los sucesivos proyectos de reforma de la legislación local, pero sería el Proyecto de Maura de 1907, el que por primera vez recogiese la posibilidad de formar mancomunidades provinciales. En $1908^{261}$, la Diputación de Palencia, consciente de la sensibilidad de Madrid hacia la cuestión regional y por mandato de la Comisión Provincial, designaba a Eduardo Junco Martínez, abogado del Estado, y a Juan Díaz-Caneja, director de la Sociedad Económica de Amigos del País de Palencia, como ponentes en el Sexto Congreso Agrícola Castellano, a celebrar en Santander, para defender la ponencia que llevaba por nombre Mancomunidades. Su estudio, ventajas e inconvenientes de la Asociación de las provincias de Castilla la Vieja para el fomento de los interese públicos. La Diputación de Palencia, dispuesta a encabezar cualquier iniciativa que estuviese encaminada a mejorar el estado económico de la provincia, apoyaba la creación de la Mancomunidad a que se refería el Real Decreto de 18 de diciembre de 1913, siempre que se circunscribiese a la defensa de los intereses agrícolas, «(...) elemento principal de la riqueza de Castilla.» ${ }^{262}$

A pesar de que el Proyecto de Maura no llegó a buen puerto por las circunstancias mencionadas, los catalanistas, con Prat de la Riba a la cabeza, no cejaron en su empeño de conseguir la formación de una Mancomunidad de las provincias catalanas. Por iniciativa del líder de la Liga Regionalista, los cuatro presidentes de las diputaciones catalanas elaboraron una ponencia que contenía las bases de lo que debía ser la futura Mancomunidad catalana. Estas bases preveían el traspaso de competencias desde las corporaciones provinciales al nuevo ente administrativo, conjuntamente con la cesión de diversas competencias por parte del Estado. Prat de la Riva, presentó su propuesta de la nueva entidad territorial al presidente del Consejo de Ministros, Canalejas. El político liberal era partidario de extender el modelo mancomunado al resto de España con carácter discrecional, puesto que no todas las regiones de España se encontraban en la misma situación económica.

\footnotetext{
${ }^{261}$ A.D.P.P, L.A.C.P. 108, 27-VI-1908.

${ }^{262}$ A.D.P.P, L.A.P.D. $113,8-\mathrm{V}-1914$.
} 
En coherencia con el pensamiento de Canalejas respecto a las mancomunidades, su ministro de Gobernación, Barroso Castillo presentó un Proyecto de mancomunidades en mayo de 1912 a los presidentes de las diputaciones catalanas, quienes introdujeron las correcciones que, a su juicio, eran convenientes para que fuera defendido por los parlamentarios catalanes en las Cortes. El proyecto de Barroso Castillo contemplaba la posibilidad de que las provincias representadas por las diputaciones pudiesen mancomunarse con fines exclusivamente administrativos. La iniciativa para formar una Mancomunidad correspondería al Gobierno, las diputaciones provinciales o a los ayuntamientos que contasen con una población mayor del $10 \%$ de las provincias que formasen parte de la futura Mancomunidad. Esta institución dispondría de un carácter voluntario y siempre cabría la posibilidad de disolverla. Antes de su formación, las instituciones interesadas en mancomunarse debían redactar unos estatutos donde constaran los servicios provinciales delegados, los servicios estatales que se solicitarían, el periodo de duración de la mancomunidad y las provincias que la formarían. Para que pudiese constituirse la Mancomunidad, debía contar con la aprobación de dos tercios de las diputaciones provinciales afectadas. El órgano deliberativo de esta nueva entidad administrativa era la denominada Junta General de Diputados y un Consejo permanente. El Gobierno se reservaba la facultad de suspensión de la Mancomunidad en el caso de que se extralimitase en sus funciones o incumpliese algunas de las disposiciones del estatuto constitutivo de la misma, previa autorización de las Cortes. Este proyecto, inspirado en el de Maura de 1907, contó en el seno del propio Partido de Canalejas con sus mayores detractores, pues, como se ha señalado, el Partido Liberal era partidario de potenciar las diputaciones provinciales como institución administrativa local en detrimento de la región, pues consideraban que la eliminación del caciquismo ${ }^{263}$, que se pretendía con estas reformas, perjudicaría sus intereses electorales. Liberales tan señalados como Moret y Alcalá Zamora mostraron su desacuerdo con el Proyecto de Barroso Castillo, pero finalmente la habilidad y capacidad para el consenso de Canalejas consiguieron que el proyecto fuese aprobado en el Congreso con el apoyo del Partido liberal, excepto la facción moretista de los catalanistas y de los tradicionalistas, en contra votaron los conservadores y los radicales se abstuvieron.

\footnotetext{
${ }^{263} C f r$. GONZÁLEZ CASANOVA, José Antonio, Las Diputaciones provinciales en España. Historia política de las Diputaciones en España desde 1812 hasta 1985, op. cit., p.79.
} 
El asesinato de Canalejas ${ }^{264}$ provocó que su Proyecto de mancomunidades, aun llegando al Senado, no prosperase como ley y, como en otras ocasiones, quedó como un ejemplo más de las intenciones descentralizadoras irrealizables de parte de la clase política dinástica. El proyecto de Canalejas fue retomado por el Gobierno conservador de Eduardo Dato. El ministro de Gobernación, Sánchez Guerra, presentó al rey el Real Decreto de 18 de diciembre de $1913^{265}$, que autorizaba la Mancomunidad de provincias para fines exclusivamente administrativos, previa autorización del Gobierno, que sería el encargado de vigilar que los estatutos de las mancomunidades no entrasen en contradicción con la legislación administrativa, ni con la normativa constitucional. Las mancomunidades se componían de una Junta General formada por las provincias mancomunadas, un Consejo permanente, nombrado por esas provincias y por un presidente. Basada, como se ha dicho, en el Proyecto de Barroso Castillo, disponía de los mismos requerimientos que aquel para formar una Mancomunidad, la iniciativa para su formación correspondía al Gobierno, las diputaciones provinciales o los ayuntamientos que contasen con una población mayor del $10 \%$ de las provincias que formasen parte de la futura Mancomunidad. Dados los recelos que este proyecto levantaba entre las filas más centralistas de ambos partidos dinásticos, que veían en el Real Decreto el primer paso hacia el federalismo y, como consecuencia lógica de sus apriorismos ideológicos, la desintegración del Estado unitario, la Exposición de Motivos del mismo resumía muy bien el espíritu de esta reforma:

«Con ello, y con la declaración terminante de ser siempre voluntaria la asociación y poder extinguirse por la iniciativa de cualquiera de las diputaciones mancomunadas, claramente se advierte que se alejan todos los peligros y quedan sin fundamento cualesquiera clase de recelos.»

\footnotetext{
${ }^{264}$ En la sesión del día 15 de noviembre de 1912, La Comisión Provincial y la Diputación de Palencia manifestaban su pesar por el asesinato del político liberal. A.D.P.P., L.A.C.P. 116, 15-XI-1912.

${ }^{265} \mathrm{Cfr}$. ORDUÑA REBOLLO, Enrique y COSCULlUELA MONTANER, Luis, Historia de la Legislación de Régimen Local, op. cit., p.166. Orduña Rebollo considera que dada la experiencia anterior respecto del fracaso de los proyectos largamente debatidos, Eduardo Dato decidido a sacar adelante su Proyecto de mancomunidades, pensó que la mejor forma de hacerlo era mediante una norma de urgencia, el Real Decreto de 18 de diciembre de 1913.
} 
El Real Decreto establecía que las mancomunidades podían solicitar la delegación de servicios propios de la Administración Central, petición que el Gobierno no podía aceptar sin antes obtener una ley especial de concesión de las Cortes. A diferencia del Proyecto de Maura de 1907, que explicitaba de forma clara las competencias que las mancomunidades podían solicitar al Estado, Beneficencia, Instrucción Pública y Obras Públicas, el Real Decreto de 1913 no hacía mención expresa de las competencias susceptibles de ser traspasadas por el Estado, por tanto, en teoría cualquier atribución estatal podía ser objeto de traspaso a las mancomunidades.

Únicamente las diputaciones catalanas hicieron uso del derecho a mancomunarse, constituyéndose la Mancomunidad catalana el 6 de abril de 1914. Sin embargo, el interés por esta nueva forma de vertebración territorial no solo prendió en Cataluña, otras regiones mostraron su vocación regionalista. A comienzos de 1914, el presidente de la Diputación de Madrid, Díaz Agero, había manifestado al rey Alfonso XIII, su predisposición a mancomunarse con Castilla la Nueva y Castilla la Vieja, incluyendo a Santander y excluyendo a León, Palencia, Salamanca, Valladolid y Zamora por estimarlas leonesas $^{266}$. En respuesta a la iniciativa de la Diputación de Madrid, la Diputación de Burgos lanzaba su propia propuesta de Mancomunidad que incluía a las provincias de Castilla la Vieja y a León. En la sesión del día 13 de enero de $1914^{267}$, la Comisión Provincial de la Diputación de Palencia informaba de la carta de la Diputación de Burgos comunicando su opinión sobre la conveniencia de celebrar una reunión para que en vista del Real Decreto de 18 de diciembre de 1913, sobre mancomunidades, pudiera llegarse a un acuerdo respecto de la forma y fines de la futura Mancomunidad castellana y las futuras provincias que podrían agruparse, para formar una o varias mancomunidades.

\footnotetext{
${ }^{266}$ Cfr. ALMUIÑA FERNÁNDEZ, Celso, «El regionalismo castellano-leonés: orígenes y primeras reivindicaciones político-económicas (1859-1923)», en I Congreso de Historia de Castilla y León. v.3, Valladolid, Diputación Provincial de Valladolid, 1982, pp. 343-377.

${ }^{267}$ A.D.P.P., L.A.C.P. 118, 13-I-1914.
} 
Un ejemplo más del interés de la Diputación palentina por la posibilidad de crear una mancomunidad en Castilla la Vieja, fue la proposición del diputado provincial César Gusano Rodríguez ${ }^{268}$ para que la Diputación de Palencia se dirigiese a las de Santander, Burgos, Valladolid, León, Zamora, Salamanca, Ávila, Soria, y Segovia, invitándolas a hacer uso del derecho concedido en el citado Real Decreto. El político palentino llegaba incluso a sugerir un nombre para la futura entidad, Mancomunidad de Castilla la Vieja, y proponía que la capitalidad se alternase por sorteo anual entre las provincias mancomunadas y la Diputación, a quien correspondía la capitalidad, asumiría los gastos para el sostenimiento de las oficinas y personal de la Mancomunidad. En la sesión del Pleno de la Diputación del día 8 de mayo de $1914^{269}$, se discutió la posición que habría de adoptar la Diputación de Palencia en la reunión que se celebraría en Burgos en el mes de junio, después de analizar las ventajas e inconvenientes de la futura Mancomunidad castellana. Finalmente, se acordó designar una Comisión compuesta por el presidente de la Diputación palentina, Manuel Diez-Quijada Gallo y los diputados provinciales, Santander Gallardo, Redondo Martín, García de los Ríos y Gusano Rodríguez, para que asistiesen a la Asamblea de Burgos, fijando su postura en defensa de la constitución de una Mancomunidad castellana siempre que esta «se encaminara a la defensa de la agricultura». Los días 18 y 19 de junio de 1914, se reunieron varios diputados por las provincias de Castilla y León en la Sección Segunda del Congreso para aproximar posturas de cara a la Asamblea de diputaciones castellanas y leonesas que debía celebrarse en Burgos el día 20 de junio, con el tema de la Mancomunidad castellana sobre la mesa. Representaba a Palencia Abilio Calderón Rojo, diputado a Cortes electo por el Distrito de Palencia por el Partido Conservador. En la reunión de Burgos se decidió que el concepto de administración que representaba el Real Decreto de 18 de diciembre de 1913 era asumible por las diputaciones de Castilla, por tanto, se darían los pasos necesarios para poner en marcha la unión de las Diputaciones bajo el nombre de Mancomunidad castellana.

\footnotetext{
${ }^{268}$ A.D.P.P., L.A.P.D. $113,4-\mathrm{V}-1914$.

${ }^{269}$ A.D.P.P., L.A.P.D. $113,8-\mathrm{V}-1914$.
} 
Todas estas iniciativas no llegaron a buen puerto, Castilla perdió el tren ${ }^{270}$ de la Mancomunidad y, al igual que González Casanova ${ }^{271}$, muchos pensaban que en Castilla no había sentimiento regional, pues los castellanos se identificaban más con la idea de España. En Castilla se defendía el concepto de descentralización entendido como autonomía de los municipios, concepto muy alejado del sentimiento catalán de región entendida como entidad cuasinacional.

\section{El Regionalismo}

Al igual que había sucedido con la cuestión de las mancomunidades, Cataluña fue una vez más pionera en las aspiraciones de lograr una mayor autonomía en su ámbito territorial con respecto al Estado. Después de la celebración de la Asamblea de parlamentarios españoles, celebrada el 19 de julio de 1917 en Barcelona, el día 30 de octubre se celebró una segunda Asamblea de parlamentarios españoles en Madrid. En esta segunda Asamblea, entre otras conclusiones, se llegó al convencimiento, y así se solicitaba al Gobierno, de que era necesaria una reforma de la organización territorial que incluyese el concepto administrativo de región. Se especificaba que el Estado era dueño de unas competencias que de ninguna forma podía asumir la región y, al demostrar una concepción pragmática de la actividad política, explicitaba cuáles debían ser los medios económicos destinados a sufragar el coste de los servicios prestados por cada administración derivados de sus respectivas competencias.

«(...) se fijarán claramente los impuestos que el Estado se reserva para atender los servicios que queden a su cargo y aquellos que se traspasen a la región para sufragar las atenciones que implican el ejercicio de las atribuciones que se le reconocen, estableciéndose un régimen de absoluta separación de haciendas.»

\footnotetext{
${ }^{270} C f r$. PALOMARES IBÁÑEZ, Jesús María, «Crecimiento económico, tensiones sociales, y fase inicial del movimiento regionalista en Castilla y León en los comienzos del siglo XX», Las Cortes de Castilla y León, 1188-1998: Actas de la Tercera Etapa del Congreso Científico sobre la historia de las Cortes de Castilla y León. Vol. II. Fuensaldaña, Cortes de Castilla y León, 1990, p. 290.

${ }^{271} C f r$. GONZÁLEZ CASANOVA, José Antonio, Las Diputaciones provinciales en España. Historia política de las Diputaciones en España desde 1812 hasta 1985, op. cit., p.88.
} 
Ante este panorama, la Diputación de Palencia se posicionaba a favor de una mayor autonomía administrativa y fiscal de las diputaciones provinciales. En la sesión del Pleno de la Diputación del día 23 de noviembre de $1918^{272}$, el diputado provincial del Partido Conservador, César Gusano, presentó una proposición que resumía muy bien la postura de la Corporación palentina y de casi todas las diputaciones españolas de Régimen Común, frente a los anhelos regionalistas de algunos territorios del Estado, especialmente Cataluña. El Diputado provincial defendía la necesidad de dotar a las haciendas provinciales de más ingresos de los que aportaba el Contingente Provincial, puesto que las diputaciones provinciales dependían casi en exclusiva de este impuesto sobre la riqueza de los municipios para gestionar las funciones que por ley tenían encomendadas. Ante las peticiones de mayor autonomía por parte de Cataluña, la Diputación de Palencia defendía la vigencia de la estructura administrativa española, pero con modificaciones sustanciales en lo referido a la cesión de competencias del Estado a los entes provinciales y dotación de medios económicos para poder gestionar los mismos de forma adecuada. Se pedía la modificación del art. 74 de la Ley Orgánica Provincial de 29 de agosto de 1882 y se especificaban las competencias que se atribuían a las diputaciones, y lo que era más importante, ampliando las mismas hasta el límite compatible con la soberanía de Estado. En estas modificaciones se solicitaba la creación de haciendas provinciales y municipales, puesto que se consideraba que una mayor autonomía municipal conllevaría una mejor administración de los bienes de los pueblos de la provincia. En definitiva, se pensaba que la descentralización dentro del sistema local vigente significaría una mejor gestión de los recursos propios.

César Gusano no se olvidó de una cuestión que era causa de fricción entre Estado y diputaciones provinciales y que había constituido una reclamación histórica, tal era la obligación por parte del Estado de sufragar los gastos que originasen los servicios inherentes a su competencia y cuyo sostenimiento venía imponiéndose a las provincias, como las atenciones de Segunda Enseñanza, parte de las de Beneficencia, como Manicomio y Hospital de incurables, las del Consejo de Agricultura, las de la Sección Administrativa de Primera Enseñanza y las de Corrección pública.

${ }^{272}$ A.D.P.P., L.A.P.D. 123, 23-XI-1918. 
Este asunto ya se había discutido en la Asamblea de diputaciones celebrada en Madrid meses antes, por constituir Instrucción Pública y Beneficencia dos de los capítulos presupuestarios que mayor gasto suponían para las mermadas arcas provinciales en la mayor parte de las diputaciones provinciales españolas de Régimen Común, que se consideraban en este punto en inferioridad de condiciones respecto a las de Régimen Foral ${ }^{273}$. En la mencionada sesión, se hacía un llamamiento a los representantes palentinos en Cortes para que «(..) gestionen un concierto parecido al que tienen las Vascongadas y Navarra, para el pago de las contribuciones ${ }^{274}$.

Las diputaciones provinciales, mancomunadas o coordinadas iban a constituir una parte fundamental en este fenómeno regionalista. Las diputaciones castellanas, en la Asamblea de diputaciones castellano-leonesas celebrada en Segovia el 24 de enero de 1919, mostraron su desconfianza hacia la región como entidad supraprovincial y en el caso de constituirse las provincias en regiones, se opondrían a cualquier traspaso de atribuciones que no fuesen propias de las funciones que tenían concedidas las diputaciones provinciales. El Gobierno Romanones, consciente del anhelo regionalista que había prendido en parte de la sociedad española, especialmente en catalanes y vascos, elaboró un Proyecto de 22 Bases que no aportaban nada nuevo al ya vetusto debate sobre la organización territorial del Estado liberal español. Las primeras 21 Bases estaban dedicadas a la reforma municipal, la 22 contemplaba la formación de las regiones a partir de los municipios. A tenor de lo dispuesto en los arts. 3 y 4 , de la Base 22 , las diputaciones provinciales desaparecían ${ }^{275}$, puesto que se reconocía la formación de las regiones a partir de los municipios, no de las provincias. El art. 3 establecía en lo que respecta a la formación de la Región que:

«(...) el Gobierno formulará el proyecto de ley para estatuirla, designado en él claramente la materia de común interés para aquellos municipios que haya de atribuirse el poder regional y dejando siempre incólumes las autonomías municipales y la soberanía de la nación.»

\footnotetext{
${ }^{273}$ En 1876, la Diputación Provincial de Palencia ya había solicitado la abolición de los fueros de las provincias vascongadas y de Navarra, al considerar que eran instituciones altamente perjudiciales para los intereses del resto de las provincias de España. A.D.P.P., L.A.P.D. 42, 3-I-1876.

${ }^{274}$ A.D.P.P., L.A.P.D. $123,23-X I-1918$.

${ }^{275} C f r$. GONZÁLEZ CASANOVA, José Antonio, Las Diputaciones provinciales en España. Historia politica de las Diputaciones en España desde 1812 hasta 1985, op. cit., p.113.
} 
Se deducía pues, que serían los municipios, las regiones y el Estado, los organismos encargados de repartirse las competencias administrativas correspondientes a las atribuciones que les eran propias. Por lo tanto, la institución de la Diputación Provincial no aparecía reflejada como sujeto de competencia alguna en el nuevo organigrama de la Administración territorial española. El art. 4, referido a las provincias catalanas, sí mencionaba a las diputaciones provinciales y lo hacía para establecer las condiciones necesarias para el mantenimiento de las mismas: «requerirá la votación favorable de la mayoría de los ayuntamientos que representen también la de habitantes en la provincia respectiva» ${ }^{276}$. Por lo tanto, la pervivencia de las diputaciones no dependía del Estado, sino de la voluntad de los ayuntamientos que componían la provincia. Así pues, el Proyecto Romanones no contemplaba la desaparición automática de las diputaciones, pero si preveía mecanismos que implicaban que ese proceso pudiese llevarse a cabo. Este Proyecto, como había sucedido con anterioridad con otros que también abordaban la siempre inconclusa reforma de la Administración Local, no llegó a convertirse en Ley. Sin embargo, el proyecto de regionalización no cayó en el olvido y volvió a plantearse en el la Dictadura de Primo de Rivera. Personajes tan significados del conservadurismo español como Calvo Sotelo o Gil Robles, eran partidarios de reformar el Régimen Local español, planeando una vez más la representatividad de la provincia como entidad territorial en favor del concepto de región. La Diputación Provincial de Palencia no era ajena a este sentimiento regionalista del Directorio Militar y acordó que en la visita que realizaría una representación de la Diputación Provincial al general Primo de Rivera y, ante la posible reforma de la Administración Local en el sentido citado, se propusiera que Palencia fuese elegida como futura capital de la región.

El día 12 de enero de 1924 se promulgó el Real Decreto que ordenaba la disolución de todas las diputaciones provinciales de España, excepto las de Álava, Guipúzcoa, Vizcaya y la de Navarra. El art. 5 del Real Decreto de 12 de enero de 1924 disponía que las Corporaciones Provinciales elevasen al Ministerio de Gobernación, en un plazo de quince días prorrogado posteriormente a treinta, una Memoria breve detallando los defectos que observasen las diputaciones en su funcionamiento, proponiendo, a su vez, las medidas correctoras para esas deficiencias.

\footnotetext{
${ }^{276}$ González Casanova llega a la conclusión de que, aunque este art. hacía referencia a las cuatro provincias catalanas, lo establecido en él era válido para el resto de las provincias españolas. Ibidem, p. 112.
} 
Esta disposición perseguía como fin último que la Dirección General de Administración conociese la situación real de las diputaciones provinciales en el ámbito de sus atribuciones ${ }^{277}$. Junto a esta solicitud, la Subsecretaría de Gobernación pidió a las diputaciones que expresasen su opinión acerca del «problema regional». La opinión de la Diputación se reflejaba en la citada Memoria con la aprobación de una ponencia sobre este asunto. Debe decirse que en las páginas de este documento queda reflejada otra ponencia sobre el mismo tema que no fue aprobada. La ponencia aprobada defendía el mantenimiento de la personalidad de la provincia como organismo intermedio entre el Estado y los municipios, no obstante, admitía la posibilidad de crear un ente administrativo superior, la región. Para la Diputación de Palencia, la constitución de la región debía fundamentarse en dos premisas básicas, racionalización en la asignación de las atribuciones a las distintas provincias que componían la región, y libertad para los municipios y provincias a la hora de mancomunarse conforme a una legislación administrativa no restrictiva ${ }^{278}$. Destacaba un concepto que sobrevolaba la ponencia, la independencia de gestión de aquellos asuntos en los que la Diputación Provincial, a pesar de no intervenir en su gobierno, cargaba con su sostenimiento. En resumen, se respondió con un «no» a la descentralización del poder sin una previa cesión del Estado a las diputaciones provinciales de Régimen Común de los servicios públicos y funciones administrativas inherentes a las administraciones provinciales. De este modo, se pretendía que la provincia poseyera autonomía para gestionar los servicios públicos que el Estado le otorgase, algo que no sería posible si no iba acompañado de la autonomía necesaria para recaudar tributos que costeasen esos servicios.

\footnotetext{
${ }^{277}$ ANUARIO DE LA VIDA LOCAL. 1924. Administración Provincial: Mancomunidades, Diputaciones Provinciales y Cabildos Insulares. Tomo I. Madrid. Dirección General de Administración. 1925.

${ }^{278}$ Cfr. ORDUÑA REBOLLO, Enrique, «Regionalismo y Asambleas de Diputaciones. Postura de la Diputación de Palencia (1923-1930)», Tello Téllez de Meneses, Nº 60 (1989), pp. 243-244.
} 
La región era vista como un medio de lograr una mayor eficacia organizativa y racionalización de servicios, pero sin que eso significase pérdida de poder político del Estado en el ámbito provincial. La Diputación de Palencia defendía, al igual que había hecho en la Asamblea de Segovia en 1919, un regionalismo que no supusiese merma de la unidad nacional ${ }^{279}$. La ponencia no aprobada insistía más en el tema organizativo que en el puramente funcional, al destacar el nulo espíritu regional existente en la provincia de Palencia y calificaba a la región como un ente o concepto puramente imaginativo sin ningún valor histórico real ${ }^{280}$. Para los defensores de esta ponencia, el statu quo administrativo provincial de más de un siglo de existencia había generado un fondo común de tradición provincial que sería perjudicial no tener en cuenta y la región era una entelequia administrativa fuera de contexto histórico en España ${ }^{281}$.

Al igual que con otros intentos de articular administrativamente el territorio nacional, el espíritu regionalista de Primo de Rivera se fue diluyendo en el tiempo y el dictador se posicionó en contra de una división regional para España ${ }^{282}$, la provincia, con ella las Diputaciones provinciales continuarían representando al Estado en sus respectivos territorios ${ }^{283}$.

\footnotetext{
${ }^{279} C f r$. PALOMARES IBÁÑEZ, Jesús María, «El regionalismo castellanoleonés y las gestiones para conseguir el estatuto de autonomía (1900-1936)», Nación y Regionalismo en España, Córdoba, Diputación de Córdoba, 1985, pp.75 y ss.

${ }^{280}$ Para la Diputación Provincial de Palencia, Castilla era un hecho histórico y no un territorio geográfico limitado, no era un organismo central propulsor de energías regionales, ni eje político en torno al cual girasen aspiraciones nacionalistas. A.D.P.P., Memoria de deficiencias y soluciones de 1924, C-R/ 1,12.

${ }^{281}$ A.D.P.P, Memoria de deficiencias de 1924, C-R/ 1,12.

${ }^{282} C f r$. PAREJO ALFONSO, Luciano José, «La Región y la legislación histórica de régimen local», en FERNÁNDEZ RODRÍGUEZ, Tomás Ramón, Las Autonomías Regionales, Madrid, Instituto Nacional de Prospectiva (INP), 1977, pp. 155 y ss.

${ }^{283}$ Curiosamente, lo que no logró la política, lo hizo posible el turismo. En 1928 se aprobó el Real Decreto de 25 de abril, que dividía a España en regiones a efectos turísticos. Palencia quedaba integrada en la Región Central. De la importancia que en esta época empezaba a cobrar el turismo como actividad económica da muestra el hecho de que la Diputación de Palencia pagase a varios medios de información nacional, por ejemplo, 1.000 pts. al diario madrileño La Nación, por publicar en sus páginas propaganda provincial, fotografías de monumentos e instalaciones, sobre aspectos turísticos de la provincia e incluso el desarrollo de ciertos servicios administrativos, especialmente los de Beneficencia. A.D.P.P., L.A.C.P. 145, 20-VII-1929.
} 


\section{El Estatuto Provincial de 1925}

Tras la promulgación del Real Decreto del 12 de enero de $1924^{284}$ y las supuestas simpatías de Primo de Rivera por la opción regionalista, las diputaciones esperaban con expectación la nueva norma que regularía su organización $\mathrm{y}$ funcionamiento, el Estatuto Provincial. Tan pronto fue publicado se disiparon los temores de las corporaciones provinciales, pues ya en la Exposición de Motivos quedaba bien claro que la provincia, y no la región, había de ser el marco institucional de desenvolvimiento de la Administración Local ${ }^{285}$ en el nuevo régimen dictatorial. En el preámbulo del Estatuto, José Calvo Sotelo, director General de Administración Local del Directorio Militar de Primo de Rivera, exponía su convicción de la necesidad de un Estatuto Provincial para completar la «obra de reorganización local». Para el político conservador, el Estatuto Municipal de 1924, que había reformado la administración de los ayuntamientos, podía servir de ejemplo para la reforma a nivel provincial. Como en el frustrado proyecto de Maura ${ }^{286}$, Calvo Sotelo pretendía con su reforma que la provincia fuera un ente administrativo en el que no tuviese cabida el caciquismo, despolitizado, con la única misión de gestionar de forma adecuada los intereses de la provincia en beneficio de sus habitantes, en resumen, un nuevo intento de descentralización de la Administración Local. Esto conllevaba que las diputaciones provinciales dejasen de ser mera correa de transmisión de las políticas estatales a través del gobernador civil, como máximo representante del Estado en la provincia y que al tiempo no ejerciesen de superiores jerárquicos de los ayuntamientos a fin de evitar que estos fuesen herramientas del caciquismo de las comisiones provinciales ${ }^{287}$.

\footnotetext{
${ }^{284}$ Contemplaba la designación de los diputados provinciales, a título provisional, por los Gobernadores Civiles.

${ }^{285}$ No obstante, el Estatuto Provincial contemplaba, en su art. 6, la posibilidad de aplicar el denominado régimen de Carta intermunicipal, que facultaba a los ayuntamientos para sustituir a la Diputación Provincial por otro u otros organismos, alterando su estructura orgánica, administrativa y económica.

${ }^{286}$ Cfr. BERMEJO GIRONÉS, Juan Ignacio, El Estatuto Municipal: Antecedentes y Motivaciones, en Cincuentenario del Estatuto Municipal: estudios conmemorativos, Madrid, INAP, 1975, pp. 64 y ss.

${ }^{287}$ Cfr. GONZÁLEZ CASANOVA, José Antonio, Las Diputaciones provinciales en España. Historia política de las Diputaciones en España desde 1812 hasta 1985, op. cit., p. 122.
} 
El Estatuto Provincial de 1925 aspiraba a dotar a las provincias de plena autonomía, tanto en su forma de elegir a sus representantes como en la no intromisión del Estado en el funcionamiento de las mismas, exceptuando el ámbito fiscal y presupuestario $^{288}$. Las diputaciones continuaban siendo las entidades administrativas encargadas de defender los intereses provinciales y de representar a la provincia. Calvo Sotelo pensaba que la institución provincial, que había nacido como parte del sistema vertebrador del territorio en la España liberal, se había convertido con el tiempo en un instrumento de control de los caciques sobre los ayuntamientos, que estrangulaba la vida municipal e impedía el desarrollo de los municipios:

«Las diputaciones, en efecto, salvo honrosas excepciones, forzadas a vivir en penuria económica lamentable, sólo abordaron con amplitud la tarea política, esclavos de ella, trocáronse de tutores en verdugos de la vida municipal, y sirvieron de refugio a desaforadas pasiones oligárquicas y diseminaron la gangrena del caciquismo en los más apartados rincones y lugares del país. ${ }^{289}$

Para Calvo Sotelo, muchos de los males que aquejaban a las diputaciones provinciales se debían a la falta de autonomía de estas instituciones, sus acuerdos eran revocables por la autoridad gubernativa, que también podía suspender a los diputados, el gobernador presidía la Diputación Provincial con voz y voto en sus deliberaciones y podía suspender los acuerdos alcanzados por la misma. En palabras del propio Calvo Sotelo, no era factible que las diputaciones diesen un solo paso ni pergeñasen decisión alguna, sin la mediación anterior o posterior del poder Ejecutivo. En consecuencia, este Estatuto pretendía ser el marco jurídico sobre el que se desarrollara una nueva relación de las entidades locales entre sí, y entre estas y el Estado, basada en la independencia y la no intromisión, con el objetivo de lograr un funcionamiento más racional de ayuntamientos y diputaciones en beneficio del desarrollo socioeconómico de los pueblos de España.

\footnotetext{
${ }^{288}$ Cfr. SÁNCHEZ-ARCILLA BERNAL, José, Historia de las instituciones político-administrativas contemporáneas (1808-1975), Madrid, Dykinson, op. cit., 1994, p. 286.

${ }^{289}$ Estatuto Provincial de 1925, p. 7.
} 
El Estatuto contemplaba varias medidas encaminadas a eliminar esa dependencia dañina, señalaba, por ejemplo, que la Diputación, reunida en Pleno o en Comisión, sería presidida por un diputado provincial y que el gobernador dejaba de tener voto en las sesiones. Solo los tribunales tendrían la capacidad para suspender y destituir a los diputados provinciales, los acuerdos provinciales solo podrían ser revocados por los tribunales, con una única excepción en la que el gobernador podría hacer uso de su facultad de suspensión, el de la infracción manifiesta de las leyes con perturbación grave del orden público. En los casos restantes, la suspensión solo se podría acordar por el presidente de la Diputación o por el Tribunal Contencioso-Administrativo a petición del gobernador. La Disposición octava del Estatuto establecía que las diputaciones se harían cargo del sostenimiento de estos tribunales mientras el Estado no asumiese esta partida. A este efecto, se dividían las provincias de Régimen Común en cinco grupos constituidos en base a las causas incoadas al año; Palencia se encontraba encuadrada en el grupo B, entre aquellas provincias que incoaban entre 25 y 50 asuntos al año. No obstante, la autonomía que se perseguía con este tipo de medidas no era completa, puesto que aún se mantenían disposiciones como la que recogía la obligatoriedad de remitir para su aprobación por el gobernador los presupuestos provinciales ordinarios y extraordinarios. En resumen, solo en casos de extrema gravedad podía el Estado intervenir en el ámbito de actuación de las diputaciones provinciales. Al igual que ya había sucedido en el Estatuto Municipal de 1924, los tribunales eran las instancias autorizadas para entender sobre las reclamaciones contra los acuerdos provinciales. Estas medidas reforzaban, como se ha dicho, la independencia de las corporaciones provinciales pero el objetivo primordial del Estatuto era conseguir la descentralización de competencias. En primer lugar, transfería a las diputaciones la construcción y conservación de caminos vecinales $\mathrm{y}$, junto a esta competencia, lo que era más importante y muestra de la buena voluntad de estas medidas, la cantidad necesaria para llevar a cabo este servicio, con el mandato de que el numerario asignado no fuese nunca inferior a la cantidad invertida por el Estado en esa misma partida presupuestaria. Calvo Sotelo lo expresaba de esta manera: «Y el traspaso, lo repetimos, será doble: del servicio y de la Hacienda precisa para dotarlo.» 290

\footnotetext{
${ }^{290}$ Estatuto Provincial de 1925, p. 14.
} 
El Estatuto Provincial también preveía otras medidas descentralizadoras, algunas obras (pantanos, puertos, carreteras, etc.) y los servicios que, aun con cierto interés nacional, dispusieran de un carácter eminentemente provincial podrían ser encomendados a las diputaciones por el Estado, previa fijación de un coeficiente de auxilio que permitiese a las instituciones provinciales desarrollar estas atribuciones ${ }^{291}$. El legislador quería evidenciar ya, desde la propia exposición previa al articulado, su intención de desarrollar las atribuciones que permitieran a las diputaciones: «(...) vigorizar la energías de muchas provincias y premiar a las más emprendedoras.» ${ }^{292}$ y, en muestra de su firme voluntad de sacar adelante este proyecto, enumeraba las facultades que habrían de desarrollar las Corporaciones provinciales: «(...) desde la construcción de ferrocarriles al tendido de líneas telegráficas, desde la Beneficencia hasta la Sanidad, sin omitir la Cultura ni olvidar los deberes sociales, las diputaciones podrán fomentar cuanto signifique interés moral o material de las provincias. ${ }^{293} \mathrm{En}$ la Memoria de deficiencias de 1924 de la Diputación Provincial de Palencia, se señalaba que siete octavas partes del presupuesto eran absorbidas por las obligaciones de Beneficencia ${ }^{294}$ y por otras obligaciones que privativamente incumbían al Estado, sobre las que ninguna intervención ni fiscalización ejercía la institución provincial, y que gravaban indebidamente el Presupuesto Provincial.

\footnotetext{
${ }^{291}$ La Diputación de Palencia consideraba que el Estado debía asumir todas las obligaciones comprendidas en el Capítulo I, art. 1 del Presupuesto de gastos de las diputaciones, y también el personal y material de las Secciones de Presupuestos Municipales. A.D.P.P., L.A.C.P. 145, 24-V-1929.

${ }^{292}$ Estatuto Provincial de 1925, p. 15.

${ }^{293}$ Estatuto Provincial de 1925, p. 15.

${ }^{294} \mathrm{El}$ gasto era tan grande que se intentaba ahorrar en cualquier capítulo. En 1924, se consideró que la empresa que suministraba electricidad a los Establecimientos de Beneficencia, «Electra Popular Vallisoletana» cobraba un precio excesivo y se decidió anunciar en concurso este servicio. Tras un primer concurso desierto, se adjudicó el servicio de suministro eléctrico de los Establecimientos de Beneficencia, del Palacio Provincial, Gobierno Civil y habitaciones particulares del gobernador a la sociedad Unión Industrial Palentina. A.D.P.P., L.AC.P. 136, 7-X-1924. A partir del 1 de julio de 1925 se acordó que los costes del alumbrado y servicio telefónico del Gobierno Civil, habitaciones particulares del gobernador, Audiencia Provincial y cuartel de la Guardia Civil, la Diputación costeaba el servicio telefónico del Cuartel de la Guardia Civil desde el 31 de diciembre de 1902, dejasen de estar sufragadas por la Diputación Provincial. El gobernador manifestó su queja por esta cuestión respondiendo la Diputación que el Estatuto Provincial no imponía la obligación de costear estos servicios con cargo al Presupuesto Provincial. Por Real Orden de 28 de mayo de 1889, la Diputación Provincial y, en su nombre, la Comisión Provincial estaban facultadas para decidir si adquirían con fondos provinciales determinados enseres (ropa de cama y mesa, cubiertos, vajillas, útiles de comedor y cocina) para la casa del gobernador. En sesión del Pleno de la Diputación de 1 de abril de 1890, se había acordado facilitar solo la casa y los muebles al gobernador. A.D.P.P., L.A.P.D. 69, 1-IV-1890.
} 
Para remediar esta situación, proponía la Comisión Provincial separar los servicios propios y peculiares de la provincia, atribuidos a la Diputación Provincial, de aquellos otros propios y exclusivos del Estado, que se satisfacían con cargo al Presupuesto Provincial ${ }^{295}$. Además, solicitaba el fortalecimiento de la Hacienda provincial con recursos y arbitrios propios que le permitiesen sustituir el Contingente Provincial. Además de estas transferencias, el Estatuto fijaba en el Título IV, en su Capítulo III, las obligaciones mínimas en materia de Beneficencia, Sanidad, Enseñanza técnica, industrial, artística o agrícola, Fomento de instituciones de carácter social y caminos vecinales. En Beneficencia, el art. 127 contemplaba la obligatoriedad para las diputaciones provinciales del sostenimiento de una Casa provincial de Maternidad y Expósitos, Casa de Caridad para indigentes y Casa de reclusión de dementes pobres. No obstante, se autorizaba a las diputaciones a concertar con los establecimientos privados o públicos de la provincia estos servicios. El art. 128, regulaba las obligaciones en Sanidad, subvencionar las obras de carácter de sanitario, preferentemente las de abastecimiento de agua y evacuación de agua residuales que llevasen a cabo los ayuntamientos de la provincia, y sostener un Instituto de Higiene.

En cuanto al fomento de instituciones de carácter social, en el art. 132 se hacía especial hincapié en la necesidad de fomentar las Cajas colaboradoras del Instituto Nacional de Previsión. Por último, el art. 133 obligaba a las diputaciones a dotar de caminos vecinales al territorio de su competencia, de tal forma que todos los núcleos poblados que excediesen de 75 habitantes estuviesen comunicados. La construcción y conservación de los caminos vecinales correría a cargo de las diputaciones provinciales, pero el Estado subvencionaría este servicio durante un periodo de diez años con una cantidad no inferior a la que figurase en el presupuesto del ejercicio de 1925. El último art. de este Capítulo, el 134, suponía un respiro para las maltrechas haciendas provinciales, puesto que eximía a las diputaciones provinciales de las cargas y aportaciones que conforme a diversas leyes, ${ }^{296}$ les fuesen exigibles para el sostenimiento de los servicios de Institutos, Escuelas Normales, Inspección de Primera Enseñanza, Bibliotecas y Secciones administrativas de Primera enseñanza. Estos servicios pasaban a ser competencia del Estado a partir de la promulgación del Estatuto Provincial de 1925.

\footnotetext{
${ }^{295}$ A.D.P.P., Memoria de deficiencias y soluciones de 1924, C-R/1,12.

${ }^{296}$ Ley de 29 de junio de 1887, Ley de 29 de junio de 1890, Ley de 2 de marzo de 1917 y Real Decreto de 3 de marzo de 1917.
} 
En 1918, la Diputación Provincial de Palencia ya manifestaba ${ }^{297}$ que era imposible la vida de las diputaciones si a estas no se les dotaba de más recursos que el Contingente Provincial, que en su opinión era una losa de plomo que mataba todas las iniciativas e impedía el desenvolvimiento de la riqueza de las provincias. Recordaba la institución provincial que, en diferentes asambleas de las diputaciones y de modo especial en la celebrada en Madrid hacía pocos meses, se había acordado que era preciso que las atenciones de Segunda Enseñanza, muchas de las de Beneficencia (Manicomio y Hospital de incurables), Consejo de Agricultura, Sección Administrativa de Primera Enseñanza e Inspección y las de Corrección Pública, pesasen sobre el Presupuesto General del Estado y no sobre las arcas provinciales.

Este nuevo espíritu regeneracionista no solo se quedaba en una mayor independencia administrativa y reorganización de competencias, sino que se complementaba con una reforma de la organización y estructura de las diputaciones. El número de diputados se reducía, quedando el margen entre 18 como máximo y 10 como mínimo. Los diputados provinciales llamados directos serían elegidos por sufragio universal (las mujeres cabeza de familia podían ser electoras y elegibles) aunque un régimen corporativista como el de Primo de Rivera no podía obviar su orientación ideológica, «(...) máxime después de haberla establecido en la esfera municipal» ${ }^{298}$, y reservaba la elección de diputados provinciales corporativos, en igual número que los directos, a los ayuntamientos, entre sus concejales, a los que el Estatuto definía como los verdaderos depositarios de la soberanía provincial. El pleno de la Diputación se reuniría en dos periodos de sesiones al año, con el objetivo primordial de ratificar las cuentas del año anterior en el primer periodo y la aprobación de los presupuestos para el próximo ejercicio, en el segundo periodo de sesiones.

\footnotetext{
${ }^{297}$ A.D.P.P., L.A.D.P. 123, 23-XI-1918.

${ }^{298}$ Estatuto Provincial de 1925, p.16.
} 
Los diputados directos, seis en el caso de Palencia, formarían la Comisión Provincial, verdadero órgano rector de la Diputación, con un mandato de seis años. El presidente y vicepresidente de la Diputación serían elegidos de entre los diputados directos. Los diputados corporativos tendrían un mandato por dos años y debían cesar antes de ese tiempo si cesaban como concejales de sus respectivos ayuntamientos. La provincia se convertía en circunscripción única, suprimiéndose los Distritos formados por uno o dos Partidos Judiciales. Esta medida se tomaba con la esperanza de que la oligarquía caciquil perdiese la influencia sobre los modestos Partidos rurales en el más grande escenario electoral de las circunscripciones únicas. Las Audiencias Territoriales serían las encargadas de revisar los escrutinios de las elecciones a diputados provinciales. Otro aspecto que reformaba el Estatuto de 1925 era la Hacienda provincial, fundamental para poder asumir todas las nuevas atribuciones que le eran encomendadas a las diputaciones provinciales, puesto que de poco serviría que la Diputación tuviera mayor competencia administrativa sino contaba con suficientes recursos económicos para desarrollar sus funciones.

A comienzos del siglo XX, la Hacienda local se encontraba en una situación calamitosa y las diputaciones se veían impotentes para sacar adelante los servicios que tenían encomendados con una dependencia casi exclusiva del Impuesto de Consumos y del Repartimiento General ${ }^{299}$. Calvo Sotelo se quejaba de que las haciendas provinciales, a diferencia de las municipales, no habían sido objeto de ninguna reforma desde hacía medio siglo: «(...) las haciendas provinciales vegetan tal fueron creadas hace medio siglo.» ${ }^{300}$ El político gallego hacía mención de los proyectos de reforma de Maura de 1907 y de Canalejas de 1912, a los que consideraba sin ningún afán renovador de la Hacienda provincial pues mantenían el Contingente Provincial como la fuente de ingresos fundamental de las diputaciones. Distinta valoración hacía del proyecto de Cambó de 1922, que trataba de eliminar el Contingente, posibilidad que era factible por los recursos que se preveían para las diputaciones de las contribuciones especiales y participaciones de impuestos gestionados por el Estado, como el Impuesto sobre el Patrimonio.

\footnotetext{
${ }^{299} C f r$. GARCÍA RUIPÉREZ, Mariano, Manual de Hacienda para archiveros municipales, Murcia, Ediciones Tres Fronteras, 2008. p. 70.

${ }^{300}$ Estatuto Provincial de 1925, p. 20.
} 
En opinión de Calvo Sotelo, el Contingente era un ingreso insuficiente y pernicioso porque gravaba a los pueblos de forma desigual y además, provocaba contactos inevitables entre ayuntamientos y diputaciones, «(...) abriendo portilla al favor y la captación política.» ${ }^{301}$, por lo que prudente y beneficioso era reformarlo, sin que esto quisiera decir que los ayuntamientos quedasen libres de todo tipo de contribución dineraria a las arcas provinciales, habida cuenta de que la principal fuente de ingresos de las diputaciones debían ser las aportaciones municipales. No obstante, se señalaba un tope máximo de aportación forzosa ordinaria de cada municipio, que equivaldría al 90, al 85 o al 80\%, según los casos, de lo que importase el Contingente del año económico 1924-25, salvo para los municipios de más de 200.000 habitantes, en cuyo caso la aportación forzosa podría ser igual a la cuota total del Contingente satisfecho en el ejercicio económico mencionado. Con este sistema se quería poner un tope a la «(...) voracidad creciente de las Diputaciones.» ${ }^{302}$, forzadas al aumento constante del Repartimiento ${ }^{303}$ por la evolución de la economía a nivel nacional e internacional. Esta reducción del aporte municipal sería compensada con la cesión por parte del Estado del 5\% de la Contribución Territorial Rústica ${ }^{304}$ y lo que recibía por el Impuesto de Cédulas Personales ${ }^{305}$. La Hacienda provincial proyectada en el Estatuto Provincial estaría basada en las rentas, las contribuciones especiales, derechos, tasas, arbitrios y recargos. No se olvidaba Calvo Sotelo de la cuestión regional, la figura administrativa de la región quedaba regulada en el Libro Tercero del Estatuto. En él, se establecían las condiciones que debían producirse para que fuese legal la constitución de la región. En primer lugar, se necesitaba la aprobación de las tres cuartas partes de los ayuntamientos que formasen la provincia para crear la región y, además estos debían representar las tres cuartas partes de los electores de la provincia.

\footnotetext{
${ }^{301}$ Estatuto Provincial de 1925, p. 22.

${ }^{302}$ Estatuto Provincial de 1925, p. 22.

${ }^{303}$ Véase Anexo III. Porcentaje del Contingente Provincial en la etapa 1875-1924/25, p. 471.

${ }^{304}$ Los diputados provinciales se quejaban de que los propietarios de terrenos en los que hubo plantados viñedos siguiesen contribuyendo por una riqueza que ya no existía debido a la plaga de la filoxera.

${ }^{305}$ Impuesto provincial desde el día 1 de enero de 1926. Estaban sujetos a este impuesto todos los españoles y extranjeros mayores de 14 años. Los ayuntamientos eran los encargados de su recaudación, elaboraban los padrones y liquidaban ante la Diputación. Este impuesto gravaba las rentas del trabajo, las contribuciones directas y los alquileres.
} 
Por si este tipo de condicionamientos fuesen ya de por si restrictivos, el legislador añadía, además, un reaseguro para la constitución válida de la región, puesto que, una vez elaborado el Estatuto Regional por la correspondiente Comisión, se requería para su aprobación que todos los ayuntamientos interesados se reuniesen el mismo día y que el voto favorable fuese de las tres cuartas partes del número legal de concejales de cada Corporación Municipal, de las tres cuartas partes de los ayuntamientos de la Provincia que además representaran las tres cuartas partes de los electores de la misma. Aparte de este galimatías procedimental, la última palabra sobre la aprobación final de la región no la tenían los ayuntamientos, pues el art. 308 del Estatuto Provincial especificaba que el Gobierno era quien redactaría de forma definitiva el Estatuto Regional, tomando como base el proyecto sometido a su sanción, conforme al apartado E del art. 305, que puntualizaba que el Gobierno resolvería previa audiencia del Consejo de Estado en pleno. El Estatuto se dotaba de instrumentos legales para que, en caso de considerarlo oportuno, pudiese bien suspender los acuerdos adoptados por la región (art. 308), en caso de que estos supusiesen grave perjuicio para los intereses públicos o de la seguridad del Estado, o incluso disolver la región (art. 310), por causas de orden público o seguridad nacional.

El Estatuto Provincial llegó a promulgarse pero, como tantos otros proyectos de reforma del ámbito local, no regeneró la vida provincial como esperaba su autor en el prólogo: «Si se quisiera condensar en pocas palabras su esencia, podríamos decir que todo en él es una inmensa, una vibrante exaltación del espíritu local.» ${ }^{306}$, eran las palabras de Calvo Sotelo. Nunca se celebraron elecciones y los diputados provinciales fueron designados por el Gobierno. En 1930, el Ejecutivo del general Berenguer decidió poner en vigor parte de la Ley Provincial de 1882 y el Estatuto de 1925 quedó para la historia como un nuevo fracaso en el tortuoso camino de la descentralización del régimen liberal español. Al fin y al cabo, los esfuerzos de Calvo Sotelo por librar del caciquismo a provincias y municipios también tenían fines políticos, por mucho que el régimen donde se pretendían implantar fuese una Dictadura ${ }^{307}$.

\footnotetext{
${ }^{306}$ Estatuto Provincial de 1925, p. 31.

${ }^{307}$ Cfr. GONZÁLEZ CASANOVA, José Antonio, Las Diputaciones provinciales en España. Historia política de las Diputaciones en España desde 1812 hasta 1985, op. cit., p. 122.
} 
Después de la revisión del contexto legislativo restauracionista en el ámbito provincial, puede concluirse que todos ellos fracasaron en su objetivo reformista, no tanto por un problema de organización de las diputaciones provinciales, como por un impedimento político. La reforma del Régimen Local era una necesidad que todos los actores políticos admitían, pero los partidos dinásticos no estaban dispuestos a dar su apoyo a reformas que pusiesen en peligro su posición de privilegio puesto que el poder local, provincial y estatal se entrelazaban en el sistema caciquil de la Restauración. Esta fue la clave para entender el porqué del fracaso parlamentario de todos aquellos proyectos reformadores y el paradójico éxito relativo ${ }^{308}$ del proyecto de Calvo Sotelo en una etapa, la Dictadura, en la que los partidos estaban fuera del juego político.

Los liberales, que siempre se opusieron a los proyectos reformistas de los conservadores, fueron los pioneros en proponer la reforma de la vida local en 1882 pero, a la larga, los propios parlamentarios liberales se opusieron a los proyectos de Canalejas o Romanones, conscientes de que peligraba su posición privilegiada en el poder local, puesto que sus representantes en el ámbito local eran también caciques. Temían que si salían adelante los proyectos reformistas conservadores, debido a su poder social, estos podrían ganar sin necesidad de acudir a artimañas electorales y ellos perderían poder, y eso en un sistema como el de la Restauración significaba perder influencia a nivel estatal $^{309}$. Si a esto se añade la influencia creciente de las fuerzas no dinásticas, ex carlistas, regionalistas como la Lliga, republicanos, federales, y socialistas en los comicios municipales y provinciales, se comprenderá mejor el recelo de conservadores y liberales hacia unas reformas que podían abrir la puerta del poder a partidos contrarios al sistema restauracionista. En otras palabras, no solo se ponía en riesgo el entramado caciquil sino también la supervivencia del sistema turnista. En resumen, por la propia configuración del sistema, la reforma del Régimen Local, tanto municipal como provincial, conllevaba la reforma de la estructura política global por lo que solo cuando el sistema canovista dejó de funcionar, en la Dictadura de Primo de Rivera, se pudo intentar el ansiado cambio de la vida local.

\footnotetext{
${ }^{308}$ A pesar de que fueron aprobados, tanto el Estatuto Municipal de 1924 como el Estatuto Provincial de 1925 , no pudieron llegar a desarrollar su proyecto reformista por el breve tiempo de aplicación.

${ }^{309} \mathrm{Cfr}$. GONZÁLEZ CASANOVA, José Antonio, Las Diputaciones provinciales en España. Historia política de las Diputaciones en España desde 1812 hasta 1985, op. cit., p. 131.
} 


\section{La Diputación Provincial palentina en la Restauración}

\section{Naturaleza}

Varios factores otorgaban cierta peculiaridad jurídica a las diputaciones provinciales decimonónicas. En primer lugar, su carácter legal, ya que la organización de la institución provincial y su funcionamiento estaban estructurados en base a disposiciones legales. Todas las diputaciones provinciales, salvo las diputaciones forales, compartían cierto carácter unificador, de modo que así evitaban peculiaridades territoriales en su estructura. En segundo término, y como consecuencia de su carácter legal, las diputaciones formaban parte de una estructura administrativa estatal $\mathrm{y}$, en función del color político del Gobierno de turno, se concedía a esta institución una mayor o menor autonomía en la gestión de los asuntos provinciales. Por último, destacar el carácter electivo de los miembros de la Diputación, algo que también varió con los distintos gobiernos de la Restauración del siglo XIX. Durante la etapa primorriverista, la Diputación Provincial pasó a tener carácter de persona jurídica ${ }^{310}$, con capacidad plena para conservar o enajenar bienes de toda clase, celebrar contratos, establecer servicios públicos y ejercitar acciones civiles, criminales, administrativas o contenciosoadministrativas.

\footnotetext{
${ }^{310}$ Art. 5 del Estatuto Provincial de 1925.
} 


\section{La Diputación y el gobernador provincial}

La legislación provincial dejaba claro que el ejercicio del gobierno de la

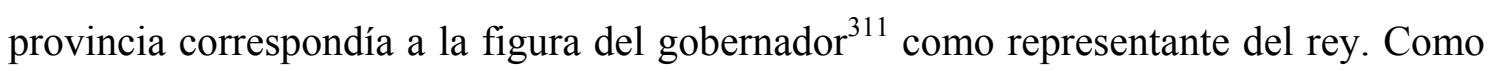
jefe de la Administración Provincial presidía con voz y voto las sesiones, tanto de la Diputación como de la Comisión Provincial ${ }^{312}$, comunicaba y ejecutaba los acuerdos de la Diputación Provincial y suspendía estos acuerdos ${ }^{313}$, cuando procediese según las leyes $^{314}$. La Diputación podía, a su vez, presentar Recurso de Alzada ${ }^{315}$ ante el Gobierno contra la suspensión de sus acuerdos por parte del gobernador ${ }^{316}$. Además, disponía de la facultad de inspección ${ }^{317}$, directamente o a través de delegados, de las oficinas de la Diputación Provincial, sobre todo de la Sección de Cuentas. Debía vigilar el cumplimiento de las leyes generales por la institución provincial ${ }^{318}$, así como que los acuerdos de la Diputación y Comisión Provincial observasen la legislación provincial. El gobernador era el encargado de transmitir, a la Diputación y a la Comisión Provincial, las disposiciones del Gobierno que le eran comunicadas por el ministro de la Gobernación.

\footnotetext{
${ }^{311}$ Art. 14 de la Ley Provincial de 29 de agosto de 1882.

${ }^{312}$ Art. 2. Disp. 8 de la Ley Provincial de Bases de 16 de diciembre de 1876. Art. 28 de la Ley Provincial de 29 de agosto de 1882. A partir de la promulgación del Estatuto Provincial de 1925, era un diputado provincial quien ejercía el cargo de presidente, tanto de la Diputación como de la Comisión Provincial.

${ }^{313}$ Los acuerdos de la Diputación se comunicaban al gobernador al tercer día de su adopción.

${ }^{314}$ En caso de suspensión de los acuerdos de la Diputación Provincial y de la Comisión Provincial, el gobernador debía dar cuenta razonada de la causa de suspensión al Gobierno, en el plazo de las 48 horas siguientes y también comunicarlo a la Diputación, si estaba reunida. En otro caso, se le comunicaba a la Comisión Provincial, con la expresión de causas y fundamentos jurídicos en los que se basaba. El gobernador podía actuar por sí mismo o a instancia de parte para proceder a la suspensión.

${ }^{315}$ Por ejemplo, en mayo de 1910, la Comisión Provincial presentó recurso de alzada, ante el ministro de la Gobernación, por la suspensión por el gobernador del acuerdo de la Asamblea Provincial, referente a la declaración de vacante del cargo de diputado provincial, por el Distrito de Astudillo-Baltanás, de Evaristo Rodríguez Blanco, nombrado gobernador civil de Lugo. A.D.P.P., L.A.C.P. 114, 30-V-1910.

${ }^{316} \mathrm{El}$ gobernador remitía al Ministerio de la Gobernación, en el plazo de diez días, los recursos de alzada que se interpusieran contra su resolución de suspensión.

${ }^{317}$ Art. 28 de la Ley Provincial de 29 de agosto de 1882.

${ }^{318} \mathrm{El}$ gobernador no podía modificar ni revocar las resoluciones de la Diputación Provincial cuando fuesen declaratorias de derechos o hubiesen servido de base a una sentencia judicial. Tampoco las resoluciones adoptadas en favor de la Administración Central.
} 
Mencionadas las facultades del gobernador y su importancia como parte del entramado de la Administración Local, no extraña que cuando Guzmán Rodríguez, ex diputado provincial, comunicaba a la Comisión Provincial su nombramiento por la reina regente como gobernador de la provincia de Palencia, el diputado provincial Joaquín Monedero y Monedero, en nombre de la Comisión Provincial, se mostrase así de satisfecho «(...) se congratula de que un diputado provincial sea el encargado de gobernar la provincia, porque conocedor de sus necesidades podía consagrarse a hacer administración.»» 319

Las relaciones no eran siempre fluidas entre el gobernador y la Diputación Provincial, pero no puede olvidarse que esta institución había sido concebida como la prolongación del Estado en las provincias y el Gobierno reconocía el papel de las diputaciones. Así, cuando el gobernador civil de la provincia presidía, en mayo de 1916, la sesión del Pleno de la Diputación, dirigía estas palabras de elogio a los diputados provinciales:

«(...) el importantísimo papel que la Constitución y las leyes confieren a estos organismos, entre los que descuellan la creación y conservación de servicios que tengan por fin la comodidad de los habitantes de la provincia, el fomento de sus intereses morales y materiales, los Establecimientos de Beneficencia y de Instrucción Pública, las Obras Públicas de interés provincial y los demás que taxativamente se determinan en su Ley rutinaria.» ${ }^{320}$

\footnotetext{
${ }^{319}$ A.D.P.P., L.A.C.P. 61 , 2-XII-1885.

${ }^{320}$ A.D.P.P, L.A.P.D. 121, 9-V-1916.
} 


\section{Elecciones}

El sistema canovista descansaba sobre la base de unos partidos políticos de notables, que legitimaban su acción de gobierno mediante la celebración de procesos electorales generalmente manipulados. Esto fue así sobre todo hasta los inicios del siglo $\mathrm{XX}$ y se explica por los lazos de dependencia que creaban las relaciones verticales de carácter económico y clientelar, lo que derivaba en una sociedad sin apenas interés político, en la que la máxima expresión política era el voto obediente ${ }^{321}$. No obstante, en provincias como Palencia, la interpretación clásica de la Restauración como un sistema clientelar de notables, no explica satisfactoriamente el comportamiento político de los ciudadanos, habida cuenta de la importancia que en esta sociedad alcanzaban las relaciones familiares ${ }^{322}$ y de vecindad. En gran parte de la zona norte de la provincia de Palencia $^{323}$, persistía, en esta época, una sociedad basada en comunidades aldeanas, con un porcentaje importante de propiedad comunal cuya máxima preocupación era la dureza de la vida cotidiana, con una gran desconfianza hacia todo lo que proviniese del exterior y con una visión muy negativa del Estado, a quién veían como un ente recaudador que desposeía a estas comunidades de su principal fuerza de trabajo, los mozos llamados a quintas.

\footnotetext{
${ }^{321}$ Vid. VILLA ARRANZ, Juan, Caciquismo y comunidades tradicionales en Castilla durante el primer tercio del siglo $X X$, Valladolid, Universidad de Valladolid, 1997. Los votantes no participaban en las elecciones como individuos ajenos al entorno político en el que vivían, por el contrario, eran partícipes de una compleja red de vínculos socioeconómicos que afectaban sensiblemente a su comportamiento político.

${ }^{322}$ Sirva como ejemplo de la importancia de las relaciones familiares en el entramado político de la Restauración en Palencia, el caso de la familia Calderón, políticos por excelencia durante esta etapa en la provincia. Las relaciones que se establecían a nivel político se veían reforzadas si existía un vínculo familiar de por medio, y así lo entendió Abilio, que se casó en primeras nupcias con Arsenia Arroyo, hermana de Jerónimo Arroyo, arquitecto que participó activamente en la vida social y política de la ciudad, y también en su segundo matrimonio con Dolores Manrique del Mazo, hija y heredera de un gran terrateniente de Astudillo. Su hermano, Valentín, contrajo matrimonio con Pilar Martínez de Azcoitia Herrero, perteneciente a una de las familias con más solera de Palencia, con intereses en la banca y en la industria harinera.

${ }^{323}$ La zona de la Valdavia, la Ojeda, Boedo y la Pernía.
} 
Al comienzo de la Restauración, la elección de diputados provinciales ${ }^{324}$ se regía por lo dispuesto en la Ley Electoral de 20 de agosto de $1870^{325}$. Cada Partido Judicial elegía tres diputados provinciales, si el número de estos no llegaba a 20, se aumentaban los elegibles en los partidos con mayor población y si excedían de la cifra de 30 , se reducía el número de elegibles en los partidos con menor población ${ }^{326}$. La Ley Provincial de 29 de agosto de 1882, establecía en cuatro el número de diputados provinciales $^{327}$ elegibles en cada provincia, resultante, ya no de la elección en cada Partido Judicial, sino de la agrupación de dos Partidos Judiciales en un Distrito Electoral. Si el número de Partidos Judiciales fuera impar, el que contase con mayor número de habitantes, formaba por sí solo un Distrito Electoral, que elegía cuatro diputados. En las provincias con seis, siete, que era el caso de Palencia, u ocho, debían formarse cinco agrupaciones electorales que constituirían por sí solas los Partidos Judiciales con mayor número de habitantes. En la sesión del Pleno ${ }^{328}$ de la Diputación, de 24 de agosto de 1882, se daba cuenta de la entrada de una circular del ministro de la Gobernación en la que se solicitaba a la Diputación Provincial la elaboración de un proyecto para dividir la provincia en Distritos Electorales, conforme a las Bases contenidas en el art. 9 de la Ley Provincial de 29 de agosto de 1882 aún no promulgada, y que en el proyecto se propusiera la capitalidad de cada Distrito. La provincia de Palencia, compuesta por siete Partidos Judiciales, era dividida en cinco agrupaciones o Distritos Electorales, formando por si solos distritos los tres Partidos Judiciales con mayor número de habitantes, con arreglo al censo oficial de población del 31 de diciembre de 1877. Los Partidos Judiciales más poblados eran Cervera de Pisuerga, con 33.464, Palencia ${ }^{329}$, con 33.267 y Saldaña, con 29.572 habitantes respectivamente. La capitalidad de cada Distrito recaería en el pueblo cabeza de Partido, en este caso, Cervera de Pisuerga, Palencia, y Saldaña.

\footnotetext{
${ }^{324}$ En su art. 16, la Ley Electoral de 20 de agosto de 1870 contemplaba el sufragio universal masculino para las elecciones municipales, la elección de diputados provinciales, diputados a Cortes y compromisarios para la elección de senadores. La elección de diputados provinciales era de carácter unipersonal.

${ }^{325}$ Salvo las modificaciones que introducía la Ley Provincial de 16 de diciembre de 1876 en su Disposición $1^{\mathrm{a}}$, arts. 1 y 2.

${ }^{326}$ Art. 2. Disposición $1^{\text {a }}$ de la Ley Provincial de 16 de diciembre de 1876.

${ }^{327}$ Art. 8. Capítulo II. Título II. de la Ley Provincial de 29 de agosto de 1882.

${ }^{328}$ A.D.P.P, L.A.P.D. 54, 24-VII-1882.

${ }^{329} \mathrm{La}$ capital estaba dividida en cuatro distritos electorales: Consistorio, Hospital, Escuelas y Mercado Viejo.
} 
Los cuatro Partidos Judiciales restantes formarían dos agrupaciones, AstudilloBaltanás, con 19.110 y 18.962 habitantes respectivamente y Carrión de los CondesFrechilla, con 22.430 y 25.449 habitantes respectivamente ${ }^{330}$. La división en Distritos Electorales $^{331}$ de la provincia correspondía al Gobierno con la ayuda de las diputaciones provinciales. A su vez, los Distritos Electorales se dividían en colegios y secciones.

La legislación provincial de la Restauración hasta la Dictadura de Primo de Rivera, en lo relativo a los procesos electorales provinciales, se remitía a las leyes electorales vigentes en el periodo ${ }^{332}$. La convocatoria de elecciones provinciales, tanto ordinaria como extraordinaria ${ }^{333}$, correspondía al gobernador de la provincia, quien la anunciaba en un plazo de cinco días después de la orden de convocatoria ${ }^{334}$. El gobernador debía remitir a la Secretaría de la Diputación Provincial, con ocho días de antelación a la fecha de apertura de esta, las Actas de las Juntas de escrutinio de los Distritos electorales. Los colegios se constituían ${ }^{335}$ de la misma forma que en las elecciones municipales y los ayuntamientos eran los encargados de formar el número de secciones que considerasen oportuno ${ }^{336}$.

\footnotetext{
${ }^{330}$ Real Decreto de 31 de agosto de 1882.

${ }^{331}$ Art. 31 de la Ley Provincial de 29 de agosto de 1882.

${ }^{332}$ La Disposición Transitoria $2^{\text {a }}$ de la Ley Provincial de 29 de agosto de 1882 establecía que hasta que fuera reformada la Ley Electoral para diputados a Cortes, las elecciones de diputados provinciales se harían en la forma establecida en los Títulos III y IV de la misma, con una serie modificaciones, seis concretamente.

${ }^{333}$ En los casos de renuncias o vacantes extraordinarias, se procedía a celebrar elecciones parciales. Art. 99 de Ley Electoral de 20 de agosto de 1870. Art. 58 de la Ley Provincial de 29 de agosto de 1882.

${ }^{334}$ En su art. 59, la Ley Provincial de 29 de agosto de 1882, ampliaba este plazo a ocho días. Las elecciones debían celebrarse dentro de un plazo no inferior a quince días, ni superior a 30, después de la convocatoria.

${ }^{335} \mathrm{La}$ forma de constituirse los colegios electorales era la misma para las elecciones a diputados a Cortes que para diputados provinciales. Diez días antes de la fecha señalada para la elección, el ayuntamiento del pueblo, cabeza de cada sección, anunciaba por medio de edictos la designación del edificio en el que se iba a constituir el Colegio electoral, convocando a los electores para que concurriesen a votar.

${ }^{336}$ Art. 36 de la Ley Municipal de 20 de agosto de 1870.
} 
La Comisión Inspectora del Censo ${ }^{337}$, presidida por el juez de primera instancia de la capital del Distrito electoral ${ }^{338}$, una vez recibida la propuesta de los interventores $^{339}$, se encargaba de comprobar que sus nombres constasen en la lista del censo, para proceder, a continuación, a proclamarles como interventores designados en el proceso electoral ${ }^{340}$.

Documento 01. Oficio comprobación de firmas para nombramientos de Interventores.

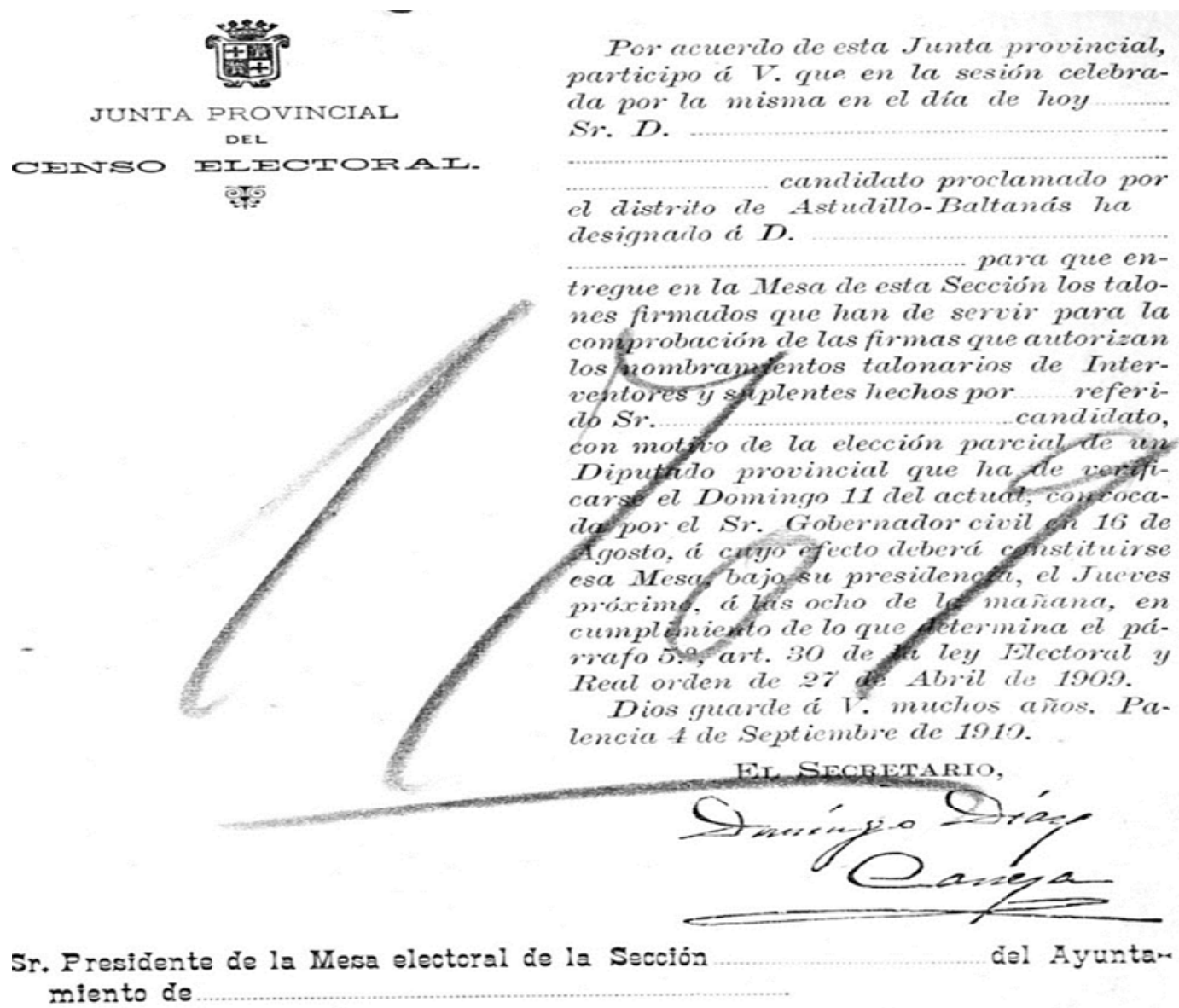

Fuente: A.D.P.P.

\footnotetext{
${ }^{337}$ El domingo anterior al día señalado para la elección, a las once de la mañana, se constituía la Comisión Inspectora del Censo electoral, en sesión pública, en el local destinado para la instalación del colegio de la cabeza del Distrito.

${ }^{338}$ En los Distritos que comprendían, dentro de su demarcación, más de una cabeza de Partido Judicial presidía la Junta de escrutinio, a falta del juez de la capital, el más antiguo de los otros jueces del mismo Distrito.

${ }^{339} \mathrm{La}$ designación de los interventores de cada Mesa electoral se realizaba por escrito en cédulas, que firmaban los electores de las respectivas secciones o por medio de Actas notariales, extendidas en papel de oficio y autorizadas por un notario del Colegio de la demarcación territorial del Distrito Electoral. Art. 64 de la Ley Electoral de 28 de diciembre de 1878.

${ }^{340}$ Art. 68 de la Ley Electoral de 28 de diciembre de 1878.
} 
La votación ${ }^{341}$ se realizaba en domingo ${ }^{342}$, se efectuaba de forma simultánea en todas las secciones del Distrito Electoral, comenzaba a las ocho de la mañana y finalizaba a las cuatro de la tarde, hora en la que se declaraba cerrada y se iniciaba el recuento de los votos emitidos ${ }^{343}$. Cuando finalizaba el tiempo establecido para votar, se realizaba el escrutinio provisional de la votación ${ }^{344}$ y se formaban las Actas correspondientes $^{345}$, que eran archivadas en la Comisión Inspectora del Censo Electoral del Distrito. La Mesa, antes de disolverse, designaba a uno de los interventores para que acudiese, en representación de la sección, a la Junta de escrutinio general ${ }^{346}$ que tenía lugar en el pueblo cabeza de Distrito a los tres días de concluida la elección en los colegios electorales. Antes de las diez de la mañana del día siguiente a la elección, en la zona exterior del colegio electoral se exponía una copia con los nombres de los electores $^{347}$ que habían votado y un resumen de los votos obtenidos por los candidatos, documentos certificados por el presidente de la Mesa y los interventores ${ }^{348}$.

\footnotetext{
${ }^{341}$ La votación era secreta y se efectuaba de la siguiente manera, el elector se acercaba a la mesa y, dando su nombre, entregaba por su propia mano al presidente una papeleta de papel blanco, doblada, en la cual estaba escrito el nombre del candidato a quien daba su voto para diputado provincial. El presidente depositaba la papeleta en la urna destinada al efecto, después de certificarse en caso de duda, por el examen que hacían los interventores de las listas del censo electoral, de que en ellas estaba inscrito el nombre del votante y decía en alta voz: «(el nombre del elector) vota.» En todo caso, el presidente tenía, constantemente, a la vista del público la papeleta desde el momento de la entrega hasta que la depositaba en la urna.

${ }^{342}$ Las elecciones ordinarias para diputados provinciales se celebraban en la primera quincena del tercer mes del año económico, en el mismo día para todas las provincias y Distritos y en los mismos colegios y secciones establecidos para las municipales.

${ }^{343} \mathrm{El}$ criterio sostenido en diferentes resoluciones ministeriales respecto al cómputo de votos, en los casos en los que existían más papeletas que el número de votantes, era el de restar o sustraer los sufragios que aparecían de más a los que figuraban en mayoría, con el objeto de adjudicarles a la minoría, por si con aquellos pudieran igualar a los que han sido proclamados, en cuyo caso, habría motivo para declarar nulas las votaciones. En 1912, un vecino y elector de Saldaña solicitaba que se declarase la nulidad de las elecciones en el distrito municipal de Saldaña, por haberse computado once papeletas más que el número de electores. A.D.P.P, L.A.C.P. 116, 3-I-1912.

${ }^{344}$ El presidente de la Mesa electoral leía en voz alta las papeletas, que extraía una a una de la urna, confrontando los interventores el número de papeletas leídas con el de electores votantes anotados en las listas numeradas. Una vez finalizado el escrutinio, el presidente anunciaba en voz alta el resultado, especificando, según las notas que habían tomado los interventores, el número de papeletas leídas, el de los electores que habían votado y el de los votos que había obtenido cada candidato.

${ }^{345} \mathrm{El}$ presidente y los interventores de la Mesa firmaban el Acta de la sesión.

${ }^{346}$ Compuesta por un secretario comisionado por cada Colegio Electoral, elegido por la Mesa después de concluir la votación.

${ }^{347}$ Cada elector votaba tres candidatos, si la papeleta de votación contenía más nombres, el voto se computaba únicamente para los que ocupasen los tres primeros lugares. Art. 11 de la Ley Provincial de 29 de agosto de 1882.

${ }^{348}$ Art. 90 de la Ley Electoral de 28 de diciembre de 1878. Un duplicado se enviaba al gobernador de la provincia, quien ordenaba su publicación en el $B O P$.
} 
Durante la Dictadura primorriverista ${ }^{349}$, el Ministerio de Gobernación era el encargado de convocar los procesos electorales para la elección de los diputados provinciales directos $^{350}$. En la convocatoria, publicada en la Gaceta y en el Boletín Oficial de la Provincia, se fijaba la fecha de proclamación de candidatos, votación, escrutinio general y revisión del mismo por la Audiencia Territorial ${ }^{351}$. Entre el escrutinio y la revisión del mismo, por la Audiencia Territorial en pleno, debían transcurrir al menos veinte días y, en cualquier caso, la revisión debía haberse realizado antes del primer día del último mes del año económico. La elección de diputados provinciales directos tenía lugar en la segunda quincena del décimo mes del año económico, cada seis años. Una vez realizado el primer proceso electoral, se celebraban los años en los que no tenían lugar elecciones municipales. Cada provincia formaba una sola circunscripción ${ }^{352}$, dividida en los mismos distritos y colegios fijados para las elecciones municipales y el procedimiento electoral era el de representación proporcional. Respecto de la elección de diputados provinciales corporativos, esta tenía lugar los años que se celebraban para la renovación de los diputados directos, el domingo siguiente a la elección de estos y, el resto de años, en la primera quincena del undécimo mes del ejercicio económico. El gobernador civil publicaba en el BOP la convocatoria señalando el domingo en el que debían reunirse todos los ayuntamientos de la provincia, a las diez de la mañana, para realizar esta votación, así como la fecha de proclamación de candidatos, escrutinio y revisión del mismo por la Audiencia Territorial. $^{353}$

\footnotetext{
${ }^{349} \mathrm{Al}$ igual que había sucedido con la Ley Provincial de 29 de agosto de 1882, el Estatuto Provincial de 1925 se remitía a la legislación electoral, Ley Electoral de 8 de agosto de 1907, para todo aquello relacionado con los procesos electorales que no estuviese recogido en el citado Estatuto.

${ }^{350}$ Los diputados provinciales directos eran elegidos por representación proporcional y circunscripción provincial única.

${ }^{351}$ Art. 53 del Estatuto Provincial de 1925.

${ }^{352} \mathrm{En}$ aquellas provincias cuya capital tuviese un censo de electores igual o mayor al resto del conjunto de los municipios que la formaban, el Gobierno podía formar dos circunscripciones, una constituida por la capital y otra, por el resto de la provincia. Art. 55 del Estatuto Provincial de 1925.

${ }^{353}$ Art. 61 del Estatuto Provincial de 1925. La proclamación de candidatos tenía lugar ante la Junta Provincial del Censo el mismo día que se verificaba la de los candidatos a diputados provinciales directos.
} 
En cada Ayuntamiento, constituían la Mesa electoral el alcalde, como presidente, y dos concejales escrutadores designados por elección ${ }^{354}$. El secretario del Ayuntamiento actuaba también como tal de la Mesa, extendiendo la documentación correspondiente $^{355}$. Los votos emitidos por los concejales, en las elecciones a diputados provinciales corporativos, tenían valor proporcional al número de electores del Municipio respectivo inscritos en el censo. La totalidad de los electores del Municipio inscritos en el censo era dividida por el número de concejales directos que correspondían al respectivo Ayuntamiento completo y el cociente de esa división expresaba el valor del voto de cada concejal en los escrutinios de las elecciones de diputados provinciales. ${ }^{356}$

El escrutinio general se realizaba, para toda clase de diputados provinciales, ante la Junta Provincial del Censo, el jueves siguiente al domingo en el que se hubiesen celebrado las elecciones. Si en el acto de proclamación de los electos no se formulaban reclamaciones $^{357}$, contra la validez de la elección ni contra la aptitud legal del electo, se estimaba definitivo el escrutinio realizado en la Junta Provincial del Censo. Había elección parcial para cubrir vacantes ${ }^{358}$, en el tiempo intermedio hasta la próxima elección ordinaria, cuando al constituirse la Corporación, cada seis años, resultaba incompleta aun llamando a los diputados suplentes o cuando, después de constituirse la Diputación, dejase de haber diputados, titulares y suplentes admitidos a ejercer los cargos en número suficiente para completar dos terceras partes de la Diputación Provincial o la Comisión Provincial. La documentación electoral se enviaba al Presidente de la Audiencia Territorial, a cuya demarcación correspondía la provincia.

\footnotetext{
${ }^{354}$ Los concejales solo podían votar un nombre.

${ }^{355}$ Las papeletas de votación, depositadas por los concejales en la urna y escrutadas por el presidente, en presencia de la Corporación municipal, eran marcadas con la firma del presidente y de los concejales escrutadores y con el sello del Ayuntamiento.

${ }^{356}$ Art. 66 del Estatuto Provincial de 1925.

${ }^{357}$ Cuando había reclamaciones, el escrutinio, tanto de diputados directos como corporativos, era revisado por la Audiencia Territorial en pleno. Las reclamaciones debían realizarse por escrito e ir firmadas, debiendo presentarlas ante el presidente de la Audiencia Territorial en el plazo de los ocho días siguientes a la terminación del escrutinio. La Audiencia Territorial notificaba su resolución al gobernador civil para que pudiesen constituirse las diputaciones provinciales, el primer día del año económico.

${ }^{358}$ Art. 50 del Estatuto Provincial de 1925. En ningún caso podía haber más diputados provinciales corporativos que directos, ni viceversa, por razón de vacantes.
} 
Cualquier candidato ${ }^{359}$ o elector ${ }^{360}$, inscritos en los censos municipales de la provincia, podía reclamar contra la validez de las elecciones y la aptitud legal de los candidatos electos. La Audiencia Territorial, al revisar el Acta de escrutinio general, tenía que acordar una de las siguientes declaraciones:

1. Validez de la elección y aptitud y capacidad de todos los candidatos proclamados.

2. Nulidad total o parcial de la elección realizada, y necesidad de celebrar una nueva convocatoria, total o parcial.

3. Validez de la elección, nulidad total o parcial de la proclamación hecha por la Junta Provincial del Censo y consiguiente proclamación de todos o parte de los candidatos derrotados, según fuese la nulidad total o parcial.

4. Validez de la elección y aptitud y capacidad de parte de los candidatos proclamados e incapacidad de los restantes o validez de la elección e incapacidad de todos los candidatos proclamados.

5. Nulidad total o parcial de la elección y castigo del candidato o candidatos a que afectase, cuando del expediente se desprendiesen indicios suficientes de haber mediado venta de votos en forma y número de cierta importancia.

La Audiencia, para formular cualquiera de las declaraciones citadas, podía realizar descuentos parciales de votos, por motivos que determinasen la nulidad de una o varias secciones $y$ no de todas, $y$ que fueran imputables a uno o varios candidatos, pero no a todos, en cuyo caso, debía acordarse la nulidad total de una elección, a no ser que los votos anulados pudieran, en su cómputo alternativo, decidir el resultado definitivo.

\footnotetext{
${ }^{359}$ Sentencia dictada por la Sala Civil de la Audiencia Territorial de Valladolid, referente a la protesta formulada por Cesáreo de la Guerra Castellanos, candidato derrotado en las últimas elecciones provinciales por el distrito de Carrión-Frechilla, contra la admisión de Mariano Vázquez de Prada como diputado provincial por este Distrito. Se declaraba la nulidad de su proclamación y de su elección, ordenando que se procediese a una nueva elección en el Distrito para cubrir la vacante. A.D.P.P, L.A.C.P. $125,10-\mathrm{VII}-1917$.

${ }^{360}$ Admitidas las demandas contenciosas de dos vecinos contra los acuerdos de la Diputación Provincial en virtud de los cuales fueron admitidos como diputados provinciales por los distritos de Herrera de Pisuerga y Saldaña, Velasco y Quintana, y Modesto Hompanera. A.D.P.P., L.A.C.P. 46, 24-IV-1877.
} 
En teoría, el sistema electoral estaba diseñado para garantizar la limpieza de los procesos electorales, pero esto no era óbice para que los actores políticos intentaran artimañas fraudulentas que lograsen inclinar la balanza electoral a su favor. Así, en las primeras elecciones provinciales y municipales de la Restauración, que se celebraron en el año 1877 (sufragio censitario), fueron dirigidas en Palencia por el gobernador civil, Rodríguez Díez ${ }^{361}$, para que los candidatos procedentes del antiguo Partido Moderado triunfasen sobre los candidatos procedentes del Partido Unionista. A los pocos diputados de esta ideología que salieron elegidos, Mateo Herrero y Mariano Osorio, se les calificó su Acta como grave, declarándolas nulas. Otro factor que afectaba indirectamente al resultado de las elecciones era el porcentaje de población que podía ejercer el voto. Hasta 1890, el método de elección era el sufragio censitario, por lo que la población llamada a elegir a los diputados provinciales representaba solo una parte de la población total de la provincia. En 1887, la población total ascendía a 188.845 pero el número de electores que participaron en los procesos electorales de 1880, 1882 y 1884 no llegaba al $20 \%$ del total, y de ese porcentaje raramente votaba más de un $50 \%{ }^{362}$.

Tabla 02. Elecciones provinciales de 1880, 1882 y 1884 en Palencia.

\begin{tabular}{|c|c|c|c|c|c|c|c|c|}
\hline \multicolumn{3}{|c|}{ Electores } & \multicolumn{3}{c|}{ Diputados elegidos } \\
\hline \multicolumn{3}{|c|}{ Cifra total } & \multicolumn{3}{c|}{ Votaron } & 1880 & 1882 & 1884 \\
\hline 1880 & 1882 & 1884 & 1880 & 1882 & 1884 & 10 & 20 & 12 \\
\hline 35.490 & 42.329 & 39.892 & 9.255 & 30.420 & 17.151 & & & \\
\hline
\end{tabular}

Elaboración propia. Fuente: Fondo Documental del Instituto Nacional de Estadística. Reseña geográfica y estadística de España, 1888.

\footnotetext{
${ }^{361}$ Vid. GONZALO ANDRÉS, Donato, Los políticos de Palencia y su provincia. (Bocetos y semblanzas). Tomo II, Palencia, Imprenta de Abundio Z. Menéndez, 1891, p.125.

${ }^{362}$ Fondo Documental del Instituto Nacional de Estadística. Reseña geográfica y estadística de España, 1888 .
} 
En no pocas ocasiones, el resultado de los procesos electorales dependía únicamente de la voluntad de los líderes del Partido Conservador y Liberal. En las elecciones de marzo de 1903, por ejemplo, para la elección de diputados a Cortes, se presentaban por el Partido Conservador, Abilio Calderón y Antonio Monedero, pero este último declaraba al periódico el Día de Palencia que a causa de las repetidas presiones de sus jefes, había retirado su candidatura ${ }^{363}$. No obstante, en algunas zonas, el clientelismo no era tan importante como el prestigio de la Iglesia y el peso de la tradición, como lo atestigua la elección a diputado en Cortes del carlista Matías Barrio y Mier por el distrito norteño de Cervera de Pisuerga, en las elecciones a diputados a Cortes de 1871, 1891, 1893, 1896, 1898, 1899, 1901, 1905 y 1907. En los distritos electorales de Cervera de Pisuerga y Saldaña, muy pocos municipios permanecieron dominados de forma duradera por una facción política, pues esto solo sucedía en los pueblos que contaban con un terrateniente ligado por lazos de parentesco con las facciones del Partido Conservador, mauristas o datistas en el primer tercio del siglo $\mathrm{XX}^{364}$. Este hecho demuestra que en ciertas poblaciones, las relaciones clientelares no eran tan significativas a la hora de determinar el signo del voto, como se había pensado. La legislación electoral contribuía, además, a crear escenarios electorales poco convencionales, como sucedió en las elecciones de diputados provinciales celebradas el 14 de marzo de $1915^{365}$. La Diputación Provincial de Palencia, entonces, contaba con 20 diputados repartidos en cinco Distritos Electorales que integraban la provincia, en aplicación del art. 29 de la Ley Electoral de 8 de agosto de $1907^{366}$, resultaron elegidos, de esta forma, ocho diputados y cero diputados, elegidos en virtud del art. 52 de la Ley Electoral de 8 de agosto de $1907^{367}$.

\footnotetext{
${ }^{363}$ El Día de Palencia, 20-III-1903.

${ }^{364}$ Vid. VILLA ARRANZ, Juan, Caciquismo y comunidades tradicionales en Castilla durante el primer tercio del siglo $X X$, op. cit.

${ }^{365}$ Fondo Documental del Instituto Nacional de Estadística. Anuario de 1915.

${ }^{366}$ En los distritos en los que el número de candidatos fuese menor que el de llamados a elegir, la proclamación de candidatos equivalía a su elección y les eximía de someterse a votación.

${ }^{367}$ Eran proclamados diputados provinciales electos aquellos que hubiesen obtenido el mayor número de votos de los escrutados y computados en el Distrito Electoral.
} 
Esta circunstancia no siempre se producía, por ejemplo, en las elecciones de diputados provinciales celebradas el 11 de marzo de $1917^{368}$, la Diputación Provincial de Palencia contaba con 20 diputados repartidos en cinco Distritos Electorales. Seguía en vigor el art. 29 de la Ley Electoral de 8 de agosto de 1907, resultando elegidos, de esta forma, cuatro diputados y cuatro diputados elegidos en virtud del art. 52 de la Ley Electoral de 8 de agosto de 1907. Votaron 20.566 electores, los diputados provinciales proclamados electos obtuvieron un número de 46.842 votos, votando 98 individuos por cada 100 electores de los distritos en los que se verificó elección ${ }^{369}$. El Día de Palencia $^{370}$, comentaba en sus páginas la dura pugna electoral que habían mantenido los mauristas $^{371}$ contra todo tipo de presiones ejercidas por los idóneos y liberales, los llamados pactistas, en los Distritos de Astudillo-Baltanás y Carrión-Frechilla. El periódico señalaba que de no haber mediado atropellos y coacciones, hubiesen triunfado los mauristas, y advertía de que los miles de votos conseguidos por estos constituían un claro ejemplo de que la ciudadanía estaba en contra de la unión de los conservadores y liberales, a la vez que se felicitaba del fracaso sufrido por el «pastel idóneo-liberal»» ${ }^{372}$. Sin embargo, no cabe duda de que parte de la legislación electoral generó situaciones como la descrita en las elecciones provinciales de marzo de 1915, en las que los ocho diputados provinciales fueron elegidos sin someterse a votación, por lo que factores como estos contribuyeron, en parte, a crear una historiografía que elaboró una visión muy negativa de la Restauración. No obstante, fuentes documentales, como el citado periódico, muestran que los ciudadanos eran soberanos y que, pese a ciertas irregularidades, los procesos electorales reflejaban en gran medida las preferencias políticas de la población, por lo menos así había sido desde 1890.

\footnotetext{
${ }^{368}$ Fondo Documental del Instituto Nacional de Estadística. Anuario de 1917.

${ }^{369}$ El porcentaje más alto de todas las provincias de España.

${ }^{370}$ El Día de Palencia, 12-III-1917.

${ }^{371}$ García Muñoz Jalón, que se presentaba a las elecciones provinciales por el Partido Maurista, envió un telegrama a Maura, el 13 de marzo de 1917, para comunicarle el gran resultado obtenido por este partido en el Distrito de Astudillo-Baltanás, por el que fue elegido diputado provincial, «A pesar de la oposición y de algunos pucherazos no han podido derrotarme, consiguiendo únicamente quitarme el primer puesto que saqué en la elección de 1913». Su compañero de partido López Francos no obtuvo la elección. Archivo de la Fundación de Antonio Maura. Caja 182/11.

${ }^{372}$ Los resultados fueron los siguientes: Distrito Astudillo-Baltanás: $1^{\mathrm{o}}$ Eladio Santander Gallardo (conservador), $2^{\circ}$ Enrique Rodríguez García (liberal), $3^{\circ}$ García Muñoz Jalón (maurista), $4^{\circ}$ Florencio García Acítores (liberal), $5^{\circ}$ Leonardo Moro Mazón (liberal), $6^{\circ}$ Manuel López Francos (maurista). Distrito Carrión-Frechilla: $1^{\circ}$ Celestino Garrachón García (liberal), $2^{\circ}$ Román Arturo Redondo (liberal), $3^{\circ}$ Mariano Vázquez de Prada (conservador), $4^{\circ}$ Jesús Fernández Lomana (conservador), $5^{\circ}$ Cesáreo de la Guerra Castellanos (maurista). El Día de Palencia, 12-III-1917.
} 
La sociedad española había cambiado desde 1875 y cada vez era mayor la participación de la ciudadanía en todo aquello que tuviese que ver con la política, como demuestra el alto porcentaje de votantes que participaban en los procesos electorales provinciales. En las elecciones de diputados provinciales celebradas el 6 de junio de $1919^{373}$, en las que siguió aplicándose el art. 29 de la Ley Electoral de 8 de agosto de 1907, resultaron elegidos, de esta forma, nueve diputados y cuatro diputados, en virtud del art. 52. De un número de electores de 26.638, que figuraban en las listas electorales, votaron 20.160 electores, votando 75,68 individuos de cada 100 electores de los Distritos en los que se verificó elección ${ }^{374}$. En las Elecciones de diputados provinciales, celebradas el 12 de junio de $1921^{375}$, se celebraron elecciones en tres Distritos de la provincia de Palencia, aplicándose, en dos de ellos, el art. 29 de la Ley Electoral de 8 de agosto de 1907, resultando elegidos, de esta forma, dos diputados y doce diputados, elegidos en virtud del art. 52 de la Ley Electoral. De un total de 28.051 electores, que figuraban en la lista del censo rectificado de 1920 de los distritos donde se verificaba elección, votaron 21.340 , un $76 \%$ del electorado.

\footnotetext{
${ }^{373}$ Fondo Documental del Instituto Nacional de Estadística. Anuario de 1919.

${ }^{374}$ El porcentaje más alto de todas las provincias de España.

${ }^{375}$ Fondo Documental del Instituto Nacional de Estadística. Anuario de 1921.
} 


\section{Constitución}

Desde 1876 hasta 1925, celebradas las elecciones provinciales, la primera actuación, antes de constituir la Diputación Provincial, era comprobar las credenciales de los diputados electos, con especial énfasis en verificar si estos cumplían los requisitos exigidos para su elección. La propia Diputación interina estaba facultada para nombrar una Comisión al efecto. El procedimiento para constituir la Diputación interina era el siguiente, los diputados provinciales se reunían en el salón de sesiones y se daba lectura a la lista que había formado la Secretaría, con presencia de las Actas presentadas, constituyéndose en la forma que preveía el art. 46 de la Ley Provincial de 29 de agosto de 1882, debiendo abandonar el gobernador ${ }^{376}$ el local y ejerciendo como presidente el vocal de más edad, y como secretarios los dos más jóvenes de entre los presentes. A continuación, se nombraba una Comisión Permanente de Actas, compuesta de cinco vocales, y otra Comisión Auxiliar, que examinaba las Actas de los miembros de la Comisión Permanente. Una vez ratificada la renovación, no podían formar parte de la Comisión Auxiliar los diputados del bienio anterior ${ }^{377}$. El nombramiento de ambas comisiones se realizaba en dos actos y en votación secreta por medio de papeletas que contenían los nombres de los cinco, o tres diputados que debían constituir una y otra Comisión, y que representaban diferentes Distritos. Los diputados votaban por orden de lista, entregando la papeleta doblada al presidente, el cual la depositaba en la urna.

\footnotetext{
${ }^{376}$ En la sesión del día 3 de enero de 1883, el diputado provincial Victoriano Guzmán Rodríguez manifestaba que, en la sesión anterior, del 2 de enero de 1883, no había constado la protesta hecha por Mateo Collantes y Elpidio Abril García, respecto a que después de la constitución de la Mesa interina ocupase la presidencia el gobernador. El diputado provincial Mateo Collantes manifiesta su agrado por la petición de su compañero Guzmán, para que constara en Acta su protesta sobre la presidencia en la sesión del día 2, por haberla ocupado el gobernador después de haberse constituido interinamente la Corporación, faltando a lo dispuesto en el artículo 46 de la Ley Provincial. El gobernador recordaba a Collantes que le había concedido la palabra para tratar del Acta del día 3, y no del Acta correspondiente a la sesión del día 2. Tras insistir Collantes, el gobernador avisaba al diputado provincial que, de persistir, no podría continuar en el uso de la palabra y que en lo que se refería a ocupar la presidencia lo hacía con arreglo a la ley, como representante del Gobierno y «(...) en tal concepto no podía consentir discusión de ningún género». Abandonaron el salón de sesiones los diputados provinciales, Guzmán Rodríguez, Mateo Herrero Ortega, Marcelo Barrios Barriga, Filiberto De Prado Salas, Manuel Polanco Lavandero, Elpidio Abril García, Mateos Collantes, Álvarez Miranda, De Pereda Fuente y Rizo Chavarino. A.D.P.P., L.A.P.D. $55,4-1-1883$

${ }^{377}$ Real Orden de 21 de marzo de 1885.
} 
Después de votar los diputados presentes y de preguntar dos veces un secretario «¿Falta algún Sr. diputado por votar?», se procedía al escrutinio, sacando el presidente una por una las papeletas, leyéndolas en voz alta y llevando lista los dos secretarios. Todos los diputados podían pedir una segunda lectura y leer por sí mismos las papeletas que deseasen. Después del escrutinio y una vez leído el resultado de la votación ${ }^{378}$ por uno de los secretarios, se quemaban las papeletas y se consignaba en el Acta el resultado.

El presidente, en vista del escrutinio, proclamaba miembros de la Comisión Permanente de Actas a los cinco, y de la Comisión Auxiliar a los tres, que habían obtenido la mayoría de los votos. La Comisión Auxiliar se ocupaba del examen de las Actas de los vocales nombrados para la Comisión Permanente y presentaba su dictamen que quedaba sobre la mesa durante veinticuatro horas ${ }^{379}$. Mientras no fuesen aprobadas las Actas de los cinco diputados ${ }^{380}$, miembros de la Comisión Permanente, la Diputación no podía ocuparse de otros asuntos. Aprobadas las Actas de los diputados que componían la Comisión Permanente, esta procedía a clasificar la demás Actas, en Primera y Segunda clase ${ }^{381}$, entendiéndose por Primera clase las que no contuviesen protestas ni reclamaciones, o que estuviesen fundadas en hechos $\mathrm{u}$ omisiones conocidamente leves, las de Segunda, las que descubrieran hechos o suscitasen dudas de mayor gravedad ${ }^{382}$, aun cuando nadie hubiese reclamado ${ }^{383}$.

\footnotetext{
${ }^{378} \mathrm{Si}$ dos diputados del mismo Distrito resultaban con igual número de votos, decidía la suerte. En el caso de que algunos de los cinco Distritos, en que estaba dividida la provincia, resultara sin representación, en la Comisión Permanente de Actas se procedía a elegir un vocal entre los diputados que le representasen.

${ }^{379}$ En 1896, Abilio Calderón Rojo promovía un incidente acerca de la interpretación del art. 47 de la Ley Provincial, con arreglo a que los dictámenes de la Comisión Auxiliar de Actas, leídos el día 3 de noviembre de 1896, cerca de las dos de la tarde, debían quedar sobre la mesa durante el plazo de veinticuatro horas y, mientras no transcurriese ese tiempo, consideraba ilegal ocuparse de ellas. Los diputados provinciales, García Crespo y Alonso Villazán, señalaban que la sesión del día 3 se había abierto a las doce horas, y designada la del día 4 para las once horas, el plazo de veinticuatro horas contaría desde este tiempo, por lo que podían discutirse las Actas, «(...) ya que tan rigorista es el Sr. Calderón, al dar las campanadas las doce». El presidente suspendió la sesión hasta las doce horas. A. D. P. P., L.A. P. D. 81, 4-XI-1896.

${ }^{380} \mathrm{Si}$, a consecuencia del dictamen de la Comisión Auxiliar, se declarase la gravedad del Acta de algún individuo de la Comisión Permanente, se procedería a elegir a otro en su lugar.

${ }^{381}$ Solo las de Primera podían discutirse por la Diputación constituida interinamente, debiendo ser las de Segunda discutidas después de la constitución definitiva. Art. 50 de la Ley Provincial de 29 de agosto de 1882.

${ }^{382}$ Para calificar las Actas de gravedad se tomaba como base el Reglamento del Congreso de los Diputados, por carecer la Diputación Provincial de uno propio que contemplase esta contingencia. Las Actas declaradas graves por la Comisión Permanente de Actas pasaban al examen y discusión de la Diputación definitivamente constituida. Las Reales Órdenes de 17 de marzo de 1893 y de 26 de febrero de 1895 estipulaban que la Diputación interina podía aprobar las Actas sobre las que informase la Comisión Permanente de Actas consideradas leves, pero no anular Acta alguna. Una vez constituida definitivamente la Diputación, se votaría la validez o la nulidad de las Actas graves.
} 
Cuando la Diputación declaraba nula el Acta de algún diputado provincial, este podía interponer un recurso ante el organismo encargado de resolver asuntos de esta índole, que en la etapa de la Restauración correspondía a la Audiencia Provincial ${ }^{384}$. En el momento de la discusión de un Acta, todos los diputados provinciales podían presentar documentos relativos a la capacidad o incapacidad del elegido, debiendo manifestar la Comisión Permanente de Actas si retiraba el dictamen para formular otro, u optar por continuar con la discusión. Discutida y aprobada un Acta, el presidente declaraba como admitido al diputado Provincial interesado.

La historiografía ha considerado a la Restauración como una etapa de calma en relación a la disputa política y, a pesar de que las elecciones estaban amañadas, la oposición asumía su papel sin discusión ${ }^{385}$, a la espera de su turno de Gobierno. Sin embargo, las fuentes documentales consultadas demuestran que por lo que respecta al ámbito local, la realidad distaba de esta imagen idílica de paz, siendo muy frecuentes las disputas y confrontaciones por motivos políticos. Demuestra la anterior aseveración que en noviembre de 1886 se discutía la gravedad del Acta de José Agustín Zulaica, que se presentaba por el Partido Liberal-Fusionista por el distrito de Cervera de Pisuerga. El diputado provincial Guzmán Rodríguez sostenía que, «(...) discutiéndose las Actas, no hay más remedio que hablar de partidos políticos y de la filiación de cada uno, y de aquí que constantemente se diga tal o cual Diputación es fusionista, conservadora o republicana». El diputado provincial, Joaquín Monedero y Monedero, conservador, pedía que se hiciese constar en Acta que ninguno de los candidatos que luchaban frente a los ministeriales (liberales-fusionistas) en el distrito de Cervera, pertenecían al Partido Conservador. Guzmán Rodríguez, reclamaba a la Presidencia que le mantuviese en el uso de la palabra y señalaba que «(...) sorprendiéndose grandemente que el Sr. Monedero, que no quiere hacer política en la Diputación, empiece por descomulgar del Partido Conservador a los que con este carácter lucharon en Cervera.»> ${ }^{386}$

\footnotetext{
${ }^{383}$ Real Orden de 21 de marzo de 1885.

${ }^{384}$ Art. 53 de la Ley Provincial de 29 de agosto de 1882.

${ }^{385}$ En 1877, el diputado provincial Gómez Inguanzo se manifestaba partidario de declarar la gravedad del Acta de Aguilar de Campoo hasta obtener copia literal certificada del censo electoral de Barruelo. Félix Montaves, que aspiraba a ser elegido por ese Distrito, declaraba que la negligencia de un alcalde en remitir copia del censo no debía perjudicar al candidato que, según las Actas, había obtenido mayoría de votos y solicitaba la aprobación del Acta de su elección. Ese mismo día, se recibía la copia literal del censo de Barruelo y se acordaba admitir como diputado provincial por el distrito de Aguilar de Campoo a Félix Montaves. A.D.P.P., L.A.P.D. 48, 22-III-1877.

${ }^{386}$ A.D.P.P., L.A.P.D. $62,3-\mathrm{XI}-1886$.
} 
La base de todo el sistema electoral descansaba en la Comisión Inspectora del Censo, que debía constituirse en la forma prevenida en el art. $51^{387}$ de la Ley Electoral de 1878. La Comisión Inspectora del Censo de Cervera no se ajustó a las prescripciones contenidas en el artículo citado, por tanto, cuanto emanó de la Comisión llevaba un vicio de nulidad. Tras discutir sobre la elaboración del censo electoral de Cervera, se acordó la nulidad de las elecciones verificadas en ese Distrito. En febrero de 1887, la Sala de lo Civil de la Audiencia de Valladolid declaraba válidas las elecciones de diputados provinciales verificadas en el Distrito de Cervera el 5 de septiembre de 1886, anuladas por la Diputación. En consecuencia, eran proclamados representantes por dicho distrito Manuel Polanco Díaz de Labandero, Ángel de Cos Vallejo y José Agustín Zulaica y Ascúe, ya fallecido ${ }^{388}$.

Examinadas las Actas presentadas por los diputados provinciales por la Comisión Auxiliar de $\operatorname{Actas}^{389}$, se elegía al presidente, vicepresidente y secretarios para que la Diputación Provincial se constituyera de forma definitiva. Los diputados provinciales electos $^{390}$, que habían presentado sus Actas, debían concurrir a las once de la mañana del día designado para la apertura de las sesiones. En la mayor parte de la documentación consultada, la constitución definitiva de la Diputación Provincial resultaba un mero trámite, pero no faltaban ocasiones en las que la rivalidad política salía a relucir y este acto reglamentario se convertía en escenario de disputas.

\footnotetext{
${ }^{387}$ Estas listas constituían el censo electoral del Distrito, los libros del registro, como protocolo o matrícula del mismo, estarían bajo la inmediata inspección de una Comisión Permanente, que se denominaría Comisión Inspectora del Censo Electoral, compuesta del Alcalde Presidente y de cuatro electores nombrados por el Ayuntamiento del pueblo cabeza del Distrito, los cuales se renovarían por mitad cada dos años y serían personalmente responsables con el secretario municipal, que lo sería también de la Comisión, de todas las faltas que se cometiesen en la formalidad y exactitud de los asientos. Cada concejal solamente podría nombrar la mitad de los que hubiesen de ser elegidos.

${ }^{388}$ A.D.P.P., L.A.P.D. 63, 18-II-1887.

${ }^{389}$ La Comisión Auxiliar de Actas se limitaba a examinar si había protestas sobre la elección de los diputados provinciales y si estas podían afectar a la validez o nulidad de la elección para que pudieran ser discutidas por la Asamblea Provincial, previo dictamen de la Comisión Provincial. Las Comisiones podían reclamar, por conducto del presidente de la Diputación, los documentos necesarios para apreciar la validez de las operaciones electorales y la aptitud de los diputados electos liberales-fusionistas, como en la elección de la presidencia de la Corporación Provincial en noviembre de 1892.

${ }^{390}$ Los diputados debían pasar nota a la Secretaría de su lugar de residencia en la capital y cuando residían fuera de ella, punto de residencia o vecindad legal.
} 
Delgado González, del Partido Conservador, resultó elegido presidente de la Diputación, por diez votos a favor y diez papeletas en blanco ${ }^{391}$. Guzmán Rodríguez, pedía que constasen en el Acta varias aclaraciones que importan a la formación liberal a la que pertenecía. Según él, una vez realizada la votación para elegir al presidente de la Diputación, en la que no hubo mayoría de votos, el presidente de edad, sin haber repetido la votación proclamó al señor Delgado González presidente. Los diputados liberales-fusionistas abandonaron el salón para no sancionar con su presencia actos que consideraban ilegítimos. Yágüez Pascual, compañero de partido de Guzmán, afirmaba que:

«(...) sin representar la mayoría es ilegal la presidencia de la Corporación, y en tal concepto si el Partido Conservador por su caduca historia no podía llevar a aquel lugar a ninguna persona con mayor votación, era culpable tan solo él mismo, y había de reconocer que le estaba vedado ocupar el elevado sitial a no ser por razón de edad, ya que en otras ocasiones y por falta de sufragios en el cuerpo electoral, tampoco había podido ese Partido arribar a dicho puesto.. ${ }^{392}$

\footnotetext{
${ }^{391}$ A.D.P.P., L.A.P.D. 74, 5-XI-1892. Las papeletas en blanco, las ilegibles y las que contuviesen otro nombre diferente de los diputados admitidos, eran nulas, pero servían para computar el número de diputados presentes. La Real Orden de 22 de agosto de 1887 prohibía el voto en blanco, no obstante, en la sesión del 10 de noviembre de 1888, en la que se votaba al presidente de la Diputación, se depositaron siete papeletas en blanco. El diputado provincial Guzmán Rodríguez se preguntaba si con arreglo a la citada Real Orden, debía considerarse válida la elección del presidente. El diputado provincial Martínez Arto defendía que de admitirse «(...) no habría ni Congreso, ni Senado, ni ayuntamientos, ni diputaciones porque con una papeleta en blanco, de un bien o mal intencionado, podrían invalidarse votos lícitos y legítimos haciendo inútil la existencia de dichos organismos». Además, Martínez Arto, señalaba que no podía averiguarse quiénes habían votado en blanco, puesto que se faltaría al secreto de la urna, «(...) por más que algunos diputados no tuvieron reparo, como sucede al que se sienta a mi lado a llevar una papeleta en blanco». El aludido, Gutiérrez Marín, comentaba que era falso que hubiese votado en blanco y añadía que «(...) si su señoría quiere tomarme como vulgarmente se dice por pito, busque a cualquier otro, porque yo no he de consentirlo y me extraña tanto más esta conducta, cuando siempre conservé su amistad". Martínez se disculpó, aunque manifestó que era cierto que las papeletas en blanco existían. A.D.P.P., L.A.P.D., 64, 10-XI-1888. A pesar de las papeletas en blanco, la presidencia de edad, proclamó presidente de la Diputación Provincial a Rodríguez Lagunilla, por haber obtenido la mitad más uno de la mayoría absoluta del número total de diputados que corresponde a la provincia. Yagüez Jalón presentaba una protesta de nulidad. Esta circunstancia se repitió en la elección de vicepresidente, y en la elección de secretarios.
}

${ }^{392}$ A.D.P.P., L.A.P.D. 74, 8-XI-1892. 
Guzmán Rodríguez presentó Recurso de Alzada contra la elección de presidente ante el ministro de la Gobernación ${ }^{393}$ y pidió la nulidad de los actos que se iban realizando por la Diputación Provincial, por no estar en su opinión constituida legalmente ${ }^{394}$. En más de una ocasión se impugnó la constitución de la Asamblea Provincial. A partir de la aprobación del Estatuto Provincial de 1925, la Diputación celebraba sesión plenaria para constituirse el primer día hábil del año económico siguiente, al que se hubiese efectuado la elección para la renovación total de los diputados directos ${ }^{395}$. Además, se reunía cada dos años, en igual fecha, para dar posesión a los diputados corporativos que debían firmar parte de la Corporación Provincial durante los dos años siguientes ${ }^{396}$. Cada seis años, el primer día hábil del ejercicio, se celebraba la sesión constitutiva de la Diputación provincial, designándose una Mesa interina compuesta por el diputado directo de mayor edad como presidente y de los dos más jóvenes, uno directo y otro corporativo, como secretarios. Aprobadas las Actas leves, se procedía en votación secreta a nombrar presidente, vicepresidente y dos secretarios entre los diputados admitidos.

Las votaciones para presidente y vicepresidente se realizaban en actos distintos por papeletas que contuvieran un solo nombre, resultando elegido el que obtuviese mayoría absoluta de votos. En caso de empate decidía la suerte. La elección de los secretarios se realizaba en un solo acto también en votación secreta, por papeletas que contenían un solo nombre, siendo elegidos los que reunían un mayor número de votos. En caso de empate decidía la suerte. En primer lugar, se elegía al presidente ${ }^{397}$, en votación secreta $^{398}$, e inmediatamente después se elegía al vicepresidente, ambos cargos para un mandato establecido de seis años.

\footnotetext{
${ }^{393}$ A.D.P.P., L.A.P.D. $69,11-\mathrm{XI}-1892$.

${ }^{394}$ La Real Orden de 28 de diciembre de 1892 anulaba la constitución de la Asamblea y disponía que se procediese de nuevo a la elección de presidente y demás cargos de la misma, bajo la Presidencia de la Mesa de edad, dando, por tanto, la razón al diputado provincial Guzmán Rodríguez. A.D.P.P., L.A.P.D. 75, 7-I-1893.

${ }^{395}$ Art. 83 del Estatuto Provincial de 1925.

${ }^{396} \mathrm{La}$ convocatoria para estas sesiones se publicaba en el $B O P$ y se comunicaba personalmente a todos los diputados, tanto titulares como suplentes. Estos últimos se retiraban de las sesiones cuando comparecían los titulares.

${ }^{397}$ Votaban los diputados directos y corporativos, pero el cargo de presidente solo podía recaer en un diputado directo.

${ }^{398}$ Todas las votaciones se realizaban por votación secreta por medio de papeletas. Se exceptuaban los casos de las designaciones conferidas a la Mesa y aquellas para las que estuviese legal o reglamentariamente establecido otro procedimiento. El presidente y los secretarios eran los encargados de realizar el escrutinio de los votos, el primero sacaba las papeletas de la urna una a una y leía en voz alta los nombres que contenía, los segundos llevaban las listas.
} 
Finalizado el régimen dictatorial, mediante el Real Decreto de 15 de febrero de 1930, en su art. 8, el Gobierno se reservaba, a través del Ministerio de Gobernación, la facultad de nombrar presidente y vicepresidente de la Diputación. El gobernador de la provincia podía abrir en nombre del Gobierno el primer periodo de sesiones plenarias de cada año, ocupando la Presidencia de la sesión, sin que en este caso la Diputación pudiese deliberar ni votar resolución alguna. Las elecciones de cargos se realizaban por el orden expuesto, publicando el presidente de edad el resultado de cada escrutinio. Concluida la elección de los secretarios, ocupaban sus puestos estos y el presidente que declaraba definitivamente constituida la Diputación ${ }^{399}$ y lo comunicaba al gobernador de la provincia.

En octubre de 1910, El Diario Palentino criticaba la poca seriedad de la sesión del Pleno de la Diputación Provincial, ya que en una de las votaciones se habían contabilizado más papeletas en la urna, que número de diputados provinciales presentes. El diario se permitía aconsejar a los diputados provinciales mayor seriedad conforme al cargo que ostentaban ${ }^{400}$. No sería la última vez que la prensa local y la Diputación Provincial de Palencia se enfrentasen, en 1917, la Diputación palentina dejaba ver su malestar a causa de una noticia del periódico El Progreso de Castilla ${ }^{401}$, del 4 de mayo de 1917, en la que según el diputado Gusano Rodríguez se ofendía a la Diputación Provincial $^{402}$. En el suelto del periódico se decía «(...) Sr. Gobernador, Sr. Ministro de la Gobernación: la Diputación de Palencia lleva como de ser un baldón de ignominia y ustedes tienen la obligación de velar por su prestigio, ya que los diputados provinciales que así proceden tratan de envilecer y degradar a la Corporación.»» ${ }^{403}$

\footnotetext{
${ }^{399} \mathrm{Si}$ algún diputado había sido proclamado por dos o más Distritos, debía optar por el que considerase oportuno en una de las primeras cuatro sesiones y si no lo hacía, se procedía a sortear, dando cuenta de la vacante.

${ }^{400}$ El Diario Palentino, 30-X-1910.

${ }^{401}$ De carácter republicano, este periódico había comenzado a publicarse en 1884 . En 1917 estaba dirigido por Ramiro Álvarez González, que había sido alcalde de Palencia por el Partido Republicano Federal. Contó entre sus colaboradores con nombres tan significados en la vida provincial como Matías Peñalba, Francisco Vighi o Jerónimo Arroyo.

${ }^{402}$ A.D.P.P., L.A.P.D. $123,5-\mathrm{V}-1917$.

${ }^{403}$ A.D.P.P., L.A.P.D. $123,5-V-1917$. La documentación consultada no aclara cuál fue la razón última del artículo y, por desgracia, no se conservan ejemplares digitalizados de este periódico. Se ha querido señalar este episodio como un ejemplo significativo de las complejas relaciones establecidas entre el ámbito político local y la prensa, en función de la ideología de ambos poderes.
} 
La minoría liberal, encabezada por el diputado provincial Nájera de la Guerra, no veía la necesidad de discutir el asunto en la sesión y no entendía la premura del bando conservador, encabezado por Gusano Rodríguez, que defendía que una afrenta pública como la del periódico necesitaba reprimenda inmediata. Gusano Rodríguez era partidario de recurrir a los tribunales contra el periódico, pero Nájera de la Guerra consideraba suficiente la publicación de la rectificación sin necesidad de recurrir a la justicia. Se acordó, que el director del periódico, Ramiro Álvarez González, acudiese a una conferencia que tendría lugar en la Presidencia de la Diputación a la que concurrirían además del presidente, dos diputados provinciales, uno liberal y otro conservador $^{404}$. El director del periódico no admitió ir a la Diputación y sugirió que se celebrase la conferencia en la redacción del periódico. Gusano Rodríguez se declaró partidario de recurrir a los tribunales pero el diputado provincial Garrachón García sugirió dar un plazo de veinticuatro horas al director del periódico para que explicase el carácter injurioso del artículo, pero no se admitió su propuesta ${ }^{405}$. Finalmente se acordó denunciar los hechos que aparecían en el citado artículo ante el fiscal de la Audiencia Provincial. Nájera de la Guerra preguntó si el procedimiento a entablar se iniciaría de oficio o a instancia de parte. Gusano Rodríguez le indicaba que además de la actuación del fiscal, los diputados que quisieran podrían mostrarse como parte. Nájera de la Guerra renunció a personarse como parte y defendió la posición de que si se desestimaba la petición de la Asamblea no debían recaer sobre esta los gastos que se ocasionen. Se acordó que los gastos que ocasione la querella, serían satisfechos del peculio particular de los que la interpusiesen ${ }^{406}$.

Una vez constituida de forma definitiva la Diputación provincial, comenzaba a funcionar. El pleno de la Diputación no se reunía de forma permanente, por ello se convocaban sesiones a lo largo del año para discutir los asuntos que requiriesen el dictamen de esta institución. El procedimiento de convocatoria de estas sesiones varió en el tiempo, dependiendo de la consideración administrativa que el Gobierno otorgaba a las corporaciones provinciales.

\footnotetext{
${ }^{404}$ A.D.P.P., L.A.P.D. 123, 7-V-1917.

${ }^{405}$ A.D.P.P, L.A.P.D., 123, 8-V-1917.

${ }^{406}$ A.D.P.P., L.A.P.D. $123,8-\mathrm{V}-1917$.
} 
En la primera etapa de la Restauración, las diputaciones provinciales debían reunirse los primeros días útiles de los meses quinto y décimo del año económico ${ }^{407} \mathrm{y}$ en la primera sesión de cada periodo semestral debía fijarse el número de sesiones ordinarias a celebrar ${ }^{408}$, el número de las que habían de celebrarse como ordinarias, los días consecutivos en que debían tener lugar, hora en la que debían abrirse y tiempo de duración. Las sesiones secretas se celebraban en los casos que taxativamente se determinaban en el art. 64 de la Ley Provincial ${ }^{409}$.

En el caso de las sesiones extraordinarias ${ }^{410}$, eran el Gobierno, el gobernador provincial o la Comisión Provincial los encargados de su convocatoria ${ }^{411}$. Todas las cuestiones procedimentales eran seguidas con el máximo rigor, pues cualquier resquicio legal era aprovechado por los diputados provinciales, tanto liberales como conservadores, para impugnar la validez de las sesiones celebradas, no se sabe muy bien si por un exceso de celo administrativo, o como una excusa perfecta para torpedear la labor de la Diputación de signo político contrario a los polemistas. Sirva de ejemplo la agria polémica desatada entre el vicepresidente de la Comisión Provincial, Manuel de las Heras Herreros (conservador) y el vocal Guzmán Rodríguez (elegido por Carrión por el Partido Liberal-Fusionista), a cuenta de la comunicación por parte del gobernador recibida a las once horas de la mañana para convocar a la Comisión Provincial a sesión extraordinaria el 12 de diciembre de 1892, celebrada a las doce horas y treinta minutos.

\footnotetext{
${ }^{407}$ Octubre y marzo respectivamente.

${ }^{408}$ Art. 60 de la Ley Provincial de 29 de agosto de 1882. En diciembre de 1885, la Diputación Provincial de Palencia consultaba al Ministerio de la Gobernación sobre la interpretación de este artículo, el Ministerio, en respuesta de 9 de febrero de 1886, dictaminaba que las sesiones acordadas para el periodo semestral no podían dejar de celebrarse por carecer de asuntos para debatir, por la falta de asistencia de los diputados provinciales que tuvieran la obligación de hacerlo o porque no se hubiera dictado dictamen, ya que en caso de concurrir alguna de estas causas, la sesión sería negativa y se contabilizaría como celebrada. Archivo Histórico Nacional, Legajo 49/16-17.

${ }^{409}$ Cuando la naturaleza del asunto lo exigiese y la Diputación a petición del presidente, del gobernador o de cinco vocales lo acordase.

${ }^{410}$ En estas sesiones, no se podía tratar ningún otro asunto que no fuese por el que se había convocado la sesión extraordinaria.

${ }^{411}$ Art. 61 de la Ley Provincial de 29 de agosto de 1882.
} 
El objeto de la reunión fue resolver el incidente de competencia que promovía el procurador Pedro de Cea, en nombre de los vecinos y el Ayuntamiento de Pedraza de Campos, y la capacidad o incapacidad del alcalde de Frechilla. Guzmán Rodríguez protestaba por estar citados a las doce horas y recibir la comunicación a las doce horas y treinta minutos. El vicepresidente se defendía aduciendo que en cuanto se recibió el Oficio del gobernador a las once horas, se pasó aviso para efectuar la reunión a las doce horas. Una vez reunidos los cinco vocales de la Comisión provincial en la sala de sesiones, el vocal Guzmán indicó que no asistiría sin la comunicación oficial, ya que consideraba que era requisito indispensable recibir comunicación oficial para asistir a las reuniones extraordinarias y no era posible emitir opinión acerca de asuntos que eran conocidos media hora antes, ya que a las doce horas había solicitado que los expedientes quedasen en la mesa para informarse sobre ellos. Guzmán Rodríguez emitió una protesta de nulidad por cuanto se acordó y se retiró del salón de sesiones ${ }^{412}$. El vicepresidente replicó que el sábado último Guzmán Rodríguez había asistido a una sesión extraordinaria sin necesidad de comunicación previa. Guzmán Rodríguez contestaba que lo tratado en aquella reunión, la exclusión de dos mozos que habían fallecido, era urgente para evitar la nulidad del sorteo, urgencia que no apreciaba en el caso que les ocupaba. El vocal Ovejero Pastor (conservador), señalaba que las cuestiones de competencia eran improrrogables. Guzmán Rodríguez renunció a hacer uso de la palabra y se retiró de la sala de sesiones.

En la Dictadura, la Diputación Provincial celebraba dos periodos de sesiones plenarias, una en cada semestre del año económico. El primer periodo se dedicaba al examen y censura de las cuentas del ejercicio anterior y el segundo periodo a la discusión y aprobación del presupuesto del ejercicio siguiente. En las sesiones plenarias tenían voz y voto tanto los diputados directos, como los corporativos. La Corporación Provincial pretendía que las actuaciones relativas a temas de gran importancia ${ }^{413}$ para sus administrados, fuesen de carácter público, por lo que asuntos de tanta trascendencia como los presupuestos provinciales, eran publicados en el $B O P^{414}$.

\footnotetext{
${ }^{412}$ A.D.P.P. L.A.C.P., 77, 13-XII-1892.

${ }^{413}$ En el $B O P$ se publicaba un extracto de los asuntos principales tratados en las sesiones de la Diputación Provincial de Palencia. Se pretendía con ello que los ciudadanos tuviesen conocimiento de lo acordado para, en caso de estimarlo, presentar recurso contra los acuerdos tomados.

${ }^{414}$ Art. 64 de la Ley Provincial de 29 de agosto de 1882.
} 


\section{Las Comisiones de la Diputación Provincial}

La Diputación Provincial había sido concebida como un ente deliberante de la Administración Provincial por lo que la totalidad de sus miembros no participaba en la fase de tramitación de los expedientes, al reservarse esa función a algunos de los vocales, bien en solitario o de forma más común, reunidos en comisiones ${ }^{415}$. Estas debían preparar los asuntos sometidos para su posterior discusión en el Pleno de la Diputación Provincial. A partir de 1870 se institucionalizó de forma definitiva la figura de la Comisión Provincial ${ }^{416}$, compuesta por cinco diputados elegidos entre los vocales que formaban parte de la Diputación Provincial. La Comisión tenía carácter permanente y una duración de dos años, lo que la diferenciaba de otras comisiones creadas ad hoc para la tramitación y resolución de algún asunto. Dado su carácter de permanencia, sus miembros estaban obligados a residir largos periodos de tiempo en la capital de la provincia $^{417}$, aunque la nueva Ley Provincial de 29 de agosto de 1882 no contemplaba la figura de la Comisión Permanente como figura asociada a los diputados provinciales residentes en la capital. Sin embargo, la interpretación de la nueva legislación entrañaba no pocas discusiones, como la acaecida en la sesión celebrada el 17 de septiembre de 1882, en la que el diputado provincial Antonio Reyero, que no pertenecía a la Comisión pero era residente, exponía que por hallarse en vigor la Ley Orgánica Provincial de 29 de agosto de 1882, en su concepto, era ilegal e innecesaria la reunión de los diputados provinciales residentes ${ }^{418}$.

\footnotetext{
${ }^{415}$ Art. 65 de la Ley Provincial de 29 de agosto de 1882.

${ }^{416}$ Arts. 5 y 92 de la Ley Provincial de 29 de agosto de 1882. Órgano colegiado permanente creado por la Ley provincial de 20 de agosto de 1870 , la totalidad de cuyos miembros constituían también una parte del Pleno de la Diputación. Entre 1876 y 1888 fue Tribunal Contencioso-Administrativo Provincial, (heredando también en este ámbito las competencias del Consejo Provincial), hasta 1882, año en que dichas competencias pasaron a depender de la Audiencia Provincial. A partir del año 1925, con la aprobación del Estatuto provincial, pasa a denominarse Comisión Provincial Permanente. Estaba compuesta por los Diputados provinciales directos que en unión de los corporativos constituían el pleno y sus competencias eran todas las no reservadas al Pleno, aunque perdía dos de sus funciones básicas, la condición de superior jerárquico de los ayuntamientos y el carácter de órgano asesor del gobernador civil, función que quedaba reservada a los abogados del Estado afectos al Gobierno civil. Solo mantenía sus atribuciones como órgano de Gobierno y administración de la Diputación con un carácter subordinado a los otros dos, el Gobernador y el Pleno de la Diputación.

${ }^{417}$ Arts. 92 de la Ley Provincial de 29 de agosto de 1882. Debido a esta circunstancia, la Ley posibilitaba que los vocales de la Comisión Provincial pudieran percibir dietas compensatorias. La Comisión Provincial se reunía cuantas veces fuese necesario para tratar los temas de su competencia, según el orden establecido en la primera sesión de cada mes.

${ }^{418}$ Las leyes entraban en vigor desde su publicación en las capitales de provincia y cuatro días después en los pueblos.
} 
Los diputados provinciales, Yágüez Palón y Rodríguez Olea, discrepaban de esta afirmación y defendían que la nueva Ley no estaba en vigor porque establecía reformas profundas de las diputaciones, imposibles de realizar en tan breve espacio de tiempo desde su publicación oficial, y citaban como precedente la Ley Provincial de 27 de agosto de 1870, que no había entrado en vigor hasta enero de 1871. Antonio Reyero rectificó su posición ante los argumentos expuestos por sus compañeros ${ }^{419}$. De conformidad con lo dispuesto en el art. 94 de la Ley Provincial de 29 de agosto de 1882, y al art.3 del Real Decreto de 12 de junio de 1899, la Comisión Provincial acordaba, en la primera sesión de cada mes, el orden de las sesiones ordinarias a celebrar. Todo lo concerniente al gobierno interior de las oficinas, distribución de negociados y demás, quedaba a cargo de la Comisión Provincial. Hasta 1925, la Comisión Provincial se encargaba ${ }^{420}$ de la ejecución de los acuerdos de la Diputación Provincial y de preparar todos los asuntos que debía resolver aquella, tenía competencias en Quintas ${ }^{421}$, verificaba los acuerdos de los ayuntamientos y resolvía las reclamaciones respecto de la elección de los concejales en las elecciones municipales ${ }^{422}$. La Comisión Provincial tenía un rango administrativo semejante al de la Diputación Provincial o al gobernador provincial, como ya quedaba constatado en la legislación que establecía su creación y funcionamiento $^{423}$.

\footnotetext{
${ }^{419}$ A.D.P.P. L.A.C.P., 58, 17-IX-1882

${ }^{420}$ Arts. del 98 al 102 de la Ley Provincial de 29 de agosto de 1882.

${ }^{421}$ Resolvía las incidencias de quintos.

${ }^{422}$ Art. 2. Disposición $3^{\text {a }}$ de la Ley Provincial de Bases de 16 de diciembre de 1876. Varios ejemplos de las reclamaciones ante la Comisión Provincial sobre irregularidades en procesos electorales municipales: protesta de los candidatos en las elecciones al Ayuntamiento de Dueñas por la compra de votos, por los que se llegaron a pagar de cuatro a ocho duros y por las coacciones y amenazas de la autoridad local para que los electores votasen una determinada candidatura. A.D.P.P, L.A.C.P., 115, 6-XII-1911. Protestas de vecinos y electores de Palencia contra la validez de las elecciones municipales del día 12 de noviembre de 1911, declaraban que se habían ejercido coacciones contra los electores, por medio de ofrecimientos y dádivas «(...) conduciéndoles a los corrales de la plaza de toros, donde los dependientes del diputado a Cortes don Abilio Calderón Rojo les recibían y anotaban en candidaturas impresas de los Srs. Donis y Valcárcel, los nombres de los detenidos, ofreciéndoles cantidades si votaban la candidatura conservadora, de donde salían reclutados hasta los colegios electorales por el cajero de los Srs. Calderón, don Benito González y otros dependientes del dicho señor». A.D.P.P., L.A.C.P. 115, 6-XII-1911.

${ }^{423}$ Art. 2. Disposición. $3^{\mathrm{a}}$ y $4^{\mathrm{a}}$ de la Ley de Bases de 16 de diciembre de 1876.
} 
El Real Decreto de 24 de marzo de 1891, legislación básica junto a las Reales órdenes aclaratorias, referente a las elecciones de concejales en materia electoral (derecho de reclamación de los electores), contemplaba una serie de reglas sobre este particular, entre ellas, la séptima señalaba que la Comisión Provincial carecía de competencias para atender los recursos electorales que se presenten directamente ante la misma y que debían devolverse a los alcaldes respectivos, para que se cursasen en la forma debida. (Una vez vencido el plazo para presentar reclamación, participaban de oficio en la Comisión Provincial, en pliego certificado, si se habían interpuesto reclamaciones o no $)^{424}$.

Las fuentes documentales consultadas demuestran que, en algunos casos de reclamaciones electorales municipales, se producían votos particulares discrepantes de los vocales de la Comisión Provincial en contra de la decisión mayoritaria de sus compañeros y en defensa de la capacidad legal de alcaldes y concejales, seguramente afines ideológicamente, para desempeñar sus cargos. La mayoría de las veces, el vocal discrepante lo era en los casos de pueblos que estaban dentro de su Distrito de elección, como Rodríguez García Delgado, elegido por el Distrito de Astudillo-Baltanás, que disentía en el caso de Hérmedes de Cerrato, donde se solicitaba la nulidad de las elecciones municipales, en concreto, de la elección de concejales ${ }^{425}$. Las decisiones de la Comisión Provincial sobre estos asuntos eran recurribles ante el Ministerio de Gobernación, vía gobernador civil, en Recurso de Alzada.

Además, la Comisión Provincial confeccionaba una Memoria comprensiva que elevaba a la Diputación Provincial con los asuntos que esta debía atender en cada periodo semestral ${ }^{426}$. En esta etapa la Comisión Provincial asumió las funciones de carácter contencioso-administrativo que tenían encomendadas los consejos provinciales, lo que les convertía de facto en verdaderos Tribunales Contenciosos ${ }^{427}$.

\footnotetext{
${ }^{424}$ A.D.P.P, L.A.C.P., 117, 4-XI-1913.

${ }^{425}$ A.D.P.P., L.A.C.P. 132, 6-III-1920

${ }^{426}$ Disposición $2^{\text {a }}$ del art. 98 de la Ley Provincial de 29 de agosto de 1882.

${ }^{427} \mathrm{De}$ acuerdo con esta atribución, resolvían las cuestiones referidas a todo lo concerniente a los contratos y remates celebrados con los ayuntamientos para toda clase de servicios y obras públicas. Dado el carácter de esta nueva función, la Ley exigía que al menos dos de los vocales de la Comisión Provincial fuesen letrados.
} 
El Estatuto Provincial de 1925, establecía que la Comisión Provincial debía reunirse una vez al menos cada quince días ${ }^{428}$ y le confería la atribución de adoptar todos los acuerdos relativos a las materias de competencia provincial que por ley no estuviesen reservadas exclusivamente a la Diputación en Pleno.

Hasta 1900, la Comisión Provincial aprobaba los proyectos, presupuestos, pliegos de condiciones facultativas y económicas y presupuestos ${ }^{429}$. A partir de esa fecha ${ }^{430}$, se estableció que cuando la subasta se realizase para contratos que necesitasen para su validez la aprobación de la Diputación Provincial, del gobernador de la provincia o del Gobierno, los pliegos de condiciones habrían de ser previamente aprobados por la Corporación Provincial o autoridad a quién correspondiese autorizar el contrato, dando publicidad a los acuerdos por medio del Boletín Oficial de la Provincia, con el objeto de que se pudiera reclamar contra ellos en el plazo de diez o veinte días, según la cuantía de las subastas ${ }^{431}$. En consecuencia, la Asamblea debía examinar y aprobar todos los pliegos de la contratación de los servicios. La innovación consistía en la obligación de aprobar previamente las condiciones para toda clase de subastas y adjudicaciones $^{432}$.

La legislación administrativa considerada por la Comisión Provincial a la hora de emitir sus dictámenes era tan prolija que se producían quejas: «(...) la ingente cantidad de Reales Órdenes y de Reales Decretos, opuestos en la mayor parte de las ocasiones a la letra y el espíritu de la misma Ley que pretenden aclarar.» ${ }^{433}$ Además de la Comisión Provincial, en las primeras sesiones se determinaba el número de comisiones permanentes necesarias para informar sobre los ramos que la Ley le confería, determinando el número de vocales que formaría parte de ellas.

\footnotetext{
${ }^{428}$ Art. 90 del Estatuto Provincial de 1925.

${ }^{429}$ Facultada por el párrafo 3 del art. 92 de la Ley Provincial de 29 de agosto de 1882.

${ }^{430}$ Instrucción de 26 de abril de 1900, art. 4.

${ }^{431}$ A.D.P.P., Memoria Año Económico Primer Semestre 1900, C-R / 1,14, p. 3.

${ }^{432}$ Celebrada cualquier subasta, se precisaba convocar a la Diputación Provincial a reunión extraordinaria para la adjudicación definitiva.

${ }^{433}$ A.D.P.P., Memoria Año Económico Segundo Semestre 1902, C-R / 1,16, p. 6.
} 
Cuando en 1904, desde algunos ámbitos se pedía la desaparición de las comisiones ejecutivas de las diputaciones provinciales, el gobernador civil de la provincia de Palencia defendía su importancia y estimaba que eran organismos indispensables, «(...) llamados a producir grandes beneficios si se limitan al cumplimiento de los deberes marcados en las leyes por las que re rigen.» ${ }^{434}$

Además de la Comisión Provincial, la Diputación Provincial de Palencia se organizaba en cuatro Comisiones ordinarias, compuestas de cinco miembros cada una, Hacienda y Cuentas, Fomento y Beneficencia, Gobierno y Administración y Presupuestos. La Diputación podía nombrar Comisiones especiales ${ }^{435}$ para asuntos determinados ${ }^{436}$, que cesaban en sus funciones una vez resuelto el tema que propició su formación. El nombramiento de todas estas comisiones se verificaba en votación secreta por medio de papeletas, y en actos diferentes ${ }^{437}$. Estas Comisiones y la Comisión Permanente de Actas, tenían una duración de dos años y sus miembros, en caso de vacantes, eran reemplazados de la misma forma que habían sido nombrados. Todas las Comisiones, tanto las ordinarias como las especiales, nombraban su presidente y secretario en el acto de constitución y señalaban los días de reunión ${ }^{438}$. Cuando no asistía el presidente ejercía como tal, el vocal presente de más edad. Las Comisiones eran convocadas por su presidente, por el de la Diputación ${ }^{439}$ o por el que hiciese las veces de estos. Las facultades de las mismas se reducían a informar de las proposiciones que la Diputación juzgara conveniente consultar, así como de los asuntos de despacho ordinario y demás que se les encargase.

\footnotetext{
${ }^{434}$ A.D.P.P., L.A.C.P. 100, 11-I-1904.

${ }^{435}$ Las Comisiones debían abstenerse de entender de asuntos que no fuesen de su competencia. Si se les entregaba algún asunto de esta índole para el despacho, debían ponerlo en conocimiento de la Diputación para que resolviese qué Comisión debía informarlo.

${ }^{436}$ En 1877, la Comisión Especial nombrada por la Diputación Provincial de Palencia se trasladó a Madrid para gestionar y obtener del Gobierno la resolución de importantes asuntos de interés general para la provincia y especialmente, la condonación de contribuciones y concesión de moratorias para los pueblos que instruyeron expedientes justificativos por la pérdida de sus cosechas a causa de la sequía, así como la devolución del capital e intereses vencidos de la tercera parte del 80\% de Bienes Propios enajenados que existen en la Caja de Depósitos. A.D.P.P., L.A.C.P.P. 46, 4-I-1877.

${ }^{437} \mathrm{Si}$ por ausencia, licencia, enfermedad o dejar de pertenecer a la Diputación no existía mayoría en alguna Comisión se completaba para que pudiese dar dictamen. Debían estar presentes tres miembros como mínimo para poder dictaminar. En caso de empate, decidía el voto del presidente de la Comisión correspondiente.

${ }^{438}$ Todos los diputados provinciales podían asistir con voz, pero no con voto, a las reuniones de las Comisiones en las que no estuviesen incluidos o a las que no perteneciesen.

${ }^{439}$ Las Comisiones de Ceremonia y Etiqueta eran nombradas por el presidente de la Diputación y en su ausencia, por el vicepresidente de la Comisión Provincial.
} 


\section{Funcionamiento}

El presidente de la Diputación Provincial abría la sesión con esta fórmula «Ábrase la sesión», y la cerraba con la fórmula «Se levanta la sesión». Una vez levantada, no se permitía hablar a ningún diputado y cuanto se hiciese era nulo. Para abrir la sesión era necesaria la presencia de la mitad más uno del número de diputados provinciales que correspondían a la provincia. Después de leída el Acta de la sesión anterior, se daba cuenta por el secretario ${ }^{440}$ de los oficios o comunicaciones dirigidos por el gobernador, diputaciones de otras provincias, alcaldes, jefes de Hacienda y otras

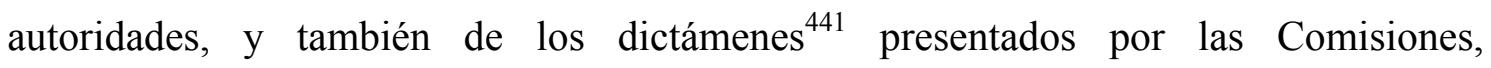
proposiciones de los diputados provinciales ${ }^{442}$, peticiones dirigidas a la Diputación y excusas de los diputados provinciales que no podían asistir a las sesiones. Terminado el despacho ordinario, durante media hora los diputados podían formular preguntas, presentar mociones e interpelaciones. Luego, se trataba el orden del día ${ }^{443}$ relativo a los asuntos preparados para acuerdo, designando el presidente, o en su caso el vicepresidente por el orden que le parecía mejor, los asuntos comprendidos en el orden del día para su despacho.

\footnotetext{
${ }^{440}$ Debían dar cuenta de las comunicaciones, peticiones y solicitudes que se dirigiesen a la Diputación, hacer el recuento o escrutinio de votos y publicar su resultado para consignarlo en Acta, extender las Actas de las sesiones y suscribirlas después de ser aprobadas y copiadas en el libro correspondiente y extender por escrito el orden del día anunciado por el presidente para fijarla a la puerta del salón de sesiones. En caso de ausencia, era sustituido por los dos diputados más jóvenes. En caso de vacante, se procedía a la elección, haciendo de secretarios los de la Mesa interina.

${ }^{441}$ Todos los dictámenes debían quedar sobre la mesa como mínimo durante veinticuatro horas. El presidente señalaba día para su discusión. Las Comisiones podían retirar sus dictámenes antes de ponerles a votación para enmendarlos o variarlos.

${ }^{442}$ Todo diputado podía presentar por escrito todas las proposiciones que estimara convenientes, pero debían ir firmadas por tres diputados, o por el proponente y otros dos para autorizar su lectura.

${ }^{443} \mathrm{Se}$ consideraban nulas las sesiones en las que se tratasen asuntos no anunciados en el orden del día, según el art. 70 de la Ley Provincial de 29 de agosto de 1882, doctrina que se desarrollaba en la Real Orden de 8 de marzo de 1894, la llamada «Doctrina Aguilera».
} 
La dinámica de las sesiones imponía, a veces, una lectura benévola de la Ley, como ocurrió cuando el vicepresidente de la Comisión Provincial, Alejandro Nájera de la Guerra, en la sesión del día 3 de junio de 1919, respondía a la interpelación de un diputado provincial sobre la oportunidad de tratar un asunto ${ }^{444}$ que no estaba incluido en el orden del día, respondiendo a aquel que era atribución suya el someter los asuntos que debían incluirse en el orden del día y que prefería no tratar el tema propuesto en esa sesión por no ser urgente. Sin embargo, ante la insistencia del diputado Santander Gallardo y el apoyo de otros vocales, el vicepresidente accedía a someter a votación la declaración de urgencia del asunto, avisando de la ilegalidad a cometer, acordándose la urgencia del asunto a discutir por cuatro votos contra uno. El Vicepresidente emitió un voto particular, puesto que consideraba que era la Asamblea quien debía decidir sobre ese asunto y no la Comisión Provincial y que además el solicitante debía presentar los justificantes prescritos por la Ley en esos $\operatorname{casos}^{445}$.

Ningún diputado podía hacer uso de la palabra sin haberla pedido ni obtenido o haber sido invitado por el presidente ${ }^{446}$ a usarla. Los diputados dirigían siempre la palabra a la Asamblea y nunca a una fracción de la misma o a un individuo. El presidente concedía la palabra a los diputados ${ }^{447}$ por el orden al pedirla, y alternando uno en contra y otro a favor, pero si se trataba de un dictamen ${ }^{448}$ en contra de una proposición, el autor de esta obtenía con preferencia la palabra para impugnarla en el primer turno, si así lo reclamaba.

\footnotetext{
${ }^{444}$ La posible renuncia del diputado provincial por el distrito de Astudillo-Baltanás, Muñoz Jalón, por la necesidad de ausentarse largos periodos de tiempo para curarse de una enfermedad (se había tenido conocimiento extraoficial de que se había presentado su solicitud de renuncia).

${ }^{445}$ A.D.P.P., L.A.C.P. $127,3-\mathrm{VI}-1919$.

${ }^{446} \mathrm{El}$ presidente podía llamar al orden al diputado que se excediese y a la cuestión, al que se separase de ella de forma notoria. Llamado por tres veces al orden un diputado en la misma sesión, el presidente preguntaba a la Diputación si se le retiraba la palabra.

${ }_{447}$ Durante la discusión de una proposición, cualquier diputado podía promover una cuestión de orden con objeto de encauzar el debate y pedir la observancia del Reglamento y la lectura de sus artículos.

${ }^{448}$ Las Comisiones en defensa de sus dictámenes consumían turno. Sus miembros tenían preferencia sobre los otros diputados que hubiesen pedido la palabra a su favor.
} 
Ningún diputado tenía la palabra más de una vez en cada discusión, excepto para contestar a alguna pregunta o para rectificar ${ }^{449}$. Podía hacerse uso de la palabra cuando otro diputado la cediera en su turno. Si el presidente quería participar en una discusión debía abandonar la Presidencia y no volver a ocuparla hasta que se tratase de un nuevo asunto $^{450}$. Todo discurso se pronunciaba de viva voz y sin interrupción ${ }^{451}$, salvo si transcurrían las horas señaladas y no se acordaba prorrogarlas ${ }^{452}$ Después de leída una proposición y antes de empezar la votación ${ }^{453}$ se podía pedir la palabra con la expresión «Para votar», a objeto de solicitar brevemente la aclaración o explicación necesaria, así como después de la votación para explicar el voto de forma breve y concisa.

\footnotetext{
${ }^{449} \mathrm{Si}$ se profería alguna palabra mal sonante y ofensiva hacía algún diputado, este podía reclamar la palabra una vez hubiese concluido el turno del que había proferido la palabra ofensiva, y si las explicaciones no satisfacían al ofendido o a la Corporación Provincial, el presidente podía ordenar a un secretario que escribiese dichas expresiones deliberando enseguida sobre ellas.

${ }^{450}$ Aunque esta medida no afectaba a los diputados provinciales, en las discusiones en las que estaban comprometidos asuntos personales de algún diputado, generalmente el interesado se retiraba de la sesión hasta que concluyese el asunto en cuestión. En 1885, leído un informe respecto al expediente de elecciones de Cevico de la Torre, Valentín Calderón García, creía que no debía tomar parte en el debate Nieto Moro, al ser pariente de uno de los reclamantes y por prohibirlo la Ley Municipal. Nieto respondía que, siendo dudoso que fuera aplicable el art. 106 de la Ley Municipal a las sesiones de la Comisión Provincial, era suficiente que Calderón hubiese puesto en duda su imparcialidad en ese asunto para que él se diese por recusado y se retirase de su puesto dejando libertad a sus compañeros para que decidieran «(...) como siempre lo más justo y legal». A.D.P.P., L.A.C.P., 61, 19-VI-1885.

${ }^{451}$ Solo el presidente, para desempeñar las funciones de su cargo, podía interrumpir al diputado que estaba en el uso de la palabra.

${ }^{452} \mathrm{Se}$ declaraba un punto suficientemente discutido cuando se consumían tres turnos a favor y tres en contra además de las rectificaciones y alusiones correspondientes. A.D.P.P., L.A.C.P.P. 61, 19-VI-1885.

${ }^{453}$ Los diputados, durante la discusión y antes del voto, podían pedir la lectura de leyes, órdenes y documentos que estimasen oportunos y que se encontrasen en la Biblioteca o Archivo Provincial.
} 
En las deliberaciones ${ }^{454}$ se requería la presencia de la mayoría absoluta del número de diputados provinciales ${ }^{455}$ correspondientes a la provincia. En la adopción de acuerdos, se necesitaba el voto de la mayoría de los diputados concurrentes ${ }^{456}$. Las Actas de la Comisión Provincial demuestran que el absentismo injustificado era más frecuente de lo deseable y, en ocasiones, retrasaba la toma de decisiones importantes para la actividad diaria de las distintas dependencias provinciales. En noviembre de 1885, el presidente de la Diputación Provincial, Crisógono Manrique llamaba la atención sobre el incumplimiento del art. $66^{457}$ de la Ley Provincial de 29 de agosto de 1882, ya que muchos diputados que venían desempeñando el cargo desde hacía tres años, se habrían presentado escasamente en ese tiempo a una solo sesión, imposibilitando la buena marcha de la Asamblea, como sucedió al tratar de los presupuestos. ${ }^{458}$ En 1886, la situación era de tal gravedad que cuando el vocal de la Comisión Provincial, Álvarez Miranda, excusaba su ausencia de la sesión del día 9 de junio de 1886, por encontrarse enfermo, su compañero de Comisión, el vocal Joaquín Monedero y Monedero, se oponía a que se admitiese la excusa sin que a ella se acompañase el respectivo justificante.

\footnotetext{
${ }^{454}$ La Diputación no discutía ni resolvía sobre asuntos que no hubiesen sido objeto de dictamen de la Comisión correspondiente. Quedaban excluidos los asuntos comprendidos en el despacho ordinario, las preguntas e interpelaciones, los asuntos de mero trámite, las mociones de Presidencia que podían ser resueltas de plano y las proposiciones declaradas urgentes.

${ }^{455}$ Cualquier diputado podía pedir que se contasen los presentes en la votación, a fin de comprobar si había número suficiente. En la sesión del 29 de agosto de 1885, se comunicaba que en las sesiones anteriores no pudieron despacharse los asuntos señalados en el orden del día por falta de asistencia del número de vocales que estipulaba el párrafo $2^{\circ}$, inciso $3^{\circ}$, art. 48 de la Ley Provincial de 29 de agosto de 1882. Tampoco en la siguiente sesión se consiguió el suficiente número de vocales. El diputado provincial Nieto Moro, indicaba que no podía demorarse el despacho de asuntos urgentes por los perjuicios que ocasionarían a la provincia: huérfanos y desamparados por la epidemia de cólera. En su opinión, la Comisión Provincial por el rigorismo de la ley se veía imposibilitada «(...) de ejercer la virtud más sublime, la caridad, concediendo el ingreso en el Establecimiento de Beneficencia y los socorros de lactancia». Los contratistas reclamaban que se solventasen sus deudas y «(...) todos exigen de nosotros lo que estamos legalmente imposibilitados de concederles». Solo asistieron a la sesión el Presidente, Pereda Fuente, y los vocales Nieto Moro y Manuel Villameriel. Se reclamaba que se citase al vicepresidente y a Calderón García, «(...) quien sobradamente sabe, porque así se le significó en la última sesión, que la licencia concedida ha caducado desde el momento en que se declaró el cólera». A.D.P.P., L.A.C.P. 61, 29-VIII-1885.

${ }^{456} \mathrm{Si}$ algún diputado no se hallaba presente en una votación pública, en la sesión inmediata, podía adherirse a la mayoría o a la minoría, pero si la votación había sido secreta, el que no hubiese tomado parte en ella solo tendría la facultad para consignar que se adhería al acuerdo de la Diputación.

${ }^{457}$ Obligatoriedad de asistencia a las sesiones.

${ }^{458}$ A.D.P.P., L.A.P.D., 57, 4-XI-1885.
} 
La presidencia advertía a Monedero que hasta ese momento ni la Diputación, ni la Comisión Provincial, habían exigido justificación escrita de las excusas, «(...) mereciendo entero crédito las comunicaciones de los diputados dirigidos al Gobierno y al presidente. ${ }^{459}$ Los diputados provinciales Francisco Ruiz de Navamuel y Leoncio Trigueros Pérez, exponían que ellos habían faltado a algunas sesiones por enfermedad sin que se les hubiese exigido certificación facultativa. Se acordó que hasta que se restableciese el diputado Miranda, el vocal suplente Prado Salas ocupase su puesto, con el voto de Joaquín Monedero en contra. A comienzos del siglo XX, la situación no había mejorado en este aspecto y después de dos sesiones consecutivas, los días 23 y 24 de abril de 1903, en las que por no contar con un número suficiente de diputados provinciales para deliberar, según el art. 67 de la Ley Provincial de 29 de agosto de 1882, se acordó imponer multas de 25 pts. a los diputados ausentes, en cumplimiento de lo dispuesto en la Real Orden de 16 de octubre de 1894, se pusieron los hechos en conocimiento del ministro de Gobernación por conducto del gobernador de la provincia $^{460}$. Las sesiones de los días 27 y 28 tampoco se pudieron celebrar por falta de diputados provinciales $^{461}$. En diciembre de ese año, el gobernador imponía 25 pts. de multa $^{462}$ a varios diputados provinciales, García de los Ríos, Guijelmo Aguado, por no haber excusado su ausencia en la sesión anterior de la Comisión Provincial y les citaba para que concurrieran a la sesión que se celebraría el día 11 de diciembre. García de los Ríos se extrañaba de las frases y conceptos que le dirigía Ramón Calderón, presidente de la Comisión Provincial por no haber asistido a la sesión a anterior. Frases y conceptos que estimaba depresivos para el diputado aparte de algunas equivocaciones de citas legales. García de los Ríos creía que no era aplicable el art. 67 de la Ley Provincial de 29 de agosto de 1882 a los vocales de la Comisión Provincial, porque no habían precedido los apercibimientos consiguientes. El gobernador daba por terminada la discusión y manifestaba a García de los Ríos que le había permitido discutir la providencia por tolerancia ${ }^{463}$.

\footnotetext{
${ }^{459}$ A.D.P.P., L.A.C.P. $65,9-\mathrm{VI}-1886$.

${ }^{460}$ A.D.P.P, L.A.P.D. $95,25-I V-1903$.

${ }^{461}$ En el año 1903, del total de 36 sesiones previstas, once se declararon negativas por falta de asistencia del número suficiente de diputados.

${ }^{462}$ A.D.P.P, L.A.C.P. 101, 7-XII-1905.

${ }^{463}$ A.D.P.P, L.A.C.P. 101, 11-XII-1905.
} 
Curiosamente, García de los Ríos se vio afectado por estos mismos hechos, diez años después, cuando pedía explicaciones a la minoría liberal respecto a una nota oficiosa publicada en el Diario Palentino, acerca de su falta de asistencia a la sesión suspendida el día 11 de octubre a las catorce horas, para continuar a las dieciséis $\operatorname{horas}^{464}$.

La Asamblea Provincial decidía en votación ${ }^{465}$ ordinaria $^{466}$ si las proposiciones se tomaban en consideración o no; en caso afirmativo, pasaban a la Comisión respectiva o a la especial que se nombrase. También podía acordarse su discusión inmediata en el orden del día. En caso de empate se repetía la votación al día siguiente o en la misma sesión, si el asunto tenía carácter urgente $^{467}$, y si se producía un segundo empate el presidente resolvía con su voto de calidad.

\footnotetext{
${ }^{464}$ A.D.P.P, L.A.P.D. $113,27-X-1913$.

${ }^{465}$ Las votaciones podían ser públicas o secretas. Las públicas podían, a su vez, ser ordinarias y nominales. Las secretas se verificaban por medio de bolas o papeletas. La votación secreta por bolas tenía lugar cuando a petición de tres diputados se acordaba por la Diputación. En la votación por bolas, a cada diputado le entregaba el portero una bola blanca y otra negra y al ser llamado por el secretario, depositaba en la urna colocada al efecto la bola blanca, si aprobaba y negra si desaprobaba. El presidente y los secretarios contaban las bolas y cualquiera de los dos hacía pública la votación. Todos los diputados tenían derecho a votar mientras no se cerrase la votación. Al comienzo, los diputados presentes no podían excusarse de tomar parte en ellas. Las votaciones nominales y secretas empezaban siempre por los secretarios, continuaban por los diputados, por el orden que fuesen llamados, y votaba el último el presidente. Antes de que se cerraran las votaciones nominales y las secretas, un secretario preguntaba «¿Falta algún diputado por votar?» y se admitían los votos de aquellos que no habían votado. Después, votaba el presidente y anunciaba «Se cierra la votación». Cuando se discutía un asunto en su totalidad, primero se votaba la totalidad y después sus partes.

${ }^{466} \mathrm{En}$ la votación ordinaria se levantaban los diputados que aprobaban y permanecían sentados los que desaprobaban. El presidente anunciaba el resultado de las votaciones ordinarias con las palabras «Aprobado o desaprobado en votación ordinaria», sin expresar el número de votos en contra y a favor. Si había duda sobre el número de votos, se repetía la votación, haciéndose el recuento por los secretarios. Ningún diputado podía entrar o salir del salón de sesiones mientras se contaban los votos. En 1893, por ejemplo, hubo un voto de censura propuesto por Delgado Gonzalo, Alonso Villazán y Monedero y Monedero, del Partido Conservador contra Abilio Calderón Rojo, del Partido liberal-fusionista, secretario interino de la Diputación, por abandonar el local por breves momentos sin consentimiento de la Asamblea, viéndose obligado el presidente a suspender la sesión hasta que no regresó a su puesto. A.D.P.P., L.A.P.D., 75, 7-IV-1893. La votación nominal se verificaba contestando los diputados por el orden en el que fueran llamados sí o no, según fuese el voto de aprobación o desaprobación. La votación nominal procedía si lo acordaba la Diputación a petición del presidente, si lo pedían los diputados y cuando no había conformidad, en el recuento de una votación ordinaria. En este caso podían tomar parte los diputados que entraban de nuevo en el salón.

${ }^{467}$ Cuando se presentaba en tiempo hábil una proposición que su autor o autores calificaban de urgente, se decidía primero sobre su admisión y luego sobre su urgencia, decidiéndose si se discutía sin informe de la Comisión o debía pasar a una Comisión, fuera ordinaria o especial.
} 
En la etapa de la Dictadura, se celebraba sesión válida siempre que hubiese mayoría absoluta del número de diputados que formasen legalmente el Pleno de la Diputación Provincial o la Comisión Provincial. En segunda convocatoria, se consideraban validos los acuerdos ${ }^{468}$ adoptados por la mayoría de los diputados presentes, cualquiera que fuese su número, excepto que se requiriese un quórum especial y extraordinario ${ }^{469}$. Si se desechaba el dictamen de una Comisión, la Diputación acordaba que pasase el asunto a una especial que se nombraba en el acto. De cada sesión, el secretario de la Diputación extendía un Acta, en la que constaba el nombre del presidente y de los diputados presentes, los asuntos tratados y lo resuelto sobre ellos, el resultado de las votaciones y la lista de las nominales cuando las había. Las Actas eran firmadas por el presidente, el secretario y uno o varios diputados. Una vez aprobado el acuerdo, se procedía a ejecutarlo. Todos los acuerdos, relativos a materias de competencia de la Diputación Provincial, eran ejecutivos sin perjuicio de los posibles recursos posteriores ${ }^{470}$. El gobernador, como máxima autoridad de la Administración Provincial, era el encargado de que los acuerdos de la Diputación se llevasen a término y también de la posible suspensión de los mismos. La suspensión podía iniciarse de oficio o a instancia de parte $^{471}$ y debía ser notificada a la Diputación en el plazo de tres días, a contar desde el acuerdo. Contra las providencias del gobernador, decretando la suspensión del acuerdo, la Diputación podía presentar Recurso de Alzada ante el Gobierno ${ }^{472}$. El Gobierno debía resolver en un plazo de sesenta días tras la remisión del expediente, escuchando antes al Consejo de Estado, y si este plazo transcurría sin resolución alguna, los acuerdos de la Diputación se consideraban firmes sin posibilidad de revocarlos o modificarlos en vía gubernativa.

\footnotetext{
${ }^{468}$ Ningún diputado podía abstenerse pues la abstención estaba equiparada a la falta de asistencia y era sancionada con arreglo al art. 94 del Estatuto Provincial de 1925.

${ }^{469}$ Art. 95 del Estatuto Provincial de 1925.

${ }^{470}$ Art. 78 de la Ley Provincial de 29 de agosto de 1882.

${ }^{471}$ Cuando el acuerdo en cuestión recayese en asuntos que no fueran de competencia de la Diputación, por la posible actuación delictiva de la Corporación o por infracción manifiesta de las leyes siempre que resultasen perjudicados directamente los intereses del Estado o los de otras provincias. También podían suspenderse los acuerdos si se consideraban dañados los intereses de particulares y los agraviados lo solicitaban en un plazo de diez días desde la toma de la resolución.

${ }^{472}$ El gobernador debía remitir al Ministerio de Gobernación en un plazo de diez días los recursos de alzada que se interpusieran.
} 
Las diputaciones provinciales, como cualquier otra corporación administrativa, estaban sujetas a responsabilidad civil y penal, tanto en el ejercicio de funciones que no eran de su exclusiva competencia, como cuando ejercían atribuciones propias. Las corporaciones incurrían en responsabilidad ${ }^{473}$ cuando infringían de forma manifiesta la ley atribuyéndose facultades que no les competían o abusando de las propias, desobedeciendo al Gobierno en los que procedía por delegación, por desacato a sus superiores jerárquicos, por negligencia u omisión en sus actuaciones o malversación en la administración de sus fondos. La responsabilidad se podía exigir a la Diputación Provincial o a los diputados provinciales ${ }^{474}$, ante la Administración o ante los tribunales de justicia. Correspondía al Gobierno en exclusiva la exigencia de la responsabilidad administrativa, que comprendía el apercibimiento, la multa y la suspensión. El apercibimiento procedía en los casos de omisión, negligencia y abuso de facultades cuyas consecuencias no fuesen irreparables, la multa ${ }^{475}$ en el caso de reincidencia de faltas castigadas ya con apercibimiento, así como en casos de negligencia de consecuencias irreparables, abuso de autoridad y desobediencia que no estuviesen contemplados como delitos.

La suspensión ${ }^{476}$ procedía en los casos de reincidencia en las faltas castigadas ya con multas, en los de extralimitación grave de carácter político y en los de resistencia a la autoridad del Gobierno ${ }^{477}$. El Gobierno, tras escuchar al Consejo de Estado, formulaba el correspondiente expediente sancionador que era confirmado mediante Real Orden. Solo por sentencia ejecutoria de los tribunales podían ser disueltas las diputaciones provinciales y destituidos sus vocales. Los delitos cometidos por la Diputación provincial y los diputados en el ejercicio de sus funciones eran juzgados en primera instancia por la Audiencia de la capital de provincia.

\footnotetext{
${ }^{473}$ Arts. 130 y 131 de la Ley Provincial de 29 de agosto de 1882.

${ }^{474}$ Solo se exigía la responsabilidad a los diputados que hubieran incurrido en la omisión o tomado parte en el acto o acuerdo que la motivara.

${ }^{475} \mathrm{Las}$ multas no podían exceder de $500 \mathrm{pts}$.

${ }^{476} \mathrm{La}$ suspensión era transmitida por el gobernador a la Diputación Provincial o a los diputados provinciales el mismo día que se recibía desde el Ministerio de la Gobernación, expresando la causa que la había motivado. Tanto la Diputación, como los diputados provinciales podían, vía gobernador, exponer su defensa ante el Gobierno en el plazo de tres días desde la comunicación de la suspensión. La suspensión no podía superar los sesenta días, transcurrido este plazo sin que por parte de la Audiencia se hubiese incoado auto contra los apercibidos, esos volverían a ejercer de hecho y de derecho sus funciones.

${ }^{477} \mathrm{La}$ publicidad del acto en el que se hubiese cometido la infracción, la invitación a otras corporaciones a cometerla y producir la alteración del orden público se consideraban agravantes de la falta de resistencia y desobediencia al Gobierno.
} 


\section{El presidente y el vicepresidente}

Hasta 1925 , el gobernador provincial ${ }^{478}$ ocupaba la presidencia de la Diputación con voz y voto, lo cual no impedía que la Corporación Provincial pudiese elegir de entre sus vocales a un presidente y vicepresidente ${ }^{479}$ que en ausencia del gobernador ejercían las funciones propias de su cargo. Como sucedía en otras cuestiones, la Ley Provincial de 29 de agosto de 1882 no explicitaba las incompatibilidades del cargo de presidente y vicepresidente de la Diputación Provincial. La Real Orden de 31 de enero de 1883, señalaba que el cargo de vicepresidente de la Comisión era incompatible con el de presidente de la Diputación Provincial ${ }^{480}$, viniendo esta orden a suplir el silencio que la Ley guardaba sobre este asunto.

El presidente representaba a la Diputación Provincial en todos los actos a que asistía con tal carácter, abría y cerraba las sesiones cuando no las presidía el gobernador de la provincia, cuidaba de mantener el orden, dirigía las discusiones, concedía la palabra según se hubiese pedido, fijaba los puntos que se habían de discutir y votar, presentaba en sesión las manifestaciones que estimaba conveniente, en el momento que juzgase oportuno, anunciaba al fin de cada sesión los asuntos que se debían tratar en la siguiente, firmaba las Actas y acuerdos de la Diputación y ejercía todas las demás funciones propias del cargo.

\footnotetext{
${ }^{478}$ Durante el Sexenio Revolucionario, el gobernador provincial tenía la facultad de presidir la Diputación Provincial, pero sin posibilidad de ejercer el voto en las deliberaciones del Pleno.

${ }^{479}$ Arts. 28 y 51 de la Ley Provincial de 29 de agosto de 1882.

${ }^{480}$ En noviembre de 1883, el diputado provincial Yágüez Jalón, basándose en la citada Real Orden, renunció al cargo de vocal de la Comisión Provincial quedándose con la presidencia de la Diputación provincial. El diputado provincial Guzmán Rodríguez disentía de la opinión de Yagüez Jalón y consideraba que al disponer la Ley Provincial, en su art. 12, que la Comisión Provincial se compusiera de tantos diputados como Distritos formasen la provincia, quiso que todos ellos estuviesen representados, y a esto respondían los turnos. Por esta causa, entendía Guzmán Rodríguez que antes de renunciar como vocal de la Comisión Provincial, Yagüez Jalón debía presentar la renuncia como vicepresidente de la Comisión Provincial, que debía a la confianza de los diputados, solventando así el inconveniente que la citada Real Orden pretendía remediar. Luis Martínez de Azcoitia no estaba de acuerdo con Guzmán Rodríguez y consideraba que el presidente de la Diputación Provincial podía optar por ese cargo o el de vocal de la Comisión Provincial. El diputado provincial Monedero Diezquijada, señalaba que el caso de Yágüez Jalón no era de renuncia, sino de incompatibilidad y por lo tanto no le era aplicable la Real Orden citada. A.D.P.P., L.A.P.D., 55, 3-XI-1883. Se acordó consultar la cuestión de la incompatibilidad al Gobierno. En la sesión del 5 de noviembre de 1883, se hacía efectiva la renuncia de Yágüez Jalón como vocal y vicepresidente de la Comisión Provincial por incompatibilidad con el cargo de Presidente de la Diputación Provincial y era elegido José Barrio como vicepresidente de la Comisión Provincial. A.D.P.P., L.A.P.D., 55, 5-XI-1883.
} 
Respecto de las atribuciones del presidente de la Diputación Provincial, el Estatuto Provincial de 1925 contemplaba que el presidente ordenase los pagos ${ }^{481}$ que se efectuaban con fondos provinciales, presidiese remates y subastas para ventas, arrendamientos, suministros y toda clase de adjudicación de servicios y obras provinciales, remitiera a los tribunales correspondientes los expedientes de los recursos interpuestos contra acuerdos de la Diputación o Comisión Provincial, rindiese y comprobase las cuentas de la administración del patrimonio y de los establecimientos provinciales y las de gestión de los presupuestos de la Diputación.

El vicepresidente ejercía, en su caso, idénticas funciones que el presidente. Si presidente y vicepresidente no asistían a las sesiones, presidía el vicepresidente de la Comisión Provincial y a falta de este, el diputado de más edad.

\footnotetext{
${ }^{481}$ Como ordenador de pagos, el presidente de la Diputación era responsable si ordenaba pagos no incluidos en la distribución mensual, si al ordenar un pago, el remanente del crédito correspondiente no era suficiente para pagarlo, si ordenaba el pago de atenciones voluntarias en detrimento de las que fuesen forzosas por ley, si ordenaba pagos cuya procedencia no estuviera justificada y si disponía, para fines distintos de aquellos para los que fueran votados, de recursos obtenidos de empréstitos concertados por la Diputación. En 1887, se publicaba una Real Orden relativa a la suspensión de varios diputados provinciales, Herrero Ortega, Barrios Barriga, Guzmán Rodríguez, entre otros, que adoptaron los acuerdos del 11 de octubre de 1883 y 29 de agosto de 1885, atribuyendo al vicepresidente de la Comisión Provincial la ordenación de pagos en ausencia del presidente elegido por la Diputación o del vicepresidente de la Diputación, diez meses de suspensión. A.D.P.P., L.A.P.D., 63, 13-IV-1887. Quedaban excluidos de la suspensión, Herrero Ortega, Barrios Barriga y Guzmán Rodríguez, puesto que la suspensión gubernativa solo podía afectar a los diputados provinciales por faltas administrativas cometidas en el ejercicio de su cargo, una vez cesados y, aun cuando volvieran a ser elegidos, no procedía la corrección porque vendría a recaer sobre funciones ya concluidas y en este caso se hallaban los citados diputados.
} 


\section{Los diputados provinciales}

El desempeño del cargo de diputado provincial era de carácter gratuito ${ }^{482}$, honorífico y obligatorio, sujeto a responsabilidad y, una vez aceptado, no renunciable a no ser por causa justa ${ }^{483}$. Hasta la Dictadura de Primo de Rivera, el tiempo de permanencia en el cargo era de cuatro años y cada dos años se producía una renovación de la mitad de los Distritos. La primera renovación se realizaba por sorteo ${ }^{484}$ y en las renovaciones sucesivas, por antigüedad. Entre 1876 y 1925, para ser elegido diputado provincial se exigían unas condiciones similares a las que se necesitaban para ser diputado a Cortes. La regulación jurídica de estos requisitos varió a lo largo del tiempo en función del carácter político que ostentaba el poder, exceptuando el referido a la edad que se mantuvo invariable en los veinticinco años como límite inferior mínimo para acceder a la condición de diputado provincial ${ }^{485}$. Respecto a las condiciones para ser elector de diputados provinciales, la legislación provincial, en cuanto a las condiciones de edad, naturaleza y vecindad ${ }^{486}$, remitía a las leyes electorales generales. A partir de 1890 se reimplantó el sufragio universal masculino ${ }^{487}$ por lo que no tenía sentido imponer restricciones para acceder a la condición de elector. Sin embargo, en el periodo comprendido entre 1876 y 1890, la legislación establecía ciertas restricciones a la condición de elector provincial.

\footnotetext{
${ }^{482}$ El art. 92 de la Ley Provincial de 29 de agosto de 1882, señalaba que tanto los vocales de la Comisión Provincial, de la Comisión Mixta, Comisión de Reclutamiento y del Tribunal de lo Contencioso, como el presidente de la Diputación tenían derecho a reclamar que se les abonasen las dietas cuando el último presupuesto se hubiese liquidado sin déficit, el próximo se presentase nivelado y quedasen cubiertos todos los gastos necesarios con los ingresos ordinarios y no conllevasen ningún recargo en los repartimientos provinciales

${ }^{483}$ Art. 57 de la Ley Provincial de 29 de agosto de 1882. Por ejemplo, por causa de salud, Demetrio Betegón y Joaquín Monedero dimitían de sus cargos de diputados provinciales, en septiembre de 1877. El gobernador civil elevaba este asunto al ministro de Gobernación para que emitiera la resolución pertinente. A.D.P.P., L.A.P.D. 48, 1-X-1877.

${ }^{484}$ En la sesión del Pleno de la Diputación Provincial, de 19 de abril de 1884, se celebraba el sorteo de los diputados provinciales a quienes correspondía cesar en la próxima renovación, a tenor de lo dispuesto en el art. 57 y Disposición $4^{\text {a }}$ Adicional de la Ley Provincial de 29 de agosto de 1882. Cinco bolas negras con los números de extracción y cinco bolas blancas con los nombres. Los Distritos se habían numerado: Astudillo-Baltanás: 1, Carrión-Frechilla: 2, Cervera: 3, Palencia: 4, Saldaña: 5. Cesaban los diputados cuyos Distritos correspondían a los números uno, dos y tres. Se removían las bolas en los globos y el diputado secretario extraía los nombres y un diputado los números, con el siguiente resultado: Cervera: 4, Saldaña: 5, Palencia: 1, Astudillo: 2 y Carrión: 3. A.D.P.P., L.A.P.D. 56, 19-IV-1884.

${ }^{485}$ Art. 4 de la Ley Electoral de 20 de julio de 1877.

${ }^{486}$ Cuatro años de vecindad consecutiva en la Ley Provincial de 29 de agosto de 1882.

${ }^{487}$ Ley de 26 de junio de 1890.
} 
La Ley Provincial de 29 de agosto de 1882 señalaba, en su art. 33, dos condiciones fundamentales: ser varón mayor de edad y acreditar saber leer y escribir ${ }^{488}$. En caso de que no se supiese ni leer ni escribir, también podían elegir diputados provinciales aquellos que fuesen contribuyentes por contribución de inmuebles, cultivo y ganadería ${ }^{489}$, subsidio industrial y de comercio $^{490} \mathrm{y}$ los licenciados del Ejército. Naturalmente, era obligatorio poseer la nacionalidad española y, en la etapa de la Restauración, la vecindad ${ }^{491}$ era condición necesaria para acceder al cargo de diputado provincial, aunque, a diferencia de otros periodos, no como condición única, sino como alternativa del requisito de naturaleza ${ }^{492}$. Otro condicionante para ser elegible como diputado provincial, era el nivel de renta, requisito que se mantuvo, en la Ley Provincial de 2 de octubre de 1877 bastante matizado ${ }^{493}$, y desapareció en la Ley Provincial de 29 de agosto de 1882. Dada la naturaleza gratuita del cargo de diputado provincial, resultaba casi imposible que se presentase a la elección alguien que no poseyera bienes propios que le permitiesen mantenerse. En la documentación revisada, aparece un caso que por excepcional confirmaba la regla de la boyante situación económica de los diputados provinciales de Palencia, desde 1906, se concedió una pensión para el exdiputado provincial Manuel Valerio por imposibilidad física para el trabajo y pobreza, en pago de los servicios desinteresados que prestó a la provincia. En aquel año esta pensión ascendía a 8.730 pts. $^{494}$

\footnotetext{
${ }^{488}$ Los ciudadanos que, aun sabiendo leer y escribir, careciesen de medios de subsistencia, recibiesen esta en los Establecimientos benéficos públicos o privados y estuviesen empadronados como mendigos y autorizados para implorar la caridad pública, tampoco podían ejercer el derecho de elegir a los diputados provinciales.

${ }^{489}$ Cuota pagada con un año de antelación al momento de inscribirse como elector.

${ }^{490}$ Cuota pagada con un año de antelación al momento de inscribirse como elector.

${ }^{491} \mathrm{El}$ tiempo que se requería de vecindad varió en la legislación vigente en la Restauración, aunque lo habitual era que oscilase entre dos y cuatro años (Art. 19 de la Ley Provincial de 2 de octubre de 1877 y art. 35 de la Ley Provincial de 29 de agosto de 1882).

${ }^{492}$ Art. 35 de la Ley Provincial de 29 de agosto de 1882. No obstante, este artículo era interpretado con laxitud, como queda reflejado en las Actas del Pleno de la Diputación, ante la discusión sobre la validez y capacidad de Santiago Manrique del Pozo como diputado provincial por el distrito de Astudillo-Baltanás por no ser natural de la provincia de Palencia y llevar cuatro años consecutivos de vecindad en la misma. El Pleno de la Diputación señalaba que era norma de interpretación que tratándose de la capacidad electoral de un individuo, la ley fuera interpretada en un sentido amplio, ya que el propósito del legislador no era, según la Diputación, otro que el elector tuviese «(...) afectos o intereses morales o materiales en la provincia, arraigo en ella» A.D.P.P., L.A.P.D. 110, 5-X-1910, y este arraigo lo mismo podía sentirlo tanto el domiciliado como el residente. Se da la circunstancia de que en abril de 1899 se había declarado la gravedad del Acta del diputado provincial por el Distrito de Saldaña, Eliseo Delgado, por no llevar cuatro años de vecindad.

${ }^{493}$ Los elegibles que perteneciesen a poblaciones superiores a 25.000 habitantes estaban exentos de la exigencia de un nivel determinado de renta. Art. 19 de la Ley Provincial de 2 de octubre de 1877.

${ }^{494}$ A.D.P.P. C-L $9 / 1$.
} 
Además, se daba la circunstancia de que aunque para ser elegido no se requería nivel de renta, si se exigía para ser elector ${ }^{495}$, por lo que resultaba poco probable que los electores eligiesen representantes con una situación económico-social tan divergente de las suyas propias. En resumen, si bien la legislación no imponía el nivel de renta como un requisito imprescindible para ser elegido diputado provincial, el acceso al cargo estaba restringido a la clase social más pudiente de la época. Lo que no era exigible para presentarse a las elecciones era acreditar la ideología política del candidato, como así lo entendía la Comisión Provincial en 1911, cuando un vecino de Palenzuela solicitaba que se le expidiese certificación del expediente electoral de la elección del diputado provincial Antonio Yagüez Jalón, donde constase el carácter republicano del político. La Comisión Provincial acordaba que no procedía expedir la certificación, ya que el solicitante no ostentaba cargo oficial alguno para reclamar este tipo de certificaciones $^{496}$.

En la etapa dictatorial ${ }^{497}$, para ser proclamado candidato por la Junta de Censo Electoral había que reunir alguna de las siguientes condiciones: haber desempeñado el cargo de concejal, el de diputado provincial o regional, el de diputado a Cortes o el de senador por elección dentro de la misma provincia, ser propuesto para candidato por dos diputados o ex-diputados provinciales o regionales, dos diputados o ex-diputados a Cortes, o dos senadores o ex-senadores, ser $^{498}$ propuesto por la centésima parte del número total de electores inscritos en el censo electoral de la provincia y ser propuesto por ayuntamientos cuyo número de concejales fuese al menos una vigésima parte del total de estos existentes en la provincia.

\footnotetext{
${ }^{495}$ Art. 34 de la Ley Provincial de 29 de agosto de 1882. En la sesión de la Comisión Provincial del 14 de febrero de 1897, varios diputados provinciales votaban en contra de incluir a dos vecinos de Calzada de los Molinos en las listas de compromisarios por no cumplir la principal premisa y condición que exigía la Ley, la vecindad. El presidente, que era el gobernador civil que presidía esta sesión, y otros diputados provinciales votaban a favor de incluirles en las listas de electores para compromisarios. El vicepresidente, defendía que no habiéndose impugnándose el carácter de mayores contribuyentes, estaban bien incluidos en las listas. El voto de calidad del gobernador era definitivo a la hora de resolver los empates, lo cual no impedía que la facción vencida impugnase los acuerdos y presentase con frecuencia recurso de alzada ante el ministro de la Gobernación.

${ }^{496}$ A.D.P.P, L.A.C.P. $115,29-\mathrm{IX}-1911$.

${ }^{497} \mathrm{Se}$ redujo el número de diputados, clasificándolos en corporativos, o representantes de los ayuntamientos, y directos, con representación proporcional y circunscripción provincial única, en igual número ambos, entre cinco y nueve de cada clase.

${ }^{498}$ Solo se aplicaba para los diputados directos.
} 
Además de estas condiciones, se exigía tener capacidad para ser concejal y ser natural de la provincia o llevar dos años de vecindad consecutiva en la misma. La elección de los diputados provinciales directos tenía lugar la segunda quincena del décimo mes del año económico, cada seis años. En la Diputación Provincial de Palencia el número de diputados provinciales directos era de seis, el número de diputados provinciales corporativos ${ }^{499}$ era igual al de diputados directos.

Las leyes no solo contemplaban una serie de requisitos para lectores y elegibles, también era prolija respecto a la incapacidad ${ }^{500}$ y la incompatibilidad ${ }^{501}$ para ejercer el $^{2}$ cargo de diputado provincial. En la ley de 29 de agosto de 1882, las principales causas de incapacidad ${ }^{502}$ para ser diputado provincial poseían doble naturaleza, aquellas que disminuían el ejercicio de los derechos del ciudadano, los que por sentencia ejecutoria estuviesen privados de derechos políticos, los que en el momento de celebrarse las elecciones se hallasen procesados criminalmente o se hubiese dictado contra ellos auto de prisión y no se hubiese subrogado confianza en los casos permitidos por la ley, los sentenciados por penas aflictivas o correccionales, mientras no hubiesen extinguido sus condenas y obtenido rehabilitación con arreglo a las leyes, y las que regulaban las relaciones de algunos ciudadanos con la administración provincial, que pretendían evitar situaciones de privilegio en el caso de que estos personas accediesen al cargo de diputado provincial.

\footnotetext{
${ }^{499}$ Solo podían ser diputados provinciales corporativos los concejales de los ayuntamientos. Su mandato era bienal. También cesaban en el cargo si dejaban de pertenecer a la Corporación Municipal por la que habían sido elegidos.

${ }^{500}$ Las leyes regulaban las situaciones en las que electores y elegibles se encontraban disminuidos en el ejercicio de sus derechos. La legislación provincial aplicaba la incapacidad a los elegibles, no obstante, las leyes electorales también contemplaban esta situación para los electores.

${ }^{501}$ En la sesión de 3 de octubre de 1902, se declaraba la incompatibilidad del diputado Herrero Abia y la vacante del cargo por el distrito de Saldaña, según los arts. 37, 41 y 59 de la Ley Provincial de 29 de agosto de 1882, por desempeñar el cargo de secretario del Gobierno Civil de Zamora, hecho que le impedía asistir a las sesiones. La Ley Provincial prohibía que los vocales de la Comisión Provincial pudiesen ausentarse de la capital de la provincia sin licencia y las excusas debían ser fundadas.

${ }^{502} \mathrm{La}$ Diputación examinaba y resolvía todos los casos de incapacidad, incompatibilidad o excusa en la primera de las sesiones que se celebraba, inmediatamente después de haber llegado a su conocimiento los casos citados.
} 
En este último supuesto se encontraban: los contratistas y sus fiadores de las obras, suministros y servicios que se pagasen con fondos provinciales y municipales y los administradores de dichas obras y servicios, los recaudadores dentro de la provincia $^{503}$ y sus fiadores, los que tuviesen contienda administrativa o judicial pendiente con la Diputación o los establecimientos sujetos a su dependencia y administración, los deudores de la provincia, si contra ellos se hubiese expedido apremio o ejecución y los inhabilitados por sentencia judicial ${ }^{504}$. El Estatuto Provincial de 1925 señalaba como causas de incapacidad para acceder al cargo de diputado provincial las siguientes: el ser religioso profeso, los interesados en contratas o suministros dentro de la provincia, el resto de las causas de incapacidad ya estaban contempladas en la Ley de 29 de agosto de 1882.

Por lo excepcional del caso, se destaca el procesamiento y prisión de los diputados provinciales, Ignacio Herrero Abia y Eliseo Delgado González, acusados por delito de falsedad del testamento de la finada Catalina Martín. La Comisión Provincial en sesión de septiembre de 1909 señalaba que:

«(...) cierto es que conforme a los principios de derecho se debe reputar inocente al acusado mientras una sentencia ejecutoria no lo declare culpable; pero el común de las gentes, lejos de atenerse a este principio, se aviene a conceptuar casi siempre a conceptuar delincuentes a todos los que los tribunales declaran procesados, lo cual, en sentir de la sección, constituye una razón poderosísima para que los individuos de las corporaciones provinciales contra quienes se dicte auto de procesamiento por cualquier motivo, dejen de pertenecer a ellas, no definitivamente, sino por el tiempo que subsista el auto, o sea mientras con fundamento o sin él, con justicia o sin ella, haya un motivo racional en que apoyarse, para suponer que han podido realizar algún acto contrario a las leyes y penado.» ${ }^{505}$

\footnotetext{
${ }^{503}$ El diputado provincial Ibarlucea presentaba proposición para que se declarase incapacitado a Polanco Aguado por tener contratos retribuidos con varios ayuntamientos y hallarse, por tanto, dentro de las prescripciones del caso $1^{\circ}$ del art. 38 de la Ley Provincial de 29 de agosto de 1882, (recibía retribución del Ayuntamiento de su localidad natal, Santoyo, por cobrar los intereses de sus inscripciones). Polanco Aguado justificaba su capacidad como diputado provincial, aduciendo que no era contratista de ningún servicio que se pagase con fondos municipales ni provinciales, sino mandatario y de este cargo había renunciado dentro del plazo de ocho días siguientes a la aprobación de su Acta. Se votó la proposición de incapacidad de Polanco Aguado en votación nominal y fue desechada. Abilio Calderón Rojo señalaba que en esa sesión se ventilaban cuestiones de familia de los conservadores y que la cuestión de la incapacidad no hubiese salido a la luz, si este no hubiera solicitado los votos de fusionistas, republicanos y algunos más para llegar a la presidencia de la Diputación. Finalmente, Polanco Aguado renunció a los cargos de Presidente y diputado provincial, «(...) reconocida mi capacidad por la Corporación y para que todo el mundo se convenza de que no he luchado por la Presidencia, ni tengo interés ninguno en seguir un momento más en esta, hago renuncia formal de la misma y del cargo de diputado, consignándolo en el Acta». Se aceptó la renuncia del cargo de presidente, pero no de diputado. Guijelmo Aguado, primo carnal de Polanco Aguado, fue elegido presidente de la Diputación Provincial. A.D.P.P, L.A.P.D. 81, 14XI-1896.

${ }^{504}$ Art. 38 de la Ley Provincial de 29 de agosto de 1882.

${ }^{505}$ A.D.P.P., L.A.C.P. 109, 10-IX-1909.
} 
Visto el art. 13 de la Ley Provincial de 29 de agosto de $1882^{506}$, y la Real Orden 21 de marzo de 1887, se acordó por parte de la Comisión Provincial hacer presente este hecho al Gobierno de la provincia para que lo pusiese en conocimiento del ministro de la Gobernación. La provincia se quedó con 18 diputados provinciales al confirmar el Tribunal Supremo la sentencia de la Audiencia Provincial que imponía a los diputados provinciales Delgado González y Herrero Abia, representantes del Distrito de Saldaña, la pena de ocho años de prisión correccional, interdicción civil ${ }^{507}$ y suspensión de empleo, cargo público y derecho de sufragio ${ }^{508}$.

Por lo que respecta a las incompatibilidades, la Ley Provincial de 29 de agosto de 1882, explicitaba de forma muy clara los supuestos que imposibilitaban el acceso a la Diputación Provincial en calidad de diputado provincial $^{509}$. El cargo de diputado provincial era incompatible con el de diputado a Cortes, con el cargo de alcalde, teniente de alcalde o concejal, con todo empleo activo del Estado, de la provincia o de alguno de sus municipios ${ }^{510}$. Este último punto se prestaba a confusión en algunos casos, por lo que el vicepresidente de la Comisión Provincial, Mateo Herrero Ortega, exponía en enero de 1883 que: «No estando resuelto de un modo claro y terminante por la novísima Ley Provincial si los cargos de notario y vicepresidente de la Comisión son o no incompatibles, (...) que en caso de serlo, siendo él notario de Sotobañado, renunciaría al cargo de notario.» ${ }^{511}$ Casi veinte años después de la entrada en vigor de la Ley Provincial de 29 de agosto de 1882, en el año 1901, se discutía el Acta de Ordóñez Pascual, diputado electo por el distrito de Astudillo-Baltanás.

\footnotetext{
${ }^{506}$ La Diputación, en una de las tres primeras sesiones después de constituida, acordará la distribución de los diputados en cuatro secciones de igual número, cuidando de que no hubiese dos diputados de un mismo distrito en ninguna de ellas. Cada una de estas secciones constituía durante un año la Comisión Provincial, acordando la Diputación el turno que debían seguir las secciones.

${ }^{507}$ Restricción de la aptitud jurídica de la persona, derivada de sanción civil añadida a la penal.

${ }^{508}$ A.D.P.P, L.A.P.D., 107, 5-XI-1910.

${ }^{509}$ Art. 36 de la Ley Provincial de 29 de agosto de 1882.

${ }^{510}$ Renuncias del cargo de diputados provinciales de los representantes del Distrito de Cervera de Pisuerga, Ángel Gómez Ingüanzo, nombrado gobernador civil de Lérida, y del Distrito de Palencia, Guillermo Jubete Tejerina, nombrado depositario interino de Fondos Provinciales. A.D.P.P., L.A.C.P. 118, 31-III-1914.

${ }^{511}$ A.D.P.P., L.A.C.P. $59,17-I-1883$.
} 
Se debatía sobre su inclusión en la Segunda Clase $^{512}$ y la mayoría de la Comisión de Actas proponía que se declarase su gravedad, aunque una minoría emitía un voto particular para que se incluyese el Acta en las de la Primera Clase ${ }^{513}$. La Ley Provincial, aclaraba el diputado provincial Rodríguez Blanco, partidario de incluir el Acta en las de la Segunda Clase, se oponía a que se incluyeran en la Primera categoría de las Actas, las que suscitasen dudas de mayor gravedad. Se daba una circunstancia que podía influir en la nulidad de la elección, esta era el haber desempeñado el cargo de representante del Ministerio Público, que llevaba anejos autoridad y jurisdicción ${ }^{514}$, durante los seis meses anteriores a las elecciones, según circular del fiscal supremo de 20 de febrero de 1894. Herrero Abia, firmante de un voto particular, afirmaba que lo que se pretendía era aplazar el Acta de Ordóñez para que no tomase parte en la constitución de la Asamblea. Rodríguez Banco quería que se discutiese el Acta de Ordóñez Pascual una vez constituida la Asamblea, y por eso quería declararla de Segunda Clase. Se procedió a votar y se desechó el voto particular, declarándose grave el Acta de Ordóñez, que quedó sobre la mesa para su discusión por la Asamblea Provincial, una vez constituida según establecía el art. 52 de la Ley Provincial de 29 de agosto de 1882. Constituida la Diputación, se admitió como representante del distrito de Astudillo-Baltanás a Ordóñez Pascual ${ }^{515}$, otorgando, en cierta forma, la razón al planteamiento de Herrero Abia.

\footnotetext{
${ }^{512}$ De las que determinaba el art. 49 de la Ley Provincial de 29 de agosto de 1882.

${ }^{513}$ A.D.P.P., L.A.P.D. 89, 25-IV-1901.

${ }^{514} \mathrm{El}$ precepto $3^{\circ}$, art. 7 de la Ley Electoral, señalaba que se hallaban incapacitados para ser admitidos como diputados a Cortes los que hubiesen desempeñado un año antes en el Distrito o circunscripción, en los que se realizase la elección, cualquier empleo, cargo o comisión de nombramiento del Gobierno o ejercido función en las carreras judicial y fiscal, aun cuando fuera con carácter de interinidad o sustitución. El texto prevenía que estas incapacidades no eran aplicables a los concejales ni a los diputados provinciales. El art. 42 de la Ley Provincial señalaba que para que hubiese incapacidad era preciso que se hubiese ejercido jurisdicción. Por jurisdicción se entendía el poder o autoridad para gobernar, o la potestad de juzgar y hacer ejecutar lo juzgado.

${ }^{515}$ A.D.P.P., L.A.P.D. 89, 27-IV-1901.
} 
En el Estatuto Provincial de 1925, estas cuestiones quedaban clarificadas ya que consideraba incompatible el cargo de diputado provincial con el de notario, registrador de la propiedad y secretario judicial, con el desempeño de funciones públicas retribuidas, aunque se hubiese renunciado a la retribución ${ }^{516}$, con el del alcalde, teniente de alcalde y concejal jurado ${ }^{517}$, y con el desempeño de cargos de gerente, director, consejero, administrador, abogado o técnico de entidades o particulares que tuviesen concertado con la Diputación o sus establecimientos suministros, obras o servicios de cualquier género.

La legislación provincial también establecía unos requisitos para eludir el cargo de diputados, antes o después de ser elegido diputado provincial: ser mayor de sesenta años, estar impedido físicamente, haber sido senador, diputado a Cortes, diputado provincial, alcalde y concejal, hasta dos años después de haber cesado en sus respectivos cargos ${ }^{518}$.

\section{Empleados de la Administración Provincial}

El reglamento de funcionarios y subalternos provinciales de 1926 definía a los funcionarios provinciales, en su Art. 1, como todos los de la Diputación (administrativos, técnicos y subalternos) que, nombrados por la misma, realizaban funciones permanentes, figurando en la plantilla o el escalafón y percibían sueldo o asignación fija a cargo del Presupuesto Provincial ${ }^{519}$. Los funcionarios tenían la categoría de administrativos, que formaban un solo cuerpo bajo una sola plantilla y escalafón independientemente de la dependencia a la que se hallasen adscritos, y la categoría de técnicos, aquellos que con independencia de la plantilla y escalafón del cuerpo administrativo, requerían por razón de su servicio, aptitudes o título facultativo o profesional distinto de los administrativos ${ }^{520}$.

\footnotetext{
${ }^{516}$ Se exceptuaba el profesorado oficial del Estado, región o municipio, cuando tuviesen su residencia en la capital de la provincia.

${ }^{517}$ Con el de concejal cuando se trataba de diputados directos.

${ }^{518}$ Art. 43 de la Ley Provincial de 29 de agosto de 1882.

${ }^{519}$ A.D.P.P. Reglamento de funcionarios y subalternos provinciales

${ }^{520}$ A.D.P.P. Art. 2 del Reglamento de funcionarios y subalternos provinciales.
} 
Por razón del cargo que desempeñaban, se dividían en comunes y especiales. Comunes eran los que, requiriendo para su desempeño el mismo título o grado de aptitud, estaban comprendidos dentro del escalafón formado, con categorías distintas, a las que correspondía distinto sueldo. Especiales, los que requiriendo título o aptitudes determinadas, no tenían opción a figurar en el escalafón, por no consentir la naturaleza del cargo más que una sola categoría y sueldo ${ }^{521}$. El ingreso de los funcionarios administrativos y comunes tenía lugar siempre por la última categoría, mediante oposición ante el tribunal ${ }^{522}$. Los empleados subalternos ingresaban siempre por la última categoría, salvo en caso de destinos especiales ${ }^{523}$, siendo provistas las vacantes en la forma y turno que prevenía el art. $57^{524}$ del citado Reglamento. En 1925, los empleados provinciales, a fin de poder optar al desempeño de los nuevos servicios creados por el Estatuto Provincial, debieron cumplimentar unas instancias en las que hacían constar la forma de ingreso y funciones de cada uno dentro de sus respectivos puestos de trabajo,

Los oficiales y auxiliares eran destinados a la Sección o Negociado, según sus aptitudes y conveniencias del servicio, por acuerdo de la Comisión Provincial y a propuesta del secretario y la conformidad del presidente. El oficial de mayor categoría, que debía ser letrado, prestaba servicio a las órdenes del secretario, sustituyéndole en caso de enfermedad y ausencia temporal. Se encargaba de los asuntos en los que interviniese la Diputación referentes al Censo y a las listas electorales, también de Quintas y de agrupaciones y segregaciones de municipios.

\footnotetext{
${ }^{521}$ A.D.P.P. Art. 4 del Reglamento de funcionarios y subalternos provinciales.

${ }^{522}$ Art. 35 del Reglamento de funcionarios y subalternos provinciales, aprobado por Real Decreto de 2 de noviembre de 1925.

${ }^{523}$ En febrero de 1910, el diputado provincial, Marcos Pérez, declaraba que ni el maquinista de la imprenta de la Diputación, ni el escribiente temporero con destino en la Secretaría de la Diputación, nombrados con carácter interino el 1 de febrero de ese año, reunían las aptitudes necesarias para el desempeño de su cargo. Pedía el diputado provincial que se sometiese a los dos empleados a las pruebas necesarias para comprobar su aptitud y, en caso de no tener las condiciones necesarias para el desempeño de su trabajo se les destituyese.

${ }^{524}$ Reservando dos terceras partes de las plazas que habían de cubrirse a los licenciados de guerra y la tercera parte restante de libre provisión por la Corporación Provincial.
} 
Los oficiales tendrían las obligaciones siguientes:

1. Cuidar de la tramitación y despacho de los asuntos, informar de los expedientes, consultar y citar las disposiciones legales y proponer las resoluciones que correspondiesen con arreglo a la ley y dentro de los plazos que la misma señalase.

2. Presentar a la firma los expedientes y cumplimentar los acuerdos y providencias que en los mismos recayesen, siendo responsables del retraso que en su tramitación se observase.

3. Responder de la exactitud de las minutas, de acuerdos y oficios, que rubricarán bajo su responsabilidad, sin cuyo requisito no podrían ponerse al despacho de sus superiores, rubricando igualmente, los demás documentos que integrasen cada documento.

4. Clasificar en grupos los expedientes: en tramitación, pendientes de resolución, y pendientes de ejecución.

5. Presentar a la Comisión Provincial, en los tres primeros días de cada mes, relación de los asuntos despachados en el anterior y de los que quedasen pendientes, dando explicación sucinta, si alguno sufre dilación, de las causas que las motivaban.

6. Informar a los interesados que lo reclamasen, del estado de los asuntos que les afectaran, guardando reserva respecto a los documentos e informes que integrasen los expedientes mientras se hallasen pendientes de resolución.

7. Despachar cuando las necesidades del servicio lo reclamaran a juicio del secretario e interventor, según los casos, los expedientes que se les enviasen, aun cuando no correspondieran a su Negociado.

Los auxiliares prestaban servicios en las dependencias que le señalaba el secretario de acuerdo con el presiente. Sus obligaciones eran:

1. Guardar la mayor escrupulosidad y cuidado en la formación de los extractos, redacción de notas y extensión de comunicaciones y cuantos trabajos se les confiaran.

2. Auxiliar a los demás compañeros en el cumplimiento de los servicios, cuando estos por su número o urgencia lo requiriesen. 
Respecto del personal subalterno de la Diputación Provincial, los servicios mecánicos de la Diputación corrían a cargo de los porteros y ordenanzas. El portero mayor, como jefe del personal subalterno, tenía encomendadas las siguientes funciones:

1. Ordenar y distribuir los servicios que cada uno debía prestar, de acuerdo con las instrucciones recibidas del secretario.

2. Cuidar con el mayor esmero de los servicios de limpieza, procurando que estos se realizasen antes de las horas de oficina.

3. Inspeccionar antes de abrirse las dependencias, cerciorándose personalmente del estado en que se encontraban y procurar que todo se hallase con el mayor orden.

4. Llevar un libro con los nombres y domicilios de los diputados, empleados administrativos y facultativos de la Corporación Provincial.

5. Organizar el servicio de las dependencias, de modo y forma que en ningún momento dejasen de estar debidamente atendidas.

En el Informe de la Comisión de Presupuestos a la Diputación Provincial sobre la reorganización del personal de la Diputación en 1903, se establecían las siguientes Bases:

1. Primera

A los efectos del aumento gradual de sueldo solo se considerarían empleados provinciales:

- $1^{\mathrm{o}}$. Secretario y empleados de Secretaría con excepción del oficial mayor de la Comisión Mixta de Reclutamiento y del archivero.

- $\quad 2^{\circ}$. Contador, empleados de contaduría, jefe y personal de la Sección de Cuentas Municipales.

- $3^{\circ}$. Depositario y auxiliar de Depositaría.

- $4^{\circ}$. Portero y ordenanzas

2. Segunda

- El aumento de sueldo se haría anualmente y siempre sobre el sueldo de entrada del destino desempeñado por el empleado e independientemente del sueldo actual que disfrutase, fijando los siguientes salarios: 
Tabla 03. Salarios del personal de la Diputación Provincial en 1903.

\begin{tabular}{|c|c|}
\hline Dependencias & Sueldo en pts. \\
\hline \multicolumn{2}{|l|}{ Secretaria } \\
\hline 1 secretario & 5.000 \\
\hline 1 oficial $1^{\mathrm{a}}$ & 2.500 \\
\hline 1 oficial $2^{\mathrm{a}}$ & 2.000 \\
\hline 2 auxiliares & 1.500 \\
\hline 2 escribientes & 1.125 \\
\hline \multicolumn{2}{|l|}{ Contaduría } \\
\hline 1 contador & 3.000 \\
\hline 1 oficial tenedor de libros & 2.000 \\
\hline 1 auxiliar & 1.500 \\
\hline 1 escribiente & 1.125 \\
\hline \multicolumn{2}{|l|}{ Cuentas municipales ${ }^{525}$} \\
\hline 1 oficial jefe de la Sección & 2.500 \\
\hline 1 oficial $2^{\mathrm{a}}$ & 1.500 \\
\hline 1 escribiente & 1.125 \\
\hline \multicolumn{2}{|l|}{ Depositaría } \\
\hline 1 depositario & 2.500 \\
\hline 1 escribiente & 1.125 \\
\hline \multicolumn{2}{|l|}{ Portería } \\
\hline 1 portero mayor & 1.125 \\
\hline 2 ordenanzas & 1.000 \\
\hline
\end{tabular}

Elaboración propia. Fuente: A.D.P.P., C 91/2.

\footnotetext{
${ }^{525}$ Esta sección se veía a menudo desbordada de trabajo, como consecuencia del gran número de cuentas municipales y diversos ejercicios sin examinar. La Comisión Provincial habilitaba horas extraordinarias, de seis a ocho de la tarde, para el examen de las cuentas atrasadas, dedicando las horas ordinarias de oficina al despacho de las cuentas corrientes.
} 
El personal de la Diputación Provincial de Palencia recibía por su trabajo una remuneración, que, si se exceptuaba a los altos funcionarios, permitía llegar a final de mes con bastantes dificultades y si la situación económica empeoraba, los salarios no eran suficientes para llevar una vida desahogada y mínimamente digna. En 1884, la Comisión Provincial ya alertaba de la necesidad de mejorar el sueldo de auxiliares y escribientes que, en su opinión y dada la carestía de los artículos de primera necesidad, no disponían de lo necesario para vivir ${ }^{526}$. Ese año no se había podido gratificar por falta de fondos los servicios de los empleados de Quintas y Censo Electoral.

La penuria salarial era de tal calibre que los funcionarios y trabajadores de la Diputación Provincial palentina no podían hacer frente a cualquier contingencia vital extraordinaria. Ante el fallecimiento del oficial de $2^{\mathrm{a}}$ de la Diputación, en mayo de 1892, Darío Martínez, la Comisión Provincial, previa la declaración de urgencia a que se refería el párrafo $3^{\circ}$, art. 98 de la Ley Provincial, acordó, por la imposibilidad material de sus familiares para hacer frente al deceso del oficial, que con cargo al Capítulo I, Art. 1 del Presupuesto de Gastos de representación de la Asamblea se satisficieran los derechos de entierro, honras fúnebres e inhumación, abonando a sus herederos los haberes del mes correspondiente ${ }^{527}$. Ante la precariedad salarial de sus trabajadores, la Diputación Provincial intentó mejorar esta situación. Sin embargo, a pesar de la disposición favorable de la institución provincial hacia una mejor remuneración salarial de sus empleados, la legislación, Real Decreto de 3 de mayo de 1892, señalaba que las diputaciones provinciales no podían aumentar los sueldos y conceder comisiones y subvenciones a sus empleados sin la previa autorización del Ministerio de Gobernación. Esta dependencia respecto de la Administración Central creaba situaciones paradójicas que solo contribuían a ralentizar medidas que a todas luces eran de justicia social.

\footnotetext{
${ }^{526}$ En ocasiones se gratificaba a los funcionarios provinciales con el haber de una mensualidad como estímulo para el cumplimiento de sus deberes. A.D.P.P., L.A.C.P. 60, 5-I-1884.

${ }^{527}$ A.D.P.P., C $63 / 3$.
} 
Por ejemplo, en el año 1903, el Ministerio de Gobernación enviaba a la Diputación Provincial una Real Orden en la que negaba el aumento gradual de sueldos que la Diputación había consignado en su Presupuesto Ordinario ${ }^{528}$, porque no se podían subir los sueldos al exceder la plantilla del personal máximo, que fijaba el art. 2 del Real Decreto de 3 de mayo de 1892, y porque, según el art. 10 del citado Real Decreto, no podían aumentarse los sueldos sin la previa autorización del Ministerio de Gobernación. La Real Orden de 3 de diciembre de 1903, rectificaba la anterior y vistas las alegaciones del presidente de la Diputación Provincial, que aducía que el aumento referido de sueldos no conllevaba un aumento de las cuotas del Contingente Provincial, y los trabajos ${ }^{529}$, que realizaban los funcionarios objeto del incremento salarial, el Ministerio de Gobernación accedía a esta subida.

En 1908, se producía un ejemplo más de las situaciones singulares a las que se podía llegar a causa de la laberíntica burocracia de la Restauración. La Diputación Provincial había destinado una partida presupuestaria, en el art. 1 del Capítulo I del Presupuesto de Gastos, para abonar al Tesoro el Impuesto de Utilidades ${ }^{530}$ que debían pagar los empleados, en un intento de aliviar la carga fiscal sobre unos salarios ya de por sí paupérrimos. El Ministerio de Gobernación comunicaba a la Diputación Provincial, mediante Real Orden de 29 de octubre de 1908, que no podía autorizar la partida de 3.250 pts. consignada para el pago del Impuesto de Utilidades a los empleados cuyo sueldo no excediera de 3.000 pts., puesto que conllevaría cargar a la Caja Provincial con las obligaciones que la ley imponía a los particulares. En el colmo del absurdo, el propio Ministerio sugería la solución para que las diputaciones provinciales pudieran «(...) estimular el celo de sus funcionarios»: Conceder gratificaciones, y en este concepto no tendría el Ministerio inconveniente en que se destinase la cantidad de 3.250 pts. , pero como gratificación ${ }^{531}$.

\footnotetext{
${ }^{528}$ Se habían consignado 2.000 pts. en el Capítulo XII, «Otros gastos», para aumentar el sueldo de los empleados provinciales.

${ }^{529}$ Los trabajos que los funcionarios realizaban y que no se comprendían dentro de las funciones de sus respectivos destinos, debían recompensarse con alguna gratificación extra.

${ }^{530}$ Par aquellos empleados provinciales cuyo sueldo no excediese de 1.500 pts., otras diputaciones provinciales ya venían practicando esta medida. La cantidad ascendía a 3.600 pts. A.D.P.P., C-L 9/2.

${ }^{531}$ A.D.P.P., C-L 9/3. En el Presupuesto de 1922-23 desapareció esta partida presupuestaria.
} 
En el Presupuesto de 1910, la Diputación Provincial recogía una partida presupuestaria, en forma de gratificación trimestral, para el personal de la Diputación cuyo sueldo no excediese de 3.000 pts. ${ }^{532}$, en proporción al descuento que gravaba sus sueldos por el pago del Impuesto de Utilidades. Ese mismo año, por primera vez, se destinaba una partida presupuestaria de 5.500 pts. para las cartillas de ahorro del Instituto Nacional de Previsión, en beneficio de los empleados de la Diputación con sueldos menores de 1.500 pts. En línea con esta política de complementar los salarios más reducidos, la Diputación Provincial, en el Presupuesto de 1919, consignaba una partida presupuestaria para gratificaciones trimestrales para los porteros y ordenanzas de la Diputación Provincial y del establecimiento tipográfico de la misma. Puesto que no disfrutaban de quinquenios, eran remunerados con una gratificación equivalente al descuento que el Estado les imponía en concepto del Impuesto de Utilidades ${ }^{533}$.

En 1923, la Comisión Provincial aceptaba la propuesta del diputado provincial Nájera de la Guerra sobre la mejora de los sueldos de los funcionarios de la Diputación, fundamentándose en que, tras el encarecimiento de la vida por la Primera Guerra Mundial, todos los organismos del Estado habían obtenido aumentos salariales. El aumento suponía un 14\% sobre los sueldos del aquel año, importando una cantidad de 16.703 pts., lejos de las 37.900 pts. que había solicitado la Asociación de Funcionarios de la Diputación Provincial ${ }^{534}$. En 1922, el presidente de la Asociación de Funcionarios de la Diputación comunicaba a la Comisión provincial la constitución de la nueva Junta Directiva y solicitaba autorización para que tres funcionarios pudieran asistir a la Asamblea de empleados de diputaciones que iba a celebrarse los días 14, 15 y 16 de octubre de 1922 en Madrid, para tratar, entre otros asuntos, la equiparación de sueldos entre los funcionarios del Estado y los empleados de las diputaciones provinciales ${ }^{535}$.

\footnotetext{
${ }^{532}$ Bases aprobadas por la Diputación Provincial el 9 de octubre de 1906 y Real Orden de 29 de octubre de 1908.

${ }^{533}$ A.D.P.P., C-L $11 / 3$

${ }^{534}$ A.D.P.P., L.A.C.P. $135,8-\mathrm{I}-1923$.

${ }^{535}$ A.D.P.P., L.A.C.P. $134,10-\mathrm{X}-1922$.
} 
La Diputación Provincial consideraba ajustado a sus funciones el número de trabajadores que prestaban sus servicios en las dependencias provinciales en circunstancias normales. Con motivo de la discusión de los presupuestos provinciales de 1901, varios diputados provinciales, García de los Ríos y Valentín Calderón Rojo entre otros, opinaban que el número de empleados que desempeñaban cargo retribuido en la Diputación era excesivo, entendiendo que podía reducirse sin afectar a los servicios ${ }^{536}$. Proponían amortizar todas las plazas que quedasen vacantes o que se hallasen expresamente consignadas en la plantilla del Real Decreto de 3 de mayo de 1892, el denominado Decreto Elduayen ${ }^{537}$.

En la Memoria de Deficiencias y soluciones de $1924^{538}$, según el jefe de Negociado, «(...) en época normal y para servicios generales, el número de funcionarios puede ser algo excesivo, en cambio, en alguna época, especialmente la de quintas, resulta insuficiente». En 1924, la plantilla de la Diputación Provincial se componía del siguiente

Tabla 04. Personal de la Diputación Provincial de Palencia en 1924.

\begin{tabular}{|c|c|c|c|c|c|c|}
\hline Secretaría & 1 Secretario & 2 Oficiales letrados & \multicolumn{2}{|c|}{1 Oficial Beneficencia } & $\begin{array}{l}1 \text { Oficial } \\
\text { Secretaría }\end{array}$ & $\begin{array}{l}1 \text { Auxiliar } \\
\text { mecanógrafo }\end{array}$ \\
\hline $\begin{array}{c}\text { Construcciones } \\
\text { Civiles }\end{array}$ & 1 Delineante & & & & & \\
\hline Contaduría & 1 Contador & \multicolumn{2}{|c|}{1 Aspirante a oficial de Contaduría } & 2 Auxiliares & & \\
\hline Depositaría & 1 Depositario & 1 Auxiliar & & & & \\
\hline $\begin{array}{c}\text { Personal } \\
\text { subalterno }\end{array}$ & 1 Portero mayor & 2 Porteros de $2^{\mathrm{a}}$ y $3^{\mathrm{a}}$ & & & & \\
\hline $\begin{array}{l}\text { Personal técnico } \\
\text { de Beneficencia }\end{array}$ & 1 Médico director & 1 Médico auxiliar & 1 Practicante & 1 Capellán & & \\
\hline $\begin{array}{c}\text { Personal } \\
\text { administrativo }\end{array}$ & 1 Oficial interventor & 1 Auxiliar & & & & \\
\hline
\end{tabular}

Elaboración propia. Fuente: A.D.P.P., Memoria de deficiencias y soluciones de 1924, C-R/ 1,12.

\footnotetext{
${ }^{536}$ A.D.P.P., L.A.C.P. 88, 8-X-1900.

${ }^{537}$ Pretendía este Real Decreto regular los gastos de personal de las diputaciones provinciales.

${ }^{538}$ A.D.P.P., Memoria de deficiencias y soluciones de 1924, C-R/ 1,12, p. 31.
} 
El cargo de funcionario de la Diputación era incompatible con otro activo o comisión de la Administración Central, Regional, Provincial y Municipal, con toda retribución, gratificación, comisión o encargo de alguna empresa constituida en España o en el extranjero de cualquier actividad económica que tuviese relación contractual con la Diputación Provincial y con el ejercicio de la abogacía en los tribunales, en aquellos asuntos que tuviesen relación directa o indirecta con la Administración del Estado, provincia o municipio, siempre que fuese en contra de los intereses de esas corporaciones $^{539}$. Si el funcionario se encontraba en alguna de esas situaciones y se justificaba este hecho documentalmente, disponía de un plazo de ocho días para optar entre su empleo en la Diputación o el empleo incompatible con su labor como funcionario provincial. Si optaba por dejar su puesto en la Diputación cesaba inmediatamente en su cargo y se anunciaba vacante para cubrir su puesto.

Los funcionarios provinciales tenían derecho a una licencia anual de quince días, con sueldo íntegro y, para asuntos propios, tenían derecho a un mes de licencia sin sueldo $^{540}$. Por enfermedad debidamente justificada ${ }^{541}$, con certificación facultativa, se podía conceder licencia con sueldo entero siempre que no se excediese de dos meses, justificando documentalmente cada dos meses que subsistía la enfermedad, desde el tercer mes hasta el sexto se percibía la mitad del sueldo y si la enfermedad se prolongaba más de seis meses el funcionario estaba obligado a solicitar la excedencia forzosa, si bien, una vez recobrada la salud, tenía derecho a ocupar la primera vacante que ocurriese en su categoría o en las inferiores ${ }^{542}$. Los jefes de las dependencias provinciales podían conceder a los funcionarios a sus órdenes hasta ocho días de licencia por asuntos propios y por una vez al año, dando cuenta al presidente y secretario de la Diputación Provincial. Se consideraban excedencias forzosas, además de las producidas por reformas de las plantillas, las de los funcionaros que tenían que cumplir con sus obligaciones militares. ${ }^{543}$

\footnotetext{
${ }^{539}$ A.D.P.P., Art. 14 del Reglamento de funcionarios y subalternos provinciales.

${ }^{540}$ A.D.P.P., Art. 10 del Reglamento de funcionarios y subalternos provinciales.

${ }^{541}$ El 17 de junio de 1911 se concedía tres meses de licencia al secretario por extracción de una catarata en el ojo izquierdo, «(...) padecimiento que, sin duda alguna, ha contraído en el desempeño de sus funciones, en el que siempre desplegó toda su actividad, celo e inteligencia». A.D.P.P., L.A.C.P. 115, 17VI-1911.

${ }^{542}$ A.D.P.P., Art. 11 del Reglamento de funcionarios y subalternos provinciales.

${ }^{543}$ Las vacantes producidas por el servicio militar solo podían proveerse de forma interina, hasta que el funcionario, al que se le reservaba el cargo, se reintegraba a su puesto una vez terminada su estancia en el Ejército, que además, a efectos de antigüedad, era contabilizada en el escalafón.
} 
Los funcionarios y empleados provinciales podían incurrir en responsabilidad civil, administrativa y penal, dependiendo de la naturaleza de la falta, omisión o causa que lo motivase. Las faltas se clasificaban en graves o leves. Como faltas graves ${ }^{544}$ se definían, la ausencia reiterada de la oficina durante las horas reglamentarias ${ }^{545}$, sin licencia ni causa justificada ${ }^{546}$, el abandono del servicio, la informalidad o retraso en el despacho de asuntos cuando este hecho perturbase el funcionamiento de la administración provincial, la omisión, a sabiendas o por negligencia, de informes injustos, los hechos constitutivos de delito público, etc. Se consideraban faltas leves ${ }^{547}$, la ausencia no reiterada a la oficina, la desobediencia no reiterada, el retraso en el desempeño de las funciones que tenía encomendadas siempre que no perturbase sensiblemente el servicio, etc. En el art. 37 del Reglamento de funcionarios y subalternos provinciales, se contemplaba la posibilidad de recurrir los acuerdos de destitución y suspensión en forma de recurso contencioso-administrativo ante el Tribunal provincial y, en caso de revocación, el interesado tenía derecho a recibir el pago de los haberes no percibidos a cargo de la Corporación, sin perjuicio del reintegro y la responsabilidad personal de los diputados provinciales que habían votado el acuerdo de suspensión o destitución.

\footnotetext{
${ }^{544}$ Las faltas graves se castigaban con la suspensión de empleo y sueldo y, dependiendo de la gravedad de los hechos, incluso con la destitución. La suspensión, requería el voto favorable de las dos terceras partes de la Comisión Provincial y la destitución, de las dos terceras partes del Pleno de la Diputación. Por ejemplo, en julio de 1892, se acordó la suspensión de quince días de sueldo al depositario provincial por dirigir frases y comentarios ofensivos hacia el diputado provincial García Benito. A.D.P.P., L.A.C.P. 74, 4-VII-1892.

${ }^{545}$ La Comisión Provincial, en sesión de 13 de noviembre de 1883, señalaba la necesidad de cumplir el reglamento respecto a la entrada y salida de las oficinas y de que los jefes de las diversas dependencias provinciales inculcasen a sus dependientes el cumplimiento de sus deberes. En la sesión del Pleno de la Diputación de octubre de 1900, se produjo un enfrentamiento entre varios diputados provinciales a cuenta de la falta de asistencia al trabajo de los empleados provinciales. El diputado provincial Merino González denunciaba que había funcionarios que cobraban el sueldo sin tomarse la molestia de ir a la oficina, el diputado provincial García Crespo interpelaba a Merino González para que dijese los nombres, contestando este que «(...) no soy yo el llamado a poner de manifiesto lo que deben saber los jefes». A.D.P.P., L.A.P.D. $88,15-\mathrm{X}-1900$.

${ }^{546}$ En la sesión del 25 de junio de 1892 , se acordaba suspender de empleo y sueldo a Teodosio García Cacharro, escribiente de Secretaría por reiteradas faltas de asistencia a la oficina y, tras ser apercibido con la destitución, la Comisión Provincial trasladó este hecho a la Diputación para que llevase a efecto la separación del servicio del funcionario.

${ }^{547} \mathrm{Las}$ faltas leves conllevaban el apercibimiento y suspensión de haberes de uno a quince días, y eran castigadas por el presidente de la Diputación.
} 


\section{Previsión social de los trabajadores de la Diputación}

El primer liberalismo de Sagasta no se tomó muy en serio avanzar por la vía del reformismo social, tampoco los liberales Canalejas y Moret hicieron reformas profundas, ni siquiera los regeneracionistas como Joaquín Costa las plantearon. Fueron precisamente los conservadores renovadores, como Francisco Silvela y su Manifiesto de la Unión Conservadora, los que comenzaron a apuntar en esa dirección. Sería Eduardo Dato el primero en legislar sobre la previsión social. La imprevisión y el paro ponían a los grupos populares, en general y a las clases trabajadoras en particular, al borde de la necesidad. La cuestión social en la Restauración comenzó por asociar trabajadores y pobres, lo que justificaba aplicarles de algún modo el remedio de la beneficencia ${ }^{548}$. Los sectores más ideologizados de la clase obrera comenzaron a reclamar mejoras sociales en términos de derecho, y no como concesión de las clases acomodadas. Los mismos defensores del reformismo reconocían que los trabajadores y la previsión debían marcar el rumbo de la política social.

Los hitos del reformismo social en España comenzaron con algunas medidas contra el trabajo infantil en 1873 y $1884^{549}$, en 1883 se creó la Comisión de Reformas Sociales $^{550}$, y en 1903, el Gobierno Silvela creó el Instituto de Reformas Sociales ${ }^{551}$. Esta etapa culminó con la creación del Instituto Nacional de Previsión (INP) ${ }^{552}$ en 1908. Hasta 1919 no pudo implantarse el retiro obrero obligatorio y el liberal Romanones estableció la jornada de ocho horas en 1918. El punto de partida de las políticas de protección social en España se puede situar en la creación de la Comisión de Reformas Sociales en 1883, que se encargaba del estudio de cuestiones relacionadas con la mejora de las condiciones de vida de la clase obrera. Fue el primer intento gubernativo en España de institucionalizar la llamada cuestión social.

\footnotetext{
${ }^{548}$ Vid. PÉREZ SÁNCHEZ, Guillermo Ángel, Ser trabajador: vida y respuesta obrera. (Valladolid 1875 1931), Valladolid, Universidad de Valladolid, 1996.

${ }^{549}$ La Ley Benot prohibía el trabajo a los menores de diez años, jornadas superiores a ocho horas para los niños de quince años, de cinco horas para las niñas de catorce años, y eliminaba el trabajo nocturno.

${ }^{550} C f r$. CALLE VELASCO, María Dolores de la, «La Comisión de Reformas Sociales, 1883-1903. Política social y conflicto de intereses en la España de la Restauración», Investigaciones históricas: Época moderna y contemporánea, $\mathrm{N}^{\mathrm{N}} 10$ (1990), pp. 263-266.

${ }^{551}$ Fue la primera institución que reconoció la intervención social como un deber ético propio del Estado democrático. Se le encargó preparar la legislación del trabajo, asesorar y apoyar las tareas legislativas y de Gobierno en materia social.

${ }^{552}$ El INP fue creado el 27 de febrero de 1908. Por Real Decreto de 20 de noviembre de 1920 dejó de depender del Ministerio de Gobernación y pasó al recién creado Ministerio de Trabajo.
} 
La transformación que supuso el paso de una sociedad agraria a otra industrial, generó grandes desajustes sociales que se plasmaron en una conflictividad creciente entre el proletariado y la clase dirigente española, que arbitró una serie de medidas de carácter social para evitar el ascenso de las posturas revolucionarias obreras. La Comisión de Reformas Sociales fue el germen del futuro Instituto Nacional de Previsión, creado en 1908, e indirectamente también influyó en la creación del Ministerio de Trabajo en 1920. Hasta 1900, un trabajador accidentado, enfermo o anciano o una viuda se convertían automáticamente en un marginado, candidato a entrar en una institución benéfica gestionada por la Iglesia y por las diputaciones provinciales. El significado que la previsión introdujo en la cultura social a principios del siglo XX fue revolucionario, el imaginario social reformista contemplaba la pobreza como un defecto social a erradicar y las necesidades sociales como un fracaso a evitar mediante los servicios públicos. El Estado tenía la obligación de anticiparse, de hacer imposible la pobreza cubriendo las necesidades de los ciudadanos y estos tenían derecho a recibir sanidad, enseñanza y seguridad, después de satisfacer sus obligaciones fiscales. En esos años de cambio de cultura social se estaban estructurando las grandes instituciones del movimiento obrero. En 1906, se creó la Inspección de Trabajo, con la función de vigilar el cumplimiento de lo dispuesto en la Ley de Accidentes de Trabajo de 1900. La creación del Instituto Nacional de Previsión, suponía el paso de los seguros sociales voluntarios al régimen de libertad subsidiada, un escalón intermedio en el largo camino hacia la protección social ${ }^{553}$. Entre las responsabilidades específicas del INP se encontraba la administración de las pensiones de retiro a favor de los asalariados y se le encomendaban tareas de gestión y propaganda para defender las ventajas de la previsión popular.

\footnotetext{
${ }^{553} \mathrm{Vid}$. CUESTA BUSTILLO, Josefina, GÓMEZ MOLLEDA, María Dolores, Los Seguros Sociales en la España del siglo XX. Hacia los Seguros Sociales obligatorios. La crisis de la Restauración, Madrid, Ministerio de Trabajo y Seguridad Social, 1988.
} 
La Diputación Provincial de Palencia no era ajena a las necesidades del mundo obrero y, de acuerdo al espíritu de los tiempos, en 1895, aprobaba las Bases ${ }^{554}$ para la concesión de auxilios a las familias de los obreros que fallecieran en el ejercicio de sus trabajos, y a ellos mismos si se inutilizaban perpetua o temporalmente:

1. 250 pts. a la viuda e hijos legítimos del obrero que falleciese en la provincia en accidente fortuito en el ejercicio de su trabajo, siempre que fueran menores de diecisiete años o impedidos para el trabajo. También a los padres o abuelos que fuesen impedidos para el trabajo o excedieran de sesenta años. Viudas sin hijos, cien pts.

2. 125 pts. al obrero que por accidente quedase imposibilitado para trabajar.

3. Al obrero que contrajese enfermedad o sufriera lesión que necesitase para curarse más de sesenta días consecutivos, se le socorrería con 45 pts., y con 65 pts. si el mal se prolongaba más de noventa días.

El sujeto de auxilio debía ser natural de la provincia, o casado con una mujer natural de la misma, no pagar contribución directa al Estado y observar buena conducta. Los beneficios no podían aplicarse a los empleados de Ferrocarriles, Minas, Canales. Estado, Provincia o Municipio o a los que recibieran socorro por parte de los patronos. En 1910, el diputado provincial Juan Díaz-Caneja Candanedo presentaba una moción para que, de conformidad con la Ley de 27 de febrero de 1906 y el Real Decreto de 24 de diciembre de 1906, se organizase y difundiese la previsión popular, para conseguir las pensiones de retiro y estimular el ahorro, «(...) y de esta suerte los centenares de españoles que no tienen más que un diario jornal de sueldo reducido y un porvenir lóbrego puedan gozar en el día de mañana de una modesta pensión, que les proporcione lo necesario para atender a su subsistencia de modo digno y sobre todo, de modo independiente.» ${ }^{555}$ Se proponía que la moción pasase a la Comisión de Presupuestos de la Asamblea, y se consignase en los próximos presupuestos de 1911 la cantidad de 5.000 pts. para esta obra social.

\footnotetext{
${ }^{554}$ A.D.P.P., L.A.P.D. 80, 8-IV-1895.

${ }^{555}$ A.D.P.P., L.A.P.D. 107, 17-V-1910
} 
Se acordó que la Comisión de Presupuestos se pusiese en contacto con el Instituto Nacional de Previsión para estudiar la forma, el tiempo, la cantidad y los controles que habían de prestarse para conseguir, antes del 31 de diciembre de 1910, el aseguramiento de todo el personal dependiente de la Asamblea, que percibiese un sueldo inferior a 1.500 pts., y la adquisición de cartillas infantiles que se acordasen, una vez fijadas las condiciones que se exigirían a los que resultasen favorecidos. Las pensiones de los empleados provinciales eran de escasa cuantía y salvo excepciones, permitían solo cubrir sus necesidades vitales. En el Presupuesto de 1921-22 se consignaba una partida presupuestaria para pagar la cantidad de 8.600 pts., cantidad muy elevada para la época, al secretario de la Corporación, Domingo Díaz Caneja, por cumplir la edad reglamentaria ${ }^{556}$ para jubilarse, aunque la realidad demostraba la existencia de un enorme desierto entre las pensiones de los puestos de gestión y el resto en términos cuantitativos $^{557}$. Las jubilaciones del secretario, interventor y jefe de la sección de presupuestos, se regulaban por lo dispuesto en los arts. 33 y 43 del Reglamento de funcionarios provinciales. El resto del personal, mientras no fueran incluidos en el Montepío Nacional de Funcionarios de la Administración Local, se regía por lo dispuesto en el Reglamento de la Diputación Provincial ${ }^{558}$. Todos los funcionarios tenían derecho a haberes pasivos. Salvo el caso de inutilidad física para el ejercicio del cargo, la jubilación forzosa estaba fijada a la edad de setenta años ${ }^{559}$. La cuantía de la pensión variaba según una escala establecida conforme a los años de servicio, aquellos funcionarios que hubiesen completado treinta y cinco años de servicio en la Diputación Provincial tenían derecho a las cuatro quintas partes de su sueldo ${ }^{560}$, los que tuviesen veinticinco años de servicio, tres quintas partes, y lo que tenían veinte años, dos quintas partes.

\footnotetext{
${ }^{556}$ Bases de la Diputación Provincial de 9 de abril de 1919. A.D.P.P., C-L/ 12,2.

${ }^{557}$ Pensión jubilación capellán de la Beneficencia Provincial: 1.200 pts. . Pensiones de viudedad: oficial $1^{\mathrm{a}}$ : 1.250 pts., depositario fondos provinciales: 858,82 pts., oficial $1^{\mathrm{a}}$ tenedor de libros: 625 pts., auxiliar Depositaría: 547,50 pts., administrador Beneficencia Provincial: 429,40 pts., maquinista imprenta provincial: 365 pts., peón caminero: 365 pts. . Pensiones de orfandad: huérfano secretario de Diputación: 858,82 pts., huérfano de archivero: 429,40 pts. A.D.P.P., C-L/ 12,3.

${ }^{558}$ En julio de 1910, el Instituto Nacional de Previsión advertía que en los reglamentos de la Diputación Provincial no se fijaba la edad de jubilación de sus empleados, así que desempeñaban sus cargos hasta que físicamente se incapacitaban, socorriéndoles entonces la Asamblea con la pensión vitalicia que estimase oportuna, y que nunca podía rebasar el límite de las que concedía el Estado.

${ }^{559} \mathrm{La}$ jubilación voluntaria se podía conceder a los sesenta y cinco años de edad y antes de esa edad a aquellos que tuviesen cuarenta años de servicio o acreditasen imposibilidad física para el desempeño del trabajo.

${ }^{560} \mathrm{El}$ sueldo regulador para la jubilación era el de mayor cuantía que hubiese disfrutado el funcionario por lo menos durante dos años, contando los quinquenios. En la jubilación forzosa por edad o inutilidad para el servicio no se tenían en cuenta los dos años del sueldo mayor.
} 
El personal subalterno, capataces, peones camineros y cargos similares disfrutaban de una pensión de una peseta diaria, siempre que llevasen quince años al servicio de la Corporación Provincial. Las viudas ${ }^{561}$ y huérfanos ${ }^{562}$ de los funcionarios de la Diputación Provincial tenían derecho a pensiones vitalicias, siempre que aquellos hubiesen prestado quince años de servicio como mínimo en la Diputación, la cuantía dependía de la categoría profesional del funcionario fallecido ${ }^{563}$.

En 1923, el diputado provincial Hortelano de Urcullu preguntaba cómo se encontraba la constitución de la Caja Colaboradora del Retiro Obrero, pues en Burgos se hallaba ya establecida, habiendo contribuido su Diputación Provincial con 25.000 pts. $^{564}$. Presidencia contestaba señalando que pronto se fundaría la Caja Regional Colaboradora, que estaría integrada por las provincias de Valladolid, Palencia y Segovia, con domicilio social en Valladolid, finalmente Segovia se desligó del proyecto y se unió a Burgos. Sus principales objetivos eran el asociacionismo, la previsión y el intervencionismo social. A finales del año 1924, quedaron aprobados los estatutos de la nueva Caja $^{565}$. Las diputaciones provinciales de Valladolid y Palencia aportaron cada una 25.000 pts. como capital inicial, el Instituto Nacional de Previsión aportó 20.000 pts., al constituirse la Caja. La capitalidad de las Cajas Colaboradoras las decidía el Instituto Nacional de Previsión, que dio preferencia a Valladolid, pero Palencia consiguió una sucursal que funcionaba con autonomía cubriendo las cantidades recaudadas en la propia provincia. La Dirección General del Trabajo y Acción Social, había desestimado la pretensión de la Diputación de que tuviese carácter provincial y no regional $^{566}$.

\footnotetext{
${ }^{561}$ Solo tenían derecho a percibir pensiones de viudedad las viudas no separadas o divorciadas judicialmente del marido, que hubiesen contraído matrimonio con el funcionario fallecido antes de que este hubiese cumplido los cincuenta años de edad, y solo mientras permaneciesen viudas.

${ }^{562}$ Los huérfanos varones disfrutaban de la pensión a prorrata hasta que cumplían los diecisiete años de edad, las mujeres mientras no se casasen o ingresasen en una orden religiosa.

${ }^{563}$ Secretario, interventor y jefe de Sección de Presupuestos: 2.000 pts. con más de quince y menos de veinte años de servicio, 2.500 con más de veinte y menos de treinta y cinco años de servicio, y 3.000 pts. con más de treinta y cinco años de servicio. La cuantía iba disminuyendo conforme lo hacía la categoría profesional del empleado provincial. Las viudas y huérfanos del personal subalterno de la Diputación percibían una pensión de 600 pts., 650 pts., y 700 pts. según la proporción establecida de los años de servicio del empleado fallecido. A.D.P.P. Reglamento de funcionarios y subalternos provinciales de 1926. ${ }^{564}$ A.D.P.P., L.A.C.P. $131,21-$ XII-1923.

${ }^{565}$ Anales del Instituto Nacional de Previsión, No 62, Año XVI, p. 262.

${ }^{566}$ A.D.P.P., L.A.C.P. 137, 24-II-1925.
} 
En mayo de 1930, el delegado de la Caja Colaboradora de Previsión Social «Valladolid-Palencia», recordaba a la Diputación el derecho que le concedían los estatutos de la Caja, del que no había hecho uso, de designar un diputado provincial para que ejerciese como vocal en el Consejo directivo de la misma, la Diputación nombró para ese cargo al vocal de la Comisión Provincial, Santander Gallardo. A partir de esta fecha la Diputación Provincial emprendió una campaña de propaganda enviando a todos los ayuntamientos de la provincia una relación detallada de lo que era el INP, para conseguir el mayor número de imposiciones.

\section{Estructura}

La estructura interna de la Diputación Provincial varió muy poco a lo largo de la Restauración, organizándose en varias dependencias básicas para su funcionamiento, Secretaría, Contaduría, Depositaría, Intervención y otras dependencias de menor rango administrativo.

\section{Secretaría}

La Ley de 29 de agosto de $1882^{567}$ contemplaba la fórmula de la libre designación para el acceso al cargo de secretario de la Diputación Provincial. El secretario se encargaba de la preparación y tramitación de los asuntos que debían tratar la Diputación y la Comisión Provincial, la redacción de las Actas y acuerdos, la correspondencia y el cuidado y conservación del Archivo. Además firmaba con el presidente los acuerdos y decretos de la Comisión Provincial, los testimonios de las Actas de la Diputación y, como jefe de la Secretaría provincial, tenía a su cargo a una serie de empleados a los que debía vigilar y dirigir, distribuyendo el trabajo entre ellos y dictando las reglas más adecuadas para el despacho de los asuntos ${ }^{568}$, con sujeción al Reglamento de servicio interior.

\footnotetext{
${ }^{567}$ Art. 104.

${ }^{568}$ En la sesión de la Comisión Provincial de 13 de noviembre de 1883 , se acordó que el secretario debía informarse mediante los jefes de las dependencias provinciales del número de negocios que se habían despachado y de los que se hallasen en tramitación cada mes, para que la Diputación pudiese formarse un juicio exacto del estado de los servicios provinciales. Secretaría daba cuenta del retraso en el despacho de varios asuntos y de la necesidad de habilitar horas extraordinarias para su ultimación.
} 
Sus principales funciones eran:

1. Redactar el Acta de cada sesión, consignando el nombre del presidente y diputados que asistiesen, los que excusasen su ausencia, hora de inicio y finalización, síntesis de los acuerdos adoptados, fundamentos de los votos de las minorías, expresión de las votaciones cuando fuesen nominales y cualquier incidente digno de mención.

2. Vigilar la ejecución de los acuerdos de la Diputación, así como su notificación a los interesados.

3. Informar previamente y por escrito los expedientes en los que el presidente de la Diputación hubiese decretado la suspensión de los acuerdos tomados por el Pleno o la Comisión Provincial.

4. Asistir, sin voto, a las sesiones del Pleno y de la Comisión Provincial, dando cuenta de la correspondencia, expedientes, y del resto de asuntos pendientes de resolución.

5. Asistir y dar cuenta de los asuntos como secretario a la Comisión de Presupuestos, y las comisiones especiales o auxiliares que se formasen en la Diputación Provincial.

6. Preparar la relación de asuntos pendientes de despacho de la Comisión y del Pleno de la Diputación, para la convocatoria y orden del día, asegurándose de que las citaciones circulasen con la anticipación oportuna.

\section{Contaduría}

El contador tenía a su cargo la oficina de cuenta y razón, de fondos provinciales. Se encargaba de registrar las entradas y salidas de los fondos, conjuntamente con el ordenador de pagos autorizaba los libramientos, realizaba los asientos en los libros que llevaba al efecto, preparaba los presupuestos que debía aprobar la Diputación Provincial y supervisaba las cuentas de los ayuntamientos. La poca disponibilidad presupuestaria hacía imposible que las plantillas de las diferentes dependencias provinciales pudiesen llevar a cabo su trabajo de forma ágil y diligente. 
En 1892, el jefe de Contaduría, Felipe Moratinos, dirigió un escrito a la Comisión Provincial, en el que solicitaba que con cargo al presupuesto asignado para material de Contaduría se nombrase un temporero en los meses de enero, abril, julio y octubre, para que ayudase a cumplir el servicio de resúmenes de balances y cuentas de todos los ayuntamientos de la provincia, en cada uno de los cuatro trimestres del año, que posteriormente había que remitir a la Dirección de la Administración Local. El jefe de contaduría justificaba esta petición por ser «(...) imposible de todo punto, ni aun habilitando horas extraordinarias, puede esta sección con el exiguo personal que cuenta dar cumplimiento a el cúmulo de servicios que la incumben» ${ }^{569}$. En la sesión del 22 de julio de 1892, La Comisión Provincial acordó que estando casi terminando el mes de julio, la petición del jefe de contaduría debía ser rechazada, dejando para octubre la posible resolución de la petición.

De la excelencia profesional de los funcionarios de esta dependencia habla lo sucedido en 1908, cuando la Diputación Provincial de Valladolid realizaba una petición a la Diputación Provincial de Palencia para que se le concediese permiso al contador de fondos provinciales de la Diputación de Palencia, Rodríguez de Valenzuela y practicase una liquidación general de lo recaudado por el arrendatario del Contingente Provincial de la Diputación de Valladolid. De este modo podrían resolverse las diferencias surgidas entre el contratista y la Contaduría de la Diputación de Valladolid, la Diputación de Palencia autorizó este traslado temporal ${ }^{570}$.

\footnotetext{
${ }^{569}$ A.D.P.P., C 63/3.

${ }^{570}$ A.D.P.P., L.A.C.P. $115,10-\mathrm{II}-1908$
} 


\section{Depositaría}

La Oficina de la Depositaría provincial era la encargada de la custodia de los fondos y valores de la Corporación Provincial, así como de la realización de los ingresos y pagos de la misma. El depositario era el único encargado de la custodia de los fondos provinciales y, como tal, prestaba las fianzas que exigía la Diputación Provincial. El depositario no podía hacer pagos ni recibir cantidades sin la autorización del ordenador de pagos y el contador ${ }^{571}$.

En caso de existir dos cajas en la Diputación, el depositario, junto con el ordenador de pagos y el contador, guardaría una de las tres llaves de la caja general, y la única llave de la caja diaria ${ }^{572}$. Las funciones del depositario eran:

1. Pagar los libramientos autorizados por el ordenador y visados por el interventor.

2. Administrar los bienes de toda clase de la Diputación, rindiendo cuentas trimestrales.

3. Recaudar los impuestos legales y satisfacer las contribuciones y arbitrios que correspondieran a la Corporación o a sus establecimientos.

4. Formalizar y documentar las cuentas anuales.

A partir de la entrada en vigor del Estatuto Provincial de $1925^{573}$, una vez terminadas las operaciones del día, no podía permanecer en la Depositaría mayor suma de metálico que la acordada por la Comisión Provincial.

\footnotetext{
${ }^{571} \mathrm{El}$ art. 277 de Estatuto Provincial variaba algo las condiciones de la Ley Provincial de 29 de agosto de 1882, al exigir el visado previo del interventor para efectuar los pagos por parte del depositario.

${ }^{572} \mathrm{La}$ caja diaria custodiaba los fondos destinados a las atenciones de cada mes.

${ }^{573}$ Respecto de este tema, el Estatuto Provincial se remitía al Reglamento de Hacienda Municipal, aprobado por Real Decreto de 23 de agosto de 1924.
} 


\section{Hacienda}

Al Negociado de Hacienda Provincial le correspondía la administración, inspección y recaudación de todos los recursos que integraban aquella, especialmente la de los impuestos y arbitrios establecidos por la Diputación Provincial. Si la Diputación establecía la forma de recaudación directa de los impuestos, rentas, arbitrios y exacciones provinciales, por medio de agentes y delegados, los funcionarios que se nombraban a tal efecto, guardarían, en el desempeño de su función recaudatoria e inspectora $^{574}$, relación inmediata con el Negociado de Hacienda.

El Negociado de Hacienda, para una mejor organización del servicio económico de la Diputación, funcionaba de forma coordinada con la Intervención y Depositaría Provincial. Estaban adscritos a este Negociado un oficial y dos auxiliares. El Negociado de Hacienda tenía las siguientes funciones:

1. Informar y tramitar todas las materias relacionadas con patrimonio, recursos y rentas provinciales.

2. Asuntos relativos a exacciones, contribuciones especiales, derechos y tasas, imposiciones, arbitrios, impuestos y recursos cedidos por el Estado, cesiones de recursos municipales, recargos provinciales, recursos especiales, cédulas personales, y toda clase de recursos de la Hacienda provincial.

3. Todo lo referente a la recaudación y contabilidad de esos recursos era competencia de la oficina de Intervención Provincial.

\footnotetext{
${ }^{574}$ A.D.P.P., Art. 65 del Reglamento de funcionarios y subalternos provinciales de 1926.
} 


\section{Intervención}

La Oficina de Intervención Provincial, era la encargada de la fiscalización de los gastos e ingresos de la Diputación provincial, así como de la inspección e investigación de las rentas y arbitrios provinciales. Además del interventor, formaban parte de esta oficina el tenedor de libros, oficiales y auxiliares ${ }^{575}$. Las funciones de esta dependencia eran entre otras:

1. Preparar y conservar los presupuestos ordinarios y extraordinarios, las cuentas y los balances trimestrales y las liquidaciones generales de cada presupuesto.

2. Examinar y autorizar las nóminas de los empleados provinciales.

3. En los expedientes de fianzas y reintegros, proponer las medidas que hubiesen de adoptarse para asegurar la responsabilidad de los funcionarios o particulares a quienes se les exigiese.

4. Impulsar las operaciones de recaudación, proponiendo en su caso a la Comisión Provincial las medidas y correcciones procedentes para que esas operaciones se llevasen a cabo.

5. Negarse al pago de gastos que no tuviesen consignación en el Presupuesto o que contraviniesen alguna disposición legal vigente.

6. Formar el inventario de bienes y valores de la Diputación Provincial.

\section{Otras dependencias}

Además de los servicios de Secretaría, Contaduría, Depositaría, Hacienda e Intervención, la Diputación Provincial contaba con otras dependencias relacionadas con las atribuciones asignadas por ley. Los servicios citados contaban con todo un conjunto de empleados formado por escribientes, oficiales, auxiliares, archiveros, etc., pero también dependían de la institución provincial los Establecimientos de Beneficencia o de Instrucción Pública. Los empleados de estas dependencias recibían su sueldo de los fondos provinciales aunque, en algunos casos, dependían administrativamente del Estado $^{576}$.

\footnotetext{
${ }^{575}$ A.D.P.P., Reglamento de funcionarios y subalternos provinciales de 1926.

${ }^{576}$ Los profesores de la Enseñanza Secundaria eran nombrados por el Gobierno. El resto de los empleados provinciales, eran nombrados por la Diputación Provincial, y era esta institución la que tenía potestad para separarlos de sus puestos de trabajo. Art, 74, Disposición 4a de la Ley Provincial de 29 de agosto de 1882.
} 


\section{Beneficencia}

El Negociado de Beneficencia, Sanidad e Higiene se encargaba de la administración de los servicios provinciales de este ramo. Formaban parte de este Negociado un oficial y un auxiliar, y de la sección administrativa de los Establecimientos de Beneficencia, otro oficial y un auxiliar. Las competencias de este Negociado se resumían en, los ingresos en el Hospicio y Maternidad, los ingresos y aprobación de cuentas del Hospital y Manicomio, Colegio de sordo-mudos y ciegos, reformatorios, Tribunal para niños y del Instituto de Higiene (a partir de la promulgación del Estatuto Provincial). Además, formaban parte de sus competencias los subsidios de maternidad y paro forzoso, mandas y legados, tratamientos antirrábicos y subvenciones benéficas.

\section{Fomento, Instrucción Pública y Obras Provinciales}

Este Negociado se encargaba de los servicios administrativos relacionados con las materias que competían al fomento de la agricultura, ganadería, etc., al establecimiento y creación de Escuelas de Artes y Oficios, Biblioteca Provincial, etc., y lo referido a las Obras Provinciales. El personal adscrito a este Negociado estaba compuesto por un oficial y tres auxiliares ${ }^{577}$. Formaban parte de sus competencias: el despacho de los asuntos concernientes a carreteras provinciales, caminos vecinales, viveros forestales, campos agro-pecuarios, subastas, difusión de la enseñanza agrícola, Instrucción pública, ahorro y previsión, expropiaciones, minas, montes, aguas, electricidad, construcciones civiles, exposiciones y concursos, ferias y mercados, biblioteca y museos provinciales.

\footnotetext{
${ }^{577}$ En enero de 1884, el director de Obras Provinciales advertía de la imposibilidad de formar con el reducido personal de la sección los anteproyectos de las carreteras que la Diputación quería incluir en el Plan de Carreteras Provinciales, a menos que se dejasen desatendidos los que se estaban construyendo. A.D.P.P., L.A.C.P 60, 5-I-1884.
} 
Adscrita a este Negociado estaba la Oficina de Vías y Obras, cuyo jefe era el ingeniero-director, que entre otras funciones tenía:

1. Estudio y redacción de los proyectos de obras provinciales, su replanteo y la dirección y vigilancia de las mismas.

2. Medición de obras ejecutadas y expedición de las certificaciones de ellas.

3. Recepción provisional o definitiva de las obras terminadas cuando lo dispusiese la Diputación Provincial.

4. Distribuir el personal subalterno de capataces $^{578}$ y peones camineros ${ }^{579}$ con arreglo a la conveniencia de servicio.

5. Formular los presupuestos de conservación y reparación de las obras públicas provinciales.

\section{Competencias}

\section{Introducción}

En la Restauración, las diputaciones provinciales continuaron ejerciendo de nexo de unión entre las Administraciones Central y Local. La Diputación Provincial ejercía sus atribuciones en dos ámbitos de actuación, el político y el socioeconómico. Las competencias de las diputaciones no variaron esencialmente hasta el advenimiento de la Dictadura primorriverista. La insatisfacción de las corporaciones provinciales con sus atribuciones se manifestaba en las múltiples reivindicaciones planteadas. Buena muestra de ello fueron los acuerdos adoptados por las corporaciones provinciales reunidas en Asamblea.

\footnotetext{
${ }^{578} \mathrm{El}$ capataz era el jefe de cada sección, entre 15 a $30 \mathrm{~km}$ consecutivos, en las que se dividían las carreteras. Era el jefe inmediato de los peones camineros y auxiliares que trabajaban en su sección.

${ }^{579}$ Para ser nombrado en propiedad peón caminero, se debía ser mayor de veinte años y menor de treinta y cinco, ser licenciado del ejército, no tener impedimento alguno para el trabajo, saber leer, escribir y contar, y acreditar buena conducta con certificación del jefe a cuyas órdenes había servido. En el caso de que el Ministerio de la Guerra no hiciese propuestas, podían ser nombrados peones camineros los trabajadores y peones auxiliares, físicamente útiles, con certificación facultativa, de buena conducta y que no excediesen de cuarenta años. El peón caminero que había servido durante dos años sin que constase nota desfavorable en su expediente personal, tenía opción a ser elegido peón capataz. El nombramiento de peones capataces correspondía a la Dirección General de Obras Púbicas.
} 
Sirva de ejemplo la Asamblea de diputaciones provinciales, celebrada en Barcelona el 5 de diciembre de 1906, en la que se votaron por mayoría los siguientes acuerdos:

1. Serían competencia de la Comisión Provincial, el examen y aprobación de los presupuestos, repartos y cuentas de los ayuntamientos.

2. Los bienes, derechos y contratos de las diputaciones relativos a la Beneficencia quedarían exentos de toda clase de impuestos.

3. Las atenciones de enseñanza e Instrucción Pública a cargo de las diputaciones, por ser funciones propias del Estado, serían satisfechas por este.

4. Las diputaciones podrían crear y sostener escuelas especiales con la aprobación del Gobierno.

5. El Gobierno se haría cargo del coste económico de servicios que venían desempeñando las diputaciones (dementes pobres, enfermos incurables y presos correccionales).

6. La exclusiva competencia de las diputaciones sobre el nombramiento de todos los funcionarios, tanto los del orden profesional o técnico, como los del orden administrativo que se pagasen con fondos provinciales ${ }^{580}$.

\footnotetext{
${ }^{580}$ La competencia exclusiva sobre los funcionarios provinciales era una vieja aspiración de la Diputación palentina. En 1887 , ante la promulgación de la Real Orden de 27 de abril de 1887, por la que se resolvía que Dámaso López Cadierno tenía derecho a la categoría, consideración y sueldo de médico de $1^{\mathrm{a}}$ más antiguo de la Beneficencia Provincial, en contra del acuerdo de la Diputación Provincial que había nombrado para ese cargo a otro facultativo, el diputado provincial Nieto Moro recordaba que las diputaciones no dependían del Gobierno, «(...) sino de los electores de quienes han recibido el mandato, con cuya representación se honran y cuyos intereses tienen el deber de defender.» A.D.P.P., L.A.P.D. 63, $25-\mathrm{V}-1887$.
} 
Estas peticiones no fueron atendidas, pero constituían un fiel reflejo de los anhelos competenciales de los entes provinciales y mostraban de forma clara cuáles eran las principales debilidades en la labor gestora de la Diputación Provincial en la Restauración. Las reivindicaciones de las diputaciones provinciales no fueron escuchadas por lo que el descontento iba en aumento y, en 1924, la Diputación palentina $^{581}$ manifestaba su deseo de una reforma drástica del funcionamiento de las diputaciones, ya que en su opinión «(...) lo que nació como un organismo para defender los intereses de los municipios, se ha convertido en una oficina de favores políticos» ${ }^{582}$. La Diputación Provincial no pedía el control de los centros burocráticos, sino lo que, en 1868, Ducrocq denominaba en su libro sobre el Derecho Administrativo «desconcentración» ${ }^{583}$, una verdadera descentralización orgánica a base del reconocimiento de una personalidad y esfera propia de actuación de las corporaciones provinciales, en otras palabras, un régimen de libre gestión, exento de la tutela del Gobierno central, aunque no de la fiscalización legal del poder público ${ }^{584}$.

En el periodo de la Dictadura de Primo de Rivera, el Estatuto Provincial no cambiaba sustancialmente las atribuciones de las diputaciones provinciales, encomendándolas la organización de los servicios propios de la Administración Local, que no fuesen de competencia municipal, y los servicios que el Estado traspasase a las corporaciones provinciales $^{585}$. Sin embargo, parte de las reivindicaciones históricas de las Diputaciones provinciales fueron atendidas, como el traspaso de la Segunda Enseñanza y la Corrección Pública al Estado.

\footnotetext{
${ }^{581}$ En 1924, el subsecretario de Gobernación solicitó a las diputaciones provinciales un informe sobre el problema regional, el saneamiento de la Hacienda provincial, y la sustitución del Contingente Provincial. 582 A.D.P.P., Memoria de deficiencias y soluciones de 1924, C-R/ 1,12.

${ }^{583}$ Ducrocq asimilaba este concepto al de descentralización administrativa. Vid. DUCROCQ, Théophile Gabriel Auguste, Cours de Droit Administratif, Paris, Ulan Press, 2012.

${ }_{584}^{584}$ A.D.P.P., Memoria de deficiencias y soluciones de 1924, C-R/ 1,12.

${ }^{585}$ Art. 4 del Estatuto Provincial de 1925.
} 


\section{Competencias políticas}

\section{Tutela ayuntamientos}

Durante la Restauración, exceptuando la etapa primorriverista, las diputaciones continuaron ejerciendo, como lo hicieran a lo largo del siglo XIX, el control y tutela de los ayuntamientos, en la condición de superior jerárquico de las entidades locales que les atribuía la Ley. No obstante, en las primeras leyes provinciales de esta etapa, esta función de control pasaba desde la Comisión Provincial al gobernador civil y a la propia Diputación $^{586}$. Con la aprobación de la Ley Provincial de 29 de agosto de 1882, la Comisión Provincial volvía a ejercer el control sobre los ayuntamientos, no solo respecto de los acuerdos adoptados por las corporaciones municipales sino también en todo lo referido a su administración ${ }^{587}$. A partir de la promulgación del Estatuto Provincial de 1925, las diputaciones provinciales dejaron de tener la consideración de superiores jerárquicos de los ayuntamientos y por tanto de ejercer la tutela sobre los mismos.

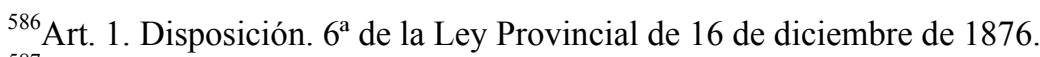

${ }^{587}$ Arts. 75 y 99 de la Ley Provincial de 29 de agosto de 1882. 
Esta tutela y control se manifestaba mediante los permisos y autorizaciones que los ayuntamientos debían solicitar en toda una seria de actuaciones de competencia municipal, como las incidencias sobre quintas, reclamaciones y protestas en las elecciones municipales ${ }^{588}$, así como las incapacidades, incompatibilidades y excusas de los concejales, revisión de los acuerdos de las corporaciones municipales ${ }^{589}$ y girar visitas de inspección para controlar el estado de los servicios ${ }^{590}$, cuentas ${ }^{591}$ presupuestos $^{592}$, obras ${ }^{593}$ y archivos municipales.

\footnotetext{
${ }^{588} \mathrm{La}$ Comisión Provincial daba cuenta al Ministerio de la Gobernación de la anulación de las elecciones municipales. En este sentido, el 27 de abril de 1881, la Comisión Provincial comunicaba al citado Ministerio la anulación de la elección municipal verificada en Astudillo. Archivo Histórico Nacional AHN Legajo 2337/1. No obstante, los acuerdos de la Comisión Provincial en esta materia también eran recurribles en recurso de alzada, por ejemplo, Eugenio Martínez Santos, vecino de Cervera de Pisuerga, interponía en 1888 un recurso de alzada contra el acuerdo de la Comisión Provincial por el que se declaraba con capacidad para el cargo de concejal a Eugenio Marcos Pérez en la citada localidad. AHN Legajo 451/3. En 1981, Saturnino Fernández presentaba un recurso de alzada contra el acuerdo de la Comisión Provincial que declaraba válidas las elecciones municipales celebradas el 10 de mayo de ese año en Lantadilla. AHN Legajo 1374/2. En 1885, un vecino de Santoyo presentaba un recurso ante la Comisión Provincial para que se declarasen nulas las elecciones verificadas para la renovación del Ayuntamiento por no haberse elaborado el padrón de vecindad, que era la base de las listas y del censo electoral. A.D.P.P., L.A.C.P., 61, 18-VI-1885.

${ }^{589}$ Ante las reclamaciones de particulares sobre la formación y publicación de las listas de compromisarios para las elecciones del Senado, la Comisión Provincial recordaba que este era un acto de exclusiva competencia de los ayuntamientos y que la Comisión Provincial tenía sobre el particular las atribuciones que estaban determinadas por el art. 27 de la Ley Provincial de 8 de febrero de 1877, sobre elección y organización del Senado, o sea, la resolución de las apelaciones interpuestas contra los acuerdos de los ayuntamientos.

${ }^{590}$ En la sesión del 17 de junio de 1876, la Comisión Provincial proponía al gobernador la destitución del Ayuntamiento de Dueñas en vista de las informalidades y defectos graves observados en su administración por el delegado nombrado para inspeccionar el estado de sus servicios. A.D.P.P., L.A.C.P. 45, 17-VI-1876. En 1887, se acordó la designación de varios diputados para que girasen visitas a los pueblos para informarse sobre el estado de su administración, en vista de la situación económica y la «(...) la necesidad de reducir a la obediencia a los ayuntamientos que se han colocado fuera de la ley» A.D.P.P., L.A.P.D. $63,24-\mathrm{V}-1887$.

${ }^{591}$ En mayo de 1876, la Diputación Provincial apercibió al alcalde de Frechilla para que enviase al fiscal del Partido Judicial el correspondiente atestado a fin de formar la causa para averiguar las personas responsables de la ocultación de las cuentas municipales del periodo 1865/68. A.D.P.P., L.A.C.P. 45, 17 V-1876

${ }^{592}$ Declarado sin valor ni efecto legal el repartimiento girado por el Ayuntamiento de Grijota para cubrir el déficit del presupuesto municipal de 1874/75, contra el que varios vecinos habían presentado reclamación ante la Comisión Provincial. A.D.P.P., L.A.C.P. 45,23-V-1876. En 1891, el Ayuntamiento de Palencia solicitó a la Comisión Provincial autorización para establecer un arbitrio extraordinario sobre las especies de consumos no comprendidas en la tarifa general para cubrir el déficit de 14.000 pts. que resultaban de su presupuesto. A.D.P.P., L.A.C.P. 70, 17-VII-1891.

${ }^{593}$ En octubre de 1876, la Diputación Provincial autorizaba a un Ayuntamiento de la provincia a retirar de la Caja General de Depósitos la tercera parte del $80 \%$ de sus bienes propios, para construir un puente, lavaderos y unos pozos. A.D.P.P, L.A.C.P., 45, 5-X-1876. En mayo de 1882, el Ayuntamiento de Mazariegos solicitó autorización a la Diputación Provincial para convertir en títulos al portador las inscripciones que poseía en equivalencia de sus antiguos bienes propios para ejecutar obra de saneamiento de terrenos y limpieza de arroyos. A.D.P.P., L.A.C.P. 58, 13-V-1882.
} 
En definitiva, las diputaciones provinciales ejercían el control sobre los aspectos más sensibles de la Administración municipal, presupuestos y elecciones. Esta tutela no solo obedecía a un mandato legal, sino también a una necesidad administrativa, dada la escasez de personal con la que contaban la mayoría de los pueblos la provincia. En la década de 1890, la provincia de Palencia se componía de 250 ayuntamientos y la mayoría de ellos carecían de trabajadores capacitados ${ }^{594}$ «(...) cuyos secretarios ${ }^{595}$ carecen de conocimientos, salvo honrosas excepciones, para la aplicación de nuestro laberíntico y caótico derecho administrativo, montón de escombros bajo cuyo peso gimen los que no gozan de los favores de quien a la sazón gobierna, le ha llamado uno de los políticos contemporáneos.» 596

\footnotetext{
${ }^{594}$ Dado el considerable número de cuentas que existen sin rendir por parte de los ayuntamientos, en 1891 se acordaba publicar una circular en el $B O P$ en la que se señalaban los plazos para el cumplimiento de los pagos sin perjuicio de la imposición de multas por parte la Comisión Provincial de hasta cien pts. A.D.P.P., L.A.C.P. 70, 20-II-1891.

${ }^{595}$ En esta época, muchos secretarios municipales necesitaban dedicarse a las faenas de la agricultura para poder vivir, porque sus haberes anuales no llegaban a 500 pts.

${ }^{596}$ A.D.P.P., L.A.C.P. $74,20-\mathrm{V}-1892$.
} 


\section{Competencias económicas y administrativas}

\section{Introducción}

A comienzos del último cuarto del siglo XIX, la provincia de Palencia no difería en el terreno socio-económico del resto de provincias castellanas. Los pueblos palentinos basaban su precaria economía en una agricultura de subsistencia, condicionados por un sistema de comunicaciones muy deficiente que incidía de forma muy negativa sobre la capacidad productiva de la provincia ${ }^{597}$. Las condiciones higiénico-sanitarias dejaban mucho que desear, aunque las tasas de alfabetización eran de las más altas de España ${ }^{598}$. A pesar de contar con menos centros escolares que otras provincias castellanas ${ }^{599}$, la tasa de analfabetismo en Palencia era un $5 \%$ inferior a la tasa media regional ${ }^{600}$. La agricultura, constituía el pilar fundamental de la economía palentina, sin embargo, en la etapa de la Restauración, el norte de la provincia experimentó un crecimiento de la actividad extractiva, con la explotación de numerosas minas de carbón ${ }^{601}$. A la altura de 1900, la población total de la provincia era de 192.478 habitantes $^{602}$ y la población activa se componía de 79.000 personas. El sector primario ocupaba el $73 \%$ de la población, la industria un $10 \%$, y el resto lo constituía la población empleada en el sector terciario. El desarrollo minero en el norte de la provincia, Barruelo y Guardo, ejerció como foco de atracción de emigrantes en busca de trabajo.

\footnotetext{
${ }^{597} \mathrm{La}$ comercialización de los productos básicos de la agricultura palentina, cereal y harinas, se veía enormemente dificultada por la falta de infraestructuras de comunicación que permitiesen articular un mercado a nivel regional y nacional.

${ }^{598}$ En 1887 la tasa de analfabetismo era de un $37,13 \%$, y en el año 1900 se había reducido hasta un $33,90 \%$. En estos años, las tasas medias de analfabetismo a nivel nacional eran de un $68,0 \%$ y $63,78 \%$ respectivamente. Vid. TUÑÓN DE LARA, Manuel, Historia del movimiento obrero español. Madrid, Taurus, 1972, p. 319.

${ }^{599}$ La mayoría de las provincias de Castilla La Vieja contaban con más centros escolares que los que por Ley se exigían (Ley de Claudio Moyano).

${ }^{600}$ Estimada en un $41,8 \%$ en 1887.

${ }^{601}$ En febrero de 1912, la Diputación de Oviedo dirigió un Oficio al resto de diputaciones provinciales en las que existían cuencas carboníferas para recabar su apoyo y ejecutar una acción común en defensa del fomento de la producción nacional de hulla y la utilización de carbones nacionales como combustibles de la Marina de Guerra española. La Comisión Provincial de Palencia, de acuerdo con la Cámara Oficial de Comercio e Industria, el Consejo Provincial, la Sociedad Económica y la Jefatura de Minas, apoyó esta proposición. Las sociedades Antracita palentina, Minas de Castilla la Vieja y Jaén, Minas de Hulla de Villaverde de la Peña, Minera Cántabro-Asturiana y Minera de San Luis, se adhirieron al Proyecto de Ley de Protección de Industrias Hulleras.

${ }^{602}$ Instituto Nacional de Estadística.
} 
El crecimiento de la población industrial trajo parejo el nacimiento del movimiento obrero en esta zona y la subsiguiente lucha por los derechos sociales de los trabajadores de las minas. En la capital, el sector industrial estaba copado por la pujante actividad de la fabricación de mantas, las fábricas de harinas y la industria tejera. En la etapa restauracionista, Palencia experimentó una sensible mejora en sus infraestructuras de comunicaciones, de hecho, desde 1840, el Canal de Castilla había posibilitado el transporte del trigo castellano hasta Alar del Rey y a partir de 1866, con la inauguración del ferrocarril ${ }^{603}$, el cereal era transportado hasta el puerto de Santander, desde donde partía hacia Cuba.

Este era el panorama socioeconómico en el que tuvo que desenvolverse la actividad gestora de la Diputación Provincial de Palencia en ámbitos tan fundamentales para la vida provincial como el de Beneficencia, Sanidad, Instrucción Pública, Agricultura, Obras Públicas, Corrección Pública y Calamidades. Solo conociendo las posibilidades y las necesidades de la población de la provincia de Palencia en esa época, se puede entender la realidad de la actuación administrativa de la Diputación palentina en el uso de las facultades que la legislación le atribuía.

\footnotetext{
${ }^{603}$ La inauguración de la línea de ferrocarril, Valladolid-Santander redujo en dos terceras partes el tráfico mercantil del Canal de Castilla en el periodo 1875-1889. Cfr. BIELZA DE ORY, Vicente, El sector agropecuario y forestal en Historia General de España y América. T. XVI-1, Revolución y Restauración (1868-1931). Madrid, Rialp, 1982, p. 405.
} 


\section{Hacienda provincial}

Documento 02. Repartimiento o Contingente Provincial entre los ayuntamientos de la provincia de Palencia.

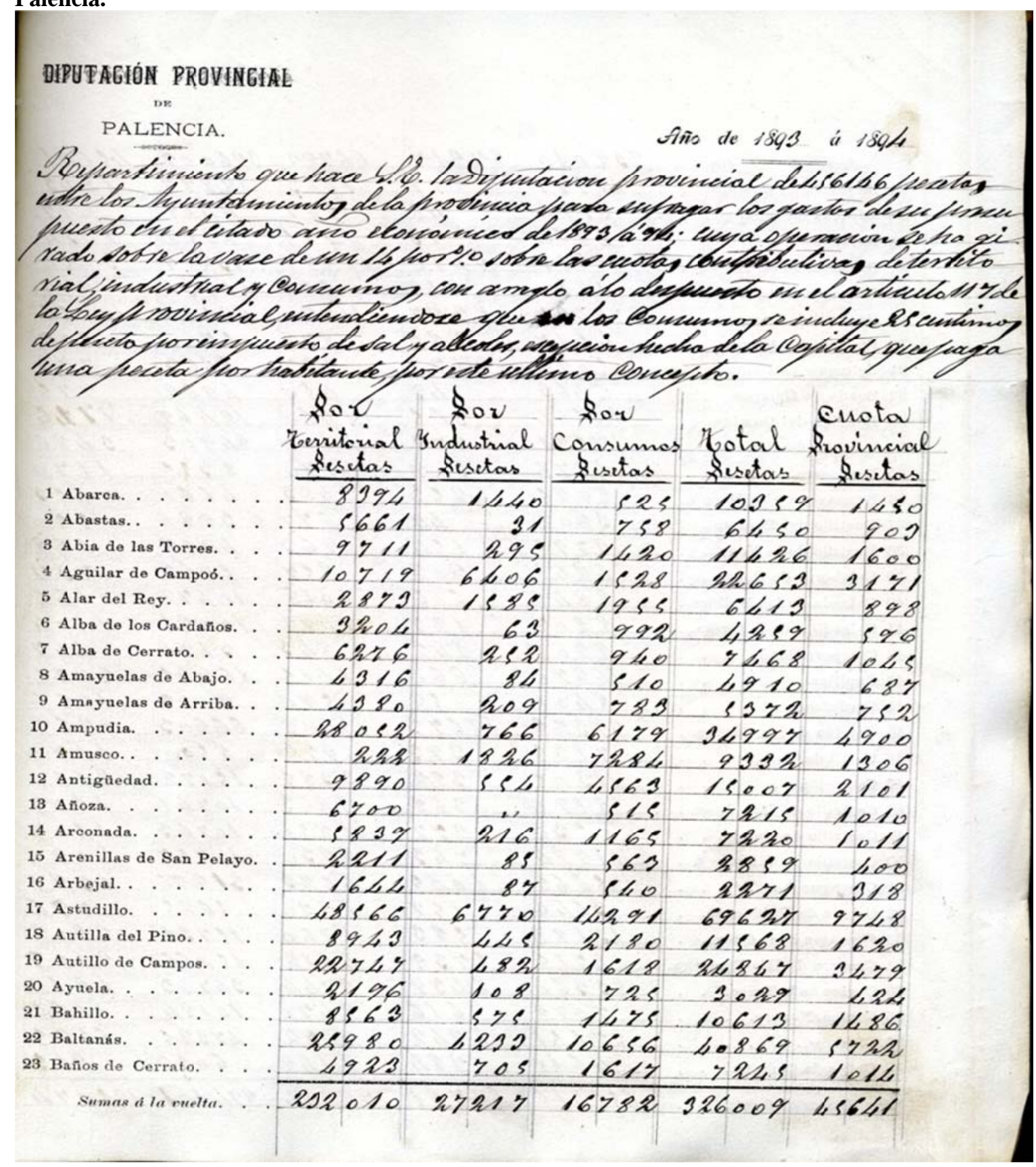

Fuente: A.D.P.P. 
En la exposición de motivos del Estatuto Provincial de 1925, Calvo Sotelo dejaba clara su intención de dotar a las diputaciones provinciales de un servicio de Hacienda eficaz que sirviese a los intereses reales de los pueblos de las provincias. La ausencia casi total de precedentes legales sobre esta materia fueron un obstáculo difícil de solventar para el legislador, porque en su opinión las haciendas provinciales, a diferencia de las haciendas municipales, «vegetan tal fueron creadas hace medio siglo.» ${ }^{604}$ Señalaba Calvo Sotelo el fracaso de los proyectos de Maura en 1907, y de Canalejas en 1912, que no aspiraban a transformar de forma drástica la vetusta maquinaria recaudatoria de la Restauración, y en ambos casos se mantenía el Contingente Provincial, una cuota que se recaudaba sobre las contribuciones que los pueblos pagaban al Tesoro, y era el único recurso hacendístico de entidad. El proyecto de Cambó de 1922 si contemplaba la supresión del Contingente Provincial, pero no la aportación municipal. A partir de la entrada en vigor del Estatuto Provincial de 1925, también integraban la Hacienda provincial recargos sobre otros impuestos, como los impuestos municipales que gravaban los solares sin edificar y los terrenos incultos, recargos sobre impuestos del Estado $^{605}$ y contribuciones especiales por obras y servicios, con derechos y tasas que las diputaciones provinciales podían imponer y percibir ajustándose a lo dictaminado en el Estatuto Provincial, junto con los arbitrios sobre la riqueza radicante en la provincia:

1. Un recargo de hasta el $100 \%$ sobre el arbitrio municipal que gravaba las solares sin edificar. Este recargo era liquidado por los respectivos ayuntamientos, a quienes en concepto de premio de cobranza abonaba la Diputación el 2\%.

2. Recargo del $100 \%$ sobre el arbitrio que gravaba los terrenos incultos.

3. Recargo del 20\% sobre las cuotas del Impuesto sobre Derechos Reales y Transmisión de Bienes.

4. Recargo del 10\% sobre el Impuesto del Timbre que correspondía al Estado en los actos, contratos o documentos que declaraba sujetos a tributación la Ley de 19 de octubre de $1920^{606}$.

\footnotetext{
${ }^{604}$ Estatuto Provincial de 1925 , p. 20.

${ }^{605}$ Derechos reales y Timbre.

${ }^{606}$ Modificada por la Ley de 26 de julio de 1922.
} 
Para completar la reforma de la Hacienda provincial, se autorizaban diversos recursos extraordinarios, como base de empréstitos destinados exclusivamente a sufragar gastos extraordinarios. Respecto del órgano estatal encargado de ejercer la acción tutelar en materia económica, este era el Ministerio de Hacienda y, en el terreno provincial, esta función recaía en el Ministerio de la Gobernación ${ }^{607}$. La administración y recaudación de los fondos provinciales estaba a cargo de las diputaciones provinciales, que la efectuaban mediante sus agentes y delegados. Los agentes de la recaudación eran responsables ante la Diputación ${ }^{608}$, quien a su vez era responsable civil subsidiaria, en caso de negligencia u omisión de los recaudadores. La Comisión Provincial de Palencia era consciente del malestar que generaba en los pueblos la presencia de los comisionados encargados de recaudar los débitos del Contingente Provincial, y así lo reflejaba en un escrito presentado en la sesión de julio de 1889:

«En la imposibilidad de que durante la presente estación puedan hacerse efectivos los descubiertos que por Contingente Provincial adeudan ayuntamientos, y considerando que la presencia de las comisiones en los distritos en el momento de hallarse practicando en estos las operaciones de recolección solo conduce al aumento del malestar económico que afecta a la Hacienda de los pueblos y a devengar costos que deben recaer única y exclusivamente sobre los concejales, la Comisión, en uso de las atribuciones que le confiere el párrafo 30, art. 98 de la Ley Provincial, acordó por mayoría, en 22 del corriente, la supresión de todas los apremios hasta el día 1 de septiembre próximo, que volverán contra los actuales deudores que para la fecha indicada no solventen sus descubiertos y para el día predicho no se hallen al corriente en el pago de lo repartido.» ${ }^{609}$

Para «(...) evitar a los pueblos la plaga de comisionados» ${ }^{610}$ encargados de solicitar los despachos ejecutivos, procedimiento que se utilizaba para la cobranza, en 1896 se creó un cuerpo especial de agentes ejecutivos con excelentes resultados que sin embargo, debido a lo escaso de sus sueldos, renunciaron a sus cargos en la mayoría de los casos. Se ofrecieron los despachos a los secretarios de los ayuntamientos, pero esta opción fue rechazada para evitar problemas con los pueblos inmediatos a los de su residencia.

\footnotetext{
${ }^{607}$ Calvo Sotelo consideraba que la vida económica provincial tenía profundos matices políticos y que, dado que en ocasiones se contraponían los intereses estatales y provinciales, era aconsejable que fuese el órgano político por excelencia del poder Ejecutivo quien ejerciese la función de inspección de la economía provincial.

${ }^{608}$ Art. 142 de la Ley Provincial de 29 de agosto de 1882.

${ }^{609}$ A.D.P.P., C-R / 99,5.

${ }^{610}$ A.D.P.P., Memoria Año Económico Primer Semestre 1896-1897, C-R / 1,10, p. 24.
} 
Finalmente para recaudar el pago del Repartimiento se hubo de volver a los comisionados que, en opinión de la Comisión Provincial «(...) en la generalidad de los casos, solo se cuidan de cobrar dietas que no han devengado.»» ${ }^{611}$

En la etapa dictatorial, la cobranza de los fondos provinciales estaba a cargo de la Comisión Provincial, y era esta institución la que nombraba a los agentes de la recaudación, que eran responsables ante ella ${ }^{612}$. Las Diputaciones podían arrendar el cobro de sus exacciones, a excepción de los siguientes:

1. Contribuciones especiales autorizadas en el art. $218^{613}$ del Estatuto Provincial de 1925.

2. Tasas de administración.

3. Recargo de arbitrio municipal sobres solares sin edificar.

4. Recargo de arbitrio municipal sobre terrenos incultos.

5. Recargos y cesiones cuya recaudación corriese a cargo del Estado.

Según la nueva normativa recaudatoria recogida en el Estatuto Provincial de $1925^{614}$, la Diputación Provincial debía intentar cobrar a domicilio los impuestos y arbitrios cuya recaudación tuviesen a su cargo. Además, las corporaciones provinciales podían establecer en sus ordenanzas de ingresos el abono recíproco de intereses de demora entre el Erario provincial y los contribuyentes en la forma en que lo determinaba el art. 560 del Estatuto Municipal ${ }^{615}$.

\footnotetext{
${ }^{611}$ A.D.P.P., Memoria Año Económico Primer Semestre 1896-1897, C-R / 1,10, p. 25.

${ }^{612}$ Art. 261 del Estatuto Provincial de 1925.

${ }^{613}$ Contribuciones de personas o clases especialmente interesadas en determinadas obras, servicios, o instalaciones provinciales, se debían acomodar a lo prevenido en el Real Decreto de 21 de febrero de 1922.

${ }^{614}$ Art. 210, Capítulo II.

${ }^{615}$ Estatuto Municipal: Art. 560. Salvo lo especialmente dispuesto en este libro, podrán los ayuntamientos establecer en sus Ordenanzas de ingresos el abono recíproco de intereses de demora entre el Erario municipal y los contribuyentes, en la siguiente forma: A) Cuando el Ayuntamiento, en virtud de reclamación presentada a su debido tiempo y en legal forma, acuerde devolver a algún contribuyente cuotas de impuestos o arbitrios municipales ingresados ya por éste en la Caja municipal, deberá abonarle intereses simples al 5\%, computables desde el décimo quinto día después del de la reclamación hasta el de la devolución. B) Los contribuyentes que por cualquier causa se retrasaren en el pago de cuotas de impuestos o arbitrios municipales más allá de quince días, a partir del último en que hubieran debido satisfacerlas, según las Ordenanzas correspondientes, abonarán junto con la cuota y con independencia de los recargos de apremio que procedan, intereses simples al 5\% a contar desde el décimo quinto día de aquel en que haya vencido la obligación hasta el día del pago.»
} 
Además del cobro del Contingente Provincial, hasta 1925, Las diputaciones provinciales podían exigir derechos y $\operatorname{tasas}^{616}$ por la prestación de servicios públicos que beneficiasen a personas determinadas o a requerimiento de estas:

1. Tasas de administración por los documentos que expidiese la Administración provincial a instancia de parte.

2. Servicios de laboratorios provinciales de Sanidad, Higiene, Agricultura, Enseñanza, Comunicaciones, y demás creados y sostenidos por la Diputación.

3. Asistencias y estancias en los hospitales, dispensarios, manicomios y establecimientos provinciales, cuando se trataba de personas pudientes, o sus gastos debían serlo por entidades que lo fuesen.

4. Enseñanzas técnicas, generales o profesionales.

5. Visitas de museos y exposiciones

\footnotetext{
${ }^{616}$ Además, las diputaciones podían establecer derechos y tasas sobre los aprovechamientos especiales de los que fuesen susceptibles las propiedades, servicios e instalaciones de las provincias destinadas al uso público o de común aprovechamiento.
} 
En la etapa de la Dictadura, las exacciones provinciales ${ }^{617}$ podían ser:

1. Contribuciones de las personas interesadas en determinadas obras, instalaciones o servicios provinciales ${ }^{618}$.

2. Derechos y tasas por el uso de determinados bienes, instalaciones o servicios provinciales de servicio público ${ }^{619}$, pero cuyo aprovechamiento no fuese de uso común, o en los que el uso público no excluyese un aprovechamiento especial por determinadas clases y personas.

3. Impuestos y arbitrios autorizados por la ley.

4. Multas en los casos y cuantía autorizados por la ley.

\footnotetext{
${ }^{617}$ Todas las reclamaciones sobre la aplicación y efectividad de las exacciones provinciales, tenían carácter económico administrativo a los efectos del procedimiento legal a seguir, debiendo entablarse ante el Tribunal Económico-Administrativo provincial. Cada exacción provincial era objeto de una ordenanza que había de ajustarse a lo dispuesto en los arts. 321 al 326 del Estatuto Provincial de 1925. La doctrina que regulaba los mencionados arts. 321 al 326, se refería a la forma de contribuir, a las exacciones legalmente acordadas, bases de percepción, tipos de gravamen, términos y formas de pago, responsabilidad por incumplimiento de la Ordenanza, fecha de aprobación de esta, comienzo de su vigencia y el plazo de vigor.

${ }^{618}$ Tenían la consideración de obras, instalaciones o servicio provinciales a efecto del Estatuto: $1^{\circ}$ Los que servían directamente al cumplimiento de los fines atribuidos por preceptos legales de la competencia de la Diputación, $2^{\circ}$ Los que por delegación del Estado realizasen las diputaciones provinciales y las obras públicas que tuviesen a su cargo por preceptos legales, $3^{\circ}$ Los que mediante subvenciones u otros auxilios a las diputaciones provinciales, ejecutasen el Estado, cualquiera de los municipios de la provincia, o la Mancomunidad a la que perteneciese la Diputación o empresa concesionaria.

${ }^{619}$ Tenían consideración de obras, instalaciones y servicios públicos los que servían directamente al cumplimiento de los fines atribuidos por preceptos legales de la competencia de las diputaciones, los que por delegación del Estado realizasen las diputaciones provinciales, y las obras públicas que tuviesen a su cargo por precepto legal, y los que mediante subvenciones u otros auxilios de las diputaciones provinciales ejecutasen el Estado, cualquiera de los municipios de la provincia o la empresa concesionaria.
} 
En la etapa de la Dictadura de Primo de Rivera, constituían la imposición provincial:

1. Arbitrios ordinarios o extraordinarios que las diputaciones venían aplicando con la aprobación del Gobierno, siempre que conservasen su forma consuetudinaria o que la modificación obtuviese el beneplácito de los ayuntamientos ${ }^{620}$.

2. Imposiciones sobre la riqueza de la provincia.

3. Contribuciones ${ }^{621}$ e impuestos que el Estado cedía total o parciamente a las diputaciones provinciales.

4. Arbitrios, impuestos y recursos que los ayuntamientos cedían total o parcialmente a las diputaciones provinciales.

5. Recargos provinciales autorizados sobre contribuciones y arbitrios del Estado, o de los ayuntamientos.

6. A partir del día 1 de julio de 1925, la percepción del Impuesto de Cédulas Personales $^{622}$, correspondió a las diputaciones provinciales. Era obligación de los ayuntamientos la formación del padrón y cobranza del mencionado impuesto, las diputaciones podían intervenir en esas operaciones al objeto de fiscalizarlas, y a realizarlas de forma directa cuando los ayuntamientos incurriesen en notoria negligencia o morosidad. El Impuesto de Cédulas Personales estaba regulado por tarifas ${ }^{623}$.

\footnotetext{
${ }^{620}$ Se entendía que los ayuntamientos prestaban su apoyo tácito a la modificación de un arbitrio provincial cuando la reforma había obtenido el voto favorable de la mayoría de los diputados corporativos y o se opusiesen a ella los diputados corporativos.

${ }^{621}$ Las diputaciones percibían el 5\% de las cuotas de Contribución Territorial que correspondían al Tesoro sobre la riqueza rústica y pecuaria existente en la provincia. Esta cesión era liquidada y abonada trimestralmente por las respectivas delegaciones de Hacienda.

${ }^{622}$ Estaban sujetos al pago del Impuesto Cédulas Personales, todos los españoles y extranjeros de ambos sexos, mayores de 14 años, domiciliados en la Península, islas adyacentes, Canarias y territorios de África con soberanía española. Estaban exentos de su pago, los pobres de solemnidad, las religiosas de clausura, y las Hermanas de la Caridad. También los penados en el tiempo de cumplimiento de su condena, los dementes recluidos en manicomios, y los militares y asimilados mientras se hallasen en servicio activo.

${ }^{623}$ Tarifa primera: por rentas de trabajo, Tarifa segunda: por contribuciones directas, Tarifa tercera: por alquileres, Tarifa primera: por rentas de trabajo. Véase Anexo VI. Tarifas Impuesto Cédulas Personales, p. 497.
} 
Dados los antecedentes negativos de las anteriores reformas de la Hacienda local $^{624}$, la Ley Provincial de 29 de agosto de 1882 contemplaba la posibilidad de que los recursos propios no fueran suficientes para financiar las necesidades presupuestarias de las diputaciones provinciales y posibilitaba a estas financiarse mediante un Repartimiento $^{625}$ entre los pueblos de la provincia en proporción de lo que, por contribuciones directas y por el Impuesto de Consumos ${ }^{626}$, pagase cada uno. Este impuesto se mostró a lo largo de su vigencia claramente insuficiente para sufragar el coste de las atenciones que las diputaciones provinciales tenían concedidas. En el caso particular de Palencia, la Diputación Provincial hubo siempre de luchar con la resistencia de los ayuntamientos a pagar este recargo impositivo ${ }^{627}$. A cuenta de este Impuesto surgieron divergencias ${ }^{628}$ en el seno de la propia Diputación Provincial, dada la importancia de la cuantía del mismo, pues se tomaba como referencia para la cuota a pagar del Contingente Provincial.

\footnotetext{
${ }^{624}$ Proyecto de Hacienda municipal y provincial de Laureano Figuerola de 19 de enero de 1870, que eliminaba las contribuciones estatales como fuente de financiación de las diputaciones provinciales.

${ }^{625}$ Para aprobar el Repartimiento se requería el voto de la mayoría absoluta del total de los diputados que correspondían a la provincia.

${ }^{626} \mathrm{La}$ Contribución sobre Consumos había desaparecido en el Sexenio Revolucionario, y con ella el recargo que se aplicaba como recurso provincial, pues se consideraba que gravaba los productos alimenticios y afectaba a las clases menos favorecidas, pero que suponía una fuente importante de recursos hacendísticos para las estatales, arcas provinciales y municipales. Fue reimplantado en 1874 .

${ }^{627} \mathrm{En} 1875$ a los ayuntamientos morosos se les aplicaba un recargo de 6\% anual. A.D.P.P., C-L/ 4,1. En ese año, 97 de los 247 pueblos consignados para el repartimiento debían alguna cantidad de dinero a la Diputación Provincial en concepto del Contingente provincial.

${ }^{628}$ En enero de 1882, varios diputados provinciales, Juan Solórzano, Rodríguez Olea y Pedro Herrero, mostraban su desacuerdo con las nuevas Bases que, de acuerdo con la Ley, había elaborado una Comisión especial nombrada por la Diputación Provincial a ese efecto y que clasificaban a los pueblos de la provincia en tres categorías, Art. 7 de la Ley de 31 de diciembre sobre Impuesto de Consumos. Pascual Herrero, elegido diputado provincial por Saldaña, catalogado de primera clase, protestaba porque opinaba que debería clasificarse como de segunda clase. Los diputados provinciales Yágüez Jalón, Valentín San Juan y Ambrosio Escobar, defendían el criterio de la Comisión especial a la hora de elaborar el dictamen sobre la citada clasificación. Por once votos a favor y seis en contra, se acordó mantener el dictamen de la Comisión especial. La clasificación era la siguiente: Primera Categoría: Astudillo, Baltanás, Carrión de los Condes, Barruelo, Paredes de Nava, Dueñas y Saldaña. Segunda Categoría: Torquemada, Amusco, Cevico de la Torre, Villaviudas, Osorno, Frómista, Cervera, Aguilar de Campoó, Frechilla, Villada, Villarramiel, Fuentes de Nava, Grijota, Becerril de Campos, Villamuriel de Cerrato, Herrera de Pisuerga y Guardo. Tercera Categoría: resto de pueblos de la provincia.
} 
Las quejas de la Comisión Provincial sobre la falta de recursos por la morosidad de los ayuntamientos aparecen continuamente reflejadas en las Actas de las sesiones y en las memorias económicas que elaboraba. En noviembre de 1883, por ejemplo, las arcas se encontraban exhaustas, no se había recaudado un solo céntimo por cuenta del ejercicio corriente y los atrasos ascendían a la cantidad de $401.464,65$ pts. $^{629}$. La Comisión Provincial arbitraba varias medidas para paliar la situación: acuerdo del 9 de noviembre de 1883 para el apremio contra los ayuntamientos que no se hallasen al corriente en sus pagos ${ }^{630}$, conforme al inciso $1^{\circ}$, art. 98 de la Ley Provincial de 29 de agosto de $1882^{631}$. De lo adeudado, se consiguió cobrar la cantidad de 209.652,07 pts. El alcalde del Ayuntamiento de Palencia propuso a la Diputación un concierto como medio de solventar los atrasos que adeudaba en concepto del Contingente Provincial y que en julio de 1883 ascendía a 67.091, 24 pts. ${ }^{632}$ La Comisión Provincial señalaba, en la Memoria del Segundo Semestre del Año Económico 1884-85, la necesidad de tomar medidas urgentes «(...) para no ser los últimos en la senda de la prosperidad y del progreso.» ${ }^{633}$ La Comisión Provincial temía que de no a revertir la situación de parálisis de la Corporación Provincial creada por la falta de recaudación, se corría el riesgo de que el Gobierno llegase a pensar en la utilidad de la provincia y la agregara a otra «(...) que tenga una idea más elevada de las importantes atribuciones que la Ley vigente confiere a estos organismos que tienen y deben tener vida propia.» ${ }^{634}$

\footnotetext{
${ }^{629}$ A.D.P.P., Memoria Año Económico Segundo Semestre 1883-1884, C-R / 1,23.

${ }^{630}$ Las Reales Órdenes de 19 de marzo de 1879 y 30 de abril de 1880 , responsabilizaban a los ayuntamientos de los débitos de sus vecinos con la provincia.

${ }^{631}$ Procurar la exacta ejecución de los acuerdos de la Diputación Provincial, recurriendo al gobernador o al Gobierno, según proceda, en casos de omisión, negligencia u oposición por parte de las corporaciones, empleados, dependientes o particulares encargados de cumplir dichos acuerdos.

${ }^{632} \mathrm{La}$ Diputación accedió a que la deuda se subsanase en ocho anualidades, a razón de 8.386 pts. cada anualidad, hasta el 30 de junio de 1891. Cada mes el Ayuntamiento debía ingresar en la Depositaría de los fondos provinciales la cantidad de 698,86 pts. El Concierto quedaba anulado si no se pagaba alguna mensualidad. A.M.A.P., L.A.P.A., A-21-100, 8-VIII-1883.

${ }_{633}$ A.D.P.P., Memoria Segundo Semestre Año Económico 1884-85, C-R/ 1,4, p. 6.

${ }^{634}$ A.D.P.P., Memoria Segundo Semestre Año Económico 1884-85, C-R/ 1,4, p. 7.
} 
Otros pueblos se acogieron a la fórmula del concierto ${ }^{635}$ para pagar sus deudas con la Diputación Provincial, como Frómista o Grijota, en 1883. Entre quince y veinte pueblos se encontraban en un estado tan anómalo en el pago del Contingente provincial que la Diputación juzgaba imposible obtener el pago de la deuda si se les exigía de una sola vez y, en consecuencia, se autorizaba a la Comisión Provincial para que celebrase conciertos con los pueblos ${ }^{636}$, fijando plazos para satisfacer las cantidades adeudadas ${ }^{637}$. La Comisión Provincial señalaba, en la Memoria del Segundo Semestre del Año Económico 1883-1884, la necesidad de que los pueblos comprendieran que si la Diputación tenía que realizar los fines ${ }^{638}$ que se determinaban en el párrafo $1^{\circ}$, del art. 74 de la Ley Provincial de 29 de agosto de 1882, era preciso satisfacer con puntualidad las cantidades repartidas en las contribuciones, que no eran suficientes para cubrir todos los servicios que prestaba la Diputación, y recordaba que el presupuesto de la Diputación de Palencia era el más bajo de todas las diputaciones de Tercera Clase. Además de la pereza fiscal de los pueblos, parte del problema en la recaudación de los impuestos provinciales era la insuficiente dotación de medios personales de la Diputación Provincial de Palencia dedicados a esta labor.

\footnotetext{
${ }^{635} \mathrm{Con}$ el tiempo, los conciertos se fueron formalizando bajo la base de un máximo de veinte anualidades para el Ayuntamiento de Palencia y diez para el resto.

${ }^{636}$ Solo se concedía a los pueblos que adeudasen, por lo menos, el importe íntegro del Contingente Provincial de dos presupuestos. Para suspender el apremio era condición indispensable satisfacer el $10 \%$ de lo adeudado por atrasos en el acto de solicitud de concierto, pagando el resto en los años que la Comisión Provincial señalase y con el 6\% de intereses de demora, Instrucción de 20 de abril de 1884. Por el art. 65 de esta Instrucción, se declaraba responsables a los concejales y alcaldes de los impagos municipales en caso de negarse las corporaciones municipales a pagar las deudas.

${ }^{637}$ Se formó una Comisión encargada de gestionar con el delegado de Hacienda y el Banco de España, la retención que estas instituciones hacían del $4 \%$ ingresado en sus cajas por el concepto de municipalidades, lo que les impedía cumplir con sus obligaciones tributarias con la Diputación Provincial. A.D.P.P., L.A.CP. 55, 5-II-1883.

${ }^{638}$ Beneficencia (huérfanos, expósitos, ancianos), hospitales, Instrucción pública, bagajes, caminos y carreteras.
} 
En 1884, la Comisión Provincial advertía de la necesidad de que la Sección de Cuentas provincial se instalase en un local independiente de la Oficina de Gobierno ${ }^{639}$, para que «(...) los empleados de cuentas no se consagraran a otros trabajos más que a los relativos al examen de estas y buena falta, hace por cierto, porque hay ayuntamientos que no han rendido cuentas desde hace veinte años.» ${ }^{640}$ La necesidad de destinar el personal de cuentas a las operaciones de reemplazo durante tres meses, producía un retraso en el examen de cuentas municipales ${ }^{641}$. En ese año, aún había pendientes de cobro créditos procedentes de los recargos sobre las contribuciones de Territorial, Industrial, Consumos y Sal, que a la Diputación correspondía percibir en los años en que su cobranza había estado a cargo del Estado ${ }^{642}$, y que no podían cobrarse por falta de la liquidación correspondiente, ni saberse su cuantía, y que fueron reclamados sin eficacia desde el año 1877. La situación, lejos de mejorar, empeoró en los siguientes años y en julio de 1887, la Diputación se encontraba en descubierto ${ }^{643}$ con todos los contratistas de suministros y obras públicas, por falta de los ingresos consignados en el Presupuesto, y sin la realización de los recursos provinciales repartidos ente los ayuntamientos con arreglo a la Ley Provincial de 29 de agosto de 1882. Todas las obligaciones quedaron desatendidas, incluidas las de Beneficencia. Puesto que la Ley ${ }^{644}$ capacitaba a la Diputación para el nombramiento y suspensión de las comisiones de apremio, y en su defecto a la Comisión Provincial, esta acordó, en la sesión del 26 de agosto de 1887, que la Contaduría enviase una circular a todos los ayuntamientos solicitando el pago del Contingente Provincial.

\footnotetext{
${ }^{639}$ Las oficinas de la Diputación se encontraban en el ex convento de San Francisco desde la década de 1840 y compartían el edificio con la Delegación de Hacienda y el Gobierno Civil.

${ }^{640}$ A.D.P.P., Memoria Año Económico Segundo Semestre 1883-1884, C-R/ 1,23, p. 28. Ocho años después la situación no había mejorado y la Diputación Provincial se vio obligada a contratar a dos agentes ejecutivos, previo examen, para actualizar las cuentas atrasadas de los ayuntamientos. Los sueldos de estos agentes corrían por cuenta de los ayuntamientos morosos.

${ }^{641}$ Facultad conferida a la Diputación Provincial por el art. 23 de la Real Orden de 31 de mayo de 1886, art. 54 de la Instrucción de 1 de junio de 1886, y Real Orden de 2 de diciembre de 1891. A.D.P.P., Memoria Año Económico Primer Semestre 1898-1899, C-R/1,15.

${ }^{642}$ A.D.P.P., Memoria Año Económico Primer Semestre 1883-1884, C-R / 1,12, p. 26.

${ }^{643}$ A.D.P.P., Expedientes de descubierto, C/ 99,5.

${ }^{644}$ Art. 114 de la Ley Provincial de 29 de agosto de 1882.
} 
En 1893, La Comisión Provincial esperaba que la reforma de la Ley Municipal $^{645}$ produjese mejor resultado que las multas empleadas para normalizar la situación de los pueblos, que a pesar de los requerimientos de la Diputación y el Gobierno civil no cumplían y adeudaban cantidades desde hacía años ${ }^{646}$. La esperanza de la Comisión Provincial no se cumplió, como da fe el hecho de que aún, en 1896, persistían las dificultades para cobrar el Repartimiento. Además de la baja producción agrícola $^{647}$, fuente principal de la riqueza de la provincia, la principal causa que impedía que se cobrasen las cantidades adeudadas era la resolución de la Junta Central del Censo Electoral de 15 de diciembre de $1890^{648}$. La Comisión Provincial, a pesar de estar en contra del espíritu de esa resolución, no despachó ninguna ejecución durante el periodo de las elecciones generales de diputados a Cortes y senadores y las que se celebrarían en septiembre para renovar la Asamblea en los distritos de Astudillo-Baltanás, CarriónFrechilla y Palencia, suspendiendo además los procedimientos contra los ayuntamientos morosos.

\footnotetext{
${ }^{645}$ Establecía la incapacidad electoral activa y pasiva para todos los que no hubiesen rendido sus cuentas, bien como concejales, bien como depositarios y recaudadores.

${ }^{646} \mathrm{La}$ cantidad que se adeudaba por los repartimientos anteriores al ejercicio 1892-93, del ejercicio $1892-$ 93 y del primer trimestre de 1893-94, era de 220.462, 90 pts. La cantidad existente en las arcas provinciales, a fecha de 31 de marzo de 1893, era de 295.762, 05 pts. A.D.P.P., Memoria Año Económico Primer Semestre 1893-1894, C-R / 1,11.

${ }^{647}$ Entre otras causas, por la falta de mano de obra por el llamamiento de los reservistas del reemplazo de 1891, a los excedentes de cupo de los años 1893, 1894 y 895 y a los sorteados el 13 de septiembre de 1896, por el conflicto cubano. Además , también tenían influencia sobre la cobranza del Repartimiento, principal fuente de ingresos de la Diputación Provincial, los fenómenos atmosféricos como las tormentas y otros, como la sequía y las heladas, que disminuían la producción de cereales y caldos y aumentaban las deudas pendientes de recaudar.

${ }^{648} \mathrm{La}$ resolución tipificaba como delito la cobranza del Contingente Provincial durante el periodo electoral en el párrafo $2^{\circ}$ de art. 91 de la Ley de 26 de junio de 1890. En junio de 1893, la Comisión de Hacienda había dirigido un escrito a la Diputación en el que señalaba que la Comisión Provincial no podía recaudar el Contingente Provincial durante el periodo de elecciones y, en el caso de las elecciones municipales, no se podía apremiar.
} 
Si los bienes propios ${ }^{649}$ y los impuestos no eran suficientes, algo que sucedía con frecuencia en la etapa decimonónica de la Restauración, las diputaciones estaban autorizadas por ley a establecer arbitrios especiales, con la aprobación del Gobierno y el consentimiento de los pueblos ${ }^{650}$. No obstante, los recursos de los municipios eran escasos y las diputaciones se veían a menudo obligadas a contratar empréstitos ${ }^{651}$ para poder sufragar las atenciones que por ley tenía concedidas. El Estatuto Provincial de 1925, facultaba a las diputaciones para apelar al crédito público, emitiendo a corto o largo plazo empréstitos ${ }^{652}$. Las diputaciones no podían acordar la emisión ni puesta en circulación de empréstitos ${ }^{653}$ si su producto no iba destinado íntegramente a la creación de servicios propios de la competencia provincial, tampoco podían las corporaciones provinciales arbitrar, por vía de empréstito ni mediante uso del crédito, recursos aplicables a satisfacer obligaciones ordinarias.

\footnotetext{
${ }^{649}$ Algunos agentes y apoderados encargados por los ayuntamientos de la cobranza de los intereses del $80 \%$ de los bienes propios, cobraban por sus servicios 2.5000 pts. por la cobranza de 10.000 pts. En 1887 , la Diputación Provincial se ofreció a cobrar esos intereses de forma gratuita. En 1888, se acordó entre los pueblos de la provincia y la Diputación que, a través del depositario provincial, la diputación se encargarse de cobrar los intereses de bienes propios. En 1888, la Diputación Provincial mantuvo una fuerte polémica con el periódico La Ley de Madrid, a cuenta de la circular de la Diputación Provincial a los ayuntamientos de la provincia para que se pronunciasen sobre la posibilidad de que la cobranza de sus inscripciones se realizase por la institución provincial, a lo que la mayoría de las corporaciones municipales contestaron afirmativamente. El periódico se denominaba La Ley. Política-AdministraciónIndustria-Agricultura. Se editaba en Madrid, pero por desgracia no se conserva más que un número de enero de 1892, en Prensa Histórica, en el que no se menciona el hecho descrito en el Libro de Actas de la Comisión Provincial, dado que este sucedió en el año 1888. La Comisión Provincial se negó a expedir a favor de un agente de apremio, verificación del ejercicio de su profesión con honradez lo que provocó las críticas del citado periódico. En opinión del vocal d la Comisión Provincial Nieto, el periódico «(...) altera los hechos, diciendo que la Diputación tiende las redes para que caigan los pueblos incautos, que conculcamos las leyes, que solo hemos conseguido la apoderación de alguna que otra aldea, cuando, en realidad, se cuenta con los poderes de las más importantes municipalidades» .A.D.P.P., L.A.C.P. 67, 20III-1888.

${ }^{650}$ Art. 119 de la Ley Provincial de 29 de agosto de 1882.

${ }^{651}$ Las contracciones de deuda por las diputaciones provinciales debían ser aprobadas por el Gobierno, y no por ley.

${ }^{652}$ Librando letras de cambio o expidiendo pagarés a la orden con vencimiento no superior a los noventa días, contra la Caja provincial.

${ }^{653}$ Las diputaciones podían lanzar al mercado los títulos de empréstitos empleando variados procedimientos: venta en firme, mediante subasta pública, asegurada o no por bancos, y negociación en Bolsa por medio de agente colegiado.
} 
Con el único fin de atender el pago de los intereses y amortizaciones de los empréstitos legalmente acordados, las diputaciones provinciales podían establecer una serie de recargos:

1. Un recargo que no excediese del $10 \%$ de lo que por Contingente Provincial se había repartido a cada Ayuntamiento en el año económico 1924/25.

2. Un recargo de hasta el $10 \%$ sobre las tarifas máximas aprobadas y en vigor para la percepción de los arbitrios provinciales vigentes en cada Diputación Provincial.

3. Un nuevo recargo de soltería sobre el impuesto de cédulas personales, hasta un $50 \%$ del recargo autorizado en el art. 227 en las tres tarifas.

4. Un recargo hasta el 10\% sobre las cuotas del Tesoro de la Contribución Rústica y Pecuaria devengadas en el territorio de la provincia.

5. Un recargo hasta el 5\% sobre el Impuesto de Cédulas Personales, con la excepción siempre de la especial del cónyuge, y de la clase $13^{\mathrm{a}}$ de la tarifa tercera.

La autorización de estos recargos correspondía al Ministerio de la Gobernación, previo informe del Ministerio de Hacienda y cumplimiento de lo dispuesto en el art. $528^{654}$ del Estatuto Municipal. La Diputación Provincial palentina fue siempre una defensora convencida de la necesidad de conceder autonomía fiscal a las diputaciones y en 1921, se mostraba de acuerdo con las conclusiones aprobadas por la Asamblea de diputaciones provinciales celebrada en Madrid en diciembre de ese año ${ }^{655}$, en la que, entre otras cuestiones, se solicitaba que se concediese a las corporaciones provinciales plena autonomía para elegir arbitrios ${ }^{656}$, más en consonancia con la vida propia de cada una, aunque se mantuviese la necesidad de la aprobación del Estado.

\footnotetext{
${ }^{654} \mathrm{La}$ autorización de los recargos extraordinarios correspondía al Ministerio de Hacienda, previa comprobación de que, en la tramitación del Presupuesto Extraordinario de Gastos y en el cálculo de la cifra del empréstito, se habían observado todas las prescripciones del Estatuto Municipal de 1924, y de que la importancia de las obras proyectadas justificaba el aumento de la carga.

${ }^{655}$ Que tenía como objeto el estudio y reforma de las haciendas provinciales.

${ }^{656}$ En 1920 ante la pretensión por parte de la Diputación de imponer un arbitrio sobre carbones en acuerdo adoptado el 21 de enero de 1920, previa autorización del Ministerio de la Gobernación, Ángel Huidobro, presidente de la Asociación Patronal de Mineros de la Provincia, presentaba recurso de alzada contra este acuerdo, así como Juan Díaz Caneja, en representación de la Sociedad Carbonera Española. La Diputación creía que «Nada más justo que la minería, coopere con las demás fuentes de riqueza al levantamiento de cargas». A.D.P.P., L.A.P.D. 128, 18-II-1920.
} 
Los presupuestos de las cuarenta y cinco diputaciones de Régimen Común y de la Mancomunidad de Cataluña, sumaban, en 1925, aproximadamente cien millones de pts., de los cuales unos 71 millones procedían del Contingente Provincial, correspondiendo el resto a varios conceptos ${ }^{657}$, con una cifra de unos seis millones de pts. en $\operatorname{arbitrios}^{658}$. No obstante, la recaudación era muy dispar en las diferentes provincias, así algunas, como Madrid y Santander, recaudaban más del 95\% del contingente, otras como Huelva, Palencia o Cádiz, no llegaban al 70\%, quedando en general reducido el centenar de millones en un $10 \%$ como consecuencia de morosidades y fallos recaudatorios ${ }^{659}$.

La Ley Provincial de 29 de agosto de 1882 autorizaba a las diputaciones provinciales a aplicar los medios de apremio ${ }^{660}$ a primeros y segundos contribuyentes dictados a favor del Estado para hacer efectiva la recaudación ${ }^{661}$. Podían embargarse todos los bienes muebles y semovientes del deudor, incluso los ganados y todos los frutos agrícolas ya recolectados. Se exceptuaban los siguientes bienes:

1. Ganados destinados a la labor y acarreo de frutos de la tierra cultivada por el deudor,

2. Carros, arados y demás aperos de labranza, libros, instrumentos y herramientas que el deudor necesite para el ejercicio personal de su profesión,

3. La casa del deudor y su familia, la ropa de uso diario del deudor y su familia y los equipos y armas de los militares de acuerdo a su grado.

4. Si se procedía contra los sueldos o pensiones, solo se embargaba la cuarta parte de ellos, si no llegaban a 2.000 pts. anuales, una tercera parte en los sueldos de entre 2.000 a 4.500 pts. y la mitad en los sueldos de 4.500 pts. en adelante.

\footnotetext{
${ }^{657}$ Rentas propias y tasas por servicios de los establecimientos provinciales.

${ }^{658}$ Estatuto Provincial de 1925, p. 21.

${ }^{659}$ En el primer semestre de 1929, el recién creado Servicio de Recaudación y Tributos del Estado, había recaudado un $92,33 \%$ en la provincia de Palencia, el mayor de todas las provincias de España. El porcentaje anual fue de un 91,675, también el más alto a nivel estatal. A.D.P.P., L.A.C.P. 146, 11-I-1930. ${ }^{660}$ En 1882, en una sesión de la Comisión Provincial, se acordaba enviar comisiones de apremio contra todos los pueblos que se hallasen en descubierto de sus cuotas del Repartimiento Provincial ante el «(...) angustioso estado de fondos de la Caja Provincial que no permite satisfacer ni aun las más apremiantes atenciones». A.D.P.P., L.A.C.P. 58, 22-V-1882.

${ }^{661}$ Art. 114 de la Ley Provincial de 29 de agosto de 1882.
} 
El procedimiento de ejecución para la venta de bienes muebles y semovientes era el siguiente:

1. El comisionado de la Diputación pasaba el expediente al alcalde del Ayuntamiento solicitando una providencia de apremio inmediata para convertir en definitivo el embargo preventivo hecho al deudor.

2. El comisionado, acompañado de dos testigos auxiliares que proporcionaba el alcalde, se personaba en la casa del deudor y procedía a realizar la traba ${ }^{662}$ de los bienes muebles y semovientes necesarios para cubrir el descubierto del deudor por principal, recargos y costes.

3. Hecha la traba, el comisionado requería al deudor para que nombrase depositario, si se negaba a nombrarle o el nombrado no aceptaba el nombramiento, el comisionado era el encargado de nombrar depositario de los bienes embargados.

4. El deudor nombraba un perito para la tasación de los bienes embargados, lo propio hacia el comisionado y en caso de discordia, el alcalde nombraba un tercer perito.

5. Hecha la tasación, el alcalde decretaba la venta y se notificaba al deudor el decreto de venta.

6. La subasta se realizaba bajo la presidencia del alcalde. Se consideraba postura inadmisible la que no cubriese los dos tercios de la tasación

7. Si no había ninguna postura, si el comisionado ejecutor lo consideraba oportuno, todo o parte de los efectos embargados eran trasladados a otro pueblo donde fuese más fácil la venta.

8. Si aun así no se podían vender los bienes suficientes para cubrir el débito, se ponían a la venta los bienes restantes durante cinco días en pública almoneda, valorando los bienes en la tercera parte del tipo que sirvió de base en la primera subasta.

\footnotetext{
${ }^{662}$ Embargo de bienes
} 
El procedimiento de ejecución contra bienes inmuebles se ejecutaba de la siguiente forma:

1. El comisionado procedía a notificar la providencia de apremio al deudor y efectuaba de forma inmediata el embargo. Al mismo tiempo se requería al deudor que exhibiese los títulos de propiedad.

2. A continuación, el comisionado procedía a capitalizar las fincas rústicas al 4\%, por el líquido imponible si estaban arrendadas, y sobre las dos terceras partes del líquido imponible ${ }^{663}$ si el dueño cultivaba las tierras. Las fincas urbanas se capitalizaban al 5\% sobre la base del líquido imponible.

3. El alcalde declaraba la providencia de apremio fijando la fecha de celebración de la subasta, quince días después del anuncio de la misma.

En caso de ser responsable el Ayuntamiento, bien por no haber recaudado una contribución, bien por no haber ejecutado en tiempo oportuno el Contingente Provincial o porque sus disposiciones hubiesen entorpecido la recaudación de impuestos, se procedía de la siguiente forma:

1. Declarada la responsabilidad del Ayuntamiento, la autoridad económica enviaba al alcalde Oficio certificado, en el cual se especificaba el débito y se ordenaba disponer lo necesario para su cobro.

2. El alcalde citaba a los concejales para celebrar sesión del Ayuntamiento.

3. En esa sesión, el alcalde conminaba a los responsables a pagar la deuda dentro del tercer día desde su comunicación y daba cuenta a la autoridad económica del objeto de la sesión.

4. Si los responsables efectuaban el pago dentro de los días señalados, se daba por finalizado el expediente.

5. Si los responsables no pagaban, la autoridad económica abría expediente, encabezado con la declaración de responsabilidad.

6. A continuación, se nombraba un comisionado ejecutor con un despacho especial autorizándole a personarse en el pueblo y entablar la vía de apremio contra los deudores.

7. El comisionado se presentaba al alcalde con el despacho y le requería para que entablase la vía de apremio.

\footnotetext{
${ }^{663}$ Cuantía fijada sobre la riqueza de contribuyente que servía como base para señalar su cuota tributaria.
} 
8. El embargo se hacía comenzando por los bienes muebles y semovientes y, si eso no era suficiente para cubrir el débito, se continuaba con los bienes inmuebles.

Toda esta normativa hacendística se justificaba por la demora de los ayuntamientos en el pago del Contingente Provincial, que por poner solo un ejemplo, a 31 de octubre de 1896, la cantidad total adeudada a la Diputación Provincial en concepto de descubiertos por el cobro de este impuesto ascendía a $217.370,90$ pts. ${ }^{664}$ En 1900, se aprobó una nueva instrucción ${ }^{665}$ de apremios para el cobro de deudas, que permitía retener hasta el $66 \%$ de los ingresos municipales para saldar las deudas que impedían que la Diputación Provincial hiciese frente a sus obligaciones presupuestarias $^{666}$. Muchos ayuntamientos estaban al corriente del pago con el Estado pero, de forma reiterada no pagaban ${ }^{667}$ a la Diputación, lo que les correspondía en concepto del Contingente Provincial. El arriendo de la recaudación de este impuesto, en los términos que lo verificaba el Estado, suponía, en opinión de la Comisión Provincial, una buena medida para solucionar el problema de las deudas ${ }^{668}$. Otra posibilidad contemplada para el cobro de las deudas pendientes era el nombramiento de siete ejecutores, uno por Partido Judicial, que llevaran a cabo la revisión de oficio de las cuentas municipales atrasadas.

\footnotetext{
${ }^{664}$ A.D.P.P., Memoria Año Económico Primer Semestre 1896-1897, C-R / 1,10.

${ }^{665}$ Instrucción de 26 de abril de 1900 . Esta Instrucción permitía retener el $66 \%$ de los ingresos que recibía el ayuntamiento en primer lugar y en segundo lugar, se podía retener los bienes de los concejales.

${ }^{666}$ En la sesión del Pleno de la Diputación, del día 1 de octubre de 1902, el gobernador llamaba la atención sobre el hecho de que el Ayuntamiento de la capital fuera el mayor deudor de la Diputación Provincial, «(...) y claro está que su conducta repercute en los pueblos, quienes tienen que ofrecer alguna resistencia al pago del Contingente, haciendo con esto imposible la vida provincial.» A.D.P.P., L.A.P.D. 94, 1-X-1902.

${ }^{667}$ En 1908, los alcaldes de 24 pueblos de la provincia solicitaron a la Diputación que se disminuyese el Contingente que se les había repartido, y se hacían eco de los rumores que señalaban como causa de la elevación de las cuotas del Impuesto la construcción del edificio de la Diputación Provincial, el palacio provincial.

${ }^{668}$ A.D.P.P., Memoria Año Económico Primer Semestre 1900, C-R / 1,14.
} 
En 1910, se aprobaban las condiciones que habían de regir en el contrato ${ }^{669}$ de arriendo de la recaudación del contingente provincial de 1910-11 ${ }^{670}$ :

1. La duración del contrato era hasta el 31 de diciembre de 1914, prorrogable 3 años más, si ninguna de las partes manifestaba el propósito de suspender el servicio. El servicio comenzó a regir el 1 de enero de 1911.

2. El premio de cobranza que recibía el contratista era del 3\%, sobre las cuotas corrientes, y el 5\%, sobre los ingresos de atrasos, premios cobrados por trimestres vencidos.

3. El contratista se comprometía a entregar a las arcas provinciales, el último día hábil de cada mes, una cantidad que, unida a los ingresos realizados directamente en Caja Provincial por los ayuntamientos, representase la doceava parte de los repartimientos aprobados.

4. Respecto a los débitos por atrasos, el contratista se comprometía a ingresar, en cada trimestre, la cantidad correspondiente por dicho concepto, verificándose el último día hábil de los meses tercero, sexto, noveno y doceavo.

5. La cobranza se dividía en dos periodos: el voluntario, los dos primeros meses de cada trimestre, y el ejecutivo, el día primero de los meses tercero, sexto, noveno y doceavo, en los que el contratista desplegaría los apremios con arreglo a la Instrucción de 26 de abril de 1900.

6. Los ayuntamientos podían reclamar ante la Diputación o la Comisión Provincial, contra las infracciones legales de la citada Instrucción cometidos por el contratista o sus agentes.

\footnotetext{
${ }^{669} \mathrm{El}$ objetivo de este contrato era la recaudación en toda la provincia de las cuotas que debían satisfacer los ayuntamientos a la Diputación por el concepto de Contingente de años anteriores con arreglo a los conciertos celebrados entre los ayuntamientos y la Diputación para el pago de los atrasos, cuotas del Repartimiento de Segunda Enseñanza y cualquier otro Repartimiento.

${ }^{670} \mathrm{La}$ recaudación del Contingente Provincial se concedió a los hermanos Espegel.
} 
En 1913 se habían suscrito varios conciertos entre la Diputación Provincial y algunos ayuntamientos para el pago de las deudas por resultas de contingente provincial, Segunda Enseñanza y Caminos vecinales. Contaduría proponía a la Comisión Provincial, en marzo de ese año, que se remitiesen a los ayuntamientos a quienes se había concedido concierto, relación de las cantidades adeudadas para que prestasen su conformidad a los plazos y cantidades que debían ingresar anualmente, devolviendo a contaduría copia firmada por los ayuntamientos interesados ${ }^{671}$.

El Estatuto Provincial de 1925, explicitaba el procedimiento de apremio que establecían las disposiciones vigentes para los débitos la Hacienda Pública ${ }^{672}$, dirigiéndose en primer término sobre las rentas e ingresos de los municipios que podían retener en un $20 \%{ }^{673}$. El embargo se limitaría, en primer lugar, al 9\% de las rentas cuando la Hacienda Pública, conforme a lo dispuesto en la Instrucción de 26 de abril de 1900, hubiese retenido el $66 \%$, ya que en ningún caso podían producirse embargos acordados por el Estado y la Diputación Provincial ${ }^{674}$ del $75 \%$ de los ingresos de un mismo Ayuntamiento. Una vez iniciado el procedimiento de apremio, el presidente de la Diputación lo ponía en conocimiento del alcalde respectivo. Si el Ayuntamiento se oponía al procedimiento, el alcalde debía comunicarlo al presidente de la Diputación Provincial en el plazo de cinco días, institución que, de continuar con el procedimiento, debía elevar en los cinco días siguientes todos los antecedentes al Tribunal Provincial de lo Contencioso, para que este resolviese en única instancia ${ }^{675}$. La Administración Provincial tenía la obligación de promover la investigación de los tributos y, para este fin, podía reclamar todos los antecedentes y documentos necesarios de particulares, autoridades y funcionarios de cualquier orden. Asimismo, la Diputación Provincial tenía la facultad de imponer las sanciones ${ }^{676}$ correspondientes en los casos de ocultación o defraudación.

\footnotetext{
${ }^{671}$ A.D.P.P., C $100 / 4$

${ }^{672}$ Atrasos de los ayuntamientos a la Diputación por recursos o recargos provinciales cuya recaudación correspondía a los primeros o las cuotas del Repartimiento Provincial.

${ }^{673}$ Instrucción de apremio de 26 de abril de 1900.

${ }^{674} \mathrm{Las}$ diputaciones provinciales no podían dictar reglas sobre los trámites y recargos de los procedimientos recaudatorios y las facultades de los agentes ejecutivos que excedieran en rigor o ampliasen las competencias de la Hacienda del Estado.

${ }^{675}$ No podía ser objeto de recurso de apelación. Art. 271 del Estatuto Provincial de 1925.

${ }^{676}$ Las multas que se imponían por el incumplimiento de las ordenanzas de exacciones debían satisfacerse con el papel creado al efecto por la entidad provincial, la parte superior del papel se entregaba a los multados, constando en este documento la causa, cuantía de la multa y la fecha en que se debía abonar, firmado por el funcionario autorizado, la parte inferior se unía al expediente de sanción como comprobante.
} 
La Diputación pretendía recaudar las contribuciones y los impuestos del Estado en la provincia, y puesto que se había aprobado, el 26 de junio de 1926, el Reglamento de funcionarios civiles de la Diputación, se contemplaba la creación de un servicio recaudatorio ${ }^{677}$. Si el Estado finalmente concedía la recaudación de sus impuestos a la Diputación $^{678}$, se implantaría un servicio combinado para la cobranza de las contribuciones y de cédulas personales al que se añadiría la Caja Provincial de Ahorros $^{679}$. Se defendía la implantación de la Caja Provincial de Ahorros, al pensar que fomentaría el ahorro por las facilidades que suponía para el ciudadano el poder efectuar las operaciones en su propio pueblo, sin desplazarse a la capital, y a su vez la recaudación de las contribuciones y las cédulas se realizarían con mayor eficacia por la facilidad que para los contribuyentes supondría el no tener que sujetarse al pago del impuesto en el poco tiempo que permanecían en la localidad los recaudadores que efectuaban la cobranza del mismo.

Para demostrar la eficacia de los servicios provinciales en la gestión de la recaudación de impuestos, la Diputación palentina elaboró una Memoria en la que se comparaba el estado de la recaudación de impuestos en que el cobro estaba arrendado, tomando como referencia el ejercicio económico $1923 / 24^{680}$, y el año 1927, en la que la recaudación de los ingresos propios de la Diputación se realizó de forma directa, sin estar arrendados. La Diputación Provincial recaudaba sus recursos de forma directa y de forma indirecta ${ }^{681}$.

\footnotetext{
${ }^{677}$ En el Presupuesto Especial de Gastos del Presupuesto de 1929, en el art. 2 del Capítulo Único «Ingresos generales», se destinaban 30.000 pts. para los primeros gastos de la implantación del Servicio de Recaudación de la Diputación Provincial con el que se esperaba recaudar 225.00 pts. A.D.P.P., C-L/ 14,1 .

${ }^{678}$ El Real Decreto de 5 de septiembre de 1928 otorgaba a las diputaciones provinciales la recaudación de los impuestos del Estado en la provincia a partir de enero de 1929.

${ }^{679}$ A.D.P.P., Memoria de desenvolvimiento y situación económica de los ejercicios 1923/24 -1927. C-R/ $1,19$.

${ }^{680} \mathrm{Se}$ tomaba como referencia el ejercicio de 1923/24, por ser este el que estaba en vigor en el cambio de régimen tras el golpe de Primo de Rivera. A.D.P.P., Memoria de desenvolvimiento y situación económica de los ejercicios 1923/24 -1927. C-R/ 1, 19.

${ }^{681}$ Por mediación del Estado, por tanto, debía esperar a que la Delegación de Hacienda ingresase en las arcas provinciales lo recaudado. De esta cantidad se deducía lo adeudado en cada ejercicio por la Diputación Provincial a la Hacienda Pública, y la parte a pagar a la Caja Central de Fondos Provinciales.
} 
Tabla 05. Estado comparativo de lo recaudado en pts. en los ejercicios 1923/24 y 1927 a fecha de 6 de marzo de 1928.

\begin{tabular}{|c|c|c|c|c|}
\hline \multirow[t]{2}{*}{ Ejercicios } & \multirow[t]{2}{*}{ Recaudación } & \multicolumn{3}{|c|}{$\begin{array}{c}\text { Comparación } \\
\text { ejercicios anteriores }\end{array}$} \\
\hline & & $1923 / 24$ & $1924 / 25$ & $1925 / 26$ \\
\hline $1923 / 24$ & $865.869,76$ & & & \\
\hline $1924 / 25$ & $838.012,49$ & - 27.857,27 & & \\
\hline $1925 / 26$ & $1.370 .489,04$ & $+504.619,28$ & $+532.476,55$ & \\
\hline 1927 & $1.620 .470,07$ & $+754.600,31$ & $+782.457,58$ & $+249.981,03$ \\
\hline
\end{tabular}

Elaboración propia. Fuente: A.D.P.P., Memoria de desenvolvimiento y situación económica de los ejercicios 1923/24 -1927. C-R/1, 19

Figura 01. Estado comparativo del superávit con que se habían liquidado los presupuestos de 1923/24 y de 1927 por Presupuesto Corriente en pts.

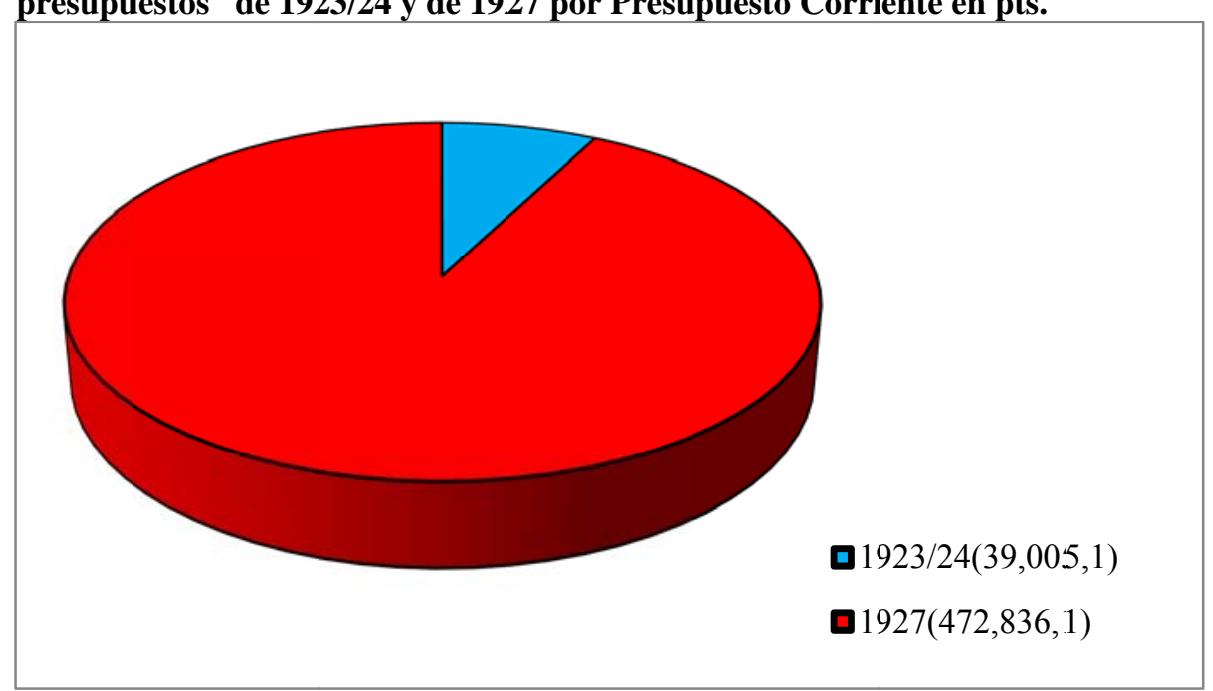

Elaboración propia. Fuente: C-R 1/19. Memorias presupuestos 1923/24 y 1927. 
Figura 02. Estado comparativo del superávit con que se habían liquidado los presupuestos de 1923/24 y de 1927 por Presupuesto Refundido (Ordinario más Adicional) en pts.

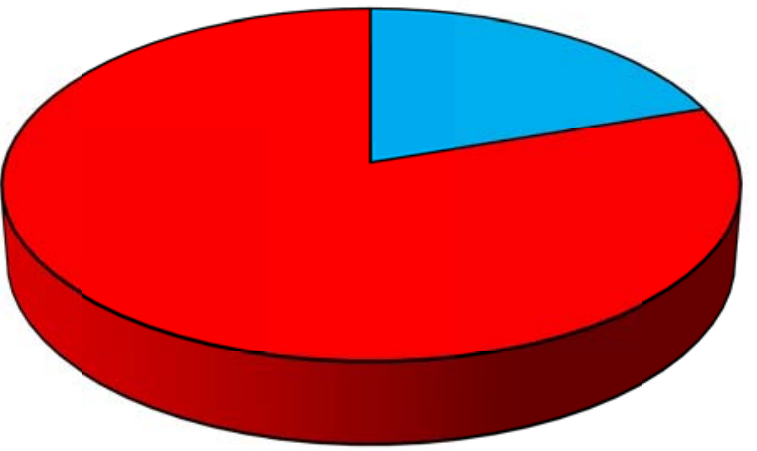

口1923/24 (371,126,05)

ㅁ1927 $(1,508,542,56)$

Elaboración propia. Fuente: C-R 1/19. Memorias presupuestos 1923/24 y 1927.

Figura 03. Estado comparativo de la recaudación de ingresos en los ejercicios 1923/24 y 1927 por Presupuesto Corriente en pts.

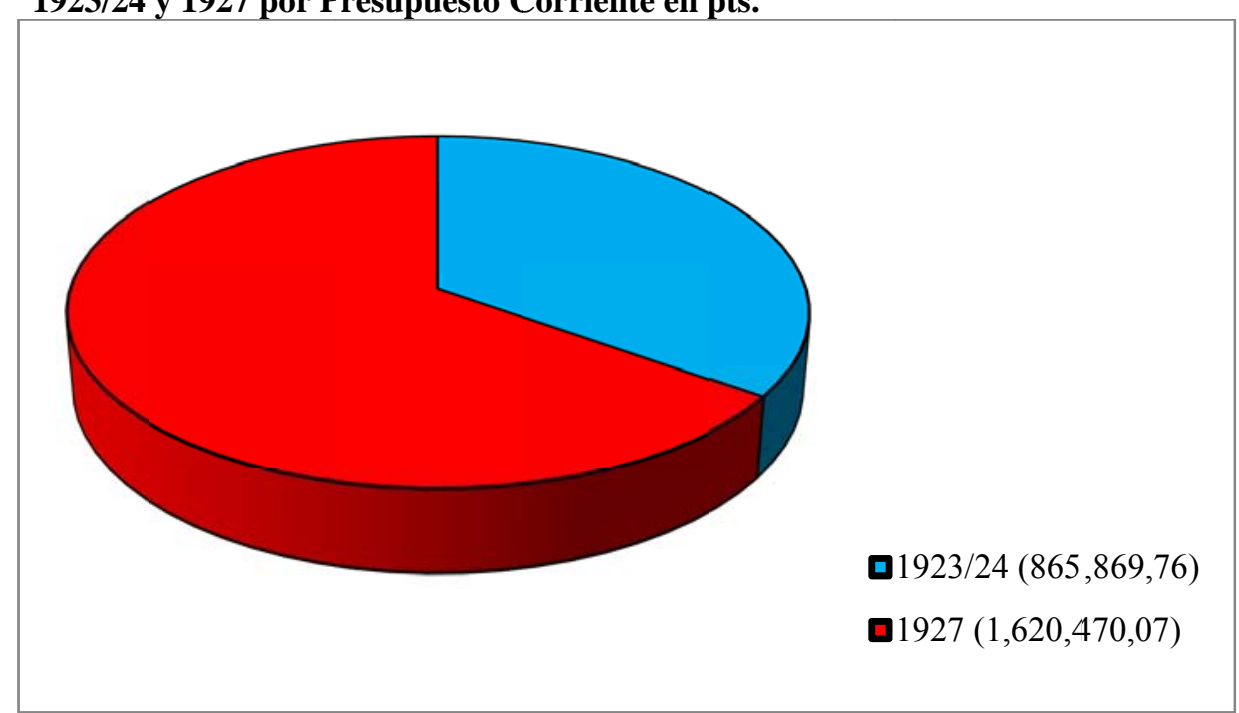

Elaboración propia. Fuente: C-R 1/19. Memorias presupuestos 1923/24 y 1927. 
Figura 04. Estado comparativo de la recaudación de ingresos en los ejercicios 1923/24 y 1927 por resultas en pts.

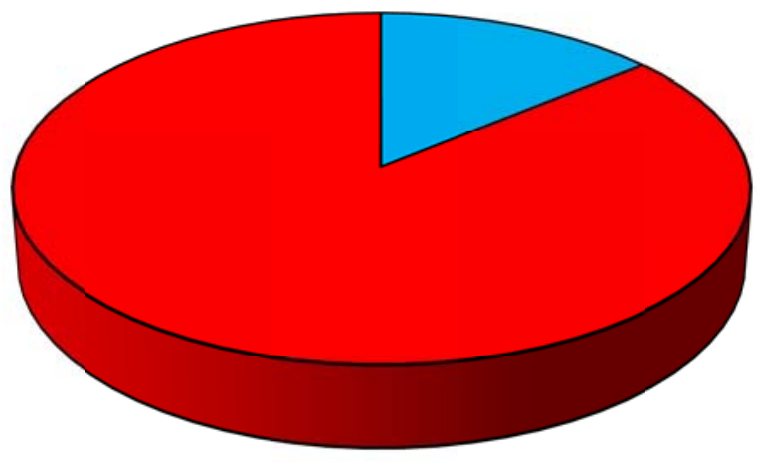

$1923 / 24(14,233,33)$

口1927 (87,495,23)

Elaboración propia. Fuente: C-R 1/19. Memorias presupuestos 1923/24 y 1927.

Figura 05. Total de lo recaudado por Presupuesto Corriente y resultas en los ejercicios 1923/24 y 1927 en pts.

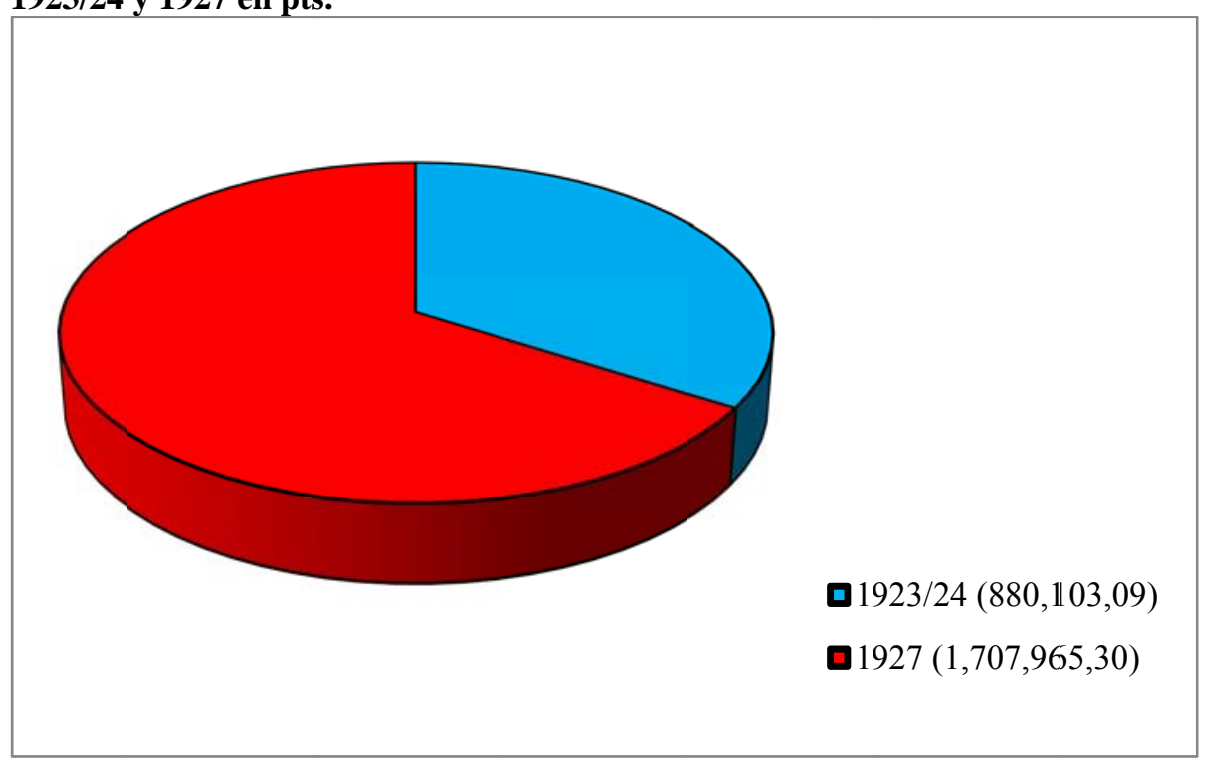

Elaboración propia. Fuente: C-R 1/19. Memorias presupuestos 1923/24 y 1927. 
Tabla 06. Situación de la Hacienda Provincial por valores del Presupuesto en el fin de los siguientes ejercicios 1923/24, 24/25, 25/26, y 1927.

\begin{tabular}{|c|c|c|}
\hline Ejercicios & Fecha de liquidación & Exceso del activo sobre el pasivo \\
\hline $1923 / 24$ & $31-$ III-1924 & $461.019,46$ \\
\hline $1924 / 25$ & $30-$ VI-1925 & $590.556,30$ \\
\hline $1925 / 26$ & $30-$ VI-1926 & $1.485 .692,35$ \\
\hline 1927 & $31-$ XII-1927 & $1.577 .928,25$ \\
\hline
\end{tabular}

Elaboración propia. Fuente: C-R 1/19. Memorias presupuestos 1923/24 y 1927.

Figura 06. Situación de la Hacienda Provincial por valores del Presupuesto en fin de los siguientes ejercicios 1923/24,24/25,25/26, y 1927.

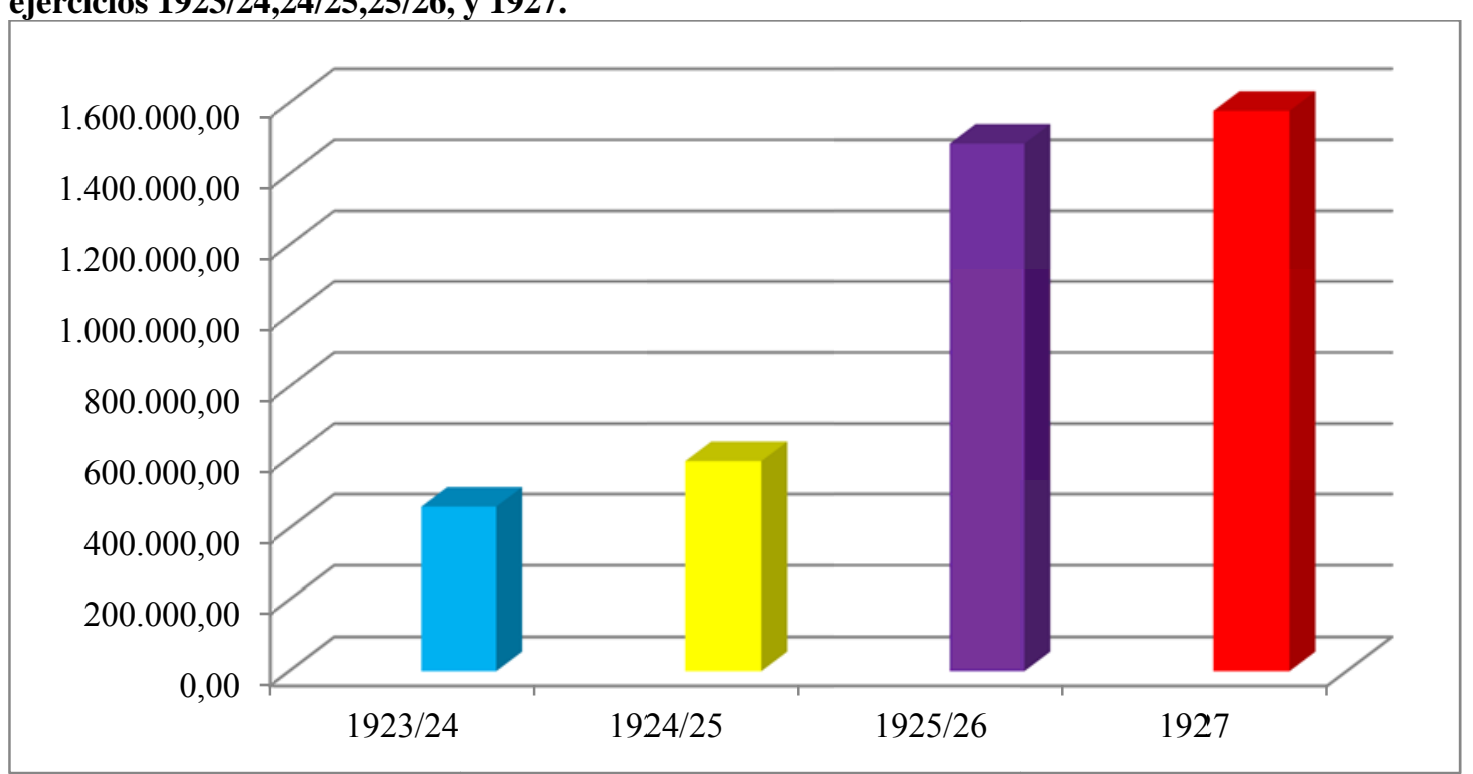

Elaboración propia. Fuente: C-R 1/19. Memorias presupuestos 1923/24 y 1927. 
Los datos hablan por sí mismos, la gestión directa de los servicios de recaudación de la Diputación consiguió casi doblar el volumen total de dinero recaudado el año 1927, respecto al ejercicio tomado como referencia de 1923/24, año en el que la recaudación se había arrendado. La manifestación de que la idea de la Diputación Provincial palentina, de que a mayor descentralización y gestión de servicios por parte de esta institución, máxima eficacia en los servicios encomendados, era cierta, y en un ámbito tan fundamental para la Administración Provincial como era el de la recaudación de impuestos. 


\section{Presupuestos y cuentas ${ }^{682}$ provinciales}

El art. 33 de la Ley de Administración y Contabilidad de 1 de julio de 1911, definía al Presupuesto de las diputaciones provinciales como la enumeración de las obligaciones que estas instituciones debían satisfacer en cada ejercicio económico con relación a los servicios que debían mantener y el cálculo y determinación de los recursos o medios que realizables para cumplir con esas atenciones. Las diputaciones provinciales estaban obligadas por ley ${ }^{683}$ a formar todos los años ${ }^{684}$ un Presupuesto Ordinario $^{685}$ que comprendiese los gastos e ingresos de la institución provincial $^{686}$, destinado a atender todas las obligaciones y servicios que tenía asignados la Corporación Provincial, constituyendo una Comisión a tal efecto.

Los gastos debían quedar cubiertos con los ingresos propios de la institución provincial $^{687}$, entendiendo por estos las rentas y productos de toda clase de bienes, derechos o capitales que por cualquier concepto perteneciesen a la provincia o a los establecimientos dependientes de la Diputación ${ }^{688}$. La Ley Provincial de 29 de agosto de 1882 señalaba que los créditos abiertos y no invertidos en el plazo del año económico, quedaban anulados $^{689}$. Durante el periodo de ampliación debían finalizar las operaciones de cobranza de los recursos presupuestados y la liquidación y pago de los servicios realizados durante el año.

\footnotetext{
${ }^{682}$ Las cuentas reflejaban la ejecución del Presupuesto.

${ }^{683}$ Art. 109 de la Ley Provincial de 29 de agosto de 1882 y art. 193 del Estatuto Provincial de 1925.

${ }^{684} \mathrm{El}$ año económico provincial comenzaba en el segundo semestre de año natural, era el mismo que regía para los presupuestos y cuentas generales de la nación.

${ }^{685} \mathrm{El}$ Real Decreto de 30 de noviembre de 1899 preceptuaba que las diputaciones provinciales discutirían y aprobarían sus presupuestos ordinarios dentro de los quince primeros días del mes de octubre.

${ }^{686} \mathrm{El}$ art. 110 de la Ley Provincial de 29 de agosto de 1882 dictaminaba que los gastos comprendidos en los presupuestos provinciales debían ser cubiertos con ingresos independientes de los del Estado, recaudados y repetidos con arreglo a la citada Ley.

${ }^{687}$ Los ingresos del Estado no podían ser contabilizados en el Capítulo de Ingresos del Presupuesto Provincial. Este nuevo sistema impositivo se tradujo en una insuficiencia crónica de recursos presupuestarios de las haciendas provinciales, que privadas de los recargos a las contribuciones estatales, solo contaba con el Repartimiento efectuado entre los pueblos, que se obtenía sobre una proporción de lo que estos recaudaban por las contribuciones directas (Territorial e Industrial), e indirectas (Consumos), pagadas por los pueblos al Tesoro, que, en no pocas ocasiones, acusaban prácticas fraudulentas y de ocultación a la hora de confeccionar los amillaramientos, una especie de padrones de riqueza que servían de referencia para fijar la base imponible sobre el Impuesto de la Contribución Directa.

${ }^{688}$ El Estatuto Provincial de 1925 establecía, en su art. 208, la obligación de las diputaciones, concretamente las comisiones provinciales, de elaborar todos los años un inventario general de los bienes y derechos que constituían el patrimonio de la Diputación, con un apartado especial de los bienes privativos de los establecimientos dependientes de la Corporación Provincial. En 1927, el valor patrimonial de los bienes propios de la Diputación Provincial ascendía a la cantidad de 1.771.747,60 pts.

${ }^{689}$ Art. 111 de la Ley Provincial de 29 de agosto de 1882.
} 
Las resultas $^{690}$ que quedaban después de este periodo eran objeto de un Presupuesto Adicional ${ }^{691}$. Cuando los recursos consignados en el Presupuesto Ordinario no eran suficientes para cubrir atenciones imprevistas, satisfacer alguna deuda o cualquier otra circunstancia no prevista ${ }^{692}$, la Diputación debía formar un Presupuesto Extraordinario $^{693}$ en la misma forma y por el mismo procedimiento que el Ordinario. Respecto de los plazos de redacción y aprobación ${ }^{694}$ de los presupuestos provinciales, la Ley Provincial de 29 de agosto de 1882, dictaminaba que las diputaciones debían redactar, discutir y aprobar sus presupuestos ordinarios dentro de los primeros quince días del mes de abril ${ }^{695}$, y el Adicional durante el mes de febrero. A partir de la entrada en vigor del Estatuto Provincial de 1925, el periodo de formación y aprobación del Presupuesto Provincial varió. En su art. 199 se señalaba que en la reunión del Pleno de la Diputación, a celebrar en el segundo semestre de cada año económico, tras deliberar sobre la propuesta de la Comisión especial creada para formar el Presupuesto Provincial, se debían introducir las variantes que se considerasen oportunas en el Presupuesto vigente, o no realizar modificación alguna y aprobar el Presupuesto del ejercicio anterior.

\footnotetext{
${ }^{690}$ Derechos pendientes de pago y obligaciones pendientes de cobro.

${ }^{691}$ La figura del Presupuesto Adicional desapareció a partir de la promulgación del Estatuto Provincial de 1925, que en su art. 199 prohibía este tipo de presupuesto, remitiendo al art. 304 del Estatuto Municipal de 1924, respecto de la extinción de créditos no invertidos, resultas de ejercicios cerrados y devolución de ingresos indebidos. El citado artículo disponía que las obligaciones reconocidas y no satisfechas y los derechos liquidados que no se hubiesen realizado el último día del año del Presupuesto, se comprenderían como resultas en la cuenta que se abriese al nuevo Presupuesto.

${ }^{692} \mathrm{En}$ el caso de que la provincia fuese condenada al pago de una cantidad, la Diputación después de ejecutada la sentencia, debía proceder a formar un Presupuesto Extraordinario, excepto si el acreedor acordase aplazar el cobro de modo que se pudiesen consignar en los presupuestos ordinarios las sumas necesarias para saldar las cantidades adeudadas. Los diputados provinciales eran personalmente responsables de los posibles perjuicios ocasionados por la falta o retraso en la formación del Presupuesto Extraordinario elaborado para el fin mencionado.

${ }^{693} \mathrm{El}$ art. 198 del Estatuto Provincial de 1925 prohibía expresamente compensar el déficit de ejercicios ordinarios por medio de presupuestos extraordinarios.

${ }^{694}$ Para la aprobación del Presupuesto Provincial se requería el voto de la mayoría absoluta del total de los diputados provinciales. En caso de no ser aprobado en el inicio del año económico, regía el Presupuesto del año anterior. La discusión de los presupuestos comenzaba por las enmiendas presentadas a cualquiera de sus artículos o capítulos.

${ }^{695} \mathrm{El}$ día 20 de abril, las diputaciones remitían al Ministerio de la Gobernación, por conducto del gobernador, el presupuesto aprobado «(...) para el solo efecto de corregir las extralimitaciones legales, si las hubiera, o impedir que se perjudiquen los intereses generales de los pueblos.» $\mathrm{Si}$ antes del 15 de junio el Gobierno no había dictado resolución, ni se había devuelto el Presupuesto a la Diputación, regía el votado por la Corporación Provincial. El Presupuesto Adicional era remitido al Ministerio de la Gobernación antes del día 28 de febrero y el Gobierno debía dictar resolución o devolverlo a la Diputación antes del día 15 de abril. De no ser así, se entendía que quedaba aprobado y empezaba a regir.
} 
La Ley Provincial de 29 de agosto de 1882, establecía que el Presupuesto Provincial debía destinar ciertas partidas obligatorias para atender los siguientes servicios $^{696}$ :

1. Personal y material de sus oficinas y dependencias y establecimientos provinciales de Beneficencia, Sanidad e Instrucción Pública.

2. Conservación y administración de las fincas de la provincia.

3. Construcción, conservación y administración de las Obras Públicas.

4. Suscripción a la Gaceta de Madrid y Colección Legislativa.

5. Fondo de imprevistos y para Calamidades públicas.

6. Anuncios, impresiones $y$ otros gastos que se consideren necesarios o convenientes.

7. Todos los gastos exigidos por la ley a las provincias.

8. Gastos de representación del presidente.

Como se ha dicho anteriormente, si los recursos propios de la Diputación Provincial no eran suficientes para cubrir los gastos del Presupuesto, esta podía establecer un Repartimiento ${ }^{697}$ entre los pueblos de la provincia en proporción de lo que por contribuciones directas y por el Impuesto de Consumo pagase cada uno al Tesoro ${ }^{698}$.

\footnotetext{
${ }^{696} \mathrm{La}$ distribución mensual de fondos era de exclusiva competencia de la Diputación Provincial y, en caso de no estar reunida, de la Comisión Provincial. La ordenación de pagos correspondía al presidente de la Diputación.

${ }^{697} \mathrm{La}$ cuota a pagar por este concepto era incluida en el presupuesto de cada pueblo y su importe se ingresaba en la Depositaría Provincial en la época de recaudación ordinaria o antes, si los ayuntamientos lo entregaban de forma voluntaria.

${ }^{698}$ En 1884 la Comisión encargada de gestionar los asuntos estadísticos solicitaba a la Diputación que elevase al Gobierno una exposición en la que se hiciese constar lo exageradamente que estaba gravada la propiedad en la provincia, a causa de la sobrevalorada clasificación de sus terrenos y de los altos tipos en que estaban inspiradas las cartillas evaluadoras. A.D.P.P., L.A.C.P. 56, 18-IV-1884. Algunas cartillas eran tan deficientes que no se podía formar juicio sobre la riqueza de los pueblos, y así lo reconocía el Consejo Provincial de Agricultura en el dictamen emitido a cerca de este asunto. La Comisión de Hacienda encargó en 1889 un informe respecto de las cartillas evaluatorias sobre la riqueza rústica de los Partidos Judiciales de Baltanás, Carrión de los Condes, Cervera de Pisuerga, Frechilla, Palencia y Saldaña. A.D.P.P., L.A.P.D. 68, 18-V-1889. Estas cartillas evaluaban la riqueza rústica, los tipos evaluadores vigentes en 1889 databan de 1860 .
} 
El Estatuto Provincial de 1925 introdujo algunas variaciones respecto de las obligaciones presupuestarias de las corporaciones provinciales ya contempladas en la Ley de 29 de agosto de 1882 :

1. Los servicios de competencia provincial establecidos en el art. $107^{699}$ de Estatuto Provincial.

2. Cumplir las obligaciones mínimas establecidas en el Capítulo III, Título IV del libro $\mathrm{I}^{700}$ del Estatuto.

3. Satisfacer los gastos de recaudación de arbitrios, impuestos, tasas, derechos o rentas provinciales

\footnotetext{
${ }^{699}$ Construcción y conservación de caminos y de las carreteras no incluidas en el Plan General del Estado, construcción y explotación de ferrocarriles y tranvías interurbanos, establecimiento de líneas telegráficas dentro del territorio de la provincia en los pueblos que no las tuviesen a cargo del Estado, desecación de terrenos pantanosos y construcción de pantanos y canales de riego, encauzamiento de los ríos con nacimiento y que discurrieran en la provincia, establecimiento y sostenimiento de instituciones de Beneficencia, Higiene y Sanidad, concursos y exposiciones, instituciones de crédito popular, agrícola y municipal de ahorro y de seguros sociales, establecimiento de escuelas de agricultura, granjas y campos de experimentación, fomento de la ganadería y de la riqueza forestal, conservación de monumentos artísticos e históricos y recaudación de las contribuciones del Estado en la provincia.

${ }^{700}$ Beneficencia: Sostenimiento de una Casa Provincial de Maternidad y Expósitos, de un Casa de Beneficencia Hospitalaria, de una Casa de Caridad para reclusión de indigentes y otra para reclusión de dementes pobres; Sanidad: Obras de carácter sanitario en los pueblos ( abastecimiento de agua potables y evacuación de aguas residuales), Sostenimiento de un Instituto de Higiene; Enseñanza: subvención a establecimientos de enseñanza agrícola, industrial y artística y concesión de becas a estudiantes pobres; Social: subvención a instituciones de carácter social de la provincia, Cajas colaboradoras del Instituto Nacional de Previsión y construcción de viviendas baratas; Obras Públicas: construcción de caminos provinciales.
} 
La Comisión de Presupuestos examinaba los proyectos de presupuestos generales confeccionados por la Comisión Provincial. Las cuentas quedaban aprobadas si obtenían el voto de la mayoría de los vocales que componían la Diputación Provincial $^{701}$, sin contar a los vocales de la Comisión Provincial que no tenían voto en ese acto. Una vez aprobado el presupuesto por la Comisión de Presupuestos, la Comisión Provincial lo remitía al Ministerio de la Gobernación vía gobernador provincial para su aprobación ${ }^{702}$ y el Ministerio, tras dar su conformidad el Tribunal de Cuentas del Reino, enviaba un escrito ${ }^{703}$ al presidente de la Diputación Provincial para que este trasladase, previo conocimiento de la Comisión Provincial, dicho Presupuesto a la Contaduría de Fondos Provinciales para que lo llevase a efecto. No era infrecuente que el Ministerio de Gobernación devolviera el Presupuesto, bien el Ordinario o el Adicional $^{704}$ al Ordinario ${ }^{705}$, para su rectificación. Esto sucedió en varias ocasiones, por ejemplo el 16 de julio de 1877, el Ministerio de Gobernación, devolvía el Presupuesto Adicional a la Comisión Provincial por entender que era conforme a la Ley ${ }^{706}$. No se habían consignado en el Presupuesto los créditos correspondientes a los servicios de Instrucción Pública ${ }^{707}$ y Obras Públicas, se recordaba la obligación de enmendar el Presupuesto y enviar un ejemplar del mismo corregido ${ }^{708}$. En julio de 1889, por Real $\operatorname{Orden}^{709}$ de 2 de julio de 1889, se eliminaban por el Ministerio de Gobernación las partidas que figuraban en el Capítulo I, art. 1, de 1.000 pts., Capítulo IV, art. 2, 3.000 pts. y el Capítulo XI, 48.000 pts.

\footnotetext{
${ }^{701}$ Art. 128 de la Ley Provincial de 29 de agosto de 1882.

${ }^{702}$ Art. 120 de la Ley Provincial de 29 de agosto de 1882. El Ministerio estaba obligado a corregir las extralimitaciones legales del Presupuesto Provincial.

${ }^{703}$ Un ejemplo de este escrito: «S.M. el rey (q.D.G.) y, en su nombre, la reina regente del Reino, ha tenido a bien autorizar el Presupuesto Ordinario de esa Diputación para 1894-95 en la cifra y forma en que ha sido votado por la misma, importando el total de ingresos 555.501,80 pts. e igual suma de gastos. Al propio tiempo se devuelve un ejemplar del Presupuesto y nota detallada de las cantidades que comprende autorizada con el sello de este Ministerio lo que con remisión del Presupuesto y nota de referencia tengo el honor de trasladar a V.S. para su conocimiento y efectos que procedan. Dios guarde a V.S. muchos años.» A.D.P.P., C-L/ 6, 3.

${ }^{704}$ Los arts. 111 y 120 de la Ley Provincial de 29 de agosto de 1882 y la Ley de Contabilidad de 20 de septiembre de 1865 señalaban que el Presupuesto Adicional tenía como fin la liquidación de las resultas que hubiere de ejercicios anteriores y los aumentos de los créditos, ya incluidos en el Presupuesto Ordinario.

${ }^{705}$ El Presupuesto Ordinario junto con el adicional recibía el nombre de Refundido.

${ }^{706}$ Art. 2, Disposición $10^{\mathrm{a}}$, de la Ley de 16 de diciembre de 1876.

${ }^{707}$ Los presupuestos de Instrucción Pública y Beneficencia los elaboraban las propias instituciones y lo remitían a la Diputación Provincial, bajo la denominación de Adicional Refundido. El Presupuesto del Instituto de Segunda Enseñanza y de la Escuela Normal era supervisado por la Junta Provincial de Instrucción Pública antes de ser remitido a la Diputación.

${ }^{708}$ A.D.P.P., C-L/ 4,1.

${ }^{709}$ La Real Orden era el procedimiento administrativo habitual por el que el Ministerio de Gobernación validaba el Presupuesto Provincial.
} 
Quedando en suspenso las partidas de 10.000 pts. y 4.000 pts. destinadas al pago de estancias de dementes y obras de carreteras respectivamente, mientras no fuesen debidamente justificadas $^{710}$. Otro ejemplo, por la Real Orden de 28 de octubre de 1904, el Ministerio de Gobernación no aprobaba el art. Único del Capítulo X del Presupuesto de Ingresos del Presupuesto para 1905, por valor de 75.000 pts., en concepto de la venta de solares que había adquirido la Diputación para la construcción de un Palacio Provincial. Se necesitaba la aprobación ${ }^{711}$ del Gobierno ${ }^{712}$ para la venta de todos los bienes inmuebles no comprendidos en el párrafo $1^{\circ}$ del art. 77 de la Ley Provincial de 29 de agosto de $1882^{713}$. La Diputación, en desacuerdo con la Real Orden del Gobierno, con fecha de 21 de noviembre de 1904 elevó una instancia al Ministerio de Gobernación solicitando la retirada de la citada Real Orden, contestando el Ministerio con fecha de 24 de diciembre de 1904, reiterando su negativa a autorizar la venta de solares.

El art. 4 del Real Decreto de 30 de noviembre de 1899, que modificaba el art. 120 de la Ley Provincial de 29 de agosto de 1882, disponía que las diputaciones provinciales remitirían al Ministerio de la Gobernación el presupuesto aprobado por la Diputación Provincial el día 30 de octubre de cada año «(...) para el solo efecto de corregir las extralimitaciones legales, si las hubiere, e impedir que se perjudiquen los intereses generales de los pueblos, debiendo dictarse resolución antes del día 15 de diciembre». En 1918, volvió a modificarse la Ley en materia presupuestaria y el art. 120 de la Ley Provincial de 29 de agosto de 1882, era modificado por Real Decreto de 21 de diciembre de 1918, «Las Diputaciones remitirán al Ministerio aprobado el Presupuesto Ordinario el día 20 de enero de cada año para el solo efecto de corregir las extralimitaciones legales, (...) debiendo dictarse resolución antes del día 15 de marzo siguiente.»> ${ }^{714}$

\footnotetext{
${ }^{710}$ A.D.P.P., C-L/ 6,1.

${ }^{71}$ Párrafo $2^{\circ}$ del art. 77 de la Ley Provincial de 29 de agosto de 1882.

${ }^{712} \mathrm{E}$ Gobierno consideraba que siendo la situación económica desahogada de la Diputación, y careciendo de un edificio en propiedad, algo que casi todas las diputaciones tenían, con peores situaciones económicas, no cabía conceder el permiso para la venta de los solares mencionados.

${ }^{713}$ A.D.P.P., C-L/ 8,5.

${ }^{714}$ A.D.P.P., C-L/ 11,3 .
} 
La aprobación del Estatuto provincial de 1925 supuso el cambio de la estructura de los presupuestos ${ }^{715}$. El director general de la Administración envió un comunicado por telégrafo al Gobierno Civil de la Provincia de Palencia en el que le comunicaba que: «No siendo posible aplicar para el ejercicio económico 1925/26 el párrafo 2º art. 196 del Estatuto Provincial por la completa transformación que el mismo impone al presupuesto de las diputaciones. Sírvase V.S. significar a esa Corporación que debe aplicar el suyo votado para el próximo año salvo en aquello que estuviere reclamado y a reserva siempre de las resoluciones que este Ministerio oportunamente adopte.»» ${ }^{716}$

La Ley de 29 de agosto de 1882 no recogía de forma expresa la posibilidad de impugnación de los presupuestos provinciales, contingencia que sí aparecía formulada en el Estatuto Provincial. Los diputados provinciales, los ayuntamientos y cualquier particular interesado, podían alzar un recurso contra los presupuestos aprobados, dentro de los ocho días siguientes a la publicación del Presupuesto ${ }^{717}$, formulando sus recursos o reclamaciones ante el gobernador civil $^{718}$. Se podía impugnar por diversas causas:

1. Por no haberse ajustado su elaboración y aprobación a los trámites que establecía el Estatuto Provincial.

2. Por haberse omitido el crédito necesario para el cumplimiento de las obligaciones que la ley señalaba a la Diputación Provincial, o consignarse para atenciones que no fuesen de competencia provincial.

3. Por ser manifiestamente insuficientes los ingresos con relación a los gastos presupuestados $^{719}$.

\footnotetext{
${ }^{715}$ Véase Anexo I. Modelo Presupuesto Provincial General de Gastos e Ingresos, p. 438.

${ }^{716}$ A.D.P.P., C-L/ 13,1.

${ }^{717}$ Las diputaciones provinciales debían publicar, al principio de cada reunión semestral, un estado de la recaudación e inversión de sus fondos durante el semestre anterior. Art. 125 de la Ley Provincial de 29 de agosto de 1882. En las obras provinciales que se hiciesen por administración, se publicaban mensualmente por la Comisión Provincial, nota de los gastos, especificando los jornales, materiales empleados y particulares que los habían vendido, contratistas, lugar de realización de la obra y otras circunstancias de interés.

${ }^{718} \mathrm{El}$ gobernador civil trasladaba las reclamaciones y observaciones al Presupuesto Provincial al Ministerio de Gobernación. El Ministerio dictaba resolución, pudiéndose entablar contra ella recurso contencioso ante la Sala Tercera del Tribunal Supremo. Los ayuntamientos podían protestar y reclamar contra la aprobación de las cuentas provinciales.

${ }^{719}$ Los acuerdos de las diputaciones que presupuestaban gastos sin que se habilitase crédito para ello en el Presupuesto en curso y sin aprobar uno Extraordinario, se consideraban nulos. Las transferencias de créditos sobrantes de un Capítulo a otro se consideraban lícitas siempre que los respectivos servicios no quedasen sin dotación presupuestaria, y lo aprobase la Comisión Provincial por mayoría absoluta de sus miembros, si no excediesen del $5 \%$ del total del Presupuesto de Ingresos, y la Diputación Provincial en Pleno y por la misma mayoría si excedían de ese límite.
} 
En caso de no haber reclamación ni proceder la revisión del Presupuesto, el gobernador comunicaba de forma inmediata al presidente de la Diputación Provincial el visto bueno para poner en vigor los presupuestos. La Diputación Provincial era consciente de que su existencia se justificaba en buena medida por su labor gestora, y los presupuestos constituían el fiel reflejo del buen hacer de la administración provincial. Cuando en 1898 se ponía en duda la continuidad de las diputaciones provinciales, la Diputación palentina respondía presentando las cuentas de su gestión desde 1876, para la tranquilidad del contribuyente, que podía comprobar así en qué se había invertido su dinero ${ }^{720}$.

En los primeros años de la Restauración, la penuria presupuestaria de la Diputación Provincial era de tal, que por ejemplo, de las 1.000 pts. consignadas para material de Secretaría en el Presupuesto del ejercicio económico 1875/76, destinadas a la reparación del mobiliario del salón de sesiones de la Diputación, no se pudo invertir ni una sola peseta por la escasez de recursos de la provincia ${ }^{721}$. Contaduría consideraba que un presupuesto debía ser equilibrado respecto a los gastos e ingresos. Los superávits se obtenían exclusivamente de la disminución de los gastos realizados sobre los presupuestos y la Comisión Provincial indicaba que esta disminución del gasto no se realizaba a costa de desatender los servicios esenciales de la Diputación Provincial. La institución provincial palentina fue siempre muy austera en la elaboración de los presupuestos provinciales y aunque el Presupuesto Ordinario contemplaba déficit en la mayor parte de los ejercicios económico. A partir del año 1903 gastos e ingresos se equilibraron, 22 años antes de que el Estatuto Provincial impusiese por ley la obligación de confeccionar los presupuestos sin déficit ${ }^{722}$.

\footnotetext{
${ }^{720}$ A.D.P.P., C-L/ 4,1. Véase Anexo II-Presupuesto Provincial en pts. por capítulos 1878-1899, p. 470.

${ }^{721}$ A.D.P.P., C-L/ 4,1.

${ }^{722}$ Véase Anexo IV-Presupuesto Provincial en pts. 1875-1931, p. 473.
} 
En cada presupuesto había dos liquidaciones, una por Presupuesto Ordinario y otra por Presupuesto Adicional. Las liquidaciones del Presupuesto Ordinario contenían exclusivamente los recursos y obligaciones a que se refería dicho presupuesto, el Adicional, las resultas ${ }^{723}$ de ejercicios anteriores. El superávit del Presupuesto Ordinario era siempre mucho menor que el del Presupuesto Adicional ya que la suma de la existencia en Caja más los créditos pendientes de pago excedían en gran cantidad a las obligaciones pendientes de pago y ello constituía las resultas de ejercicios anteriores, al incorporar a estos al Presupuesto corriente de cada ejercicio para formar el Presupuesto Refundido, quedando este desnivelado por el exceso de ingresos sobre los gastos, lo cual generaba un superávit.

A partir de la entrada en vigor del Estatuto Provincial de 1925, la formación de los presupuestos correspondía a una Comisión especial ${ }^{724}$ compuesta por seis diputados, tres directos y tres corporativos, y su aprobación a la Diputación en Pleno, requiriéndose el voto favorable de la mayoría absoluta de los diputados directos y corporativos. En la reunión del pleno de la Diputación, celebrada en el segundo semestre de cada año económico a propuesta de la Comisión especial de presupuestos, se deliberaba sobre las variantes que convendría introducir en el Presupuesto vigente o la necesidad de prorrogarlo para el ejercicio siguiente. La discusión de los presupuestos por la Diputación en Pleno comenzaba por la de las enmiendas que se presentasen a cualquiera de sus artículos o capítulos, después solo podían discutirse las variantes introducidas o las propuestas en los presupuestos vigentes ${ }^{725}$. Cuando surgían atenciones imprevistas para satisfacer las deudas o cualquier otra circunstancia no prevista en el Presupuesto Ordinario, y para los que evidentemente no se habían consignados recursos, se formaba un Presupuesto Extraordinario, de la misma forma y procedimiento que el Ordinario. Quedaban expresamente prohibidos los presupuestos adicionales, los créditos no invertidos, las resultas de ejercicios cerrados, y la devolución de ingresos indebidos se regían por lo dispuesto en el art. 304 del Estatuto Municipal de $1924^{726}$.

\footnotetext{
${ }^{723}$ Las resultas eran las partidas presupuestarias que habiendo sido consignadas en un Presupuesto Ordinario, no habían podido ser satisfechas y se consignaban en el siguiente Presupuesto Refundido.

${ }^{724} \mathrm{La}$ Comisión de presupuestos era elegida en sesión plenaria, pudiendo votar cada diputado solo dos nombres.

${ }^{725}$ Art. 197 del Estatuto Provincial de 1925.

${ }^{726} \mathrm{Al}$ final de cada ejercicio quedaban anulados los créditos abiertos y no invertidos durante su vigencia. Las obligaciones reconocidas y no satisfechas y los derechos liquidados que no se hubiesen realizado el último día del año del Presupuesto, se comprendían como resultas en la cuenta que se abría al nuevo Presupuesto.
} 
Tanto el Presupuesto Ordinario como el Extraordinario se remitían por el presidente de la Diputación Provincial, dentro de los cinco días siguientes a su aprobación, al gobernador civil.

Gracias a la Memoria de Deficiencias de 1294, puede conocerse cuál era la situación presupuestaria de la Diputación palentina en esta época. El Presupuesto de Gastos de 1924 de la Diputación Provincial ascendía a 1.369.901 pts., faltaba por consignar la cantidad que arrojasen las liquidaciones de los ejercicios de Enseñanza correspondientes a los años 1922 y 1923 , que ascendían a 320.000 pts. Sumados los gastos consignados y las deudas pendientes, el Presupuesto Pasivo de la Diputación se elevaba a 1.711.901 pts. El Presupuesto de Ingresos, ascendía a 1.369.901 pts., nivelado con el de Gastos, pero de forma ficticia ${ }^{727}$, en opinión de la Comisión Provincial $^{728}$. Según la Comisión Provincial, la situación de la Hacienda provincial era muy delicada e iba camino de la insolvencia de no atender el Gobierno central las peticiones que se le hacían desde la institución provincial. El Presupuesto de Gastos había ido creciendo anualmente desde 1918:

Tabla 07. Presupuesto de Gastos en pts. de la Diputación Provincial de Palencia entre los años 1918 y 1924 y porcentaje de participación en el mismo de los pueblos de la provincia.

\begin{tabular}{|c|c|c|}
\hline Año & Presupuesto gastos & \% a pagar por los pueblos \\
\hline 1918 & 659.490 & 14,19 \\
\hline 1920 & $860.366,35$ & 25 \\
\hline 1924 & 1.369 .901 & 25,43 \\
\hline
\end{tabular}

Elaboración propia. Fuente. A.D.P.P., Memoria de deficiencias y soluciones de 1924, C-R/1,12.

\footnotetext{
${ }^{727}$ Para cuadrar gastos e ingresos, estos últimos se habían elevado de 879.283 pts., en el año 1923 , hasta 1.369.901 pts., en 1924, incluyendo en esta partida 259.130 pts. de deudas que mantenían los pueblos con la Corporación Provincial, sabiendo de antemano esta institución que no podría recaudarse por la falta de capacidad tributaria de los ayuntamientos y además siendo imposible su cobro en un solo ejercicio.

${ }^{728}$ A.D.P.P., Memoria de deficiencias y soluciones de 1924, C-R/1,12.
} 
En la citada Memoria, la Comisión provincial señalaba algunas causas para este ascenso continuado de los gastos:

1. Causas internas de la Administración Provincial

- Construcción del Palacio Provincial ${ }^{729}$.

- Facilidad en el otorgamiento de pensiones y subvenciones.

- Aumento del número de funcionarios.

- Arrendamientos (cinco hectáreas de huerta).

- Régimen de ingreso en Establecimientos de Beneficencia.

\section{Causas externas a la Administración provincial}

- Aumento del coste del mantenimiento de los asilados por la carestía de la vida causada por la Primera Guerra Mundial ${ }^{730}$

Para la Comisión Provincial, la principal causa de la subida de gastos era la conducta seguida por el poder central respecto de las corporaciones provinciales y ponía como ejemplo el caso de la Instrucción Pública ${ }^{731}$. En la Memoria de deficiencias de 1924 quedaba patente el descontento de la institución provincial con respecto de la actuación del Estado en este asunto:

«El Estado, que considera la función de la enseñanza como un servicio fundamental de su soberanía y, que según las leyes, nombra a los funcionarios, impone a la provincia la carga del sostenimiento del personal y material de los citados centros docentes, en los que no tiene intervención administrativa alguna, desconociendo el principio fundamental económico de los servicios de que quien manda paga.» ${ }^{732}$

En consecuencia, con el pensamiento expuesto, la Diputación Provincial solicitaba al Gobierno que examinase los servicios del Estado que sufragaban las provincias sin intervenir en su administración ni en su organismo y mientras tanto, suspendiese el pago de las liquidaciones correspondientes desde 1917.

\footnotetext{
${ }^{729} 1.200 .000$, pts., incluyendo el mobiliario.

${ }^{730}$ En 1915, el sostenimiento de los asilados ascendía a 276.701, 40 pts., en 1920, 393.767 pts., y en 1924 a 461.313 pts. A.D.P.P., Memoria de deficiencias y soluciones de 1924, C-R/ 1,12.

${ }^{731}$ Hasta 1917, las diputaciones pagaban una cuota con cargo al Capítulo de Instrucción Pública de entre 42.000 a 48.000 pts. A partir de marzo de 1917, se impuso a las diputaciones provinciales el pago de las diferencias entre ingresos y gastos del sostenimiento del Instituto de Segunda Enseñanza, de la Escuela Normal de Maestros de la capital y de la Inspección de Primera Enseñanza. A.D.P.P., Memoria de deficiencias y soluciones de 1924, C-R/ 1,12.

${ }^{732}$ A.D.P.P., Memoria de deficiencias y soluciones de 1924, C-R/ 1,12, p. 36.
} 
Así, la Diputación podría satisfacer las reclamaciones de los pueblos de la provincia, pues de otro modo no podría atender los gastos que originaban las nuevas liquidaciones del Estado. La Comisión Provincial volvía a señalar la posibilidad de, que en el futuro, se concediese libertad a las corporaciones provinciales para recaudar tributos $^{733}$ por medio de conciertos económicos con los pueblos, dada la imposibilidad de aumentar el porcentaje tributario que soportaban estos, el Contingente Provincial, por la pobreza de los municipios que basaban su economía en una agricultura muy poco productiva.

La Diputación, si lo consideraba conveniente, procedía a examinar las cuentas generales nombrando una Comisión especial para tal fin $\mathrm{y}$, en caso de estimarlo procedente, podía pedir los documentos relacionados con las cuentas y recabar información directa de las personas que aparecían reflejadas en esos documentos. A partir de la entrada en vigor del Estatuto Provincial de 1925, el interventor provincial se encargaba de formar las cuentas provinciales correspondientes a cada año. Las cuentas eran tres, de ingresos, de gastos y de resultas y se presentaban acompañadas de los documentos que acreditaban su exactitud. Las cuentas se publicaban en el Boletín Oficial de la Provincia los primeros diez días del tercer mes del año económico siguiente a que comprendían. La aprobación provisional ${ }^{734}$ de las cuentas correspondía a la Diputación Provincial en pleno y la definitiva, al Tribunal Supremo de Hacienda Pública $^{735}$. Hasta 1925, Contaduría se encargaba de elaborar las cuentas correspondientes a cada año económico y una vez formadas, en el plazo de los dos meses siguientes al ejercicio del que procedían, las remitía con los documentos justificativos para su aprobación a la Comisión Provincial. Un extracto de las mismas se insertaba en el Boletín oficial de la Provincia, quedando expuestos los originales al público en la Secretaría, hasta que la Diputación se reuniese para su aprobación.

\footnotetext{
${ }^{733}$ Esta facultad solo sería factible con la aprobación de un Estatuto Provincial, que concedería personalidad jurídica a las provincias, aunque en 1924, cuando se hacía esa petición por parte de la Diputación Provincial, todavía no se había aprobado el Estatuto Provincial de 1925.

${ }^{734} \mathrm{La}$ aprobación provisional requería el voto favorable de la mayoría de los diputados corporativos, suplentes y titulares, y de los diputados directos suplentes que durante el ejercicio económico a que se referían las cuentas no hubiesen sustituido a los respectivos titulares. Contra la aprobación provisional de las cuentas provinciales, podían recurrir los cuentadantes o personas directa o subsidiariamente responsables, y los ayuntamientos de la provincia ante el Tribunal Supremo de la Hacienda Pública.

${ }^{735}$ Real Decreto de 19 de junio de 1924.
} 
El balance final de gastos e ingresos de la Diputación palentina al final de la etapa comprendida entre 1875-1931, fue de un extraordinario equilibrio, como demuestran los datos, desmintiendo así las voces que consideraban a estas instituciones entes despilfarradores de recursos públicos en beneficio de los componentes de la propia institución. Los gráficos muestran la igualdad entre lo que se recaudaba y se gastaba por parte de la Diputación Provincial de Palencia en las atenciones que tenía asignadas por la ley.

Figura 07. Porcentaje de gastos e ingresos de la Diputación Provincial de Palencia entre los años 1875-1931.

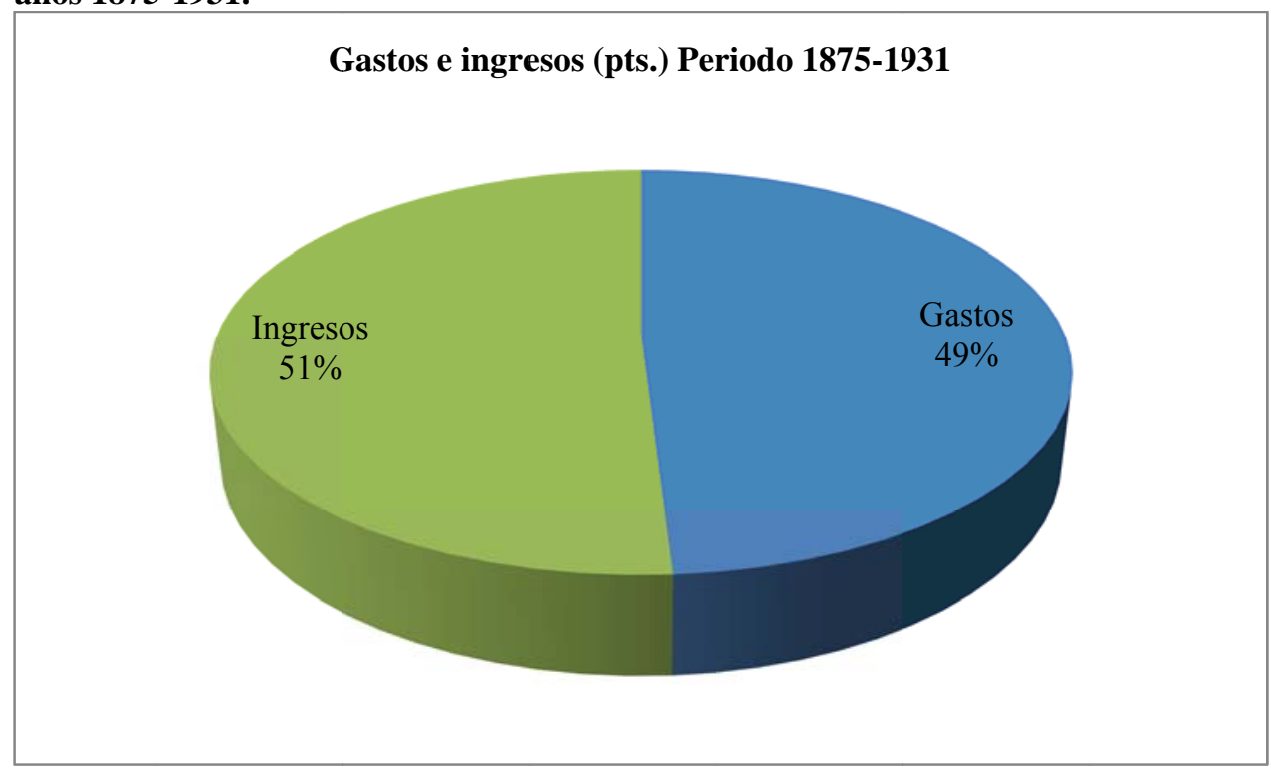

Elaboración propia. Fuente: A.D.P.P. 
Figura 08. Evolución anual del gasto e ingreso totales de la Diputación Provincial de Palencia en el periodo 1875-1931.

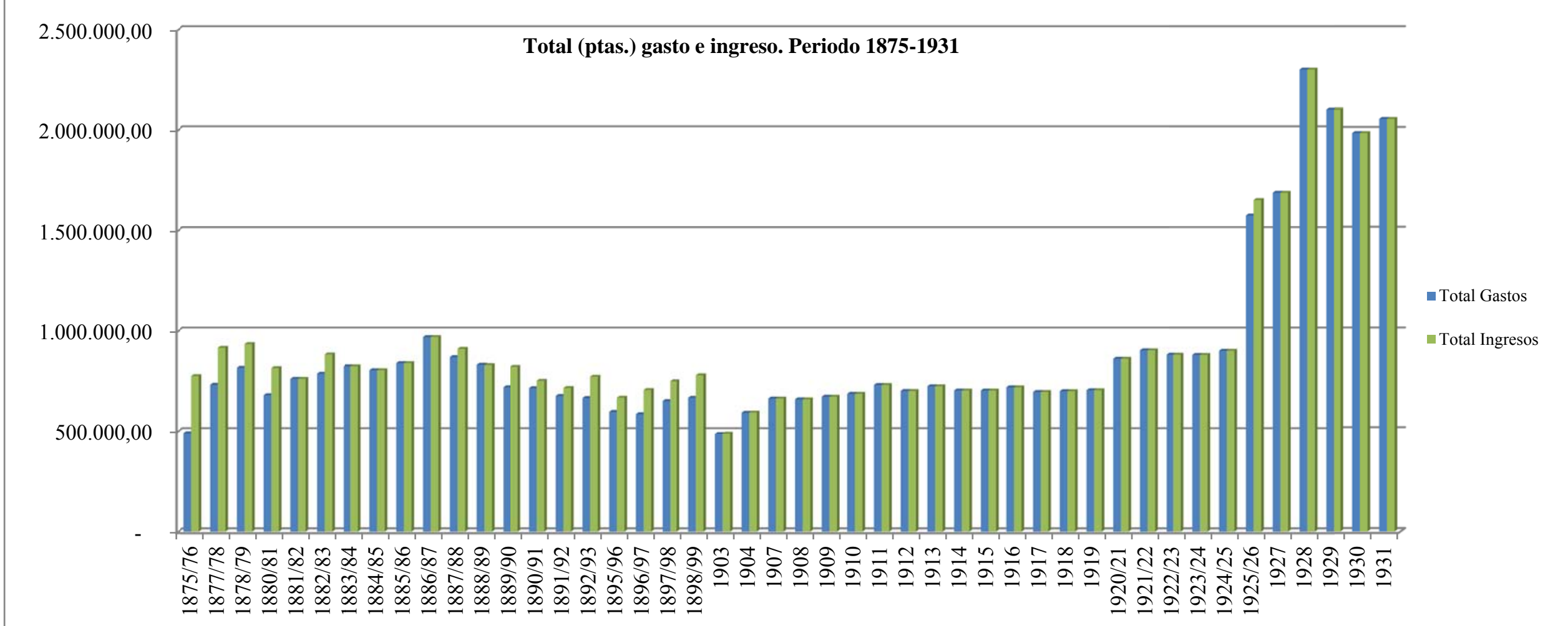

Elaboración propia. Fuente: A.D.P.P. 
En enero de 1930, el patrimonio de la Diputación Provincial estaba compuesto por $^{736}$ :

1. Cinco inscripciones intransferibles de la Deuda Perpetua de la Beneficencia, al $4 \%$ interior, con un valor nominal de $74.753,91$ pts. y valor efectivo de 54.570, 81 pts.

2. Una inscripción intransferible de la Deuda Perpetua Interior de «Particulares y Colectividades», con un valor nominal de $11.639,51$ pts. y efectivo de $8.496,84$ pts.

3. Siete acciones del Banco de España, valor nominal de 30.500 pts. y efectivo de 20.475 pts.

4. Diez acciones del Banco de Crédito Local de España, valor nominal y efectivo de 5.000 pts.

5. 732.500 pts. nominales y efectivas en Deuda Amortizable al 3\%, que constituían el fondo de la Diputación para responder de la gestión en la recaudación de contribuciones e impuestos del Estado cedidos a la institución provincial.

6. Edificio destinado a Palacio Provincial, tasado en 888.000 pts.

7. Edificio destinado a Cárcel Correccional tasado en 30.057 pts.

8. Edificio de los establecimientos de Beneficencia Provincial, tasado en 339.859 pts.

9. Edificio de la Estación Enológica, tasado en 73.729 pts.

10. Terrenos edificados que forman parte del manicomio de San Juan de Dios, sección hombres y mujeres, tasado en 50.000 pts.

11. Un solar, denominado «La Serna», destinado a Granja Avícola, tasado en 75.000 pts.

12. Una huerta al pago de «Carrecastro» de una hectárea, 92 áreas y 53 centiáreas, donde se había construido un pabellón destinado a residencia veraniega de los asilados de Beneficencia, con capilla, y otra casa independiente para vivienda de las Hijas de la Caridad y del hortelano, tasado todo en 125.000 pts.

13. Un almacén de maquinaria de la sección de Vías y Obras, tasado en 25.000 pts.

14. Una tierra cercada con espino artificial, con una casita de ladrillo, cedida por Moisés Díaz Santamaría, para vivero, enclavada en la carretera de Castrojeriz, tasada en 2.700 pts.

\footnotetext{
${ }^{736}$ A.D.P.P., L.A.C.P. 146, 11-I-1930.
} 


\section{Quintas}

Desde su creación, las diputaciones provinciales, a través de la Comisión Provincial $^{737}$, tenían asignada la facultad de decisión sobre las incidencias de Quintas. $\mathrm{Al}$ igual que el reparto de contribuciones, constituía una función delegada por el Estado. La Comisión Provincial debía fallar sobre los recursos que se presentasen de acuerdo a la Ley de Reemplazo del Ejército ${ }^{738}$, Ley de Reclutamiento y Reemplazo del Ejército de 28 de agosto de 1878, reformada con arreglo a la Ley de 8 de enero y Ley 8 de julio de 1882, y Real Decreto de 31 de enero del mismo año, y Ley de Reclutamiento y Reemplazo del Ejército de 11 de julio de 1885, modificada por la Ley de Reclutamiento y Reemplazo del Ejército de 21 de agosto de 1896. Además, velaba para que las corporaciones municipales cumpliesen con las normas vigentes sobre el procedimiento a seguir en las operaciones de reemplazo, y en ocasiones, fue necesario intervenir para que se cumpliese con la legislación ${ }^{739}$. A raíz de la publicación de la Ley de 21 de agosto de 1896, las competencias en materia de Quintas pasó definitivamente a ser compartida con otros organismos, como la Comisión Mixta de Reclutamiento. Su periodo de vigencia se extendió desde 1896, año de su creación, hasta el año 1925. Estaba presidida por el gobernador civil o vicepresidente de la Comisión Provincial y el vicepresidente era el coronel jefe de la Zona Militar, quien heredó en esta materia las competencias de la Comisión Provincial. En calidad de vocales actuaban dos diputados provinciales $^{740}$ y las funciones de secretaría las ejercía el secretario de la Diputación provincial, además, formaban parte de ella un jefe de zona, un jefe de Caja de Recluta, un médico civil nombrado por la Comisión Provincial y un médico militar nombrado por el comandante en jefe del cuerpo del Ejército o capitán general de Distrito.

\footnotetext{
${ }^{737}$ La Comisión Provincial ejerció esta facultad entre los años 1869 y 1895.

${ }^{738}$ Art. 2. Disposición. $4^{\text {a }}$ de la Ley Provincial de 16 de diciembre de 1876. Art. 99 de la Ley Provincial de 29 de agosto de 1882.

${ }^{739}$ En el año 1884, la Comisión Provincial de la Diputación de Palencia, en vista del desconocimiento de las disposiciones aplicables a la revisión y olvido de la circular publicada sobre las operaciones del llamamiento y declaración de soldados por parte de los ayuntamientos para el reemplazo del Ejército, acordó que, por la Secretaría, se publicasen las instrucciones convenientes para que se ajustasen a las reglas de la circular citada. A.D.P.P., L.A.C.P. 60, 23-I-1884.

${ }^{740} \mathrm{El}$ art. 177 del Reglamento para la aplicación de la Ley de Reclutamiento y Reemplazo del Ejército de 30 de junio de 1911, señalaba que las diputaciones provinciales debían designar en el mes de octubre dos diputados provinciales y otros dos suplentes para desempeñar el cargo de vocales de la Comisión Mixta de Reclutamiento. La Diputación sufragaba los gastos de estos vocales en el ejercicio de sus funciones, por ejemplo, en 1920, se pagó el coste de 48 botellas de vino (141, 25 pts.), yemas y pasteles (230 pts.), consumidas durante el periodo de juicio de exenciones. A.D.P.P., L.A.C.P. 132, 7-V-1920.
} 
Documento 03. Cubierta del Libro de Actas de la Comisión Mixta de Reclutamiento.

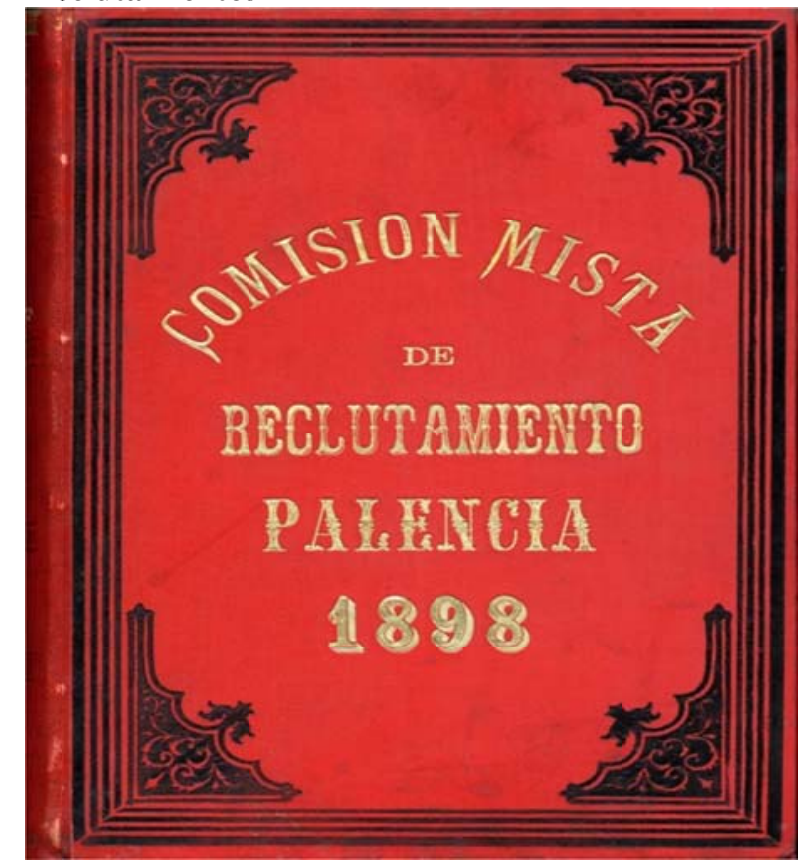

Fuente: A.D.P.P.

La composición de las comisiones mixtas de Reclutamiento era ajena a la estructura orgánica de la Diputación Provincial, ya que era un órgano que no dependía de esta institución, aunque mantenía una fuerte vinculación con la misma. La Ley de Bases de 29 de marzo de 1924 y el Reglamento de desarrollo, aprobado por Real Decreto Ley de 27 de febrero de 1925, crearon las Juntas de Clasificación y Revisión de Reemplazo, que asumían las competencias ejercidas hasta entonces por la Comisión Mixta de Reclutamiento. 
En la época de operaciones de reemplazo, el personal de la sección de cuentas de la Diputación apoyaba la labor de la Comisión Mixta de Reclutamiento, dada la gran carga de trabajo que suponía la clasificación de los quintos. Desde la institución provincial se reconocía el trabajo de su personal con remuneraciones extraordinarias ${ }^{741}$. La principal función de la Comisión Mixta de Reclutamiento ${ }^{742}$ era la de revisar todas las reclamaciones de los reemplazos realizados por los ayuntamientos, relativas a la inclusión y exclusión de mozos por diversas causas (talla, enfermedad, motivos familiares, redención en metálico, etc.).

La Diputación de Palencia defendió siempre la presencia del estamento militar en la provincia, consciente de las sinergias positivas que suponía la presencia de militares en la ciudad de Palencia. En 1889, y en consonancia con el pensamiento anteriormente señalado, la Diputación palentina se dirigió al Ministerio de la Guerra para que dejase sin efecto la supresión de la Zona Militar de Palencia ${ }^{743}$, ya que perjudicaba a los intereses generales de la provincia, cuya defensa y desarrollo encomendaba la ley a las diputaciones ${ }^{744}$. La relación entre la Diputación Provincial y el Ejército fue siempre cordial en aras de un interés mutuo y si, en alguna ocasión, la Diputación no pudo satisfacer las peticiones castrenses fue tan solo porque los imponderables presupuestarios se lo impedían, como en 1915, cuando el coronel director de la Escuela Militar Oficial de Palencia, solicitó a la Diputación Provincial el suministro de mobiliario para las aulas y libros de texto y la institución provincial no pudo acceder a esta demanda ${ }^{745}$ por falta de medios.

\footnotetext{
${ }^{741}$ En sesión de la Comisión Provincial de enero de 1898, se acordó destinar 2.443 pts. para distribuirlas de forma equitativa entre los oficiales y auxiliares que actuaron bajo la dirección del jefe de Secretaría en las operaciones de reemplazo. A.D.P.P., L.A.C.P. 90, 4-I-1898.

${ }^{742} \mathrm{El}$ art. 123 de la Ley de Reclutamiento vigente en 1909 imponía a los curas párrocos la obligación de facilitar a las Comisiones Mixtas de Reclutamiento una relación de los mozos inscritos en sus parroquias que se hallasen comprendidos en las prescripciones de los arts. 27 y 40 de la citada Ley. Las relaciones de los párrocos se confrontaban con las actas de alistamiento, rectificación y cierre de los ayuntamientos.

${ }^{743}$ Palencia pertenecía a la VII Región Militar, con capital en Valladolid.

${ }^{744}$ A.D.P.P., L.A.P.D. 68, 8-XI-1889.

${ }^{745}$ A.D.P.P., L.A.C.P. 119, 19-XI-1915.
} 


\section{Beneficencia}

\section{Introducción}

Caridad, filantropía, beneficencia, y bienestar social. Estos han sido los grandes conceptos con los que sucesivamente se ha comprendido y gestionado el problema de la pobreza a lo largo de la historia. Caridad, entendida como respuesta moral y religiosa, filantropía como solución ética y racional y beneficencia como defensa de un modelo de vida burgués. En el Antiguo Régimen, la atención a los problemas de enfermedad, pobreza, soledad, marginación y falta de trabajo se canalizaba a través de fundaciones particulares legadas por nobles o clérigos, encuadradas en parroquias, monasterios, capillas, cofradías y hospitales. Los primeros pasos de la desacralización de este mundo vinieron de las propuestas preliberales del reformismo ilustrado y de la beneficencia liberal burguesa en el siglo $\mathrm{XIX}^{746}$. La concepción que tenía el liberalismo de la beneficencia $^{747}$ divergía de la que se tenía en el Antiguo Régimen, de la noción caritativa se pasó al concepto de justicia social ${ }^{748}$. Sin embargo como recoge la Memoria de la Comisión Provincial del Primer Semestre del ejercicio 1898/99,

«No obstante, no quiere esto decir que la provincia tenga el deber de cuidar de la suerte de los individuos que por sí pueden bastarse, no, (...) porque la beneficencia tiene fronteras determinadas, a diferencia de las de la caridad, que son mucho más extensas.» ${ }^{749}$

El liberalismo concebía la pobreza como un fracaso personal, resultado natural de las diferentes capacidades concurriendo en libre competencia en la sociedad, y por lo tanto la pobreza no era una cuestión a erradicar, había que admitirla como una consecuencia inherente y necesaria de la libre competitividad, una especie de ley de selección natural darwiniana que regía la sociedad.

\footnotetext{
${ }^{746}$ Vid. MAZA ZORRILLA, Elena, Pobreza y Asistencia Social en España. Siglos XVI al XIX, Valladolid, Universidad de Valladolid, 1987.

${ }^{747}$ «Hacer hombres útiles a la sociedad y a sí mismos». A.D.P.P., C-R/ 1,12 (A). La Ley de 20 de junio de 1849 junto con el Reglamento de 14 de mayo de 1852, organizaba la beneficencia en la España liberal.

${ }^{748}$ Definición legal de beneficencia: «Caridad social y particular ejercida oficialmente o por medio de fundaciones o sociedades consagradas a socorrer a los desvalidos, niños abandonados, enfermos, pobres, ancianos, sordo-mudos, ciegos y locos». A.D.P.P, C-R/ 1,11(A). La propia Ley Provincial de 29 de agosto de 1882 recogía en su articulado (art. 74) la obligación de la provincia de remediar en lo posible los perjuicios parciales que causa el bien del mayor número a los que carecían de lo necesario para vivir.

${ }^{749}$ A.D.P.P., C-R/ 1,15 (A), p. 14.
} 
En el Antiguo Régimen, la pobreza se mostraba fundamentalmente por la falta de propiedad, que pertenecía en exclusiva a los estamentos privilegiados, para el liberalismo estaba relacionada con las habilidades del individuo y su estatus social, con su capacidad de trabajo y de ascenso social. En consecuencia los programas liberales solo pretendían controlar la pobreza por encima de un mínimo necesario para que pudiera darse el enriquecimiento de las élites, y por debajo de un máximo peligroso que pusiese en riesgo el sistema. El sistema benéfico liberal se orientaba a garantizar la defensa de unos umbrales mínimos de seguridad. La pobreza no podía descender por debajo de un nivel en el que las necesidades primarias no satisfechas llegaran a poner en riesgo la pervivencia del propio sistema, razón por la que la beneficencia estaba pensada para evitar esa situación límite. Por este motivo, los padrones de pobres y las condiciones de los servicios benéficos eran cambiantes, según las coyunturas más o menos peligrosas, y los perfiles exigidos para ser clasificado como pobre se referían, no tanto a los umbrales de pobreza, cuanto a los recursos disponibles. La beneficencia liberal pretendía evitar conflictos sociales, rehabilitar la fuerza de trabajo y crear ciudadanos colaboradores y contribuyentes.

La beneficencia burguesa no dejaba crecer la necesidad social hasta unos límites que impidiesen la rotura del equilibrio social, pero tampoco permitía que se erradicase del todo de forma que se comprometiese la reproducción del poder y la pervivencia de su riqueza. El Estado se servía de las instituciones de beneficencia municipal y provincial para garantizarse el control de las clases populares y, como consecuencia, los dirigentes locales adquirirán un papel protagonista en este escenario social. La beneficencia domiciliaria, la municipal y la provincial surgieron al igual que otras instituciones relacionadas con la Sanidad y la Enseñanza, para dar respuesta a los riesgos de la falta de trabajo. Al liberalismo moderado de mediados del siglo XIX le pareció excesiva la agresividad con que los municipios habían despojado a la vieja iniciativa privada asistencial, y desde la Ley de Beneficencia de 1849, frenaron el proceso municipalizador en beneficio de otro proceso complementario de provincialización. 
Desde entonces, las diputaciones provinciales trataron de concentrar servicios asistenciales de destino provincial (hospitales provinciales, hospicios provinciales) e instituciones de gestión de la beneficencia con este mismo carácter, como eran las Juntas Provinciales de Beneficencia ${ }^{750}$. Ayuntamientos y diputaciones provinciales forcejearon constantemente a propósito de la beneficencia, su control y el destino de los fondos a ella dedicados. La provincialización significó la reorientación hacia el ámbito rural de buena parte de los recursos de la vieja caridad. La pobreza se podía clasificar en tres grados ${ }^{751}$ : población que hoy diríamos en riesgo de exclusión social, los pobres oficiales $^{752}$ y los «asistidos», sujetos que eran atendidos por las instituciones benéficosanitarias. La beneficencia pública se estructuraba en tres escalones administrativos: nacional, provincial y municipal, con un órgano de gobierno, la Junta, que tenía como principal función el asesoramiento a las respectivas corporaciones. Suprimidas las Juntas Provinciales ${ }^{753}$, las diputaciones provinciales asumieron todas sus funciones. El Gobierno revolucionario de 1868 dispuso que las corporaciones provinciales asumiesen la dirección y el mantenimiento de los establecimientos de beneficencia.

La legislación conservadora en materia benéfica de la primera Restauración no tuvo la finalidad de conducir hacia unos servicios públicos con cargo a los presupuestos estatales, sino que fue más bien un instrumento de control de los ayuntamientos y diputaciones provinciales, y de recuperación del papel protagonista de la Iglesia ${ }^{754}$. El Gobierno central consideraba que las fuerzas locales se habían extralimitado en sus competencias asistenciales y esto había generado caciquismo con el manejo de las de las instituciones benéficas a su cargo. Las leyes aprobadas en la Restauración consiguieron minimizar el carácter público de la política social e incrementar el espacio familiar y eclesiástico de la beneficencia.

\footnotetext{
${ }^{750}$ Vid. LÓPEZ ALONSO, Carmen et al, Cuatro siglos de Acción Social. De la beneficencia al bienestar, Madrid, Siglo XXI, 1985.

${ }^{751}$ Vid. CARASA SOTO, Pedro, Pauperismo y Revolución Burguesa. Burgos (1750-1900). Valladolid, Secretariado de Publicaciones, D.L., 1987. p.75.

${ }^{752}$ Ancianos, enfermos, expósitos y abandonados. Los expósitos una vez finalizada su crianza eran considerados acogidos a todos los efectos del Reglamento de Beneficencia.

${ }^{753}$ Reales Decretos de 4 de noviembre y 17 de diciembre de 1868.

${ }^{754}$ Vid. MARTíN VALVERDE, Antonio et al, La Legislación Social en la Historia de España. De la Revolución liberal a 1936, Madrid, Congreso de los Diputados, 1987.
} 
Volvía a retomarse la caridad como base ideológica de la asistencia social y la Iglesia era la principal encargada de llevar a cabo la labor asistencial, con lo que el canovismo pretendía ganarse el apoyo del clero en su lucha por restar apoyos al movimiento carlista y a los movimientos sociales emergentes de carácter socialista ${ }^{755}$. Los instrumentos básicos de la acción legislativa de la Restauración fueron, para limitar el carácter público de la beneficencia, el Real Decreto de 27 de abril 1875 y el Real decreto de 27 de enero de 1885 y para potenciar la beneficencia particular, el Real Decreto e Instrucción de 14 de marzo de 1899. En el último cuarto del siglo XIX se multiplicaron las órdenes religiosas como personal asistente al frente de instituciones benéficas, como objetivo último de esta política subyacía el deseo del Gobierno de que las administraciones locales junto con la Iglesia se sirviesen de la beneficencia para resolver la cuestión social ${ }^{756}$, dada la inexistencia de previsión social en esta primera etapa de la Restauración. Los ilustrados ya habían advertido que los grupos populares más afectados por la pobreza despreciaban el valor de la vecindad y no se sentían especialmente vinculados a un territorio, consecuencia de haberse habituado a un cierto nomadismo incentivado por la vida errante en busca de trabajo y la mendicidad itinerante. La familia y el domicilio fueron instrumentos al servicio de la burguesía en su objetivo de integrar y radicar a las oleadas de trabajadores que llegaban a las ciudades en busca de una oportunidad, la condición previa de domiciliación en la ciudad o la provincia, era requisito indispensable para acceder a todos los servicios de beneficencia municipal y provincial.

\footnotetext{
${ }^{755} C f r$. CARASA SOTO, Pedro, «Beneficencia y "cuestión social": una contaminación arcaizante», Historia Contemporánea, № 29 (2004), p. 625-670.

${ }^{756}$ Manera eufemística de referirse al conflicto entre patronos y obreros, entre capital y trabajo, que se utilizó en el último cuarto del siglo XIX por los conservadores y liberales de la Restauración. En Palencia, en 1884, la clase obrera vivía en viviendas antiguas, pequeñas y de pésimas condiciones higiénicas. Además exceptuando los trabajadores de percha y telar, las condiciones salariales del resto de la población obrera, eran malas y su situación económica muy precaria debido al alto precio de los artículos de primera necesidad y los impuestos municipales. BOP 20-X-1884.En esa época, el sector primario ocupaba al $32,65 \%$ de la población activa, el sector secundario al $38,9 \%$, y el sector terciario al $28,39 \%$. El Diario Palentino 13-XII-1884.
} 
Beneficencia era la partida que mayor porcentaje del Presupuesto acaparaba en las diputaciones provinciales de Régimen Común, entre un $30 \%$ y un $40 \%$ de media ${ }^{757}$. En el caso de la Diputación Provincial de Palencia, el gasto de la partida de beneficencia suponía el 39,32\% del presupuesto total de gastos.

Figura 09. Porcentaje de Gasto en Beneficencia Pública sobre el total del Presupuesto de Gasto de la Diputación Provincial de Palencia en el periodo 1875-1931.

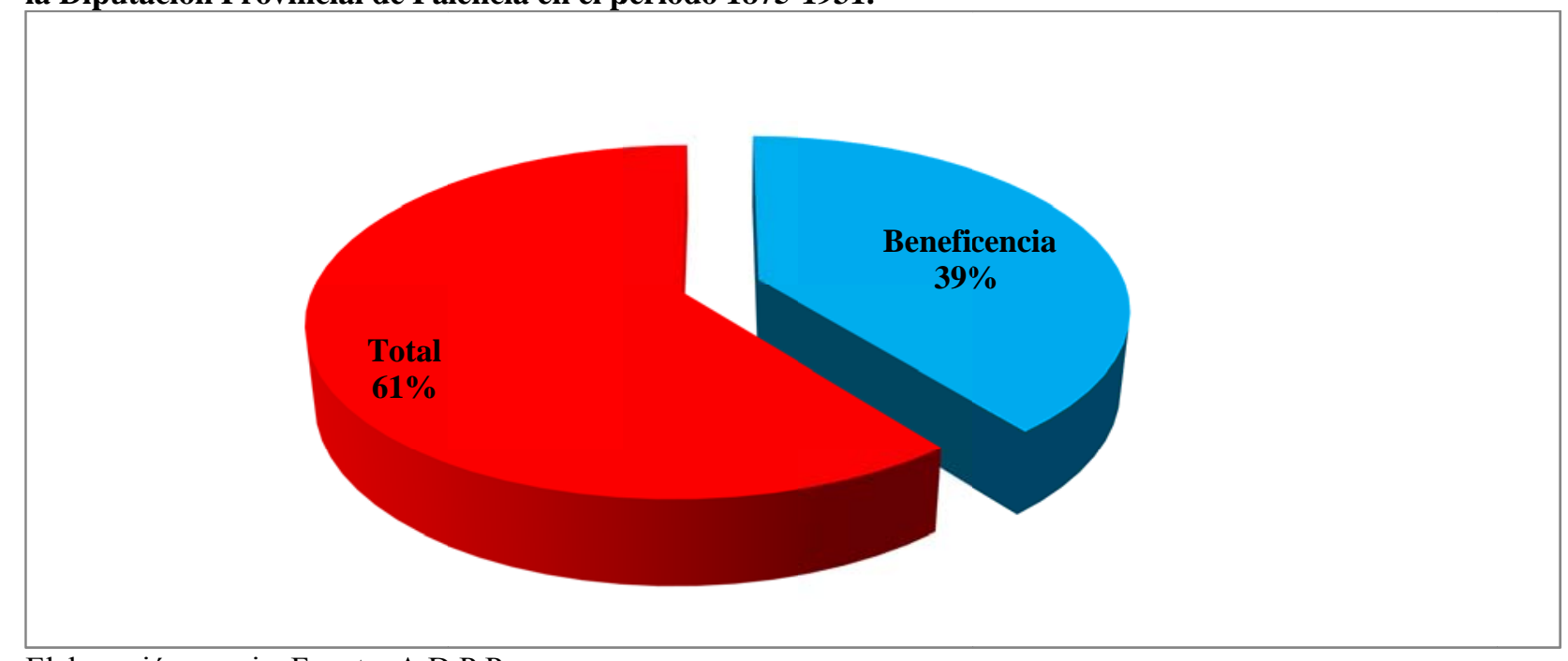

Elaboración propia. Fuente: A.D.P.P.

\footnotetext{
${ }^{757}$ Cfr. MORAL RUIZ, Joaquín del, Hacienda central y haciendas locales, Madrid, Instituto de Estudios de Administración Local, 1984, p. 146.
} 
Figura 10. Gasto en pts. en Beneficencia Pública en los ejercicios económicos del periodo 1875-1931.

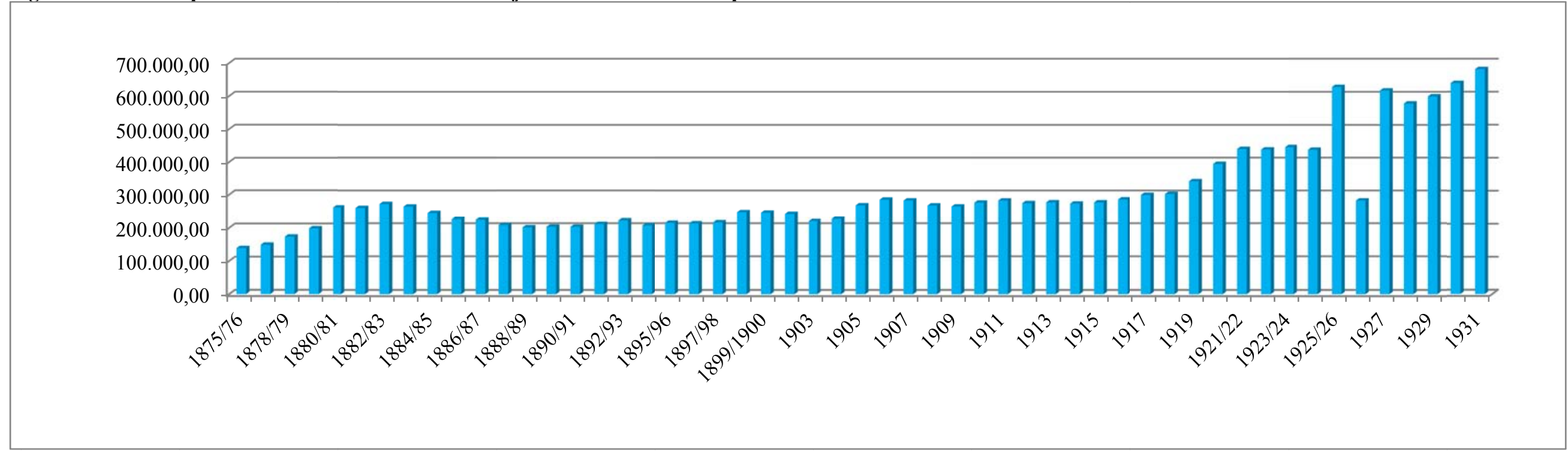

Elaboración propia. Fuente: A.D.P.P. 
En Palencia, tras el motín del pan de 1766, la administración borbónica intentó dar una respuesta satisfactoria a las evidentes carencias asistenciales de la política social del Antiguo Régimen, con la creación del Hospicio Real de Palencia ${ }^{758}$. Ante la insuficiencia presupuestaria de esta institución, la Sociedad de Amigos del País fundó en 1818 su propia entidad asistencial, la Casa de la Beneficencia, que incluía entre sus prestaciones la asistencia domiciliaria. En 1821, se crearon las Juntas Municipales de Beneficencia y la Sociedad de Amigos del País, cedió en favor del Hospicio sus derechos sobre la Casa de la Beneficencia. En 1841, la Casa Hospicio ${ }^{759}$, se dotó de un Reglamento interno y las actuaciones sobre esta materia pasaron a ser competencia de las diputaciones provinciales. En 1850, se instaló en el ex convento de San Francisco, estableciéndose en la fachada norte del viejo edificio.

Imagen 01. Edificio de los Establecimientos Provinciales de Beneficencia en la plaza de la Maternidad (actual plaza de Abilio Calderón.

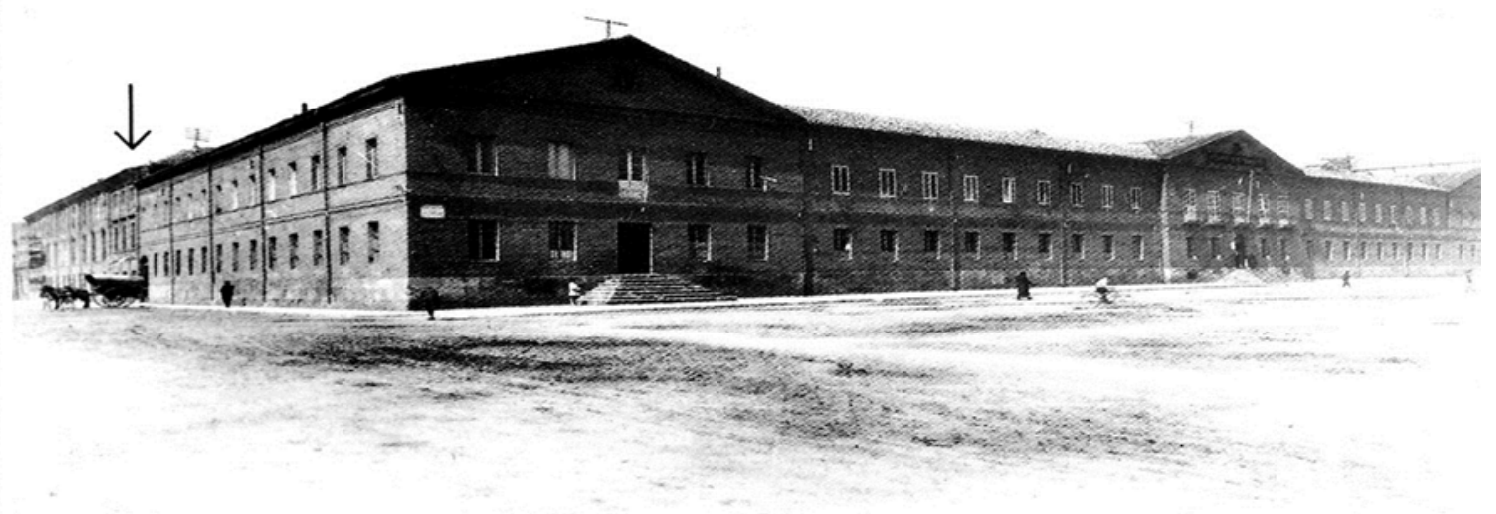

Fuente: A.D.P.P. Biblioteca Tello Téllez de Meneses (BTTM).

\footnotetext{
${ }^{758}$ El Hospicio tenía un patronato triple: el Obispado, el Municipio y el Cabildo.

${ }^{759}$ Llamada igualmente Casa de Beneficencia.
} 
Con arreglo a la legislación ${ }^{760}$, la Diputación Provincial debía sostener con sus fondos un Establecimiento de Beneficencia, para dar asilo y refugio a las personas desamparadas o que no podían proporcionarse la subsistencia, e instruir a los jóvenes de ambos sexos, un hospital para dementes y un hospital para pobres de la provincia. La Casa de Beneficencia reunía en un mismo espacio a la Casa de la Misericordia ${ }^{761}$, Inclusa o Expósitos y la Casa de la Maternidad ${ }^{762}$.

De acuerdo con lo dispuesto en el art. 74 de la Ley Provincial de 29 de agosto de 1882, correspondía a la Diputación el gobierno y la administración de los establecimientos benéficos ${ }^{763}$ citados y nombrar, de entre sus vocales, un director y un vicedirector ${ }^{764}$, cuyos cargos eran honoríficos y gratuitos. El día 9 de febrero de $1881^{765}$, se aprobó la creación del cargo de inspector general de los ramos de la Beneficencia Provincial, de carácter honorífico, obligatorio, meritorio y no remunerado. El diputado provincial Antonio Reyero fue nombrado inspector general.

\footnotetext{
${ }^{760}$ Arts. 41, 71 y 105 de la Ley de 23 de enero de 1882, art. 3 de la Ley de 20 de junio de 1849, y art. 3 del Reglamento de 14 de mayo de 1852.

${ }^{761}$ Establecimiento fundado el 31 de julio de 1766 por el Real Supremo Consejo de Castilla con objeto de recoger a pobres. En virtud de la Ley de 20 de junio de 1849, la Diputación Provincial se hizo cargo de este servicio.

${ }^{762}$ Este departamento estaba destinado para albergar a aquellas mujeres que «habían concebido ilegítimamente» y para evitar los infanticidios que provocaba la «vergüenza». Podían ingresar todas las mujeres que lo solicitasen y se hallasen el séptimo mes de gestación. Aquellas mujeres que fuesen objeto de malos tratos por sus padres o tutores o abandonadas por sus padres o parientes, podían ingresar excepcionalmente antes del séptimo mes de embarazo. Junto a la Casa de la Maternidad se estableció la Inclusa a partir de 1851, que hasta entonces había permanecido en el Hospital de San Bernabé. En la pared exterior del edifico de la Inclusa había un torno para recibir a los niños que de forma anónima se depositaban, comunicado con una habitación en la que permanentemente había una Hija de la Caridad. Tras recibir al niño, se anotaba en un registro la hora de entrada, colocándole en el cuello un cordón de seda, del que colgaba un plomo en el que constaba grabado el número que correspondía al niño y el año de ingreso.

${ }^{763} \mathrm{Con}$ el nombre de Establecimientos Provinciales de Beneficencia, la Diputación de Palencia denominaba al edificio que dividido en pabellones se destinaba a Asilo de ancianos, Maternidad y Hospicio provincial.

${ }^{764}$ Sustituía al director en caso de ausencia enfermedad.

${ }^{765}$ A.D.P.P., L.A.P.D. 50, 9-II-1881.
} 
Las personas a las que se acogía en la Beneficencia se clasificaban de acuerdo a la legislación ${ }^{766}$ de la siguiente forma:

1. Los pobres de ambos sexos inutilizados para el trabajo, o que tuviesen sesenta años cumplidos y fuesen solteros o viudos, ingresaban por turno de antigüedad y por el de gracia con arreglo a las bases establecidas por la Diputación en la Casa de Misericordia.

2. Los niños expuestos en el torno o abandonados en cualquier lugar de la provincia, los expósitos, que ingresaban en la Casa de Expósitos.

3. A aquellos que sin ser absolutamente pobres ni impedidos, ingresasen por orden de la Diputación Provincial mediante el pago de la retribución que se estipulara, a estos se les denominaba pensionistas ${ }^{767}$.

Los niños acogidos y los expósitos eran considerados a efectos legales como hijos adoptivos del establecimiento benéfico, el resto como amparados. Correspondía ${ }^{768}$ al director de la Beneficencia la tutela de todos los acogidos, los expósitos y acogidos menores de veintitrés años en general ${ }^{769}$ y lo relativo a su prohijamiento, al estado de las personas, sus derechos y obligaciones. Estos derechos no se alteraban al salir de los Establecimientos de la Beneficencia.

\footnotetext{
${ }^{766}$ Art. 12 del Reglamento de 14 de mayo de 1852, art. 6 del Reglamento de 23de julio de 1903 y Sentencia del Tribunal Supremo Tercera de 28 de noviembre de 1904.

${ }^{767}$ La pensión no podía ser en ningún caso menor de 1,50 pts.

${ }^{768}$ Art. 212 del Código Civil.

${ }^{769}$ Una vez cumplidos los veintitrés años, si eran válidos para el trabajo, debían abandonar los Establecimientos de Beneficencia sin derecho a ingresar de nuevo. Los mayores de esa edad que padeciesen algún defecto físico o enfermedad continuaban en la Beneficencia hasta que pudieran trabajar una vez recuperados de su dolencia. Los acogidos mayores de dieciséis años que solicitasen abandonar la Beneficencia de forma voluntaria, podían hacerlo previo informe del director.
} 
También correspondía al director prestar su consentimiento al matrimonio de los educados en la Beneficencia ${ }^{770}$. La Casa de Maternidad ${ }^{771}$ estaba dividida en dos salas, la sala general ${ }^{772}$ y la sala particular ${ }^{773}$ o cuartos de preferencia. Los nacidos en estas salas eran trasladados a establecimiento de expósitos, siempre que la madre hubiera fallecido ${ }^{774}$ como consecuencia del parto, o manifestado su voluntad de dejar al recién nacido en el establecimiento benéfico. Si la madre optaba por criar a su hijo, debía obtener el permiso del director y reconocer legalmente a su descendiente. El tópico malthusiano achacaba a los pobres una natalidad desmedida y descontrolada que resultaba peligrosa, porque el crecimiento demográfico superaba al de los recursos. Los pobres tenían formas peculiares de control de natalidad que no llegaban a excluir el infanticidio ${ }^{775}$. Las casas de expósitos trataban de remediarlo en parte, en relación con este afán protector de la infancia, y atendiendo a los nuevos modelos familiares de la burguesía liberal, se crearon instituciones protectoras de la maternidad «heterodoxas», como las casas de Maternidad y las casas Cuna. La asistencia al niño trataba de defender socialmente la descendencia del matrimonio y se crearon centros docentes gratuitos para los hijos de los pobres, los asilos de párvulos, roperos y dispensarios, casas Cuna y establecimientos de alimentación denominados «gotas de leche».

\footnotetext{
${ }^{770}$ Art. 46 del Código Civil

${ }^{771}$ La Casa de Maternidad y Expósitos de Palencia fue fundada en 1549, y clasificada como provincial el 4 de diciembre por Real Orden de 5 de abril de 1846, pasando a cargo de la Diputación Provincial en virtud de la Ley de 20 de junio de 1849.

${ }^{772}$ Esta sala acogía a las mujeres que no contaban con los recursos necesarios para sufragar su estancia. Para ser admitidas debían presentar la cédula de vecindad o una papeleta del alcalde en la que constase: nombre y apellidos, edad y naturaleza, para que en caso de defunción, se pudiese extender el correspondiente certificado sin ningún tipo de duda. Si las peticionarias querían ocultar sus circunstancias personales, que era lo más habitual, podían presentar este documento en pliego cerrado y entregarlo a la superiora de las Hijas de la Caridad. Antes de decretarse su ingreso eran reconocidas por el facultativo de la Casa de Maternidad para determinar el tiempo de embarazo.

${ }^{773}$ En la sala particular ingresaban las mujeres que aun hallándose en el cuarto o quinto mes de embarazo, solicitasen su ingreso en el establecimiento siempre que garantizasen de forma suficiente, a juicio del director, el pago de sus estancias. En estos casos se omitía el reconocimiento médico previo al ingreso. A esta clase de acogidas se les identificaba por un número que les era asignado al ingresar, sin que por ninguna causa se revelase el nombre de la acogida, aun en el caso de que la interesada manifestara su conformidad para que su nombre constase en el documento de ingreso. No se admitían en esta sala a las jóvenes que hubiesen «concebido ilegítimamente por segunda vez o hubieran observado mala conducta».

${ }^{774}$ Una vez certificado por el facultativo el fallecimiento de una acogida, tanto en la sala general como en la sala particular, el director, de común acuerdo con la superiora de la Orden de las Hijas de la Caridad y cumpliendo las formalidades exigidas en el Código Civil, ordenaba que se diese entierro a la fallecida con el «mayor sigilo posible». A.D.P.P., art. 310 del Reglamento de los Establecimientos de Beneficencia de la Provincia de Palencia de 1913.

${ }^{775}$ Cfr. GUTIÉRREZ RESA, Antonio, (Edición.), Orígenes y desarrollo del trabajo social, Madrid, Ediciones Académicas, 2010, p.123.
} 
Por regla general, ninguna persona podía ingresar en los Establecimientos de Beneficencia en calidad de acogidos, a no ser en virtud de acuerdo de la Diputación Provincial o la Comisión Provincial, y orden por escrito del director, anotándose el ingreso en el registro respectivo y la hoja biográfica de la persona acogida. Se establecían tres grupos o secciones para el ingreso en la Beneficencia, previo el necesario expediente ${ }^{776}$ :

1. Huérfanos menores de 14 años que careciesen de familia que legalmente debiera socorrerles y de bienes suficientes para sustentarse.

2. Niños menores de esa edad que sin ser huérfanos se hallaran sus padres imposibilitados para el trabajo y careciesen de bienes con los que hacer frente a la subsistencia, o de familia obligada a facilitarles alimentos con arreglo al Código Civil.

3. Pobres de ambos $\operatorname{sexos}^{777}$ que por su edad sexagenaria o padecimientos físicos se hallasen imposibilitados para el trabajo y carecieran de ascendientes, descendientes o colaterales que legalmente tuvieran obligación de socorrerlos.

En el año 1876, la Casa de Maternidad y Expósitos acogía a 366 beneficiarios y contaba con 21 empleados. La Casa de Misericordia empleaba a nueve trabajadores y en ella residían $328 \operatorname{acogidos}^{778}$. En mayo de 1878, con el voto en contra de varios diputados provinciales, se acordó encomendar la administración y servicio interior de los Establecimientos de Beneficencia a las Hermanas de la Caridad ${ }^{779}$. El 10 agosto de 1878 se firmó el convenio ${ }^{780}$ con las Hermanas de la Caridad para el establecimiento en la Casa de Maternidad y Expósitos, con iguales condiciones que las que regulaban el convenio celebrado con la Diputación de Valladolid ${ }^{781}$. El día 25 de enero de 1879 llegaban a Palencia las Hermanas de la Caridad encargadas del régimen y gobierno interior de la Casa de Maternidad y Expósitos.

\footnotetext{
${ }^{776}$ A.D.P.P., Reglamento de los Establecimientos de Beneficencia de 1913. Bases de la Diputación de 10 de octubre de 1906.

${ }^{777}$ En este caso, se establecían turnos de antigüedad para el ingreso y, en su caso, el turno de gracia. Si después de ocho días de recibir la notificación de la orden de admisión, el interesado no había ingresado en la Beneficencia, se entendía que renunciaba a ese derecho. Ninguna persona menor de sesenta años podía ingresar en concepto de anciano, ni de impedido para el trabajo sin certificado del facultativo de la Beneficencia Provincial que acreditase dicha circunstancia. Tampoco podían ingresar aquellos que sufriesen alguna enfermedad contagiosa $u$ otra dolencia el día de su ingreso.

${ }^{778}$ A.D.P.P., L.A.P.D. 42, 24-IV-1876.

${ }^{779}$ A.D.P.P., L.A.P.D. 49, 1-V-1878.

${ }^{780}$ Contrato celebrado entre el director del Real Noviciado y la Diputación Provincial de Palencia.

${ }^{781}$ A.D.P.P., L.A.P.D. $49,12-$ VII-1878.
} 
En 1880, la Casa de Maternidad acogía a 91 asilados, ocho Hermanas de la Caridad al cargo de la misma y 160 amas de lactancia ${ }^{782}$. Como se ha dicho, el Capítulo de Beneficencia se llevaba buena parte de los escasos recursos con los que contaba la Diputación Provincial de Palencia para hacer frente a todas las atenciones que la legislación le imponía. Desde el comienzo de la Restauración hasta la promulgación del Estatuto Provincial de 1925 , Contaduría ${ }^{783}$ tuvo que hacer malabares presupuestarios para atender de forma digna las necesidades de las personas que por diversas circunstancias necesitaban de los servicios de la Beneficencia Provincial. Por lo tanto, desde el comienzo de esta etapa se planteó un problema grave de coste de las atenciones benéficas, que originó un especial celo en la Administración Provincial a la hora de establecer las condiciones que habían de reunir los aspirantes a entrar en los distintos departamentos de los Establecimientos de Beneficencia, y en la rendición de cuentas por parte de sus administradores. En 1875, por orden del diputado de área, se redujo a la mitad el presupuesto de la Casa de Maternidad respecto a 1874 (de 24.148 pts. se pasó a 12.076 pts.) debido a la falta de explicación en la distribución de los artículos comprendidos en el Capítulo VI, Beneficencia, del Presupuesto de Gastos. Como consecuencia, el director de los Establecimientos de Beneficencia envió una nota, adjunta al libro del Presupuesto Ordinario de la Beneficencia, a la Contaduría de fondos provinciales, en la que indicaba que en la elaboración del Presupuesto de 1876 se había puesto especial cuidado para evitar cualquier tipo de estafa en las diferentes partidas de este Capítulo ${ }^{784}$.

El director mostraba su interés en que el contribuyente pudiera conocer la administración interior de los Establecimientos de Beneficencia, y el Presupuesto confeccionado contenía una relación detallada de los gastos en personal acogido y trabajadores de los centros de expósitos y maternidad ${ }^{785}$.

\footnotetext{
${ }^{782}$ A.D.P.P., C-L/ 4,2.

${ }^{783} \mathrm{El}$ director de la Beneficencia remitía las cuentas justificadas de los diferentes suministros de los establecimientos benéficos a la Comisión de Hacienda, cuyo negociado, una vez revisadas, las elevaba a la Comisión provincial para su aprobación, una vez selladas y datadas con la fecha de la sesión de su aprobación se remitían a Contaduría.. En caso de no aprobarse las cuentas se devolvían para su reforma. ${ }^{784}$ A.D.P.P., C-L/ 4,1.

${ }^{785}$ El Presupuesto contenía un cuadro sinóptico sobre la distribución del importe de los presupuestos de la Casa de Expósitos y Maternidad, ya que «la premura del tiempo» había impedido realizarlo sobre la Casa de Maternidad. A.D.P.P., C-L/ 4,1.
} 
La relación era tan minuciosa que, por ejemplo, en la Relación Sexta ${ }^{786}$ reflejaba el aumento de los honorarios del director por trabajar dos horas más por la tarde, no solo de nueve a catorce horas. Se justificaba el aumento del presupuesto en cada relación ${ }^{787}$, o su disminución.

En 1897, se discutía el nombramiento de un nuevo director de la Beneficencia, y el diputado provincial García Crespo, que optaba al cargo, sacaba a relucir el tema de un posible fraude en la contabilidad de los Establecimientos de Beneficencia. Denunciaba que un director de la Beneficencia que tenía un caballo de su propiedad, había mantenido al mismo en los establecimientos benéficos a costa de la Diputación, y no había tenido reparo en aprobar las cuentas de la Beneficencia más tarde como vocal de la Comisión Provincial. El presidente de la Diputación llamaba la atención a García Crespo y le rogaba comedimiento $^{788}$. Por mayoría se aprobaba el nombramiento de García Crespo como director de la Beneficencia Provincial, quien aclaraba que el diputado provincial al que se refería no formaba parte de la Corporación actual ${ }^{789}$, y que si se le pedía, podía aportar pruebas que demostrasen lo comentado. Se acordó crear una Comisión especial formada por cuatro diputados, representantes de igual número de facciones existentes en la Corporación Provincial, para que con el presidente instruyesen las diligencias comprobadoras del hecho denunciado por García Crespo ${ }^{790}$, también se acordó autorizar al presidente para que llevase a cabo la información acerca de los hechos denunciados por García Crespo. El diputado provincial Jubete Tejerina, preguntó a García Crespo si se refería a Abilio Calderón Rojo, cuando hablaba de las irregularidades de un director de la Casa de Beneficencia, y también preguntaba el presidente. García Crespo no desveló el nombre del diputado provincial en cuestión. El hecho demuestra la extrema sensibilidad que había sobre las cuentas de la Beneficencia Provincial, habida cuenta de que como se ha dicho, casi la mitad del Presupuesto Provincial iba destinado a costear las atenciones de este Capítulo.

\footnotetext{
${ }^{786}$ Capítulo I, Administración Provincial, de la Primera Sección, Gastos obligatorios, del Presupuesto de Gastos, art. 6, Sueldos empleados. Véase Anexo I. Modelo Presupuesto Provincial General de Gastos e Ingresos, p. 438.

${ }^{787} \mathrm{El}$ detalle de gastos se hacía por relaciones.

${ }^{788}$ A.D.P.P, L.A.P.D. 82, 4-XI-1897.

${ }^{789}$ Rodríguez Blanco era el vicedirector de la Casa de la Beneficencia.

${ }^{790}$ A.D.P.P, L.A.P.D. 82, 5-XI-1897.
} 
En 1915, Contaduría llamaba la atención sobre las deficiencias en las cuentas de los artículos de droguería facilitados a los Establecimientos de Beneficencia, ya que los vales no estaban autorizados ni por los médicos de Beneficencia, ni llevaban el $\mathrm{V}^{\mathrm{o}} \mathrm{B}^{\mathrm{o}}$ del director de la misma ${ }^{791}$. Es otro ejemplo más del cuidado que se ponía en todo lo relativo al suministro de insumos a las distintas dependencias de la Beneficencia Provincial, celo que llegaba al extremo de que los vocales de la Comisión Provincial que visitaban ${ }^{792}$ la Casa de Beneficencia, se quejaban de la dureza de los garbanzos que se servían a los acogidos, y se preguntaba al contratista si los garbanzos suministrados eran iguales a la media que había servido para formalizar el contrato ${ }^{793}$.

El suministro de los Establecimientos de Beneficencia se realizaba por subasta y administración ${ }^{794}$. En los quince días primeros de cada año, el administrador con la conformidad del director, remitía a la Diputación o a la Comisión Provincial una nota de los efectos que debían adquirirse por subasta según el Presupuesto, así como las materias primas que necesitarían los talleres en ese año. En 1924, por ejemplo, solo estaban subastados la carne, el pan, el pimiento y el tocino. Si quedaba desierta la subasta de los artículos con destino a los Establecimientos de Beneficencia en primera y segunda sesión, el aprovisionamiento se hacía por administración, con autorización del Ministerio de Gobernación por Real Orden, previa consulta de precios y muestras, mensualmente. Aunque este procedimiento no era del agrado de la Diputación Provincial pues, como afirmaba en 1917 el director de los Establecimientos de Beneficencia ${ }^{795}$, los artículos adquiridos por administración se elevaban tanto en el precio que sobrepasaban el precio fijado en el Presupuesto.

\footnotetext{
${ }^{791}$ A.D.P.P., L.A.C.P. 119, 26-I-1915. La contabilidad de los Establecimientos de Beneficencia era llevada por el administrador, ayudado por el secretario contador. El administrador, de acuerdo con el director, formaba los presupuestos de gastos e ingresos con sujeción a los modelos, y en las épocas que determinasen las disposiciones generales que rigiesen para la contabilidad provincial.

${ }^{792} \mathrm{La}$ Comisión Provincial realizaba visitas rutinarias mediante sus vocales a los Establecimientos de Beneficencia.

${ }^{793}$ A.D.P.P., L.A.C.P. 118, 14-VII-1914. Cuando finalizaban los contratos de subasta y administración para el suministro de varios artículos con destino a los Establecimientos de Beneficencia, debía fijarse un anuncio durante diez días para el nuevo periodo.

${ }^{794} \mathrm{El}$ art. 36 del Real Decreto de 4 de enero de 1883 señalaba la obligación de realizar subasta para todos los suministros de beneficencia, bagajes, papel para el Boletín Oficial de la Provincia, alimentación, carreteras provinciales, acopios y caminos municipales subvencionables. El párrafo $2^{\circ}$, del art. 125 de la Ley Provincial de 29 de agosto de 1882, contemplaba la obligación de publicar en el BOP el pormenor de los gastos ocasionados en las obras hechas por administración, aquellos cuyos presupuestos fuesen inferiores a 2.000 pts.

${ }^{795}$ A.D.P.P., L.A.C.P. $124,26-V I-1916$.
} 
La falta de presupuesto se tradujo en continuas reformas de las Bases que regulaban la admisión de los asilados, de carácter más restringido en épocas de mayor dificultad económica, y en un cuidado extremo en la revisión y autorización del gasto en el ámbito benéfico. No faltan en la documentación consultada ejemplos de ambos factores. Para hacer frente a las atenciones en esta materia, la Diputación Provincial contaba con personal escaso en cantidad y, salvo excepciones, en cualificación profesional. En los fondos documentales examinados no aparece ninguna relación del personal destinado en los Establecimientos de Beneficencia hasta 1913, evidentemente algunos puestos profesionales habían surgido posteriormente a 1876, como el personal de talleres, pero merece la pena reflejar aquí esta información porque nos permite alcanzar una idea aproximada de la estructura interna de los departamentos de Maternidad y Misericordia en lo que respecta al personal que desarrollaba su trabajo en ellos.

La relación contenía las siguientes categorías profesionales:

Un diputado director ${ }^{796}$, un diputado vicedirector, un administrador ${ }^{797}$, un secretario contador y un capellán ${ }^{798}$.

\footnotetext{
${ }^{796}$ Cuyas funciones estaban reguladas por la Instrucción del Real Decreto de 27 de enero de 1885 . El diputado director tenía la facultad de amonestar y suspender total o parcialmente de empleo y sueldo a los empleados, dando cuenta a la Diputación o Comisión Provincial para que resolvieran de forma definitiva. Entre sus funciones estaban: inspeccionar, junto con la superiora y el administrador, la entrega de los comestibles, enterándose de la calidad y peso, así como del condimento de la comida y de su distribución, ajustar los gastos a las consignaciones que aparecían en el Presupuesto Provincial, en la parte que a estos Establecimientos correspondía, expedir vales que sirviesen de justificante a las cuentas que presentaran aquellos que hubieran contratado algún servicio o suministrado algún efecto adquirido por administración, realizar las compras de efectos cuando su adquisición no se efectuaba por subasta, y presenciar, junto con la superiora y el administrador, la entrega de los efectos de toda clase que hubiesen sido adquiridos por subasta o administración, remitiendo a la Asamblea las certificaciones consiguientes.

${ }^{797}$ Eran funciones del administrador y del secretario contador llevar el registro del personal asilado, debiendo remitir una copia a la Diputación en los quince primeros días de los meses de abril y septiembre, el registro de expósitos y huérfanos dados a nodrizas externas, y de los que una vez terminada la infancia se hallaban bajo la tutela del establecimiento por no haber cumplido los veintitrés años, el registro de los acogidos y expósitos que cumplieran veinte años, para remitirlo al Ayuntamiento de la capital, de acuerdo con el art. 27 de la Ley de Reclutamiento y anotar, al margen de las partidas correspondientes, la fecha en que se había dado un niño a lactar o criar, personas a cuyo cargo se había puesto, su vecindad y demás circunstancias para conocer la situación de cada niño.

${ }^{798}$ Entre sus funciones estaban las de instruir a los asilados de ambos sexos en los deberes de la religión católica, apostólica, romana y vigilar sus costumbres, llevar escritas con orden y claridad las partidas sacramentales de bautismo y defunción en los libros formados anualmente, con papel sellado de pobres, foliados y rubricados por el director, explicar, de acuerdo con los arts. 40 y 41 de la Instrucción General de Beneficencia, el Evangelio en la misa que se celebraba en los días festivos, inculcando a los asistentes la humildad cristiana, el amor al trabajo y las obras de misericordia y procurar que todos los acogidos en el establecimiento aprendieran estas cuestiones sin excepción alguna, velar por que en todos los departamentos, patios y sitios de recreo del Establecimiento, se observasen las prescripciones de decencia y moralidad, corrigiendo las faltas que se cometiesen en este sentido, y dando cuenta de las mismas al director. Además se pagaban derechos parroquiales al cura de San Lázaro, a cuya iglesia se hallaban afectos los Establecimientos de Beneficencia. A.D.P.P., L.A.C.P. 84, 2-VII-1896.
} 
También, las Hijas de la Caridad y un médico, un auxiliar, una comadrona, un practicante, un practicante barbero, un maestro de Instrucción Primaria ${ }^{799}$, un maestro de Música $^{800}$, un maestro de los talleres ${ }^{801}$ establecidos en la Beneficencia, dos celadores $^{802}$ y un suplente, y de los acogidos se elegían los denominados cabos ${ }^{803}$, y un portero $^{804}$.

Por lo que respecta a la cuestión de la admisión de asilados, ya en 1878, para evitar la concesión arbitraria de asilo en los Establecimientos de Beneficencia se proponían por parte del diputado provincial Rodríguez Olea ${ }^{805}$ una serie de condiciones:

1. Que no se concediese ingreso en la Casa de Misericordia a aquellos que pagasen contribución o poseyeran cualquier clase de bienes.

2. Que no se admitiera en la Casa de Expósitos a quienes fuesen hijos de personas que pagasen contribución, a no ser que fueran huérfanos de padre, o de padre y madre.

\footnotetext{
${ }^{799} \mathrm{El}$ nombramiento del maestro de Instrucción Primaria se hacía conforme a la Ley de 9 de septiembre de 1857, y Reales Órdenes de 1 de marzo de 1859 y 15 de marzo de 1876. Asistía a la escuela en horario de ocho a once horas de la mañana, y por la tarde desde las catorce a las diecisiete horas. Preparaba a los niños para el examen que tenía lugar anualmente de acuerdo con la Junta de Instrucción Pública. Debía adoptar para la enseñanza los métodos más reconocidos por su sencillez y claridad, y para la escritura, los tipos castizos de letra española. Tenía que corregir las faltas de estudio y aplicación, persuadiendo y estimulando, antes de imponer castigos, los cuales tenían que ajustare a lo que se disponía en la Ley en el Reglamento del Ramo. La escuela de Instrucción Primaria de niñas estaba a cargo de una Hija de la Caridad designada por la superiora.

${ }^{800} \mathrm{La}$ enseñanza en la escuela de Música estaba a cargo de un profesor de reconocida aptitud y buena conducta nombrado por la Diputación Provincial. Las lecciones de solfeo e instrumental debían enseñarse por métodos y principios de reconocida competencia. El maestro de música reclamaba el director el instrumental, papel y demás accesorios de la escuela de música, además de poner en conocimiento del mismo los avances que hiciesen los alumnos.

${ }^{801}$ En cada taller, había un maestro director de los trabajos a cuyo cargo estaba la enseñanza de los asilados destinados en ellos. El nombramiento de los maestros de taller correspondía a la Diputación, mediante oposición. Al encargarse el maestro del taller correspondiente, recibía un inventario de los efectos que en el mismo existían, debiendo ser rectificado cada semestre y remitido a la dirección. Recibían de la Hija de la Caridad encargada del almacén, previa presentación del vale expedido por el director, los útiles y materias primas necesarias para la elaboración de los efectos. Era incompatible el cargo de maestro de Taller con el ejercicio de la misma actividad en el ámbito privado. Por ningún motivo se permitía que en los talleres se fabricase efectos para particulares, ni corporaciones que no dependiesen de la Diputación Provincial, sin la orden estricta del director. Las jóvenes asiladas podían confeccionar objetos, hacer bordados y otras labores «propias de su sexo», con autorización del director, para las personas que se lo encargasen, corriendo de su cuenta la adquisición de las materias primas necesarias.

${ }^{802}$ Para desempeñar este cargo era necesario ser mayor de veinticinco años y menor de cuarenta, hallarse en plenitud de sus derechos civiles y políticos, no haber sufrido penas de presidio y hallarse hábil para el trabajo. Sus obligaciones eran todas las relativas al servicio del Establecimiento y vigilancia de los varones acogidos.

${ }^{803}$ Las obligaciones de los mismos eran las relativas al aseo y limpieza del departamento de varones y de las salas que se les encomendase por el director. Uno de los dos, cuidaba de los niños mayores de seis años y menores de nueve, el otro de la conservación de la ropa y el calzado, y de que todos los acogidos tuviesen completo el equipo que les correspondía.

${ }^{804}$ Este cargo era desempeñado por uno de los acogidos con mejor conducta. Debía saber leer y escribir.

${ }^{805}$ A.D.P.P., L.A.P.D. $49,8-X I-1878$.
} 
3. Que se concediera socorro domiciliario de siete pts. mensuales a los pobres que pagasen menos de diez pts. de contribución y tuvieran hijos gemelos.

Rodríguez Olea defendía que de no darse estas circunstancias, no se concedieran socorros domiciliarios. Esta proposición pasó a la Comisión de Beneficencia para que emitiera su dictamen sobre ella, y por nueve votos en contra y siete a favor no se aprobó el dictamen, en previsión del descontento social que la adopción de estas medidas generaría. Con la entrada en vigor de la Ley Provincial de 29 de agosto de 1882, su art. 74 imponía una seria de reformas en la Administración Provincial en los ramos de Beneficencia, Instrucción Pública, Obras y Servicios Generales. En la Memoria del Primer Semestre del año económico de 1883-1884, la Comisión Provincial ya señalaba la necesidad de llevar a cabo estas reformas:

«Sin estas reformas los fondos de la provincia continuarán gastándose con escaso resultado, y los contribuyentes llegarán muy tarde a convencerse de las ventajas de la descentralización administrativa.» ${ }^{806}$

En materia de Beneficencia Provincial, en el año $1883^{807}$ se proponían una serie de reformas:

1. Las amas externas encargadas de la lactancia de los huérfanos cobrarían un salario de 12,50 pts. hasta que estos cumpliesen dieciocho meses de edad, 10 pts. los dieciocho meses siguientes, y 7.50 pts. hasta que cumplieran seis años.

2. Se adquiriría una vaca para paliar la falta de nodrizas.

3. Se mejoraría el taller de zapatería.

4. Se creaba el taller de sastrería y el de carpintería.

5. Establecimiento de un departamento de hidroterapia y un gimnasio.

Sin embargo la realidad presupuestaria se imponía y solo un año más tarde, en abril de $1884^{808}$, se suprimieron los socorros domiciliarios que venía costeando la Diputación Provincial y se acordaba que las pensiones de lactancia se percibieran únicamente durante un año. También quedó establecido que cuando se solicitase el ingreso de dos individuos de una misma familia en los asilos benéficos, tan solo se concediese a uno solo, y este fuera el de menos edad.

\footnotetext{
${ }^{806}$ A.D.P.P., Memoria Año Económico 1883-1884, C-R /1,12, p. 7.

${ }^{807}$ A.D.P.P., L.A.P.D. 55, 9-XI-1883. En 1883, Maternidad acogía a 28 «desamparados», Misericordia a 28 sexagenarios o impedidos para el trabajo, había 49 pensiones de lactancia, y la Diputación Provincial sufragaba las estancias causadas por cuatro dementes pobres en el Manicomio de Valladolid.

${ }^{808}$ A.D.P.P., L.A.C.P. $60,24-\mathrm{V}-1884$.
} 
En sesión del 9 de agosto de 1884, la Comisión Provincial estableció que en ningún caso podrían disfrutar de los auxilios de la Beneficencia Provincial los que satisficiesen más de diez pts. de Contribución al Tesoro.

El número de acogidos en los Establecimientos de la Beneficencia Provincial en el ejercicio de $1883-1884^{809}$ era de:

1. 49 pensiones de lactancia.

2. 28 acogidos en Maternidad.

3. 28 sexagenarios o impedidos para el trabajo en Misericordia.

4. Cuatro dementes acogidos en el Manicomio de Valladolid

El Presupuesto ${ }^{810}$ de Beneficencia comprendía diferentes partidas, a modo de ejemplo, en 1884 las cantidades asignadas a cada una de ellas eran las siguientes:

Tabla 08. Gasto en pts. asignado a los diferentes conceptos de la Beneficencia Provincial por la Diputación de Palencia el año 1884.

\begin{tabular}{|c|c|c|}
\hline Concepto & Gastos & Ingresos \\
\hline Víveres, utensilios y combustibles & 71.156 & \\
\hline Botica & 540 & \\
\hline Camas, ropa, vestuario y útiles de cocina & 19.843 & \\
\hline Facultativos & 4.778 & \\
\hline Practicantes, enfermeros y sirvientas & $55.363,5$ & \\
\hline Empleados & 3.054 & \\
\hline $\begin{array}{l}\text { Sueldos y gastos de cátedras u objetos de } \\
\text { educación }\end{array}$ & 2.750 & \\
\hline Gastos reproductivos & 6.984 & \\
\hline Culto y clero & 2.049 & \\
\hline Gastos generales & 5.600 & \\
\hline Ingresos eventuales & & 3.685 \\
\hline
\end{tabular}

Elaboración propia. Fuente: A.D.P.P. C-L/ 6,1.

\footnotetext{
${ }^{809}$ Circulares 63,64, y 65 del B.O.P. de noviembre de 1878.

${ }^{810}$ El Presupuesto de la Beneficencia Provincial se clasificaba en Ordinario y Extraordinario. El Ordinario, comprendía las partidas que la administración del establecimiento consideraba necesarias para cubrir los servicios durante el año natural. Cuando por un nuevo servicio o aumento de gasto en alguno de los establecidos se hacía indispensable acudir a un Presupuesto Extraordinario, se solicitaba la ayuda de la Diputación para que actuase de acuerdo con la Ley de Contabilidad. En todas las cuentas de gastos el director consignaba su conformidad como prueba de que se había ejecutado el servicio, elevándolas posteriormente a la Diputación para su examen, censura, aprobación y pago.
} 
Evidentemente, toda esta serie de reformas iban encaminadas a reducir el gasto en Beneficencia pues, a diferencia de otros Capítulos del Presupuesto, como Instrucción Pública $^{811}$, la diferencia entre los ingresos que generaban los Establecimientos de Beneficencia y los gastos era abismal ${ }^{812}$. En el ejercicio $1885-86$, por ejemplo, el gasto en Beneficencia era de 224.967 pts., por unos ingresos de $15.644,73$ pts. ${ }^{813}$ Las dificultades recaudatorias incidían en la penuria presupuestaria de la Caja provincial y esto a su vez generaba situaciones extremas como en 1884, cuando el director de los establecimientos provinciales de Beneficencia solicitaba 5.000 pts. para satisfacer los cuatro meses que se adeudaban a las amas de cría. El pleno de la Diputación Provincial acordó, una vez que se había comprobado que no había existencias en Caja, que se expidieran comisiones de apremio «para evitar el espectáculo de que las criadoras hagan entrega de los expósitos.» ${ }^{814}$ En 1888, se suprimían socorros que venían facilitándose a los pobres para ir a tomar baños ${ }^{815}$, por considerar que no cubría necesidades vitales de los asilados, en vista de la acuciante necesidad de recortar gastos. En 1891, la situación lejos de mejorar había empeorado, la situación de la Hacienda provincial era crítica, con un descubierto de 225.562,20 pts. y un número importante de aspirantes al ingreso en las Casas de Misericordia y Maternidad, y sin más recursos que lo recaudado por el Contingente Provincial. La Comisión Provincial advertía a la Diputación palentina que se imponía el estricto cumplimiento del art. 18 de la Ley 20-VI-1849: «Los establecimientos de Beneficencia públicos o privados no podrán admitir a pobres o mendigos válidos», y lo justificaba de la siguiente manera:

«que en épocas de bonanza pudo ser interpretado lo más laxamente posible, y hasta pasar desapercibido, bastando para la admisión de los pobres los certificados de imposibilidad para el trabajo expedidos por los médicos municipales, que en esta materia no habrán sido tan escrupulosos como fuera de desear.» ${ }^{816}$

\footnotetext{
${ }^{811} \mathrm{~A}$ partir del año 1907 , los ingresos de Instrucción suponían un porcentaje similar al de gasto en este Capítulo. Véase Anexo V. Presupuesto Provincial en pts. en Beneficencia, Instrucción Pública, Corrección Pública y carreteras 1875-1931, p. 485.

${ }^{812}$ Véase Anexo V. Presupuesto Provincial en pts. en Beneficencia, Instrucción Pública, Corrección Pública y carreteras 1875-1931, p. 485.

${ }^{813}$ A.D.P.P., C-L/ 5,2

${ }^{814}$ A.D.P.P. L.A.P.D. $60,19-\mathrm{VIII}-1884$.

${ }^{815}$ A.D.P.P., L.A.C.P. $67,24-$ VIII-1888.

${ }^{816}$ A.D.P.P., L.A.C.P. $73,7-X I-1891$.
} 
La situación no era nueva, en 1885 el director de los Establecimientos de Beneficencia Provincial ya había señalado la conveniencia de que los facultativos de la Beneficencia reconocieran a los que ingresasen en la Casa de la Misericordia en el concepto de impedidos para el trabajo, a fin de adquirir la evidencia de que el padecimiento era cierto. La Diputación estableció que se practicase reconocimiento a todos los asilados que no contasen sesenta años. En 1896, se hizo necesaria la solicitud de un crédito de 209.815 pts. para el pago de las obligaciones de Beneficencia. En esa fecha los Establecimientos de Beneficencia acogían a los siguientes beneficiarios: 93, en Maternidad-Expósitos, y 314 en Misericordia ${ }^{817}$.

Ante el aumento incesante de peticiones para ingresar como asilados en las distintas dependencias benéficas provinciales, en 1897 se acordó que el ingreso en los Establecimientos de Beneficencia (Casa de Expósitos, Maternidad, Casa de Misericordia), Manicomio y Hospital de San Bernabé y San Antolín, se hiciese por estricto orden de antigüedad, conforme al acuerdo de 8 de julio de 1892, estableciendo un escalafón por $\operatorname{sexo}^{818}$. Los ancianos que quisieran ingresar habrían de esperar el turno de antigüedad o aprovechar el de gracia, mediante propuesta para estos últimos de los vocales representantes de los Distritos respectivos ${ }^{819}$. Raro era el mes en que cuatro o cinco ancianos no causaban vacante en la Casa de Misericordia, pasando al Hospital provincial donde casi todos fallecían ${ }^{820}$.

\footnotetext{
${ }^{817}$ A.D.P.P. Memoria Año Económico Primer Semestre 1896-1897, C-R / 1,10, p. 25.

${ }^{818}$ A.D.P.P., Memoria Año Económico Primer Semestre 1897-1898, C-R / 1,9. El diez de diciembre de 1880, el Director de los Establecimientos de Beneficencia había comunicado a la Comisión de Beneficencia la separación por sexos en la Casa de Misericordia. Los dormitorios de los varones estaban a cargo de un celador y los de las mujeres a cargo de una Hija de la Caridad designada por la superiora. Las camas de cada uno de los celadores estaba en un punto estratégico de los dormitorios para vigilar a los acogidos de su sala.

${ }^{819}$ Un anciano había ingresado por orden del Gobierno de la provincia y, en vista que no concurrían en su caso ninguna de los dos casos contemplados, se ordenó su salida del asilo.

${ }^{820}$ A.D.P.P., L.A.C.P. 72, 16-XII-1890.
} 
Imagen 02. Ancianos acogidos en la Casa de Misericordia de la Beneficencia Provincial.

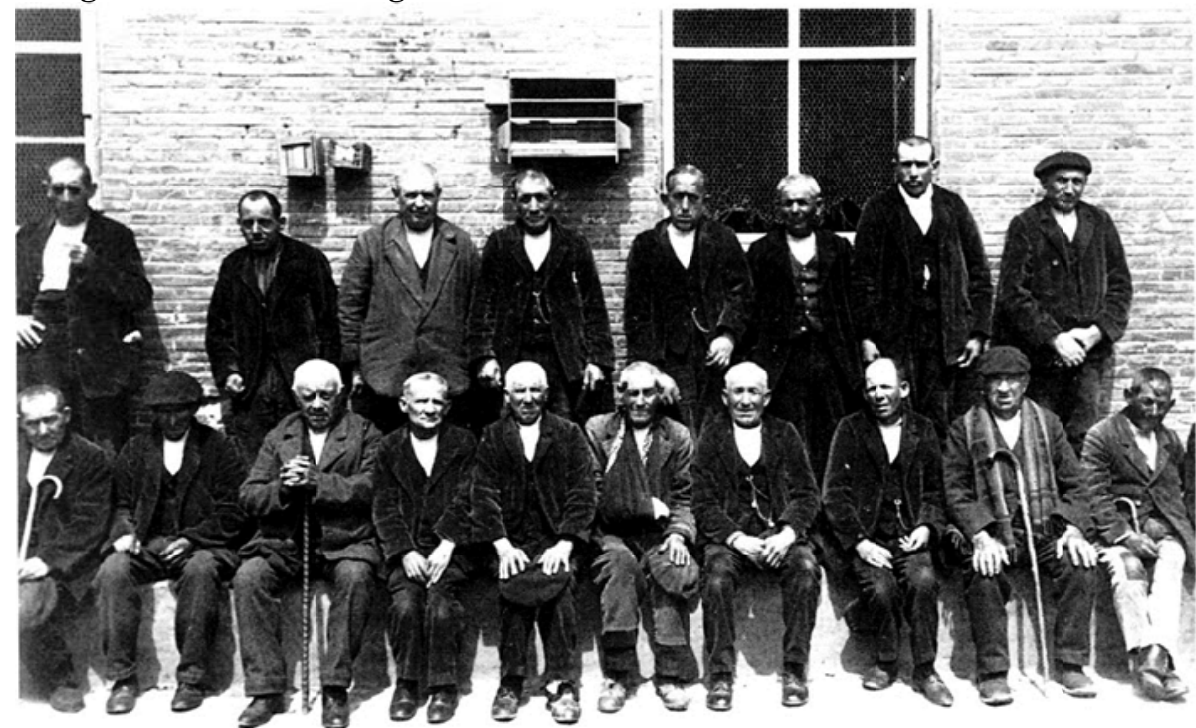

Fuente: A.D.P.P. (Archivo fotográfico).

Las Bases aprobadas el 10 de octubre de 1906, señalaban que los pobres casados no podrían ingresar en la Casa Misericordia, una medida más destinada a restringir la entrada en la Beneficencia Provincial de solo aquellas personas en situación de pobreza extrema y sin ningún tipo de asistencia familiar.

La Beneficencia no solo comportaba un gasto en cuanto al mantenimiento de los asilados, la precariedad de los edificios en los que se encontraban localizadas las diferentes dependencias que la conformaban, supuso una constante sangría presupuestaria por las diversas reformas y mejoras que se llevaron a cabo a lo largo de la etapa investigada. La población asilada desbordaba las instalaciones que les acogía, pues no habían sido diseñadas para atender las necesidades específicas de una actividad de atención socio-sanitaria. Con motivo de la epidemia de cólera de 1885 tuvieron que concederse licencias a los acogidos en los asilos benéficos que teniendo familia quisieran reunirse con ella, para que permaneciesen en los pueblos hasta que la epidemia hubiese remitido. Se les entregaba el presupuesto en metálico de la ración que podría ser de un real diario para su manutención. 
La Comisión Provincial, recomendaba que se realizasen las obras que fuesen indispensables en el edifico de asilo para evitar las aglomeraciones de acogidos que podrían producir el desarrollo de alguna enfermedad contagiosa ${ }^{821}$. El problema no solo era la saturación de las instalaciones, sino la imposibilidad funcional de que estas pudieran servir como recurso de asilo ante contingencias de carácter catastrófico. En la sesión de la Comisión Provincial del 5 de noviembre de 1885, se acordó que ante la imposibilidad de recoger en la Casa de Expósitos a los muchos huérfanos a causa del cólera, se facilitase la pensión que se satisfacía por los expósitos que lactasen fuera del asilo. La situación de los Establecimientos benéficos era tan precaria, que no fue hasta abril de 1886, cuando el Ayuntamiento de Palencia concedió el servicio de agua para estas dependencias ${ }^{822}$. El Ayuntamiento tenía obligación de ceder agua a la Casa de Maternidad según escritura otorgada el 29 de julio de 1886 ante notario. Según constaba en el contrato de 6 de mayo de 1909, firmado entre la Diputación Provincial y el Ayuntamiento capitalino, este debía suministrar 6.0001 diarios perpetuamente a los Establecimientos de Beneficencia. El Ayuntamiento en los meses de junio a septiembre de 1913 dejó de suministrar agua y se hizo necesario utilizar el agua del depósito del Otero. La Diputación solo pagó lo consumido, y no lo que por contrato se debía suministrar, y verificó la veracidad del caudal de los depósitos que le había comunicado el Ayuntamiento ${ }^{823}$. A partir del 1 de julio de 1894, las dependencias benéficas provinciales contaron con luz eléctrica.

\footnotetext{
${ }^{821}$ Los dormitorios, comedores y demás locales que lo requiriesen se blanqueaban una vez al año, generalmente en verano. Los locales citados, y las salas de trabajo, escuelas, corredores, patios, etc., se barrían diariamente, y los comedores tras cada comida. Los sábados por la tarde se hacía una limpieza general, haciéndola también en la fachada del exterior. Para que los dormitorios, salas y talleres estuviesen ventilados, se dejaban abiertas las ventanas de los primeros por el día, y de los talleres por la noche, siempre que el tiempo lo permitía.

${ }^{822} \mathrm{El}$ Ayuntamiento acordó acceder a la petición de la Diputación Provincial y abastecer a los Establecimientos de Beneficencia con 2.7601 diarios de agua, para que, unidos al caudal que se suministraba y junto al que se proyectaba traer con las obras que se estaban ejecutando, se pudiese conceder los 3.6001 que reclamaba la institución provincial. El agua procedía de los manantiales del Valle de la Monjas y de la Bodega de Ramírez, que se estimaba podía generar 1,60 1 por segundo, y en épocas de aguas abundantes hasta 31 por segundo. A.M.A.P., L.A.P.A., A-21-102, 16-IV-1886.

${ }^{823}$ A.D.P.P., L.A.C.P. $118,16-$-II-1914.
} 
Los edificios eran tan antiguos, que las reformas eran una constante obligatoria debido al deterioro de las instalaciones. En 1890, hubo que revestir una pared de ladrillo en la Casa de Maternidad por estar en ruinas ${ }^{824}$. El 30 de enero de 1889, el director de los Establecimientos de Beneficencia dirigía una carta a la Diputación Provincial solicitando un aumento de las partidas consignadas con objeto de acondicionar las instalaciones de la Casa de Misericordia para poder acoger a unos 50 ancianos de ambos sexos «(...) que esperan su turno en la calle para ser acogidos, muchos de ellos mueren de hambre y frío antes de ingresar.» ${ }^{825}$

El director señalaba que las obras serían de poca envergadura, y también solicitaba el aumento de las raciones, pues denunciaba que en el Presupuesto de hacía dos años se consignaban 50 raciones más que en el presente. En el escrito se adjuntaba un Presupuesto Adicional con las cantidades que se consideraban necesarias para atender a los mencionados ancianos ${ }^{826}$. En 1911 se promulgó la Real Orden de 28 de julio, por la que el delegado de Hacienda cedía a la Diputación Provincial el local que ocupaba la Caja de Recluta en la planta principal del ex convento de San Francisco, para destinarlo a enfermería $^{827}$ y dormitorio de párvulos de la Casa de Maternidad en concepto de usufructo gratuito, y con la obligación de costear las obras de conservación y reparación del mismo ${ }^{828}$. Por fin, y tras muchos años de peticiones infructuosas, en 1920, tras solicitar la Diputación Provincial al delegado provincial de Hacienda la cesión de los locales del ex convento de San Francisco donde esta tenía instalado el Archivo y las oficinas de la Junta Provincial de Primera Enseñanza para el aislamiento de los enfermos de una epidemia grave de sarampión, al carecer Diputación de locales para este fin ${ }^{829}$, la Delegación de Hacienda cedió estos locales para uso exclusivo de la Beneficencia Provincial. La cesión se considera beneficiosa especialmente para casos de epidemias, como la de sarampión de ese año, para poder aislar a los enfermos de los sanos ${ }^{830}$.

\footnotetext{
${ }^{824}$ A.D.P.P., L.A.C.P. 72, 12-V-1890.

${ }^{825}$ A.D.P.P., C-L/ 6,1

${ }^{826}$ En el Presupuesto Refundido aprobado de la Diputación Provincial se consignaban las cantidades solicitadas por el director de los Establecimientos de Beneficencia.

${ }^{827}$ La enfermería se dividía en dos secciones, Medicina y Cirugía. Se establecía la separación por sexo, edad, y enfermedades contagiosas e infecciosas. Las camas de los enfermos constaban de un catre de hierro, un pajero, dos colchones, dos sábanas, dos mantas, una almohada con su funda y una sobrecama. Además la enfermería tenía 200 sábanas, 60 chambras, cien gorras de tela, 200 pañuelos de bolsillo, 80 servilletas, diez mantas, 20 fundas de pajero y 20 fundas de colchones.

${ }^{828}$ A.D.P.P., L.A.P.D. $111,4-\mathrm{X}-1911$.

${ }^{829}$ A.D.P.P., L.A.C.P. 132, 31-VIII-1920.

${ }^{830}$ A.D.P.P., L.A.C.P. $132,7-I X-1920$.
} 
En 1923, se acordó solicitar al Ministerio de Fomento $^{831}$ y al alcalde del Ayuntamiento de Palencia la cesión de locales para ampliar las dependencias de la Beneficencia, que debido al aumento de acogidos tenía necesidad de ampliar sus locales, especialmente la Casa $\mathrm{Cuna}^{832}$.

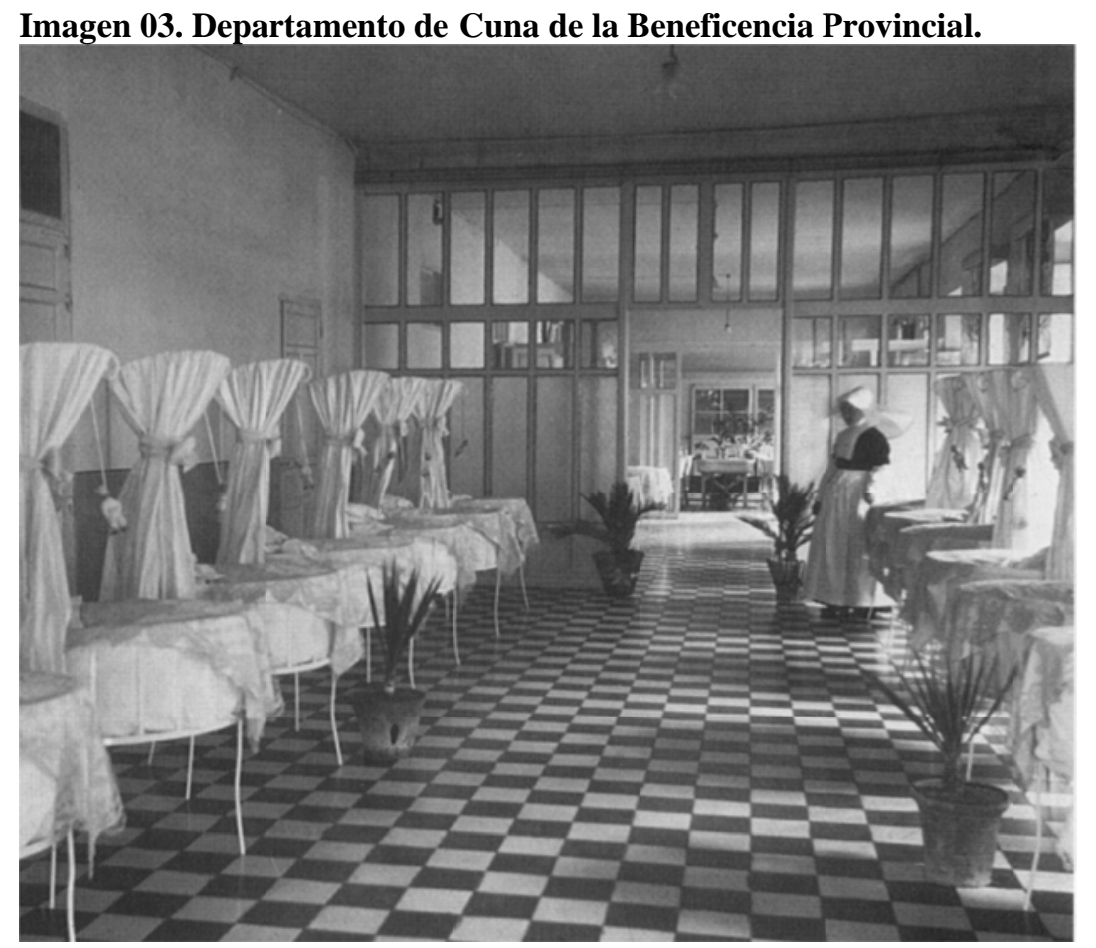

Fuente: A.D.P.P. (Archivo fotográfico).

Al Ministerio de Fomento se le pedía que revertiese a la Diputación Provincial el edificio donde se hallaba instalada la Estación Enológica, que fue propiedad de la Diputación y se la cedió al Estado para ese propósito en el año 1903. Al Ayuntamiento se le solicitaba la cesión de la Plazuela que se destinaba a mercado semanal. En ocasiones, cuando el Presupuesto Provincial no era suficiente para atender las necesidades de reparación y reforma, se utilizaban las limosnas del indulto cuadragesimal ${ }^{833}$, como en 1891, cuando fueron destinadas a la Casa de Maternidad para terminar la galería, la cantidad se entregaba directamente a la superiora de las Hijas de la Caridad de la Casa de Beneficencia $^{834}$.

\footnotetext{
${ }^{831}$ Por Real Decreto de 18 de abril de 1900 se había dividido al antiguo Ministerio de Fomento en dos departamentos ministeriales: Instrucción Pública y Bellas Artes, y Agricultura, Industria, Comercio y Obras Públicas, encargado este último de los asuntos relacionados con el ferrocarril, carreteras, canales y puertos. ${ }^{832}$ A.D.P.P., L.A.C.P. 135, 7-VII-1923.

${ }^{833}$ Por el indulto cuadragesimal, llamado «la bula de carnes», la Iglesia permitía a los fieles consumir carne en los días de abstinencia a cambio de unas cuotas en forma de limosnas

${ }^{834}$ A.D.P.P., L.A.C.P. 73, 4-IX-1891.
} 
Una buena parte del presupuesto de la Beneficencia Provincial se lo llevaba la manutención y vestuario ${ }^{835}$ de los beneficiarios acogidos. En el ejercicio de 1896/97, los 314 asilados en la Casa de Misericordia suponían un gasto de 91 cent. diarios a la Diputación Provincial, en régimen externo, se sufragaba la lactancia de 241 niñas y niños. El pago de estancias por los asilados en el Hospital de San Bernabé y San Antolín, y en San Juan de Dios, 73 acogidos, desde el 1 de abril hasta el 30 de septiembre de ese periodo, ascendían a 6.939 y 16.640 pts. respectivamente ${ }^{836}$. En mayo de 1903, el patronato del Hospital de San Bernabé y San Antolín imponía el precio de 1,50 pts. por estancia de enfermo y día, a lo que se oponía la Diputación Provincial que, no obstante, tuvo aceptar el precio por carecer de recursos para construir un hospital «a la altura que la ciencia reclama.» ${ }^{837}$ Abad Miguel, diputado provincial y médico, explicaba que la alimentación de los acogidos en la Casa de Beneficencia era mucho más económica que la de los enfermos ingresados en el Hospital San Bernabé y San Antolín, ya que los enfermos necesitaban caldos de gallina, jerez, específicos y reconstituyentes, mientras que los asilados vivían con el rancho, desayuno y cena, que no llegaba a peseta por individuo. En octubre de ese mismo año, ante la posibilidad de reducir el gasto mediante un mayor racionamiento de la comida a los asilados, el diputado provincial Rodríguez Blanco ${ }^{838} \mathrm{se}$ mostraba contrario a hacer variaciones en la alimentación de los Establecimientos de Beneficencia, porque a su juicio las estancias de los acogidos eran más baratas que en otras provincias, y porque podían dar lugar a conflictos como había sucedido en otros lugares. Abad Miguel, partidario de variar el régimen de comidas, comentaba que los cambios en la alimentación de los asilados se fundamentaban en el dictamen facultativo y no restaban valor nutritivo a la dieta. Se aprobó el dictamen sobre alimentación y vestuario de los acogidos propuesto por la Comisión de Presupuestos con el voto en contra de Rodríguez Blanco, como había predicho este diputado provincial, por lo que no tardaron en llegar las quejas de los acogidos en la Casa de Beneficencia con motivo de la variación del racionado ${ }^{839}$.

\footnotetext{
${ }^{835}$ Todos los domingos por la mañana loa asilados recibían una camisa limpia, las otras pendas de vestuario se renovaban cuando era necesario. Para evitar que los asilados intercambiasen la ropa, cada uno de ellos tenía asignado tres camisas rotuladas con su número. Las sábanas, fundas y almohadas se renovaban quincenalmente, las mantas, colchones y relleno de paja cuando era necesario.

${ }^{836}$ A.D.P.P., Memoria Año Económico Primer Semestre 1896-1897, C-R / 1,10.

${ }^{837}$ A.D.P.P., L.A.P.D. 95, 5-V-1903.

${ }^{838}$ A.D.P.P., L.A.P.D. 95, 17-X-1903.

${ }^{839}$ A.D.P.P., L.A.C.P. 100, 26-I-1904.
} 
El racionamiento de los asilados sanos consistía en un plato de sopa de ajo y una sexta parte de un kilo de pan para el desayuno, en la comida un plato de sopa, otro de garbanzos y un pedacito de tocino con la misma cantidad de pan que en el desayuno. Los párvulos, de hasta siete años, los encargados, sirvientes y amas de cría en la comida comían diariamente carne aunque en cantidad muy escasa, el resto de la población asilada no comía carne más que los domingos y en cantidad mínima. La merienda consistía en un trozo de pan, a todo el que lo solicitaba, y la cena en un plato de alubias y sopa o fréjoles, con la ración de pan correspondiente, y una pequeña cantidad de vino con la misma restricción en su consumo que el de la carne. En un intento de paliar la difícil situación económica de la Beneficencia Provincial, desde el año $1924^{840}$, los ingresos recaudados por el Impuesto sobre el Almacenaje y Paralización de Mercancías en las estaciones de la provincia, se destinaban a las instituciones benéficas de la provincia, 2.500 pts. en el ejercicio $1924-25^{841}$.

Si había un sector de la población especialmente vulnerable, este era el de la infancia. Por este motivo, la Diputación Provincial fue especialmente cuidadosa a la hora de establecer las condiciones de ingreso y permanencia de los niños en la Casa de Expósitos y Maternidad. La mayoría de la reformas de la Bases que regulaban el acceso a la Beneficencia Provincial tenían como objeto a la infancia, en especial las referidas a las llamadas pensiones de lactancia ${ }^{842}$.

\footnotetext{
${ }^{840}$ Ingresadas en la Caja Provincial durante el mes de marzo de 1924 por el Gobernador, 500 pts. que las compañías de ferrocarriles del Norte, La Robla y Secundarios le entregaron por derechos de almacenaje y paralización del material con destino a beneficencia, se acordó donarlos al presidente de la Asociación Palentina de Caridad, 306 pts., y a la Asociación «Gota de Leche», 194 pts. A.D.P.P., L.A.C.P. 136, 10-IV1924. La institución de la «Gota de leche» (Goutte de lait), fue importada a España en 1904 por el doctor Rafael Ulecia, había sido impulsada en Francia desde finales del siglo XIX por el doctor León Dufour para ofrecer alimento a los niños pobres que no podían ser amamantados por sus madres. En el Reglamento de Sanidad Provincial de 1926, esta institución pasó a formar parte de los Institutos de puericultura y asistencia infantil.

${ }^{841}$ A.D.P.P., C-L/ 12,5 .

${ }^{842} \mathrm{La}$ lactancia de los niños estaba a cargo de nodrizas internas y externas. Las nodrizas internas eran admitidas previa el reconocimiento facultativo que acreditaba la aptitud física, la abundancia de secreción láctea y el no padecimiento de enfermedad contagiosa ni cutánea. Este reconocimiento se practicaba cada quince días. Las nodrizas internas estaban subordinadas a la hija de la Caridad encargada de la Inclusa. Las mujeres que aspiraban a ser nodrizas externas debían presentar un certificado en el que constase el estado civil, su estado físico, conducta y condiciones físicas, permiso del marido si era casada, referencia a la partida de nacimiento en la que contase que su hijo tenía más de seis meses y menos de diez años. El facultativo de la Beneficencia, visto este documento, procedía a reconocer a la interesada y a emitir su informe acerca de la idoneidad de la candidata para ser nodriza. El director resolvía finalmente sobre la admisión de las candidatas. Las nodrizas externas estaban obligadas a presentar en los establecimientos de Beneficencia a los niños que se les hubiese confiado siempre que fuesen requeridas para ello por el director.
} 
Ya en 1880, se proponía restringir la concesión de este tipo de socorros $^{843}$ a casos muy particulares:

1. Se concederían en primer lugar a los padres pobres, cuyas esposas hubiesen dado a luz a dos o más gemelos.

2. También a los niños pobres cuyos padres o madres hubiesen fallecido.

3. Que no se dispensase este beneficio de no mediar una gravísima necesidad.

En 1884, se pasaba de la proposición al hecho, y se aprobaban las primeras reformas ${ }^{844}$ en este aspecto:

1. Las pensiones de lactancia quedaban limitadas a los gemelos y a los huérfanos de madre siempre que sus padres reuniesen las circunstancias de vecindad en la provincia y pobreza, calificada esta por la contribución que se pagaba.

2. No tendrían derecho a disfrutar de este auxilio los que contribuyan por cualquier concepto con cuota superior a diez pts.

Se adoptaban estas reformas porque, a juicio de la Diputación, las pensiones de lactancia en la mayoría de los casos no respondían a una verdadera necesidad, siendo varios los casos de madres que después de hallarse disfrutando de las que por sus hijos les fueron concedidas, abandonaban su crianza y se dedicaban al oficio de nodrizas mercenarias. 
Los párrocos y los médicos ${ }^{845}$ de la Beneficencia municipal debían comunicar al director del asilo cada mes el estado de salud o padecimientos que tuviesen los expósitos que se hallaban en lactancia fuera de la Casa Cuna y el tratamiento que recibían de las criadoras. Ante el aumento del gasto en pagos a amas de cría, tanto internas como externas, y considerando que de no modificarse las reglas establecidas no se podrán pagar las obligaciones, la Comisión Provincial proponía en 1890 a la Asambllea Provincial una reforma de las bases sobre pensiones de lactancia en la forma siguiente ${ }^{846}$ :

1. Amas externas de lactancia quince pts. al mes hasta que los expósitos cumplieran dieciocho meses.

2. Desde los dieciocho meses hasta los cuatro años diez pts. mensuales.

3. Desde los cuatro años hasta los seis años, siete pts. por cada niño a su cuidado.

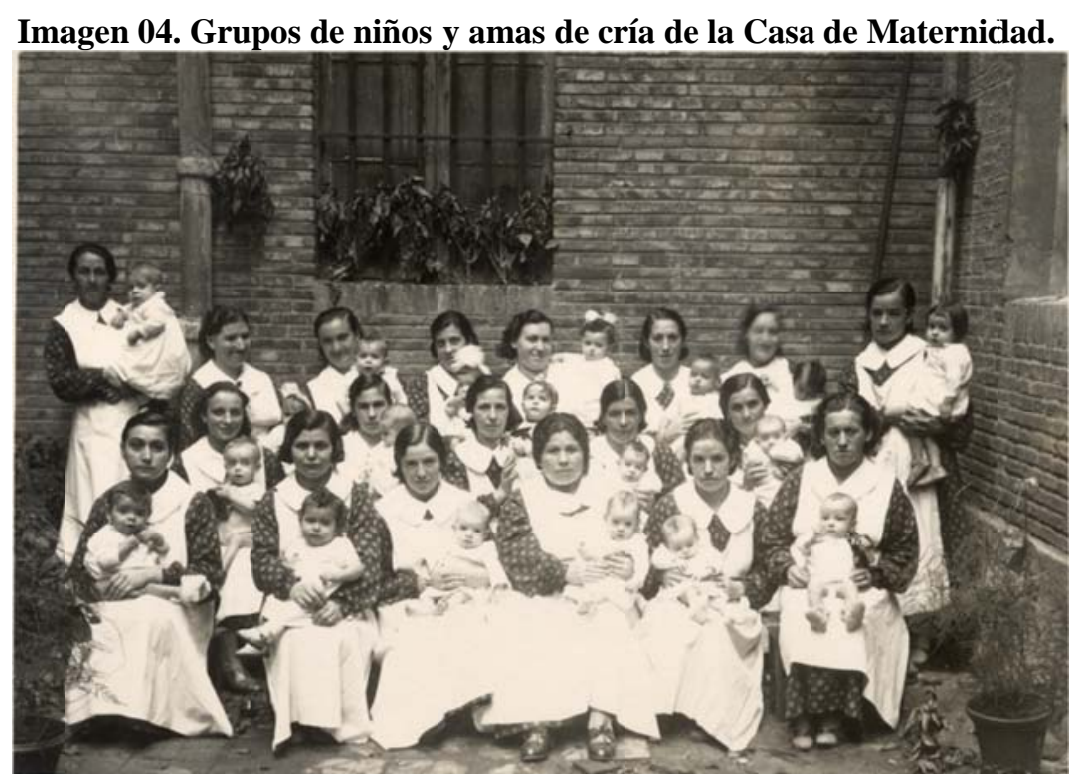

Fuente: A.D.P.P. (Archivo fotográfico)

\footnotetext{
${ }^{845}$ A.D.P.P., L.A.C.P. 61, 30-V-1885. Independientemente de las atribuciones concedidas a los jueces municipales por Real Orden de 10 de abril de 1889, respecto de la vigilancia de las nodrizas que criaban niños expósitos, y de las atribuciones privativas de las Juntas Locales de protección de la infancia en virtud de lo dispuesto en el art. 6 de la Ley de 12 de agosto de 1904, art. 32 y siguientes del Reglamento de 21 de enero de 1908 para su ejecución y Real Decreto de 24 de febrero de 1908, y de las que encomendaba la Instrucción General de Sanidad a los médicos municipales y provinciales, los curas párrocos de los pueblos donde residían nodrizas externas, a cuyo cargo se habían puesto niños procedentes de la Inclusa, tenían el carácter de inspectores honorarios de esos expósitos, pudiendo informar lo que creyesen oportuno respecto de la salud, crianza, educación, e instrucción de los mismos y de ejercer la representación del director en esos asuntos. Los médicos titulares de los partidos donde residieran las nodrizas tenían también ese carácter de inspectores honorarios respecto de la crianza de los niños, de acuerdo con lo que disponía el art. 3, párrafo $4^{\circ}$, del Reglamento de 14 de junio de 1891.

${ }^{846}$ A.D.P.P., L.A.C.P. 72, 8-XI-1890.
} 
El Presupuesto Provincial se veía gravado por no presentarse los padres a recoger a los niños una vez terminado el plazo de lactancia, y se imposibilitaba el ingreso de otros niños que necesitaban el auxilio de la Beneficencia ${ }^{847}$. El director de los Establecimientos de Beneficencia pedía, en 1891, que se dirigieran comunicaciones a los alcaldes con las notas de estancias causadas desde el día que había terminado el plazo reglamentario de permanencia en el asilo hasta el día que lo abandonaban, para que se cobrasen por la vía de apremio a los padres. Para la Comisión Provincial este tipo de abusos incrementaban los gastos de Beneficencia en demasía, e impedían que se dedicasen partidas presupuestarias a las Obras Públicas, «(...) cuyos gastos son siempre reproductivos» ${ }^{848}$. El 9 de noviembre de 1891 fueron, una vez más, reformadas las reglas establecidas ${ }^{849}$ por Diputación para el ingreso en la Casa de Expósitos, y así los que solicitasen el ingreso habían de justificar por medio del Registro Civil la inscripción en él de sus hijos. En 1904, la situación no había variado mucho, y la Diputación Provincial se veía obligada a solicitar al administrador de la Beneficencia Provincial un informe con el número de acogidos de ambos sexos que se encontraban en la Casa de Misericordia y Maternidad, indicando los nombres de los jóvenes que habían sido acogidos por tiempo determinado y aún continuaban asilados, y el de los niños recogidos durante el periodo de lactancia que aún no habían sido entregados a sus padres por no haberse estos presentado a recogerlos ${ }^{850}$. En 1911, el diputado provincial García de los Ríos presentaba una enmienda a los arts. 3, 4 y 5 del Capítulo $6^{\circ}$ del Presupuesto de Gastos, en la que se proponía la supresión de las pensiones de lactancia. Finalmente se acordó que continuasen la concesión de pensiones de lactancia, limitando el tipo contributivo a ocho pts., pero esta circunstancia ponía de manifiesto que debido a los múltiples fraudes que se habían detectado en la concesión de este tipo de socorros, la Diputación Provincial se debatía entre la necesidad de recortar gastos y el mantenimiento de ciertas prestaciones que por su naturaleza era muy complicado eliminar.

\footnotetext{
${ }^{847}$ A.D.P.P., L.A.C.P. 73, 5-VII-1891. Las Bases de 9 de noviembre de 1891 que regulaban la admisión en los Establecimientos de Beneficencia, establecían, en el caso de los niños, que una vez cumplidos los diecisiete años no debían continuar acogidos a no ser que acreditasen hallarse imposibilitados para el trabajo. ${ }^{848}$ A.D.P.P., Memoria Segundo Semestre Año Económico 1891-92, C-R/ 1,4, p. 34.

${ }^{849}$ Reforma de la Circular de 20 de noviembre de 1878 , en lo referente a la admisión de pobres en el Hospicio y Casa de Misericordia previo reconocimiento facultativo de los que no fuesen sexagenarios y en lo que referente a los huérfanos, habían de serlo de padre y madre. «Los Reglamentos de otras provincias con más medios ya contemplan estas medidas, y a pesar de esas limitaciones no pasan por la nota de crueles e inhumanos». A.D.P.P., Memoria Segundo Semestre Año Económico 1891-92, C-R/ 1,4, p. 35.

${ }^{850}$ A.D.P.P., L.A.C.P. $100,26-\mathrm{I}-1904$.
} 
En este mismo sentido, el diputado provincial Fernández Lomana abogaba por la supresión de los socorros domiciliarios de cuarenta cént. para aquellos llamados a ingresar por turno en la Casa de Misericordia y que optaban por permanecer en su domicilio ${ }^{851}$. Fernández Lomana pensaba que los abusos a que daban lugar este tipo de socorros repercutían sobre los gastos que la Asamblea Provincial pretendía contener dentro de los límites del Presupuesto. El diputado provincial García de los Ríos pedía que en vez de suprimir los socorros, se limitase el número de estos, señalando la cuota contributiva de ocho pts. por Contribución Territorial, Urbana e Industrial para la calificación de la pobreza. Finalmente se desechó la enmienda de Fernández Lomana, pero una vez más estaba en la palestra el debate entre asistencia y recortes. En 1913, ante la continua petición por parte de los ayuntamientos de la provincia de pensiones de lactancia, se acordó comunicar mediante el $B O P$ que no existía consignación para el presupuesto de 1914, y se hallaba agotada la partida de 1913 para socorros de lactancia, y que era inútil que se instruyeran expedientes para este fin por parte de los ayuntamientos ${ }^{852}$. En 1917, el diputado provincial Diezquijada Gallo, director de la Casa de Beneficencia, se lamentaba de la situación en que se encontraba la Casa de Maternidad por la falta de nodrizas que se encargasen de la lactancia de los niños que ingresaban por el torno, que tenían que ser alimentados con leche de vaca, ya que a pesar del aumento de su salario, se había producido una disminución considerable del número de amas de cría externas ${ }^{853}$ debido a los cada vez más numerosos requisitos que se exigían para poder ejercer como tal y, como consecuencia de esta circunstancia, había aumentado la mortalidad infantil en este establecimiento. Cinco años después, en 1922, la situación no había variado y, de nuevo, el director de los Establecimientos de Beneficencia avisaba de la gran mortalidad que se daba entre los niños de la Cuna debido, en su opinión, a la falta de amas de cría, que a veces se hallaban lactando a dos y tres niños, y defendía la conveniencia de aumentar la pensión hasta 25 pts. a las amas externas por el primer periodo de lactancia (hasta los dieciocho meses) y solo a los nacidos en los establecimientos, o que ingresasen por el torno $^{854}$.

\footnotetext{
${ }^{851}$ A.D.P.P., L.A.P.D. $111,19-X-1911$.

${ }^{852}$ A.D.P.P., L.A.C.P. 117, 2-XII-1913.

${ }^{853}$ A.D.P.P., L.A.P.D. 123, 9-V-1917.

${ }^{854}$ A.D.P.P., L.A.P.D. 130, 2-III-1922.
} 
En 1927, el director de los Establecimientos de Beneficencia proponía a la Comisión Provincial que se exigiese a las amas externas para el cobro de la pensión de lactancia un certificado trimestral firmado por el alcalde, párroco y juez, donde se hiciese constar la conducta de la ama de cría con el lactante, y un escrito médico que acreditase que estaba en condiciones de seguir lactando y las condiciones del niño ${ }^{855}$. Era un ejemplo más del grado de exigencia que la Comisión Provincial imponía a aquellas mujeres que quisieran ejercer como amas externas y que, como se ha dicho, contribuyó a reducir las peticiones para este trabajo, de forma que ponía en peligro la existencia de este tipo de socorro benéfico.

Ligada a la asistencia a la infancia estaba la educación. La educación reglada estaba fuera del horizonte cotidiano de los pobres, les molestaba la sujeción a la escuela, pero la burguesía consideraba que era imprescindible ahormar a estos grupos populares con la entrada en un centro de instrucción, por eso lo primero que se asoció a los hospicios fueron, junto a los talleres y escuelas de oficios, las escuelas de primeras letras. La Diputación Provincial defendió siempre la instalación de talleres de oficios como lugar de socialización de los jóvenes asilados, que de otra forma tenían muy complicado integrarse en el mundo laboral. Justificaba el establecimiento de una panadería en el Hospicio Provincial contra aquellos que acusaban a la institución provincial de competencia desleal para con las industrias del ramo. la Diputación Provincial señalaba los beneficios que comportaba este establecimiento por la compra de insumos y contratación de un maestro panadero en la propia capital, sin olvidar las ventajas que conllevaba para los asilados, pues permitía el aprendizaje de un oficio a los jóvenes acogidos y generaba beneficios con la venta del pan fabricado. Con los mismos argumentos se defendían el establecimiento de la sastrería, de la zapatería y de la imprenta, en este caso se señalaba que a excepción hecha de los libros de contabilidad y presupuestos, no se hacía ningún trabajo para las corporaciones ni particulares, estando solo circunscrito a las de la Diputación y establecimientos que de esta dependían ${ }^{856}$. Lo mismo sucedía con el lavadero del Hospicio, que suponía un alivio económico en el coste que se producía antes de la instalación.

\footnotetext{
${ }^{855}$ A.D.P.P., L.A.C.P. $143,11-$ VIII-1927.

${ }^{856}$ A.D.P.P, C-R/ 1,11 (A), p. 19.
} 
También se instalaron talleres de carpintería y albañilería en el Hospicio. ${ }^{857}$ Esta política de instalación de talleres, no solo pretendía formar a los jóvenes asilados en un oficio, también aspiraba a que los establecimientos fueran cada vez más autosuficientes y así se justificaba la adquisición de un terreno con destino a vivero para vides americanas, las únicas posibles tras la plaga de la filoxera y huerta para la Casa de la Beneficencia ${ }^{858}$. Los acogidos que prestaban servicio en los talleres de carpintería, zapatería, sastrería y aprendices de la imprenta provincial ${ }^{859}$ recibían nóminas de gratificación.

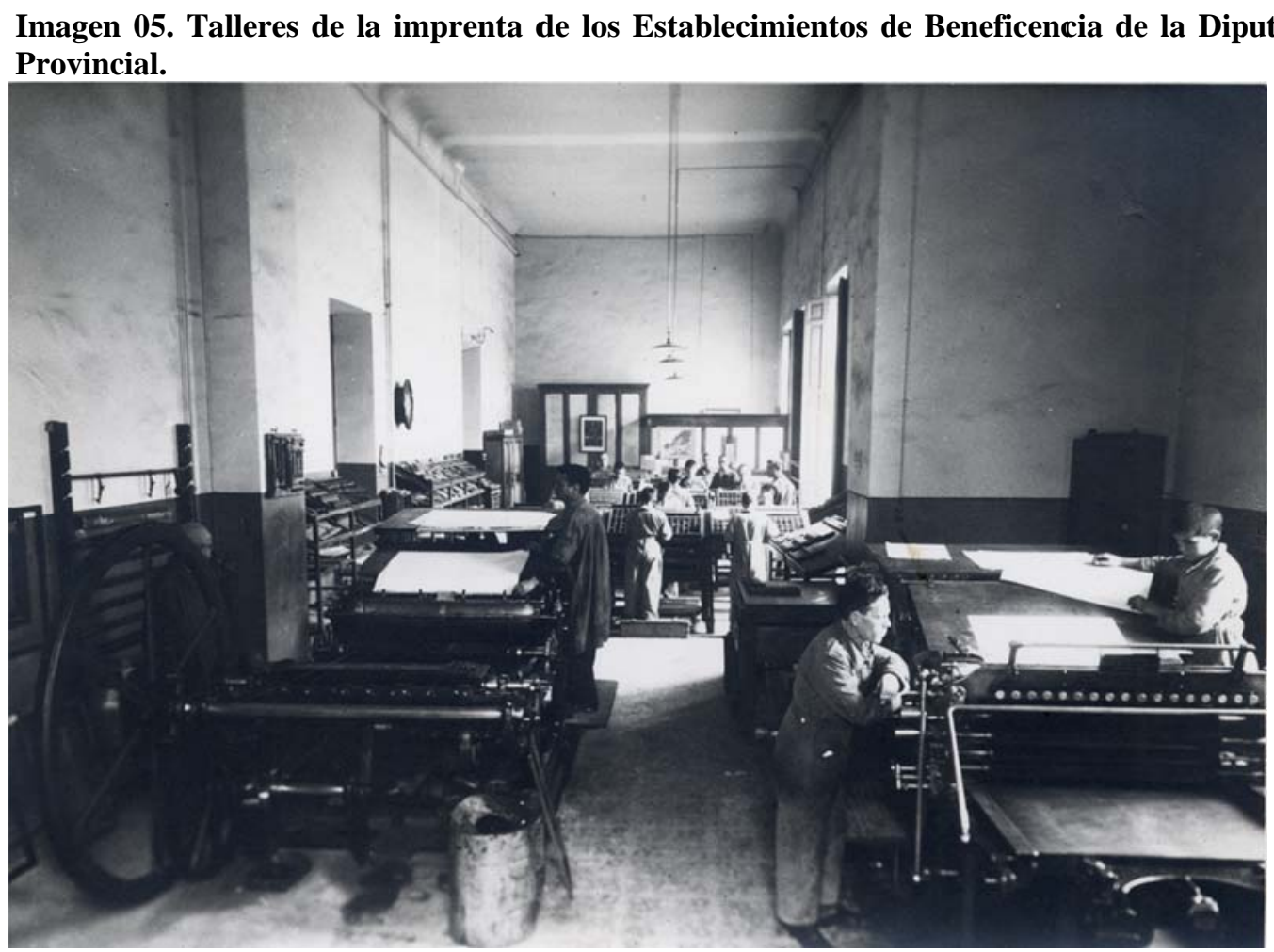

Fuente: A.D.P.P. (Archivo fotográfico)

\footnotetext{
${ }^{857}$ A.D.P.P., L.A.C.P. 90, 13-VII-1898.

${ }^{858}$ A.D.P.P., L.A.C.P. $85,15-\mathrm{V}-1897$.

${ }^{859} 75$ pts. para el personal de talleres, y 25 pts. para el de imprenta.
} 
En 1913 se estableció una Caja en la Beneficencia con el fin de recoger los ingresos que los asilados en los Establecimientos benéficos pudieran ahorrar. Dichos fondos permanecían en la Caja sin que pudiesen ser destinados a ninguna actividad especulativa y todos los acogidos menores de veintitrés años estaban obligados a imponer en la Caja una parte de sus haberes, jornales, gratificaciones y demás remuneraciones que percibiesen por sus trabajos ${ }^{860}$. La Caja era administrada $^{861}$ por el director de los Establecimientos benéficos ${ }^{862}$, el administrador de los mismos ${ }^{863}$, el capellán, la superiora de las Hijas de la Caridad, y el secretario del asilo ${ }^{864}$.

No solo se preocupaba la Beneficencia Provincial de los niños acogidos en sus establecimientos, fue también muy meritoria la labor que se llevó a cabo en la escolarización y educación de los menores sordos, mudos y ciegos. Una vez desestimada la proposición de establecer un colegio de sordomudos y $\operatorname{ciegos}^{865}$ en la provincia, se propuso la celebración de un Concierto ${ }^{866}$ con la Diputación Provincial de Burgos para su asistencia. El mantenimiento de los niños sordomudos y ciegos pobres de la provincia no suponía un coste excesivo para las arcas provinciales, pero sumado al resto del presupuesto de gastos de la Beneficencia suponía una carga más para los exiguos fondos provinciales.

\footnotetext{
${ }^{860}$ Los acogidos residentes en los Establecimientos que percibían hasta una pts., depositaban en la Caja el $50 \%$, desde una pts. hasta dos, el $60 \%$, desde dos hasta cinco, el $75 \%$, de cinco hasta quince pts., el $85 \%$, y desde quince pts. en adelante, el 90\%. Los acogidos que prestaban servicios fuera de la Beneficencia, hasta la cantidad de cinco pts. depositaban en la Caja el 50\%, de cinco hasta diez pts. , el 65\%, y desde diez pts. en adelante, el $70 \%$. Una vez cumplidos los veintitrés años, los acogidos podían reclamar el saldo que resultase a su favor, pero hasta cumplir esa edad no podían disponer de esos fondos sin la conformidad del director. A.D.P.P., art. 348 del Reglamento para el régimen y gobierno de los Establecimientos de la Beneficencia de la provincia de Palencia. 1913.

${ }^{861}$ Anualmente, cada 30 de junio, se realizaba un arqueo y recuento de fondos, y se extendía Acta de los resultados de los mismos.

${ }^{862}$ Como administrador y ordenador de pagos.

${ }^{863}$ Como depositario.

${ }^{864}$ Como interventor.

${ }^{865}$ De acuerdo con una Real Resolución de 19 de marzo de 1852, cada provincia debía establecer una escuela para atender a los sordomudos y ciegos. A pesar de haberse habilitado para tal fin la casa de Alejandro Casado, en la calle Ramírez, no llegó a funcionar y los alumnos fueron enviados al colegio de Burgos.

${ }^{866}$ El 24 de diciembre de 1861, la Diputación de Palencia había contraído el compromiso de apoyar la instalación de un colegio de sordo-mudos y ciegos en la ciudad de Burgos, que habría de ser sostenido por las provincias del distrito universitario de Valladolid, pagando a la Diputación de Burgos la cuenta de gastos de instalación que le correspondiese a la provincia de Palencia por los acogidos oriundos de la misma, pero el Concierto no se ratificó hasta el 1 de julio de 1881.
} 
En 1897, se propuso el plazo de cuatro años para la educación de los sordo-mudos y ciegos ${ }^{867}$, una vez discutida la proposición ${ }^{868}$ respecto a la reforma de las Bases en lo que se refería a la permanencia de los pensionistas en el colegio de Burgos de sordomudos y ciegos, se aprobó aumentar un año más de los que se indicaba en las Bases, cinco en vez de cuatro. Como sucedía en otras atenciones benéficas, el coste por acogido fue en aumento a lo largo de los años y en 1905, la Comisión Provincial de la Diputación de Burgos comunicaba que desde el 1de septiembre de ese año, las estancias en el Colegio de Sordo-mudos y ciegos que causen los pensionados de la provincia de Palencia, se cobrarían a razón de 2 pts. diarias en vez de 1.50 pts., como se venía cobrando hasta entonces por cada individuo ${ }^{869}$. Suprimido el colegio de sordo-mudos y ciegos de Burgos en 1906, la Comisión Provincial consiguió que la Junta directiva del colegio de sordomudos y ciegos de Vizcaya, establecida en Deusto, admitiera a cinco alumnos pensionados por la Diputación Provincial palentina ${ }^{870}$.

Ya se ha señalado que además de la atención a los niños y ancianos pobres, la Beneficencia Provincial dedicaba una parte importante de sus recursos de este Capítulo al cuidado de los que entonces se denominaban dementes. Hasta 1889, los dementes pobres de la provincia eran atendidos en diferentes manicomios de la nación, el de Valladolid, dependiente de la Diputación de esa provincia, acogía el mayor número, pero también había asilados en otros lugares, como el Manicomio de San Braulio de Llobregat, en la provincia de Barcelona, gestionado por la Orden de San Juan de Dios. Con el tiempo, la Diputación Provincial de Palencia llegó al convencimiento de que debía contar con instalaciones propias para atender a estos enfermos, puesto que cada vez era mayor el coste que debía afrontar por las estancias devengadas en otros manicomios. Solo entre los meses de abril y septiembre de 1883, se había pagado con fondos provinciales al Manicomio Provincial de Valladolid por las estancias de enfermos mentales pobres de la provincia de Palencia las siguientes cantidades:

\footnotetext{
${ }^{867}$ A.D.P.P., L.A.C.P. 82, 6-XI-1897.

${ }^{868}$ De los diputados provinciales Guigelmo Aguado, García Crespo y Díez Gómez.

${ }^{869}$ Desde el año 1887 hasta el año 1902 el coste de las pensiones de sordo-mudos y ciegos ascendió a $28.468,25$ pts. A.D.P.P., C-R/ 1,16 (A).

${ }^{870}$ A.D.P., L.A.C.P. 123, 6-X-1917. La Diputación satisfacía a la Diputación de Burgos 2.550 pts. anuales por nueve alumnos, mientras que el coste a pagar en el colegio de Deusto era de 4.165 pts.
} 
Tabla 09. Pago en pts. por estancias de enfermos mentales en el Manicomio Provincial de Valladolid.

\begin{tabular}{|c|c|c|c|c|c|c|c|}
\hline Meses & Abril & Mayo & Junio & Julio & Agosto & Septiembre & Total \\
\hline Pts. & $1.751,25$ & $1.768,75$ & $1.733,75$ & $1.832,50$ & 1.735 & 1.660 & $10.841,25$ \\
\hline
\end{tabular}

Elaboración propia. Fuente: A.D.P.P., Memoria Año Económico 1883-1884, C-R /1,12.

En Sesión del Pleno de la Diputación ${ }^{871}$, se propuso nombrar una Comisión para girar una visita al Manicomio de Valladolid, formada por el médico de la Beneficencia, varios diputados provinciales y el arquitecto provincial, para informarse sobre la asistencia de los enfermos que tenía la provincia allí acogidos y, en base a su informe, sopesar la posibilidad de establecer un manicomio en el antiguo Hospicio de San Juan de Dios, dado el número creciente de enfermos mentales que sostenía la Diputación Provincial. Desde 1885 hasta 1887, el edificio del convento de San Juan de Dios, contra el parecer de la Diputación Provincial, había estado ocupado por el batallón de El Príncipe y en sesión de la Comisión Provincial de 15-VII-1887 se acordó que se trasladen allí los dementes de la provincia $^{872}$ acogidos en el Manicomio de Valladolid.

Formuladas las Bases para la instalación de los dementes en el Hospital de San Juan de Dios, propiedad de la Diputación, se acordó remitirlas al prelado de la Diócesis para que pudieran ser aprobadas por los religiosos de San Juan de Dios, a cuyo cuidado se encomendaban los dementes ${ }^{873}$. Los gastos de instalación de la Comunidad de religiosos de San Juan de Dios, corrían de su cuenta ayudada por el obispo ${ }^{874}$. La Diputación Provincial quedaba obligada a abonar las estancias que causasen los alienados ${ }^{875}$ mediante un convenio que tendría una duración de treinta años. Los que pretendieran ingresar como pobres en el establecimiento frenopático provincial no podían satisfacer por Contribución Territorial e Industrial cuotas superiores a catorce pts., siendo 25 pts. para los que justificasen en forma que la riqueza por la que contribuían en los amirallamientos no era propia de los mismos, sino de las personas de quienes eran sus administradores hasta el momento de declararse su incapacidad ${ }^{876}$.

\footnotetext{
${ }^{871}$ A.D.P.P., L.A.P.D. 56, 16-IV-1888.

${ }^{872}$ Desde 1904, se admitía en el manicomio no solo a los dementes pobres naturales de la provincia, también a aquellos que habiendo nacido en otras provincias llevasen diez años consecutivos de vecindad (ganada con arreglo a la Ley Municipal vigente) con residencia y de forma ininterrumpida. Art. 12 del Real Decreto de 12 de julio de 1904.

${ }^{873}$ A.D.P.P., L.A.C.P. $61,24-$ VIII-1888.

${ }^{874} \mathrm{El}$ prelado diocesano contribuyó con una aportación de 25.000 pts.

${ }^{875} 1,25$ pts. al mes por estancia diaria.

${ }^{876}$ A.D.P.P., L.A.P.D. $62,28-\mathrm{V}-1885$.
} 
Terminadas las obras del Manicomio de San Juan de Dios, el superior de los religiosos encargados del cuidado de los dementes comunicaba a la Diputación Provincial que estos podían instalarse en el edificio desde el día 1 de julio de 1889. Se acordaba asimismo, participar a la Diputación de Valladolid, en cuyo hospital se hallaban la mayor parte los dementes pobres de Palencia, para que no pusiera obstáculo alguno a su salida ${ }^{877}$. Al igual que sucediera con los establecimientos de la Casa de Maternidad y la Casa de Misericordia, en 1900, cuando solo habían transcurrido doce años desde su acondicionamiento para acoger a los enfermos mentales pobres, se vio la necesidad de ampliar el Manicomio de San Juan de Dios por el hacinamiento que padecía debido al ingreso de gran cantidad de dementes ${ }^{878}$ y por la facilidad con que según la Comisión Provincial se expedían las certificaciones facultativas.

El 9 de noviembre de 1891 se habían fijado las Bases restrictivas de la pobreza para el ingreso en el manicomio, pero había quejas constantes de la Comisión Provincial sobre la facilidad con la que algunos facultativos verificaban la existencia de padecimientos mentales. En la 1897, la Comisión Provincial advertía sobre el «alarmante» aumento de dementes «que ya no caben en el departamento de mujeres y sucederá lo propio en el de varones, sino se adoptan medios para contener esa especie de invasión maniaca que va tomando caracteres alarmantes.» ${ }^{879}$ En 1911, las Hermanas Hospitalarias del Sagrado Corazón de Jesús, se hacían cargo de la sección de mujeres del Manicomio Provincial. Ese año, los Establecimientos de Beneficencia y hospitales acogían a fecha de 30 de octubre:

Tabla 10. Acogidos en los Establecimientos de Beneficencia el año 1911.

\begin{tabular}{|c|c|}
\hline Casa de Expósitos y Maternidad & 31 niños y 34 niñas \\
\hline Casa de Misericordia & Lactancia externa: 24 niños y 26 niñas \\
\hline Hospital San Antolín y San Bernabé & 86 hombres, 47 mujeres y 96 adolescentes \\
\hline Manicomio San Juan de Dios & 95 enfermos pobres \\
\hline
\end{tabular}

Elaboración propia. Fuente: A.D.P.P., Memoria Año Económico Segundo Semestre 1900, C-R / 1,14.

\footnotetext{
${ }^{877}$ A.D.P.P., L.A.C.P. 71, 6-VI-1889.

${ }^{878}$ A.D.P.P., Memoria Año Económico Primer Semestre 1900, C-R /1,14, p. 23.

${ }^{879}$ A.D.P.P., C-R / 1,9 (A), p. 44.
} 
El acuerdo ${ }^{880}$ al que llegaron ese mismo año la Diputación Provincial de Palencia y el Instituto Benéfico de San José para epilépticos de Carabanchel, para que los que sufriesen esa enfermedad pudieran ser trasladados desde el Manicomio de San Juan de Dios, alivió en parte la situación de hacinamiento que se vivía en dicho establecimiento. De todas formas, la Comisión Provincial no cejaba en su intento de buscar soluciones para poder aliviar a las cuentas provinciales de la pesada carga que suponía el mantenimiento de unos enfermos que raramente eran recuperables, por lo que el pago de sus estancias se prolongaba en los presupuestos sin solución de continuidad.

Con la esperanza de que esta situación mutase en favor de la Diputación Provincial, se invocaba el art. 5 del Real Decreto de 19 de mayo de 1885, sobre la permanencia de enfermos mentales en sus casas que no fueran un peligro para sus familias y causasen molestias, y sobre la necesidad de que fuese el Juzgado de Primera Instancia, previa instrucción del oportuno expediente, el que decidiese sobre la reclusión de este tipo de enfermos. La Comisión Provincial se quejaba sobre la necesidad de que muchos de los dementes recluidos lo estuviesen a cargo de sus familias, y no ingresados, ya que por esta razón aumentaban las estancias a pagar. Desde el traslado de los dementes desde el Manicomio de Valladolid iniciado el 1 de julio de 1888, hasta el 30 de septiembre de 1902, el total gastado por la Diputación Provincial de Palencia ascendía a la cantidad de $466.732,75$ pts. $^{881}$

\footnotetext{
${ }^{880}$ A.D.P.P., L.A.C.P. 92, 30-I-1900.

${ }^{881}$ A.D.P.P., Memoria Segundo Periodo Semestral de 1902. C-A/ 1, 16.
} 
En 1913 se daba un paso más para dificultar el ingreso de más acogidos en el Manicomio Provincial de San Juan de Dios por cuenta de los fondos provinciales, y se exigían una serie de documentos para poder ingresar:

1. Solicitud de ingreso del pariente más cercano al enfermo mental.

2. Certificación del Acta de Nacimiento o Partida de Bautismo del enfermo.

3. Acreditación de llevar diez años consecutivos de residencia en la provincia, aunque se fuese natural de la misma.

4. Certificado de la cuota contributiva que satisfacía el enfermo, su mujer, padres, abuelos y hermanos si tenía.

5. Informes del alcalde, párroco y juez municipal acerca de la posición social de los familiares citados del enfermo, precisando el grado de parentesco existente entre el enfermo y la persona que hubiera solicitado su ingreso.

6. Certificación facultativa en la que constase la necesidad y conveniencia de la reclusión del enfermo, visada por el subdelegado del Partido, quién debía hacer constar la verdadera urgencia del ingreso.

7. Informe del alcalde de la vecindad de enfermo respecto de la necesidad de reclusión del enfermo por no poder permanecer en su domicilio sin peligro para sus familiares.

Basta reflejar el coste de las estancias de enfermos mentales pobres de un solo año, para advertir el esfuerzo económico que la Diputación Provincial debía hacer si quería dispensar una atención básica a este tipo de enfermos. En el año 1915, las estancias de dementes pobres de la provincia en el Manicomio de San Juan de Dios alcanzaba la cifra de 43.000, a razón de 1,25 pts. por estancia y día, con arreglo al contrato celebrado entre la Diputación Provincial y los religiosos de la Orden Hospitalaria el 7 de octubre de 1888. El Manicomio de San Juan de Dios no solo acogía a los enfermos mentales pobres dependientes de la Diputación Provincial de Palencia, también albergaba a enfermos de otras provincias, cuyas estancias eran sufragadas por las diputaciones provinciales de los lugares de origen de los dementes. Sin embargo, estas no siempre cumplían con sus obligaciones y la Diputación palentina se veía obligada a remitir una contaduría por escrito a las diputaciones deudoras para que se hicieran cargo del traslado de los enfermos a sus respectivos manicomios y pagasen las hospitalizaciones que adeudaban ${ }^{882}$.

${ }^{882}$ A.D.P.P., L.A.C.P. $118,13-\mathrm{I}-1914$. 
En 1919, la Diputación Provincial acordaba renovar por veinte años el contrato ${ }^{883}$ entre Diputación y la Orden de San Juan de Dios y las Hermanas Hospitalarias del Sagrado Corazón para la asistencia y curación de dementes (hombres y mujeres respectivamente) pobres de la provincia con arreglo a lo establecido en las Bases del 2 de octubre de $1888^{884}$. La Diputación Provincial se mostraba conforme con la atención dispensada por la Orden de San Juan de Dios a los enfermos mentales de la provincia, lo cual no quiere decir que en ciertas ocasiones chocasen los intereses de ambas instituciones, como ocurrió en 1926 cuando la Comisión Provincial denegaba la elevación en 50 cént. por estancias de enfermos pobres que solicitaba el superior del manicomio de San Juan de Dios, que justificaba esa petición en el elevado precio que habían alcanzado los artículos básicos. La Comisión Provincial argumentaba que por el contrario, los artículos de primera necesidad habían bajado los precios de una forma apreciable respecto a años anteriores ${ }^{885}$.

\footnotetext{
${ }^{883} \mathrm{El}$ anterior fue firmado el 7 de octubre de 1888 .

${ }^{884}$ A.D.P.P., L.A.C.P. 127, 28-I-1919.

${ }^{885}$ A.D.P.P., L.A.C.P. 142, 8-I-1926.
} 
El tercer pilar de la atención benéfica provincial, lo constituía el Hospital de San Bernabé y San Antolín. Evidentemente, las atenciones en este recinto eran de carácter sanitario, pero se ha considerado que dado que solo se dispensaba atención sanitaria a los pobres de la provincia, era conveniente incluir en el apartado de Beneficencia lo relacionado con esta institución, ya que la Diputación Provincial tenía competencias específicas en Sanidad que nada tenían que ver con el poder adquisitivo de los usuarios de los servicios sanitarios. Desde el año 1874, la Diputación provincial tenía contratado con el Obispado y el Cabildo de la catedral, patronos del Hospital de San Bernabé y San Antolín, la asistencia de los enfermos pobres de la provincia, los médicos de la Beneficencia Provincial intervenían en los reconocimientos de los que ingresaban en el Hospital por cuenta de la Diputación Provincial. Una vez admitidos dependían del Patronato, limitándose la Diputación a girar visitas de inspección cuando lo estimaba oportuno. Para ingresar en este hospital se requerían una serie de documentos ${ }^{886}$ :

1. Certificado con referencia al amillaramiento ${ }^{887}$ y padrones de Industrial respecto de las cuotas contributivas que satisfacía el enfermo y las personas obligadas a suministrarle alimentos. Si la cuota contributiva ${ }^{888}$ excedía de ocho pts. por cualquier concepto, el enfermo no podía disfrutar de los auxilios de la Beneficencia Provincial.

2. Informes suscritos por el alcalde, párroco y juez municipal, acerca de la posición social del enfermo, sus padres, abuelos y hermanos si tenía, indicando al final del documento el tiempo que llevaba de vecindad en la provincia el enfermo.

3. Certificación facultativa de la enfermedad que padecía el interesado en ingresar en el Hospital, haciendo constar en el informe si esta era curable o incurable.

\footnotetext{
${ }^{886}$ A.D.P.P., art. 370 del Reglamento de 1913 para el régimen y gobierno de los Establecimientos de la Beneficencia de la provincia de Palencia.

${ }^{887}$ Relación numerada y por orden alfabético de los dueños o usufructuarios de bienes inmuebles y ganadería sometidos a Contribución, que hubiese en cada término municipal, expresando separadamente y en conjunto, individuo por individuo, cada uno y todos los objetos de imposición que el dueño o usufructuario poseyera. Se regía por el Reglamento de 30 de septiembre de 1835, en el cual se prescindía de los edificios y solares, pues estos eran objetos de una Contribución especial, separada de aquella por el art. 29 de la Ley de Presupuestos de 5 de agosto de 1893, figurando, no en los amillaramientos, sino en los registros de edificios y solares.

${ }^{888}$ Las certificaciones referentes a las cuotas contributivas, se referían al año corriente y a los cuatro anteriores.
} 
Desde 1891 hasta 1902 el coste para la Diputación Provincial del mantenimiento de estos enfermos ascendió a 210.155 pts. En 1902, el director del Hospital de San Bernabé y San Antolín trasladó a la Comisión Provincial el acuerdo de los patronos sobre el aumento del precio de las estancias en vista de la carestía de los artículos de primera necesidad y de la disminución en un $20 \%$ de las rentas propias del establecimiento ${ }^{889}$, según el contrato celebrado el 27 de marzo de 1903 entre la Diputación Provincial y el Patronato del Hospital de San Antolín y San Bernabé, las estancias de enfermos pobres de la provincia pasaban a pagarse a razón de 1,50 pts. por estancia y día. Puesto que las estancias en el Hospital de San Bernabé y San Antolín, se sufragaban a costa del Capítulo de Beneficencia, la asistencia de los enfermos sufría de los mismos males presupuestarios que la Casa de Beneficencia y el Hospital de San Juan de Dios. En 1915, la Diputación Provincial se veía imposibilitada para sufragar las estancias de enfermos pobres ${ }^{890}$ de la provincia en el Hospital de San Bernabé y San Antolín de los meses de octubre, noviembre y diciembre de 1914 por falta de crédito y no existir sobrante en los restantes capítulos de la Ley Económica Provincial ${ }^{891}$. Ante esta situación, la Comisión Provincial acordaba dirigirse a los alcaldes de los pueblos de los enfermos incurables pobres que llevasen muchos años ingresados en el Hospital de San Bernabé y de San Antolín, para que en caso de haber familiares o personas obligadas por el Código Civil a facilitarles alimentos, les preguntasen si estarían dispuestos a hacerse cargo de sus ascendientes o colaterales con una pensión de una peseta diaria. A la vez, se acordaba preguntar lo mismo a los hermanos de los pobres, a cambio de una pensión de 1,25 pts. por la asistencia, que era lo que se pagaba a los religiosos de San Juan de Dios por la estancia, mantenimiento y curación de los maniacos ${ }^{892}$.

\footnotetext{
${ }^{889}$ A.D.P.P., L.A.C.P. 98, 27-VI-1902.

${ }^{890}$ En 1915 era considerado pobre el trabajador cuyo jornal fuese inferior a 2,50 pts. Ser pobre conllevaba la asistencia médica-farmacéutica gratuita para el trabajador y su familia.

${ }^{891}$ A.D.P.P., L.A.C.P. 118, 23-XI-1914.

${ }^{892}$ A.D.P.P., L.A.C.P. $119,17-$ VIII-1915.
} 
La situación llegó al extremo de que en 1915, varios diputados provinciales ${ }^{893}$ presentaron una proposición para que se nombrase un visitador para vigilar el cumplimiento de los contratos celebrados con el Patronato del Hospital de San Bernabé y San Antolín, y Hermanos de San Juan de Dios, respecto a la asistencia y curación de los enfermos pobres de la provincia que ingresasen en dichos establecimientos ${ }^{894}$, pues se sospechaba que en ocasiones se podía retrasar la salida de los enfermos de estas instituciones para poder seguir cobrando las estancias que devengaban. Se eligió por votación secreta diputado visitador al diputado provincial Garrachón García. Al igual que sucedía con el Hospital de San Juan de Dios, en ocasiones y casi siempre por motivos económicos, surgían roces entre el patronato del Hospital de San Bernabé y San Antolín y la Diputación Provincial, como en 1926, cuando esta recordaba al director del Patronato del Hospital de San Bernabé y San Antolín que no asumiría los costes de los ingresos por disposición gubernativa, o cuando el director del Hospital recordaba a la Diputación Provincial que respecto de los enfermos de la capital tenía la facultad de decidir sobre la necesidad de admisión, y que la Diputación debía reintegrar al Patronato íntegramente las estancias de estos ingresados y los costes de las estancias de los enfermos ingresados por orden del Gobierno de la provincia ${ }^{895}$.

En 1914, el diputado provincial García de los Ríos proponía que los enfermos pobres de la provincia que a juicio de los médicos de Beneficencia debieran operarse, fueran trasladados a un hospital donde pudiesen ser atendidos debidamente ${ }^{896}$. El diputado provincial César Gusano apoyaba la proposición de García de los Ríos, y proponía que el asunto se tratase con la Diputación de Valladolid, donde existía la Facultad de Medicina. El diputado provincial Guerra Castellanos señalaba que antes de adoptar la medida debía consultarse con el Cabildo el establecimiento de salas de operaciones en el Hospital de San Bernabé y San Antolín, y solo en el caso de que no pudiera llegarse a un acuerdo se procediese con la propuesta de García de los Ríos. Que no se llegó a un acuerdo lo certifica el pago de estancias de los enfermos pobres de la provincia operados en el Hospital Clínico de Valladolid, que en el año 1915 suponían un total 51.000 pts. ${ }^{897}$

\footnotetext{
${ }^{893}$ César Gusano, Fernández Lomana y Abilio Calderón Rojo.

${ }^{894}$ A.D.P.P., L.A.C.P. $121,11-\mathrm{V}-1915$.

${ }^{895}$ A.D.P.P., L.A.C.P. 142, 20-XII-1926.

${ }^{896}$ A.D.P.P. L.A.P.D. $113,7-\mathrm{V}-1914$.

${ }^{897}$ A.D.P.P., C-L/ 10,4
} 
Toda esta serie desencuentros se tradujeron en que la Diputación Provincial comenzara a plantearse la posibilidad de contar con un establecimiento hospitalario propio, no en vano en 1911, el gobernador de la provincia solicitaba a la Corporación Provincial que procurase contar con hospital propio, dadas las malas condiciones que reunía el Hospital de San Bernabé y San Antolín, donde no había sala destinada a partos ni a operaciones ${ }^{898}$. En 1917, la Diputación Provincial volvía a reclamar al Patronato del Hospital de San Bernabé y San Antolín el establecimiento de una sala de operaciones para que los médicos de la Beneficencia Provincial pudieran operar, ${ }^{899}$ finalmente, el 8 de mayo de 1917, se acordó la instalación de una sala de operaciones en el citado centro hospitalario ${ }^{900}$. Sin embargo, la Diputación Provincial no había olvidado su plan de construcción de un hospital propio y, ya en 1916, había autorizado al arquitecto provincial a elaborar un proyecto de hospital provincial siempre que fuese gratuito, y teniendo en cuenta que durante algunos años no se podría realizar por falta de presupuesto ${ }^{901}$. En 1927, la Diputación Provincial aun no disponía de hospital propio, pero a tenor de la documentación consultada, en su ánimo estaba depender cada vez menos del Hospital de San Bernabé y San Antolín en lo que se refería a la atención de enfermos pobres de la provincia, así se puede entender la autorización concedida a la Presidencia ${ }^{902}$ de la Diputación Provincial para firmar un contrato con el Patronato del Hospital de Villarramiel, aceptando el precio de 3 pts. por estancia de enfermo, y dar aviso al Negociado de Beneficencia para que los enfermos de los pueblos de la demarcación asignada a ese Hospital (trece en total) fueran trasladados a este desde el Hospital de San Bernabé y San Antolín.

\footnotetext{
${ }^{898}$ A.D.P.P., L.A.P.D. $111,4-X-1911$.

${ }^{899}$ A.D.P.P., L.A.C.P. 125, 9-VI-1917.

${ }^{900}$ A.D.P.P., L.A.C.P. 125, 22-VI-1917.

${ }^{901}$ A.D.P.P., L.A.C.P. 124, 14-XI-1916.

${ }^{902}$ A.D.P.P., L.A.C.P. 143, 14-II-1927.
} 
En lo que respecta a la asistencia benéfico sanitaria, el Real Decreto de 14 de junio de 1894 aprobaba el Reglamento del Servicio benéfico sanitario a las familias pobres ${ }^{903}$ en los pueblos. El art. 1 de este Reglamento señalaba la obligatoriedad de que en todas las poblaciones que no pasasen de 4.000 vecinos, en el caso de la provincia de Palencia todas excepto la capital, hubiese facultativos municipales de Medicina y Cirugía, y de Farmacia costeados por lo municipios. En los de mayor población, los ayuntamientos debían llevar un registro de pobres con derecho a la asistencia facultativa gratuita, debiendo justificar su condición de pobres mediante la correspondiente Cédula acreditativa. El art. 2 contemplaba una serie de obligaciones de los facultativos municipales, entre otras estaba la de auxiliar a las corporaciones provinciales en todo aquello que tuviese relación con la policía de salubridad y las estadísticas sanitarias. El art. 21 señalaba la obligación de la Comisión Provincial, previa comunicación del gobernador, de proveer las plazas vacantes de facultativos municipales, nombrando personal interino en el plazo de ocho días en caso de que no lo hiciesen los ayuntamientos.

En 1924, el Real Decreto de 12 de enero en su art. 5 disponía que las corporaciones provinciales debían elevar al Ministerio de Gobernación, en un plazo de quince días, prorrogado posteriormente a treinta días, una breve Memoria que detallara los defectos que las diputaciones observaran en su funcionamiento y proponiendo a su vez las medidas correctoras para esas deficiencias. Esta disposición perseguía como fin último que la Dirección General de Administración del Estado conociese la situación real de las Diputaciones provinciales en el ámbito de sus atribuciones. En la Memoria de deficiencias de $1924^{904}$, se destacaba la buena atención dispensada a los enfermos sufragados por la Diputación Provincial en el Hospital de San Bernabé y San Antolín, y en los manicomios de ambos sexos. Por el contrario, el estado de los locales destinados a estos fines propiedad de la Diputación ${ }^{905}$, como el manicomio de San Juan de Dios, era muy deficiente, contrastando con los modernos locales pertenecientes a las Comunidades religiosas.

\footnotetext{
${ }^{903}$ Según el Reglamento aprobado por este Real Decreto, se consideraba pobres a aquellos vecinos que no contribuyesen directamente con cantidad alguna al erario público, ni estuviesen incluidos en los repartimientos provinciales y municipales.

${ }^{904}$ A.D.P.P C-R/ 1,12 (A).

${ }^{905}$ Locales propiedad de la Diputación y cedidos a la Orden de los Hermanos de San Juan de Dios en 1888 , que tenían asignada una partida presupuestaria de 1.250 pts. anuales para gastos de conservación, totalmente insuficiente para mantener en buen estado las edificaciones.
} 
La Diputación Provincial se quejaba del nulo interés de las Comunidades religiosas por realizar mejoras por su cuenta, pues en el caso de la Orden de San Juan de Dios, en el contrato de cesión del edificio, la condición séptima del mismo señalaba, «A la terminación del contrato, y si ambas partes contratantes no estuvieran de acuerdo para su renovación, será devuelto el convento a la Diputación, quedando en beneficio de la provincia las obras y mejoras que hubieran hecho, sin que tengan derecho a reclamar el importe de estas la Comunidad.» ${ }^{906}$ Evidentemente, esta cláusula no incitaba a realizar mejoras sino por el propietario del inmueble.

La Real Orden de 17 de enero de 1925, ordenaba a los presidentes de las diputaciones la remisión a la Dirección de la Administración una Memoria como complemento de la que fue presentada para cumplir con el citado Real Decreto, en la que debía constar:

- Aumento y disminución habidas en los ingresos, especialmente por el Contingente Provincial,

- Reformas y mejoras introducidas en los servicios provinciales,

- Atrasos cobrados y deudas pagadas. Los datos debían comprender hasta el 31 de diciembre de $1924^{907}$.

Esta circunstancia nos permite conocer de forma exhaustiva las dificultades con que se encontraba la Diputación Provincial de Palencia en el ejercicio de sus facultades, especialmente en el ámbito de la Beneficencia, por ser este el Capítulo que absorbía la mayor parte de la dotación presupuestaria de la Corporación provincial. La principal carencia de este servicio resultaba ser la falta de capacidad de los Establecimientos de Beneficencia para albergar a toda la población que permanecía asilada en los mismos. Estos establecimientos se acondicionaron para acoger a una población de 200 personas, y en la fecha de redacción de esta Memoria contaban con una media de 500 acogidos, más del doble de su capacidad. Este «sobrante» de población asilada se instalaba en dos claustros del antiguo convento de San Francisco, que no contaban con las más mínimas condiciones de higiene.

${ }^{906} \mathrm{C}-\mathrm{R} / 1,12$ (A). p. 18.

${ }^{907}$ A.D.P.P., L.A.C.P. $141,11-$ II- 1925. 
Las condiciones higiénico-sanitarias constituían el otro gran problema de este tipo de Establecimientos. La lectura detenida de la Memoria nos descubre una serie de circunstancias que hoy denominaríamos «tercermundistas». Resaltar, a modo de ejemplo, la falta de locales de aislamiento en caso de epidemia, extremo este que producía una tasa elevada de mortalidad entre la población asilada cuando enfermedades contagiosas como el sarampión invadían estas estancias. No existía local de maternidad como tal, y en el servicio de tocología no había sala para intervenciones. En 1906, había comenzado a funcionar la consulta pública de ginecología y enfermedades pediátricas en los Establecimientos de Beneficencia, a cargo del facultativo de la misma ${ }^{908}$. Respecto de la Cuna, no contaba con sala de aislamiento para infecciosos, no existía incubadora para prematuros y se calentaba con una estufa de carbón, poco saludable para recién nacidos. Ese mismo año, se habían declarado varios casos de viruela benigna entre los niños hacinados en la sección de $\mathrm{Cuna}^{909}$. Los dormitorios de la parte más alta no tenían ventanas en los pasillos y carecían de todo tipo de servicios e higiene, en la sala de operaciones y curas faltaba material para la práctica de la cirugía, la cirugía general estaba concertada con el Hospital de San Bernabé y San Antolín, pero la cirugía ocular se practicaba en el Establecimiento de Beneficencia. En diciembre de 1923, se había instalado una clínica oftalmológica a cargo del doctor Díaz Caneja. La escuela de primera enseñanza de niños que albergaba la Beneficencia estaba a cargo de un profesor nombrado por concurso y el local habilitado para tal fin presentaba buenas condiciones de iluminación según esta Memoria, algo escaso de espacio por el alto número de alumnos, y tenía un material pedagógico insuficiente y anticuado. La escuela de niñas, a cargo de las Hermanas de la Caridad, tenía mejores condiciones de habitabilidad y un mejor material escolar.

\footnotetext{
${ }^{908}$ A.D.P.P. L.A.C.P. $102,8-$ VIII-1906.

${ }^{909}$ A.D.P.P., L.A.C.P. 136, 11-XI-1924.
} 
Funcionaban talleres de zapatería, carpintería, sastrería, y una imprenta ${ }^{910}$, en el taller de zapatería se fabricaba y reparaba el calzado de los asilados, el taller de sastrería estaba a cargo de una de las Hermanas de la Caridad, contaba con máquinas de coser y fabricaba ropa para los asilados. La imprenta tenía material anticuado y defectuoso y había quejas sobre trabajos realizados ajenos a la Diputación pero con cargo a ella, lo que gravaba el Presupuesto Provincial ${ }^{911}$.

Las soluciones que se proponían eran la ampliación de los Establecimientos de Beneficencia, construyendo un edificio nuevo con buenas condiciones de salubridad para Maternidad, con una sala independiente para partos, operaciones y aislamiento de enfermos, instalando en este edificio el de la Cuna. También habría que instalar calefacción e incubadora para los niños con problemas, que en 1924 presentaban una tasa de mortalidad de casi el $100 \%{ }^{912}$. Se solicitaba al Estado el edificio destinado a Estación Enológica, que se hallaba sin uso, para descongestionar la población asilada en los Establecimientos de Beneficencia y en caso de no atenderse la petición, se aconsejaba fijar un número determinado de asilados no mayor que la capacidad del edificio, estableciendo para los excedentes pensiones domiciliarias que serían otorgadas a los que voluntariamente quisiesen vivir fuera del establecimiento, y forzosamente a aquellos que del examen de sus expedientes de ingreso, resultase que tendrían hijos de posición relativamente acomodada ${ }^{913}$. También se proponía ampliar los locales destinados a enfermerías, construir un pabellón para infecciosos ${ }^{914}$, y habilitar un local independiente para los operados oftalmológicos, dotando de baños a ambos locales. Respecto de los dormitorios situados en los desvanes del ex convento de San Francisco, se proponía desalojarlos por la falta de salubridad y, o bien habilitar un nuevo local para este fin, o reducir la población asilada.

\footnotetext{
${ }^{910}$ En la que se imprimía entre otras publicaciones el $B O P$, las listas electorales y muchos impresos para las dependencias de la Corporación. El director de la Beneficencia tenía la facultad de autorizar a los varones acogidos la asistencia a talleres, comercio e industrias que no existiesen en los establecimientos benéficos, previo convenio de las condiciones y jornales que el acogido había de tener, continuando este asilado en la Beneficencia.

${ }^{911}$ A.D.P.P., C-R / 1, 12 (A).

${ }^{912}$ A.D.P.P., C-R / 1, 12 (A).

${ }^{913}$ A.D.P.P., L.A.C.P. 137, 13-II-1924.

${ }^{914}$ El art. 38 del Reglamento de Sanidad provincial de 1925 obligaba a las diputaciones provinciales a establecer en cada uno de los Establecimientos provinciales de Beneficencia un pabellón de aislamiento para los primeros casos de enfermedades infecciosas e infectocontagiosas que pudiesen presentarse entre los asilados de los respectivos establecimientos.
} 
Otras soluciones que se aportan eran acondicionar los lugares de recreo descubiertos, con la instalación de cajas para las basuras, instalar un lavadero mecánico, arreglar todos los retretes, cambiar el método de subasta por el de administración, etc. Todos los intentos de reducir el número de asilados eran pocos y varios diputados provinciales solicitaban en una moción que se modificasen las Bases de ingreso en los Establecimientos de Beneficencia, volviendo al tipo anterior al 9 de enero de $1924^{915}$.

Al final, todas las reformas encaminadas a endurecer el acceso a la Beneficencia Provincial surtieron el efecto buscado, la reducción del número de acogidos. En noviembre de 1924, Benito Quintero, director de los Establecimientos de Beneficencia, explicaba el buen resultado de las reformas que había introducido en los distintos departamentos y la reducción de la población asilada, hasta el punto de haberse retirado por ser innecesarias bastantes camas y quedar vacantes para alguna necesidad imprevista. La población asilada a fecha de 1 de enero de 1924 era de 318 personas, el 1 de enero de 1925, la cantidad se había reducido a 236 asilados. Gracias a esta reducción, el problema de la capacidad había quedado resuelto, de modo que la Comisión Provincial, previo informe del director de la Beneficencia, había restablecido los turnos de antigüedad y gracia, pudiendo ingresar personas que estaban en turno desde $1907^{916}$. Se había mejorado el racionado variando los artículos y alternándolos para que les fuese lo más grato posible a los asilados sin recargar el presupuesto, sucediendo lo mismo con el presupuesto de enfermería, donde se facilitaba todo lo que prescribía el facultativo. Gracias a estas reformas se consiguió dotar a los servicios de Beneficencia de más amplitud en los locales sin necesidad de hacer un nuevo hospicio, porque con ello se gravaría a los pueblos con un recargo sobre el Contingente Provincial, y no había necesidad porque con las reformas la población asilada se encontraba en buenas condiciones higiénicas ${ }^{917}$.

\footnotetext{
${ }^{915}$ Cuota de contribución para tener derecho a ingreso: ocho pts. para los que tenían tres hijos, doce pts. para los que tuviesen cinco y 16 pts. para los que pasasen de cinco.

${ }^{916}$ A.D.P.P., L.A.P.D. 137, 4-XI-1924.

${ }^{917}$ A.D.P.P., L.A.P.D. $137,4-X I-1924$.
} 
La Memoria también posibilita conocer el número de acogidos en el manicomio de San Juan de Dios entre los años 1919 y 1923:

Tabla 11. Cuadro estadístico de enfermos mentales sostenidos por la Diputación palentina durante el periodo 1919-1923.

\begin{tabular}{|c|c|c|c|}
\hline & Varones & Hembras & Total \\
\hline $\begin{array}{l}\text { Ingresos totales } \\
\text { Promedio anual: } 37\end{array}$ & 96 & 91 & 162 \\
\hline $\begin{array}{l}\text { Curados } \\
\text { Promedio anual: } 12\end{array}$ & 31 & 30 & 61 \\
\hline $\begin{array}{l}\text { Fallecidos } \\
\text { Promedio defunciones: } 13\end{array}$ & 33 & 32 & 65 \\
\hline $\begin{array}{l}\text { Bajas por otras causas } \\
\text { Promedio defunciones: } 3,3\end{array}$ & 10 & 8 & 18 \\
\hline Enfermos 31/I/1924 & 64 & 104 & 168 \\
\hline
\end{tabular}

Elaboración propia. Fuente: Memoria de deficiencias de 1924. A.D.P.P. C-R /1-19 (A).

En el año 1927 se habían llevado a cabo algunas de las reformas que se proponían en la Memoria de 1924:

1. Maternidad y Cuna reunían las mínimas condiciones higiénicas exigibles.

2. La enfermería y la sala de operaciones estaban dotadas con el material quirúrgico necesario.

3. Se habían levantado dos pabellones nuevos, y había espacio suficiente para todos los asilados.

4. Se había instalado calefacción en todo el edificio, y lavadero mecánico.

5. Se habían construido nuevos retretes y lavabos, y reformado los existentes. 
6. Se había mejorado la alimentación y vestuario de los asilados. La dirección de Beneficencia pensaba que el sustento de la población asilada era suficiente y mejor en comparación con el de la clase trabajadora de la provincia. Respecto al vestuario todos los niños, jóvenes y ancianos tenían calcetines, calzoncillos y camisetas $^{918}$.

En 1927, la situación presupuestaría provincial había mejorado, y como consecuencia la inversión en los servicios de la Beneficencia creció de forma sensible con respecto al año en el que se proclamó la Dictadura de Primo de Rivera.

Tabla 12. Estado comparativo de lo invertido en pts. en Beneficencia en los ejercicios 1923/24 y 1927.

\begin{tabular}{|c|c|c|}
\hline Ejercicios & $\mathbf{1 9 2 3 / 2 4}$ & $\mathbf{1 9 2 7}$ \\
\hline Hospitalización enfermos & 79.488 & $119.854,55$ \\
\hline Dementes & 87.934 & $132.131,63$ \\
\hline Establecimientos beneficencia & $243.077,37$ & $240.386,33$ \\
\hline Obras de reparación & 5.000 & $19.806,17$ \\
\hline Becas sordo-mudos y ciegos & & 4.500 \\
\hline Total & $415.499,37$ & $408.788,68$ \\
\hline
\end{tabular}

Elaboración propia. Fuente: A.D.P.P. C-R / 1,19(A).

\footnotetext{
${ }^{918}$ El vestuario de los ancianos se componía de: dos camisetas interiores, dos camisas y una para fiestas, dos calzoncillos, un chaleco, una chaqueta, un capote, una capa, dos pares de calcetines, dos pares de zapatos, tres pañuelos de bolsillo, y dos trajes, uno para los domingos y otras fiestas, las mujeres: dos camisetas interiores, dos camisas y otra para fiestas, un refajo, dos faldas, dos batas, dos delantales, dos pañuelos de cabeza, tres pañuelos de bolsillo, dos pares de medias, un mantón y dos trajes, uno para los domingos y otras fiestas. . A.D.P.P., Memoria de los servicios de Beneficencia Provincial, C-R/ 1,22.
} 
En 1927 el superávit del Presupuesto Provincial era de 197.549,73 pts., esta cantidad fue empleada para cubrir en parte los gastos de la compra de una finca para construir una residencia de verano de los niños asilados en la Beneficencia. La finca tuvo un coste de 35.424 pts., y el coste de los pabellones de la residencia ascendió a unas 50.000 pts.

Imagen 06. Pabellón destinado a residencia veraniega de los asilados de Beneficencia.

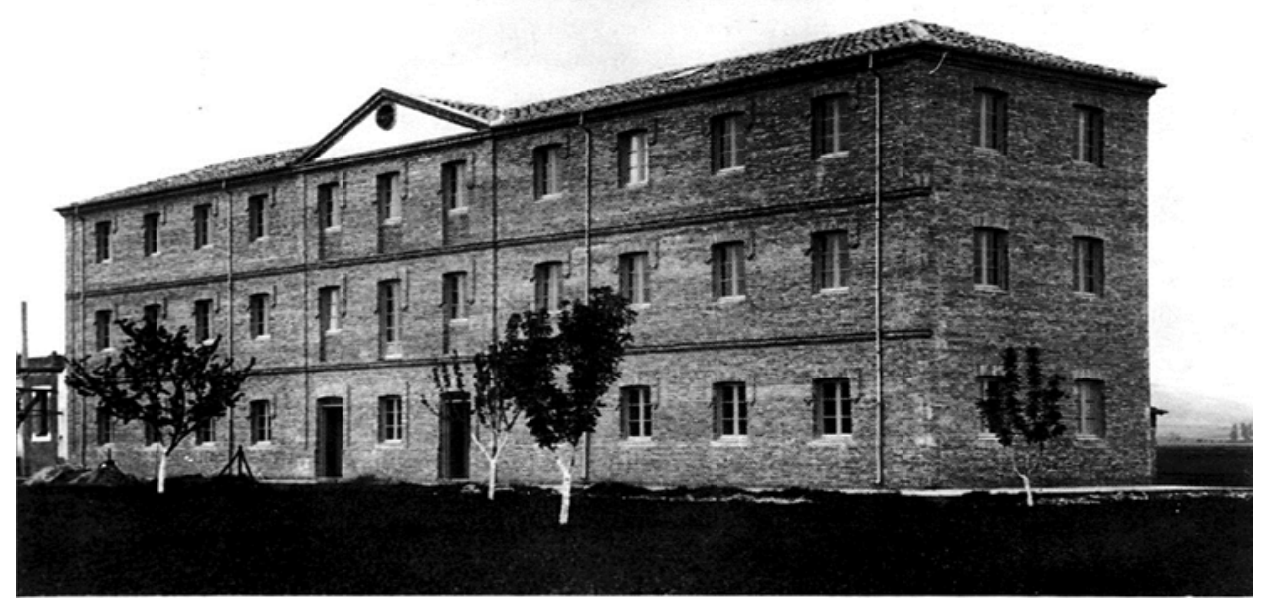

Fuente: A.D.P.P. (Archivo fotográfico)

También se mejoró el presupuesto destinado a la Clínica oftalmológica adscrita a Beneficencia, dotándola de material adecuado y del instrumental mäs moderno de la época, como el oftalmoscopio, lámpara de hendidura y microscopio corneal de Gullstrand, refractómetro de Zeiss, lámpara de fototerapia ultravioleta, etc., que solo se hallaban en clínicas universitarias de primera categoría, se adquirió también un proyector para la enseñanza de los niños y niñas asiladas. El Estatuto Provincial de 1925 había dotado a las diputaciones provinciales de una mayor autonomía fiscal, había permitido que el Estado asumiese ciertas competencias onerosas para las arcas provinciales y en definitiva, había contribuido a fortalecer económicamente a la Administración Local. Lo datos comparativos de inversión, antes y después de la entrada en vigor del Estatuto Provincial, son el mejor testigo de que las corporaciones provinciales sabían administrar de forma eficiente los recursos que el Estado ponía a su disposición, haciendo bueno el viejo lema de la Diputación palentina: a mayor descentralización, mejor gestión de la atenciones provinciales. 
Además de las atenciones que la Diputación Provincial costeaba conforme a lo prescrito en la legislación, también subvencionaba otras instituciones benéficas y benéfico sanitarias, como a los asilos de Astudillo y Carrión de los Condes, a la Junta Provincial de Protección a la infancia y mendicidad, a las Siervas de María, que en Palencia y Saldaña cuidaban de los hijos de las lavanderas mientras estas trabajaban ${ }^{919}$ y a los hospitales de Aguilar de Campoo y Carrión de los Condes (250 pts. cada uno), con la condición de que los acogidos en ellos no ingresasen en el Hospital de San Bernabé y San Antolín, donde tenían derecho de hacerlo como naturales de la provincia ${ }^{920}$. En 1928, el presidente de la Junta Provincial de Sanidad, solicitaba a la Diputación Provincial la construcción de un hospital para atender a los enfermos pobres tuberculosos, afectados por enfermedades venéreo-sifilíticas y a los niños de corta edad que no podían ser atendidos por la falta de un hospital provincial. La Diputación Provincial, una vez más condicionada por el estrecho margen de actuación que le concedían sus recursos materiales, señalaba la imposibilidad material de acometer esa obra por su alto coste y los gastos que originaría su sostenimiento ${ }^{921}$.

No obstante, ante el convencimiento de la necesidad de establecer un hospital provincial, la Diputación Provincial comenzó en octubre de 1930 a hacer gestiones para adquirir las edificaciones que los hermanos de San Juan de Dios poseían en el Manicomio y que habían abandonado, a los cuales se podrían unir los que eran propiedad de la institución provincial. Se estudiaría la adaptación de estos locales a la construcción de nueva planta $^{922}$. En diciembre de 1930, se daba lectura al pliego de condiciones para el concurso de adquisición de solares con destino a la construcción de edificaciones para instalar el hospital provincial.

\footnotetext{
${ }^{919}$ A.D.P.P., C-L/ 10,2

${ }^{920}$ A.D.P.P., C-L/ 10,2.

${ }^{921}$ A.D.P.P., L.A.C.P. 144. 29-II-1928.

${ }^{922}$ A.D.P.P., L.A.P.D. 148, 5-X-1930.
} 


\section{Sanidad}

Introducción

La sanidad y la higiene fueron valores consolidados desde la beneficencia. Para la burguesía las capas sociales empobrecidas representaban un peligro para la salud, en su opinión no estaban habituadas al cuidado del cuerpo, ni al hábito de la limpieza, ni tenían asimilada la necesaria atención a la sanidad y al correcto tratamiento de las enfermedades y accidentes. La primera asistencia sanitaria pública no fue dirigida a toda la población, solo a los necesitados y marginados, principales transmisores de enfermedades tan letales en el siglo XIX como el cólera. El servicio de la Sanidad Municipal y Provincial fue el que más influjo recibió de la beneficencia, hasta el punto que puede afirmarse que surgió como un aspecto más de la asistencia social ${ }^{923}$. Dentro de la Beneficencia Provincial se organizó un servicio de médicos titulares.

\section{La sanidad provincial}

La labor de la Corporación Provincial palentina en Sanidad abarcaba aspectos tan diversos como la ayuda técnica y material a los ayuntamientos, especialmente en el control y previsión de epidemias, la supervisión de las actuaciones de los municipios en materia de Sanidad Pública, la asistencia sanitaria a los pobres y, a partir de la entrada en vigor del Estatuto Provincial de 1925, todas aquellas atenciones consideradas obligatorias en esta materia. Dada su naturaleza jurídica, ya se ha comentado que las diputaciones provinciales ejercían la tutela administrativa sobre los ayuntamientos hasta la promulgación del Estatuto Provincial de 1925 y estaban facultadas para entender en las reclamaciones de los ciudadanos sobre los acuerdos de las corporaciones municipales. En 1876, se presentó un recurso de alzada de Ausín Hermanos ante la Diputación Provincial $^{924}$ por el acuerdo del Ayuntamiento de Palencia ${ }^{925}$ en el que se le ordenaba la eliminación de $51.281 \mathrm{~kg}$ de aceite que se consideraban nocivos para la salud por haber declarado el farmacéutico encargado de su análisis que contenía mezcla de un $9 \%$ de aceite algodonero y un $8 \%$ de adormidera, comenzando uno de los más duros enfrentamientos entre la Diputación Provincial y el Ayuntamiento de Palencia de la etapa de la Restauración.

\footnotetext{
${ }^{923}$ Cfr. GUTIÉRREZ RESA, Antonio (Edición.), Orígenes y desarrollo del trabajo social, op.cit., p. 116.

${ }^{924}$ A.D.P.P., L.A.C.P. 45, 9-VI-1876.

${ }^{925}$ En la sesión del Pleno del Ayuntamiento de Palencia de 3 de mayo de 1876, el Ayuntamiento acordó girar visita a los establecimientos donde se vendía el aceite de los Hermanos Ausín. A.M.A.P., L.A.P.A.,

A-21-097, 9-VI-1876.
} 
Los vocales de la Comisión Provincial, Joaquín Monedero y Demetrio Betegón propusieron que se revocase el acuerdo del Ayuntamiento fundándose en las informalidades del expediente ${ }^{926}$ y la vaguedad de la declaración del perito encargado del análisis, debiendo quedar a libre disposición del reclamante las existencias del aceite intervenido, ya que una vez hecho otro análisis por dos farmacéuticos, uno nombrado por el Ayuntamiento y otro por el interesado, resultó ser de oliva puro y útil para el consumo. El vocal Antonio Reyero disentía de sus compañeros, alegando que los aceites de la Casa de Ausín Hermanos, habían resultado nocivos e impuros, tanto en el análisis practicado por orden del Ayuntamiento como anteriormente cuando el gobernador de la provincia ordenó su reconocimiento recogiendo muestras de los almacenes de varios comerciantes y de los vagones que se hallaban en la estación del Ferrocarril del Norte procedentes de Miranda de Ebro, y consignados a nombre de Ausín Hermanos. Tras la votación en la sesión de la Comisión Provincial del día 9 de junio de 1876, se produjo un empate entre los partidarios de la revocación del acuerdo del Ayuntamiento y los que se mostraban contrarios a esa resolución. En la sesión de la Comisión Provincial del día 14 de junio de 1876, tras analizar la exposición de los hechos por parte de cada una de las partes implicadas, la Comisión Provincial resolvió por mayoría revocar el acuerdo del Ayuntamiento de Palencia ${ }^{927}$ y dejar a libre disposición de Ausín Hermanos el aceite intervenido $^{928}$. En la sesión de la Comisión Provincial del 13 de agosto de 1876, el vicepresidente daba cuenta de una exposición publicada en el $B O P$ que suscribían los concejales del Ayuntamiento de Palencia y en la que presentaban Recurso de Alzada ante el ministro de la Gobernación por el acuerdo de la Comisión Provincial de 14 de junio de 1876 en virtud del cual se revocó otro del Ayuntamiento relativo a la extracción de aceites existentes en los almacenes de los señores Ausín Hermanos. El vicepresidente llamaba la atención sobre la acritud del estilo y formas destempladas del escrito ${ }^{929}$.

\footnotetext{
${ }^{926}$ Hermanos Ausín había declarado que la botella de aceite analizada no estaba lacrada y además no era de su propiedad.

${ }^{927}$ El Ayuntamiento de Palencia no reconocía competencia a la Diputación Provincial para suspender un acuerdo del Pleno Municipal en uso de sus atribuciones, puesto que el Consistorio Municipal era competente en todo lo que se refería a la higiene y salubridad del municipio, según el art. 67 de la Ley Municipal. A.M.A.P., L.A.P.A., A-21-097, 9-VI-1876.

${ }_{928}$ A.D.P.P., L.A.C.P. 45, 14-VI-1876.

${ }^{929}$ A.D.P.P., L.A.C.P. $45,13-$ VIII- 1876.
} 
El enfrentamiento con el Ayuntamiento era un hecho y llegó a tal extremo que el propio gobernador de la provincia indicó al presidente de la Diputación Provincial la conveniencia de zanjar definitivamente las diferencias surgidas entre la Corporación Municipal y la Comisión Provincial de la Diputación por este asunto, y sugería llegar a un acuerdo amistoso que terminase con la tirantez que existía entre ambas corporaciones ${ }^{930}$.

En la etapa analizada, entre 1875 y 1931, la Diputación Provincial tuvo que enfrentar dos de las epidemias más mortíferas de finales del siglo XIX y principios del XX, la epidemia de cólera de 1885, y la tristemente famosa gripe española de 1918. Todo un reto para una administración corta de presupuestos, y con pocos medios humanos y materiales para afrontar contingencias sanitarias del calibre de las citadas, que además no fueron las únicas epidemias declaras en este periodo. Desde 1876, cuando se adquirieron y distribuyeron en los pueblos de la provincia linfovacuna para prevenir los desastrosos efectos de la epidemia variolosa (viruela) que con carácter alarmante se estaba desarrollado en alguno de ellos ${ }^{931}$, hasta 1931, se sucedieron con cierta regularidad brotes de enfermedades tan virulentas con la tuberculosis, el sarampión, la viruela, la varicela o la rabia, por citar solo algunos de los casos que más fallecimientos produjeron, especialmente entre la población acogida en los distintas dependencias benéficas provinciales. En 1912, varios ayuntamientos solicitan la linfovacuna a la Diputación Provincial para vacunar y revacunar a los pobres que disfrutaban de la asistencia médicofarmacéutica gratuita ${ }^{932}$, y a tal efecto se adquirieron a cargo del presupuesto provincial cien tubos del Instituto Vacurógeno de Félix Fluck de Lausanne (Suiza) ${ }^{933}$.

\footnotetext{
${ }^{930}$ A.D.P.P., L.A.C.P. $46,4-\mathrm{I}-1877$.

${ }^{931}$ A.D.P.P., L.A.P.D. 42, 28-IV-1876.

${ }^{932} \mathrm{El}$ art. 3 del Reglamento del 14 de junio de 1891 calificaba como pobres, a efectos de la beneficencia médico-farmacéutica, a los que viviesen de un jornal o salario eventual, excluyendo el caso de los tuviesen hijos jornaleros con salario constante que les permitiese hacer frente a las necesidades propias así, como a las de sus ascendentes.

${ }^{933}$ A.D.P.P. L.A.C.P. $116,25-V-1912$.
} 
En 1926, la Diputación Provincial ya se proveía de las vacunas en el mercado nacional, y lo hacía con especial atención a la seguridad sanitaria de este material. Así se ponía de manifiesto, cuando el ponente de Sanidad, el diputado provincial Martín Escobar, respecto de la petición hecha por el director del Instituto de Vacunación y Laboratorio de Higiene Selma de Zaragoza, para que se adquieran vacunas de su laboratorio, estimaba que no siendo las garantías de este laboratorio inferiores a las del Alfonso XIII, al ser este de carácter nacional, la Diputación debía proveerse de vacunas del Instituto Nacional de Alfonso XIII ${ }^{934}$.

A finales del siglo XIX, la tuberculosis causaba estragos entre la población, era una enfermedad para la que no se conocía cura, y tan solo se dispensaban remedios paliativos para los enfermos. La Diputación Provincial carecía de Sanatorio Antituberculoso, pero organizaba colonias de niños enfermos que hubiese en sus establecimientos benéficos para llevarles a sanatorios marítimos o de montaña, oficiales o particulares, abonando los viajes los gastos de sus viajes y estancias. En 1914, el secretario de la Junta Provincial antituberculosa, solicitaba a la Corporación Provincial que se concediera una cantidad de dinero para sufragar los gastos que ocasionaba el viaje de los niños pobres tuberculosos al Sanatorio de Pedrosa (Santander), también la estancia y equipo. Se concedió una pequeña cantidad, 128 pts., pues la consignación de Imprevistos está casi agotada ${ }^{935}$.

Cuando finalizaba 1884 un rumor recorría la geografía nacional, varios casos de cólera había aparecido en España. Ante esta preocupante situación, la Comisión Provincial celebró una sesión extraordinaria para tratar de los recursos y medidas a adoptar para hacer frente a la epidemia en caso de que llegase a afectar a la provincia ${ }^{936}$. Se acordó librar 36.500 pts. del Presupuesto Provincial para atender las medidas preventivas que la Junta Provincial de Sanidad ${ }^{937}$ propusiera para evitar «la invasión del cólera». También se decidió adquirir 250 ejemplares de la obra titulada El cólera morbo asiático, del médico del médico municipal de Carrión de los Condes, Lope Valcárcel Vocegas para remitirlos a los alcaldes de la provincia.

\footnotetext{
${ }^{934}$ A.D.P.P., L.A.C.P. $142,21-V-1926$.

${ }^{935}$ A.D.P.P., L.A.C.P. $118,1-V-1914$.

${ }^{936}$ A.D.P.P., L.A.C.P. 56, 11-IX-1884.

${ }^{937}$ En cada capital de provincia había una Junta Provincial de Sanidad, cuyos principales cometidos eran la vigilancia, consulta y complemento de los asuntos asignados a la sanidad municipal y el asesoramiento a las diputaciones provinciales en materia de sanidad.
} 
El diputado provincial Joaquín Monedero y Monedero apuntaba que el Presupuesto de los Establecimientos de Beneficencia era tan deficiente, que si el cólera se presentase no habría medio para combatirlo, y solo se podrían adoptar medidas de precaución ${ }^{938}$. El relato cronológico de como respondió la Diputación Provincial de Palencia a la epidemia de cólera, es la narración de la adopción consecutiva de medidas que intentaban paliar primero, la incidencia de la enfermedad y luego el efecto de esta sobre la vida provincial. En 1885, con la epidemia ya declarada, y agotado el crédito de Calamidades, la Comisión Provincial destinó 2.500 pts. para atender las medidas preventivas contra la enfermedad, cantidad claramente insuficiente para responder a las primeras necesidades que se dejaban sentir en los pueblos afectados por la epidemia ${ }^{939}$. También se concedió crédito para adquirir los instrumentos necesarios con el objeto de montar un laboratorio en la Casa de Expósitos y Hospicio, (Casa de Maternidad) donde los médicos de este establecimiento pudieran analizar el agua ${ }^{940}$.El gobernador de la provincia narraba así la secuencia cronológica de la epidemia desde su inicio:

«El primer pueblo invadido fue el de Calabazanos cuyas condiciones de salubridad dejaban bastante que desear. Allí fuimos enseguida con desinfectantes, pulverizadores y demás medios que la ciencia tiene establecidos. (...) Después de Calabazanos se presenta la epidemia con gran fuerza en Cubillas, el médico de este distrito se encontraba rendido de cansancio y solicitaba que fuese un compañero a ayudarle; las autoridades locales se vieron invadidas, (...) Atacados Cubillas y Calabazanos, pronto se vio invadido Dueñas, donde los médicos, los farmacéuticos, el capitán de la Guardia Civil, que falleció de la epidemia y las autoridades locales, lo mismo que el Ilmo. Prelado, todos rivalizaron en celo y abnegación. (...) Se ven más tarde invadidos Revilla y Pedraza, (...) En Pedraza el facultativo, el párroco y el alcalde D. Secundino Quevedo, estuvieron a la altura de su misión y de las circunstancias, como tuve ocasión de ver personalmente. (...) Invadido Ampudia y enfermo uno de sus facultativos y el cura, el médico titular de Torremormojón no dudo un solo momento en ofrecer sus servicios y en personarse en el distrito indicado para ayudar a otro compañero que por sí solo no podía atender a todos los atacados que pasaban de 110. (...) Por más que la asistencia de los médicos de Ampudia y Torremormojón nada dejaba que desear y hacían esfuerzos inauditos para atajar el mal, este aumentaba rápidamente, viéndome con este motivo obligado a publicar una circular en la que se creaban dos plazas de médicos de Beneficencia que nadie quiso aceptar. (...) El último pueblo atacado que visitamos fue el de Boadilla de Rioseco.»» ${ }^{941}$

\footnotetext{
${ }^{938}$ Cuando se manifestaba en los Establecimientos de Beneficencia alguna enfermedad contagiosa y el médico lo indicaba, se quemaban las ropas, vestidos y efectos de cama usados por las personas que padecían la enfermedad. La ropa de enfermos no contagiosos se lavaba antes de dársela a otro asilado.

${ }^{939}$ A.D.P.P., L.A.C.P. 61, 1-VIII-1885.

${ }^{940}$ A.D.P.P., L.A.C.P. 61, 5-IX-1885.

${ }^{941}$ A.D.P.P., L.A.P.D. 57, 9-XI-1885.
} 
El gobernador se felicitaba por el hecho de que el cólera no hubiese causado bajas en ninguno de los miembros de la Corporación Provincial, como desgraciadamente había sucedido en otras partes ${ }^{942}$. El cólera, o para ser más precisos, la forma de abordar la epidemia, causó duros enfrentamientos entre los miembros de la Asamblea Provincial. En sesión del Pleno de la Diputación Provincial de noviembre de 1885, el diputado provincial Guzmán Rodríguez insinuaba que su compañero Joaquín Monedero y Monedero había abandonado sus responsabilidades por miedo a contraer la enfermedad, este justificaba su ausencia durante tres meses de Palencia y de la Dirección de los asilos de Beneficencia en el momento en que el cólera se había presentado en la capital, por la enfermedad de un tío octogenario de su esposa, sacerdote, residente en Cevico de la Torre, donde también había habido cólera ${ }^{943}$. Guzmán Rodríguez afirmaba que tanto el diputado provincial Nieto Mozo, como Joaquín Monedero habían cumplido en sus distritos visitando enfermos de cólera, buscando enterradores y ofreciendo sus fortunas, pero no habían estado a la altura de las circunstancias como vocal de la Comisión Provincial y director de los Establecimientos de Beneficencia respectivamente. En su opinión, mientras el gobernador «con verdadera exposición de su vida iba de pueblo en pueblo, la Comisión Provincial se quedaba en casa, y en cambio acompañaban al Sr. Collantes ${ }^{944}$ los que ninguna obligación tenían de hacerlo.» ${ }^{945}$

Debe tenerse en cuenta que la enfermedad, dado su carácter contagioso, había tenido una especial incidencia en las dependencias benéficas, lugares que alojaban un número de asilados mayor para el que estaban adaptadas y a la altura de 1885 presentaban unas condiciones higiénico sanitarias muy deficientes, hasta el punto de que se llegó a un acuerdo con el Ayuntamiento de Palencia para que los afectados por el cólera en las Casas de Beneficencia ingresasen en el hospital instalado por este en la estación del ferrocarril del Norte ${ }^{946}$. Ante esta situación, no es de extrañar que los propios compañeros de Joaquín Monedero, director de los Establecimientos de la Beneficencia, criticasen su ausencia en momento tan crítico. El brote de cólera en 1885 fue el último de esta enfermedad que tuvo carácter epidémico en España.

\footnotetext{
${ }^{942}$ A.D.P.P., L.A.P.D. 57, 4-XI-1885.

${ }^{943}$ A.D.P.P., L.A.P.D. 57, 5-XI-1885.

${ }^{944}$ Fernando Mateos Collantes, Gobernador civil de la provincia.

${ }^{945}$ Comandante de la Guardia Civil, Manuel Carpintero, médico de Beneficencia provincial y subdelegado del Partido de Palencia, Ambrosio Arroyo de la Hera.

${ }^{946}$ A.D.P.P., L.A.P.D. 57, 6-XI-1885.
} 
En 1890, otra pandemia parecía amenazar a la población, la peste bubónica, que después de causar estragos en Europa durante la Edad Media y la Edad Moderna, había dejado de presentarse en forma de brotes catastróficos desde el siglo XVII. Ante los rumores de la posible llegada de esta enfermedad a España, la Diputación Provincial al igual que había sucedido con el cólera, arbitraba las primeras medidas en el plano de la información, más que de la prevención. La institución provincial autorizó una tirada de 500 ejemplares del folleto remitido por la Dirección de Sanidad exponiendo las prevenciones facultativas de higiene para preservarse de la peste bubónica en caso de que llegará a invadir la provincia ${ }^{947}$.

La falta de medios técnicos había sido causa directa de muchas muertes causadas por el cólera, y este hecho dejo un recuerdo indeleble en aquellos que tenían la responsabilidad de disponer las medidas necesarias para evitar la propagación de enfermedades contagiosas. En 1910, un cuarto de siglo después del episodio epidémico de cólera de 1885, a petición de la Junta Provincial de Sanidad, la Diputación Provincial accedía a adquirir pabellones desmontables sistema Docher, para que pudiesen servir de hospitales provisionales para prestar atención a los individuos que se vieran atacados por el cólera o cualquier otra epidemia contagiosa en el primer momento, y como lugar de aislamiento y observación de personas sospechosas de padecer este tipo de enfermedades $^{948}$. En 1912, el gobernador provincial advertía a la Diputación Provincial de que en caso de epidemia de cólera esta carecía de un parque sanitario de estufas de desinfección para poder trasladarlas a los ayuntamientos que no pudieran adquirirlas por falta de recursos. El Ayuntamiento de la capital ya contaba con esos medios, el presidente de la Diputación Provincial prometía al gobernador resolver esta carencia ${ }^{949}$. Todo ello es una muestra clara de que la falta de recursos económicos impedía a la Corporación Provincial cumplir de forma eficaz con las atenciones que tenía atribuidas en materia sanitaria.

\footnotetext{
${ }^{947}$ A.D.P.P., L.A.C.P. 91, 18-IX-1899.

${ }^{948}$ A.D.P.P., L.A.C.P. 114, 5-IX-1910.

${ }^{949}$ A.D.P.P., L.A.P.D. 112, 3-V-1912.
} 
La hidrofobia o rabia, fue otra de las enfermedades a las que tuvo que destinar un buen número de recursos la Diputación Provincial, dada la alta prevalencia de este padecimiento en el ámbito rural por la ausencia de la vacunación preventiva de los perros de los pueblos de la provincia. El tratamiento de la rabia tenía su centro de referencia en España en el Laboratorio Microbiológico del Dr. Ferrán, en Barcelona, y en numerosas ocasiones se libraron cantidades del Presupuesto Provincial para el tratamiento de varios casos de hidrofobia la provincia ${ }^{950}$.

En 1918, surgió una de las pandemias más mortíferas ${ }^{951}$ que ha conocido la humanidad, la denominada gripe española. En octubre de 1918, el Ministerio de la Gobernación advertía a la Diputación Provincial del peligro de contagio de la gripe que suponía el tránsito de viajeros portugueses provenientes de Francia por la provincia ${ }^{952}$. Un mes más tarde, ya se declaraban varios fallecimientos en el Manicomio Provincial a causa de la gripe. No solo se vieron afectados los Establecimientos de Beneficencia, siempre vulnerables a este tipo de enfermedades por sus deficientes condiciones sanitarias, los libros de registro de las dependencias benéficas registraban un gran número de ingresos de niños huérfanos en la Casa de Maternidad a causa de la epidemia de gripe. La situación en algunos pueblos de la provincia era de tal gravedad que, como en el caso de Torquemada $^{953}$, donde fueron enviados los médicos por la Diputación para asistir a los enfermos atacados por la gripe, se requirió la ayuda de los alumnos de Medicina para atender a los enfermos. En el Presupuesto de 1919 se destinó una partida presupuestaria para gratificar a estos alumnos por sus servicios en la epidemia ${ }^{954}$.

\footnotetext{
${ }^{950}$ A.D.P.P., C-R/ 1,11(A). Al frente del Instituto de Higiene de Barcelona, el Dr. Ferrán desarrolló un método supraintensivo de vacunación antirrábica.

${ }^{951}$ Según las estimaciones acabó con la vida de unos 50 millones de personas en un solo año, cinco veces más que la Primera Guerra Mundial. El primer caso conocido apareció en un campamento militar en Kansas, Estados Unidos, en marzo de 1918. En el verano de 1918 el virus causante de la enfermedad sufrió una mutación que lo convirtió en uno de los agentes infecciosos más letales de la historia de la Humanidad. El primer caso de esta mortal mutación parece que se produjo el 22 de agosto en Brest, el puerto francés por el que entraban la mitad de las tropas norteamericanas que se incorporaban al conflicto que asolaba a Europa.

${ }^{952}$ A.D.P.P., L.A.C.P.P. 126, 1-X-1918. Tren con inmigrantes portugueses en la estación de ferrocarril del Norte, se detuvo en la noche del 1 de octubre de 1918 en Palencia.

${ }^{953}$ A.D.P.P., L.A.C.P.P. 126, 8-XI-1918. Se acordó que la Diputación Provincial se dirigiese a los médicos de la Beneficencia Provincial para que visitasen a los enfermos de Torquemada, donde había 600 afectados por la gripe. «En estas casos es cuando la Asamblea puede hacer un bien a los pueblos, dirigiéndose al Ministerio y al Gobierno de provincia, con objeto de que faciliten los medios de desinfección y los recursos necesarios.». Recordaba el diputado provincial Vázquez de Prada que en el año 1885 los médicos de la Beneficencia habían visitado los pueblos afectados por el cólera.

${ }^{954}$ A.D.P.P., C-L/ 11,3.
} 
En la capital la situación también era preocupante, el Gobierno Militar solicitó a la Diputación Provincial otro local, ya había cedido la Escuela Militar sita en el Instituto Viejo, para atender a los enfermos de gripe, pero esta no tenía más locales aparte de los destinados a Beneficencia, Manicomio, Estación Enológica y Cárcel de Audiencia ${ }^{955}$. Cuando la epidemia cedió, una vez más quedó en evidencia la falta de recursos de la Diputación Provincial para hacer frente a contingencias de carácter sanitario de la gravedad de la gripe de 1918.

El Estatuto Provincial de 1925 y los diferentes reglamentos ${ }^{956}$ que desarrollaban su articulado, introdujeron reformas sensibles respecto de las atribuciones de las diputaciones provinciales en materia de Sanidad. Entre otras cuestiones, se señalaba la obligatoriedad de crear un Instituto de Higiene, sostenido por las corporaciones provinciales, y así la Diputación palentina acordaba dotar en el Presupuesto de 1925/26 una partida presupuestaria para dar cumplimiento al apartado C del art. 128 del Estatuto Provincial de $1925^{957}$. Los servicios que prestaba el Instituto de Higiene ${ }^{958}$ provincial creado por acuerdo de 3 de julio de 1925 eran:

1. Suministro de sueros y vacunas a todos los pueblos de la provincia que lo solicitasen.

2. Análisis de laboratorio sobre productos patológicos, algunos alimentos, medicamentos y bebidas.

3. Servicios de desinsectación y desinfección en los pueblos en que fuese preciso.

4. Transporte de enfermos infecciosos y urgentes desde los pueblos hasta el Hospital de San Bernabé y San Antolín.

\footnotetext{
${ }^{955}$ A.D.P.P. L.A.C.P.P. 126, 8-XI-1918.

${ }^{956}$ El art. 3 del Reglamento de Sanidad Provincial, aprobado por Real Decreto de 20 de octubre de 1925 , contemplaba la existencia en todas las provincias de una Inspección Provincial de Sanidad, que dependía de la Dirección general de Sanidad, organismo perteneciente al Ministerio de Gobernación. La Inspección Provincial representaba al Estado en los asuntos técnicos concernientes a la higiene y salubridad en las provincias. Al frente de cada una de esas inspecciones se encontraba un inspector provincial de Sanidad, al que correspondía asesorar, informar y cumplir las órdenes y los acuerdos del Gobierno respecto de los servicios de Sanidad e Higiene, régimen interior de los institutos, establecimientos, funcionarios y facultativos adscritos a dichos servicios.

${ }^{957}$ A.D.P.P., L.A.C.P. 141, 3-VI-1925. Los arts. 128.129 y 130 del Estatuto Provincial de 1925 establecían que las Brigadas Sanitarias y los Laboratorios Provinciales refundieran sus servicios en los Institutos de Higiene.

${ }^{958}$ Constaba de tres secciones: Epidemiología y desinfección, Análisis (clínicos, higiénicos y químicos) y Vacunaciones. El régimen administrativo de los Institutos de Higiene estaba a cargo de las diputaciones provinciales. Su dirección técnica correspondía a los inspectores provinciales de Sanidad. Las diputaciones provinciales podían conceder intervención en el régimen administrativo de los Institutos de Higiene a los ayuntamientos de la provincia por medio de los alcaldes o concejales que designasen para tal caso.
} 
Los servicios prestados por el Instituto a individuos no pobres habían de ser abonados, y se solicitaban los servicios al presidente de la Diputación Provincial por comunicación o por telegrama en casos de urgencia. Los servicios de transporte que no fuesen urgentes y casos de infecciosos que no pudiesen ser tratados en los pueblos, serían costeados por quienes reclamasen el servicio, y por aquellos que no fuesen pobres. Para el sostenimiento $^{959}$ de la Brigada Sanitaria del Instituto de Higiene se estableció un Repartimiento entre los pueblos de la provincia ${ }^{960}, 34.828$ pts. en el año 1925. El problema de la cesión de nuevas facultades por parte del Estado era que no se acompañaban también de la cesión de los medios económicos a las instituciones locales para su adecuado funcionamiento. El caso del Instituto de Higiene no fue una excepción, y ya en 1926 la Diputación Provincial se veía obligada a rechazar la oferta de una empresa para adquirir aparatos de rayos $\mathrm{X}$, en tanto no organizase su sección de electroterapia, y prefería celebrar de momento un concierto con algún centro para ofrecer estos servicios, dado el alto coste que suponía contar con personal técnico especializado para ese tipo de instalaciones que no tenía el instituto ${ }^{961}$. No obstante no era ese el mayor problema de la Diputación Provincial, pues ese año aun no contaba con un edificio donde poder instalar el Instituto, y tampoco el Estado le facilitaba la cesión de algún inmueble que pudiese cumplir esa función. Así, ante la petición al Gobierno para que cediese el edificio de la Estación Enológica, el ingeniero de la División Agronómica de experimentaciones, dependiente del Estado, rechazaba esa posibilidad ${ }^{962}$.

\footnotetext{
${ }^{959} \mathrm{La}$ Comisión designada por la Diputación para entender en el régimen administrativo del Instituto Provincial de Higiene, formulaba anualmente el presupuesto de dicho Centro, asesorada por el director técnico. La aprobación del presupuesto correspondía a la Diputación Provincial.

${ }^{960}$ Art. 130 del Estatuto Provincial.

${ }^{961}$ A.D.P.P., L.A.C.P. 142, 18-V-1926. El art. 39 del Reglamento de Sanidad provincial de 1926, disponía que siendo los rayos X un elemento indispensable para el diagnóstico y tratamiento del cáncer, la Diputación Provincia tenía que contar con una instalación de rayos $\mathrm{X}$ adecuada y completa, que no solo serviría para atender a los enfermos hospitalizados, sino también para los pacientes que acudían a los dispensarios antituberculosos y anticancerosos.

${ }^{962}$ A.D.P.P., L.A.C.P. $126,9-X-1926$.
} 
Una vez más, y la cuestión como se ha demostrado venía de lejos, el Estado imponía a las diputaciones provinciales el mantenimiento de unos servicios sobre los que en el Gobierno central ejercía el control administrativo, contraviniendo el principio ya mencionado por la Diputación palentina, de que quien paga administra. En 1927, los presidentes de las diputaciones provinciales de Logroño y Segovia exponían su opinión sobre el Real Decreto de 4 de enero de $1927^{963}$, por el que se restringían las atribuciones de las diputaciones en el régimen de los Institutos Provinciales de Higiene, limitándolas a la aprobación de cuentas y consignación de cantidades en sus presupuestos, que debían ser ratificadas por el inspector provincial de Sanidad. La Diputación Provincial de Palencia ${ }^{964}$ mostraba su conformidad sobre la necesidad de que las atribuciones de las diputaciones en esta materia se ajustasen a lo que determinaba el art. 128 del Estatuto Provincial de 1925, desentendiéndose en caso contrario las diputaciones de las funciones sanitarias, utilizando la facultad que concedía la Disposición Segunda Transitoria del citado Real Decreto. La respuesta del Gobierno llegó en forma de Real Orden de 8 de marzo de 1927 del Ministerio de Gobernación, por la que se relevaba a las diputaciones provinciales de las obligaciones de organizar y sostener el Instituto de Higiene provincial ${ }^{965}$. Las disputas a cuenta de las competencias respectivas de la Administración Central y Local continuaron casi hasta el final de periodo analizado y en 1930, el inspector provincial de Sanidad solicitaba a la Diputación Provincial que se asignase a la oficina de Inspección provincial de Sanidad un oficial y un ordenanza. La Corporación Provincial admitía que había dado orden para la incorporación a la Sección de Vías y Obras del oficial que estaba adscrito a Inspección de Sanidad, pero señalaba que no estaba en su ánimo evitar el cumplimiento de la Real Orden del Ministerio de Gobernación de 10 de enero de 1927, en su Disposición Octava, que regulaba el funcionamiento de estas oficinas, y advertía de que el traslado era de forma breve y carácter temporal. Respecto a los ordenanzas, la Diputación Provincial solo contaba con dos, y aconsejaba al inspector provincial de Sanidad que fuese un asilado quien prestase este servicio ${ }^{966}$.

\footnotetext{
${ }^{963}$ Gaceta de Madrid del 6 de enero de 1927.

${ }^{964}$ A.D.P.P., L.A.C.P. 143, 28-I-1927.

${ }^{965}$ A.D.P.P., L.A.C.P. 142, 14-III-1927.

${ }^{966}$ A.D.P.P. L.A.C.P. 146, 11-I-1930.
} 
Durante la etapa de la Dictadura de Primo de Rivera, también se quiso regular la atención a los afectados por la tuberculosis y las enfermedades venéreas. La Real Orden de 2 de septiembre de 1926 regulaba las obligaciones de las diputaciones provinciales con respecto a hospitalizaciones de tuberculosos. Se proponía al Patronato del Hospital de San Bernabé y San Antolín ampliar el número de camas dedicadas a enfermos tuberculosos y crear un Dispensario Antituberculoso, subvencionando en parte la Diputación Provincial las obras de esta dependencia ${ }^{967}$. En relación a las enfermedades venéreas, puesto que el Hospital de San Bernabé y San Antolín no admitía el ingreso de prostitutas, hasta que se encontrase una solución, estas serían admitidas en el establecimiento para esta clase de enfermos en Valladolid ${ }^{968}$. Al mismo tiempo se solicitaba al Ayuntamiento de Palencia la cesión a título gratuito del solar que este poseía en la avenida Casado del Alisal, entre las calles Valentín Calderón y José Canalejas, para la construcción de un Dispensario Antituberculoso y Antivenéreo ${ }^{969}$. En febrero de 1929 se iniciaron las obras del Dispensario Antituberculoso y en enero de 1930 se realizó la recepción provisional de las instalaciones del mismo. La recepción definitiva de las obras se produjo en noviembre de 1930 y el coste total de las obras ascendió a $294.388,17$ pts. $^{970}$.

\footnotetext{
${ }^{967}$ A.D.P.P., L.A.C.P. 143, 15-VII-1927.

${ }^{968}$ A.D.P.P., L.A.C.P. $143,15-$ VII- 1927.

${ }^{969}$ A.D.P.P., L.A.C.P. 142, 11-XI-1927. El Reglamento de Sanidad provincial, en su art. 45 señalaba la obligación de las diputaciones provinciales de establecer consultorios gratuitos de enfermedades generales y especialmente, para pretuberculosos y tuberculosos pobres, y enfermos de afecciones venéro-sifilíticas.

${ }^{970}$ A.D.P.P., L.A.C.P. 147, 1-I-1931.
} 


\section{Instrucción Pública ${ }^{971}$}

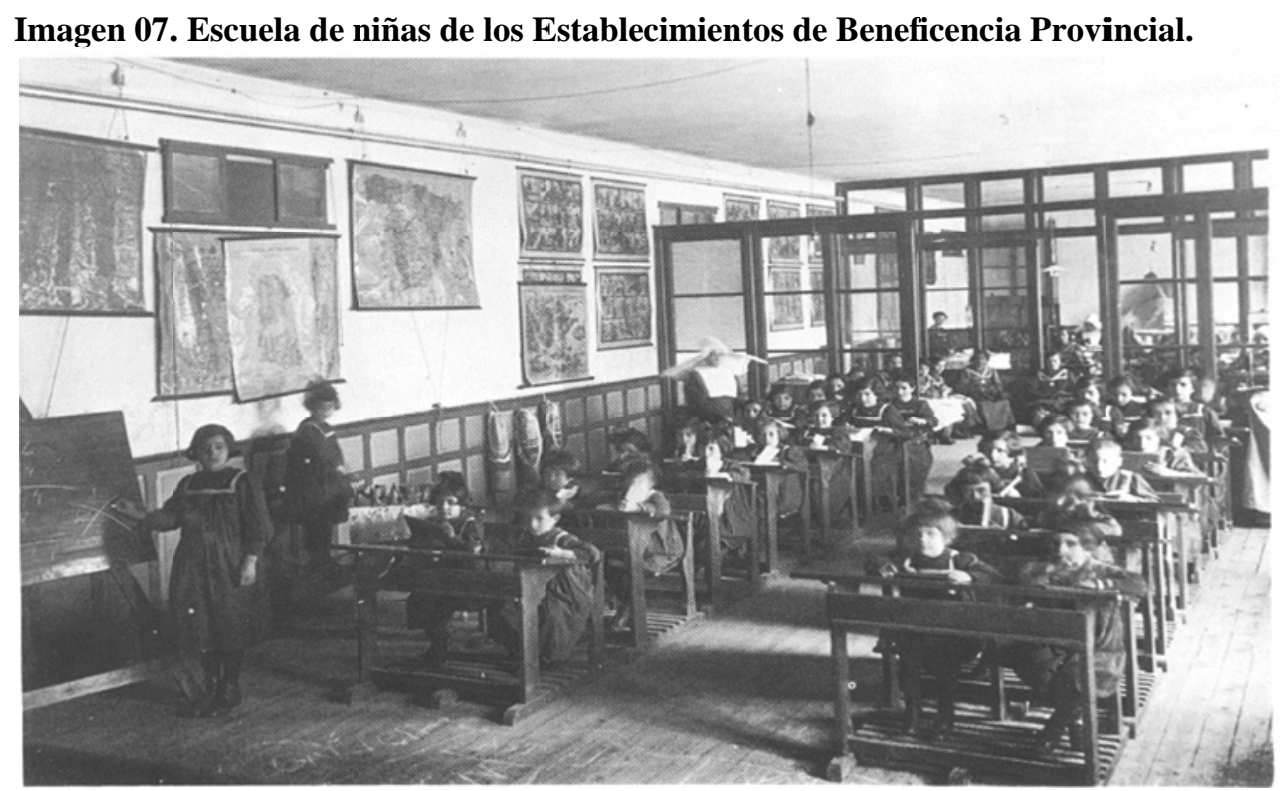

Fuente: A.D.P.P. (Archivo fotográfico).

\section{Introducción}

La génesis del sistema educativo español se efectuó en España mediante procesos semejantes a otros países europeos, pero la configuración definitiva se retrasó un par de décadas a causa de la oposición del monarca Fernando VII al régimen constitucional. El modelo educativo liberal se fundamentaba sobre tres pilares básicos: secularidad, gratuidad y libertad. Se concebía la educación como un derecho de todos los ciudadanos, de carácter gratuito, basado en el mérito y no en la capacidad económica, con libertad de enseñanza y ajena a la influencia de la Iglesia. El sistema educativo español quedó configurado en el periodo que abarca desde las Cortes de Cádiz hasta la promulgación de la primera Ley de Instrucción Pública ${ }^{972}$.

\footnotetext{
${ }^{971}$ En este periodo la educación se denominaba Instrucción Pública, no utilizándose el término educación, por lo que se ha decidido titular este epígrafe con la denominación propia de la época. En la actualidad, el concepto de educación engloba un sentido mucho más amplio que el de instrucción, que solo comprendía aspectos intelectuales de la persona, la instrucción es entendida hoy en día solo como una parte de la educación.

${ }^{972}$ Aprobada el 9 de septiembre de 1857, conocida como la «Ley Moyano», por ser Claudio Moyano el ministro que la propuso y defendió.
} 
La Ley Moyano contemplaba todos los niveles de enseñanza, con un enfoque típico del moderantismo ${ }^{973}$, reconocía los derechos y privilegios que a la Iglesia se le habían concedido por el Concordato de 1851. Aunque el Estado controlaba todas las etapas de la enseñanza, la financiación de la Enseñanza Primaria correría a cargo de los municipios y de la Secundaria se ocuparían las autoridades provinciales. Desde 1850 hasta 1970 no hubo en España otra Ley General de Instrucción Pública, por lo tanto permaneció vigente más de un siglo. De la importancia que el liberalismo concedía a la educación da buena muestra la Memoria del Primer Semestre del Año Económico ${ }^{974}$ 1883/84 de la Comisión Provincial de la Diputación palentina: «Ella sola aleja los crímenes, infunde el respeto a la propiedad, garantiza los derechos de todos, afianza el cumplimiento de los deberes de cada uno e imprime la regularidad y el orden en la sociedad.» ${ }^{975}$. No puede hacerse un mejor resumen de los principios del liberalismo español: propiedad, orden, y ciudadanos útiles para la sociedad. A causa de los avatares políticos de la España decimonónica, varios fueron los intentos de implantar una educación basada en los principios mencionados, el Reglamento General de Instrucción Pública de 1821 y el Plan General de Instrucción Pública de 4 de agosto de 1836, fueron ejemplos de este empeño reformista, pero no sería hasta 1838 cuando se promulgase una legislación que verdaderamente articulase el sistema educativo, la Ley de Instrucción Primaria de 21 de julio de $1838^{976}$. Para el liberalismo el fin último de la Instrucción Pública era formar ciudadanos útiles para la sociedad, y así se comprende que la Educación Secundaria estuviese dirigida a los hijos de la burguesía ${ }^{977}$, puesto que se consideraba que a ellos les sería necesario tener una adecuada formación para su futura función social. El principio liberal de una educación universal gratuita quedaba restringido a la Instrucción Primaria.

\footnotetext{
${ }^{973}$ Vid. VEGA GIL, Leoncio, (coordinación.), Moderantismo y Educación en España. Estudios en torno a la Ley Moyano, Zamora, Instituto Florián de Ocampo, 1995.

${ }^{974}$ Inicio segundo semestre año natural. Por Real Decreto de 23 de junio de 1926, se restableció el año natural para los servicios del Estado y prevenía la necesidad de que los ejercicios económicos de la Administración de la Hacienda Pública correspondieran con los de la provincial, debiendo las diputaciones acomodar sus ejercicios económicos con el expresado ejercicio anual a partir del año 1927 y para la ordenación de sus gastos y recursos durante el segundo semestre del año natural.

${ }^{975}$ A.D.P.P., C-R/ 1,12. p. 11.

${ }^{976}$ Solo fue posible llegar a un consenso por parte de las fuerzas políticas en lo relativo a la Educación Primaria, la Enseñanza Secundaria habría de esperar su regulación legislativa hasta la promulgación del Plan General de Estudios de 17 de septiembre de 1845.

${ }^{977} C f r$. GARCÍA COLMENARES, Pablo, MORENO LÁZARO, Javier, SÁNCHEZ GARCÍA, José Luis: Historia de Palencia. Siglos XIX-XX., El Norte de Castilla, Palencia, 1996. p. 325.
} 
En 1857 se promulgó la Ley de Instrucción Pública de 1857, la Ley Moyano, que compendiaba toda la legislación educativa anterior, unificando todos los niveles educativos. Esta Ley elevó a definitivas las regulaciones de la Segunda Enseñanza, encargó la financiación de los institutos a las provincias ${ }^{978}$, reconoció tres categorías de institutos, respaldó el sistema de oposiciones para alcanzar la condición de profesor y concedió la libertad de enseñanza para crear centros. Las dificultades financieras de las diputaciones provinciales y la dificultad para encontrar edificios para su instalación, fueron lastrando de forma sensible la instalación de nuevos centros en España. La Restauración no dio al país ninguna nueva ley general de educación, asumiendo la Ley Moyano de 1857 con algunas reformas de aspectos parciales de la misma, lo que no significa que la administración de la educación quedase anclada en las viejas estructuras del moderantismo. En 1900, con la creación del Ministerio de Instrucción Pública y Bellas Artes, se introdujeron reformas de inspiración regeneracionista. Durante la Restauración, afloraron de nuevo los conflictos entre los grupos neocatólico y liberal, que se enfrentaban a la hora de interpretar la libertad de enseñanza ${ }^{979}$. Entre las principales novedades de esta etapa cabe considerar las siguientes:

1. Creación de los primeros organismos modernos de la burocracia pública encargados de gestionar el sistema nacional de educación ${ }^{980}$.

2. Aprobación en 1923 del Estatuto del Magisterio, que definía la profesión docente en el marco de la función pública.

3. El impulso de determinadas reformas técnicas, como el Plan de Enseñanza Cíclica de 1901 y la Graduación Escolar, que ya venía implantándose desde 1898.

4. La prolongación de la escolaridad obligatoria, primero hasta los doce años, en 1901, y luego hasta los catorce, en 1923.

\footnotetext{
${ }^{978}$ Art. 119 de la Ley de 9 de septiembre de 1857 y Real Decreto de 7 de abril de 1858.

${ }^{979} \mathrm{Vid}$. TIANA FERRER, Alejandro, OSSENBACH SAUTER, Gabriela, SANZ FERNÁNDEZ, Florentino, (Coordinación.), Historia de la Educación, Madrid, UNED, 2002.

${ }^{980}$ En 1911 se crea la Dirección General de Enseñanza Primaria, en el seno del Ministerio de Instrucción Pública y Bellas Artes, creado en 1900.
} 
García Alix ${ }^{981}$, destacó por su actitud de defensa de la enseñanza oficial, algo inusual en un ministro conservador, y trató de renovar y desarrollar la enseñanza oficial dentro de la Constitución de 1876. Su política educativa se fijó dos objetivos: renovar todos los grados de la enseñanza y adecuar la legislación educativa para que se pudiesen lograr las aspiraciones regeneracionistas en esta materia. Las principales reformas se centraban en la Enseñanza Primaria, la instrucción de los obreros jóvenes, la atención a la enseñanza de adultos, la reforma de los estudios de las Escuelas Normales y la de la Enseñanza Secundaria y Universitaria. El alumnado de Segunda Enseñanza, procedente de la burguesía y las clases medias y oligárquicas de la sociedad restauracionista, se multiplicó casi por tres entre 1878 y $1932^{982}$, no obstante, esta etapa educativa solo alcanzaba en el siglo XIX en torno al 2\% o 3\% de la población, se trataba pues de un tipo de educación de élite ${ }^{983}$. El Real Decreto de 17 de agosto de $1901^{984}$ organizaba la Enseñanza Media y daba lugar a la aparición de los denominados Institutos generales y técnicos. Estos centros incluirían estudios de Institutos de Segunda Enseñanza y las enseñanzas técnicas del Magisterio (estudios elementales y superiores de Magisterio), estudios elementales de Agricultura, Industria, Comercio, Bellas Artes y Artes industriales ${ }^{985}$, y las enseñanzas nocturnas para obreros. Esta reforma pretendía crear «carreras cortas», de carácter técnico $\mathrm{y}$ artístico, pero la postura del profesorado hizo fracasar este plan ${ }^{986}$.

En la etapa de la dictadura de Primo de Rivera, hubo aspectos negativos y positivos en el ámbito educativo. Entre los primeros, destacar la reglamentación de la enseñanza privada como signo discriminatorio sobre la pública, la restricción de la libertad de cátedra, la vigilancia de los libros de texto y la designación de los directores de centro, no por el claustro de profesores sino por el Ministerio. En el lado positivo, la construcción de centros escolares de Enseñanza Primaria, la reforma del Bachillerato (Plan Callejo) ${ }^{987}$, y cierta reforma de la Universidad.

\footnotetext{
${ }^{981}$ Ministro de Instrucción Pública entre los años 1900-1901en el Gobierno Silvela.

${ }^{982} \mathrm{Cfr}$. TIANA FERRER, Alejandro, OSSENBACH SAUTER, Gabriela, SANZ FERNÁNDEZ, Florentino, (Coordinación, op. cit., p.245.

${ }^{983}$ Vid. PUELLES BENÍTEZ, Manuel, Educación e ideología en la España contemporánea, Madrid, Tecnos, 1999.

${ }^{984}$ Firmado por el Conde de Romanones, ministro de Instrucción Pública y Bellas Artes.

${ }^{985} \mathrm{El}$ art. 4 de la Ley de 24 de diciembre de 1876 disponía que las diputaciones provinciales y los ayuntamientos podían establecer en la forma que estimasen conveniente, salvando el derecho de inspección del Gobierno, enseñanzas populares de Bellas Artes, Agricultura, Industria y Comercio, incluyendo en sus presupuestos, con el carácter de gasto voluntario, las cantidades necesarias para su sostenimiento.

${ }_{986}^{9}$ id. NEGRÍN FAJARDO, Olegario, (Coordinación.), Historia de la Educación Española, Madrid, UNED, 2011.

${ }^{987}$ Contemplaba entre otras medidas la articulación curricular entre Instituto y Universidad, (Bachillerato universitario).
} 


\section{La Diputación Provincial de Palencia y la Instrucción Pública}

Palencia destacaba por sus altas tasas de alfabetización con respecto a la media nacional ${ }^{988}$. A mediados del siglo XIX, Palencia contaba con numerosos centros educativos de Enseñanza Primaria, casi uno por cada pueblo, un Seminario conciliar y un Instituto de Enseñanza Secundaria desde $1845^{989}$. Palencia pertenecía al Distrito universitario de Valladolid.

Respecto de la Segunda Enseñanza, la Diputación Provincial aprobaba el presupuesto del Instituto y debía sufragar tanto el material como el coste del personal que trabajaba en el centro docente ${ }^{990}$. A partir de la entrada en vigor de la Ley de Presupuestos de 29 de junio de 1890, el Estado cobraba a las diputaciones provinciales una cantidad igual a la que hasta esa fecha se destinaba para sufragar el coste del mantenimiento de los institutos, pagando el Estado el gasto del personal. La Diputación Provincial recaudaba e ingresaba en el Banco de España las asignaciones correspondientes a la Segunda Enseñanza $^{991}$, lo que conllevaba, muy a pesar de las instituciones provinciales, el mantenimiento de los institutos de Segunda Enseñanza. Esta atención suponía un gasto importante para las cuentas provinciales ${ }^{992}$, y hasta que el Estado asumió esta competencia, fue una fuente constante de disputa entre ambas administraciones. Por la Ley de Presupuestos de 29 de junio de 1890, el Estado seguía percibiendo las cantidades correspondientes a los derechos de matrícula, iniciándose un contencioso entre Estado y diputaciones provinciales que se prolongaría durante todo el periodo de la Restauración.

\footnotetext{
${ }^{988}$ El auxiliar de Secretaría de la Diputación Provincial, Ambrosio Gutiérrez Lázaro, autor de un trabajo sobre el analfabetismo en España, proponía en 1910 inscribir en un cuadro de honor los nombres de los diez pueblos de la provincia que según el censo electoral y estadística de reclutas carecían de analfabetos. A.D.P.P., L.A.C.P. 114, 17-VI-1910.

${ }^{989}$ Cfr. MÁDOZ IBÁÑ̃Z, Pascual, Diccionario Geográfico-Estadístico-Histórico de España y sus posesiones de ultramar, Tomo XII, Madrid., 1847, p. 539. Por Real Orden de 30 de octubre de 1845, se autorizaba la creación de un establecimiento de Segunda Enseñanza de segunda clase en la ciudad de Palencia. El segundo punto señalaba las fórmulas de mantenimiento de Instituto: aportaciones del alumnado, rentas procedentes de legados, memorias, obras pías y fundaciones y aportaciones de organismos oficiales. Dentro de esta última categoría, el Ayuntamiento financiaba al Instituto con una determinada cantidad y el posible déficit corría a cargo de los fondos provinciales.

${ }^{990}$ La Ley de Bases de 17 de julio de 1857 obligaba a las diputaciones provinciales a sostener a los institutos de Segunda Enseñanza en la parte correspondiente que no pudiese cubrirse con la renta propia de los centros. ${ }^{991}$ A.D.P.P., L.A.C.P. 70, 8-V-1891.

${ }^{992}$ En 1879, el sueldo de los catedráticos del Instituto Provincial de Segunda Enseñanza era de 3.000 pts. anuales. A.D.P.P., L.A.P.D. 49, 24-I-1879.
} 
En 1875 el director ${ }^{993}$ del Instituto de Segunda Enseñanza dirigía un escrito a la Diputación Provincial solicitando la creación de una cátedra de Agricultura ya que, en su opinión, sería útil para promover una agricultura más eficaz y productiva, poniendo de manifiesto el ruinoso estado de la actividad agrícola en la provincia. Se pedía una mayor dotación de recursos para la enseñanza de la agricultura, pero el Instituto era consciente de la precariedad presupuestaria de la Diputación y de momento se conformaba con la creación de la mencionada cátedra ${ }^{994}$. No era nada más que el inicio de una serie de reivindicaciones razonables para la mejora de la educación de la población en este nivel educativo, pero la Diputación Provincial no podía satisfacerlas por la falta de recursos presupuestarios. A pesar de ello, a lo largo de la Restauración, un 6\% del Presupuesto provincial se dedicó a las atenciones relacionadas con Instrucción Pública.

Figura 11. Porcentaje de gasto en pts. en Instrucción Pública sobre el total del Presupuesto Provincial de Gastos entre 1875-1931.

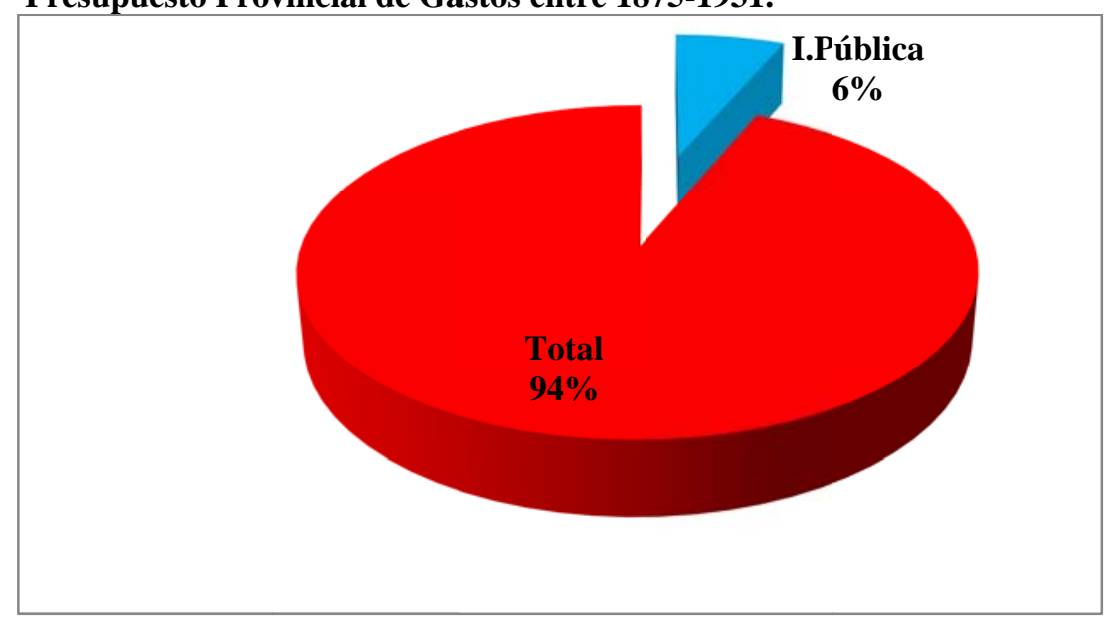

Elaboración propia. Fuente: A.D.P.P.

\footnotetext{
${ }^{993}$ El art. 161 del Reglamento de Segunda Enseñanza de 15 de julio de 1867 establecía un sueldo de 500 pts. anuales para el director del Instituto de Segunda Enseñanza.

${ }^{994}$ A.D.P.P., C-L/ 4,1.
} 
Figura 12. Gasto anual en pts. en Instrucción Pública entre los años 1875-1931.

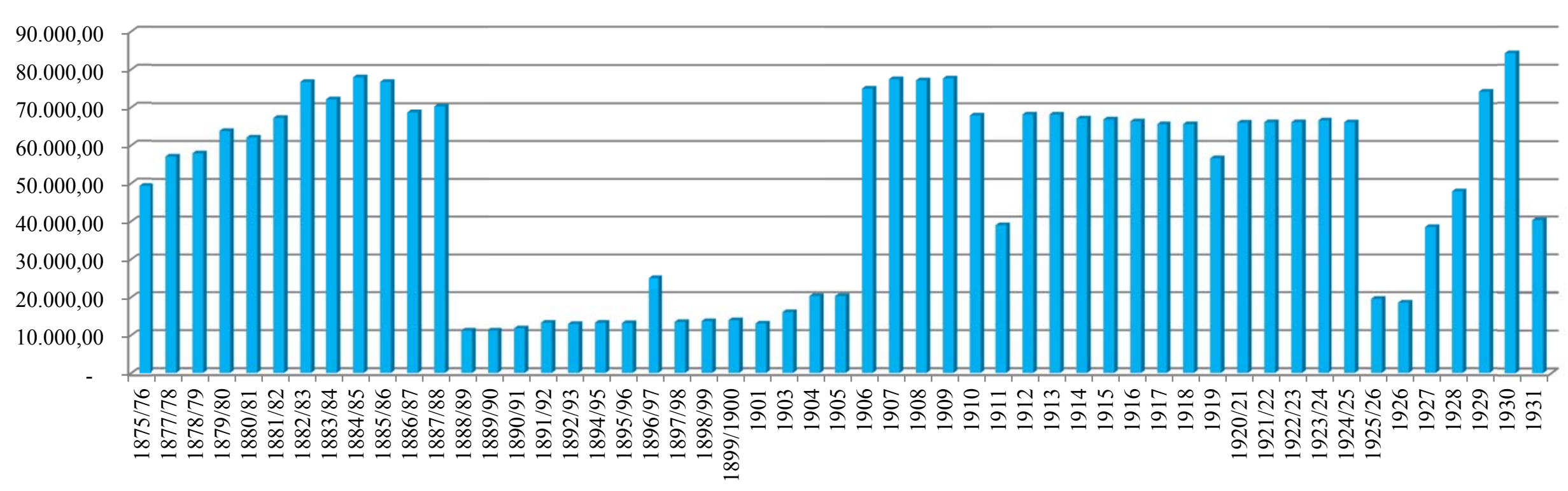

Elaboración propia. Fuente: A.D.P.P. 
La Diputación palentina procuró siempre atender las necesidades de la población en materia educativa, intentando que los estudiantes más brillantes no se vieran mediatizados en sus estudios por la falta de recursos económicos. Fueron muchas las ocasiones en las que se subvencionaron los estudios de alumnos con expedientes académicos sobresalientes, como en 1876 cuando se concedió una subvención de 1.000 pts. ${ }^{995}$ al Instituto de Segunda Enseñanza con la condición de que se concedieran cuatro becas de gracia para alumnos pobres de las Escuelas Municipales que obtuviesen la calificación de sobresaliente, para que previo examen de ingreso pudiesen seguir gratuitamente los estudios de Segunda Enseñanza.

En 1888, concedía 500 pts. para Anastasio González Arconada, vecino de Población de Campos, en atención a las especiales circunstancias que concurrían en él, para que finalizase sus estudios en el Conservatorio de Música de Madrid, y otras 500 pts. por cada año, tres, para que José Oliva Rodrigo, terminados los estudios de pintura en la Academia de Bellas Artes, pudiera perfeccionar sus técnica en Roma ${ }^{996}$. En ocasiones, la burocracia se interponía entre la Diputación Provincial y los beneficiarios de sus ayudas, como cuando no se admitió una instancia solicitando una subvención para establecer en Madrid una academia de canto donde recibirían educación gratuita los jóvenes palentinos con condiciones para el canto, por hallarse la solicitud extendida en papel de barba ${ }^{997}$. La labor de mecenazgo de la institución provincial se prolongó a lo largo de la etapa de la Restauración, en 1925 la Comisión Provincial aprobaba las Bases para la concesión de pensiones a artistas que, faltos de recursos, tuviesen condiciones excepcionales y quisieran ampliar sus conocimientos en el extranjero. Entre otras cosas se exigía haber nacido en la provincia o llevar residiendo en ella desde hacía cinco años, tener una edad comprendida entre dieciocho y cuarenta años, ingresos familiares no superiores a 4.000 pts. anuales, ampliando esta cantidad en 500 pts. por cada miembro de la familia que excediese de cinco y conviviesen con el peticionario, (hermanos solteros). ${ }^{998}$

\footnotetext{
${ }^{995}$ A.D.P.P., L.A.C.P. 42, 24-IV-1876.

${ }^{996}$ A.D.P.P., L.A.P.D. $64,5-I V-1888$.

${ }^{997}$ Este tipo de papel estaba prohibido por la Ley del Sello y Timbre del Estado. A.D.P.P., L.A.P.D. 121, 7X-1915.

${ }^{998}$ A.D.P.P., L.A.C.P. 141, 14-XI-1925. Se concedía una pensión de 250 pts. por un tiempo de diez meses. Al final se debía redactar una Memoria artística de la labor realizada y si durante el curso se tenía noticia por parte de la Diputación Provincial de poco aprovechamiento, la Comisión Provincial podía decidir anulación de la pensión.
} 
En 1926, el ponente Rodríguez Salcedo, presentaba la Bases para la concesión de las becas creadas por la Diputación Provincial en el Instituto, Escuela Normal de Maestros y Seminario Conciliar, seis becas, cuatro para hombres y dos para mujeres ${ }^{999}$ que a pesar de «su extraordinaria aplicación escolar y condiciones sobresalientes de inteligencia», no podían cursar estudios en los centros mencionados por carecer de los recursos necesarios para costearse una carrera. La ayudas monetarias también se concedían para cursar diferentes carreras universitarias a alumnos pobres que habían demostrado «(...)su aplicación y talento en los estudios de Segunda Enseñanza.» ${ }^{1000}$

En la apertura del curso 1882/83 del Instituto de Segunda Enseñanza, se trató sobre la creación de una Escuela de Artes y Oficios. La Comisión Provincial, en su Memoria Semestral del año económico 1883/84, se quejaba de que Palencia careciese de Escuela de Artes y Oficios, de Escuela Normal de Maestras y de un Colegio de internos en el Instituto. Pedía el restablecimiento de la Escuela Industrial y de Artes y Oficios palentina, y la Cámara Provincial proponía para el próximo Presupuesto el restablecimiento de esta escuela como Escuela de Artes y Oficios, ya que «contribuirá al bienestar de la clase obrera e industrial, que no pude costearse los estudios de enseñanza superior.» El Ayuntamiento de la capital se hizo eco de este asunto y solicitó al Claustro del Instituto que elaborase un proyecto de organización y funcionamiento de la Escuela, que estaría destinada a formar a los obreros. Después de algunos problemas sobre su ubicación, en 1885, finalmente se instaló en los locales del antiguo Colegio de Internos, costeando la Diputación las 732,11 pts. de gastos de instalación ${ }^{1001}$. En agradecimiento, se dio un Voto de Gracias del Claustro de Profesores del Instituto de Segunda Enseñanza por la instalación de la Escuela de Artes y Oficios ${ }^{1002}$. Ese mismo año, se agregó la Escuela de Dibujo a Artes y Oficios, ya que ambas tenían un mismo objetivo, el colectivo obrero. En 1886, la Escuela de Dibujo se trasladó a la Casa de Misericordia y las clases de Artes y Oficios fueron suprimidas debido a la poca matrícula existente, ya que los obreros preferían acudir a las clases de dibujo municipales.

\footnotetext{
${ }^{999}$ Jóvenes nacidos en la provincia, o que llevasen más de diez años consecutivos residiendo en la misma. A.D.P.P., L.A.C.P. 135, 17-VII-1926.

${ }^{1000}$ A.D.P.P., L.A.P.D. 50, 12-XI-1880.

${ }^{1001}$ Vid. ÁLVAREZ GARCÍA, María Concepción, La Enseñanza Secundaria en Palencia durante el siglo XIX (1845-190, Palencia, Diputación Provincial de Palencia, 1997, p. 229.

${ }^{1002}$ A.D.P.P., L.A.P.D. 47, 9-XI-1885.
} 
No sería hasta 1922 cuando Palencia pudo contar de nuevo con una Escuela de Artes y Oficios, gracias en parte a las gestiones de Abilio Calderón Rojo, como demuestra la gratitud de la Diputación Provincial hacia el diputado en Cortes, por «haber conseguido dotar a la provincia de una Escuela de Artes y Oficios.» ${ }^{1003}$

En 1899, se instaló la biblioteca provincial, de titularidad estatal, en el Instituto de Segunda Enseñanza. Los gastos para su instalación fueron sufragados con cargo al Presupuesto provincial, a juicio de la Comisión Provincial era un gasto necesario, puesto que «(...)puede contribuir al aumento de la cultura intelectual y reforma de las costumbres.» ${ }^{1004}$ Además del Instituto de Segunda Enseñanza, la Diputación Provincial debía también sostener la instrucción de los instructores, las Escuelas Normales ${ }^{1005}$. En Palencia se creó la Escuela Normal de Maestros con categorías de Elemental y Superior en 1861, fue suprimida por la Ley de 2 de junio de 1868 y volvió a funcionar a partir del curso 1869/70. En 1877, el diputado provincial Marcos Rodríguez consideraba que la Escuela Normal de Maestros gravaba considerablemente la economía de la provincia, unas 1.000 pts. anuales, y dado que el número de alumnos no excedía de dieciocho-diecinueve, y la Escuelas Normales de León, Burgos y Valladolid permitirían adquirir la instrucción a los que quieran seguir la carrera de maestros en la provincia, y el excesivo número de maestros en la provincia, solicitaba que se sometiera a juicio de la Diputación Provincial la supresión de la Escuela Normal de Maestros. Su compañero de Corporación, el diputado provincial Antonio Reyero recordaba que, aunque gravoso para la provincia, el sostenimiento de la Escuela Normal era un gasto obligatorio por ley. Se acordó dirigirse al ministro de Fomento ${ }^{1006}$, aconsejando la supresión de la Escuela ${ }^{1007}$.

\footnotetext{
${ }^{1003}$ A.D.P.P., L.A.P.D. 128, 7-V-1920.

${ }^{1004}$ A.D.P.P., L.A.C.P. 90, 19-X-1898.

${ }^{1005}$ La Ley de 21 de julio de 1838, llamada Plan Provisional, disponía que cada provincia sostendría una Escuela Normal de Enseñanza Primaria. La Ley de Instrucción Pública de 9 de septiembre de 1857, la Ley Moyano, también declaraba obligatorio el sostenimiento de una Escuela Normal en cada capital de provincia y otra central en Madrid.

${ }^{1006}$ El Real Decreto de 17 de junio de 1855 había dispuesto que pasaran al Ministerio de Fomento los Negociados de Instrucción Pública y, en consecuencia, la Dirección y el Consejo de Instrucción Pública, con sus dependencias en lo personal y material. La Dirección General de Instrucción Pública abarcaba los siguientes Negociados: Universidades, Institutos, Primera Enseñanza, Archivos, Bibliotecas y Museos, Bellas Artes y Fomento, Contabilidad, y el Boletín de la Propiedad Intelectual e Industrial.

${ }^{1007}$ A.D.P.P., L.A.P.D. 48, 16-IV-1877.
} 
Un año después, en 1878, el diputado provincial Antonio Reyero presentaba una proposición para que la Diputación Provincial recurriese al Gobierno para que no se suprimiera la Escuela Normal de Maestros y en su caso se estableciese en la capital la Universidad Normal, según el proyecto de Ley de Instrucción Pública que por las Cortes se discutía ${ }^{1008}$. En la sesión del pleno de la Diputación Provincial del 27 de abril de $1878^{1009}$, se votó desestimar la proposición de Antonio Reyero y solicitar la supresión de la Escuela Normal, a la vez que se pedía que se estableciese una de las Universidades Normales que se crearían por la Ley de Instrucción Pública. En 1890, por la Ley de Presupuestos de 29 de junio de 1890, al igual que había sucedido con las atenciones a los institutos de Segunda Enseñanza, el Estado pasaba a hacerse cargo del sostenimiento de las Escuelas Normales. En 1893, se realizaron gestiones por parte de la Diputación Provincial para el restablecimiento de la Universidad en Palencia, fundada por Alfonso VIII con la colaboración del obispo Tello Téllez de Meneses en el siglo XIII. Se acordó: «(...) recomendar a los representantes de la provincia en ambos cuerpos colegisladores, que coadyuven a la realización de tan fecundo cuanto transcendental pensamiento.» ${ }^{1010} \mathrm{La}$ pretensión de que Palencia volviese a contar con estudios universitarios no se olvidó, y en 1926, el diputado provincial Blanco Suárez de Puga, presentaba una moción proponiendo la instalación en la capital de una Escuela Provincial de Agricultura que expediría título de Técnicos agrícolas ${ }^{1011}$.

\footnotetext{
${ }^{1008}$ A.D.P.P., L.A.P.D. 49, 23-IV-1878. El ministro de Fomento, Francisco de Borja Queipo de Llano y Gayoso de los Cobos, intentó poner orden en la dispersa legislación sobre Instrucción Pública, debido a la gran cantidad de decretos aprobados desde la Ley de 1857, pero este proyecto no fue aprobado en la Cortes, y continuó en vigor la Ley Moyano.

${ }^{1009}$ A.D.P.P., L.A.P.D. 49, 27-IV-1878

${ }^{1010}$ Presentada al Congreso de los Diputados una proposición para establecer una Universidad Católica en Palencia o en Deusto, la Diputación Provincial consideraba que Palencia debía tener preferencia sobre otras ciudades de España, «(...) puesto que en ella fundó el rey Don Alfonso VIII de León, en el año 1208, la primera Universidad». A.D.P.P., L.A.P.D. 75, 7-VIII-1893.

${ }^{1011}$ A.D.P.P., L.A.C.P. 143,18 -XI-1927.
} 
El gasto ${ }^{1012}$ que suponían las Escuelas Normales estuvo también en la agenda del Gobierno de la nación durante la Restauración desde 1890 y así, el Real Decreto de 17 de agosto de 1901 suprimía parte de las Escuelas Normales, o para ser más precisos las integraba en los planes de estudio de los institutos de Enseñanza Media ${ }^{1013}$. Las razones que llevaron a tomar esta decisión fueron de orden económico, pues las Normales ocasionaban unos gastos que no se compensaban por la escasa matrícula, algo lógico si se tiene en cuenta la escasa consideración social y salarial de los maestros. La Real Orden de 24 de septiembre de 1903 volvió a restablecer las Escuelas Normales, Elementales y Superiores en la mayoría de las provincias.

En marzo de 1896, se publicó una Orden del director general de Instrucción Pública, respecto a la reorganización de las Escuelas Normales, que exigía cierta ampliación de los estudios, y por lo tanto un aumento del número de profesores ${ }^{1014}$. Se requería en la citada Orden que las diputaciones provinciales manifestasen si estaban dispuestas a apoyar económicamente dichas reformas y se señalaba qué enseñanzas iban a establecerse de nuevo, para que las instituciones provinciales fuesen conscientes del mayor gasto que la reforma conllevaría ${ }^{1015}$. Se tendría muy en cuenta el parecer de las diputaciones provinciales para resolver si en cada provincia debía haber Escuelas Normales de Maestros y Maestras. Las diputaciones provinciales debían tener en cuenta la demanda de estos estudios, representada en las matrículas correspondientes al último quinquenio, y los medios económicos con que contaban para mantener holgadamente las Escuelas Normales. El director de la Escuela Normal de Palencia facilitó a la Comisión Provincial un expediente con los datos relativos a las matrículas del último quinquenio, con un número total de 302 alumnos. En esas fechas, la Diputación palentina sufragaba otros centros docentes además de a la Escuela Normal: el Instituto de Segunda Enseñanza, la Escuela de Artes y Oficios de la Propaganda Católica de la capital ${ }^{1016}$, instalada en el Palacio Episcopal y a la Escuela de Capataces y Bodegueros, establecida en la Estación Enológica, con once alumnos en el curso 1895/96.

\footnotetext{
${ }^{1012}$ En 1883, dos profesores de la Escuela Normal de Palencia que cobraban entre 1.150 y 2.000 pts. anuales respectivamente, solicitaban a la Diputación Provincial que sus sueldos se elevasen a la suma de 2.500 pts., como sucedía en otras provincias. Se les aumentó el sueldo en 225 y 195 pts. respectivamente. A.D.P.P., L.A.P.D. $55,5-\mathrm{II}-1883$.

${ }^{1013}$ En 1868, Severo Catalina, director general de Instrucción pública, ya había tomada una medida similar.

${ }^{1014}$ A.D.P.P., C-R / 1,10 (A). p. 51.

${ }^{1015}$ A.D.P.P., L.A.C.P.P. 84, 16-III-1896.

${ }^{1016}$ La Escuela de Adultos fundada por La Propaganda Católica en 1869, incorporó una Escuela Práctica de Artes y Oficios en 1894.
} 
En febrero de 1897, la Diputación Provincial aprobó un dictamen de la Comisión Provincial proponiendo que se comunicase al director general de Instrucción Pública su disposición para sostener la Escuela Normal de Maestros, aceptando el presupuesto de 15.000 pts. $^{1017}$.

En la sesión del Pleno de la Diputación Provincial del día 9 de febrero de 1899 se discutía sobre la reorganización de las Escuelas Normales de Maestros ${ }^{1018}$, el diputado provincial Junco Rodríguez había emitido un voto particular defendiendo la creación de una Escuela Normal Superior ${ }^{1019}$ de Maestros con los siguientes argumentos:

«Que debe optar esta Diputación por sostener la referida Escuela Normal Superior con arreglo al Real Decreto de 23 de septiembre de 1898 fundado en las consideraciones siguientes: sería acogida la supresión de la Escuela citada con cierto desagrado en la provincia, cuando hoy precisamente se ha creído ser un axioma consagrado por todos que la difusión de la Instrucción Pública Elemental y Primaria, es la base necesaria para el principio de nuestra regeneración y cultura.») ${ }^{1020}$

A cuenta de la creación de Escuelas Normales Superiores de Maestros y Maestras surgió la polémica entre los diputados provinciales Abilio Calderón y García Crespo, este último argumentaba que también era partidario de la creación de ambas escuelas, pero el problema era el sostenimiento de las mismas:

«(...) pero nos encontramos con que para que esto era preciso un aumento de 43.000 pts. sobre las 10.185 que cuenta la escuela existente y, ante la idea sostenida por algunos diputados noveles de oponerse al aumento del Contingente, único ingreso del Presupuesto Provincial, no creímos que estábamos en el caso de contrariar sus aspiraciones, que son también las nuestras.» ${ }^{1021}$

\footnotetext{
${ }^{1017}$ A.D.P.P., L.A.P.D. 82, 11-II-1897.

${ }^{1018}$ La Escuelas Normales de Instrucción Primaria estaban reguladas por el Real Decreto de 15 de mayo de 1849. Los maestros elementales de Primera Enseñanza tenían que cursar desde la Ley Moyano las siguientes materias: Catecismo, Elementos de la Historia Sagrada, Caligrafía, Gramática castellana, Aritmética, Geometría, Dibujo lineal, Agrimensura, Geografía, Historia de España, Agricultura, Educación, Metodología y Prácticas de enseñanza. Los maestros superiores tenía que serlo elementales y estudiar Álgebra, Historia Universal y Fenómenos comunes de la Naturaleza.

${ }^{1019}$ La Escuela Normal podía ser de Grado Elemental y de Grado Superior. El Real Decreto de 23 de septiembre de 1898 disponía la instalación de Escuelas Normales Superiores en una de las provincias de cada Distrito universitario. Si la ciudad cabecera no se comprometía a aumentar el presupuesto en la cantidad necesaria para sostener la Escuela Normal Superior, cualquiera de las restantes provincias podía optar a ello.

${ }^{1020}$ En 1898, de un número total de 44.650 electores, se contabilizaban 5.675 analfabetos. A.D.P.P., Memoria Año Económico Primer Semestre 1898-1899, C-R / 1,15.

${ }^{1021}$ A.D.P.P., L.A.P.D. 87, 9-II-1899.
} 
Finalmente, se acordó por ocho votos contra cinco ${ }^{1022}$ que solo se sostuviese una Escuela Elemental, dejando a iniciativa de la Diputación Provincial el que esta deliberase si había de ser de Maestros o Maestras, dando preferencia a la de Maestras. En votación ordinaria se acordó hacer presente al ministro de Fomento que la Diputación Provincial se comprometía a sostener una sola Escuela Normal Elemental de Maestras. En mayo de 1899, el Rectorado de la Universidad de Valladolid comunicó a la Diputación Provincial la obligación de hacerse cargo de la biblioteca y mobiliario de la suprimida Escuela Normal de Maestros, el 30 de junio de $1899^{1023}$. En junio de ese año, la Corporación Provincial anunció al Rectorado de la Universidad de Valladolid que la Escuela Normal de Maestras se establecería en el edificio que había ocupado la de Maestros ${ }^{1024}$. En el año 1900, había un total de 487 escuelas públicas en la provincia, 284 desempeñadas por maestros y 203 por maestras ${ }^{1025}$.En 1904, los diputados provinciales Valentín Calderón Rojo, Jubete Tejerina, Herrero Abia y Rodríguez Blanco presentaban una propuesta para que se elevase el nivel de la Escuela Normal de Maestras, de Elemental a Superior, en virtud de las facultades que el art. 4 del Real Decreto de 29 de marzo de 1899 confería a la Diputación Provincial, de esta forma, en la Escuela Normal Superior de Maestras, podría seguirse la carrera de maestra superior ${ }^{1026}$. La Escuela Normal Superior de Maestras ${ }^{1027}$ comenzó a funcionar el 1 de octubre de $1905^{1028}$, la Diputación Provincial debía abonar directamente los gastos que ocasionasen la instalación y los alquileres de los locales para la Escuela Normal Superior de Maestras ${ }^{1029}$.

\footnotetext{
${ }^{1022}$ Votaron a favor: Herrero Harlucea, García de los Ríos, Rodríguez Blanco, Betegón Pérez, Díez Gómez, García Crespo, Gómez Ingüanzo, y Alonso Villazán; en contra: Merino Ortiz, Calderón Rojo, Jubete Tejerina, Polanco y Polanco, y el presidente, Cuadros de Medina. A.D.P.P., L.A.P.D. 87, 9-II-1899.

${ }^{1023}$ A.D.P.P., L.A.C.P. 91, 30-V-1899.

${ }^{1024}$ A.D.P.P., L.A.C.P. 92, 20-VI-1900.

${ }^{1025}$ A.D.P.P, C-R/ 1,14 (A).

${ }^{1026}$ A.D.P.P., L.A.P.D. 96, 7-X-1904.

${ }^{1027}$ La Escuela Normal Superior de Maestras de Palencia se creó por Real Decreto de 16 de junio de 1905. Se encontraba localizada en la Plazuela de San Antolín.

${ }^{1028}$ En 1905 sobre el total de lo recaudado por el Contingente Provincial (458.249 pts.), se aplicaba un 12,6\% (58.106 pts.) para cubrir las atenciones de Segunda Enseñanza, Escuela Superior de Maestras e Inspección de Primera Enseñanza. A.D.P.P., C-L/ 8,6.

${ }^{1029}$ A.D.P.P., L.A.C.P. 101, 14-IX-1905.
} 
En la Memoria de la Comisión Provincial del Segundo Periodo Semestral del año 1902, se recogía la queja sobre la morosidad del Estado a la hora de satisfacer a la Diputación Provincial lo que esta adelantaba para el sostenimiento de la Escuela Normal Elemental de Maestras, (Real Orden de 15 de octubre de 1898), cuyo presupuesto ascendía a 6.900 pts. , y percibía lo mismo que costaba la de Maestros, 10.185 pts., existiendo una diferencia de más, en los tres años transcurridos desde la supresión ${ }^{1030}$ de esta, de 9.885 pts. , que en opinión de la Comisión Provincial serían difíciles de cobrar y que debía ser tenido en cuenta para el pago de las gratificaciones que percibía la maestra que desempeña en la Escuela Práctica agregada a la Normal ${ }^{1031}$.

En el año 1906, la directora de la Escuela Normal Superior de Maestras comunicaba a la Diputación Provincial que la matrícula ese curso había aumentado considerablemente y no disponiendo de local para impartir las clases se veía en la necesidad de suspenderlas hasta que no se le proporcionase un lugar con las condiciones adecuadas. La Corporación Provincial exigía al Ayuntamiento de Palencia el cumplimiento del acuerdo por el que este se comprometía a dejar libres los locales que ocupaba la Escuela Práctica de niños en el edificio de la Escuela Normal ${ }^{1032}$. En 1908 se acometieron obras de mejora en el edificio de la Escuela Normal de Maestras que al convertirse en Escuela Superior, necesitaba mayor capacidad de las aulas en el piso principal, nuevos retretes y lavabos y construir un depósito de agua en el patio, entre otras mejoras. La Diputación Provincial dio un plazo improrrogable de quince días al Ayuntamiento de la capital para que desalojase los locales que ocupaba la Escuela Práctica de niños en el edificio de la Escuela Normal, tras los reiterados incumplimientos de abandonar estas instalaciones, desde el año $1905^{1033}$.

\footnotetext{
${ }^{1030}$ En el año 1899 se suprimió la Escuela Normal de Maestros de Palencia.

${ }^{1031}$ Anejas a las Escuelas Normales se encontraban las Escuelas Prácticas Graduadas, donde se impartían los más modernos adelantos pedagógicos, estaban reguladas por el Real Decreto de 23 de septiembre de 1898.

${ }^{1032}$ A.D.P.P., L.A.P.D. 104, 2-XI-1906.

${ }^{1033}$ A.D.P.P., L.A.C.P. 108, 25-VIII-1908.
} 
A pesar de las mejoras realizadas, en noviembre de 1910, se encargó al arquitecto provincial la realización de un plano de las condiciones que había de reunir el nuevo local de la Escuela Normal Superior de Maestras, por concluir en esta fecha el contrato de arriendo del edificio destinado a este fin, el 1 de enero de 1911, carecer de las condiciones adecuadas para albergar la Escuela Normal Superior y no haber convenido las partes una prórroga del contrato ${ }^{1034}$. El edificio que por concurso se adquiriera para Escuela Normal Superior de Maestros debía contar con las siguientes dependencias: tres aulas de $60 \mathrm{~m}^{2} \mathrm{y}$

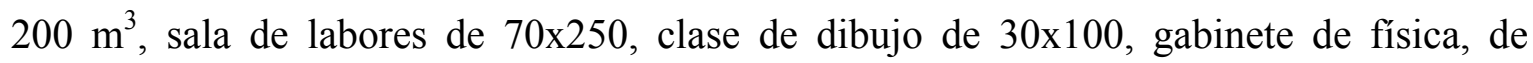
$30 \times 100$, clase de música de $24 \times 100$, sala de profesores de 20×70, despacho para la directora de $14 \times 50$, otra para el secretario de $14 \times 50$, biblioteca de $14 \times 50$, ropero de $10 \times 35$, sala de estudio de 10x400, seis urinarios-retretes, cuatro lavabos y patio con fuente, casa para la directora, casa para la portera y casa para el conserje. Las condiciones del concurso se acomodarían a las reglas establecidas por la Diputación el 25 de enero de $1901^{1035}$.

Finalmente se renovó el contrato de arriendo ${ }^{1036}$ por seis años con Pedro Hernán, dueño del edificio donde se ubicaba la Escuela Normal de Maestras, con una cláusula que prescribía que si en ese tiempo se modificaba la legislación respecto a sufragar los gastos que demandase el servicio, el contrato quedaría rescindido de forma automática ${ }^{1037}$. En 1914, quince años después de acordar su supresión, la Diputación Provincial decidió solicitar al Gobierno el establecimiento de una Escuela Normal de Maestros, pues al parecer desde el 1 de enero de 1915 el Estado se haría cargo de los citados centros de enseñanza y, a decir del diputado provincial César Gusano: «(...) la provincia contará con un Centro más de enseñanza, tan conveniente y útil, porque es la Universidad de las clases modestas.» ${ }^{1038} \mathrm{Su}$ compañero Salvador Zurita proponía que puesto que había un mes de plazo para solicitar la creación de la Escuela, se consultase a los ayuntamientos si estaban dispuestos a contribuir con los gastos que ocasionase su instalación. El presidente de la Diputación Provincial, Diezquijada Gallo, sugería dirigirse al Gobierno manifestándole que la Diputación seguiría pagando los gastos que ocasionase Instrucción Pública, y serían de cargo del Estado las nuevas Escuelas Normales ${ }^{1039}$.

\footnotetext{
${ }^{1034}$ A.D.P.P., L.A.C.P. 114, 22-X-1910.

${ }^{1035}$ A.D.P.P., L.A.C.P. 114, 22-XI-1910.

${ }^{1036}$ El alquiler del edificio destinado a Escuela Normal Superior de Maestras ascendía a 3.000 pts. anuales.

${ }^{1037}$ A.D.P.P., L.A.C.P. 115, 20-VI-1911.

${ }^{1038}$ A.D.P.P., L.A.P.D. 113, 12-IX-1914.

${ }^{1039}$ A.D.P.P., L.A.P.D. $113,14-\mathrm{X}-1914$.
} 
En octubre de 1914, la Comisión de Fomento manifestaba su aprobación a la moción de Diezquijada Gallo, César Gusano y Calderón Martínez para que la Diputación solicitase la creación de la Escuela Normal de Maestros ${ }^{1040}$, comprometiéndose a satisfacer únicamente la cantidad consignada en presupuestos anteriores para estas atenciones, y que lo que pudiera exceder fuera de cargo del presupuesto del Estado. César Gusano se mostraba en contra del dictamen de la Comisión de Fomento puesto que, en su opinión, proponer que el Estado asumiera inmediatamente el deber de satisfacer todas las atenciones de la Escuela Normal de Maestros equivaldría a rectificar el Real Decreto de 30 de agosto de 1914, que imponía esta obligación, ya que tenía la seguridad de que en 1915 el Estado asumiría estos gastos. Se aprobó el dictamen de la Comisión de Fomento por once votos a favor y cuatro en contra ${ }^{1041}$. En 1915, la Cámara de Comercio e Industria de Palencia solicitaba a la Diputación Provincial que se crease en la capital una Escuela Normal de Maestros ${ }^{1042}$, una muestra más del interés de la sociedad palentina por contar con centros de estudios superiores en la ciudad.

La Diputación Provincial, al igual que en materia benéfica, también concedía subvenciones a instituciones sin estar obligada a hacerlo por ley. En 1900, varios diputados provinciales presentaban una proposición para que se subvencionasen las Escuelas de Adultos ${ }^{1043}$ de Villada y Cisneros, de la misma forma que se había hecho con otros ayuntamientos. La proposición se tomó en consideración y pasó a la Comisión de Presupuestos $^{1044}$. En 1920, concedía una subvención de cien pts. para las colonias escolares, que tenían como fin trasladar al norte de la provincia a niños de las Escuelas Nacionales de la ciudad de Palencia y de la Beneficencia ${ }^{1045}$.

\footnotetext{
${ }^{1040}$ A.D.P.P., L.A.P.D. 113, 20-X-1914. El Ministerio de Instrucción Pública había desestimado en julio de 1914 la petición de la Diputación para instalar la Escuela Normal de Maestros en el nuevo edificio destinado a Instituto de Segunda Enseñanza. A.D.P.P., L.A.C.P. 118, 23-VII-1914.

${ }^{1041}$ Votaron en contra: Nájera de la Guerra, Gusano Rodríguez, Calderón Martínez y el presidente, Diezquijada Gallo.

${ }^{1042}$ A.D.P.P., L.A.P.D. 121, 6-X-1915.

${ }^{1043}$ Solo se admitían adultos que supiesen leer y escribir, la acción educativa se dirigía a la recuperación de analfabetos funcionales. En la capital de la provincia comenzó a funcionar, en 1859 a instancia del Rector de la Universidad de Valladolid, que pidió al Ayuntamiento de Palencia que estableciese una Escuela de Adultos utilizando los servicios de los maestros municipales.

${ }^{1044}$ A.D.P.P., L.A.P.D. 88, 4-X-1900.

${ }^{1045}$ A.D.P.P., L.A.C.P. 132, 20-VII-1920.
} 
Como se ha dicho, las diferencias entre la Diputación Provincial y el Estado, a cuenta de las atenciones de Instrucción Pública, fueron constantes a lo largo del periodo de la Restauración. En 1913, la Comisión Provincial de la Diputación Provincial de Palencia, comunicaba al vicepresidente de la Comisión Provincial de la Diputación Provincial de Segovia su conformidad con respecto a la procedencia de la vía contenciosa contra el Ministerio de Instrucción Pública y Bellas Artes, y el Real Decreto de 25 de mayo de 1913, que imponía a las diputaciones provinciales la obligación de abonar los gastos de material de la Secretaría de la Junta de Primera Enseñanza, y el Real Decreto de 5 de mayo de 1913, que obligaba a las diputaciones a facilitar local y mobiliario, un escribiente y un ordenanza para la oficina de la Inspección ${ }^{1046}$. Ese mismo año, la Diputación palentina secundaba la iniciativa de la Diputación Provincial de Jaén sobre la necesidad de que el Estado se hiciese cargo del aumento gradual de sueldos a los maestros de Primera Enseñanza, establecido en los arts. 196 y 197 de la Ley de 9 de septiembre de 1857, que en ese momento correspondía a las diputaciones ${ }^{1047}$.

En 1917, el presidente de la Diputación Provincial de Soria comunicaba a la Diputación de Palencia que cuarenta diputaciones provinciales estaban conformes con el cuestionario de temas para tratar en la sesión de la Asamblea de representantes de las diputaciones a celebrar el 14 de diciembre, con el tema del pago de la totalidad de gastos de Institutos y Escuelas Normales entre otros ${ }^{1048}$. El 23 de noviembre de 1918, la Diputación palentina acordaba la supresión del aumento gradual de sueldo a maestros y en diciembre, el presidente de la Asociación Provincial de Maestros presentaba un recurso contra ese acuerdo. La Diputación Provincial ${ }^{1049}$ justificaba esta medida porque, en su opinión, el aumento gradual de sueldos, contemplado en la Ley de 9 de octubre de 1857, tenía por objeto mejorar la situación económica de los maestros dado sus pobres salarios. Considerando que las nuevas disposiciones disponían la mejora de sus sueldos con un mínimo de 1.500 pts. anuales, era lógico, a juicio de la Asamblea Provincial, que desapareciesen de los presupuestos provinciales las cantidades asignadas para la mejora de la dotación que venían percibiendo.

\footnotetext{
${ }^{1046}$ A.D.P.P., L.A.C.P. 117, 22-VII-1913.

${ }^{1047}$ A.D.P.P., L.A.P.D. $113,10-\mathrm{X}-1913$.

${ }^{1048}$ A.D.P.P., L.A.C.P. 125, 19-XI-1917.

${ }^{1049}$ A.D.P.P., L.A.C.P. 126, 20-XII-1918.
} 
Toda esta serie de desencuentros culminó en 1923, cuando la Administración de Propiedades e Impuestos de la provincia, dependiente del Ministerio de Hacienda, hizo responsable a la Diputación Provincial de los descubiertos de Segunda Enseñanza, Escuela Normal e Inspección de Primera Enseñanza del ejercicio de 1917 por una cantidad de $25.605,08$ pts., de 1918 por $66.339,25$ pts. y de 1919 por $88.425,12$ pts. ${ }^{1050}$ Se solicitó la ayuda de los representantes palentinos en Cortes, con el apoyo de la Diputación Provincial de Burgos que también había sido apremiada, para que quedase en suspensión la Ley de Autorización de 3 de abril de 1917, en la parte referente a las atenciones de Segunda Enseñanza, quedando únicamente obligada la Diputación a satisfacer la cantidad consignada en su Presupuesto, y que se asignó en la Ley de 29 de junio de 1887, fecha en que se hizo cargo del pago de esas atenciones ${ }^{1051}$. Finalmente, se firmó un convenio de la Diputación Provincial con la Delegación de Hacienda para el pago de los débitos que se tenían con el Tesoro por el concepto de atenciones de Segunda Enseñanza y Cárcel, que ascendían a 105.944,42 pts., comprometiéndose a ingresar mensualmente la cantidad de 10.500 pts. hasta completar la suma total. El Estado, de conformidad con lo establecido en el art. 134 del Estatuto Provincial de 1925, se hizo cargo del pago de atenciones de Segunda Enseñanza, a partir del uno de julio de 1926, incluyendo el pago del alquiler de la Escuela Normal de Maestros ${ }^{1052}$.

La Diputación Provincial también tuvo una relación difícil con la Universidad de Valladolid, casi siempre por motivos económicos. En la etapa de la Dictadura de Primo de Rivera, el ministro de Instrucción pública y Bellas Artes, Eduardo Callejo ${ }^{1053}$, ordenó el establecimiento de un Patronato de la Universidad en cada capital de Distrito universitario. El Patronato nacía con un fin dinamizador del mundo universitario español y, además de reorganizar los colegios mayores, en su art. 5 se contemplaba el apoyo económico de las diputaciones provinciales ${ }^{1054}$ pertenecientes al Distrito universitario de las respectivas universidades $^{1055}$.

\footnotetext{
${ }^{1050}$ A.D.P.P., L.A.C.P. 135, 6-III-1923.

${ }^{1051}$ A.D.P.P., L.A.C.P. 135, 6-III-1923.

${ }^{1052}$ A.D.P.P., L.A.C.P. 141, 15-VII-1925.

${ }^{1053}$ Catedrático de Derecho Natural en la Facultad de Derecho de la Universidad de Valladolid.

${ }^{1054}$ Formaban parte del Consejo de Distrito del Patronato Universitario.

${ }^{1055}$ Vid. PALOMARES IBÁÑNEZ, Jesús María, La historia de un fracaso: los patronos de la Universidad de Valladolid en el siglo XX, Investigaciones históricas: Época moderna y contemporánea, № 26 (2006), pp. 237-260.
} 
En 1926, el Rector de la Universidad de Valladolid pedía que los representantes de la Diputación Provincial de Palencia, que no perteneciesen al Claustro docente, formasen parte del Consejo de Distrito del Patronato de la Universidad y así pudieran comprobar el destino y aplicación que se daba a los fondos que recibían de las diputaciones provinciales y otras entidades ${ }^{1056}$. En 1927, el Rector de la Universidad de Valladolid preguntaba al gobernador civil de la provincia, si la Diputación palentina había consignado en el presupuesto alguna cantidad para subvencionar el patrimonio de la Universidad, el vocal de la Comisión Provincial palentina, Rivas Gallego, pensaba que estaría mal visto que el resto de diputaciones del Distrito universitario contribuyesen con cantidades y Palencia no, por lo que se acordó preguntar al resto de las corporaciones provinciales con qué cantidad contribuían, y consignar esa cantidad en el presupuesto de 1928, si era posible $^{1057}$. El año 1928, el Rector de la Universidad de Valladolid solicitaba a la Diputación Provincial de Palencia la subvención de una o dos pensiones de 600 pts. para los Cursos de verano que se celebrarán en el Colegio Mayor de Santander ${ }^{1058}$, y que entre los alumnos oficiales de la Universidad de Valladolid designase a los que disfrutarían de las becas. La contestación de la Diputación Provincial fue que no había asignación presupuestaria para ese efecto, solo 500 pts. para subvención del Patronato Universitario $^{1059}$.

Al final de la Restauración, la Diputación Provincial se había «liberado» del gasto que suponían las atenciones de Segunda Enseñanza y Escuelas Normales, pero eso no significaba que no tuviera que destinar ciertas cantidades del Presupuesto de gasto a cuestiones educativas. En 1929, el Ministerio de Gobernación recordaba a la institución provincial el deber de apoyar económicamente a las Escuelas provinciales de Puericultura, fijando en los correspondientes presupuestos anuales las cantidades destinadas a tal efecto $^{1060}$. Y en 1930, el vocal de la Comisión Provincial, Mariano Calderón, era designado como representante de la Diputación en el Patronato de Formación Profesional $^{1061}$.

\footnotetext{
${ }^{1056}$ A.D.P.P., L.A.C.P.P. 135, 10-XI-1926.

${ }^{1057}$ A.D.P.P., L.A.C.P.P. 143, 28-I-1927.

${ }^{1058}$ El vicerrector de la Universidad de Valladolid, Arturo Pérez Martín, coordinó la creación del Colegio Mayor de Verano de Santander vinculado a la Universidad vallisoletana.

${ }^{1059}$ A.D.P.P., L.A.C.P. 144, 20-VI-1928.

${ }^{1060}$ A.D.P.P., L.A.C.P. 145, 10-XII-1929.

${ }^{1061}$ A.D.P.P., L.A.C.P. 146, 5-VIII-1930.
} 


\section{Obras Públicas}

\section{Introducción}

Las obras públicas fueron vistas por las administraciones locales de la Restauración como una válvula de escape a la conflictiva situación social derivada de un panorama laboral complicado. En Palencia fueron constantes las peticiones de realización de obras para intentar paliar el creciente descontento social. En 1907, por ejemplo, la Diputación palentina enviaba un telegrama al presidente del Consejo de Ministros y al ministro de Fomento, comunicándoles la angustiosa situación de los obreros de la provincia, faltos de trabajo por la pérdida de la cosecha de cereales y la destrucción del viñedo por la plaga de la filoxera. A juicio de la institución provincial, se imponía la adopción inmediata por el Gobierno de medidas extraordinarias para contener la imponente inmigración que dejaba yermos los campos, y mitigar el hambre de los hombres que se agolpaban ante los ayuntamientos pidiendo pan y trabajo. La solución que proponía la Diputación Provincial para remediar esta situación era la ejecución de obras ${ }^{1062}$ en las carreteras del Estado en la provincia, en caminos vecinales, en el canal de Alfonso XIII, etc. El ministro de Fomento se comprometió a que una vez dotado económicamente el Plan de Obras y aprobado en el Congreso el crédito necesario, se llevasen a término las solicitadas para Palencia ${ }^{1063}$.

A la Oficina de Obras Públicas de la Diputación Provincial le correspondía el estudio, dirección y vigilancia de las obras públicas provinciales correspondientes a:

1. Construcción y conservación de caminos, y de aquellas carreteras que no estuviesen incluidas en el Plan general del Estado, o que estándolo, se traspasasen a la Diputación Provincial.

2. Construcción y explotación de ferrocarriles de interés provincial.

3. Establecimiento de líneas de comunicación telegráfica dentro del territorio de la provincia, entre los pueblos que no la tuviesen a cargo del Estado.

4. Desecación de terrenos pantanosos, formación de pantanos y construcción de canales de riego que tuviesen carácter provincial.

5. Encauzamiento y rectificación de los ríos que naciesen y discurriesen por la provincia.

6. Conservación de monumentos históricos y artísticos.

\footnotetext{
${ }^{1062}$ La Diputación de Palencia aducía que este tipo de medidas tenía precedentes en el Real Decreto de 3 de febrero de 1906, que concedía este tipo de obras a Andalucía y Castilla, decía, no podía ser menos.

${ }^{1063}$ A.D.P.P., L.A.D.P. 103, 26-VII-1907.
} 
El art. 74 de la Ley Provincial de 29 de agosto de 1882 facultaba a las diputaciones provinciales para crear y conservar caminos y toda clase de obras públicas de interés provincial. En la etapa inicial de la Restauración, las leyes aprobadas en materia de infraestructuras tenía como marco normativo de referencia la Ley General de Obras Públicas de 13 de abril de 1877. La Diputación Provincial sabía que la inversión en infraestructuras de comunicación era un requisito imprescindible para lograr un desarrollo económico sostenible en la provincia, y que las dotaciones presupuestarias para esta materia redundaban en beneficio de la propia institución provincial, pues el crecimiento económico generaría mayor riqueza en los pueblos, que al fin y al cabo eran los mayores contribuyentes a la Caja Provincial. La inversión en construcción de carreteras fue una de las atenciones que mayor porcentaje de gasto conllevó, especialmente en el último cuarto del siglo XIX ${ }^{1065}$.

Figura 13. Porcentaje de gasto en carreteras provinciales sobre el total del Presupuesto de Gastos.

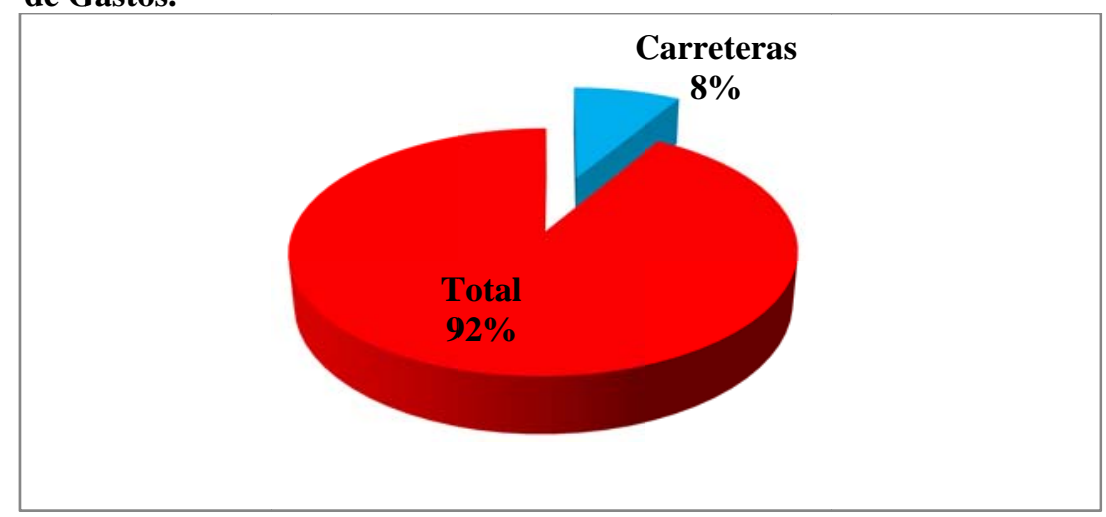

Elaboración propia. Fuente: A.D.P.P.

\footnotetext{
${ }^{1064}$ Se consideraban como tales aquellos que enlazaban un pueblo con otro, con una estación de ferrocarril, con un puerto o cala, con un mercado, carretera o camino vecinal, así como los que dentro de un municipio enlazaban las cabezas del mismo con los suburbios caso de separación mayor de $2 \mathrm{~km}$.

${ }^{1065}$ Véase Anexo V. Presupuesto Provincial en pts. en Beneficencia, Instrucción Pública, Corrección Pública y carreteras 1875-1931, p. 492.
} 
Figura 14. Gasto anual en pts. en construcción de carreteras provinciales en el periodo 1887-1925.

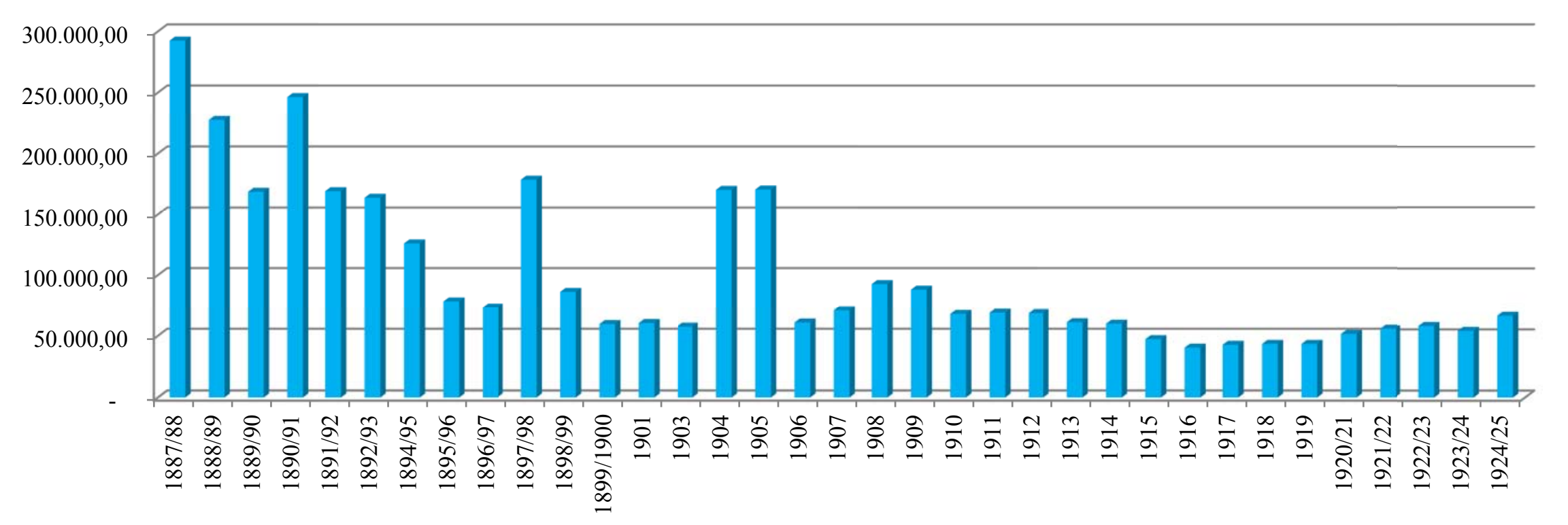

Elaboración propia. Fuente: A.D.P.P. 
El procedimiento para construir una carretera o camino vecinal estaba fijado por el Reglamento del 10 de agosto de 1877, que desarrollaba la Ley de Carreteras de 4 de mayo de 1877 y que permaneció invariable hasta el final de la Restauración. Una vez aprobada la propuesta para la construcción de la carretera por la Diputación Provincial, se elaboraba un proyecto por la Sección de Obras acompañado del presupuesto de la obra. Las obras eran subastadas y si la subasta quedaba desierta se adjudicaba por el procedimiento de administración. La Diputación Provincial no era partidaria de subastar las obras por una cantidad superior a 50.000 pts., por lo que cada proyecto era dividido en los tramos necesarios para no superar esa barrera. El expediente de la obra, una vez que no se habían presentado reclamaciones en su exposición pública durante treinta días, y con el informe positivo del ingeniero de Obras Públicas, era remitido al Ministerio de Fomento, quien mediante Real Decreto lo aprobaba, asignándole un número dentro del Plan de Carreteras Provinciales. Finalizada la obra, se acordaba su recepción provisional por dos diputados provinciales designados al efecto ${ }^{1066}$, revisado el tramo en cuestión, se levantaba Acta, indicando los defectos, si se habían encontrado, y comenzaba a correr el plazo de garantía.

Una vez finalizado este, tenía lugar la recepción definitiva y la devolución de la fianza que había depositado el constructor en calidad de garantía. Desde la recepción definitiva, la Diputación Provincial era la encargada de su conservación, tarea que también se subastaba o se hacía por administración como, por ejemplo, al no haberse presentado licitadores a la subasta para la conservación de la carretera provincial de Melgar de Yuso a Osorno, sección Astudillo a Melgar de Yuso, cuando se acordó que se conservase la carretera por administración, a cargo del personal de la Sección de Obras.

\footnotetext{
${ }^{1066}$ Dos vocales de la Comisión Provincial se personaron para verificar la recepción provisional de las obras públicas terminadas en el camino vecinal de Baltanás a Población, se designó una Comisión para la recepción definitiva de las mismas .A.D.P.P., L.A.C.P. 115, 15-VII-1911.
} 
Tal y como sucedía en Beneficencia, Sanidad e Instrucción Pública, también en materia de Obras Públicas litigaban la Diputación Provincial y el Gobierno central por la interpretación divergente de ambas administraciones sobre las competencias en este ámbito. Como siempre, lo que se dilucidaba era quién debía pagar los servicios realizados en carreteras, caminos vecinales, ferrocarriles y obras hidráulicas. Además del gasto de la construcción de carretas y caminos vecinales, lo que resultaba especialmente oneroso para las arcas provinciales era el mantenimiento de las infraestructuras viarias una vez terminadas, la Diputación Provincial solicitaba al Estado que se hiciese cargo de la conservación de dos carreteras ${ }^{1067}$ que cruzaban la provincia en gran parte de su recorrido por el considerable gasto que suponía para la provincia ${ }^{1068}$. El 1 de enero de 1890, había $116 \mathrm{~km}$ de carreteras en conservación, el 1 de marzo de $1896^{1069}$, los $\mathrm{km}$ eran 133. La siguiente tabla muestra los gastos de conservación de las carreteras provinciales en el periodo $1890-1900^{1070}$. El gasto medio por km por haberes de peones capataces ${ }^{1071}$ entre 1890 y 1900 fue de entre 33 y 21 pts. El gasto medio por km por acopio para conservación fue de $157-206$ pts. en el periodo $1890 / 94$ y de $94-101$ pts. en el periodo $1897 / 98^{1072}$.

\footnotetext{
${ }^{1067}$ A.D.P.P., L.A.C.P. 79, 31-VII-1895. Desde el 1 de marzo de 1896, las carreteras del Puente Don Guarín a Villada, y la de Mazariegos a Lagartos formaban parte del Plan General de carreteras del Estado, en virtud de la Ley de 14 de agosto de 1895, quedando a cargo de la Diputación, la de Calabazanos a Esguevillas, la de Melgar de Yuso a Osorno, y la de Villasarracino a Buenavista.

${ }^{1068}$ A.D.P.P., L.A.P.D. 42, 24-IV-1876. En 1868, el Estado dejó de sufragar el mantenimiento de la conservación de carreteras paralelas a vías férreas.

${ }^{1069}$ En esa fecha el Estado se hace cargo de la conservación de las carreteras de Mazariegos a Lagartos y de Puente Don Guarín a Villada, con lo que los km a conservar por parte de la Diputación Provincial se redujeron a la cifra de 63. En 1900 eran 74 los km a conservar por la Diputación.

${ }^{1070}$ A.D.P.P., C-A/ 1,16 (A).

${ }^{1071}$ Tres carreteras provinciales y sus enlaces en conservación en esta etapa y permanencia de un capataz en cada una de ellas.

${ }^{1072}$ Nuevo sistema de redacción de los presupuestos de acopio, que se hacía de piedra en grueso, en lugar de machacada, haciéndolo por peso, en vez de medida como anteriormente.
} 
Tabla 13. Gasto en pts. para la conservación de carreteras provinciales en el periodo 18901900.

\begin{tabular}{|c|c|c|c|}
\hline Años & $\begin{array}{c}\text { Coste medio } \\
\text { anual por } \mathbf{k m}^{\mathbf{1 0 7 3}} \\
\text { en carreteras } \\
\text { provinciales }\end{array}$ & $\begin{array}{c}\text { Coste medio } \\
\text { anual por km en } \\
\text { carreteras del } \\
\text { Estado }\end{array}$ & $\begin{array}{c}\text { Gasto medio por } \\
\mathbf{k m} \text { por haberes } \\
\text { de peones } \\
\text { camineros }^{\mathbf{1 0 7 4}}\end{array}$ \\
\hline $\mathbf{1 8 9 0}$ & 423 & & 189 \\
\hline $\mathbf{1 8 9 2}$ & 500 & 500 & 195 \\
\hline $\mathbf{1 8 9 6}$ & 243 & 321 & \\
\hline $\mathbf{1 8 9 7}$ & 312 & & \\
\hline $\mathbf{1 8 9 8}$ & 302 & & \\
\hline $\mathbf{1 9 0 0}$ & 212 & & \\
\hline
\end{tabular}

Elaboración propia. Fuente: A.D.P.P. C-A/ 1,16 (A).

En 1877, el diputado provincial Antonio Reyero proponía que por estar comprendidas en el Plan General del Estado ${ }^{1075}$ de 1877, la carretera de Valladolid a Santander, y la de San Isidro de Dueñas a Burgos, y debiendo revertir ambas al Estado, que fuese este el que se encargase de su conservación por el alto coste que suponía ${ }^{1076}$. Su compañero Crisógono Manrique señalaba que aunque era cierto que ambas carreteras iban a revertir al Estado, este no se haría cargo de su conservación hasta que los recursos del Tesoro lo permitiesen y entretanto se deteriorarían con un gran perjuicio a los muchos pueblos que atravesaban. Finalmente, se aprobó por unanimidad limitar el gasto de conservación a la tercera parte de la cantidad presupuestada inicialmente y que se invirtiera con preferencia en los puntos que fuese más preciso.

\footnotetext{
${ }^{1073}$ El gasto medio general en la segunda mitad del decenio de 1890/1900 fue menos de la mitad del que hubo en los primeros años del periodo. Véase Anexo V. Presupuesto Provincial en pts. en Beneficencia, Instrucción Pública, Corrección Pública y carreteras 1875-1931, p. 485.

${ }^{1074}$ Peones, camineros y capataces de la Diputación Provincial cobraban 25 cént. menos que los pertenecientes al Estado, haciendo igual trabajo y rigiéndose por las mismas disposiciones.

${ }^{1075}$ Aprobado por la Ley de 11 de julio 1877, en 1880 la red de carretas de Primer Orden se encontraba prácticamente concluida, la de carreteras de Segundo Orden alcanzaba casi la tercera parte de sus objetivos, y restaba casi un $70 \%$ de construir en la red de Tercer Orden. Cfr. CUELLAR VILLAR, Domingo, «Las obras públicas y el marco institucional durante la Restauración. El Ministerio de Fomento (1875-1913)», Tst: Transportes, servicios y Telecomunicaciones, № 2 (2002), pp. 43-69. En 1879, por el Real Decreto de 25 de julio se aprobaba el Plan General de Carreteras de la Provincia.

${ }^{1076}$ A.D.P.P., L.A.P.D. $48,22-X I-1877$.
} 
En 1895, por ejemplo, la cuenta de conservación de carreteras de la provincia en el mes de mayo, ascendía a 1.455, 52 pts. ${ }^{1077}$. En 1902, se solicitaba al Estado la cesión de la carretera de Astudillo a Melgar de Yuso, de cuya conservación se encargaba la provincia $^{1078}$. La Diputación Provincial sabía que la actuación de los diputados palentinos en Cortes podía favorecer la concesión de obras viarias a la provincia que no hubiesen sido incluidas en un principio en el Plan General del Estado y, al igual que en otras cuestiones relacionadas con la vida provincial, solicitó su mediación siempre que consideró que podía favorecer los intereses de la provincia. En 1885, la Diputación palentina emitía un Voto de Gracias a los diputados en Cortes, Luis Polanco y Eugenio García Ruiz, por haber gestionado la inclusión en el Plan General de Carreteras de Estado, las provinciales de Aguilar de Campoo a Brañosera, Palencia a Castrojeriz, Villoldo al puente de Reinoso de Cerrato y de Frómista a Melgar de Yuso ${ }^{1079}$. En 1883, varios diputados provinciales proponían obras de construcción o ampliación de varias carreteras ${ }^{1080}$ :

1. Cisneros-Moratinos.

2. Salinas-Barruelo.

3. Cervera-Camporredondo.

4. Cevico-Palenzuela.

5. Castrillo de Don Juan.

Los diputados provinciales eran conocedores de la importancia de las obras públicas para generar trabajo, especialmente en épocas en las que la labor agrícola no necesitaba mano de obra. El paro obrero era temido por los políticos porque sabían que conllevaba desestabilización y protestas. Por este motivo, aspiraban a que se adjudicasen obras en los territorios de sus distritos electorales, en abril de 1883, en sesión del Pleno de la Diputación Provincial se daba da cuenta de los gastos voluntarios del Presupuesto, en los que se consignaban las partidas presupuestarias para carreteras del primer grupo del Plan General Provincial ${ }^{1081}$ y subvenciones para caminos vecinales ${ }^{1082}$.

\footnotetext{
${ }^{1077}$ A.D.P.P., L.A.C.P. 83, 28-VI-1895.

${ }^{1078}$ A.D.P.P., L.A.C.P. 98, 18-VII-1902.

${ }^{1079}$ A.D.P.P., L.A.C.P. 58, 30-XII-1882

${ }^{1080}$ A.D.P.P., L.A.P.D. 55, 9-IV-1883.

${ }^{1081}$ Convencimiento de los diputados en que habrían de pasar muchas generaciones antes de que se terminasen los km que el Plan comprendía. C-R/ 1,12 (A). p. 15. Se señalaba la misión de la Diputación en el progreso del país, gracias a la mejora de las comunicaciones para el transporte de mercancías y personas.

${ }^{1082}$ Con arreglo a los requisitos establecidos en el artículo 51 de la Ley de 4 de mayo de 1877 y 61 y 62 del Reglamento de 10 de agosto de 1877.
} 
El diputado provincial Mora Alday defendía la utilidad de las obras públicas, especialmente de los caminos vecinales ${ }^{1083}$. Mateos Collantes recordaba que fue el único diputado provincial que impugnó el Plan General de Carreteras Provinciales vigente y que era partidario de defender la construcción de caminos vecinales. Guzmán Rodríguez manifestaba su desacuerdo con Mateos Collantes y Mora Alday, ya que el Distrito al que representaba Mora Alday está beneficiado por una carretera que le cruzaba ${ }^{1084}$, señalada con el número tres del primer grupo. Mateos Collantes manifestaba que no era partidario de que surgieran por ese motivo competencias entre los Partidos Judiciales y que debía contemplarse la utilidad de los caminos vecinales, ya que, en su opinión, la provincia contaba con buenas carreteras pero no con suficientes caminos vecinales. En el debate del Presupuesto Adicional del ejercicio 1888/89, el diputado provincial Joaquín Monedero y Monedero no estaba de acuerdo con la cantidad que se consignaba para Obras Públicas por las difíciles circunstancias económicas por las que atravesaba la provincia. En su opinión, antes de hacer caminos para el transporte de los productos, se necesitaba que hubiese producción, que se fomentaría haciendo canales de riego. Su compañero Guzmán Rodríguez le reprochaba que no hubiese sido consecuente con su pensamiento al conseguir dotar a Cevico de la Torre ${ }^{1085}$ de una carretera, merced a la cual aumentó su riqueza este pueblo y sus vinos adquirieron mayor precio en el mercado. Se declaraba Guzmán Rodríguez proteccionista acérrimo e independiente en materia económica y conceptuaba a Joaquín Monedero de ecléctico ${ }^{1086}$.

La situación de las carreteras provinciales, a fecha 1 de noviembre de 1883, era la siguiente: no se había ejecutado trabajo alguno en las diferentes secciones de las carreteras comprendidas en el Plan General de Carreteras Provinciales, aprobado por Real Decreto de 25 de agosto de 1879 y ningún municipio había incoado expediente alguno para poder optar a la subvención que la Diputación Provincial había acordado conceder, según disposición del gobernador civil en circular de 9 de octubre de 1879, en cumplimiento a lo dispuesto en la legislación vigente de Obras Públicas.

\footnotetext{
${ }^{1083}$ A.D.P.P., L.A.P.D. 55, 10-IV-1883.

${ }^{1084}$ Los diputados provinciales defendían la construcción de infraestructuras en sus distritos, conscientes de la importancia de unas buenas comunicaciones en el desarrollo económico y como oportunidad de ocupar a los parados de la zona. Por ejemplo, el diputado provincial Betegón García, electo por el Distrito de Frechilla, formó parte de la Comisión encargada de elaborar el Plan General de Carreteras Provinciales de 1879 y consiguió que las dos primeras en orden de preferencia para su construcción fuesen las de Mazariegos a Lagartos, y la del puente Don Guarín aVillada, ambas atravesaban el Distrito de elección del mencionado diputado provincial.

${ }^{1085}$ Incluido en el distrito electoral de Astudillo-Baltanás, del que era representante Monedero.

${ }^{1086}$ A.D.P.P., L.A.P.D. 64, 8-II-1888.
} 
En la fecha no existía ninguna obra de caminos vecinales que se hallase subvencionada por la provincia, excepto el puente de Villovieco, sobre el río Ucieza ${ }^{1087}$. La Diputación Provincial subvencionaba con un 50\% del importe de los presupuestos los proyectos de caminos vecinales aprobados por la misma ${ }^{1088}$. En 1894, por ejemplo, se subvencionaba con el 50\% las obras del camino vecinal de Barruelo a Cillamayor ${ }^{1089}$. En 1889, se fijaron las premisas ${ }^{1090}$ bajo las cuales la Diputación se encargaría de los proyectos de caminos vecinales:

1. Para no recargar el Contingente Provincial se solicitaría, en conformidad con el art. 77 de la Ley Provincial, la autorización del Gobierno para la emisión de un empréstito de 478.557,89 pts. para el año de 1889, con intereses anuales a razón de un $6 \%, 28.713,47$ pts.

2. De la cantidad que se adquiera a consecuencia de las operaciones de crédito, se consignarían en cada ejercicio económico $957.115,78$ pts. para que las obras se desarrollasen con gran actividad en los siguientes años por el mismo sistema de empréstito.

El diputado provincial García de Benito, autor de la proposición sobre caminos vecinales, señalaba que sin el apoyo económico de la Diputación Provincial, los ayuntamientos no habrían podido emprender ninguna obra de comunicación, «(...) encontrándose sin medios para transportar sus productos de una parte a otra.» ${ }^{1091}$ El diputado provincial Martínez Arto exponía que la proposición de García de Benito proyectaba la construcción de $4.453 \mathrm{~km}$ de carreteras municipales cuyo coste ascendería a 38 millones de pts. que habría de pagar la provincia, cuyo estado económico no permitía afrontar un gasto de ese valor. Propuso que no se tomase en consideración la propuesta, ni se gastase tiempo en algo que no se podía realizar. La proposición fue votada y desechada por quince votos en contra por cuatro a favor.

\footnotetext{
${ }^{1087}$ A.D.P.P., C-R/ 1,12 (A).

${ }^{1088}$ Art. 61 del Reglamento de 1 de agosto de 1877. Solo para los pueblos que estuviesen al corriente del pago del Contingente provincial y que se comprometiesen a conservar las obras. El porcentaje subvencionado por Diputación iría variando con el tiempo, en 1902 era de un $70 \%$.

${ }^{1089}$ A.D.P.P., L.A.C.P. 79, 12-X-1894.

${ }^{1090}$ A.D.P.P., L.A.P.D. 68, 2-IV-1889.

1091 A.D.P.P., L.A.P.D. 68, 2-IV-1889.
} 
Las disputas entre los diputados provinciales por conseguir obras para los distritos territoriales a los que representaban eran continuas, y en cada ocasión en la que estaba en juego la adjudicación de carreteras o caminos, el enfrentamiento surgía, poniendo en evidencia que, en contra del discurso oficial sobre el bien común independientemente de la adscripción ideológica y territorial, cada diputado provincial intentaba favorecer los intereses de aquellos que había contribuido a su elección. Con ocasión de la reforma de las Bases ${ }^{1092}$ para la concesión de subvenciones con destino a obras públicas que corrieran de cuenta de los ayuntamientos ${ }^{1093}$, el diputado provincial Yágüez Pascual señalaba que la reforma atacaba derechos adquiridos y venía a establecer un nuevo procedimiento ${ }^{1094}$. El diputado Rodríguez Lagunilla indicaba el favoritismo que se concedía a los Partidos Judiciales de Palencia, Frechilla y Baltanás en el Plan de carreteras provinciales ${ }^{1095}$, en detrimento de los partidos de Carrión de los Condes y Cervera de Pisuerga, para los que en este Plan no se consignaba presupuesto alguno ni obra. Para paliar en alguna medida esta circunstancia, se proponía que a Cervera de Pisuerga se le diese preferencia en las subvenciones para la construcción de caminos vecinales. Yagüez Pascual llamaba la atención sobre el hecho de que prescindiendo del distrito de Palencia, el de Baltanás, de los veintiún ayuntamientos que le componían, solo ocho disfrutaban de carreteras, hallándose los demás postergados, «(...) según reconociera el mismo presidente ${ }^{1096}$, que ostenta la representación del distrito». Rodríguez Lagunilla recordaba a Yagüez Pascual que la carretera de Calabazanos a Esguevillas cruzaba todo el territorio del Distrito de Baltanás y que el Distrito de Cervera no había recibido ninguna subvención. Al final, medió en la discusión el delegado provincial que advertía a los presentes que: «(...) se pretende sacar a plaza el espíritu regionalista que aquí no existe, porque los diputados representan a toda la provincia y defienden sus intereses por más que .se tengan muy en cuenta los de cada distrito.»» ${ }^{1097}$

\footnotetext{
${ }^{1092}$ Aprobadas el 9 de abril de 1890. La Base 4 señalaba que aprobado el proyecto de obras por la autoridad competente, el Ayuntamiento consignaría en su presupuesto el crédito necesario para la obra, sin ese requisito no podría obtener la subvención del 50\% del presupuesto, no pudiendo exceder en ningún caso de 10.000 pts. la cantidad con la que se subvencionase cada año a un mismo Ayuntamiento. La Base 7 concedía preferencia para la concesión de subvenciones a los ayuntamientos que tan solo solicitasen de los fondos provinciales el $25 \%$ del presupuesto aprobado de la obra a construir.

${ }^{1093}$ A.D.P.P., L.A.P.D. 74, 13-IV-1892.

${ }^{1094}$ Turno por Partidos Judiciales y división del crédito. El turno establecía el siguiente orden: 1) Cervera, 2) Carrión, 3) Saldaña, 4) Astudillo, 5) Frechilla, 6) Baltanás, 7) Palencia.

${ }^{1095}$ El personal de Diputación se encargaba de la formación de los proyectos, presupuestos, planos y condiciones facultativas, las cuales una vez aprobadas por la Diputación se devolvían a los pueblos interesados para que consignasen en su presupuesto el $30 \%$ del coste de la obra, requisito indispensable para poder iniciar la subasta de las obras.

${ }^{1096}$ Monedero y Monedero.

${ }^{1097}$ A.D.P.P., L.A.P.D. 74, 13-IV-1892.
} 
En 1895, la Diputación Provincial solicitaba al ministro de Fomento que se realizase el reconocimiento facultativo por el Cuerpo de Ingenieros de Obras Públicas de las carreteras provinciales de tercer orden ${ }^{1098}$, de Mazariegos a Lagartos y del Puente de Don Guarín a Villada, para incluirlas en el Plan General de Carreteras del Estado ${ }^{1099}$. El objetivo de la institución provincial era que el Gobierno realizase obras en la provincia dentro del Plan de Carreteras del Estado para emplear obreros, ya que por falta de medios económicos la Diputación no podía invertir casi fondos para este tipo de obras ${ }^{1100}$.

Como se ha señalado con anterioridad, una vez acabadas las obras se procedía a su recepción provisional y subsanados las deficiencias en esta primera etapa, se realizaba la recepción definitiva. Estos procedimientos han dejado un rastro documental que permite seguir la evolución de la construcción de carreteras y caminos provinciales a lo largo de la etapa comprendida entre los años 1875 y 1931. En 1882, se produjo la recepción definitiva de las obras de reparación del tramo segundo de la carretera de Mazariegos a Lagartos, y del tramo especial de empalme de nueva construcción de aquella con la de Palencia a Castrogonzalo ${ }^{1101}$. En 1893, las carreteras en construcción en la provincia eran cinco:

1. Puente Don Guarín hasta Villada

2. Calabazanos a Esguevillas

3. Villasarracino a Buenavista

4. Mazariegos a Lagartos

5. Melgar de Yuso a Osorno ${ }^{1102}$

En 1894, la recepción definitiva de las carreteras de Melgar de Yuso a Osorno, y de Mazariegos a Lagartos ${ }^{1103}$. En 1896, la recepción definitiva de la primera parte del cuarto tramo de la carretera de Villasarracino a Buenavista ${ }^{1104}$.

\footnotetext{
${ }^{1098}$ Las carreteras del Estado mantenían la misma clasificación establecida en 1857, Primer, Segundo y Tercer orden, dependiendo de su importancia y de si el ámbito de referencia era nacional, regional o local.

${ }^{1099}$ A.D.P.P., L.A.C.P. 79, 31-VII-1895. Ley de 14 de agosto de 1895.

${ }^{1100}$ A.D.P.P., C-R/ 1,8.

${ }^{1101}$ A.D.P.P., L.A.C.P. $58,2-\mathrm{I}-1882$.

${ }^{1102}$ A.D.P.P. C-R/ 1,11.

${ }^{1103}$ A.D.P.P., L.A.C.P. $79,22-\mathrm{VI}-1894$.

${ }^{1104}$ A.D.P.P., L.A.C.P. 84, 23-XII-1896.
} 
Para llevar a cabo estas tareas de construcción y conservación de las infraestructuras viarias, la Diputación Provincial contaba con personal y material propios. Adscritos a la Sección de Obras Públicas, los peones camineros ${ }^{1105}$ y capataces eran los encargados de la conservación de las carreteras provinciales. Los peones auxiliares nombrados por la Diputación Provincial para la conservación de caminos vecinales construidos con fondos del Estado dependían de la Jefatura de Caminos, Canales y Puertos y, dado el escaso sueldo que tenían, la Diputación les concedía licencia, previo permiso de la citada Jefatura, para dedicarse durante el verano a las tareas de recolección, dejando de percibir durante este tiempo sus haberes con cargo a los presupuestos provinciales.

En 1902, se señalaba la necesidad de reducir el personal de peones camineros, el estrictamente necesario pero ocupado todo el año ${ }^{1106}$, reemplazando los peones auxiliares a los camineros en épocas de mayor trabajo, ya que solo cobraban los días laborables y esto permitía a la Diputación mejorar la situación económica de peones camineros y capataces y así igualar sus haberes con los de su misma categoría del Estado ${ }^{1107}$. La Diputación Provincial también contaba con personal técnico en la Sección de Obras Públicas, un sobrestante y un director. Estos técnicos suponían un coste añadido para el presupuesto provincial y la Comisión Provincial trataba sobre la necesidad de reformar las indemnizaciones por salidas del personal técnico. Puesto que se consideraba insuficiente el pago de una cantidad fija en calidad de $\operatorname{dietas}^{1108}$, se proponía la indemnización por el mayor recorrido y se señalaban las cantidades pagadas por el Estado por este concepto. ${ }^{1109}$

\footnotetext{
${ }^{1105}$ Los diputados provinciales de cada distrito nombraban a los peones camineros que había de trabajar en las carreteras de su territorio, debían ser licenciados del Ejército.

${ }^{1106}$ Hasta 1900, los perones camineros trabajaban 275 días al año.

${ }^{1107}$ A.D.P.P. C-A 1,16 (A). En 1902, la plantilla se componía de tres capataces, con un salario anual de 730 pts. cada uno, y diecinueve peones camineros, con un sueldo de 640,50 pts. cada uno, con un total de 14.359 pts. Tras la reforma de personal, este se componía de tres capataces con un sueldo de 820 pts. por cabeza, y dieciséis peones camineros a razón de 730 pts. cada uno, con un total de 14.140 pts.

${ }^{1108}$ Por km, carretera, camino y ferrocarril.

${ }^{1109}$ Para el director facultativo: $0,12 \mathrm{pts}$. $/ \mathrm{km}$ en ferrocarril y $0,30 \mathrm{pts}$. $/ \mathrm{km}$ por carretera o camino, y para el sobrestante: $0,06 \mathrm{pts}$. $/ \mathrm{km}$ en ferrocarril y $0,10 \mathrm{pts}$. $/ \mathrm{km}$ por carretera o camino.
} 
En el inicio del siglo XX comenzó una fase expansiva del gasto estatal en infraestructuras, coincidiendo con las políticas regeneracionistas llevadas a cabo en el Ministerio de Fomento por el ministro Gasset. ${ }^{1110}$ Es en esta etapa, la inversión en la red de carreteras, el fomento de los ferrocarriles secundarios y la construcción de canales y puertos experimentó un fuerte impulso por parte del Gobierno central, lo que de alguna forma alivió las cuentas provinciales. La Diputación Provincial consignaba en sus presupuestos de 1902 los créditos necesarios ${ }^{1111}$ para subvencionar las carreteras ${ }^{112}$ que construyesen los ayuntamientos, carreteras municipales, reformas de puentes y pantanos y caminos vecinales. La normativa ${ }^{1113}$ señalaba que la Diputación Provincial se debía encargar de la formación de los proyectos, presupuestos, planos y condiciones facultativas, las cuales, una vez aprobadas por la Diputación, se devolvían a los pueblos interesados, para que consignasen en sus presupuestos el $30 \%$ de la obra, requisito imprescindible para anunciar la subasta de la obras.

${ }^{1110} C f$ r. CUELLAR VILLAR, Domingo, «Las obras públicas $y$ el marco institucional durante la Restauración. El Ministerio de Fomento (1875-1913)», Tst: Transportes, Servicios y telecomunicaciones, op. cit., pp. 71-95.

${ }^{1111}$ Presupuesto de esta partida: 290.291. 27, la Diputación Provincial subvencionaba el $70 \%$ de esta cantidad, 203.203, 85 pts.

${ }^{1112}$ Subvención a los ayuntamientos conforme a lo dispuesto en los arts. 51 y 52 de la Ley de 4 de marzo de 1877, art. 62 del Reglamento de Obras Públicas de 10 de agosto de 1877 y Bases establecidas por la Diputación Provincial el 14 de septiembre de 1886, reformadas en 13 de junio de 1899.

${ }^{1113}$ Conforme a lo dispuesto en los artículos 51 y 52 de la Ley de 4 de mayo de 1877 , artículo 62 de Reglamento de Obras Públicas de 10 de julio de 1877 y Bases del 14 de octubre de 1896, reformadas el 13 de junio de 1899. 
En 1903, el Pleno de la Corporación Provincial aprobaba el pliego de condiciones para la inclusión de las obras de caminos vecinales en el Proyecto del Estado ${ }^{114}$, entre otras condiciones se exigía que el coste medio de construcción por $\mathrm{km}$ en cada provincia no excediera de 5.000 pts. Para optar al concurso era condición indispensable la presentación del formal compromiso de los ayuntamientos de encargarse de la expropiación ${ }^{115}$ de los terrenos que ocupasen los referidos caminos y de la buena conservación de los mismos ${ }^{1116}$, puesto que muchos municipios no querían sufragar el coste de mantenimiento de las infraestructuras por ser demasiado onerosas para sus menguadas arcas. Este era el caso de los ayuntamientos de Piña y Támara, que en 1906 solicitaban que la Diputación Provincial nombrase un peón caminero que se encargase de la conservación de la carretera municipal que unía ambos pueblos. La Diputación contestaba que la conservación de los caminos vecinales con cargo al Presupuesto Provincial afectaba únicamente a los que figuraban en el contrato que había firmado la Diputación Provincial con la Dirección General de Obras el 10 de octubre de 1903.

No obstante, el diputado provincial García de Benito afirmaba que la intención de la Diputación en materia de caminos vecinales era que la conservación de los mismos se extendiese a todos los caminos construidos con las subvenciones concedidas por la Corporación Provincial, ya que «(...) es indudable que si la Diputación no nombra el personal encargado de la conservación de los caminos, siendo de cargo de los pueblos los materiales, seguramente que no tardarán en desaparecer tan importantes y necesarias vías de comunicación.» 1117

\footnotetext{
${ }^{1114}$ Real Orden de 3 de octubre de 1903. A.D.P.P., L.A.P.D. 95, 9-X-1903. En 1913, solo se habían construido en el conjunto del Estado $3.770 \mathrm{~km}$ de caminos vecinales, unos siete $\mathrm{km}$ por cada $1.000 \mathrm{~km}^{2}$ de superficie. En España, las diputaciones provinciales invertían un $10 \%$ de su presupuesto en carreteras, mientras que en Francia llegaba al 52\%. Vid. ALZOLA Y MINONDO, Pablo, Historia de las Obras Públicas en España, Bilbao, Colegio de Ingenieros de Caminos, Canales y Puertos, 1994.

${ }^{1115}$ Se pagaba en concepto de expropiación el $30 \%$ del valor tasado de las fincas.

${ }^{1116}$ Quejas de la Diputación Provincial sobre el poco cuidado y conservación de las obras realizadas en los pueblos, especialmente en los caminos vecinales, «(...) que luego de construido se abandona, como si ni hubiesen costado a la Asamblea el 70\% del importe de su presupuesto de contratas.» A.D.P.P., C-R/ 1,14. p. 8. La Base 11 que regulaba este tipo de obras, establecía que las Corporaciones municipales consignarían en sus presupuestos la cantidad anual que fijase el jefe facultativo de carreteras provinciales para la conservación de las obras. El art. 8 del Reglamento para la conservación y policía de las carreteras del Ministerio de Fomento de 1910, señalaba la obligación que tenían los alcaldes de cuidar en sus respectivos términos jurisdiccionales de que las carreteras estuviesen libres de obstáculos y de cuidar que los particulares no ocupasen temporal o definitivamente terrenos propios de las carretera. También debían impedir el vertido de basuras y aguas sucias a las carreteras y cunetas, cuidar de que el agua pudiese correr sin obstáculos por las cunetas y vigilar que las aguas de lluvia recogidas por los edificios y vertidas a las carreteras lo fuesen a nivel de las cunetas por tubos de bajada de desagüe.

${ }^{1117}$ A.D.P.P., L.A.P.D. 104, 26-IV-1906.
} 
La cuestión no se resolvió y los problemas del mantenimiento de carreteras y caminos continuaron hasta 1925, como demuestra el hecho de que en 1922 todavía seguía sin resolverse el citado caso de mal estado de conservación de la carretera municipal de Piña de Campos a Támara. Ante el requerimiento de los ayuntamientos interesados, la Diputación Provincial volvía a señalar entonces, como ya lo hiciera en 1906, que la concesión de subvenciones a los ayuntamientos por la Diputación para el desarrollo de obras públicas municipales, imponía a estos la obligación de consignar todos los años en su presupuesto la cantidad necesaria para la conservación de las obras, por lo tanto el ayuntamiento de Piña de Campos debía colocar la piedra necesaria para la conservación de la carretera citada ${ }^{1118}$.

En 1906, en la Asamblea de diputaciones en Madrid convocada por el ministro de Fomento para tratar de la construcción de los caminos vecinales, se acordaba aumentar el número de caminos vecinales y subastar las carreteras que figuraban en el Plan del Estado $^{1119}$. En septiembre de 1911, la Jefatura de Obras Públicas del Estado en la provincia remitía a la Diputación Provincial la relación de carreteras, secciones o tramos de las mismas que debían ser incluidas en los $109 \mathrm{~km}$ que correspondían a esta provincia de los $7.000 \mathrm{~km}$ asignados por la Ley de 20 de junio de 1911, cuya construcción había de quedar a cargo del Estado ${ }^{1120}$.

En 1913, la Comisión Provincial veía como el aumento del número de caminos vecinales y la imposibilidad de los ayuntamientos de hacer frente al coste de mantenimiento de los mismos, lastraban los presupuestos provinciales y consideró lo más adecuado solicitar al ministro de Fomento que el Estado se hiciese cargo de la conservación de los caminos vecinales, para ello se dirigieron cartas particulares a los representantes en Cortes de la provincia para que apoyasen esa petición ${ }^{1121}$. Ya en 1909, por Real Orden de 5 de febrero de 1909, el Estado había recibido a perpetuidad y título gratuito, sin hacerse cargo de ninguna clase de responsabilidades que pudieran existir por razón de construcción, expropiaciones, ni otro cualquier concepto, el camino vecinal de Villalobón a Valdeolmillos ${ }^{1122}$.

\footnotetext{
${ }^{1118}$ A.D.P.P., L.A.C.P. 134, 28-VIII-1922.

${ }^{1119}$ A.D.P.P., L.A.C.P. $102,22-\mathrm{V}-1906$.

${ }^{1120}$ A.D.P.P., L.A.C.P. $115,1-\mathrm{IX}-1911$.

${ }^{1121}$ A.D.P.P., L.A.C.P. 117, 24-I-1913.

${ }^{1122}$ A.D.P.P., L.A.C.P. 109, 20-II-1909.
} 
No solo la Diputación Provincial y los ayuntamientos solicitaban infraestructuras viarias, pues en 1914, la Cámara de Comercio e Industria de la provincia, dirigía una moción $^{1123}$ a la Presidencia de la Diputación para que apoyase un informe emitido por la Cámara sobre el Plan de Carreteras, por la no inclusión en el Plan General de Obras Públicas del Estado de varios tramos de nuevas carreteras que figuraban en el Plan de 1909:

1. De Paredes de Nava a Monzón.

2. De Lantadilla a Melgar de Fernamental.

3. De Cubillas de Cerrato a Dueñas. (Tramo completo)

4. De Menbrillar a Herrera de Pisuerga.

5. De Carrión a Gozón de Ucieza.

En la etapa de la Dictadura de Primo de Rivera, el Gobierno pretendía la transferencia a las diputaciones provinciales de la conservación de las carreteras de titularidad estatal. Para la Diputación Provincial esta reforma sería positiva, pues a diferencia de lo que ocurría anteriormente, por un lado el Estado cedería ingresos en favor de las diputaciones para que pudiesen hacerse cargo de las nuevas transferencias y, por otro, se terminaría con el régimen de favor que había con algunas provincias ${ }^{1124}$, que disfrutaban de carreteras a veces inútiles y otras carecían de «(...) aquellas indispensables para el sostenimiento de la vida relación social.» ${ }^{1125}$

\footnotetext{
${ }^{1123}$ A.D.P.P., L.A.C.P. 118, 2-VI-1914.

${ }^{1124}$ Gasto en piedra machacada para la conservación de carreteras provinciales en los últimos diez años, 1914-1924, en la provincia de Palencia: 64 pts. por km, en Guipúzcoa: 662 pts. por km, diez veces más.

${ }^{1125}$ A.D.P.P., L.A.C.P. $136,30-X I I-1924$.
} 
Al igual que en otras atenciones, la Memoria que las Corporaciones Provinciales debían elevar al Ministerio de Gobernación sobre los defectos que las Diputaciones observaran en su funcionamiento, permite conocer, mediante un informe elaborado por la Diputación Provincial, el estado de los servicios de Fomento encomendados a su gestión. Desde 1915 hasta 1924 las cantidades asignadas a la construcción y conservación de carreteras habían sido las siguientes:

Tabla 14. Cantidades en pts. consignadas en el Capítulo X del Presupuesto Provincial (Carreteras) en el periodo 1915/1924.

\begin{tabular}{|c|c|}
\hline Años & Cantidades \\
\hline 1915 & $47.219,75$ \\
\hline 1916 & $40.301,75$ \\
\hline 1917 & $42.601,50$ \\
\hline 1918 & $43.333,25$ \\
\hline 1919 & $43.333,25$ \\
\hline 1920 & 51.540 \\
\hline 1921 & 55.810 \\
\hline 1922 & 58.540 \\
\hline 1923 & 54.565 \\
\hline 1924 & 54.565 \\
\hline Promedio anual & 49.180 \\
\hline
\end{tabular}

Elaboración propia. Fuente: Memoria de deficiencias y soluciones de 1924. A.D.P.P C-R/ 1,12 (A). 
En 1924, el número de carreteras municipales ascendía a cinco, con una longitud total inferior a diecinueve km, habían sido construidas por la Diputación Provincial y pagadas por los pueblos interesados, cinco peones camineros ${ }^{1126}$ prestaban sus servicios en ellas. Respecto a las carreteras provinciales ${ }^{1127}$, todas ellas tenían la categoría del Tercer orden ${ }^{1128}$ del Estado, y fueron construidas en ejercicios anteriores a los diez últimos años.

Tabla 15. Carreteras provinciales en 1924.

\begin{tabular}{|c|c|}
\hline Carretera & Longitud en km \\
\hline Calabazanos-Esguevillas & 24,325 \\
\hline Tariego-Ampudia-Encinas & 6,7 \\
\hline Villasarracino-Buenavista & 29,9 \\
\hline Astudillo-Osorno & 30,02 \\
\hline Total & 90,945 \\
\hline
\end{tabular}

Elaboración propia. Fuente: Memoria de deficiencias y soluciones de 1924. A.D.P.P C-R/ 1,12 (A).

${ }^{1126}$ Interinos, nombrados por la Comisión Provincial.

${ }^{1127}$ La Diputación defendía y solicitaba la plantación de dos hileras de árboles, distanciados cinco metros cada uno, en los $90 \mathrm{~km}$ de la red provincial de carreteras. Servirían para sostener el talud de las cunetas de las carreteras, dar sombra y además, harían de frontera para las depredaciones de los vecinos colindantes y a los treinta años valdrían 900.000 pts. costando apertura de un hoyo 25 cént., y el árbol regalado por el Estado.

${ }^{1128}$ Anchura de seis metros. 
En lo que se refiere a gastos por materiales de conservación, dividiendo el total de pts. gastadas por el concepto de carreteras provinciales (acopios) cada año por el número de $\mathrm{km}(90,045)$, se obtienen valores medios del gasto anual por km entre los años $1914 \mathrm{y}$ 1923, inicio de la etapa de la Dictadura.

Tabla 16. Gasto anual por km en carretas provinciales entre los años 1914/1923.

\begin{tabular}{|c|c|}
\hline Años & Pts. \\
\hline 1914 & 72,13 \\
\hline 1915 & 60,40 \\
\hline 1916 & 38,47 \\
\hline 1917 & 72,15 \\
\hline 1918 & 72,15 \\
\hline 1919 & 72,13 \\
\hline 1920 & 72,16 \\
\hline 1921 & 77,72 \\
\hline 1922 & 99,93 \\
\hline 1923 & 97,41 \\
\hline Promedio anual del periodo $1914 / 1923$ por km & 64,46 \\
\hline
\end{tabular}

Elaboración propia. Fuente: Memoria de deficiencias y soluciones de 1924. A.D.P.P C-R/ 1,12 (A). 
La inversión total realizada por la Diputación Provincial en carreteras provinciales en el periodo 1914-1923 fue:

Tabla 17. Gasto total en pts. en carreteras provinciales en el periodo 1914/1923.

\begin{tabular}{|c|c|}
\hline Años & Cantidad en pts. \\
\hline 1914 & $3.741,47$ \\
\hline 1915 & 3.950 \\
\hline 1916 & $2.443,20$ \\
\hline 1917 & $2.849,18$ \\
\hline 1918 & $2.942,8$ \\
\hline 1919 & $3.698,05$ \\
\hline 1920 & $2.747,27$ \\
\hline 1921 & $3.062,10$ \\
\hline 1922 & $3.866,95$ \\
\hline 1923 & $3.874,15$ \\
\hline
\end{tabular}

Fuente: Elaboración propia. A.D.P.P., Memoria de deficiencias y soluciones de 1924, C-R/1,12.

En 1924, la Diputación Provincial presumía del estado de conservación de las carreteras provinciales, que contaban con $90 \mathrm{~km}$ con seis $\mathrm{m}$ de anchura y únicamente el tramo de la carretera de Calabazanos a Esguevillas, entre los $\mathrm{km}$ tres y siete, estaban en mal estado, y por causa de la cercanía de una cantera de donde salían por carretera entre 12.000 y $15.000 \mathrm{~m}^{3}$ de piedra. Era frecuente que los concursos anunciados en el BOP para la adquisición de piedra machacada con destino a la conservación de varios caminos vecinales quedasen desiertos, por lo que se autorizaba al ingeniero jefe de la Sección de Obras para que se realizase este servicio por administración ${ }^{1129}$. 
En el Presupuesto de 1924/25 se destinaba una partida de 2.500 pts. para la creación de un vivero de arbolado para las carreteras provinciales y la construcción de una casa para vivienda del encargado ${ }^{1130}$. En 1926, el aumento en la recaudación tributaria, fruto de las medidas en materia de autonomía fiscal que disponía el Estatuto Provincial de 1925, permitió a la Diputación Provincial la adquisición de un cilindro-apisonador con motor de explosión y dos carros cubas a la Casa Ferrovías y Siderurgia S.A, para la Sección de Vías y Obras ${ }^{1131}$. En 1927, se autorizaba al ingeniero jefe de la Sección de Vías y Obras a adquirir una segunda apisonadora para la conservación de caminos vecinales y dos carros cuba ${ }^{1132}$.Quedaban lejos los tiempos en los que, como en 1909, se pedía al jefe de Obras Públicas del Estado que facilitase al contratista de la carretera municipal de Carrión a Lerma, uno de los rodillos del Estado, para la comprensión artificial de la citada vía $^{1133}$.

La construcción de caminos vecinales recibió un fuerte impulso en periodo dictatorial, y en 1927 se aprobó un nuevo Plan de caminos vecinales, que establecía dos grupos ${ }^{1134}$ :

1. Caminos para cuya construcción habían ofrecido auxilio los pueblos interesados. Para determinar el orden de preferencia de estos caminos se tenía en cuenta el tanto por ciento que habían aportado los ayuntamientos en la subvención que les correspondía recibir y cuando este porcentaje era igual, se determinaba la preferencia en razón directa del número de habitantes, e inversa del coste de las obras.

2. En los caminos para los que no se ofrecían auxilios para su construcción a los pueblos interesados, se hacía una subdivisión:

a) Caminos que estaban destinados a enlazar pueblos incomunicados.

b) Caminos destinados a enlazar pueblos incomunicados entre sí, pero que ya tenían comunicaciones con carreteras, ferrocarriles, etc., habiéndose clasificado según el interés de la zona o región.

\footnotetext{
${ }^{1130}$ A.D.P.P., C-L/ 12,5

${ }^{1131}$ A.D.P.P., L.A.C.P. 142, 7-IV-1926.

${ }^{1132}$ A.D.P.P., L.A.C.P. 143, 27-II-1927.

${ }^{1133}$ A.D.P.P., L.A.C.P. 92, 9-I-1900.

${ }^{1134}$ A.D.P.P., L.A.P.D. 138, 24-II-1927.
} 
El estado de la red de caminos vecinales de la provincia de Palencia a 31 de diciembre de $1927^{1135}$ era el siguiente:

1. Plan de la Diputación Provincial:

- Caminos completamente terminados: 205,245 km

- Caminos en construcción: 23,228 km

- Caminos en proyecto: $579 \mathrm{~km}^{1136}$

2. Plan del Estado:

- Caminos terminados: $74,34 \mathrm{~km}$

En la sesión del 13 de abril de 1928, se discutió el proyecto de Mancomunidad Provincial de Diputaciones de Régimen Común para la emisión de un empréstito de 300 millones de pts. destinados a la construcción de caminos vecinales mediante la subvención del Estado. Los diputados provinciales acordaron estudiar con detenimiento el proyecto pero sin perder de vista que la situación económica de la Diputación Provincial era lo suficientemente holgada como para acometer por cuenta propia importantes empresas. El diputado provincial Martínez Bustillo no veía en la Mancomunidad peligro ${ }^{1137}$ alguno para la Diputación Provincial y, aun estando esta capacitada para realizar obras importantes por su situación económica, el Plan de caminos vecinales era de tal magnitud que en su opinión necesitaría cuantiosos recursos, para cuya obtención se necesitaría un empréstito, motivo último de la creación de la Mancomunidad. El fin que perseguía la Mancomunidad era el de procurar fondos para llevar a cabo en un plazo breve las obras correspondientes al Plan General de caminos vecinales ${ }^{1138}$, por unanimidad se acordó mancomunarse al fin expresado, de conformidad con lo establecido en los arts. 18 y 19 del Estatuto Provincial de $1925^{1139}$.

\footnotetext{
${ }^{1135}$ A.D.P.P. C-R/ 1,19 (A).

${ }^{1136}$ Coste aproximado de la construcción de los caminos en proyecto: 9.416.422. de pts., de los cuales 5.533.752,21 pts. serían subvencionadas por el Estado y 3.8882.669, 79 pts. con recursos propios de la Diputación Provincial. Había que añadir el importe de los intereses del empréstito pedido y en parte amortizado con la subvención del Estado.

${ }^{1137}$ La operación no comportaba peligro para la Diputación, dado que al pago de la amortización se destinaba única y exclusivamente la subvención del Estado para caminos vecinales. La solidaridad entre diputaciones tampoco entrañaba el riesgo de tener que pagar la parte correspondiente de otras diputaciones, ya que todas tenían garantizada la deuda con el importe de la subvención.

${ }^{1138}$ A.D.P.P., L.A.P.D. 139, 13-IV-1928.

${ }^{1139}$ A.D.P.P., L.A.P.D. 139, 13-IV-1928.
} 
El diputado provincial Velasco Inchausti señalaba, el 29 de mayo de 1928, que en la sesión del Pleno del día 13 de abril de 1928, se había acordado mancomunarse porque se creyó requisito esencial para no perder la diferencia de años en el percibo de la subvención del Estado, pero el escenario había cambiado dados los términos en que estaba concebido el Real Decreto Ley de 11 de abril de $1928^{1140}$, por lo que se acordó por unanimidad no adherirse a la Mancomunidad de Diputaciones, porque en virtud de lo dispuesto en el citado Real Decreto Ley, habían variado completamente los motivos ${ }^{1141}$ en que se inspiró el acuerdo adoptado por el Pleno en la sesión del 13 de abril de $1928^{1142}$. Así pues, en vísperas del final de la Restauración, la Diputación Provincial tenía la suficiente solvencia financiera para afrontar inversiones de cuantía significativa gracias a las medidas contempladas en el Estatuto Provincial de 1925, que había dotado de mayor independencia a las diputaciones provinciales a la hora de recaudar los impuestos propios y los cedidos por el Estado, y también al traspaso de atribuciones al Estado que antes pesaban sobre el Presupuesto Provincial. Como consecuencia, la provincia contaba con una red viaria que a pesar de las lógicas carencias, había mejorado notablemente con respecto al año de inicio de la Restauración, 1875.

\footnotetext{
${ }^{1140}$ Gaceta de Madrid de 15 de abril de 1928.

${ }^{1141}$ El Decreto autorizaba a las diputaciones de Régimen Común para que mancomunada o separadamente, pudiesen emitir empréstitos, o contratar créditos para la construcción de caminos vecinales.

${ }^{1142}$ A.D.P.P., L.A.P.D. 139, 29-V-1928.
} 


\section{Ferrocarriles}

El ferrocarril había sido uno de los motores de la Revolución Industrial en Inglaterra, y este hecho quedó marcado a fuego en la memoria de los políticos españoles de la Restauración, pues para ellos este medio de transporte representaba la modernidad que querían para España. Tampoco se puede olvidar que muchos de los diputados provinciales tenían intereses en la industria harinera y el ferrocarril era una de las mejores opciones para transportar la materia prima necesaria para este sector, el cereal. La relación valor/peso hacía de este medio el más aconsejable para transportar los productos de las dos principales actividades económicas de la provincia, el cereal y el carbón. Convencida de que las comunicaciones vertebrarían a la nación y contribuirían a hacer mercado, la Diputación Provincial de Palencia dedicó un gran esfuerzo a posibilitar la construcción de líneas férreas que comunicasen a los pueblos de la provincia entre sí, especialmente la cuenca minera del norte con el sur de la provincia, y a esta con el resto de España. Sin embargo, la suerte no siempre acompañó a la institución provincial en este intento, aunque queda patente que el ferrocarril fue un objetivo fundamental en la labor de gestión de las obras públicas de la Diputación palentina entre los años 1875 y 1931. En 1877, el diputado provincial Mateos Collantes se hacía eco del pensamiento unánime de la Diputación Provincial, cuando solicitaba al Ministerio de Fomento que la suspensión del traslado de las oficinas de los ferrocarriles del Noroeste de España a la ciudad de León fuera definitiva y se constituyese en la ciudad de Palencia ${ }^{143}$. Este era solo un ejemplo del interés provincial porque el ferrocarril formase parte de la vida económica de la provincia. Durante la Restauración, el crecimiento de las líneas de vía estrecha fue muy significativo, alcanzando en 1910 una extensión de $3.316 \mathrm{~km}^{1144}$, correspondiendo la mayor parte de ellas al tráfico de mercancías, en concreto de materias primas minerales, carbón especialmente.

\footnotetext{
${ }^{1143}$ A.D.P.P., L.A.P.D. $48,22-X I-1877$.

${ }^{1144}$ Del total del coste de las líneas secundarias, unos 470 millones de pts. en 1900, el Estado había aportado en concepto de subvenciones un $0,8 \%$. Vid. GÓMEZ MENDOZA, Antonio, Ferrocarriles y cambio económico en España (1855-1913), Madrid, Alianza Editorial, 1982.
} 
Los proyectos ferroviarios a los que se sumó la Corporación Provincial fueron numerosos y se movilizaron cuantiosos recursos humanos y materiales para que el Gobierno de la nación incluyese a Palencia en los planes de construcción de vías férreas, especialmente las que unían el noroeste peninsular con el Mediterráneo, dada el valor estratégico que jugaba Palencia por su localización geográfica, como nudo de comunicaciones entre ambos territorios. El sistema ferroviario español se estructuraba en líneas generales y secundarias, las primeras de ancho ibérico y las segundas de vía estrecha. Francesc Cambó se lamentaba en su libro Política Económica ${ }^{1145}$, de que la excesiva atención por parte del Gobierno a la red de ferrocarriles secundarios en detrimento de la red general, no había servido para que se construyesen este tipo de líneas, pero sí para no construir líneas generales.

La labor de la Diputación Provincial en esta materia, se dirigió hacia los dos ámbitos posibles de actuación, proyectos de líneas generales y, sobre todo, proyectos de ferrocarriles secundarios. En el terreno de las líneas generales, varios fueron los proyectos en los que la Diputación Provincial actuó en favor de lograr para la provincia que los futuros ferrocarriles transcurriesen por tierras palentinas. Como en otros aspectos, la Diputación Provincial solicitaba siempre la colaboración de los diputados a Cortes por la provincia, consciente de que la cercanía al poder era un valor añadido a la hora de llevar a buen puerto las aspiraciones provinciales. Así se hizo también en materia de ferrocarriles, y en 1887 se daba un Voto de Gracias al diputado a Cortes de la provincia, Lorenzo García Benito $^{1146}$, por el celo y aptitud que había demostrado con motivo del Proyecto de Ley por el cual había de concederse un ferrocarril con una subvención del Estado que partiendo de la estación del Noroeste en Palencia, condujese directamente a San Estaban de Gormaz en la provincia de Soria ${ }^{147}$.

\footnotetext{
${ }^{1145}$ Vid. CAMBÓ BATLLE, Francesc, Política Económica, Madrid, Editorial Alpha, 1999.

${ }^{1146}$ Liberal entusiasta, fue el autor del proyecto de ferrocarril de Palencia a San Esteban de Gormaz, era diputado a Cortes por el distrito de Astudillo, le unía una gran amistad con Sagasta.

${ }^{1147}$ A.D.P.P., L.A.P.D. $63,25-\mathrm{V}-1887$.
} 
El proyecto estaba pendiente de aprobación en el Senado ${ }^{1148}$, este ferrocarril permitiría abaratar el coste de transporte de los cereales de Palencia a Cataluña, único mercado importante, puesto que el de Santander había bajado considerablemente como consecuencia de los Tratados con Estados Unidos ${ }^{149}$. El trayecto más corto hasta Cataluña era desde Palencia hasta Zaragoza, por Miranda de Ebro y Castejón, con un recorrido de $428 \mathrm{~km}$, pero la línea en proyecto sería de $328 \mathrm{~km}$, un total de cien $\mathrm{km}$ menos, lo que representaba un punto en el coste del arrastre por fanega de trigo. Palencia y Medina del Campo eran los principales graneros de Castilla, y ambos dependían en buena medida del mercado de trigos de Barcelona, donde tenían que competir con el trigo procedente de la India. Además, ambas localidades servían de nexo entre Aragón y Cataluña con Galicia, Asturias y Santander, o lo que es lo mismo, entre el Atlántico y el Mediterráneo. Los diputados provinciales Luis Martínez de Azcoitia, Gumersindo Ausín y Eduardo Rodríguez Tabares fueron designados por la Comisión Provincial para que se reunieran con los senadores y diputados que representaban a la provincia y les transmitiesen la necesidad de defender ante los cuerpos colegisladores y el Ministerio de Fomento, la aprobación definitiva del ferrocarril de Palencia a San Estaban de Gormaz ${ }^{150}$.

En 1916, la Diputación daba su apoyo a la construcción de un ferrocarril entre Palencia y Gijón, y solicitaba el apoyo a este proyecto a los representantes en Cortes de Palencia, ya que sería bueno para los Partidos Judiciales de Carrión y Saldaña, para transportar sus productos y obtener mejores precios ${ }^{1151}$. En 1917, la Diputación Provincial dirigía un escrito al director de la Casa de América de Barcelona en el que manifestaba su interés en que el proyecto de ferrocarril Vigo-Barcelona contemplase discurrir por el trayecto Aranda-Palencia-Villalón-Benavente. En esta petición contaba con el apoyo de la Cámara de Comercio y la Sociedad Económica de Amigos del País de Palencia ${ }^{1152}$.

\footnotetext{
${ }^{1148}$ Parece que los diputados y senadores por la provincia de Valladolid, guiados por Gamazo, pusieron todo tipo de impedimentos para que el proyecto no fuese aprobado, ya que para su provincia era más beneficioso que se aprobase el proyecto de Medina del Campo a Calatayud. Cfr. GONZALO ANDRÉS, Donato, Los políticos de Palencia y su provincia. (Bocetos y semblanzas). Tomo II, Palencia, Imprenta de Abundio Z. Menéndez, 1891, p. 61.

${ }^{1149}$ Se consideraba que la creación de nuevas vías de comunicación para los cereales castellanos era la única forma de competir con los trigos importados desde Estados Unidos.

${ }_{1150}^{15 . D . P . P ., ~ L . A . C . P . ~} 67,16-\mathrm{III}-1888$.

${ }^{1151}$ A.D.P.P., L.A.C.P. 124, 26-VI-1916.

${ }^{1152}$ A.D.P.P., L.A.C.P. $125,11-\mathrm{VI}-1917$.
} 
En 1927, la Comisión Provincia encomendaba al diputado provincial ponente de Fomento que concretase una propuesta de las aspiraciones de la capital sobre que el trazado del ferrocarril proyectado entre Vigo y Barcelona pasase por la ciudad, en consonancia con la campaña del Diario Palentino para conseguir este fin, y que este acuerdo se hiciese público en la prensa local ${ }^{1153}$.

Respecto de las líneas de ferrocarriles secundarios, la Diputación Provincial brindó siempre su apoyo a cualquier proyecto que pudiera revertir en el aumento de la riqueza provincial, y en esta época hubo una verdadera explosión de proyectos de líneas de vía estrecha, aunque la mayoría no llegasen a materializarse. Uno de los de mayor interés para las cuencas mineras del norte de la provincia fue el proyecto del ferrocarril de La Robla a Valmaseda, «(...) que ha de poner en explotación las riquísimas comarcas carboníferas de la parte septentrional de la provincia.» ${ }^{1154}$ En 1891, la Comisión de Fomento de la Diputación Provincial emitió un dictamen relativo al ferrocarril de La Robla a Valmaseda, para el que se proponía una subvención de 5.000 pts. por km de los 70 que debían transcurrir y construirse por la provincia ${ }^{155}$, el proyecto se materializó y en 1892, se procedía a la expropiación de fincas en Mantinos y Guardo con motivo de la construcción de esta línea férrea ${ }^{1156}$. Los proyectos ferroviarios en los que puso más empeño la institución fueron los que unirían el norte de la provincia y la capital, dada la configuración geográfica de la provincia. En 1899, la Comisión Provincial apoyó una moción a la petición del diputado provincial García Crespo sobre la construcción de un ferrocarril de Guardo a Carrión ${ }^{1157}$. De la lectura de las Actas de las sesiones de la Comisión Provincial se desprende que había una empresa próxima a constituirse que iba a construir una línea de ferrocarril desde Guardo a Carrión sin subvención del Estado ni de la provincia. La Comisión Provincial acordó, que una vez se hubiese constituido la empresa, solicitaría el apoyo de los pueblos y de los poderes públicos. «La Comisión ve con gusto la asociación de capitales para el desarrollo de la riqueza de la provincia.» ${ }^{158}$

\footnotetext{
${ }^{1153}$ A.D.P.P., L.A.C.P. 143, 30-III-1927.

${ }^{1154}$ A.D.P.P., L.A.P.D. 69, 15-IV-1890.

${ }^{1155}$ A.D.P.P., L.A.P.D. 70, 16-IV-1891.

${ }^{1156}$ A.D.P.P., L.A.C.P. 77, 14-XI-1892.

${ }^{1157}$ A.D.P.P., L.A.C.P. 91, 14-XII-1899

${ }^{1158}$ A.D.P.P., L.A.C.P. 93, 30-XI-1901.
} 
En 1900, el diputado García de los Ríos solicitaba a la Diputación que gestionase con la Compañía de los Ferrocarriles del Norte, para que el tren provincial arrancase en la estación de Quintanilla de las Torres en vez de Alar del Rey. Su compañero de Corporación, Polanco y Polanco pedía que el citado tren llegase hasta Dueñas en lugar de detenerse en Palencia y así recorrería todo la provincia ${ }^{1159}$. Sin duda, en materia de ferrocarriles, el proyecto estrella fue el que debía unir a Guardo con Palencia. En 1893 ya se había solicitado al Gobierno ${ }^{160}$ una línea entre Palencia y Guardo que pasase por Carrión y Saldaña ${ }^{1161}$ y se acordó conceder una subvención de 3.000 pts. para el estudio del ferrocarril de Palencia a Guardo. En 1901, se subvencionó, por parte de la Diputación Provincial, el estudio del proyecto del ferrocarril entre Guardo y Carrión con la cantidad de 7.000 pts. y en ese año ${ }^{1162}$, el diputado provincial García Crespo presentó una moción acerca de los estudios de un ferrocarril de vía estrecha entre Palencia y Guardo. No era la primera vez que este diputado apoyaba esta iniciativa ya que en 1894, la Junta Directiva de la Sociedad Económica de Amigos del País de Palencia, de la que García Crespo era vicepresidente $^{1163}$, había dirigido una moción a la Diputación Provincial para que se subvencionasen en calidad de reintegro los estudios del anteproyecto de dicho ferrocarril.

Imagen 08. Proyecto del ferrocarril entre Guardo y Palencia. Plano General (topográfico): “Trozo 5””.

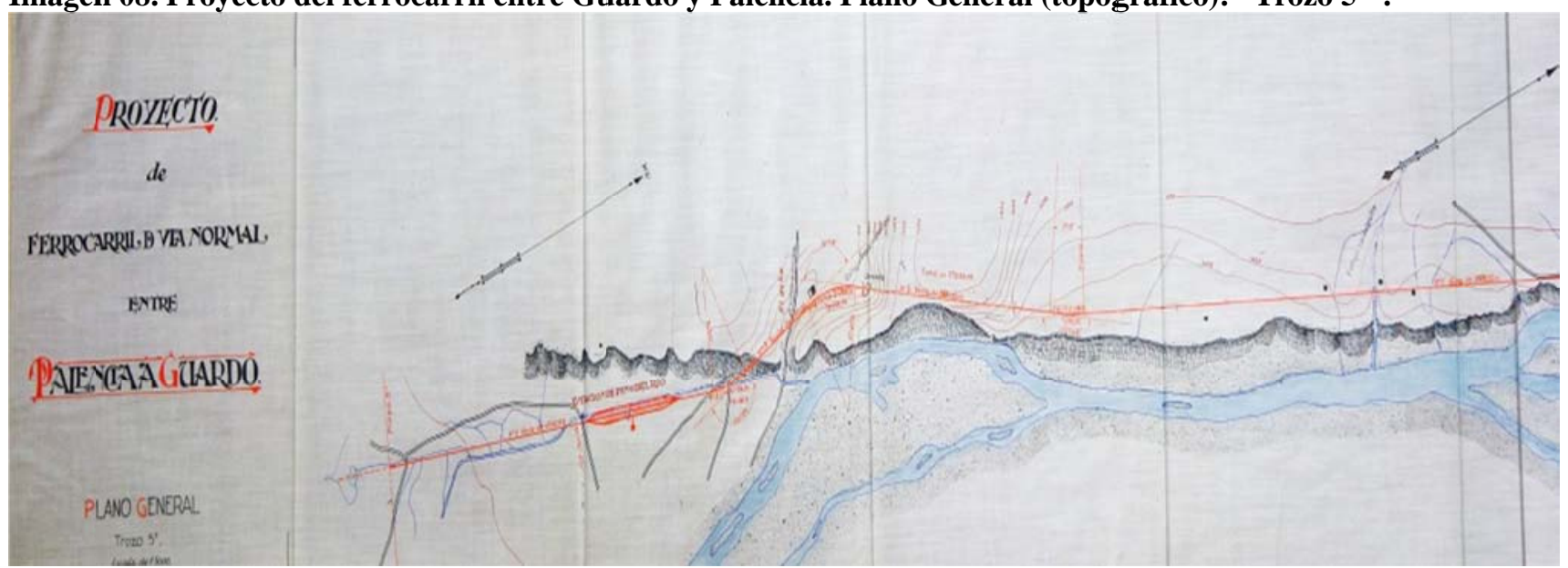

Fuente: A.D.P.P. C-L/G 443.

\footnotetext{
${ }^{1159}$ A.D.P.P., L.A.P.D. 88, 29-X-1900.

${ }^{1160}$ El Gobierno no había incluido esta línea en su Plan de Ferrocarriles Secundarios publicado en la Gaceta de Madrid del 18 de enero de 1893.

${ }^{1161}$ A.D.P.P., L.A.P.D. 89, 25-II-1901.

${ }^{1162}$ Con fecha de 8 de marzo de 1894.

${ }^{1163}$ García Crespo comentaba entonces: «(...) la Económica que está intensamente convencida de las ventajas que el ferrocarril ha de proporcionar al comercio, a la industria y a la agricultura.»
} 
No solo la Diputación creía que el ferrocarril traería riqueza y bienestar para la provincia, los pueblos se disputaban formar parte del recorrido de alguna de las líneas de este tipo y, para conseguirlo, estaban dispuestos a ceder terrenos y subvencionar la construcción de las mismas. En 1904, el Ayuntamiento de Revenga comunicaba a la Diputación Provincial ${ }^{1164}$ que estaba dispuesta a subvencionar con la cantidad de 1.000 pts. por km el ferrocarril secundario ${ }^{1165}$ de Carrión a Torquemada, que figuraba en el Plan de Ferrocarriles Secundarios de la Provincia ${ }^{1166}$, cediendo, además, el terreno que ocupase dentro del término municipal y el que se necesitase para la estación y casillas.

En 1904, los diputados provinciales Jubete Tejerina, Santander Gallardo y Doncel Aguirre también suscribían una moción recomendando a la Asamblea que al formar el Plan de las vías de comunicación de la provincia, se incluyeran los ferrocarriles secundarios de Palencia a Guardo, Palencia a Villalobón, el de enlace en Palencia del que se construyese entre Burgos y Aranda o Roa, el de Sahagún a Quintana, el de Aguilar de Campoo a Burgos y el del empalme en Osorno hacia Burgos, que se proyectaba por Lerma, Pampliega y Castrojeriz ${ }^{1167}$. Los diputados provinciales solicitaban que los diferentes ferrocarriles secundarios que discurrirían por el territorio de sus Distritos de elección ocupasen el primer lugar de la propuesta que se había de elevar al Ministerio de Fomento y así, el diputado provincial por Saldaña, Herrero Abia, pedía que figurase en primer lugar la línea Palencia a Guardo, que pasaría por Saldaña. Guigelmo Aguado, representante del Distrito Carrión-Frechilla, proponía que fuese la primera la línea la de Aranda a Palencia y Villarramiel ${ }^{1168}$. En 1908, la Diputación Provincial dirigía una petición al Gobierno de la provincia para que elevase todas las diligencias al Ministerio de Fomento de los proyectos de ferrocarriles secundarios de Medina de Rioseco a Villada por Villalón, y de Palencia a Villalón por Villarramiel ${ }^{1169}$.

\footnotetext{
${ }^{1164}$ A.D.P.P., L.A.C.P. 100, 15-X-1904.

${ }^{1165}$ La Ley de Ferrocarriles de 1877 subdividía los ferrocarriles de vía estrecha en secundarios y estratégicos. Las líneas de ferrocarriles secundarios obtenían escasa subvención del Estado vía directa, pero si se podían acoger a los beneficios de las Obras Públicas para acceder a las expropiaciones forzosas, o conseguir exacciones aduaneras para el material a importar.

${ }^{1166}$ El 7 de octubre de 1904, la Diputación Provincial aprobó el Plan de ferrocarriles secundarios.

${ }^{1167}$ A.D.P.P., L.A.P.D. 96, 27-VIII-1904.

${ }^{1168}$ Tras la votación, la línea Aranda-Palencia-Villarramiel ocupó el primer lugar de la lista, el segundo lugar lo ocuparía la de Palencia a Guardo. A.D.P.P., L.A.P.D. 96 7-X-1904.

${ }^{1169}$ A.D.P.P., L.A.C.P. $108,25-\mathrm{IX}-1908$.
} 
El 24 de julio de 1908, el alcalde de Palencia, Francisco Durán, emitía un bando municipal $^{1170}$ con motivo del paso por la estación de Palencia del ministro de Fomento Augusto González Besada, que había concedido a Palencia cuatro líneas de ferrocarriles secundarios y «(...) tiene una excelente disposición para las obras hidráulicas, que han de servir una vez construidas para que el Canal de Castilla, Canal de Alfonso XIII y Canal del Arlanza, puedan dedicarse al riego.» ${ }^{171}$ En 1910, el Ministerio de Fomento otorgó concesión de los ferrocarriles secundarios, con garantía de interés por el Estado, de Palencia a Villalón y de Medina de Rioseco a Villada, a la Compañía de Ferrocarriles de Castilla $^{1172}$. Un vez concedidas las líneas ferroviarias, si el presupuesto lo permitía, se acometía la construcción de la misma con el objetivo de poner en servicio esta infraestructura lo antes posible. En 1921, tan solo dos años después de la concesión por parte del Gobierno, el diputado provincial García de los Ríos solicitaba la concesión de la Cruz de la Orden de Alfonso XII a los ingenieros Antonio Faquineto y Gregorio Pérez Conesa por su trabajo en la finalización de los trabajos del ferrocarril secundario de Palencia a Villalón, construido en menos de dos años e inaugurado por el rey Alfonso XIII el 1 de julio de 1912. Se acordó por unanimidad del pleno de la Diputación Provincial solicitar la distinción ${ }^{1173}$.

No siempre se materializaban los proyectos con tanta diligencia. En 1916, el diputado provincial, Muñoz Jalón, dirigía un ruego a la Presidencia de la Diputación Provincial $^{1174}$ para que se interesara por la construcción del ferrocarril secundario de Palencia a Aranda. Presidencia contestaba diciendo que lo más importante en materia de ferrocarriles secundarios ${ }^{1175}$ era llegar a la igualdad entre los pueblos incluidos en el Plan General y los que no lo estaban, ya que todos tenían la necesidad de esta clase de vías de comunicación $^{1176}$.

\footnotetext{
${ }^{1170}$ El bando requería al pueblo de Palencia para que demostrase su gratitud al ministro y acudiese a saludarle a su paso por la ciudad para expresarle su reconocimiento y «(...) para que pueda ver por sí mismo que en los asuntos que afectan al porvenir de Palencia, estamos todos unidos, sin distinción alguna, con el mejor entusiasmo para conseguir el solicitado traslado del enlace del ferrocarril del Norte de la línea de Francia a Venta de Baños.»

${ }^{1171}$ A.D.P.P., C $19 / 1$.

${ }^{1172}$ A.D.P.P., L.A.C.P. $114,11-\mathrm{II}-1910$.

${ }^{1173}$ A.D.P.P., L.A.P.D. $112,15-X-1912$

${ }^{1174}$ A.D.P.P., L.A.P.D. 122, 13-XI-1916.

${ }^{1175}$ Líneas de ferrocarril de vía estrecha que atravesaban Tierra de Campos y conectaban localidades de las provincias de León, Palencia, Valladolid y Zamora.

${ }^{1176}$ Los pueblos afectados por vías férreas secundarias incluidas en el Plan General no contribuían con ninguna aportación económica a la construcción de las mismas y los que no lo estaban, tenían que sufragar el $50 \%$ del coste de la construcción, lo que equivalía a la renuncia de estas líneas, dado el lamentable estado de las haciendas municipales.
} 
Los proyectos de ferrocarriles secundarios en los que más empeño puso la Diputación Provincial fueron el ya mencionado de Guardo a Palencia, y el de Palencia a Aranda de Duero. Puesto que el Gobierno de la nación no se mostraba receptivo a las peticiones de la Diputación sobre la subvención a estas líneas, en 1923, se presentó una moción suscrita por doce diputados provinciales para que la Corporación Provincial ejecutase por cuenta propia la construcción de los ferrocarriles Palencia-Guardo y Palencia-Aranda, utilizando, en este último caso, la facultad de mancomunarse con la Diputación de Burgos, solicitando del Estado el máximo de auxilios que pudieran concederse a esta clase de obras y autorización para contratar el empréstito necesario, así como para establecer arbitrios especiales que garanticen dicho empréstito ${ }^{1177}$. El deseo de contar con una línea que uniese el norte y sur de la provincia era tal, que en 1924 la Comisión Provincial acordó dirigirse a los alcaldes de Carrión y Saldaña para que convocasen a una reunión a todos los alcaldes de sus respectivos Partidos Judiciales, para que, estos y los vecinos, hiciesen ofrecimientos para facilitar la ejecución del ferrocarril Palencia-Guardo, cediendo gratuitamente los terrenos que tendrían que expropiarse o cederlos a un bajo precio ${ }^{1178}$, incluso se llegó a un acuerdo para, junto con el Partido Judicial de Riaño, solicitar la construcción del ferrocarril de Palencia a Guardo ${ }^{1179}$. Con no menos apoyos contaba el proyecto de ferrocarril entre Palencia y Aranda. En 1925, los alcaldes del Partido Judicial de Baltanás, presidentes de sindicatos y asociaciones obreras, se dirigieron al subsecretario del Ministerio de Fomento para que la línea de ferrocarril Palencia-Aranda fuera incluida en el Plan General de Ferrocarriles, que enlazaría con la línea de secundarios y con la que se proyectaba entre Guardo y Palencia ${ }^{1180}$. Ese mismo año, se incluyeron en el Plan General del Estado, las líneas de Palencia a Guardo y de Sahagún a Burgos, pero no la de Palencia a Aranda. La Comisión Provincial invitaba a todos los ayuntamientos interesados para que, abierto el plazo para presentar observaciones, presentasen las que estimasen oportunas y ofrecieran las mayores facilidades para que los proyectos se realizasen ${ }^{1181}$.

\footnotetext{
${ }^{1177}$ A.D.P.P., L.A.P.D. 131, 14-XII-1923.

${ }^{1178}$ A.D.P.P., L.A.C.P. 136, 21-VIII-1924.

${ }^{1179}$ A.D.P.P., L.A.P.D. 137, 30-VI-1924. La Diputación de Palencia quería presentar su petición con el máximo apoyo posible y pensaba que dada la importancia minera de la zona de Riaño, con explotaciones de cobre y arsénico, este Partido Judicial vería con buenos ojos el proyecto de ferrocarril desde Guardo hasta Palencia, con una mejor salida a sus producción minera.

${ }^{1180}$ A.D.P.P., L.A.C.P. 141, 10-III-1925.

${ }^{1181}$ A.D.P.P., L.A.C.P. 141, 13-IV-1925.
} 
La Cámara Oficial de Comercio e Industria de Palencia pedía a la Diputación que patrocinase las gestiones para lograr la consecución de tres líneas esenciales para la provincia: Palencia-Guardo, prolongado por Riaño a Asturias, de un ancho normal; Villalón-Palencia, ancho normal, y Palencia-Magaz de ancho normal, y también de la línea Palencia-Aranda ${ }^{1182}$. En 1928, a la petición de la Cámara Oficial de Comercio e Industria, se unían las sociedades mineras San Luis y Antracitas de Velilla, que ofrecían también contribuir con un millón de pts. cada una como mínimo para la construcción del ferrocarril Palencia-Guardo. Varios ayuntamientos ${ }^{1183}$ ofrecían un tanto por ciento en relación con el presupuesto de ingresos de cada localidad y Presidencia de la Diputación Provincial un millón de pts. y sufragar los gastos de estudio del proyecto ${ }^{1184}$. En 1929, incluso se llegaron a aprobar, por parte de la Diputación Provincial, las Bases para la constitución de la Mancomunidad para gestionar y explotar el ferrocarril de Palencia a Guardo (aún no estaba construido). Esta Mancomunidad estaría formada por la Diputación, los ayuntamientos de Palencia, Carrión, Saldaña, Guardo y Villoldo y las sociedades mineras Antracitas de Velilla y San Luis, cada componente contribuiría con una cantidad a determinar y las sociedades mineras con 500.000 pts. cada una. ${ }^{1185}$ Un año más tarde, el ingeniero jefe de la Sección de Vías y Obras advertía a la Comisión Provincial de la escasa utilidad que en su opinión tendría la obra del ferrocarril entre Palencia y Guardo y la Comisión le encomendaba la realización de un informe que sirviera como base para el proyecto sobre el terreno, que permitiese aclarar la utilidad y rendimiento de dicha obra $^{1186}$.

El ingeniero de Obras Públicas de Diputación apreció errores y omisiones en el proyecto que el contratista, Antonio Santos Peralba Álvarez, había realizado para esta obra. En su opinión, estos fallos hacían inviable el proyecto tal y como estaba redactado, y la Comisión Provincial, tras discutir la posibilidad de dar un nuevo plazo al contratista para subsanar los errores de su proyecto, acordó que las reformas a introducir equivaldrían a redactar un proyecto nuevo, por lo que se rechazó este proyecto de forma definitiva por incumplimiento de las Bases $4^{\mathrm{a}}$ y $5^{\mathrm{a}}$ del concurso del proyecto, de esta resolución se dio cuenta a la Mancomunidad de ayuntamientos ${ }^{1187}$.

\footnotetext{
${ }^{1182}$ A.D.P.P., L.A.C.P. 143, 11-VIII-1927.

${ }^{1183}$ Palencia, Carrión, Guardo, Perales, Pino del Río, Villoldo, Torre de los Molinos, Calzada de los Molinos, Renedo de la Vega, Villalba de Guardo y Velilla.

${ }^{1184}$ A.D.P.P., L.A.C.P. 144, 2-VII-1928.

${ }^{1185}$ A.D.P.P., L.A.C.P. 145, 14-I-1929.

${ }^{1186}$ A.D.P.P., L.A.C.P. 146, 11-III-1930.

${ }^{1187}$ A.D.P.P., L.A.P.D. 148, 24-VII-1930.
} 
El ferrocarril Palencia-Guardo no llegó nunca a materializarse, ya que la Diputación Provincial y los pueblos interesados no podían costear los catorce millones de pts. a que ascenderían el coste inicial de la obra, contando con que el Estado aportaría otra cantidad igual, ofrecimiento que no se produjo. Algún diputado provincial apuntó la posibilidad de que con la subvención del Estado y con un millón de pts. que aportarían los pueblos quizás pudiera lograrse el crédito para el resto ${ }^{188}$, pero finalmente el proyecto ferroviario más anhelado por la Diputación Provincial, no se hizo realidad.

La Diputación palentina consideró siempre el ferrocarril como un pilar fundamental sobre el que sustentar la riqueza de la provincia, pues consideraba que este medio de transporte, además de permitir el tránsito de mercancías, generaba en sí mismo actividad económica, como lo demuestra el hecho de que ante el posible traslado de la Dirección técnica de los ferrocarriles secundarios a Medina de Rioseco en 1923, desde su ubicación en Valladolid, la Comisión Provincial se adhiriese a la resolución dictada por el Ayuntamiento de Palencia ${ }^{1189}$ para que no se llevase a cabo, por los perjuicios que se ocasionaría a los intereses de Palencia. Se acordó dirigir telegramas al presidente del Consejo de Ministros y ministro de Fomento para que no se produjese dicho traslado, ya que era más económico para la compañía ferroviaria adquirir los materiales en Palencia teniendo su sede en Valladolid que si esta estuviese en Medina de Rioseco, por lo que « (...) no hay razón alguna de vernos privados de tan importante elemento de vida para la población» ${ }^{1190}$. Además de los intereses económicos de la provincia, también se ocupaba la Corporación Provincial del bienestar de sus administrados, pues no puede olvidarse que el ferrocarril transportaba personas, además de mercancías, en una época en la que la red de carreteras no llegaba a todos los pueblos de la provincia.

\footnotetext{
${ }^{1188}$ A.D.P.P., L.A.P.D. 148, 29-III-1930.

${ }^{1189}$ El presidente del Ayuntamiento, César Gusano Rodríguez, y el Pleno del Ayuntamiento acordaron solicitar que no prosperase el traslado de talleres y almacenes de los ferrocarriles secundarios de Castilla, por los daños materiales y morales que esto podía ocasionar a la capital, puesto que estaban instalados en la ciudad desde su fundación. A.M.A.P., L.A.P.A., A-21-118, 23-II-1923.

${ }^{1190}$ A.D.P.P., L.A.C.P. 135, 23-II-1923.
} 
Así, en 1911, la Comisión Provincial elevaba una instancia a la dirección de la Compañía de Ferrocarriles del Norte para que estableciese un tren de mercancías con viajeros de segunda y tercera categoría que partiese de Palencia a las veinte horas y treinta minutos, para favorecer a los pueblos comprendidos entre Grijota y Villada, cuyos vecinos, tras la variación introducida en el horario el día 17 de junio de 1911, tenían que esperar hasta las veintidós horas y treinta minutos horas en la capital para subir al tren, y llegar a sus destinos a horas intempestivas ${ }^{1191}$. Como dato anecdótico de la relación de la Diputación Provincial con las compañías ferroviarias, apuntar la solicitud que en 1905 presentaban varios diputados provinciales a la Presidencia para que gestionase con las empresas de los ferrocarriles la adquisición de pases para los diputados provinciales «(...) haciendo de esta suerte más fácil el cumplimiento de las obligaciones del cargo.» ${ }^{1192} \mathrm{Se}$ solicitaba, a la Dirección de la Compañía de los Ferrocarriles del Norte y a la Compañía de Secundarios de Castilla, que expidieran billetes de libre circulación al presidente de la Diputación y vocales de las Comisiones provinciales ${ }^{1193}$, como ya lo hacían con otras diputaciones.

\section{Pantanos y canales}

La España de la Restauración basaba su actividad económica principalmente en la agricultura, en un espacio geográfico que se podía considerar de secano en un $90 \%$ de su superficie cultivable. Joaquín Costa consideraba que la inversión estatal en obras hidráulicas tendría efectos beneficiosos sobre la productividad agrícola y, a su vez, serviría para aumentar los recursos del Estado vía contribuciones de los agricultores beneficiados por estas obras ${ }^{1194}$. En consecuencia, el Estado ejerció el papel protagonista en esta materia, promoviendo la realización de canales y pantanos, pero con una dotación presupuestaria insuficiente ${ }^{1195}$.

\footnotetext{
${ }^{1191}$ A.D.P.P., L.A.C.P. 115, 1-VII-1911.

${ }^{1192}$ A.D.P.P., L.A.P.D. 97, 5-V-1905.

${ }^{1193}$ Solo dentro de la provincia.

${ }^{1194}$ Vid. VILLANUEVA LARRAYA, Gregoria, «La politica hidráulica» durante la Restauración, Madrid, UNED, 1991.

${ }^{1195}$ Vid. SÁNCHEZ ILLÁN, Juan Carlos, «Rafael Gasset y la política hidráulica de la Restauración, 19001923», Revista de Historia Económica, Año XV Primavera-Verano 1997, pp. 319-362.
} 
En este periodo se aprobó la primera Ley de Aguas española ${ }^{1196}$, que fomentaba el regadío, y en el año 1902 se aprobó el primer Plan Nacional de Obras Hidráulicas ${ }^{1197}$. Durante el reinado de Alfonso XIII, el apoyo del Estado a la construcción de infraestructuras hidráulicas continuó con más fuerza que en el reinado de su padre, Alfonso XII. El regeneracionismo fue el pilar ideológico que sustentó el apoyo al regadío, ya presente en el pensamiento de Macías Picavea ${ }^{1198}$, que consideraba que era necesario fomentar las obras hidráulicas, y en especial el regadío, como mejor herramienta para enriquecer el territorio. La Diputación Provincial no era ajena a este pensamiento, y en una provincia eminentemente agrícola, la construcción de sistemas de regadío era una prioridad en la política de Obras Públicas. Ya en 1898, el diputado provincial Cuadros de Medina, proponía que se consignara un presupuesto de 50.000 pts. para construir un pantano en el Distrito de Cervera ${ }^{1199}$, y el Pleno de la Diputación Provincial pedía al director de Obras Provinciales que realizase los trabajos necesarios para informar sobre la posibilidad, importancia y utilidad de formar un proyecto para construir un pantano destinado a riegos en el Distrito de Cervera ${ }^{1200}$.

No solo se estudiaba la posibilidad de construir pantanos, los canales de riego también estaban en la agenda de la Diputación Provincial. En 1902, se aprobada por unanimidad la proposición que animaba a adoptar las medidas necesarias para el inicio de las obras del Canal de la Granja ${ }^{1201}$, destinado a regar 800 ha y a transformar la riqueza de la provincia. La Diputación se encargaría de conseguir los terrenos necesarios que ocupase el canal y de sufragar los gastos de expropiación de esos terrenos, consignando 30.000 pts. para dicho fin en el Presupuesto Adicional ${ }^{1202}$.

\footnotetext{
${ }^{1196}$ Ley de Aguas de 13 de junio de 1879. Solo contemplaba la propiedad de las aguas superficiales. El aprovechamiento de las aguas subterráneas fue regulado mediante la Real Orden de 5 de junio de 1883.

${ }_{1197}$ Real Decreto de 25 de abril de 1902.

${ }^{1198}$ Vid. MACÍAS PICAVEA, Ricardo, La Tierra de Campos, -Estudio preliminar de Ricardo Martín de la Guardia y Guillermo Á. Pérez Sánchez-, Valladolid, Ayuntamiento de Valladolid y Diputación Provincial de Valladolid, 2006

${ }^{1199}$ A.D.P.P., L.A.P.D. 86, 16-IV-1898.

${ }^{1200}$ A.D.P.P., L.A.C.P. 90, 26-VII-1898.

${ }^{1201}$ Nacía en Villalaco y terminaba en Dueñas, atravesaba por Villalaco, Cordovilla, Torquemada, Villamediana, Magaz, Venta de Baños, Villamuriel, Palencia y Dueñas. Finalmente se denominó Canal de Alfonso XIII, fue inaugurado el 15 de marzo de 1915 en Torquemada, con la asistencia de Abilio Calderón, director general de Obras Públicas, invitado por la Diputación de Palencia como agradecimiento a sus gestiones para lograr llevar a buen fin esta infraestructura.

${ }_{1202}$ A.D.P.P., L.A.P.D. 94, 7-III-1902.
} 
En 1904 se pretendía subvencionar con el 70\%, 60\%, y 50\% respectivamente, a ayuntamientos, sociedades y particulares que dentro de la provincia realizasen obras para el aprovechamiento de aguas, tales como pantanos, acequias, embalses y pantanos ${ }^{1203}$. El desempeño de Abilio Calderón Rojo, como director general de Obras Públicas, tuvo mucho que ver con la concesión de obras hidráulicas a la provincia de Palencia, y así lo entendía la Diputación palentina cuando mostraba su agradecimiento hacia el político palentino por sus gestiones para conseguir del Gobierno la ejecución de las obras del pantano Hoz de Alba ${ }^{1204}$ y la conversión del Canal de Castilla en canal de riego, además del encauzamiento del rio Sequillo, para fomentar la riqueza agrícola ${ }^{1205}$, y por haber aprobado y firmado como ministro interino de Fomento, la Real Orden de 27 de abril de 1914, referente al proyecto de las obras del Pantano del Príncipe Alfonso ${ }^{1206}$. Abilio Calderón daba las gracias a la Comisión Provincial por el recuerdo que le había regalado con motivo de la recepción del Acta de inauguración de los pantanos Príncipe Alfonso e Infante Jaime ${ }^{1207}$.

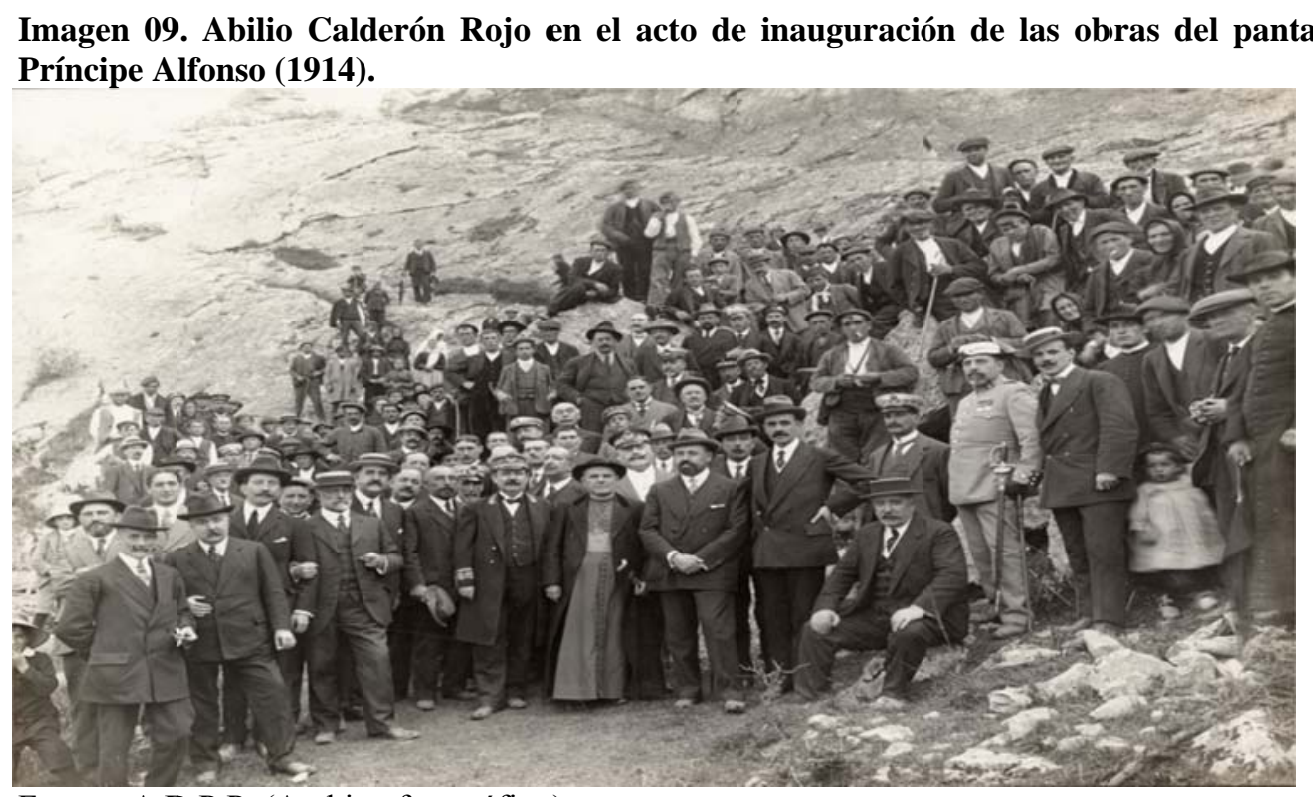

Fuente: A.D.P.P. (Archivo fotográfico).

\footnotetext{
${ }^{1203}$ A.D.P.P., C-L/ 8,4.

${ }^{1204}$ Antigua denominación del pantano Príncipe Alfonso, aguas arriba de Camporredondo.

${ }^{1205}$ A.D.P.P., L.A.C.P. 118, 11-IX-1914.

${ }^{1206}$ A.D.P.P., L.A.C.P. 118, 30-V-1914. Actualmente denominado Camporredondo.

${ }^{1207}$ A.D.P.P., L.A.C.P. 118, 7-XI-1914. Actualmente denominado Pantano de Cervera.
} 
En la etapa de la Dictadura primorriverista, se llevó a cabo una política intensa de construcción de obras hidrográficas. Palencia fue una de las provincias en las que se llevaron a cabo construcciones de este tipo. En 1923, la Diputación Provincial solicitó al Gobierno que fuera aprobado el proyecto de construcción de la acequia de Palencia, que recogería agua del Canal de Castilla para regar 6.000 ha $^{1208}$, el agua necesaria procedería del sobrante de río Carrión. La Diputación palentina justificaba su demanda por la importancia del regadío, mucho más productivo para el campo palentino: «Se dice en el Mediodía de Francia, con certera percepción de la realidad, que el agua vale más que la tierra.» El fomento de la riqueza por implantación del regadío en Aragón, con el Canal Imperial, o en Valladolid, con el río Duero, eran ejemplos que respaldaban el dicho francés. En opinión de la Diputación palentina, se señalaba que la trasformación del Canal de Castilla en canal de regadío con el aporte de los pantanos Infante Jaime y Príncipe Alfonso, podría regar 18.000 ha en la primera sección y 17.000 ha en la segunda ${ }^{1209}$.

Ya en 1913, el diputado provincial, Medina de Cuadros, había propuesto subvencionar ${ }^{1210}$ a los agricultores que convirtieran sus fincas de secano en regadío. Los defensores de esta proposición argumentaban que transformando las fincas en regables, se obtendría una producción con un valor de 1.400 a 1.800 pts. por ha ${ }^{1211}$. Los detractores de esta medida aducían que ocasionaría un gasto que absorbería la mayor parte del Presupuesto Provincial del año próximo y conllevaría mayores recargos impositivos para hacer frente a los gastos obligatorios de la Diputación Provincial. En 1928, el ingeniero jefe de la Confederación Sindical Hidrográfica del Duero, informaba a la Comisión Provincial sobre el estado de las obras de los pantanos Príncipe Alfonso ${ }^{1212}$ e Infante Jaime $^{1213}$, este último estaba terminado y funcionando. El Príncipe Alfonso, estaba terminado pero a falta de aliviadero y pruebas de compuertas, que finalizarían el 1 de octubre de $1928^{1214}$.

\footnotetext{
${ }^{1208}$ Pertenecientes a los términos municipales de Rivas de Campos, Amusco, Monzón, Fuentes de Valdepero, Husillos Palencia y Villamuriel de Cerrato.

${ }^{1209}$ A.D.P.P., L.A.P.D. 131, 21-XII-1923.

${ }^{1210} \mathrm{Se}$ subvencionaría el $50 \%$ del coste total, las fincas debían tener una extensión menor de cinco ha y mayor de 25 a. Tenía por objeto la reconstrucción de la riqueza vitícola perdida por la plaga de la filoxera, que se estimaba en doce millones de pts.

${ }^{1211}$ A.D.P.P., L.A.P.D 113, 1-X-1913.

${ }^{1212}$ En el río Carrión.

${ }^{1213}$ En el río Pisuerga. Actualmente denominado Pantano Cervera, en Ruesga.

${ }^{1214}$ A.D.P.P., L.A.C.P. $144,12-$ III-1928.
} 
El pantano del Príncipe Alfonso fue inaugurado por el rey Alfonso XIII, en agosto de 1930, después de visitar los pantanos de Requejada, y del Infante Don Jaime, el monarca se dirigió con la comitiva que le acompañaba, entre la que se encontraba el ministro de Hacienda y el Ministro de Fomento, al pantano de Camporredondo que se denominaba del Príncipe Alfonso, para proceder a su inauguración oficial. Tras celebrarse los actos protocolarios, el ministro de Fomento y las autoridades provinciales fueron obsequiados con una cena íntima en el domicilio del ex ministro de Fomento, el palentino Abilio Calderón Rojo ${ }^{1215}$.

\section{Telecomunicaciones}

Se ha incluido dentro del apartado de Obras Publicas el tendido de redes de comunicación telegráfica y telefónica ya que, al igual que las carreteras, caminos y ferrocarriles, contribuían a relacionar a los pueblos de la Provincia y de forma indirecta a crear las condiciones para aumentar la riqueza de sus pobladores, y al igual que las mencionadas infraestructuras y los pantanos y canales, eran un signo de la labor de la Diputación Provincial en pro de incorporar a Palencia a la corriente imparable de modernización que se estaba produciendo en España y Europa a finales del siglo XIX y comienzos del XX. El año 1888, la Diputación Provincial contribuyó con 750 pts. al establecimiento de una red telefónica oficial que ponía en comunicación al Gobierno Civil con la Asamblea Provincial, el Ayuntamiento de Palencia y el Gobierno Militar, cuyo presupuesto ascendía a 1.500 pts. ${ }^{1216}$ En 1899 , se planeaba instalar una red telefónica en la capital y, aunque la Diputación de Palentina excusaba su participación directa en esta clase de empresas por su alto coste y escasos fondos provinciales para afrontarlas, comunicaba a la Red Telefónica de Palencia, su disposición a prestar la ayuda que le fuese posible, estableciendo por cuenta de su Presupuesto estaciones telefónicas en la Cárcel de Audiencia, la Casa de Maternidad, la Presidencia, la Sala de Comisiones y la Secretaría. $^{1217}$

\footnotetext{
${ }^{1215} A B C, 7-$ VIII-1930.

${ }^{1216}$ A.D.P.P., L.A.C.P. 67, 10-VII-1888. El Ayuntamiento de Palencia acordó contribuir con 400 pts. A.M.A.P., L.A.P.A., A-21-102, 20-VII-1888.

${ }^{1217}$ A.D.P.P., L.A.C.P. 91, 20-XII-1899.
} 
En diciembre 1922 se presentaba el proyecto para la instalación de una red telefónica en la provincia. El anteproyecto contemplaba que la red telefónica provincial comprendiese en un principio a los pueblos cabeza de Partido Judicial y otros con un número importante de población y desarrollo industrial y mercantil. ${ }^{1218}$ En 1923, el gobernador provincial sugería que la mejor solución para que la provincia contase con una red telefónica era que el Estado fuese quien costease la instalación de la misma ${ }^{1219}$. El Estado podría utilizar para el tendido de la línea los mismos postes que le sirvieron para el establecimiento de los telégrafos y también del mismo personal que realizó la instalación telegráfica, abaratando de este modo el coste final de la obra.

En sesión del Pleno de la Diputación, se leyó el dictamen de la Comisión Provincial en el que se rechazaba la solución de que la red telefónica fuera tendida por el Estado porque «(...) por experiencia todos saben que en sus obras se eterniza, que sus servicios son extremadamente caros y malos.» ${ }^{1220}$ Además, la Comisión Provincial señalaba que si se optase por la solución del Estado, la Compañía Peninsular ${ }^{122}$ no accedería al enlace con sus líneas y también porque «(...) no debe imponerse a la Diputación tutelas de quien constantemente las ejerce arbitraria y despóticamente.» ${ }^{1222} \mathrm{La}$ Comisión Provincial recomendaba que fuera la Compañía Peninsular quien se encargase de la obra en su totalidad y la Diputación le reintegrase su importe en distintas anualidades. La moción de la Comisión Provincial fue aprobada por siete votos a favor y tres en contra. En el Presupuesto de 1923/24 se destinó una partida de 48.000 pts. ${ }^{1223}$ para abonar los gastos que originase durante el ejercicio 1923/24 la instalación de la red telefónica como primera anualidad.

\footnotetext{
${ }^{1218}$ A.D.P.P., L.A.P.D., 130, 4-XII-1922.

${ }^{1219}$ A.D.P.P., L.A.P.D., 130, 8-I-1923. Por el Real Decreto de 26 de octubre de 1907, el Estado se comprometía a establecer redes telefónicas provinciales y municipales con una pequeña subvención por parte de las diputaciones provinciales y ayuntamientos.

${ }^{1220}$ A.D.P.P., L.A.P.D., 130, 27-I-1923

${ }^{1221}$ La Compañía Peninsular de Teléfonos fue fundada en 1894 por la Ley de Ordenación de las Telecomunicaciones de 26 de octubre de 1907. Esta compañía tenía el monopolio de las líneas telefónicas interurbanas. En 1924 se fusionó con la CTNE.

${ }^{1222}$ A.D.P.P., L.A.P.D., 131, 27-I-1923

${ }^{1223}$ Esta partida tuvo que ser transferida al Capítulo destinado a satisfacer al Estado los descubiertos por diferentes atenciones que adeudaba la Diputación y convenio con la Delegación de Hacienda, por Real Orden de 30 de diciembre de 1923. La Dirección General del Tesoro propuso a la Delegación de Hacienda y a la Diputación Provincial satisfacer el crédito por débitos de Enseñanza y personal de prisiones en plazos de 10.500 pts. mensuales. Los descubiertos con el Estado por diferentes atenciones ascendían en 1923 a 330.241, 31 pts. A.D.P.P., C-L/ 12,3.
} 


\section{Fomento riqueza agrícola}

La agricultura constituía la principal fuente de riqueza de la provincia de Palencia. La Diputación Provincial consideraba que una de las principales razones de su existencia como entidad administrativa, era el fomento de toda actividad que contribuyese a mejorar el nivel de vida de los habitantes de la provincia, por lo que una buena parte de sus acciones de gobierno se encaminaron a fomentar la riqueza agrícola de Palencia y a la defensa de los intereses de sus agricultores. Tampoco puede olvidarse que muchos de los diputados provinciales tenían intereses particulares relacionados con este sector, por ejemplo, la familia Calderón se había enriquecido gracias a la industria harinera.

La lucha contra las plagas que asolaban el campo, la defensa del comercio del trigo nacional en contra del llamado trigo «exótico», y el fomento de la actividad vitivinícola, con la creación de la Estación Enológica, fueron algunos de los aspectos más destacados de la actividad de la Diputación palentina en favor de la actividad agraria. La Comisión Provincial siempre tuvo claro que tan importante como el fomento de la riqueza agrícola dentro de la provincia, era el apoyo a la actividad exportadora de la producción agrícola palentina. De acuerdo con este pensamiento, no dudó, a pesar de los impedimentos presupuestarios, en colaborar económicamente para que tanto en ferias como en exposiciones, estuviese representada la producción agro-ganadera palentina. En junio de 1875, la Comisión Provincial aprobó una ayuda de 1.000 pts. del Presupuesto Ordinario para la remisión de productos agropecuarios de la provincia a la Exposición General de Filadelfia ${ }^{1224}$ y en 1912, la Diputación Provincial se adhirió al Congreso de Viticultura que se celebró el 12 de agosto de 1912 en Pamplona por «no poder ser ajena al desarrollo y desenvolvimiento de la riqueza de la provincia.» ${ }^{1225}$. En 1925, se acordó $^{1226}$ consignar una cantidad en los presupuestos de 1926 para cooperar con la Asociación Provincial de Ganaderos en la celebración, de septiembre en la capital, de un concurso provincial de ganaderos, que estimularía a estos para que mejorasen sus razas.

\footnotetext{
${ }^{1224}$ A.D.P.P., C-L/ 4,1.

${ }^{1225}$ A.D.P.P., L.A.C.P. 115, 12-VIII-1911.

${ }^{1226}$ A.D.P.P., L.A.C.P. 141, 10-III-1925.
} 
Una de las principales cuestiones con las que tuvo que lidiar la Diputación Provincial en la gestión de la actividad agropecuaria en la provincia fue la aparición de plagas en el campo palentino, y los enemigos a batir eran tan formidables como la devastadora filoxera o la bíblica langosta. En 1876, la Comisión Provincial tuvo que destinar una partida presupuestaria para subvencionar los gastos que originase la extinción de la langosta que, en estado de canuto o mosquito, había aparecido en Dueñas ${ }^{1227}$. Tan solo dos años después, en 1878, hizo su aparición en el sur de España un pequeño insecto que causaría una verdadera hecatombe en el viñedo nacional. En noviembre de ese año, el secretario de la Junta Provincial de Agricultura emitía un informe sobre la propagación de la filoxera ${ }^{1228}$ que había aparecido en la provincia de Málaga ${ }^{1229}$, donde este funcionario había pasado un tiempo por disposición de la Junta y la Comisión Provincial ${ }^{1230}$.

Las plagas no solo atacaban a las plantas, la cabaña ganadera también era blanco de enfermedades que de no ser tratadas producían grandes pérdidas a los ganaderos de la provincia. En 1886, afectado el ganado lanar de Calabazanos y de otros pueblos de la provincia de la enfermedad de carbunculosis, la Comisión Provincial acordó adquirir directamente del gabinete histo-químico de Pasteur en París un tubo de virus mortal, dos del virus preservativo cultivado y atenuado de primer grado, dos del segundo grado y dos jeringuillas de inyección, a propuesta del subdelegado de veterinaria del Distrito del Partido de la capital. Estos materiales se entregaron al veterinario de Villamuriel de Cerrato para que, bajo la intervención de una Comisión de la Junta de Sanidad, hiciera los ensayos del recurso profiláctico del Dr. Pasteur como profiláctico de la carbunculosis del ganado lanar $^{1231}$.

\footnotetext{
${ }^{1227}$ A.D.P.P., L.A.C.P. $45,31-\mathrm{V}-1876$.

${ }^{1228}$ Phylloxera vastratix, insecto hemíptero de color pardo, amarillento y verdoso. La filoxera se propagaba tanto por su forma áptera como alada, esta última era la encargada de invadir los viñedos lejanos y sanos siguiendo la dirección de los vientos dominantes en la provincia en los meses de julio a septiembre. La filoxera atacaba a la vid en sus dos órganos esenciales, la hoja y las raíces. Al cuarto de la invasión, las cepas no brotaban y morían en la mayoría de los casos.

${ }^{1229}$ En 1878 se descubrió por primera vez la filoxera en algunos viñedos de Málaga, poco después en Gerona, y luego en Orense procedente de Portugal. Veinte años después se encontraba extendida en las provincias de Barcelona, Gerona , Lérida, Tarragona, Murcia, Almería, Granada, Córdoba, Sevilla, Málaga, Jaén, Cádiz, Lugo, Orense, Asturias, Navarra, Palencia, León, Valladolid, Salamanca y Zamora, y había sospechas de su propagación en Burgos y Cáceres.

${ }^{1230}$ A.D.P.P., L.A.P.D. 49, 6-XI-1878.

${ }^{1231}$ A.D.P.P., L.A.C.P. 65, 27-II-1886.
} 
La Diputación Provincial contaba con recursos limitados para hacer frente a plagas como la mencionada de la filoxera y, en ocasiones, tenía que negar el auxilio que le solicitaban los pueblos de la provincia, como en 1889 cuando denegó la ayuda a Dueñas, Villamediana y Villaprovedo, que habían solicitado a la institución provincial recursos para combatir la invasión de la peronospora vitis o mildiu en sus viñedos por no tener el carácter de calamidad pública. En estos casos, la Comisión Provincial consideraba que eran los presupuestos de los pueblos los llamados a subvencionar con sus fondos estas necesidades ${ }^{1232}$.

La filoxera avanzaba inexorablemente por los viñedos de las distintas regiones de la nación y en 1890, el Comité local de la Liga Vinícola de Palenzuela solicitaba a la Comisión Provincial que «(...) estimule a los viticultores a que oportuna y preventivamente traten las vides con la disolución cupro-cálcica, facilitándoles al efecto por su coste el sulfato de cobre puro que la Diputación puede adquirir a precio más económico que los viticultores.» ${ }^{1233}$ En previsión del alto coste que iba a suponer la extinción de la filoxera, el Ministerio de Hacienda estableció un impuesto contra esta plaga, una peseta por ha de viñedo ${ }^{1234}$. En 1893, la Comisión Provincial recibió de la Delegación de Hacienda, la relación nominal de ha de viñedo existentes en la provincia para proceder a la cobranza por parte de los alcaldes del impuesto con el que los agricultores debían contribuir a la extinción de la filoxera ${ }^{1235}$ y varios pueblos reclamaron contra el número de ha que se les había asignado en el Repartimiento para los gastos de extinción de este insecto ${ }^{1236}$.

\footnotetext{
${ }^{1232}$ A.D.P.P., L.A.P.D. 68, 8-XI-1889.

${ }^{1233}$ A.D.P.P., L.A.C.P. 72, 20-I-1890.

${ }^{1234}$ A.D.P.P., L.A.C.P. 77, 8-VII-1892. Art.12 de la Ley sobre la filoxera de 18 de junio de 1885 y Real Decreto de 21 de agosto de 1888.

${ }^{1235}$ A.D.P.P., L.A.C.P. 78, 25-IV-1893. 27.749 ha, 13.874, 50 pts. Los medios utilizados contra la filoxera eran variados: destruir el insecto, arranque de las cepas invadidas, empleo de insecticidas (sulfocarbonato potásico, sulfuro de carbono), sumersión del viñedo, destrucción del huevo de invierno, propagación de los enemigos naturales de este tipo de la filoxera (arácnidos), plantación en terrenos arenosos y plantación de vides americanas.

${ }^{1236}$ A.D.P.P., L.A.C.P. 78, 16-V-1893. La Delegación de Hacienda rectificó su primera certificación y en virtud de la reclamación de algunos ayuntamientos estableció el impuesto sobre 22.965 ha.
} 
En 1896, se facultó a la Comisión Provincial para adquirir vides americanas, inmunes a este insecto, con destino a un vivero en previsión de que la plaga filoxérica pudiera invadir los viñedos de la provincia ${ }^{1237}$. El gobernador convocó a la Comisión Provincial y la conminó a dirigirse a los ayuntamientos de la provincia para que recabasen datos acerca de la plaga de la filoxera. Cuadros de Medina, vicepresidente de la Comisión Provincial y viticultor ${ }^{1238}$, mostraba su agradecimiento por la diligencia mostrada por el gobernador en esta materia. Se tomaron medidas anticontagio, prohibiendo el transporte de garbanzos y sarmientos, así como el empleo de útiles y herramientas procedentes de terrenos enfermos. El diputado provincial, Abia Herrero manifestaba sus reservas sobre lo acertado de adquirir estaquillas americanas, pues en su opinión habían sido estas las que importaron la plaga filoxérica a Francia. Cuadros de Medina manifestaba su desacuerdo con Abia Herrero, pero de momento no se acordó adquirir estaquillas americanas ${ }^{1239}$. Sí se autorizó al vicepresidente de la Comisión Provincial, Cuadros de Medina, para que, con cargo al crédito presupuestario, procediese a la tirada de grabados, cartillas, instrucciones y demás medios para el conocimiento más exacto de la plaga de la filoxera por parte de los viticultores, vinicultores, braceros y maestros de Primera Enseñanza ${ }^{1240}$.

En 1897, un periódico de Madrid fue el primero que habló de la existencia de filoxera en los viñedos de la provincia, en Castil de Vela. Las medias tomadas contra esta plaga $^{1241}$ fueron las siguientes:

1. Constitución de la Juntas Locales de defensa contra la filoxera.

2. Formación de zonas de defensa e inmunes.

3. Reunión de los alcaldes y mayores contribuyentes de los ayuntamientos.

4. Empleo de insecticidas, aceites y demás sustancias conocidas en las vides de las zonas de defensa.

5. No proveerse de estaquillas de dudosa procedencia.

6. Constitución de viveros de vides americanas en los pueblos.

${ }^{1237}$ A.D.P.P., L.A.P.D. $81,17-X I-1896$.

${ }^{1238}$ A.D.P.P., L.A.C.P. 85, 20-III-1897. «Ante el alcance y extensión de la plaga que en cuatro años puede destruir el principal elemento de riqueza de la provincia», juzgaba indispensable que cuanto antes se establecieran los campos de experimentación, que se adquiriesen las estaquillas americanas y que se creasen viveros para este fin en cada Distrito.

${ }_{1239}^{12 . D . P . P ., ~ L . A . C . P . ~} 85,20-\mathrm{III}-1897$.

${ }^{1240}$ A.D.P.P., L.A.C.P. 85,15 -VII-1897.

${ }^{1241}$ A.D.P.P., L.A.P.D. 82, 10-II-1897. 
La Diputación, en previsión de que la plaga acabase con el viñedo autóctono, ya había adquirido en febrero de 1897 dos ha para plantar vides americanas, parte de ese terreno se destinó a huerta de la Beneficencia Provincial ${ }^{1242}$. Por la Real Orden de 10 de abril de 1897 se declaraba invadida la provincia de Palencia por la filoxera, el gobernador civil disponía que la Diputación Provincial consignase en su presupuesto, recaudase e ingresase en el Banco de España, la cantidad que le correspondía por el impuesto que establecía el art. 12 de la Ley de Defensa contra la filoxera ${ }^{1243}$. En julio de 1898, se distribuyeron 134 cartillas editadas en el establecimiento tipográfico de la Diputación para difundir los conocimientos relativos a esta plaga.

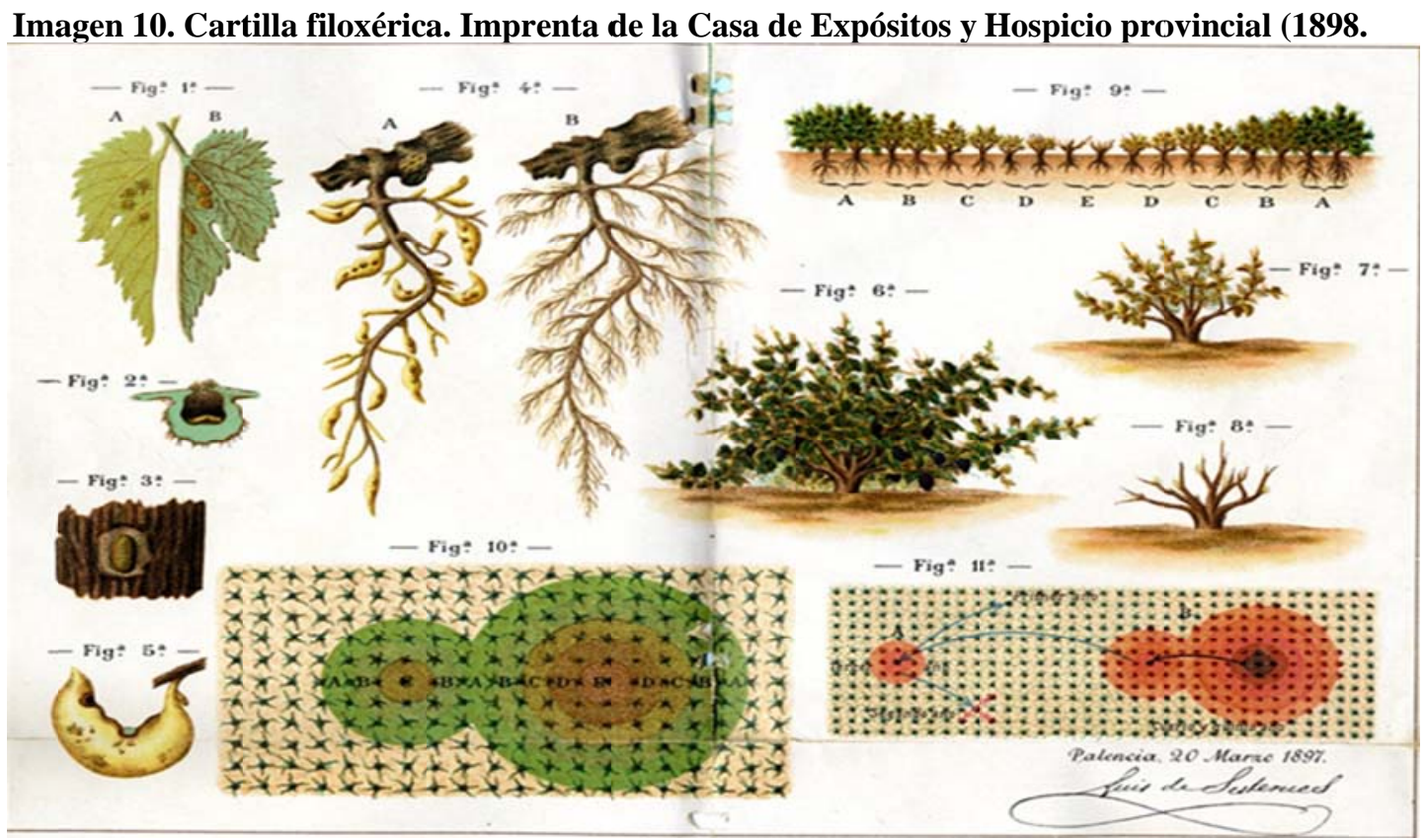

Fuente: A.D.P.P. Biblioteca Tello Téllez de Meneses.

${ }^{1242}$ A.D.P.P., L.A.P.D. $85,10-\mathrm{II}-1897$.
${ }^{1243}$ A.D.P.P., L.A.P.D. $82,17-\mathrm{IV}-1897$ 
En el verano de 1900 apareció, de nuevo, la langosta en Dueñas, Torquemada, Astudillo y Valoria del Alcor y amenazaba la cosecha que tras muchos años se presentaba con buenas perspectivas. El gobernador de la provincia advertía a la Comisión Provincial de la necesidad de tomar medidas urgentes para evitar que se desarrollase el adulto y causase graves daños a la agricultura. Se adelantaron fondos ${ }^{1244}$ por parte de la Comisión Provincial para combatir esta plaga, porque, a pesar de lo que marcaba la ley ${ }^{1245}$, los ayuntamientos acudían en masa a la Diputación Provincial en busca de ayuda, y esperar a la cobranza de los repartimientos podría conllevar la pérdida de las cosechas. ${ }^{1246}$

El mes de febrero de 1908, con motivo de la formación del apéndice al amillaramiento $^{1247}$, el vicepresidente de la Diputación Provincial consideraba que era una buena ocasión para que los pueblos se acogieran a las ventajas de las Reales Órdenes de 24 de marzo y 4 de junio de 1902, Circulares de 3 de abril y 13 de noviembre de ese año, y Resolución de 23 de octubre de 1903, para conseguir las bajas de la riqueza amirallada por daños causados en los viñedos por la filoxera ${ }^{1248}$. Ante la evidencia de que el viñedo de la provincia había sido arrasado por la filoxera, a pesar de la medidas que se habían tomado para evitarlo, y puesto que las nuevas vides americanas plantadas necesitarían tiempo para producir caldos que se pudiesen comercializar, la Diputación Provincial apoyó al presidente del Consejo Provincial de Agricultura y Ganadería de Palencia, que había dirigido un escrito al ministro de Hacienda con fecha de 29 de abril de 1908, solicitando la concesión del cultivo de tabaco para la provincia. La Diputación Provincial opinaba que la pérdida de viñedo a causa de la filoxera había originado despoblación y el cultivo del tabaco podría paliar esta situación, puesto que esta clase de cultivo requería un número importante de obreros ${ }^{1249}$.

\footnotetext{
${ }^{1244}$ A.D.P.P., L.A.C.P. 92, 11-VI-1900. Se ponían 1.500 pts. a disposición de la Junta provincial de extinción de la langosta. Además, se pagaron indemnizaciones y pluses a las tropas del Regimiento de Cazadores de Talavera 15 de Caballería, por su participación en los trabajos de extinción de la langosta en Dueñas.

${ }^{1245}$ Los arts. 18 y 19 de la Ley de 21 de julio de 1879 determinaban el procedimiento que se había de seguir para arbitrar los recursos necesarios para la extinción de las plagas, que consistía en gravar la riqueza imponible que constase señalada en los amirallamientos a cada contribuyente del término municipal afectado en rigurosa proporción con la cantidad necesaria.

${ }^{1246}$ A.D.P.P., C-R/ 1,14 (A).

${ }^{1247}$ Arts. 48 y 58 del Reglamento General para el Repartimiento y administración de la Contribución Territorial.

${ }^{1248}$ A.D.P.P., L.A.C.P. 108, 11-I-1908.

${ }^{1249}$ A.D.P.P., C $19 / 1$.
} 
Para defender esta petición se apoyaba en la opinión de los expertos, entre ellos el profesor de la Escuela General de Agricultura, quien consideraba que el tabaco era cultivable en latitudes situadas entre $\operatorname{los} 40^{\circ}$ y $46^{\circ}$ latitud norte, en las que se encontraba España, además, la naturaleza silíceo-caliza del suelo de la provincia hacía que Palencia fuera un terreno favorable para su cultivo. El Consejo provincial de Agricultura y Ganadería de Palencia, entre los diversos modelos ${ }^{1250}$ de cultivo en Europa, aconsejaba el cultivo reglamentado del tabaco con intervención del Estado, reservándose este la elaboración.

Dentro del fomento de la riqueza agrícola de la provincia, la faceta en la que la Diputación Provincial puso todo su empeño fue la defensa de la producción provincial y regional del cereal, especialmente el trigo, ante la amenaza de la competencia del producto extranjero. La importación de trigo foráneo a partir de los años ochenta del siglo XIX, generó descontento entre los agricultores nacionales, especialmente los castellanos. La política comercial de los gobiernos de la Restauración se debatió entre un librecambismo muy restringido y un proteccionismo tamizado por tratados y aranceles. La Diputación de Palencia, y con ella el resto de las castellanas, se erigieron en defensores de los intereses agrarios de Castilla, en 1884, la Diputación de Palencia envió un telegrama a la Diputación de Valladolid respecto a las medidas a tomar para conseguir resultados favorables en las compensaciones como consecuencia de las repercusiones que para la economía castellana tendría, en caso de aprobarse, el tratado comercial con Estados Unidos $^{1251}$. En 1886, la Diputación Provincial expresaba mediante un Voto de Gracias su agradecimiento al ministro de Ultramar, Germán Gamazo ${ }^{1252}$, por haber propuesto al Gobierno la reducción a un $15 \%$ de los derechos arancelarios que satisfacían las harinas y trigos nacionales por su exportación a $\mathrm{Cuba}^{1253}$.

\footnotetext{
${ }^{1250}$ Se copió el modelo francés, que permitía el cultivo con intervención del Estado, reservándose este la fabricación. Alemania imponía un derecho al cultivo libre en relación al que se satisfacía para el tabaco importado y libertad para elaborarlo. Inglaterra, prohibía el cultivo y dejaba libertad de fabricación a la industria particular.

${ }^{1251}$ A.D.P.P., L.A.C.P. 60, 22-XI-1884. El tratado nunca llegó a firmarse.

${ }^{1252}$ El político vallisoletano, miembro de la Liga Agraria, se presentaba a sí mismo como un adalid de la producción cerealista nacional.

${ }^{1253}$ A.D.P.P., L.A.P.D. 62 , 10-II-1886.
} 
En 1887, la Comisión Provincial se adhirió a la solicitud que a las Cortes dirigió la Cámara de Comercio de Valladolid para que no se aprobase el proyecto de Ley de Admisiones Temporales ${ }^{1254}$, pendiente de discusión en el Senado, por los perjuicios que ocasionaría a la agricultura castellana, «(...) principal y único elemento de riqueza de toda la región castellana.» ${ }^{1255}$ En 1890, la Diputación se quejaba de la «funesta» política arancelaria llevada a cabo por los sucesivos gobiernos desde 1869, con la aprobación de la Ley Arancelaria de 1869, y muy especialmente las modificaciones arancelarias de 1882, causa, en su opinión, de la pérdida de mercado de las harinas castellanas en las Antillas $^{1256}$.

Después de muchos años de malas cosechas debido a la sequía, a finales del siglo XIX la situación de la agricultura castellana era crítica y la Diputación Provincial recomendaba en 1894 una serie de reformas ${ }^{1257}$ a los poderes públicos para remediar la crisis de la agricultura:

1. Creación de Bancos Agrícolas para combatir la usura.

2. Reforma de los Pósitos, trasvasando sus capitales a un Banco Provincial.

3. Ley Hipotecaria para evitar las trabas que se ponían a las transmisiones de bienes.

4. Reducción del Impuesto de Derechos Reales.

5. Rebaja de las tarifas de ferrocarriles.

6. Construcción de canales de riego

7. Modificación del arancel y protección del Gobierno para evitar la competencia de los trigos extranjeros.

\footnotetext{
${ }^{1254}$ Presentado a las Cortes por el ministro de Hacienda, Puigcerver.

${ }^{1255}$ A.D.P.P., L.A.C.P. 66, 9-II-1887.

${ }^{1256}$ Hasta 1882 se exportaban a Cuba entre 400-450.000 sacos de harina anualmente, y 120-140.000 a Puerto Rico, desde la entrada en vigor de las reformas arancelarias de 1882, la exportación a Cuba descendió a la mitad, y entre una quinta y sexta parte a Puerto Rico, teniendo en cuenta que, desde 1882, Cuba consumía el doble de harina. La Habana se calculaba que consumía 1.000 sacos diarios. A.D.P.P., L.A.P.D. 69, 12-II1890.

${ }^{1257}$ Defendía estas propuestas ya señaladas en una reunión celebrada en Valladolid, el diputado provincial Monedero y Monedero, apoyado por su compañero Abilio Calderón Rojo. A.D.P.P., L.A.P.D. 76, 18-VII1894.
} 
Abilio Calderón Rojo, con intereses en el sector harinero, defendía la oportunidad de estas propuestas, sobradamente justificada en su opinión, puesto que, «Con la estadística en la mano, demuestro que de los diecisiete millones de habitantes que constituyen la nación española, quince viven de la agricultura, y a pesar de conocerlo perfectamente los gobiernos ni les oye ni les atiende.» ${ }^{1258}$ Ante esta situación, la Diputación Provincial nombró una Comisión especial ${ }^{1259}$, en noviembre de 1894, Abilio Calderón Rojo daba cuenta al Pleno de la Diputación ${ }^{1260}$ de las gestiones practicadas en Madrid por la Comisión nombrada con motivo de la crisis agrícola, recomendados por el gobernador civil de la provincia. Calderón Rojo y Hortega Aguado fueron recibidos por la regente, que mostró comprensión con las preocupaciones de la Diputación sobre el estado de la agricultura, y por el presidente del Consejo de Ministros, que prometió acometer la reforma del arancel sobre las harinas tan pronto como se abriesen la Cortes. También visitaron al diputado a Cortes por Cervera, Barrio y Mier, a Serrano, representante de Cuba, pero natural de la provincia y a Germán Gamazo.

En 1900, se presentó una Moción para que el Gobierno restableciese los derechos arancelarios sobre el trigo, harinas de trigo y salvados de procedencia extranjera ${ }^{1261}$. En 1901, Valentín Calderón Rojo declaraba, en sesión del Pleno de la Diputación Provincial, que había sabido que los fabricantes de harinas de Cataluña estaban realizando gestiones con el Ministerio de Hacienda para que se les concediese la llamada Zona Neutral ${ }^{1262}$, después de haber sido desechadas las admisiones temporales por la oposición de Castilla. Calderón Rojo afirmaba que si se hubiese solicitado una Zona Neutral para paños y telas «(...) Cataluña entera se levantaría como un solo hombre para protestar contra una medida que causaría la muerte a su industria.» La posible creación de las zonas neutrales o francas, era un tema recurrente en la agenda de las diputaciones castellanas en defensa de los intereses económicos castellanos.

\footnotetext{
${ }^{1258}$ A.D.P.P., L.A.P.D. 76, 18-VII-1894.

${ }^{1259}$ La Comisión especial fue encargada de entregar a los altos poderes del Estado las solicitudes y conclusiones que acordaron los representantes de las diputaciones castellanas que tomaron parte en la Asamblea celebrada en Madrid el 14 de octubre de 1894.

${ }^{1260}$ A.D.P.P., L.A.P.D. 76, 27-XI-1894.

${ }^{1261}$ En el año 1900 , el precio de $100 \mathrm{~kg}$ de trigo era de 27 pts. y, dada la expectativa de una buena cosecha, se esperaba que pudiese bajar más. A.D.P.P., L.A.C.P. 92, 20-VI-1900. En 1911, el precio era inferior a 25 pts. los $100 \mathrm{~kg}$, El presidente de la Cámara Agrícola de Carrión de los Condes remitía una instancia a la Diputación para que, firmada por el presidente de la misma, fuese elevada al ministro de Hacienda, solicitando el aumento del recargo de introducción de trigo o el cierre definitivo de los puertos hasta que se consiguiese el precio de 25 pts. los cien $\mathrm{kg}$ de trigo.

${ }^{1262}$ Zona libre de derechos de arancel y de algunos tributos fiscales, como el Impuesto de Consumos, arbitrios municipales y provinciales.
} 
En 1903, el diputado provincial García de los Ríos se hacía eco de los comentarios que en la prensa habían surgido sobre la creación de zonas neutrales en Barcelona, Bilbao y Vigo. El propio diputado provincial reconocía que no era un asunto nuevo, «No es nueva la pretensión de los peticionarios, siquiera estos crean que en Castilla desconocemos lo que son las zonas neutrales, porque y en tiempo de Felipe IV se solicitó la creación de puertos francos, y desde entonces acá se ha venido persiguiendo esta idea, que de implantarse, sería funesta para los agricultores.» ${ }^{1263}$ García de los Ríos temía que tras la solicitud al Gobierno de creación de zonas francas, en la idea de que no sería concedida, lo que realmente se perseguía era la creación de los denominados depósitos comerciales, que tenían la intervención de la Aduana, pero que también perjudicaban los intereses castellanos, quejándose el diputado provincial de la campaña catalana contra los castellanos «(...) si quieren los catalanes, por medio de la prensa y folletos, nos califican de ignorantes y hasta temerarios porque las zonas vienen a mejorar la producción, no teniendo razón de ser por lo tanto nuestros clamores.» ${ }^{1264}$ Evidentemente existía una disparidad de intereses entre las zonas del interior y las costeras de la nación en materia arancelaria pues, debido al déficit de infraestructuras, a las regiones costeras les era más económico importar trigo con bajos aranceles que comprarlo en el interior de España, por ejemplo en Castilla. Los intentos de estas zonas para que el Gobierno redujese los impuestos que debían pagar los productos agrícolas extranjeros al entrar en España se sucedieron a lo largo de la Restauración, en contra de los intereses de los productores nacionales.

En 1912, el diputado provincial García de los Ríos, al igual que años antes Valentín Calderón Rojo, exponía ante el Pleno de la Diputación Provincial que se había enterado por la prensa que la Diputación Provincial de Orense había solicitado al Ministerio de Hacienda la rebaja del precio de los aranceles para la entrada de maíz y centeno. Esta medida perjudicaría en su opinión la producción de cereales en las provincias de Castilla y creía que debía acudirse al Ministerio para que no se accediera a la rebaja $^{1265}$.

\footnotetext{
${ }^{1263}$ A.D.P.P., L.A.P.D. 95, 6-V-1903

${ }^{1264}$ A.D.P.P., L.A.P.D., 9-X-1901.

${ }^{1265}$ El presidente del Gobierno se hacía eco de la preocupación de la Diputación Provincial de Palencia y justificaba esa medida porque «(...) en Galicia se morían de hambre en las calles, y por consiguiente era preciso atender los clamores de aquella región, armonizando los intereses de los restantes.» A.D.P.P., L.A.P.D 112, 16-X-1912.
} 
García de los Ríos, argumentaba que si en Galicia había muertes por hambre:

«(...) aquí sucede lo mismo, por la pérdida de la cosecha, la grandísima depreciación de los trigos, cuyo precio no compensa los gastos de producción y la urgente emigración, que despuebla los campos ${ }^{1266}$ y hace subir los jornales a un precio que no se halla en armonía con los productos que obtienen los propietarios.»1267

Abilio Calderón Rojo, diputado a Cortes por Palencia capital, y su hermano Valentín, senador por la provincia, aseguraron a la Diputación Provincial que realizarían todas las gestiones posibles para defender la continuación del recargo arancelario sobre los cereales, idéntico ofrecimiento hizo Andrés Alonso López, diputado a Cortes por Carrión de los Condes. En enero 1915, la Comisión Provincial daba cuenta de un escrito del presidente de la Diputación de Valladolid, convocando una reunión ${ }^{1268}$ en Valladolid para tratar de las zonas neutrales, la Diputación de Palencia no consideró necesario acudir a la reunión puesto que ya había elevado ante el Ministerio de Hacienda súplica ante el Proyecto de Ley de Zonas Neutrales, para que se prohibiese la entrada de harinas y toda clase de cereales $^{1269}$, a no ser previo pago de derechos de aranceles e impuestos. El 28 de julio de 1915, el presidente de la Diputación de Palencia asistió invitado por el presidente de la Diputación de Valladolid a la Conferencia de diputaciones cerealistas celebrada en Madrid para tratar de la cuestión arancelaria, el presidente del Gobierno comunicó a los representantes de las veinticuatro diputaciones presentes, la imposibilidad de elevar los derechos arancelarios sobre trigos y harinas extranjeros ${ }^{1270}$. En 1916, la Comisión Provincial acordó recabar información sobre el Anteproyecto de Ley de Depósitos Francos, que en opinión de la Diputación Provincial tendría como consecuencia la implantación de las zonas francas ${ }^{1271}$.

\footnotetext{
${ }^{1266}$ En el Partido Judicial de Saldaña, tierra de vega, entre treinta y cuarenta personas salían diariamente en dirección a Ultramar « buscando un pedazo de pan y trabajo». A.D.P.P., L.A.P.D. 112, 16-X-1912

${ }^{1267}$ A.D.P.P., L.A.P.D. $112,16-X-1912$.

${ }^{1268}$ La reunión no se celebró y la Diputación de Palencia se sumó a la protesta elevada al Gobierno por la Diputación de Valladolid. A.D.P.P., L.A.C.P. 119, 5-I-1915.

${ }^{1269}$ La prensa local se hacía eco de esta circunstancia cuando en la edición del día 30 de junio de 1914, señalaba en un artículo, bajo el nombre de «Castilla en peligro», que la Diputación palentina, a través de la Comisión Provincial, había acordado en sesión celebrada el 26 de ese mes, dirigir un telegrama al presidente del Consejo de Ministros y al ministro de Hacienda solicitando la no presentación del proyecto de rebaja del arancel del maíz por ser muy perjudicial para los intereses de Castilla. El Diario Palentino, 30-VI-1914.

${ }^{1270}$ A.D.P.P., L.A.C.P. 119, 30-VIII-1915.

${ }^{1271}$ A.D.P.P., L.A.C.P. 124, 22-II-1916.
} 
A comienzos de 1921, el Presidente de la Diputación Provincial de Burgos recababa el apoyo de los representantes en Cortes de las provincias cerealistas para ejercitar una acción común y para que apoyasen las conclusiones aprobadas por la Asamblea presidida por él:

1. Cese inmediato de la importación de trigos extranjeros.

2. Prohibición temporal de la importación, o restablecimiento de los derechos arancelarios con una tarifa no inferior a diez pts. para el trigo, y de ocho pts. para el resto de cereales.

3. Regularización de los transportes ferroviarios, con preferencia a las facturaciones de trigo y demás cereales.

El diputado Provincial Garrachón García señalaba que, en los últimos años, se había hecho un gran esfuerzo inversor en maquinaria y abonos para aumentar la producción, sin un aumento significativo de la rentabilidad por la adquisición de trigos «exóticos» a precios más bajos que en Castilla, por la diferencia de clima y suelo. Pedía que el trigo importado de Argentina por el Estado se vendiera a otras naciones y no se ofreciese al mercado nacional a precio de coste. El diputado provincial Diezquijada Gallo solicitaba que se adicionase a las conclusiones formuladas en la Asamblea de Burgos, la de solicitar la rebaja de los derechos arancelarios por la importación de maquinaria agrícola $^{1272}$. La actividad de la Corporación Provincial no cesaba en este asunto y, en octubre de 1921, el presidente de la Diputación Provincial daba cuenta de las gestiones que estaban realizándose para celebrar una Asamblea general en Madrid el día 18 y siguientes del mes de octubre de ese año, con la participación de las diputaciones de las provincias cerealistas, cámaras agrarias, federaciones católico-agrarias, Consejo de Fomento, diputados a Cortes y senadores, para gestionar la reforma del arancel y demás asuntos relacionados con la agricultura ${ }^{1273}$. Al mismo tiempo, se dirigió un telegrama al ministro de Hacienda para que no accediera a la pretensión de los harineros catalanes para que se suprimiese el impuesto transitorio sobre los trigos extranjeros. Por fin en 1922, las continuas peticiones en materia arancelaria fueron atendidas y el Congreso de Diputados aprobó una enmienda prohibiendo la importación de cereales extranjeros ${ }^{1274}$.

\footnotetext{
${ }^{1272}$ A.D.P.P., L.A.P.D. 129, 10-II-1921.

${ }^{1273}$ A.D.P.P., L.A.C.P. 133, 10-X-1921.

${ }^{1274}$ A.D.P.P., L.A.C.P. 134, 8-IV-1922.
} 
Sin embargo, la intranquilidad no tardó en volver al campo castellano y en 1924, la Diputación de Valladolid enviaba un telegrama a la Diputación de Palencia para comunicarle la protesta que había realizado ante el Directorio Militar por los rumores sobre el ensayo de los bonos de exportación de 30.000 t de trigo, significándole las incalculables perjuicios que al país cerealista ocasionaría la concesión de tales bonos ${ }^{1275}$. En 1929, los diputados provinciales Martínez Bustillo, Blanco Suárez de Puga y Rojo Flores, presentaban una Moción ${ }^{1276}$ para que se solicitase a los poderes públicos el cese inmediato de la autorización para importar trigos extranjeros, ya que esto producía, en su opinión, una depreciación del precio de los nacionales, ya de por sí bajos. Martínez Bustillo, aseguraba que con los datos del Servicio Agronómico ${ }^{1277}$, el consumo nacional estaba casi cubierto, siendo necesaria la importación de una cantidad de trigo menor de la que se había producido para cubrir las necesidades del consumo nacional ${ }^{1278}$. España ocupaba el octavo lugar en la producción triguera mundial, el sexto en la de cebada y en Europa, el cuarto y tercero respectivamente. En el año 1929 se recogieron 40 millones de qq de trigo, contra un consumo nacional de 39 millones, a lo que se añadió el exceso de dos millones de la cosecha de 1928 y las importaciones, que hasta julio fueron de 675.000 t. Ante esta situación se prohibieron las importaciones y se solicitó cerrar «herméticamente las fronteras» y la colocación del trigo sobrante en Baleares, Canarias, Protectorado de Marruecos. También se pedía que el Servicio Agronómico, con la cooperación de las Juntas Locales, elaborase estadísticas fiables por la importancia que tenía contar con datos de producción y recolección rigurosos.

En febrero de 1930, desparecida ya la Dictadura de Primo de Rivera, la Diputación Provincial de Palencia consideraba que la introducción de trigos extranjeros mientras se recogía una cosecha óptima y la coacción a los harineros, bajo amenaza de fuertes multas para adquirir «trigo exótico», había dado como resultado la paralización del mercado triguero, todo ello a causa de que, en el anterior Régimen, la agricultura había sido considerada, en opinión de la Diputación palentina, como el «último mono» en las actividades nacionales.

\footnotetext{
${ }^{1275}$ A.D.P.P., L.A.P.D. 137, 2-IV-1924.

${ }^{1276}$ A.D.P.P., L.A.P.D. 138, 11-VI-1929.

${ }^{1277}$ Evaluaba la cosecha del año 1928 en 36 millones de qq.

${ }^{1278}$ Las necesidades del consumo nacional se estimaban en unos 40 millones de qq, dada la producción de 36 millones. Solo se necesitaban importar 4 millones pero en 1928 se habían importado 6 millones de t. A.D.P.P., L.A.P.D. 148, 28-III-1930.
} 
En agosto de 1930, se llevó a cabo una campaña de las diputaciones provinciales de Valladolid, Ávila y León, con el apoyo de la Diputación de Palencia, para evitar la importación de maíz sin abonar los derechos arancelarios, «haciendo ver los perjuicios que a la clase agraria de Castilla originaría dicha autorización que se traduciría en inmediata depreciación de los precios.» ${ }^{1279}$ Los diputados provinciales de la Diputación palentina advertían de que debía elaborarse una propuesta razonada para el Gobierno, ya que sus adversarios en esta lucha, los harineros del litoral, fundamentaban sus peticiones y por eso se les atendía. Se nombró una Comisión, formada por tres diputados y el presidente, para redactar las Bases que se habían de elevar al Gobierno. Hasta el final de la Restauración , la Diputación Provincial seguiría apoyando las reivindicaciones que perseguían la protección del cereal nacional y en febrero de 1932, poco antes de la caída da la Monarquía de Alfonso XIII, reclamaba al Gobierno Berenguer la toma de medidas necesarias para el restablecimiento de la normalidad de los mercados cerealistas, criticando la labor de director de Abastos, «(...) que olvidando su verdadera misión, se convirtió en agente intermediario con prima para la colocación del trigo exótico, desplazando del mercado cerealista la producción nacional.»» ${ }^{1280}$

Para la Diputación Provincial era fundamental que los trabajadores del campo, viticultores, agricultores y ganaderos, tuviesen la mejor formación posible de las técnicas y avances tecnológicos que se estaban produciendo en el campo a finales del siglo XIX, para que no quedasen al margen de la creciente mecanización de las labores agrícolas y aplicasen sus conocimientos a la mejora de la calidad de sus productos, ya fuera el vino, el cereal o el ganado. En la sesión de la Comisión Provincial del 24 de marzo de 1877 se planteaba la necesidad de instalar una Granja Modelo, para que enseñase a producir más con menos gasto, a producir artículos de gran demanda y fácil venta.

${ }^{1279}$ A.D.P.P., L.A.C.P. 146, 30-VIII-1930.

${ }^{1280}$ A.D.P.P., L.A.C.P. 147, 27-II-1931. 
Había que sembrar todas las semillas que se pudieran cultivar en la provincia, plantar toda clase de árboles, poner en valor prados y «(...)yerbas fanageras», criar ganados y toda clase de animales domésticos. Hacer comprender a los labradores las ventajas del regadío, ya que terrenos aptos para el regadío solo producían una mísera cosecha de trigo o cebada, y explotar el cultivo de la vid, «(...) la tierra, el clima y las condiciones todas de una gran parte de la provincia son a propósito para producir los vinos sueltos, frescos, poco alcohólicos y ligeramente aromáticos que usan a todo pasto las personas de buen paladar en los pueblos de Europa y América.» ${ }^{1281}$ Esa clase de uvas se producían en el Departamento de Bourdeaux, en Francia, vendiéndolas por todo el mundo a 30, 40 y hasta 60 reales la botella y esas uvas, y aun mejores, se estaban fabricando en la provincia de Palencia por particulares, vendiendo la botella a ocho o diez reales el cántaro. La Diputación Provincial pensaba que con el apoyo de la Granja Modelo se mejoraría la elaboración y la comercialización en el extranjero.

En 1878, la Junta Provincial de Agricultura, convencida también de las bondades de la enseñanza de los estudios agrarios, solicitó la creación de una Estación Agronómica en el Instituto Provincial de Segunda Enseñanza ${ }^{1282}$. En el año 1887, varios pueblos habían presentado solicitudes para albergar la Granja Escuela Experimental: La Nava de Campos, San Isidro de Dueñas, Priorato de Mave y la Granja de Cordovilla la Real. Se procedió a aceptar esta última proposición por reunir las condiciones exigidas para este tipo de instalaciones. Se acordó que la Comisión Provincial, acompañada por el presidente de la Diputación y el ingeniero agrónomo de la provincia, visitase la finca para valorar la posibilidad de su aceptación definitiva como albergue de la Granja Escuela ${ }^{1283}$. Finalmente, en enero de 1888, se propuso al Ministerio de Fomento la Granja de Cordovilla para albergar la Granja Escuela ${ }^{1284}$, tres meses más tarde, en abril de 1888 , se discutía la idoneidad de la finca de Cordovilla para albergar la Granja Escuela ${ }^{1285}$. Varios diputados consideraban un error aceptar dentro del contrato de arrendamiento la cláusula que imponía a la Diputación Provincial la obligación de sufragar las mejoras que se realizasen en la misma.

\footnotetext{
${ }^{1281}$ A.D.P.P., L.A.C.P. 48, 24-III-1877.

${ }^{1282}$ A.D.P.P., L.A.P.D. 45, 26-IV-1878.

${ }^{1283}$ A.D.P.P., L.A.C.P.P. 67, 3-I-1888.

${ }^{1284}$ Se arrendó la finca a su propietario, Policarpo Pastor Ojero, por cinco años, a partir de enero de 1888.

${ }^{1285}$ A.D.P.P., L.A.P.D. 64, 4-IV-1888.
} 
Se votó nominalmente este primer punto de la sesión y quedó aprobado el convenio en la parte referente a la cantidad ${ }^{1286}$ estipulada por el pago del arrendamiento por doce votos contra dos. Respecto de las obras referentes a los edificios existentes y los que se construyeran nuevos, también en votación nominal, quedó aprobado este segundo punto por ocho votos a favor y seis en contra. La Diputación Provincial también consideraba un sector estratégico dentro del campo palentino el cultivo de la vid, y había conseguido para la provincial el Centro de Análisis Enológico ${ }^{1287}$. En 1889, varios diputados provinciales $^{1288}$ presentaron una propuesta para que se consignasen 42.000 pts. en el Presupuesto provincial para la compra del edificio llamado «Mercado de granos o pabellón del Mercado» ${ }^{1289}$, cuartel de la Reserva que tenía acordado enajenar el Ayuntamiento de Palencia ${ }^{1290}$ con el objeto de establecer en él el laboratorio vinícola «(...) donde se van a hacer los ensayos y análisis de los mostos, vinos, alcoholes y demás bebidas espirituosas, sirviendo a la vez de depósito de las máquinas y aparatos destinados a los campos de demostración agrícola y de exposición de los productos de la agricultura y producción vinícola.» ${ }^{1291}$ En mayo de 1890, se adjudicó por 42.000 pts. el Pabellón del Mercado a la Diputación por parte del Ayuntamiento como sede para acoger el Laboratorio Enológico ${ }^{1292}$. En febrero de 1891, el Gobierno Militar de la Provincia comunicó a la Comisión Provincial su disposición favorable para trasladar las oficinas ${ }^{1293}$ del Cuerpo del Regimiento de Infantería de Reserva 60, para que el local quedase a disposición de la Diputación Provincial y utilizarlo como Estación Enológica. En la sesión del día 12 de febrero de 1892 se dio lectura a la Real Orden de 5 de febrero de 1892, que concedía la instalación de una Estación Enológica en la ciudad de Palencia. El Gobierno había puesto como condición que los locales para la Estación Enológica fueran cedidos por el Ayuntamiento, pero un vocal de la Comisión Provincial defendía que la Diputación ya había contemplado una partida presupuestaria para este concepto, y no era necesario el concurso del Ayuntamiento.

\footnotetext{
${ }^{1286} 18.000$ pts.

${ }^{1287}$ La Real Orden de 21 de enero de 1888 disponía que el Centro de Análisis Enológico se estableciese en Palencia, tenía adscrita la provincia de Burgos, con una producción vinícola entre ambas de 1.039.280 ha. A.D.P.P. C-R/ 1,8 .

${ }^{1288}$ Monedero y Monedero, Martínez Merino, García Benito, Abia Herrero y Martínez López.

${ }^{1289}$ Llamado popularmente «Cuartelillo», situada en la antigua Plaza de Mercado, hoy Abilio Calderón.

${ }^{1290}$ El Ayuntamiento de Palencia consideraba que el Pabellón del Mercado carecía de objeto y por lo tanto lo consideraba como «edificio inútil» para los efectos de su enajenación, la cual se acordó para atender a los créditos pendientes del Ayuntamiento con la Diputación Provincial y el Estado. A.M.A.P., L.A.P.A., A-21103, 13-II-1889.

${ }^{1291}$ A.D.P.P., L.A.P.D. 68, 13-II-1889.

${ }^{1292}$ A.D.P.P., L.A.C.P. 72, 8-V-1890.

${ }^{1293}$ Ubicadas en el Pabellón del Mercado, vendido por el Ayuntamiento de Palencia a la Diputación Provincial en 1890.
} 
Finalmente, se llegó a un consenso, aceptando el local ofrecido por el Ayuntamiento y sufragando la Diputación los gastos de acondicionamiento ${ }^{1294}$. En mayo de $1892^{1295}$, quedó anulada la concesión hecha al Ayuntamiento de Palencia de una Estación Enológica por no haber cumplido lo prescrito en la Real Orden de 5 de febrero de 1892, y fue transferida dicha concesión a la Diputación Provincial por Orden de la Dirección General de Agricultura de 10 de mayo de $1892^{1296}$. En 1893, fue aprobado por Real Orden de 18 de abril de 1893 el proyecto de Estación Enológica ${ }^{1297}$, un mes más tarde, se adjudicaron las obras de la primera sección de la Estación Enológica y habitaciones de capataces ${ }^{1298} \mathrm{y}$, en marzo de 1894, tuvo lugar la recepción provisional de la primera sección de la Estación Enológica ${ }^{1299}$. En abril de ese año, se subastaron las obras de la segunda sección de la Estación Enológica con un presupuesto inicial de 22.564, 70 pts. ${ }^{1300}$ y en octubre, se solicitó al Ayuntamiento de Palencia ${ }^{1301}$ la cesión del terreno necesario en la Plazuela de la Maternidad, a ambos lados del edificio de la Estación Enológica, para instalar un observatorio meteorológico, «de gran utilidad para los labradores». Dispuesto por la Dirección General de Agricultura, este servicio se debía instalar en la Estaciones Enológicas.

\footnotetext{
${ }^{1294}$ A.D.P.P., L.A.C.P. 77, 12-II-1892.

${ }^{1295}$ El director general de Agricultura, Industria y Comercio, a través del gobernador de la provincia, manifestó que habiendo transcurrido el plazo de tres meses que marcaba la Real Orden de 5 de febrero de 1892 para la aceptación de las condiciones que en ella se señalaban para la instalación de una Estación Enológica en la capital palentina sin que su Ayuntamiento hubiese aceptado la Disposición $1^{\mathrm{a}}$ de la Real Orden, y puesto que la Diputación Provincial contaba con las 25.000 pts. para atender los gastos que el establecimiento originase, se consideraba caducada la concesión para el Ayuntamiento de Palencia y se otorgaba en favor de la Diputación Provincial. A.M.A.P., L.A.P.A., A-21-104, 18-V-1892.

${ }^{1296}$ A.D.P.P., L.A.C.P. 77, 25-V-1892.

${ }^{1297}$ A.D.P.P., L.A.C.P. 78, 25-IV-1893.

${ }^{1298}$ A.D.P.P., L.A.C.P. 78, 19-V-1893. Se adjudicaron a Ceferino Morate Villanza, que se comprometió a ejecutarlas en 23.000 pts.

${ }^{1299}$ A.D.P.P., L.A.C.P. 79, 13-III-1894.

${ }^{1300}$ A.D.P.P., L.A.C.P. 79, 13-IV-1894.

${ }^{1301}$ A.D.P.P., L.A.C.P. 79, 12-X-1894.
} 
La recepción definitiva de la primera parte de la Estación Enológica y provisional de la segunda parte tuvo lugar en enero de 1895, la recepción definitiva de la Estación Enológica en diciembre de $1895^{1302}$. La tasación de la Estación Enológica a efectos del seguro era de $73.729,40$ pts. ${ }^{1303}$. Sus objetivos eran:

1. Ensayo y mejora de los distintos tipos de vinos de la región.

2. Trabajos de relación con el público: corrección de vinos enfermos o defectuosos.

3. Difusión de los conocimientos enológicos, (conferencias y enseñanzas a capataces y bodegueros)

En 1902, al existir otra Estación Enológica en la provincia de Zamora, peligraba la existencia de la de Palencia. La Comisión Provincial temía que al estar establecida en Valladolid una Escuela Regional de Agricultura, caso de desaparecer la Estación Enológica, Palencia quedaría sin ningún establecimiento de estas características, por lo que envió al ministro de Agricultura un informe en el que constaban los derechos adquiridos por la Estación Enológica palentina que, a entender de la institución provincial, reunía mayores ventajas que la que se encontraba en Toro. En 1903, Abilio Calderón Rojo, diputado en Cortes por el Distrito de Palencia, informó a la Comisión Provincial que, en el Presupuesto del Ministerio de Agricultura para el año 1904, había un crédito destinado a la ampliación, transformación y mejora de campos de experiencia, siendo fácil que se consiguiera establecer en la capital un Instituto de Agricultura si se ofrecía al Gobierno arrendar 25 ha de terreno regable que se conceptualizasen como ampliación de los campos de experimentación agrícolas ${ }^{1304}$. La Real Orden de 3 de diciembre de $1903^{1305}$ concedía la transformación en Granja Instituto Agrícola de la Estación Enológica ${ }^{1306}$.

\footnotetext{
${ }^{1302}$ Dotada con clases, bodegas, laboratorios, lagares y habitaciones para el director y personal, era la única en España que contaba con local propio. La inversión total fue de 88.890 pts. A.D.P.P., C-A/ 1,16 (A).

${ }^{1303}$ A.D.P.P., L.A.C.P. 83, 20-VIII-1895.

${ }^{1304}$ A.D.P.P., L.A.C.P. 99, 7-XII-1903.

${ }^{1305}$ Del Ministerio de Agricultura, Industria, Comercio y Obras Públicas. La Diputación Provincial daba un Voto de Gracias a Abilio Calderón Rojo por sus gestiones para conseguir que la Estación Enológica se convirtiese en Granja Instituto de Agricultura. Se ponían a disposición del Estado el edificio de la Estación Enológica, en la que se habían invertido 150.000 pts. , el campo de experimentación agrícola, valorado en más de 5.000 pts. , y 25 ha de terreno en un paraje cercano a la capital.

${ }^{1306}$ A.D.P.P., L.A.C.P. 118, 9-XII-1903.
} 


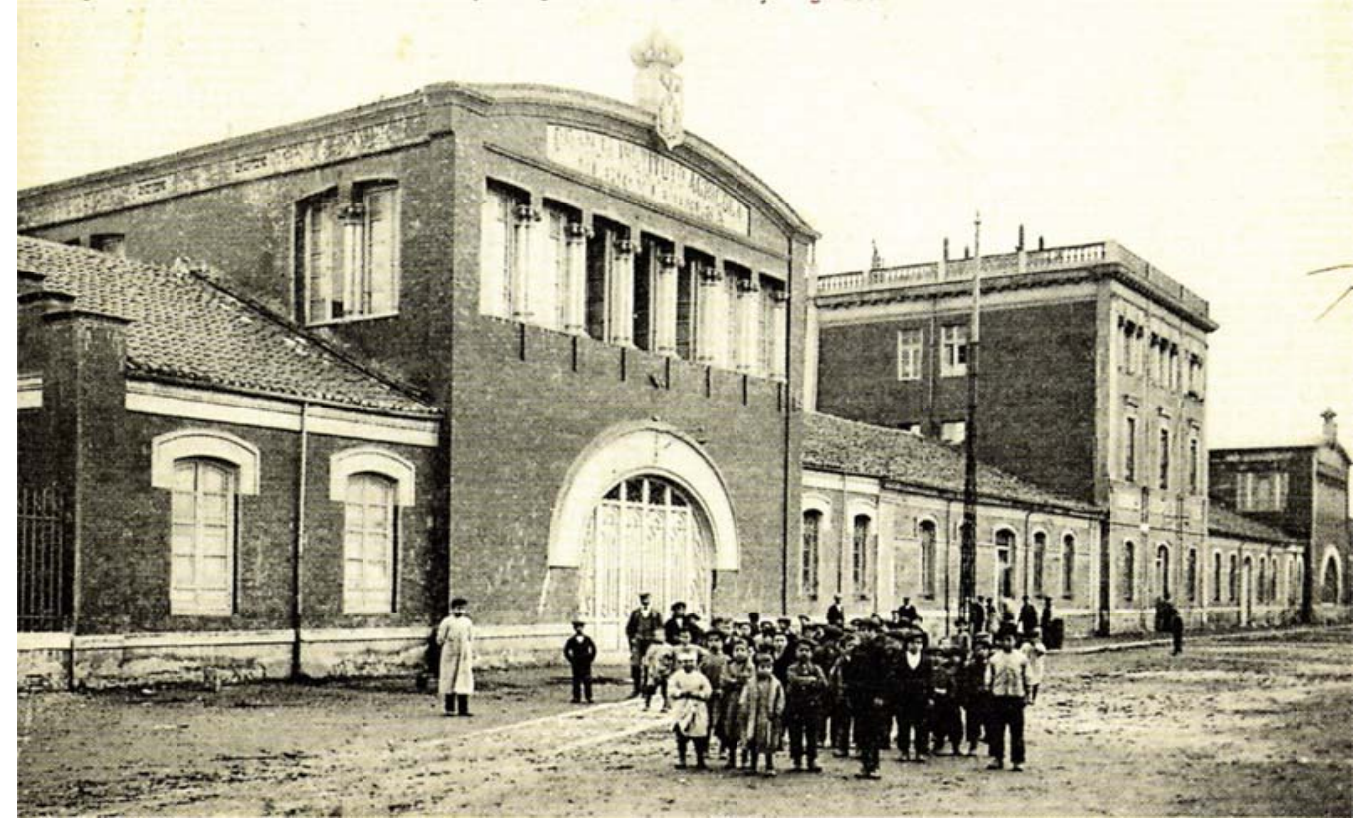

Fuente: A.D.P.P. (B.T.T.M.)

Agustín Martínez de Azcoitia ofreció a la Diputación Provincial en arrendamiento por diez años ${ }^{1307}$ la finca denominada la Serna, para el establecimiento la Granja Instituto Agrícola. Desierto el concurso celebrado para el arrendamiento, se aceptó la propuesta de Martínez de Azcoitia sin necesidad de nuevos anuncios por no exceder de 2.000 pts. la renta, ya que la Asamblea estaba facultada, en este caso, para contratar directamente ${ }^{1308}$. En 1904, Martínez de Azcoitia no accedió a prorrogar el contrato de arriendo por otros diez años y la Diputación se comprometió a adquirir una finca por el tiempo que el Gobierno sostuviese el establecimiento. Ese año, Abilio Calderón ${ }^{1309}$ escribió una carta al vicepresidente de la Diputación Provincial para comunicarle las concesiones otorgadas por el ministro de Agricultura, Industria y Comercio para obras y maquinaria con destino a la Granja Instituto Agrícola, aconsejando la adquisición de la finca la Serna para que, una vez fuera propiedad de la Diputación, pudiera ser objeto de mayor inversión por parte del Estado.

\footnotetext{
${ }^{1307}$ A razón de 2.000 pts. anuales.

${ }^{1308}$ A.D.P.P., L.A.P.D. 96, 1-II-1904.

${ }^{1309}$ En esa época director general de Administración. A.D.P.P., L.A.C.P. 100, 12-VIII-1904.
} 
Se acordó adquirir la finca la Serna por 70.000 pts., y cederla al Estado para que la utilizase mientras en la misma permaneciera la Granja Instituto Agrícola ${ }^{1310}$. Se solicitó al ministro de Fomento que en la Granja Agrícola se cultivasen injertos y barbados de vides para luego distribuirlas gratuitamente entre los viticultores «(...) a precio de coste con el objeto de fomentar la repoblación del viñedo, (...) evitando la ruina de la comarca y penuria de los agricultores.» ${ }^{1311}$ En 1911, varios diputados provinciales solicitaron que por conducto del Consejo Provincial de Agricultura, Industria y Comercio se pidiese al ministro de Fomento que ordenase al personal de la Granja Agrícola Regional ${ }^{1312}$ que dieran conferencias en las campos de experimentación que los pueblos ofrecieran para difundir los conocimientos agrarios y mejorar el estado de la producción ${ }^{1313}$. Por el Real Decreto de 20 de junio de 1924, la Granja Instituto Agrícola se transformó en División Agronómica de Experimentación, al producirse esta transformación, quedó rectificada la cesión al Estado de la finca la Serna y los locales de la Granja Instituto Agrícola ${ }^{1314}$.

Por último, debe mencionarse una actividad relacionada con el fomento de la riqueza agrícola, pero también con la construcción de carreteras. En la etapa de la Dictadura de Primo de Rivera, tanto el Directorio como las propias diputaciones provinciales mostraron gran interés en que las carreteras contasen en sus márgenes con arbolado, que en su opinión cumpliría dos funciones, servir de sustento a las propias cunetas de la red viaria e impedir que los agricultores se apropiasen de los terrenos que pertenecían a la estructura de la carretera. Es por eso que se promocionó entre los pueblos interesados la construcción de viveros de árboles destinados a plantarse en los márgenes de las carreteras. En 1925 se firmó un acuerdo entre los ayuntamientos de Astudillo, Baltanás y Dueñas y la Diputación Provincial para la cesión de terrenos para viveros forestales y campos de experimentación agrícola $^{1315}$.

\footnotetext{
${ }^{1310}$ A.D.P.P., L.A.P.D 96, 6-X-1904. Adquirida el 2 de noviembre de 1904.

${ }^{1311}$ A.D.P.P., L.A.P.D 113, 12-IX-1914. Se pedía también una tarifa especial mínima para el transporte ferroviario de las vides y que fuese lo más rápido posible para que las plantas llegasen en buen estado de conservación.

${ }^{1312}$ Además de Palencia, su radio de actuación incluía la provincia de León.

${ }^{1313}$ A.D.P.P., L.A.P.D. 111, 13-V-1911.

${ }^{1314}$ A.D.P.P., L.A.C.P. 141, 14-VIII-1925.

${ }^{1315}$ A.D.P.P., L.A.C.P. $141,7-X I-1925$.
} 
En enero de 1926, el ingeniero director de los viveros forestales, el secretario de la Diputación y el ponente Rojo Flores visitaron los viveros forestales establecidos en estos pueblos. En esta visita se haría oficial la toma de posesión de los mismos por parte de la Diputación ${ }^{1316}$. El informe de la visita señala que los terrenos cedidos en Baltanás eran de mala calidad y se aconsejaba adquirir nuevas tierras de mejor calidad, Astudillo ofrecía terrenos no aptos y Dueñas renunciaba a la subvención. En 1927, la situación de los viveros era la siguiente:

Tabla 18. Viveros forestales de la Diputación Provincial de Palencia en 1927.

\begin{tabular}{|c|c|}
\hline Viveros & Plantaciones \\
\hline Astudillo & 17.000 chopos \\
& 5.000 olmos \\
& 1.500 acacias \\
& 10.000 pinos \\
\hline Baltanás & 15.000 chopos \\
\hline Dueñas & 9.000 chopos \\
& 1.500 olmos \\
& 3.000 pinos \\
\hline Huerta Diputación & 3.000 pinos \\
& 1.000 olmos \\
& 2.000 acacias \\
\hline
\end{tabular}

Elaboración propia Fuente: A.D.P.P., L.A.C.P. 144, 12-I-1928.

En ese mismo año, Carrión de los Condes ofreció a la Diputación Provincial terrenos para la plantación de un vivero de moreras (Real Orden de 30 de marzo de 1927), con la obligatoriedad de producir más de 40.000 moreras anuales a propuesta de la Comisaría Regia de la Seda ${ }^{1317}$.

\footnotetext{
${ }^{1316}$ Los pueblos cedían una hectárea de regadío para vivero y prado artificial y para prados y cuadras y establos para el campo agropecuario de experimentación, a cambio la Diputación aportaba una subvención a los ayuntamientos.

${ }^{1317}$ A.D.P.P., L.A.C.P. $144,12-$ VII-1927.
} 


\section{Corrección Pública}

La Ley de Bases de 21 de octubre de 1869 clasificaba los establecimientos penitenciarios en Depósitos Municipales, Cárceles de Partido, Cárceles de Audiencia, Presidios, Casas de Corrección y Colonias Penitenciarias. Los ayuntamientos eran los encargados de sostener los Depósitos Municipales y las Cárceles de Partido y las diputaciones provinciales, las Cárceles de Audiencia ${ }^{1318}$. El Real Decreto de 15 de abril de 1886 disponía que todos los reos condenados a la pena de prisión correccional lo hicieran en las Cárceles de Audiencia del territorio en la que esta se hubiese impuesto. La Comisión Provincial tenía la facultad de aprobar los repartimientos para el sostenimiento de las Cárceles de Partido por el art. 2 del Real Decreto de 18 de abril de $1875^{1319}$ y los ayuntamientos cabeza de Partido tenían la obligación de anticipar las cantidades ${ }^{1320}$ necesarias para el sostenimiento de los presos pobres.

En 1886, el director general de Establecimientos penitenciarios ordenaba a la Diputación Provincial, en vista del Real Decreto de 15 de abril de 1886 respecto al cumplimiento de la pena de prisión correccional en la Cárceles de Audiencia, que se informase de forma inmediata cuáles de las cárceles de la provincia podrían sustituir a las que existían en las poblaciones en las que estaban instaladas las Audiencias de lo Criminal, en el caso de que en las de estas no se pudieran cumplir aquellas condenas ${ }^{1321}$. El arquitecto provincial comunicaba a la Comisión Provincial la imposibilidad de que en la cárcel de la capital pudiera cumplirse la pena de prisión correccional, aun llevando a cabo las obras necesarias, considerando que en las cárceles de los restantes Partidos Judiciales las condiciones eran aún peores para el cumplimiento de la pena indicada ${ }^{1322}$.

\footnotetext{
${ }^{1318}$ Las diputaciones debían atender el pago del personal, material y mantenimiento de las Cárceles de Audiencia. A lo largo de la Restauración fueron varias las disposiciones legales que regularon la atribución en materia correccional de las diputaciones provinciales, como el Real Decreto de11 de marzo de 1886, el Real Decreto de 3 de mayo de 1892, el Real Decreto de 23 de diciembre de 1902 y el Real Decreto de 22 de abril de 1910.

${ }^{1319}$ A.D.P.P., L.A.C.P. $60,20-\mathrm{V}-1884$

${ }^{1320}$ Estas cantidades debían ser custodiadas por el depositario del Ayuntamiento cabeza de Partido, y no ingresada en la Caja de la Diputación.

${ }^{1321}$ A.D.P.P., L.A.P.D. $62,26-\mathrm{IV}-1886$.

${ }^{1322}$ A.D.P.P., L.A.P.D. 62, 20-VII-1886.
} 
La situación de los establecimientos era bastante precaria, hasta el punto de que la Diputación Provincial informaba a la Presidencia de la Audiencia que debía hacer saber a los vocales de la Junta de Prisiones, que en la enfermería de la Cárcel de Audiencia solo se atendía a los presos de la misma, y que los presos de la cárcel de Partido podían ser atendidos en el hospital, o establecer una enfermería en dicho establecimiento ${ }^{1323}$, se acordó poner estos hechos en conocimiento del director general de Establecimientos penitenciarios. La Real Orden de 24 de julio de 1891 del Ministerio de Gracia y Justicia, aprobaba el proyecto y presupuesto $^{1324}$ del correccional de la ciudad, el arquitecto redactaría la Memoria del proyecto para que fuera aprobada por la Asamblea Provincial.

Imagen 12. Proyecto de edificación de la Cárcel Correccional de Palencia (1891).

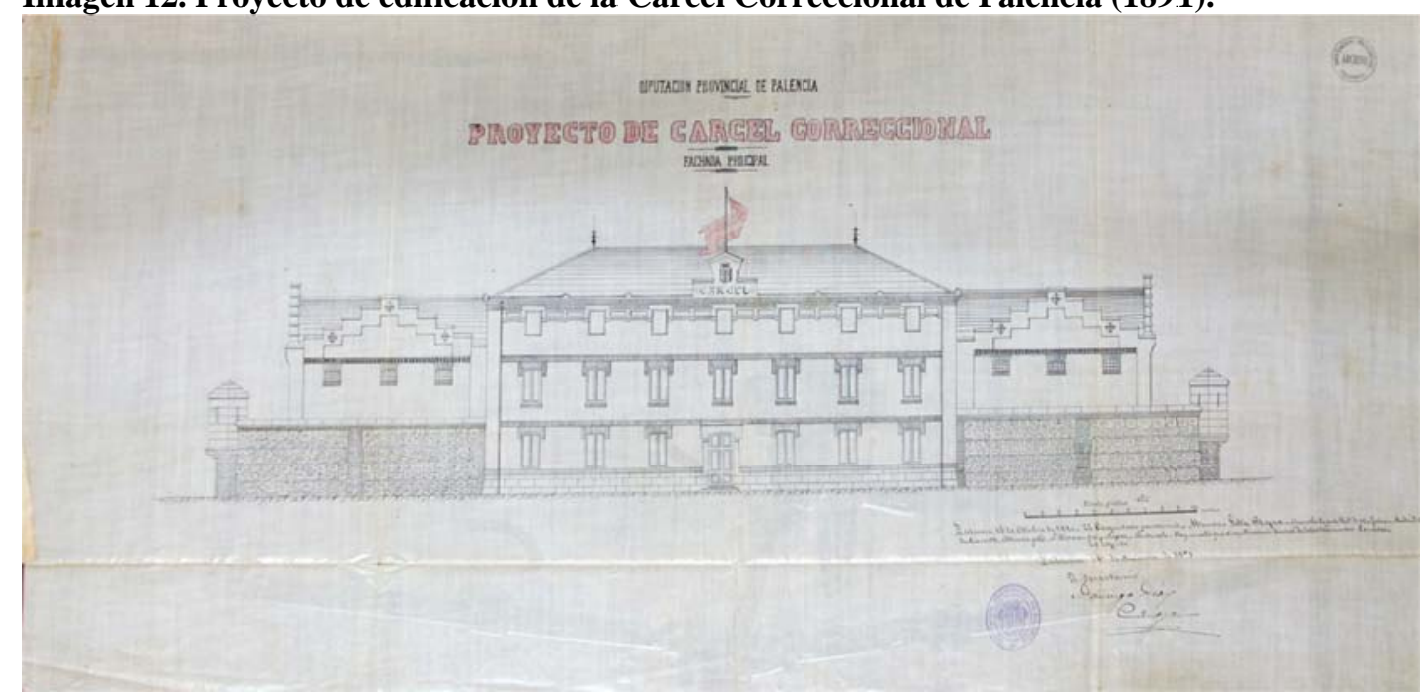

Fuente: A.D.P.P., C-1746.

En el proyecto no se contemplaban departamentos para presos de tránsito $\mathrm{y}$ Depósito Municipal, puesto que ambos contaban con un local adecuado en la Cárcel del Partido Judicial $^{1325}$. La cantidad por las que habían de subastarse las obras de la nueva Cárcel de Audiencia era de 241.212,18 pts., y las obras no debían exceder de dos años de duración, al finalizar la obra la cantidad total invertida sumaba $241.823,8$ pts. y su construcción se alargó hasta los cuatro años.

\footnotetext{
${ }^{1323}$ A.D.P.P., L.A.C.P. 72, 20-II-1890.

${ }^{1324} 80.000$ pts. a satisfacer en 4 años. A.D.P.P., C-L/ 6,2. En el Presupuesto Adicional del Presupuesto Ordinario del ejercicio de $1886 / 87$ se destinaba ya una partida presupuestaria de 99.530 pts. para la construcción de un edifico de Cárcel Correccional. A.D.P.P., C-L/ 5,2.

${ }^{1325}$ A.D.P.P., L.A.C.P. 73, 30-VI-1891.
} 
Las cantidades invertidas en los cuatro ejercicios que transcurrieron desde su inicio se distribuyeron de la siguiente forma,

Tabla 19. Cantidades invertidas por ejercicios en la construcción de la Cárcel de Audiencia de Palencia.

\begin{tabular}{|c|c|}
\hline Años & Presupuesto (pts.) \\
\hline $1890 / 91$ & 100.000 \\
\hline $1891 / 92$ & $47.274,6$ \\
\hline $1892 / 93$ & $47.274,6$ \\
\hline $1893 / 94$ & $47.274,6$ \\
\hline
\end{tabular}

Elaboración propia. Fuente: A.D.P.P., L.A.P.D. 69, 12-IV-1890.

Hasta la construcción de la nueva Cárcel de Audiencia, se decidió adaptar la Cárcel de Partido para acoger a los penados con penas de prisión correccional ${ }^{1326}$. La Comisión de la Junta Provincial de Sanidad y de la Junta Local de Prisiones proponían que la Cárcel de Audiencia fuese emplazada en el terreno frente a las puertas de Rizarzuela, limitado por la carretera general de Madrid a Santander, Huerta de Guadián y camino de Pan y Guindas. Se aprobó el emplazamiento propuesto por las Juntas citadas ${ }^{1327}$ pero, tras realizar las calicatas en el terreno elegido para albergar la Cárcel de Audiencia, el arquitecto provincial informó de la aparición de terreno inundado sobre la capa firme, que se encontraba a una mayor profundidad de lo previsto, lo cual repercutiría en los gastos de cimentación. En vista de estas nuevas circunstancias, se aprobó un nuevo emplazamiento de la cárcel, eligiendo el terreno entre la carretera de Valladolid, campo de instrucción y el vivero de Obras Públicas ${ }^{1328}$.

\footnotetext{
${ }^{1326}$ La prisión correccional conllevaba la privación de libertad sin trabajo, y conllevaba una pena de entre siete meses y tres años. Vid. RAMOS VÁZQUEZ, Isabel, La reforma penitenciaria en la historia contemporánea española, Madrid, Dykinson, 2013.

${ }^{1327}$ A.D.P.P., L.A.P.D. 70, 28-VIII-1891.

${ }^{1328}$ A.D.P.P., L.A.P.D. 70, 10-XI-1891.
} 
Después de la recepción provisional de las obras de la Cárcel de Audiencia, a cuyo acto asistió corporativamente la Comisión Provincial, el 1 de julio de 1897 se produjo la recepción definitiva de la Cárcel de Audiencia ${ }^{1329}$. En octubre de 1897, a petición del Ayuntamiento de Palencia, se cedieron los locales de la nueva Cárcel de Audiencia para acuartelar a los reclutas de Ultramar, a condición de que se devolviera el edificio en las mismas condiciones que se entregaba. El 31 de enero de 1899 se acordó el traslado de los presos de la Cárcel de Audiencia y de Partido al nuevo edificio correccional.

El Real Decreto de 6 de mayo de 1892 señalaba que los gastos de las Cárceles de Audiencia de lo Criminal, entre los que se incluían los gastos de manutención de los presos pobres durante el periodo que estuviesen a disposición de los citados tribunales, debían ser costeados por las diputaciones provinciales, que tenían que incluir una partida para este fin en su Presupuesto Ordinario de Gastos ${ }^{1330}$. La atención de Corrección Pública supuso un importante gasto para la Diputación Provincial, alcanzado un 3\% del total del Presupuesto de gasto entre los años 1886 y 1924.

Figura 15. Porcentaje de gasto en Corrección Pública sobre el total del gasto en la etapa 1886/1924.

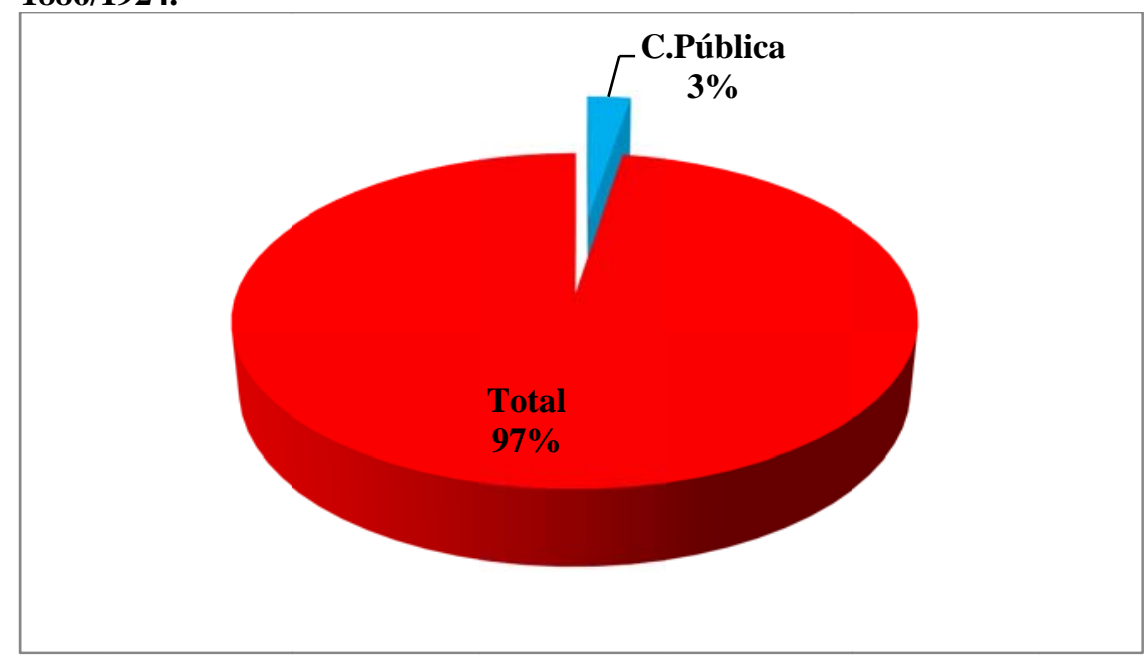

Elaboración propia. Fuente: A.D.P.P.

\footnotetext{
${ }^{1329}$ A.D.P.P., L.A.C.P.P. 84, 1-VII-1896.

${ }^{1330}$ Véase Anexo V. Presupuesto Provincial en pts. en Beneficencia, Instrucción Pública, Corrección Pública y carreteras 1875-1931, p. 485.
} 
Figura 16. Gasto anual en pts. en Corrección Pública entre los años 1884-1924.

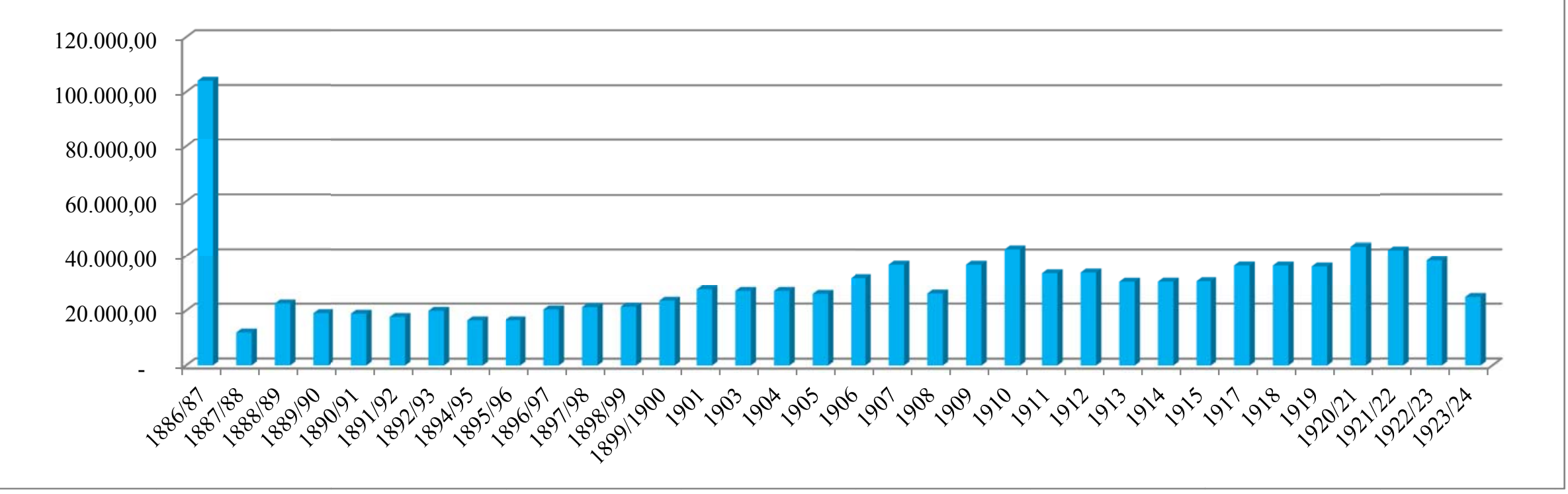

Elaboración propia. Fuente: A.D.P.P. 
En el caso de coincidir en un mismo edificio la Cárcel de Partido y de Audiencia, los gastos generales que conllevaba su mantenimiento se repartían entre el Ayuntamiento y la Diputación provincial. Sin embargo esto no siempre fue así, y el tener que compartir un mismo edificio provocó que tanto el Ayuntamiento como la Diputación Provincial polemizaran por las atenciones que consideraban de su exclusiva competencia. En 1912, el Ayuntamiento de Palencia remitió a la Diputación Provincial un justificante de pago de las obras de abastecimiento de aguas y material empleado, la Comisión Provincial consideraba que las obras se habían hecho con destino a la Cárcel de Partido, y que la Diputación era responsable del sostenimiento de la Cárcel de Audiencia y que, como mucho, solo debía pagar la mitad, ya que era el Ayuntamiento el responsable de pagar los gastos que originase la Cárcel de Partido ${ }^{1331}$. En 1919, el Ayuntamiento de Palencia solicitaba que se dejase sin efecto el acuerdo de la Diputación Provincial de 26 de septiembre de 1917 por el que los haberes del personal de prisiones que prestaba servicio en la Cárcel Provincial serían de cuenta del Ayuntamiento por compartir edificio la cárcel de Partido ${ }^{1332}$ con la de Audiencia Provincial. La Diputación propuso al ministro de Gobernación que fuera desestimada esta solicitud ${ }^{1333}$. Los gastos de la escuela de Instrucción Primaria del correccional eran de cargo de la Diputación, y también los de calefacción, además, sufragaba los socorros que ocasionaban los reclusos en la cárcel de Partido a disposición de la Audiencia de lo Criminal. Estos son algunos ejemplos de las diferentes formas de interpretar la normativa sobre las atenciones de Corrección Pública. Las diferencias no solo se daban con el Ayuntamiento de Palencia, los pueblos también tenían dudas sobre la compleja normativa en materia correccional y en 1895, el alcalde de Quintana de Puente tampoco tenía claro quién debía hacerse cargo de ciertas atenciones correccionales y consultaba a la Diputación Provincial sobre la clase de socorros que la institución provincial estaba obligada a facilitar a los presos pobres conducidos por la Guardia Civil a disposición del gobernador de la provincia, desde el juzgado de Partido al penal correspondiente. La Diputación Provincial contestaba que solo estaba obligada a sufragar los gastos de los presos que habían de cumplir sus condenas en la Cárcel de Audiencia Provincial, en este caso y previa justificación, se reintegrarían a los ayuntamientos los gastos ocasionados por los $\operatorname{presos}^{1334}$.

\footnotetext{
${ }^{1331}$ A.D.P.P., L.A.C.P. 116, 23-III-1912.

${ }^{1332}$ El Ayuntamiento de Palencia la tercera parte del gasto en personal y material de la Cárcel de Partido. Sentencia del Tribunal Contencioso-Administrativo del 6 de julio de 1893y Real Decreto de 5 de mayo de 1913.

${ }^{1333}$ A.D.P.P., L.A.C.P. 127, 10-I-1919.

${ }^{1334}$ A.D.P.P., L.A.C.P. 83, 18-VII-1895.
} 
Según Real Orden de 8 de febrero de 1889, las estancias causadas por los presos con penas superiores a prisión correccional debían ser satisfechas por el Ministerio de Gracia y Justicia, la Diputación Provincial había realizado una instancia ante este Ministerio para que se abonasen las estancias hasta el año 1900 en la Cárcel de Audiencia de este tipo de presos, pero el Ministerio no pagó ${ }^{1335}$.

Como era habitual en las atenciones en las que Estado y diputaciones provinciales compartían atribuciones, a la hora de sufragar los gastos que conllevaban el mantenimiento de los presos y de los edificios correccionales, surgían diferencias sobre qué Administración debía hacerlo. Guigelmo Aguado, exdiputado provincial y senador en 1902, se quejaba de que sus reclamaciones sobre el deber del Estado de costear las estancias de los corrigiendos desde su destino a un establecimiento penal distinto del que se hallaban, a pesar de la obligación que imponía la citada Real Orden de que fuese el Estado quien sufragara estos gastos, el Ministerio de Gracia y Justicia se excusaba con la falta de crédito para no cumplir con la ley ${ }^{1336}$. La Diputación tenía la obligación no solo de construir los edificios para las cárceles correccionales, sino también el sostenimiento de los condenados y los sueldos de los empleados de las mismas. Cuando resultaban desiertas las diferentes subastas para el racionado de los corrigiendos, como en 1892, se decidía que este fuera suministrado por la Casa de Beneficencia, dentro de los 5 cént. presupuestados para cada penado en aquel año ${ }^{1337}$. El presupuesto para estas atenciones no era nunca suficiente para atender todas las necesidades de los penados $\mathrm{y}$, en ocasiones, eran los propios corrigiendos de la Cárcel de Audiencia quienes elevaban una instancia de súplica a la Diputación Provincial para que se les facilitasen ropas interiores y exteriores. La Diputación les recordaba que esta clase de peticiones habían de venir por conducto del director del establecimiento, que era el encargado de informar sobre las necesidades y urgencias del gasto y del importe de este. También es verdad que, en ocasiones, las relaciones entre la Diputación y los directores de la Cárcel de Audiencia no eran todo lo cordiales que cabría esperar entre la Administración que mantenía a la Cárcel y su máximo representante.

\footnotetext{
${ }^{1335}$ A.D.P.P., L.A.P.D. 89, 9-X-1901.

${ }^{1336}$ A.D.P.P., C-R/ 1,16 (A).

${ }^{1337}$ A.D.P.P., L.A.C.P. 77, 23-IX-1892. A partir de 1905, Práxedes Pérez suministraba las raciones de los presos en virtud del contrato celebrado el 16 de diciembre de 1905. En 1921, se le compensó por los perjuicios que le había ocasionado la subida de precios de los artículos necesarios para el racionado de presos y penados de la Cárcel de Audiencia, de cuyo servicio fue contratista desde el 1 de enero de 1920 a 20 de marzo de 1921, a razón de 60 pts. mensuales, 900 pts. A.D.P.P., C-L/ 11,4
} 
Baste como ejemplo lo sucedido en 1895, cuando la Diputación Provincial interpuso una denuncia contra el director de la Cárcel de Audiencia ante los tribunales, por considerar ofensivas las palabras pronunciadas por él ante el vocal de la Comisión Provincial, Tiréfilo Delgado, de las que se desprendía «(...) que en Palencia no había más Diputación que el secretario, y por consiguiente era inútil que el Sr. Delgado le hablara acerca de las relaciones que debían existir entre la Corporación y el jefe de la cárcel.» ${ }^{1338}$, ya que estas podían ser constitutivas de delito según el art. 266 del Código Penal. En 1906, los reclusos solicitaban a la Diputación Provincial que se restituyera el racionado por un socorro en metálico, se desestimó la petición ${ }^{1339}$, sin embargo, en 1907 la Diputación Provincial ante la petición de los reclusos de la Cárcel de Audiencia del apoyo moral y material de la Asamblea, para consignar el nombre de la Diputación en la instancia que los penados de España pensaban dirigir al Ministerio de Gracia y Justicia solicitando el indulto con motivo de nacimiento del hijo de la reina Doña Victoria, la institución provincial admitió la propuesta ${ }^{1340}$.

El mantenimiento de las instalaciones carcelarias era junto al mantenimiento de los presos pobres la mayor partida presupuestaria del Capítulo de Corrección Pública. A los pocos años de su inauguración, ya era imprescindible la limpieza de los cinco pozos negros de la cárcel de Audiencia «(...) para evitar las emanaciones que comprometen la salud de los recluidos.» ${ }^{1341}$ y en 1909, el jefe accidental de la Cárcel de Audiencia comunica a la Asamblea Provincial las reparaciones realizadas en los patios del correccional por los propios reclusos y pedía una gratificación para los penados. La Diputación contestaba que al ser la Cárcel de Audiencia de su propiedad, debía pedirse autorización para hacer cualquier obra, accedió a pagar los materiales pero advertía de que, en lo sucesivo, la dirección de la Cárcel no podía disponer obra alguna sin conocimiento previo de la Diputación, o de lo contrario no se abonarían los gastos ocasionados $^{1342}$. La Diputación tenía contratada una póliza de seguros del edificio de la Cárcel de Audiencia con la compañía La Urbana ${ }^{1343}$.

\footnotetext{
${ }^{1338}$ A.D.P.P, L.A.C.P. 83,11-I-1895.

${ }^{1339}$ A.D.P.P., L.A.C.P. 102, 24-XI-1906.

${ }^{1340}$ A.D.P.P., L.A.C.P. 103, 26-II-1907.

${ }^{1341}$ A.D.P.P., L.A.C.P. 100, 22-X-1904.

${ }^{1342}$ A.D.P.P., L.A.C.P. 109, 15-III-1909.

${ }^{1343}$ A.D.P.P., L.A.C.P. $115,16-X I I-1911$.
} 
En 1904, la plantilla de la Cárcel de Audiencia se componía de cuatro vigilantes, un médico cirujano, un administrador, un capellán y un demandadero. En 1908, la Diputación solicitó, al Ministerio de la Gobernación y a la Dirección de Penales, que gestionasen con el Ministerio de Guerra la venida a Palencia de un destacamento de infantería que realizase labores de vigilancia del edificio de la Cárcel Correccional, que carecía de vigilancia habiendo presos peligrosos, algunos procesados por asesinato ${ }^{1344}$. La Diputación sufragaba los gastos del personal que prestaba sus servicios en la Cárcel de Audiencia $^{1345}$. La Real Orden de 17 de diciembre de 1914, del Ministerio de Gracia y Justicia, contemplaba que, desde el día 1 de enero de 1915, el personal que prestase sus servicios en las prisiones preventivas y correccionales quedasen a cargo del Estado y las diputaciones provinciales no debían consignar en sus presupuestos para haberes de este personal $^{1346}$. No obstante, esta Real Orden quedó sin efecto ${ }^{1347}$. En 1922, el Real Decreto de 18 de octubre de 1922, disponía que fuera el Estado quien se hiciese cargo de las atenciones carcelarias, la Diputación Provincial urgió al Ministerio de Gracia y Justicia para que se hiciese cargo del sostenimiento de presos y penados cuanto antes, y abonase las cantidades que se venían satisfaciendo por este concepto desde el primero de octubre $^{1348}$ de ese año. En el Presupuesto de 1923-24 se ingresaba el 5\% de lo que importaban las atenciones carcelarias durante el ejercicio 1923-24. ${ }^{1349}$ La Diputación ofrecía al Estado el edificio de la Cárcel de Audiencia, ya que constituía una carga para el Presupuesto Provincial por los gastos de mantenimiento del edificio, por lo que se propuso cederlo al Estado, que se había comprometido a sustituir los edificios de las corporaciones por los suyos propios cuando lo permitiese la situación presupuestaria, dado que en este ejercicio de 1930 tenía superávit, la Diputación creyó llegado el momento de la cesión.

\footnotetext{
${ }^{1344}$ A.D.P.P., L.A.C.P. 108, 13-III-1908. Solo había cuatro vigilantes que no podían hacer un servicio permanente de custodia y vigilancia.

${ }^{1345}$ A.D.P.P., L.A.C.P. 115, 7-XII-1911. El Estado satisfacía directamente los sueldos del personal de la Cárcel de Audiencia, pero la Diputación debía reintegrar este gasto al Tesoro.

${ }^{1346}$ Ley de 12 de junio de 1911.

${ }^{1347}$ A.D.P.P., L.A.C.P. 119, 5-I-1915.

${ }^{1348}$ A.D.P.P., L.A.C.P. 134, 4-XI-1922.

${ }^{1349}$ De conformidad con los Reales Decretos de 18 de octubre y 13 de noviembre de 19222, y Reales Órdenes de 21 y 27 de noviembre de 1922.
} 


\section{Calamidades}

La Ley Provincial de 29 de agosto de 1882 disponía, en el punto 5 del art. 115, que los presupuestos provinciales contendrían las partidas necesarias para atender los imprevistos y calamidades públicas. Las peticiones más comunes se referían a la pérdida de cosechas, y así en 1893, varios ayuntamientos ${ }^{1350}$ solicitaban a la Diputación Provincial que se les condonase la Contribución Territorial, o que se concediese un socorro del fondo de Calamidades por los daños causados ${ }^{1351}$ por las tormentas de los días 15 y 16 de septiembre de ese año. La Comisión Provincial no veía viable condonar la Contribución Territorial a algunos pueblos, puesto que la cantidad condonada debía ser asumida por el resto de los ayuntamientos, por lo que se decidió constituir una Junta Provincial de Socorros para paliar en lo posible los daños de estas catástrofes naturales. El 22 de septiembre de 1893, la Comisión Provincial dispuso que la suma consignada en el Capítulo de Calamidades fuera destinada al socorro de estos pueblos ${ }^{1352}$ para intentar remediar la crisis obrera que previsiblemente se presentaría en el invierno próximo.

La Comisión Provincial se quejaba de la actitud de los ayuntamientos, que en caso de catástrofes pretendían exagerar sus pérdidas, y mencionaba, en la Memoria del Primer Semestre del Año Económico 1893-94 el art. $99^{1353}$ del Reglamento de 30 de septiembre de 1885. La Comisión Provincial comentaba en tono jocoso las cantidades ingentes de hl de vino y $\mathrm{t}$ de cereales que los ayuntamientos declaraban como pérdidas, ya que de ser ciertas «(...) vendrían a demostrar que la provincia de Palencia es la más rica del globo terráqueo, cuando precisamente figura entre las más pobres de la nación.» ${ }^{1354}$ En su opinión, tendría que ser el Estado y no la Diputación Provincial el encargado de remediar estos desastres, como ocurrió en el año 1888, cuando varios pueblos de la provincia de Toledo perdieron sus cosechas como consecuencia de los temporales.

\footnotetext{
${ }^{1350}$ Bárcena, Castrejón, Fuentes de Valdepero, Husillos, Saldaña, Torquemada.

${ }^{1351}$ Pérdidas añadidas a las tasadas en 1.206 .550 pts. del año 1892 en varios pueblos, Torquemada y Castrejón también se habían visto afectados en 1892.

${ }^{1352}$ BOP de 30 de septiembre de 1893. El número total de pueblos a los que se socorría ascendía a 18 . Se debió acudir al crédito para hacer frente a este gasto, puesto que la cantidad consignada en el Capítulo de Calamidades era de 2.000 pts., y solo las pérdidas de nueve de los pueblos afectados ascendían a 353.190 pts.

${ }^{1353}$ El pueblo o Distrito que, a juicio de la Diputación Provincial, exagerase o faltase a la verdad en las manifestaciones de los daños sufridos, quedaría por este solo hecho sin opción al perdón solicitado, cualquiera que fuera la importancia de los daños.

${ }^{1354}$ A.D.P.P., Memoria Año Económico Primer Semestre 1893-1894, C-R / 1,11, p. 12.
} 
En septiembre de 1891, se acordó contribuir con 2.000 pts. del Capítulo $2^{\circ}$, art. 5, Calamidades, para atenuar los efectos de las inundaciones de Consuegra, Almería, Valencia y Ciudad Real, pero la Comisión Provincial se quejaba ${ }^{1355}$ de la poca atención que por parte del Estado, que era quién había solicitado a través del gobernador la ayuda a diputaciones y ayuntamientos, se prestaba a los agricultores de la provincia cuando sufrían las inclemencias del tiempo y perdían sus cosechas. Los daños por tormentas se repitieron los días 1 y 3 de mayo, 24 y 25 de junio, 10 de julio y 4 de agosto de 1896. Las localidades afectadas fueron 38, pero la Comisión Provincial advertía que de cumplirse estrictamente lo señalado en el Real Decreto de 30 de septiembre de 1885, muchos de los pueblos afectados quedarían fuera de las ayudas de la Diputación Provincial. Algunos pueblos, caso de Cervera de Pisuerga, Villarrabé o Lantadilla, solicitaban ser atendidos por el Capítulo de Calamidades, pero no justificaban las pérdidas ni aportaban pruebas, por lo que en base al citado Rea Decreto se archivaban las solicitudes. Otros pueblos, como Alar del Rey o Arbejal, presentaban sus alegaciones fuera del plazo establecido ${ }^{1356}$ por el art. 98 de citado Real Decreto, por lo que tampoco se les daba curso. En otros $\operatorname{casos}^{1357}$, los expedientes adolecían de defectos sustanciales tan graves, que la Comisión Provincial reflexionaba sobre las consecuencias que los ciudadanos sufrían a causa de la ignorancia de los que se hallaban al frente de la Administración Municipal ${ }^{1358}$, solo once pueblos fueron atendidos en sus reclamaciones por ajustarse sus expedientes en tiempo y forma al procedimiento que el Real Decreto establecía.

\footnotetext{
${ }^{1355}$ A.D.P.P., Memoria Segundo Semestre Año Económico 1891-92, C-R/ 1,8.

${ }^{1356}$ El plazo era de quince días.

${ }^{1357}$ Villabasta, Villaeles, Polentinos, Renedo de Valdavia.

${ }^{1358}$ A.D.P.P., Memoria Año Económico Primer Semestre 1896-1897, C-R / 1,10.
} 
En enero de 1891, la Comisión Provincial distribuyó entre los ayuntamientos de Saldaña y Cervera 20.000 pts. del fondo de calamidades mediante un crédito concedido por el Gobierno para paliar las pérdidas ocasionadas por un temporal de nieve. Sin embargo, la Comisión remitió la propuesta al gobernador de la provincia, quien no pudo realizar el reparto por haber cesado el día de la remisión de la citada propuesta, recibiendo orden de aplazamiento su sustituto. Se hizo una nueva distribución prescindiendo del informe de la Comisión Provincial y, como uno de los diputados provinciales del distrito de Saldaña lo juzgaba perjudicial para los intereses de sus representados, apeló a al ministro de la Gobernación, que no resolvió en tiempo y caducó el crédito, volviendo este a la Caja del Estado ${ }^{1359}$, generando disputas entre los representantes de los Distritos afectados por el temporal. En julio de 1898, se libraron 1.500 pts. para remediar los daños causados por la tromba de agua y granizo en Villamediana ${ }^{1360}$ y Torquemada, también en diciembre de 1909 un gran temporal causó graves daños en numerosos pueblos de la provincia. La Diputación Provincial señalaba que aplicaría todos sus medios para remediar en lo posible las pérdidas sufridas por las inundaciones, pero advertía de las obligaciones que pesaban sobre el Presupuesto Provincial, especialmente de Beneficencia, que absorbían la mayor parte de los ingresos y que no podían abandonarse sin graves complicaciones. En esta situación, los socorros que podían prestarse eran muy limitados y la Diputación acordó dirigirse al Gobierno para solicitar fondos, puesto que con las 40.000 pts. consignadas de la partida de Calamidades del Presupuesto Provincial solo se podría ayudar a un pueblo, pues las pérdidas ascendían a muchos millones de pts. ${ }^{1361}$

Los días 22 de junio, y los días 1 y 2 de agosto de 1898, las tormentas de pedrisco afectaron a una veintena de pueblos. La Comisión Provincial solicitaba ayuda al gobernador provincial, al obispo de la Diócesis y los poderes del Estado para socorrer a los damnificados de las tormentas ${ }^{1362}$. Se creó una Junta de Socorros por parte del Gobierno de la provincia, encargada de distribuir las ayudas recibidas para paliar los daños causados por las tormentas, el Gobierno concedió 100.000 pts. de ayuda para distribuir entre los pueblos afectados, especialmente para Torquemada y Villamediana, Germán Gamazo $^{1363}$, ex ministro de Fomento, hizo un donativo particular de 1.500 pts.

\footnotetext{
${ }^{1359}$ A.D.P.P., L.A.P.D. 70, 9-I-1891.

${ }^{1360}$ A.D.P.P., L.A.C.P. 90, 3-VIII-1898. En Villamediana fallecieron 27 vecinos.

${ }^{1361}$ A.D.P.P., L.A.P.D. 107, 4-I-1910.

${ }_{1363}^{1362}$ A.D.P.P., Memoria Año Económico Primer Semestre 1898-1899, C-R / 1,15.
} 
En diciembre de 1927, se hundió un barrio entero de casas en Frechilla, dada la pobreza de las familias afectadas, la Diputación Provincial acordó apoyar la contratación de una sociedad para reconstruir todos los inmuebles afectados, pagándose el importe de la obra en el mayor número posible de plazos. La Diputación avalaría o garantizaría el anticipo, los edificios no pasarían a ser propiedad de los interesados hasta que hubiesen completado el pago del coste de su construcción ${ }^{1364}$. Se discutió otra proposición del presidente de la Diputación Provincial, que consistía en que la institución provincial se acogiese a los beneficios prestados por el Estado a la construcción de viviendas baratas, constituyendo legalmente las cooperativas consiguientes. En este caso, el Estado anticiparía el 70\% del coste de construcción y la Diputación anticiparía el 30\% restante a los menos pobres y costearía a los más pobres el $30 \%$ con cargo a los fondos provinciales. Al final, se acordó realizar una mezcla de ambas proposiciones para dar una rápida respuesta a la cuestión y se acordó lo siguiente ${ }^{1365}$ :

1. Si los talones de la contribución de los afectados no excedía de 40 pts., la Diputación reconstruiría la casa y se la entregaría al propietario.

2. Si los talones de la contribución de los afectados era superior a 40 pts., pero no excedía de 75 pts., las casas serían reconstruidas por Diputación, costeando el 50\% del importe, y el otro 50\% sería reintegrado por los propietarios en plazos mensuales en un periodo de diez años.

3. Si los talones de la contribución de los afectados superaban las 75 pts., las viviendas reconstruidas por Diputación serían abonadas en su totalidad por los propietarios de las mismas.

Presidencia modificó las Bases de esta ponencia en el sentido de que la aportación provincial quedaría limitada al 50\% del presupuesto de reconstrucción, cargando la mitad restante a los ayuntamientos respectivos de las localidades afectadas.

${ }^{1364}$ A.D.P.P., L.A.C.P. 143, 3-XII-1927.

${ }^{1365}$ A.D.P.P., L.A.C.P. 144, 31-I-1928. 


\section{Conclusiones}

Este trabajo ha pretendido desde su inicio ofrecer una visión completa del desarrollo institucional de la Diputación Provincial de Palencia en la etapa de la Restauración, etapa comprendida entre los años 1875 y 1931. Una vez finalizada la investigación, se puede, y se debe llegar a una serie de conclusiones que, a modo de síntesis permitan, a otros investigadores y al público en general, alcanzar un conocimiento básico del tema estudiado de forma rápida y sencilla.

Llama la atención, que si bien hasta los años ochenta del siglo XX no eran demasiados los estudios sobre la historia de la Administración Local, a partir de entonces y hasta la actualidad, son pocas las provincias, entre ellas Palencia, que no cuentan con un estudio más o menos completo sobre la andadura histórica de las diputaciones provinciales desde su nacimiento, en 1812, hasta el tiempo presente. Fueron las facultades de Derecho las primeras que se interesaron por la evolución histórica de estas instituciones provinciales y, como es lógico, utilizaron a este fin la metodología propia de la Historia del Derecho. En los años noventa del siglo XX comenzaron a elaborarse trabajos que abordaban el estudio de las diputaciones provinciales desde el campo de la Historia local, centrando su estudio no tanto en el fondo de estas instituciones, como en la forma, en otras palabras, no importaba el cómo, cuándo y de qué forma surgieron y se organizaron las diputaciones provinciales y sí cuál fue su actividad e influencia en la vida provincial. Tras analizar la bibliografía existente sobre las diputaciones provinciales, puede concluirse que ha sido desde la ciencia jurídica y el Derecho Administrativo desde donde se han realizado estudios más rigurosos sobre el desarrollo institucional de la institución de la Diputación, y solo en los últimos años se ha ocupada la Historia de esta parcela fundamental de la Historia local española, adoleciendo, no obstante, la mayor parte de un vínculo que relacione la historia de la nación y del ámbito territorial de actuación de la Diputación provincial, la provincia. 
Hasta la desaparición de la escena pública de Cánovas y Sagasta, España vivió una etapa de estabilidad política que aseguraba también la estabilidad social en el país. En los albores del siglo XX, la posibilidad de alternancia pacífica en el poder fue vista más como un anhelo que como una realidad. Dejando de un lado la creciente influencia en el electorado urbano de las fuerzas no dinásticas, el problema mayor que acechaba al sistema ideado por Cánovas era la fragmentación interna de los partidos dinásticos, tanto del Partido Conservador como del Partido Liberal. A comienzos del siglo XX, la inestabilidad política impidió que se afrontasen con diligencia los problemas que empezaban a cuestionar el propio sistema de la Restauración. La cada vez más acuciante crisis económica, el problema del encaje del sentimiento regionalista catalán y nacionalista vasco en el Estado liberal centralista, el avispero marroquí, la cuestión social y el conflictivo mundo obrero, se configuraban como un conjunto de cuestiones que necesitaban de un Gobierno fuerte para su resolución, algo casi imposible habida cuenta de la referida descomposición interna de los partidos que se turnaban en el Gobierno con una frecuencia creciente.

Después de 1898, fueron muchas las voces que clamaron por una necesaria regeneración de la vida pública y retomando la tradición de los arbitristas en los siglos XVI y XVII, con su solicitud de cambios en la economía que detuviese el imparable declive de la Monarquía Hispánica y de los reformistas ilustrados del siglo XVIII, se exigían cambios a todos los niveles para convertir a España en un país moderno y plenamente europeo. En la primera década del siglo XX, desde el lado conservador y liberal, se proyectaron cambios que adaptasen el sistema decimonónico de la Restauración a la nueva situación de la nación. En este contexto, las diputaciones provinciales fueron vistas como estructuras anquilosadas que debían ser reformadas para cumplir con el objetivo principal para el que fueron creadas, dinamizar la vida provincial y fomentar la riqueza de las provincias de España. Consideradas una mera correa de trasmisión de la política del Gobierno de turno, las diputaciones provinciales pronto se situaron en el punto de mira de los reformadores que las consideraban únicamente como la sala de reunión del cacicazgo. 
Las diputaciones provinciales fueron cuestionadas como institución casi desde el inicio de su andadura administrativa, hasta el punto que incluso llegó a plantearse su desaparición en los inicios de la Dictadura de Primo de Rivera, hasta que finalmente en la etapa dictatorial, en la que se aprobó el Estatuto Provincial de 1925, no se contemplaba la eliminación de la institución, sino que mejoraba su capacidad económica y se convertía en el ariete político del Gobierno contra el poder de las élites provinciales. En resumen, el régimen, que nació con el objetivo de apartar al estamento militar de la actividad política nacional, terminó sucumbiendo a una nueva intervención castrense personalizada en la figura del general Primo de Rivera. La evolución de la sociedad española, en consonancia con lo que acaecía entonces en el resto de Europa, dejó obsoleto al sistema canovista que había sido configurado como un sistema de alternancia en el poder de los principales partidos políticos nacionales, en el que el electorado tenía un papel secundario. A partir de comienzos del siglo XX, la situación económica y social de España se complicó de tal forma que el sistema fue incapaz de dar una salida satisfactoria a estas cuestiones, surgiendo voces que pedían cambios en la estructura no solo económica de la nación, también institucional. Las diputaciones provinciales fueron consideradas más un problema que una solución para evolucionar desde un régimen oligárquico hasta uno más democrático y abierto.

Todas las cuestiones relativas al funcionamiento, organización y atribuciones de las diputaciones provinciales se contemplaban en la legislación local, puesto que la Constitución de 1876 no mencionaba expresamente la regulación del ámbito local. A pesar de que la reforma de la Administración Local formó siempre parte de la agenda de los gobiernos centrales, las leyes provinciales aprobadas fueron solo cuatro, la Ley de Bases de 16 de diciembre de 1876, la Ley Provincial de 2 de octubre de 1877, la Ley Provincial de 29 de agosto de 1882 y Estatuto Provincial de 1925. En realidad, las dos primeras fueron un remedo de la Ley Municipal y Provincial de 20 de agosto de 1870, por lo que puede considerarse que la Restauración plasmó su idea de lo que debían ser las diputaciones provinciales con la aprobación de la Ley Provincial de 29 de agosto de 1882. Esta norma, en opinión de diversos autores de Historia del Derecho, como se ha dicho, consagraba el control del Gobierno central sobre los ayuntamientos a través de las diputaciones, con la intención de asegurar la continuidad del sistema turnista, que unía en una compleja red de intereses a los ayuntamientos, provincias y Gobierno de la nación. 
Cuando el sistema comenzó a mostrar síntomas de degeneración institucional, pudo concluirse que el origen de todos los males que afectaban a la sociedad española a comienzos del siglo XX, radicaba en la configuración del entramado administrativo local, y se consideró que la normativa local, como aquí se ha apuntado, debía conceder una mayor autonomía a las diputaciones provinciales respecto del poder central. El intento reformista más serio de la Administración Local fue el de Antonio Maura de 1907, que concedía plena autonomía jurídica e independencia administrativa a las diputaciones en el ejercicio de sus atribuciones. Todos los intentos de reformar el sistema mediante una nueva estructura de la organización local fracasaron, y solo llegó a dotarse a las diputaciones provinciales de cierta soberanía administrativa en el terreno hacendístico, lo cual no era baladí, pues sin recursos económicos resultaba imposible gestionar con solvencia cualquier función que se concediese a las diputaciones provinciales. Las diputaciones fueron vistas como un agente administrativo estatal en el ámbito local, como demuestra el hecho de que dos de las principales cuestiones que abordaba el Estatuto Provincial 1925 fueran la eliminación en su articulado del concepto de superioridad jerárquica de las diputaciones sobre los ayuntamientos, y la supresión de la facultad del gobernador de presidir con voz y voto las sesiones del Pleno de la Diputación y de la Comisión Provincial.

Además de los intentos de reforma de la institución provincial, llegaron a plantearse otras formas de organización administrativa del territorio, como las mancomunidades y las regiones. El aumento del sentimiento regionalista en Cataluña estaba detrás de la inclusión de la figura administrativa de la Mancomunidad en los diferentes proyectos de reforma de la Administración Local. La posibilidad de unión entre varias provincias comenzó a plantearse ya en los proyectos reformistas de Moret de 1884 y Sánchez Toca de 1890, pero no fue hasta 1907 cuando el proyecto de Maura recogió de forma explícita la posibilidad de crear mancomunidades provinciales, con fines únicamente administrativos, para despejar cualquier veleidad federalista de sus principales defensores, las diputaciones catalanas, y evitar el rechazo del resto de diputaciones de Régimen Común, especialmente las castellanas. La Diputación de Palencia en particular, y las de Castilla en general, solo se mostraron favorables a la posibilidad de mancomunarse para defender los intereses económicos, especialmente los agrarios, de las diversas provincias que formaban Castilla La Vieja. Al final, solo las diputaciones catalanas se constituyeron en Mancomunidad en el año 1914. 
La Mancomunidad era el reflejo en el ámbito administrativo del sentimiento regionalista que prendía en Cataluña desde finales del siglo XIX. Los políticos regionalistas catalanes aspiraban a lograr del Gobierno central una reforma de la organización territorial en la que tuviese cabida constitucional el concepto administrativo de región, entendida como un ente superior a las diputaciones, que asumiría gran parte de las funciones que estas tenían atribuidas y que se constituiría como el verdadero intermediario entre el Estado y los municipios. Ante esta propuesta, la Diputación de Palencia consideró que no existía sentimiento regionalista en Castilla, y que el proyecto de creación de la región nacía como fruto de la influencia de los partidos regionalistas catalanes en los gobiernos centrales.

La Diputación palentina se mostraba partidaria de dotar de mayores medios económicos y una mayor autonomía fiscal a las diputaciones, a fin de que éstas pudieran cumplir su función en beneficio de los pueblos de las provincias que, en su opinión, no necesitaban de mayor autonomía política, sino de una mejora de la calidad de vida de sus ciudadanos. La Diputación de Palencia vio con recelo la creación de la región pues consideraba que, tal y como estaba concebida, contribuiría a un deterioro de la unidad nacional y, al igual que sucedía con la Mancomunidad, solo defendía su creación como un ente puramente administrativo que mejorase la organización de los servicios provinciales, nunca como una nueva forma de estructura territorial, puesto que existía una tradición histórica generadora de un sentimiento positivo respecto del concepto de provincia que no existía en la región, vista como una creación fuera del contexto histórico español.

La Diputación Provincial de la Restauración varió poco en su organización interna original, formada por todos los diputados provinciales reunidos en Pleno, que delegaba sus funciones en el tiempo en el que no estaba reunida en la Comisión Provincial, verdadero brazo ejecutor de la actividad administrativa de la Diputación Provincial. Tanto su organización como sus atribuciones se recogían en la legislación que regulaba la Administración Local, por tanto, la institución provincial, solo tenía capacidad para regular los aspectos relativos a su funcionamiento interno y ejercer las atribuciones reconocidas en régimen de exclusividad. Esta normativa se desarrollaba en los reglamentos, que abarcaban desde la Beneficencia hasta los derechos y deberes de los funcionarios provinciales. 
Las leyes provinciales contemplaban la forma de elección de los diputados provinciales, los requisitos de electores y elegibles, la estructura y competencias de las diputaciones, su funcionamiento y su responsabilidad administrativa. A lo largo de la Restauración fueron pocas las novedades referidas a estos aspectos y las que se incluyeron, como el sufragio universal o el cambio de funciones del gobernador civil, fueron consecuencia de la evolución de la sociedad española experimentada a comienzos del siglo XX, al mayor porcentaje de población urbana, a unos mejores niveles de alfabetización e instrucción y a una creciente participación ciudadana en la actividad política. La principal novedad vino de la mano del nuevo régimen dictatorial de Primo de Rivera pues, en consonancia con el nuevo protagonismo que quería darse a los pueblos en la Administración Local, parte de los diputados provinciales, los llamados diputados corporativos, fueron los concejales designados por los ayuntamientos para dicho cargo.

A lo largo del periodo estudiado, Secretaría, Contaduría y Depositaría continuaron siendo las principales dependencias de las diputaciones, sin olvidar los Establecimientos de Beneficencia, Obras Públicas $\mathrm{y}$, durante gran parte de la etapa estudiada, los correspondientes a ciertas competencias en materia de Corrección Pública e Instrucción Pública. Las competencias de la Diputación apenas experimentaron cambios y si existieron fue a raíz del advenimiento de la Dictadura de Primo de Rivera. El Estatuto Provincial de 1925 liberaba a las diputaciones provinciales de la pesada carga presupuestaria que suponían las principales atenciones de Instrucción Pública; además, en materia de Quintas, las diputaciones provinciales dejaban de ser competentes en los asuntos de reemplazos y reclutamiento, facultad que asumía la Junta de Clasificación y Revisión provincial. No conviene olvidar que desde la promulgación del Estatuto Provincial, las diputaciones dejaron de ejercer la tutela de los ayuntamientos. El resto de competencias, Beneficencia, Obras Públicas y Sanidad variaron poco respecto a la carga competencial que recogía la Ley Provincial de 29 de agosto de 1882, si bien cabe mencionar que en materia de Salud Pública, las diputaciones asumieron mayor protagonismo en la organización de los servicios sanitarios con la creación de los Institutos de Higiene y de los Centros Antivenéreos y Antituberculosos. 
La Diputación de Palencia no fue ajena a la confrontación política y, de este modo, la información recogida en los libros de Actas refleja que, en no pocas ocasiones, las facciones conservadoras y liberales se enfrentaban al poner en duda la validez de las Actas de diputado y al formular reclamaciones sobre cuestiones electorales, por la recaudación de los impuestos o incluso por la conveniencia de sufragar el coste de la escultura de un presidente de la I República. Sin embargo, defendieron siempre, de común acuerdo, los intereses de la provincia, especialmente en el terreno de la protección arancelaria del cereal castellano. Ante los diversos ataques sufridos por la institución provincial, los diputados provinciales supieron diferenciar entre la naturaleza de las diputaciones y las personas que las regían, convencidos, como estaban, de que la Diputación Provincial servía perfectamente a los intereses para los que fue creada y de que su función no podía desligarse de la consecución de mayores cotas de riqueza y bienestar para sus administrados.

Las diversas atenciones que la ley atribuía a las diputaciones suponían un gasto que hasta 1925, debía ser cubierto con los bienes propios de las diputaciones y, sobre todo, con la recaudación del llamado Repartimiento o Contingente Provincial. Dada la exigua riqueza de la mayor parte de los pueblos de la provincia de Palencia, los recursos que este impuesto recaudaba, cuando los recaudaba, resultaban casi siempre insuficientes para afrontar con dignidad el mantenimiento de servicios tan fundamentales como la Beneficencia o la Instrucción. Si exceptuamos el periodo comprendido entre los años 1923-1931, en la Restauración, fue tal la penuria presupuestaria que no había reunión del Pleno de la Diputación o de la Comisión Provincial en la que no saliese a colación este asunto. Los diputados provinciales señalaban el contraste entre la premura por pagar las cuotas al Tesoro por los ayuntamientos, con la pereza y desidia a la hora de cumplir con las obligaciones fiscales con la Diputación, que se veía imposibilitada siquiera para pagar las facturas de los contratistas que le suministraban. Como consecuencia, las reclamaciones al Gobierno central de una mayor dotación económica y de mayores cuotas de poder a la hora de establecer impuestos provinciales, así como del disfrute de una mayor independencia fiscal, fueron constantes. Solo el Estatuto Provincial recogió estas reivindicaciones históricas, al ceder parte de la recaudación de los impuestos estatales a las diputaciones a cambio de un rigor presupuestario que impedía que los proyectos de los presupuestos contemplasen déficit, en otras palabras, los gastos debían ajustarse a los ingresos. 
Con las mimbres presupuestarias con las que contaban las diputaciones, estas debieron hacer encaje de bolillos para poder atender los múltiples gastos que conllevaban sus atribuciones. La actuación de la Diputación de Palencia fue meritoria en este capítulo y aunque la provincia basaba su riqueza básicamente en el cultivo cerealista y la explotación del carbón en las cuencas mineras del norte, se dispuso a cumplir con sus obligaciones administrativas y sirvió de ejemplo a otras diputaciones en la gestión de sus recursos.

En 1876, la Diputación Provincial de Palencia no contaba con establecimientos para la reclusión de enfermos mentales, por lo que costeaba las estancias de los enfermos psiquiátricos pobres en las instalaciones de otras diputaciones. Los niños pobres sordomudos y ciegos de la provincia no contaban con centros especializados para su escolarización, la atención sanitaría de los pobres resultaba deficiente, las condiciones sanitarias de los Establecimientos de Beneficencia dejaban mucho que desear y su capacidad era insuficiente para asilar dignamente a aquellos que carecían de recursos económicos. Estas carencias, que afectaban a la institución provincial de Palencia a comienzos de la Restauración, nacieron como fruto de la escasa disponibilidad presupuestaria que castigó durante casi toda esta etapa a las arcas provinciales. En 1931, sin embargo, el panorama había experimentado una sensible mejora y los enfermos mentales eran atendidos en el Hospital de San Juan de Dios de Palencia. El Hospital de San Antolín y San Bernabé, que atendía a los enfermos pobres, estaba dotado de los medios imprescindibles para la adecuada asistencia sanitaria e incluso contaba con una clínica oftalmológica. Además, la construcción de infraestructuras viarias e hidráulicas mantenía un ritmo creciente, la ciudad contaba con un Instituto de Higiene y un Dispensario Antituberculoso y Antivenéreo, y las condiciones de habitabilidad y salubridad de los Establecimientos de Beneficencia cumplían con las condiciones mínimas exigibles para este tipo de instalaciones, en resumen, la Diputación de Palencia contaba con mayores recursos económicos, fruto de la reforma hacendística del Estatuto Provincial de 1925 , lo que redundaba en la mejora de la calidad de las atenciones que dispensaba en la provincia. 
La Diputación de Palencia, dentro de sus posibilidades presupuestarias, intentó siempre, y así lo demuestran las cifras y las actas del Pleno y de la Comisión Provincial, ejercer las atribuciones para las que la ley la facultaba y actuar de la forma que resultara más digna para los personas que necesitaban la atención de la institución provincial. Miles de ciudadanos, la mayoría de ellos de escasos recursos económicos, se beneficiaron de las ayudas que la Corporación Provincial dispensaba en ámbitos como la Beneficencia, con la asistencia a ancianos pobres, a los niños huérfanos, a las madres solteras, a los niños abandonados y a los trabajadores incapacitados. Además, en el ámbito de la Instrucción Pública, se costeó el mantenimiento de la Escuela Normal de Maestros y Maestras, del Instituto de Segunda Enseñanza, de la Inspección de Primera Enseñanza, de la Escuela de Artes y Oficios o de las becas a estudiantes sobresalientes en distintos campos del conocimiento. Mantuvo, también, las atenciones carcelarias pertinentes para los presos de la Cárcel de Audiencia y, en materia de Obras Públicas, subvencionó la construcción de caminos vecinales, carreteras provinciales y vías férreas secundarias. Destacó, además, por el fomento de la riqueza agrícola, con ayudas a la construcción de la Estación Enológica y de la Granja Escuela, de los pantanos de la montaña palentina, de la defensa de los aranceles al cereal y por el apoyo a la difusión de la producción provincial en las distintas ferias nacionales e internacionales, la ayuda a los soldados palentinos que lucharon en los conflictos cubano y marroquí y la defensa de los derechos de las diputaciones provinciales en las asambleas celebradas al efecto.

La actividad desplegada por la Diputación palentina, en casi todos los ámbitos de la vida provincial, fue muy intensa en esta etapa, a pesar de que cierta historiografía ha presentado una imagen muy negativa de la institución, retratándola como el consejo de reunión de los caciques provinciales. Sin embargo, de esta investigación se desprende que si existieron prácticas fraudulentas en la actividad política, nunca afectaron al compromiso de servicio a la provincia de la Diputación. Conservadores y liberales coparon, en la mayor parte de las ocasiones, los puestos de diputados provinciales y en ellos primó siempre el ánimo de la mejora socioeconómica de la provincia en su conjunto, objetivo compatible con la defensa lógica de los intereses propios y de sus paisanos, a los que debían su elección. 
Nadie mejor que la propia institución provincial para finalizar este apartado de conclusiones como resumen del espíritu que guio siempre la labor de la Diputación palentina: el presidente de la Diputación Provincial de Palencia hacía constar en la sesión de 9 de mayo de 1916 que los diputados provinciales, lo mismo liberales que conservadores, «(...) han depuesto sus ideas políticas ante el cumplimiento estricto de los deberes que la Ley Orgánica les impone». 


\section{Bibliografía}

ALMUIÑA FERNÁNDEZ, Celso, «El regionalismo castellano-leonés: orígenes y primeras reivindicaciones político-económicas (1859-1923)», I Congreso de Historia de Castilla y León., V.III, Valladolid, Diputación Provincial de Valladolid, 1982, pp. 343377.

ALÓS MARTÍN, Ignacio de, «El Regionalismo en el proyecto de reforma constitucional elaborado por la Asamblea de Parlamentarios de 1917», Estudios de historia social, № 2829 (1984), pp. 347-352.

ALTED VIGIL, Alicia, «La oposición republicana», en TOWNSON, Nigel, (Edición.), El republicanismo en España (1830-1977), Madrid, Alianza Editorial, 1994, pp. 223-264.

ÁLVAREZ GARCÍA, María Concepción, La enseñanza secundaria en Palencia durante el siglo XIX (1845-1901), Palencia, Diputación Provincial, 1997.

ÁLVAREZ JUNCO, José, El emperador del paralelo: Lerroux y la demagogia, Madrid, Alianza Editorial, 1994

ANUARIO DE LA VIDA LOCAL.1924. Administración Provincial: Mancomunidades, Diputaciones Provinciales y Cabildos Insulares. Tomo I, Madrid, Dirección General de Administración. 1925.

AVILÉS FARRÉ, Juan y ELIZALDE PÉREZ GRUESO, María Dolores y SUEIRO SEOANE, Susana, Historia política. 1875-1939., Madrid, ISTMO, 2002.

AVILÉS FARRÉ, Juan y HERRERÍN LOPEZ, Ángel, (Edición.), El nacimiento del terrorismo en Occidente. Anarquía, nihilismo y violencia revolucionaria, Madrid, Siglo XXI, 2008.

ALZOLA Y MINONDO, Pablo, Historia de las Obras Públicas en España, Bilbao, Colegio de Ingenieros de Caminos, Canales y Puertos, 1994.

BERMEJO GIRONÉS, Juan Ignacio, El Estatuto Municipal: Antecedentes y Motivaciones, en Cincuentenario del Estatuto Municipal: estudios conmemorativos, Madrid, INAP, 1975.

BERMEJO MARTÍN, Francisco y DELGADO IDARRETA, José Miguel, La administración provincial española en la Diputación Provincial de La Rioja, Logroño, Universidad de la Rioja, 1989.

BERTRAND FAUQUENOT, Luis, «Mito y verdad de Fermín Galán: la sublevación de Jaca, 12 de diciembre de 1930», Historia 16, № 109 (1985), pp. 11-32. 
BIELZA DE ORY, Vicente, «El sector agropecuario y forestal en Historia General de España y América». Tomo XVI-1, Revolución y Restauración (1868-1931). Madrid, Rialp. 1985, pp. 385-458.

BOLTES BOU, Pedro, "Orígenes de la diputación provincial barcelonesa», en Instituto de Ciencias Sociales, La provincia. Dimensiones histórica y política, Barcelona, Diputación Provincial de Barcelona, 1966, pp. 63-70.

CALLE VELASCO, María Dolores de la, «La Comisión de Reformas Sociales, 18831903. Política social y conflicto de intereses de en la España de la Restauración», Investigaciones históricas: Época moderna y contemporánea, № 10 (1990), pp. 263-266. CAMBÓ BATLLE, Francesc, Política Económica, Madrid, Editorial Alpha, 1999. CANO GARCÍA, Juan Antonio, El poder político en Valladolid durante la Restauración. La figura de César Silio, Valladolid, Universidad de Valladolid, 1997.

Gamacistas y albistas. La vida política en Valladolid durante la Restauración, Valladolid, Secretariado de Publicaciones, 2008.

CARANTOÑA ÁLVAREZ Francisco y PUENTE FELIZ, Gustavo, (Dirección.), Historia de la Diputación de León, León, Instituto Leonés de Cultura, 1995.

CARASA SOTO, Pedro, «Beneficencia en Castilla y León: trasformaciones del sistema hospitalario (1750-1909)», en ACTAS DEL I CONGRESO DE HISTORIA DE CASTILlA Y LEÓN, Edad Contemporánea, Volumen III, Valladolid, Diputación Provincial de Valladolid, 1982, pp. 299-326.

Pauperismo y Revolución Burguesa. Burgos (1750-1900). Valladolid, Secretariado de Publicaciones, D.L., 1987.

« Beneficencia y «cuestión social»: una contaminación arcaizante», Historia Contemporánea, № 29 (2004), p. 625-670.

CARR, Raymond, España: de la Restauración a la democracia, 1875-1980, Madrid, Ariel, 1983.

CHAMOCHO CANTUDO, Miguel Ángel, La Diputación Provincial de Jaén en el primer Estado constitucional, Jaén, Instituto de Estudios Giennenses, 2004.

CHUST CALERO, Manuel (Dirección.), Historia de la Diputación de Valencia, Valencia, Diputación Provincial de Valencia, 1995.

COMÍN COLOMER, Eduardo, El Anarquismo contra España: de «La Mano Negra» a la huelga de «La Canadiense», Madrid, Publicaciones Españolas, 1959. 
CORREDERA GARCÍA, María Paz, «La beneficencia en Palencia en el primer tercio del siglo XX: la sociedad de la pobreza», en ACTAS DEL II CONGRESO DE HISTORIA DE PALENCIA, Edad Contemporánea, Tomo III, Volumen II, Palencia, Diputación Provincial de Palencia, 1990, pp. 833-848.

COSTA MARTÍNEZ, Joaquín, Oligarquía y caciquismo como forma actual de gobierno en España: urgencia y modo de cambiarla, Madrid, Establecimiento Tipográfico de Fortanet, 1901.

CUELLAR VILLAR, Domingo, «Las obras públicas y el marco institucional durante la Restauración. El Ministerio de Fomento (1875-1913)», Tst: Transportes, Servicios y telecomunicaciones, № 2 (2002), pp. 71-95.

CUESTA BUSTILLO, Josefina y GÓMEZ MOLLEDA, María Dolores, Los Seguros Sociales en la España del siglo XX. Hacia los Seguros Sociales obligatorios. La crisis de la Restauración, Madrid, Ministerio de Trabajo y Seguridad Social, 1988.

DUCROCQ, Théophile Gabriel Auguste, Cours de Droit Administratif, Paris, Ulan Press, 2012.

ESTRADA SÁNCHEZ, Manuel, «Delimitación territorial y poder político: La Diputación Provincial de Santander durante la configuración del Estado liberal», I Encuentro de Historia de Cantabria, Vol. 2, Santander, Universidad de Cantabria, 1996, pp. 997-1010. FARIÑA JAMARDO, José y PERERIRA FIGUEROA, Miguel, La Diputación de Pontevedra (1836-1986), Pontevedra, Diputación Provincial de Pontevedra, 1986.

FERNÁNDEZ SANZ, Juan José, 1885: el año de la vacunación Ferrán. Trasfondo político, médico, sociodemográfico y económico de una epidemia, Madrid, Fundación Ramón Areces, 1990.

FERRERA CUESTA, José Carlos, La frontera democrática del liberalismo: Segismundo Moret (1838-1913), Madrid, Biblioteca Nueva, 2002.

FORNER MUÑOZ, Salvador, Canalejas y el Partido Liberal Democrático (1900-1910), Madrid, Cátedra, 1993.

GALVÁN RODRÍGUEZ, Eduardo, El origen de la autonomía canaria. Historia de una Diputación Provincial (1831-1925), Madrid, Ministerio de Administraciones Públicas, 1995.

GARCÍA COLMENARES, Carmen, «La Escuela Normal de Palencia: apuntes históricopedagógicos (1861-1940)», Actas del I Congreso de Historia de Palencia, Edad Moderna y Contemporánea, Volumen III, Palencia, Diputación Provincial de Palencia, 1987, pp. 523-537. 
GARCÍA COLMENARES, Pablo, «El Instituto Provincial de Palencia (1845-1915). Historia de la Segunda Enseñanza Provincial», en VV.AA., I.B. Jorge Manrique: LXXV aniversario, Palencia, 1992, pp. 15-25.

GARCÍA COLMENARES, Pablo, MORENO LÁZARO, Javier y SÁNCHEZ GARCÍA, José Luis, Historia de Palencia. Siglos XIX-XX, Palencia, El Norte de Castilla, 1996.

GARCÍA DELGADO, Santiago y MUÑOZ, José Luis y ROLDÁN, Juan, La formación de la sociedad capitalista en España, 1914-1920, Madrid, CECA, 1973.

GARCÍA-MONCÓ MARTÍNEZ, Alfonso Carlos, Eduardo Dato Iradier. Presidente del Consejo de Ministros de España, Madrid, Cinca, 2014.

GARCÍA PRIETO, Manuel y SAINZ DE VICUÑA Y GARCÍA PRIETO, Manuel, Manuel García Prieto, Marqués de Alhucemas, 1859-1938. Actuación política e intervenciones parlamentarias, Madrid, Secretaría General del Senado, 2004.

GARCÍA QUEIPO DE LLANO, Genoveva, Alfonso XIII: la modernización fallida Madrid, Temas de hoy, 1996.

GARCÍA RUIPÉREZ, Mariano, Manual de Hacienda para archiveros municipales, Murcia, Ediciones Tres Fronteras, 2008.

GARCÍA SANZ, Fernando, España en la Gran Guerra. Espias, diplomáticos y traficantes. Madrid, Galaxia Gutenberg, 2014.

GARCÍA SEGURA, María Concepción, Historia de la Diputación Provincial de Soria. Siglo XIX: años 1843-1902, 2 vols., Soria, Diputación Provincial de Soria, 2003.

GAY ARMENTEROS, Juan Cristóbal, De Burgos. El reformista ilustrado, Madrid, Gota a Gota, 2014.

GIL PECHARROMÁN, Julio, «La Unión Patriótica», Historia 16, Nº 96 (1984), pp. 2837.

La segunda república española (1931-1936), Madrid, UNED, 1995.

«Vísperas republicanas. El pacto de San Sebastián», La aventura de la historia, N 82, 2005, pp. 54-59.

GIRÓN GARROTE, José, (Coordinación.), Un cambio de siglo 1898. España, Cuba, Puerto Rico, Filipinas y Estado Unidos, Oviedo, Universidad de Oviedo, 2008.

GÓMEZ MENDOZA, Antonio, Ferrocarriles y cambio económico en España (18551913), Madrid, Alianza Editorial, 1982.

GONZALO ANDRÉS, Donato, Los políticos de Palencia y su provincia. (Bocetos y semblanzas). Tomo II, Palencia, Imprenta de Abundio Z. Menéndez, 1891. 
GONZÁlEZ CASANOVA, José Antonio, Las Diputaciones provinciales en España. Historia política de las Diputaciones en España desde 1812 hasta 1985, Madrid, Mancomunidad General de Diputaciones de Régimen Común, 1986.

GONZÁLEZ MARIÑAS, Pablo, Las Diputaciones Provinciales en Galicia: del Antiguo Régimen al Constitucionalismo, La Coruña, Diputación Provincial de la Coruña, 1978.

GONZÁLEZ-POSADA y BIESCA, Adolfo, Evolución legislativa del régimen local en España: 1812-1909, Madrid, Instituto de Estudios de Administración Local, 1982.

GUTIÉRREZ RESA, Antonio (Edición.), Orígenes y desarrollo del trabajo social, Madrid, Ediciones Académicas, 2010.

HERRERAS VIDAL, Delfina, «Beneficencia y Sanidad», en VV.AA., Historia de Palencia: siglos XIX-XX, Valladolid, El Norte de Castilla, 1996, pp. 277-288.

HERRERO PUYUELO, María Blanca, La Comisión de Reformas Sociales en Palencia (1884-1903), Ayuntamiento de Palencia, 1990.

JORDÁ FERNÁNDEZ, Antonio, Las Diputaciones provinciales en sus inicios. Tarragona 1836-1840. La guerra como alteración en la aplicación de la norma jurídica, Tarragona, Diputación Provincial de Tarragona, 2002.

JUANTO JIMÉNEZ, Consuelo, «Navarra en la Administración provincial de España del siglo XIX. La Diputación Foral», Rudimentos Legales: Revista de historia del derecho, $\mathrm{N}^{\mathrm{o}} 4$ (2002), pp. 197-215.

LABRADOR HERRAÍZ, Carmen, «La escuela en el antiguo régimen. Acciones benéficosociales y enseñanza en la provincia de Palencia», en ACTAS DEL II CONGRESO DE HISTORIA DE PALENCIA, Edad Contemporánea, Tomo III, Volumen II, Palencia, Diputación Provincial de Palencia, 1990, pp. 657-671.

LÓPEZ ALONSO, Carmen et al, Cuatro siglos de Acción Social. De la beneficencia al bienestar, Madrid, Siglo XXI, 1985.

LÓPEZ IGLESIAS, Víctor, El papel de España en la I Guerra Mundial, Letra Internacional, $\mathrm{N}^{\mathrm{o}} 119$ (2014), pp. 81-86.

LLADONOSA PUJOL, José, Historia de la Diputación de Lérida, Lérida, Diputación Provincial de Lérida, 1974.

MACIAS PICAVEA, Ricardo, La Tierra de Campos, -Estudio preliminar de Ricardo Martín de la Guardia y Guillermo Á. Pérez Sánchez-, Valladolid, Ayuntamiento de Valladolid y Diputación Provincial de Valladolid, 2006.

MADARIAGA ÁLVAREZ-PRIDA, María Rosa, Abd-el-Krim el Jatabi: la lucha por la independencia, Madrid, Alianza Editorial, 2009. 
MADOZ IBÁÑEZ, Pascual, Diccionario Geográfico-Estadístico-Histórico de España y sus posesiones de ultramar, Madrid, 1847, Tomo XII, p. 539.

MALUENDA ABADÍA, Loreto, Orígenes de la Diputación provincial de Madrid (18131843), Madrid, Universidad Complutense de Madrid, 1997.

MARTÍ MARTÍNEZ, Manuel, «Las Diputaciones provinciales en la trama caciquil: un ejemplo castellonense durante los primeros años de la Restauración», Hispania: Revista española de historia, Vol. 51, No 179, (1991), pp. 993-1041.

MARTÍN BOBILlO, Pablo, Orígenes de la Diputación Provincial de Zamora (18131823), Zamora, Diputación Provincial de Zamora, 1988.

MARTÍN-RETORTILLO BAQUER, Sebastián, La provincia: pasado, presente y futuro, Madrid, Civitas, 1991.

MARTÍN-RETORTILLO BAQUER, Sebastián y ARGULLOL MURGADAS, Enric, Descentralización Administrativa y Organización Política. Aproximación histórica (18121939), Madrid, Alfaguara, 1973.

MARTÍN TORNERO, Antonio, «El desembarco en Alhucemas. Organización, ejecución y consecuencias», Revista de historia militar, No 70 (1991), pp. 199-264.

MARTÍN VALVERDE, Antonio (y otros), La Legislación Social en la Historia de España. De la Revolución liberal a 1936, Madrid, Congreso de los Diputados, 1987.

MARTÍNEZ HERNÁNDEZ, María del Carmen, Política y administración provincial: La Diputación de Córdoba: 1925-1991, Córdoba, Diputación Provincial de Córdoba, 2004.

MARTORELL LINARES, Miguel Ángel, «El fracaso del proyecto de ley de beneficios extraordinarios de Santiago Alba en 1916: Una lectura política», Revista de Historia Económica, № 2 (primavera-verano 1998), pp. 521-555.

MAURA GAMAZO, Miguel, ROMERO MAURA, Joaquín, Así cayó Alfonso XIII. De una dictadura a otra, Madrid, Marcial Pons Historia, 2007.

MAZA ZORRILLA, Elena, Pobreza y Asistencia Social en España. Siglos XVI al XIX, Valladolid, 1987, Universidad de Valladolid.

MORADIELLOS GARCÍA, Enrique, El oficio de historiador. Madrid, Siglo XXI, 1994.

MORAL RUIZ, Joaquín del, Hacienda central y haciendas locales, Madrid, Instituto de Estudios de Administración Local, 1984.

MORENO LUZÓN, Javier, (Ed.), Alfonso XIII: un político en el trono, Madrid, Marcial Pons Historia, 2003.

MORENO NIETO, Luis, Historia de la Diputación Provincial de Toledo, Toledo, Diputación Provincial de Toledo, 1986. 
NAVAJAS ZUBELDÍA, Carlos, «La ideología corporativa de Miguel Primo de Rivera (1905-1919)», Hispania: Revista española de historia, Vol. 53, № 184 (1993), pp. 617649.

NEGRÍN FAJARDO, Olegario, (Coordinación.), Historia de la Educación Española, Madrid, UNED, 2011.

ORDUÑA REBOLLO, Enrique, Evolución histórica de la Diputación Provincial de Segovia. 1883-1990, Valladolid, Ámbito, 1986.

«Regionalismo y Asambleas de Diputaciones. Postura de la Diputación de Palencia (1923-1930)», Tello Téllez de Meneses, № 60 (1989), pp. 243-244.

«La gestión de la Diputación de Palencia durante la Dictadura de Primo de Rivera», en ACTAS DEL II CONGRESO DE HISTORIA DE PALENCIA, Edad Contemporánea, Tomo III, Volumen II, Palencia, Diputación Provincial de Palencia, 1990, pp. 725-748. Municipios y Provincias, Madrid, INAP, 2003.

Historia de la Legislación de Régimen Local, Madrid, Portal Derecho, S.A., 2008.

ORDUÑA REBOLLO, Enrique y COSCULLUELA MONTANER, Luis, Historia de la Legislación de Régimen Local, Madrid, Portal Derecho, S.A., 2008.

ORTEGO GIL, Pedro, Historia de la Diputación Provincial de Guadalajara 81813-1845), Guadalajara, Digibis Publicaciones Digitale, 2002.

Municipios y Provincias, Madrid, INAP, 2003.

ORTIZ DE ORRUÑO LEGARDA, José María, RIVERA BLANCO, Antonio y UGARTE TELLERÍA, Javier, Movimientos sociales en la España contemporánea, Vitoria, Abada, 2008 .

PALAFOX GAMIR, Jorge, « El capitalismo español en la depresión de los años treinta», Información Comercial Española, ICE. Revista de economía, № 514 (1976), pp. 110-118. PALOMARES IBÁÑEZ, Jesús María, «El regionalismo castellanoleonés y las gestiones para conseguir el estatuto de autonomía (1900-1936)», Nación y Regionalismo en España, Córdoba, Diputación de Córdoba, 1985.

«Crecimiento económico, tensiones sociales, y fase inicial del movimiento regionalista en Castilla y León en los comienzos del siglo XX», Las Cortes de Castilla y León, 1188-1988: actas de la Tercera Etapa del Congreso Científico sobre la historia de las Cortes de Castilla y León. Vol. II. Fuensaldaña, Cortes de Castilla y León, 1990, pp.247-300. 
«La historia de un fracaso: los patronos de la Universidad de Valladolid en el siglo XX», en Investigaciones históricas: Época moderna y contemporánea, $\mathrm{N}^{\mathrm{o}} 26,2006$, pp. 237-260.

PAREDES ALONSO, Javier (Coordinación), Historia Contemporánea de España. Siglo XIX, Madrid, Ariel, 2009.

PAREJO ALFONSO, Luciano José, «La Región y la legislación histórica de régimen local», en FERNÁDEZ RODRÍGUEZ, Tomás Ramón (Dirección.), Las Autonomías Regionales, Madrid, Instituto Nacional de Prospectiva (INP), 1977, pp. 155 y ss.

PASTRANA MORILLA, Helidoro, La Diputación Provincial de Valladolid: 1875-1930: política y gestión, Valladolid, Diputación Provincial de Valladolid, 1997.

PÉREZ NÚÑEZ, Javier, La Diputación foral de Vizcaya. El régimen foral en la construcción del Estado liberal (1808-1868), Bilbao, Centro de Estudios Constitucionales, 1996.

PÉREZ SÁNCHEZ, Guillermo Ángel, Ser trabajador: vida y respuesta obrera. (Valladolid 1875-1931), Valladolid, Universidad de Valladolid, 1996.

PICASSO GONZÁLEZ, Juan, El expediente Picasso, Madrid, Ediciones Morata, 1930.

PIÑA HOMS, Ramón, La Diputación Provincial de Baleares, Mallorca, Diputación Provincial de Baleares, 1979.

PONCE ALBERCA, Julio, «Un modelo de estudio de la administración provincial: la Diputación de Sevilla durante la Dictadura de Primo de Rivera y la Segunda República (1923-1936)», en SÁNCHEZ MANTERO, Rafael, (Coordinación.), En torno al 98: España en el tránsito del siglo XIX y XX: actas del IV Congreso de la Asociación de Historia Contemporánea, Huelva, Universidad de Huelva, Servicio de Publicaciones, 2000, pp. 435-452.

PRIETO TUERO, Indalecio, Crónicas de guerra: Melilla 1921, Málaga, UNED, 2001.

PUELLES BENÍTEZ, Manuel, Educación e ideología en la España contemporánea,

Madrid, Tecnos, 1999.

RAMOS PÉREZ, Vicente, Historia de la Diputación Provincial de Alicante, Vol. I (18221870), Alicante, Diputación Provincial de Alicante, 2002.

RAMOS VÁZQUEZ, Isabel, La reforma penitenciaria en la historia contemporánea española, Madrid, Dykinson, 2013. 
REBOREDO OLIVENZA, José Daniel, «La crisis agrícola de finales del siglo XIX y la Diputación de Palencia», en Actas del II congreso de Historia de Palencia, Edad Contemporánea, Tomo III, Volumen II, Palencia, Diputación Provincial de Palencia, 1990, pp. 769-783.

REQUENA GALlEGO, Manuel, (Coordinación.), Historia de la Diputación de Albacete, 2 vols., Albacete, Diputación Provincial de Albacete, 1993.

«El triunfo monárquico en las elecciones municipales de 1931 en Castilla-La Mancha», Hispania: Revista española de historia, No 190, 1995, pp. 673-691.

RIQUER PERMANYER, Borja de, Alfonso XIII y Cambó. La monarquía y el catalanismo político, Barcelona, RBA, 1994.

Historia de la Diputación de Barcelona, Barcelona, Diputación Provincial de Barcelona, 2007.

ROBLES EGEA, Antonio, «Formación de la conjunción republicano-socialista de 1909», Revista de estudios políticos, № 29 (1982), pp. 145-162.

ROMERO MAURA, Joaquín, La rosa de fuego: el obrerismo barcelonés de 1899 a 1909, Madrid, Alianza Editorial, 1989.

SÁNCHEZ-ARCILLA BERNAL, José, Historia de las instituciones politicoadministrativas contemporáneas (1808-1975), Madrid, Dykinson, 1994.

SÁNCHEZ DE TOCA, Joaquín, Regionalismo, municipalismo y centralismo, Imp. E. Velasco, Madrid, 1907.

SÁNCHEZ ILLÁN, Juan Carlos, «Rafael Gasset y la política hidráulica de la Restauración, 1900-1923», Revista de Historia Económica, Año XV Primavera-Verano 1997, pp. 319-362.

SÁNCHEZ LECHA, Alicia, Estado liberal y provincia: los orígenes de la Diputación de Zaragoza, Zaragoza, Diputación Provincial de Zaragoza, 1998.

SÁNCHEZ SÁNCHEZ, Isidro, (Coordinación.), Historia de la Diputación Provincial de Ciudad Real: (1835-1999), Ciudad Real, Diputación Provincial de Ciudad Real, 1999. SÁNCHEZ-ARCILLA BERNAL, José, Historia de las instituciones políticoadministrativas contemporáneas (1808-1975), Madrid, Dykinson, 1994.

SANTANA MOLINA, Manuel, La Diputación Provincial en la España decimonónica, Instituto Nacional de Administración Pública, Madrid, 1989.

SECO SERRANO, Carlos, Historia del conservadurismo español: Una línea política integradora en el siglo XIX, Madrid, Temas de Hoy, 2000. 
SIERRA JORRÍN, Abilio, Primer centenario de las Hijas de la Caridad al servicio de una buena obra: 25-Enero-1789, 25-Enero-1979, Palencia, Diputación Provincial de Palencia, 1979.

SUÁREZ CORTINA, Manuel, Las máscaras de la libertad: el liberalismo español 18081950, Madrid, Marcial Pons, 2003.

SUÁREZ GONZÁLEZ, Fernando, Melquiades Álvarez. El drama del reformismo español, Madrid, Marcial Pons, 2014.

SUEIRO SEOANE, Susana, «El mito del estratega. Primo de Rivera y la resolución del problema de Marruecos», Cuadernos de Historia Contemporánea, No16 (1994), pp. 122128.

TORTELLA CASARES, Gabriel, «El monopolio de petróleos y Campsa, 1927-1947», en GARCÍA RUIZ, José Luis, HERNÁMDEZ ANDREU, Juan, (Coordinación.) Lecturas de historia empresarial, Madrid, Civitas, 1994, pp. 265-302

TUÑÓN DE LARA, Manuel: Historia del movimiento obrero español. Madrid. Taurus, 1972 .

TIANA FERRER, Alejandro, OSSENBACH SAUTER, Gabriela y SANZ FERNÁNDEZ, Florentino, (Coordinación.), Historia de la Educación, Madrid, UNED, 2002.

TUSELL GÓMEZ, Javier, El problema político en la reforma de la administración local (1900-1936), Madrid, Instituto de Estudios administrativos, 1973.

La reforma de la administración Local en España (fines el siglo XIX a 1936), Madrid, INAP, 1988.

Antonio Maura: Una biografía politica, Madrid, Alianza Editorial, 1994.

TUSELL GÓMEZ, Javier y CHACÓN ORTIZ, Diego, La reforma de la Administración Local en España, 1900-1936, Madrid, Instituto de Estudios y Publicaciones, 1973.

TUSELL GÓMEZ, Javier, MONTERO GRACÍA, Feliciano y MARÍN ARCE, José María (Coordinación.), Las derechas en la España contemporánea, Madrid, UNED, 1997, pp. 45-58.

TUSELL GÓMEZ, Javier y GARCÍA QUEIPO DE LLANO, Genoveva, Alfonso XIII: el rey polémico, Madrid. Taurus Ediciones, 2001.

VALLE CURIESES, Rafael del, «El Instituto viejo»: comienzos de la segunda enseñanza en Palencia: 1845-1915, Palencia, Caja España, 1992.

VARELA ORTEGA, José, Los amigos políticos. Partidos, elecciones y caciquismo en la Restauración (1875-1900). Madrid, Alianza Editorial, 1977. 
VEGA GIL, Leoncio, (Coordinación.), Moderantismo y Educación en España. Estudios en torno a la Ley Moyano, Zamora, Instituto Florián de Ocampo, 1995.

VELARDE FUERTES, Juan, Cien años de economía española, Madrid, Encuentro, 2009. VILLA ARRANZ, Juan, Caciquismo y comunidades tradicionales en Castilla durante el primer tercio del siglo XX, Valladolid, Universidad de Valladolid, 1997.

VILLALAÍN GARCÍA, Pablo, Las elecciones municipales de 1931 en Madrid, Madrid, El Avapiés, 1987

VILLANUEVA LARRAYA, Gregoria, «La política hidráulica» durante la restauración, Madrid, UNED, 1991. 


\section{Fuentes documentales}

La primera labor que se realizó en esta investigación fue el análisis de las fuentes bibliográficas relacionadas con el tema estudiado, al objeto de conocer el panorama historiográfico existente sobre la evolución histórica de las diputaciones provinciales a lo largo de su azarosa vida institucional. En esta tarea de expurgo bibliográfico, se consultaron los fondos de la Biblioteca de la institución Tello Téllez de Meneses de la Diputación Provincial de Palencia, de la Biblioteca del Archivo de la Diputación Provincial de Palencia, de la Biblioteca Pública de Palencia y de la Biblioteca de la Universidad de Valladolid. De entre la bibliografía consultada, de la que se realiza un repaso pormenorizado en el apartado «Estado de la Cuestión», destacar por su carácter de obras de referencia en el campo de la historia del Derecho y la Administración Local, los trabajos de Manuel Santana Molina, La Diputación Provincial en la España decimonónica, de José Antonio González Casanova, Las Diputaciones provinciales en España. Historia política de las Diputaciones en España desde 1812 hasta 1985, de Enrique Orduña Rebollo y Luis Cosculluela Montaner, Historia de la Legislación de Régimen Local, y de José Sánchez-Arcilla Bernal, Historia de las instituciones politicoadministrativas contemporáneas (1808-1975). Por supuesto, también ha servido de gran ayuda la consulta de los trabajos sobre las diputaciones provinciales en las provincias de España.

Después de la citada labor de búsqueda bibliográfica, el campo de investigación se centró en las fuentes documentales primarias correspondientes a la etapa histórica estudiada. El Archivo Provincial de la Diputación de Palencia ha constituido un referente indispensable para recabar la información que permitiese articular un discurso coherente sobre la actividad de la Diputación Provincial en el campo político y en la labor de gestión de aspectos básicos para el funcionamiento de la vida socioeconómica de la provincia. La extraordinaria labor del personal de este Archivo, encabezado por su archivera, Pilar Rodríguez González, excelente profesional y mejor persona, ha contribuido a que la abundante documentación generada por la Diputación Provincial de Palencia, en el desarrollo de su labor administrativa, esté al alcance del investigador interesado en su conocimiento. 
Como fuente fundamental de información, el Archivo custodia los libros de Actas, tanto de la Diputación Provincial como de la Comisión Provincial, correspondientes a la totalidad del periodo estudiado. Asimismo, este Archivo dispone de abundante documentación sobre aspectos relativos a los procesos electorales, Quintas, Obras Públicas, Beneficencia, Instrucción Pública, Corrección Pública, Función Pública, etc. El Archivo también conserva la documentación correspondiente a los presupuestos provinciales de casi la totalidad del periodo estudiado, lo que permite obtener una visión completa de los recursos financieros de la Diputación a lo largo de cincuenta años. Tal es la cantidad y, sobre todo, la calidad de la información contenida en esta documentación, que por sí misma permitiría elaborar una exhaustiva investigación sobre la Hacienda de la Diputación Provincial en la Restauración. Además, se custodian varias Memorias de la Comisión Provincial que se revelan como fuentes de extraordinario valor, pues sintetizan la actividad de la entidad ejecutora de las funciones de la Diputación Provincial cuando no estaba reunida.

El conjunto de esta documentación constituye la fuente fundamental de información para esta investigación, aunque no la única, ya que los fondos documentales del Archivo Histórico Nacional, del Archivo Histórico Provincial y del Archivo Municipal del Ayuntamiento de Palencia han permitido contrastar y completar la información contenida en la documentación del Archivo de la Diputación Provincial de Palencia. De gran utilidad para conocer la actividad de los partidos que optaban a dirigir la Diputación Provincial, ha resultado la consulta de los fondos documentales del Archivo de la Fundación Antonio Maura, especialmente en lo relativo a la configuración del partido maurista en Palencia, ya que contiene valiosa información respecto a la articulación del juego político en el ámbito provincial en el primer cuarto del siglo XX.

Entre las fuentes documentales secundarias consultadas para la elaboración de esta investigación, resulta obligada la mención a la prensa, a la Gaceta de Madrid y al Boletín Oficial de la Provincia. Los diarios locales, El Día de Palencia y el Diario Palentino, constituyen las dos fuentes fundamentales de prensa consultadas, sin obviar el sesgo ideológico que generalmente subyace en toda publicación periodística. También ha sido de gran ayuda la consulta a los fondos documentales del Instituto Nacional de Estadística. 


\section{Anexos}




\section{Anexo-I Modelo Presupuesto Provincial General de Gastos e Ingresos}

\begin{tabular}{|l|l|l|}
\hline $1875^{1366} / 1924$ & 1925 \\
\hline Gastos & \\
\hline Primera Sección-Gastos obligatorios & \\
\hline & \\
\hline
\end{tabular}

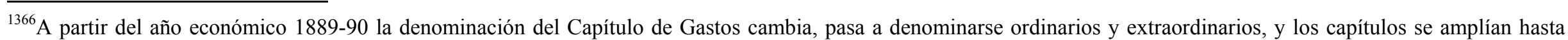
XIII, y no hay distinción entre gastos voluntarios y obligatorios. 


\begin{tabular}{|l|l|}
\hline Capítulo I Administración provincial & Obligaciones generales \\
\hline Artículo 1 Sueldos de personal y material & Servicios generales del Estado ${ }^{1367}$ \\
\hline Artículo 2 Sueldo archivero & Pactos y compromiso \\
\hline Artículo 3 Sueldo empleados comisiones especiales & Deudas \\
\hline Artículo 4 Sueldo arquitectos & Censos \\
\hline Artículo 5 Sueldo médicos & Pensiones \\
\hline
\end{tabular}

\footnotetext{
${ }^{1367}$ Junta provincial del censo. Aumento gradual del sueldo a los maestros de ambos sexos de la provincia. Sostenimiento del Consejo del Trabajo, la Diputación aportaba el $25 \%$ del total del coste. Tercera parte del coste del Servicio Antivenéreo oficial de Palencia, participación aprobada por la Junta Provincial de Sanidad por Real Orden de 8 de enero de 1929. Anticipos a los empleados provinciales cuando necesiten atender necesidades urgentes de su vida, según lo dispuesto en el art. 19 del Real Decreto de 16 de abril de 1929. Dietas y gastos que origine el Tribunal Contencioso-Administrativo provincial ${ }^{1367}$
} 


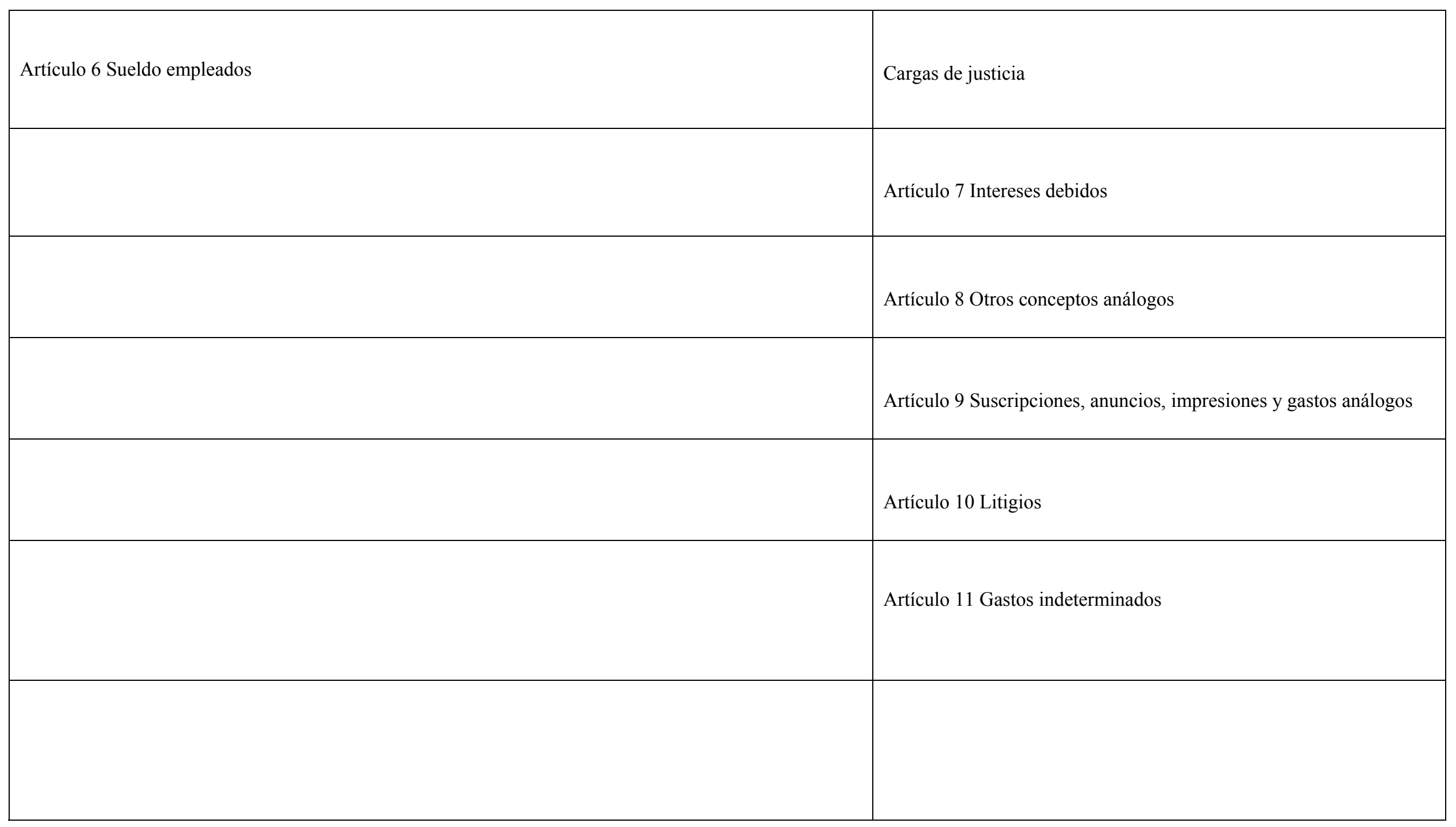




\begin{tabular}{|c|c|}
\hline Capítulo II Servicios generales & Representación provincial \\
\hline Artículo 1 Gastos quintas & De la Diputación y Comisión Provincial \\
\hline Artículo 2 Servicios de bagajes & Presidente de la Diputación ${ }^{1368}$ \\
\hline Artículo $3 B O P$ & Dietas diputados provinciales ${ }^{1369}$ \\
\hline Artículo 4 Elección diputados pro & \\
\hline Artículo 5 Calamidades públicas & \\
\hline
\end{tabular}

1368 Gastos de representación del presidente, Art. 103 del Estatuto Provincial, y de la Comisión Provincial.

${ }^{1369}$ Por asistencia a las sesiones de conformidad con lo que determina el art. 77 de Estatuto Provincial 


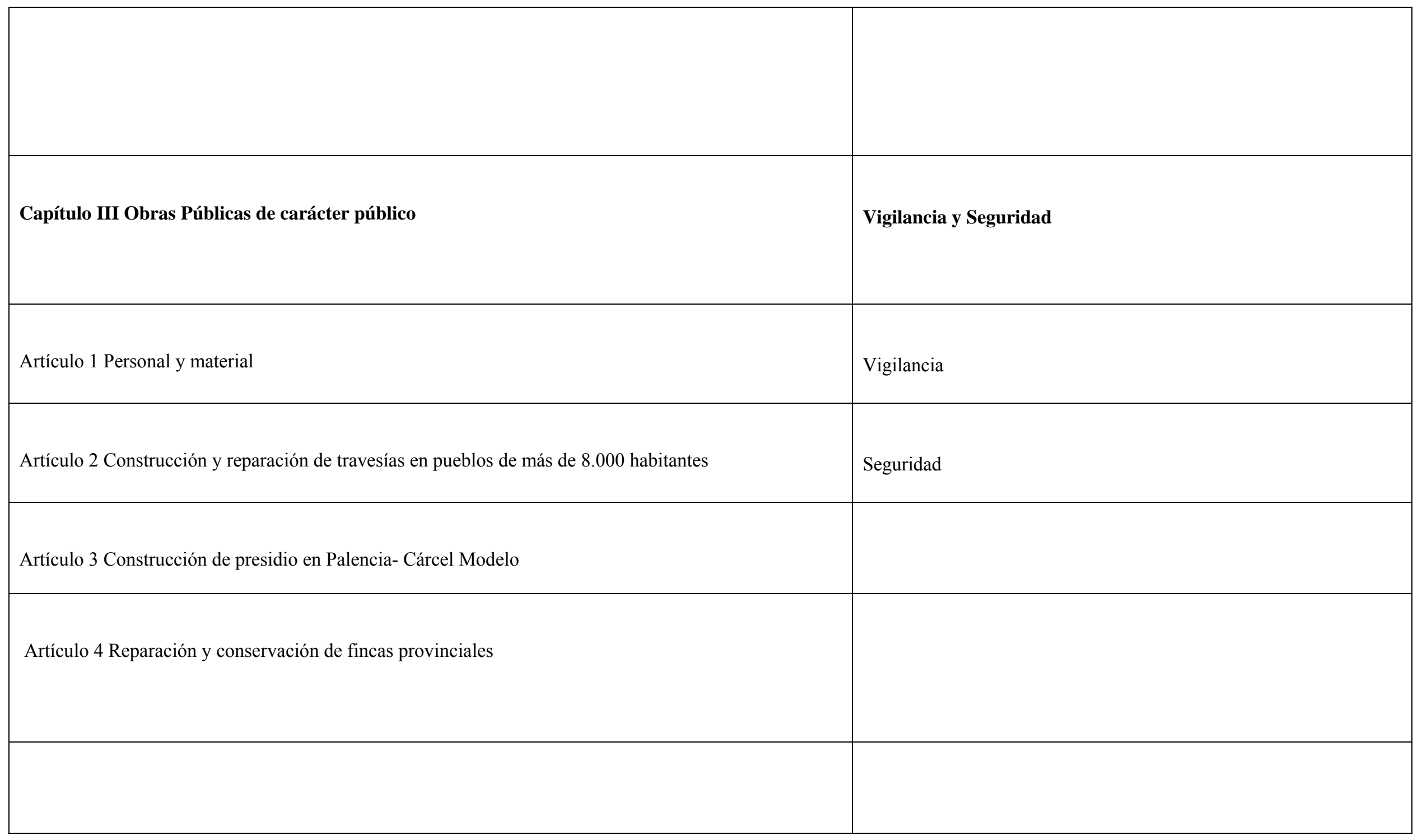




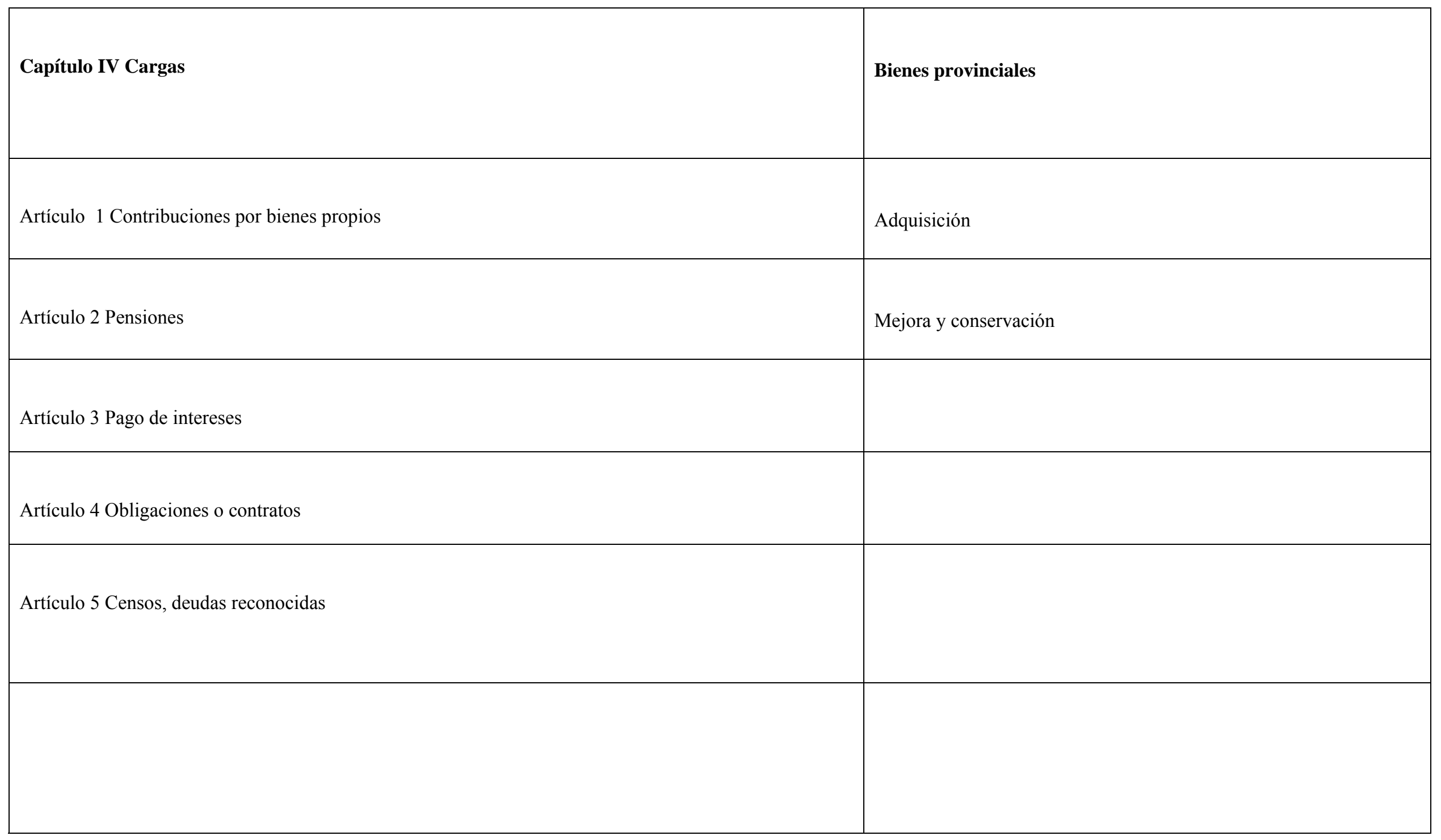




\begin{tabular}{|c|c|}
\hline Capítulo V Instrucción Pública & Gastos de recaudación \\
\hline Artículo 1 Junta provincial & De arbitrios, impuestos, tasas, derechos o rentas provinciales \\
\hline Artículo 2 Instituto $2^{\mathrm{a}}$ Enseñanza & De las contribuciones del Estado \\
\hline Artículo 3 Escuelas Normales & \\
\hline Artículo 4 Sueldo inspector provir & \\
\hline Artículo 5 Academia de Bellas Ar & \\
\hline Artículo 6 Biblioteca provincial & \\
\hline Artículo 7 Museo provincial & \\
\hline
\end{tabular}




\begin{tabular}{|c|c|}
\hline Capítulo VI Beneficencia & Personal y material \\
\hline Artículo 1 Junta provincial del ramo & De las oficinas \\
\hline Artículo 2 Hospitales & De los Establecimientos provinciales \\
\hline Artículo 3 Casas de Misericordia & Material de la Diputación Provincial y la Comisión Provincial \\
\hline Artículo 4 Casas de expósitos & Gastos generales de la Corporación \\
\hline Artículo 5 Casas de Maternidad & \\
\hline Artículo 6 Casas de huérfanos y desamparados & \\
\hline
\end{tabular}




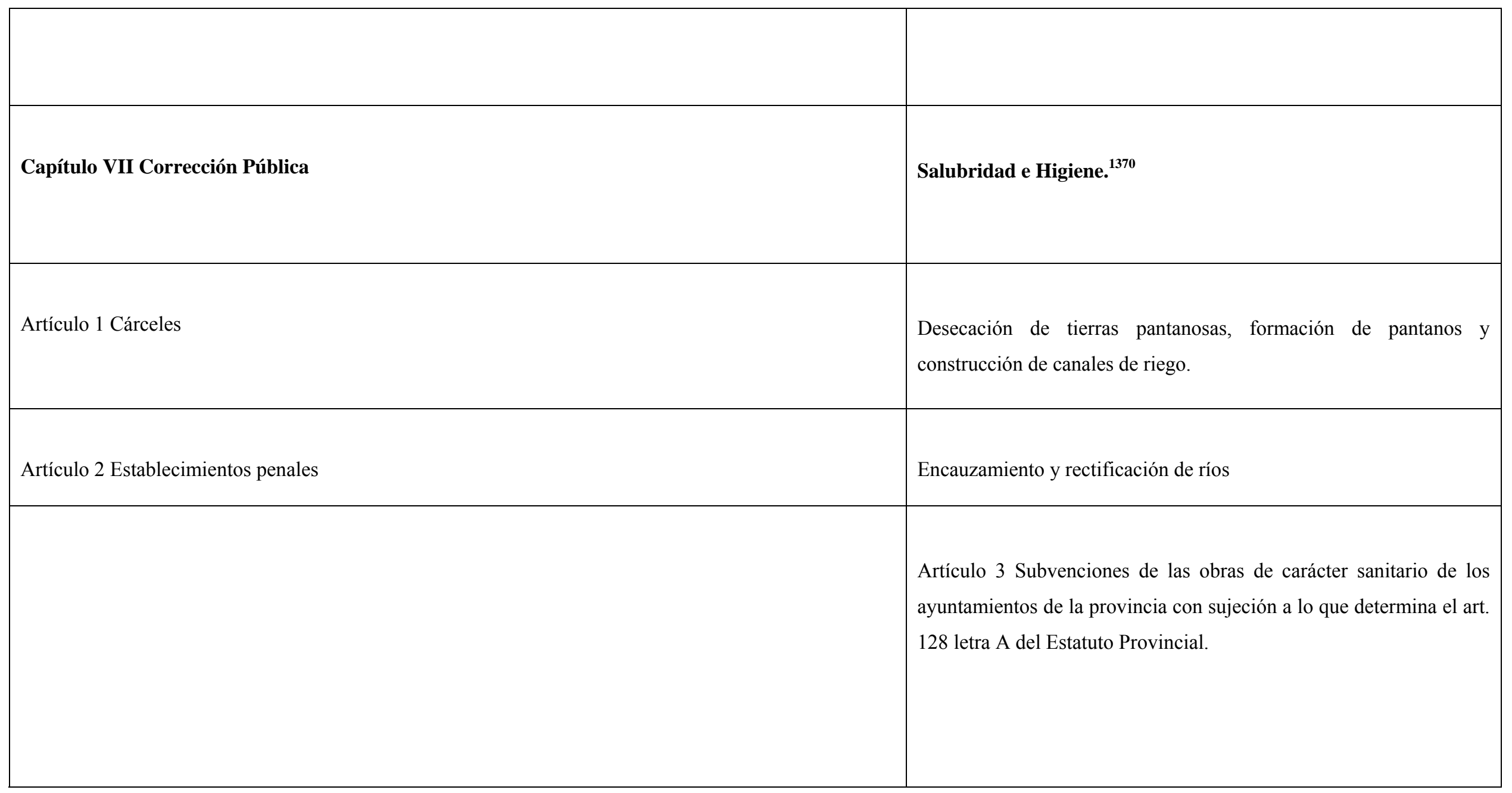

\footnotetext{
${ }^{1370}$ Subvenciones para obras de carácter sanitario en especial de abastecimiento de aguas con sujeción a lo que determinan el art. 128, letra A del Estatuto Provincial y las Bases establecidas por la Diputación Provincial
} 


\begin{tabular}{|c|c|}
\hline Capítulo VIII- Imprevistos ${ }^{1371}$ & Beneficencia \\
\hline \multirow[t]{5}{*}{ Artículo Único } & $\begin{array}{l}\text { Artículo } 1 \text { Atenciones generales: Adquisición de cajas fúnebres con } \\
\text { destino al sepelio de dementes, enfermos y asilados. }\end{array}$ \\
\hline & Artículo 2 Maternidad y expósitos \\
\hline & Artículo 3 Hospitalización de enfermos \\
\hline & $\begin{array}{l}\text { Artículo } 4 \text { Huérfanos y desamparados: Socorro a las Hermanas de } \\
\text { los Desamparados de la capital para aliviar la situación de los pobres } \\
\text { o acogidos en el citado establecimiento. }\end{array}$ \\
\hline & Artículo 5 Dementes \\
\hline
\end{tabular}

${ }^{1371}$ Gastos que ocasionaban servicios no computados en el Presupuesto Ordinario y que debían ser satisfechos por los fondos provinciales según el art. 12 del Reglamento del 20 de septiembre de 1865. 


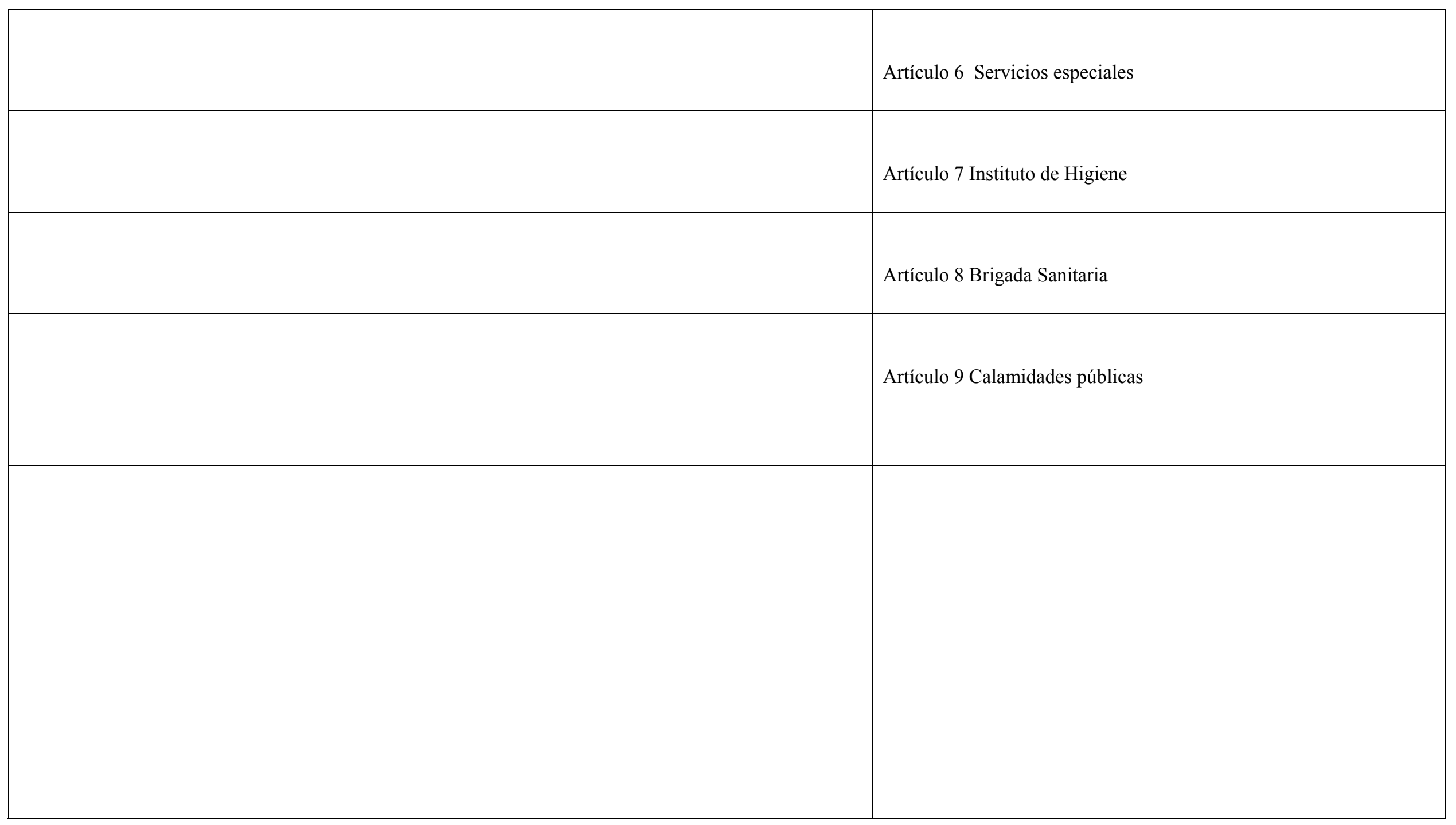




\begin{tabular}{|c|c|}
\hline \multicolumn{2}{|l|}{ Segunda Sección-Gastos voluntarios (Desde 1889-90 solo gastos) } \\
\hline Capítulo I-IX ${ }^{1372}$ Fundación y construcción de nuevos establecimientos & Asistencia Social \\
\hline Artículo Único Pagos por lo anterior & Artículo 1 Instituciones de crédito \\
\hline & $\begin{array}{l}\text { Artículo } 2 \text { Otras instituciones de carácter social: Subvenciones } \\
\text { relacionadas con la beneficencia privada en todos sus aspectos, } \\
\text { previas las normas que establezca la Diputación. Subvención a cajas } \\
\text { de ahorro o seguros contra el paro forzoso en la capital y pueblos de } \\
\text { la provincia bajo las condiciones que establezca la Diputación. } \\
\text { Bonificar con } 25 \text { pts. el subsidio de maternidad creado por el Estado } \\
\text { según Real Decreto de } 21 \text { de agosto de } 1923 \text { siempre que la obrera o } \\
\text { empleada cumpla o reúna las condiciones que previamente señale la } \\
\text { Diputación. Gatos que origine la creación de una Caja de Ahorros } \\
\text { provincial. }\end{array}$ \\
\hline
\end{tabular}

\footnotetext{
${ }^{1372}$ El guión indica cambio de numeración del Capítulo a partir del año económico 1889-90
} 


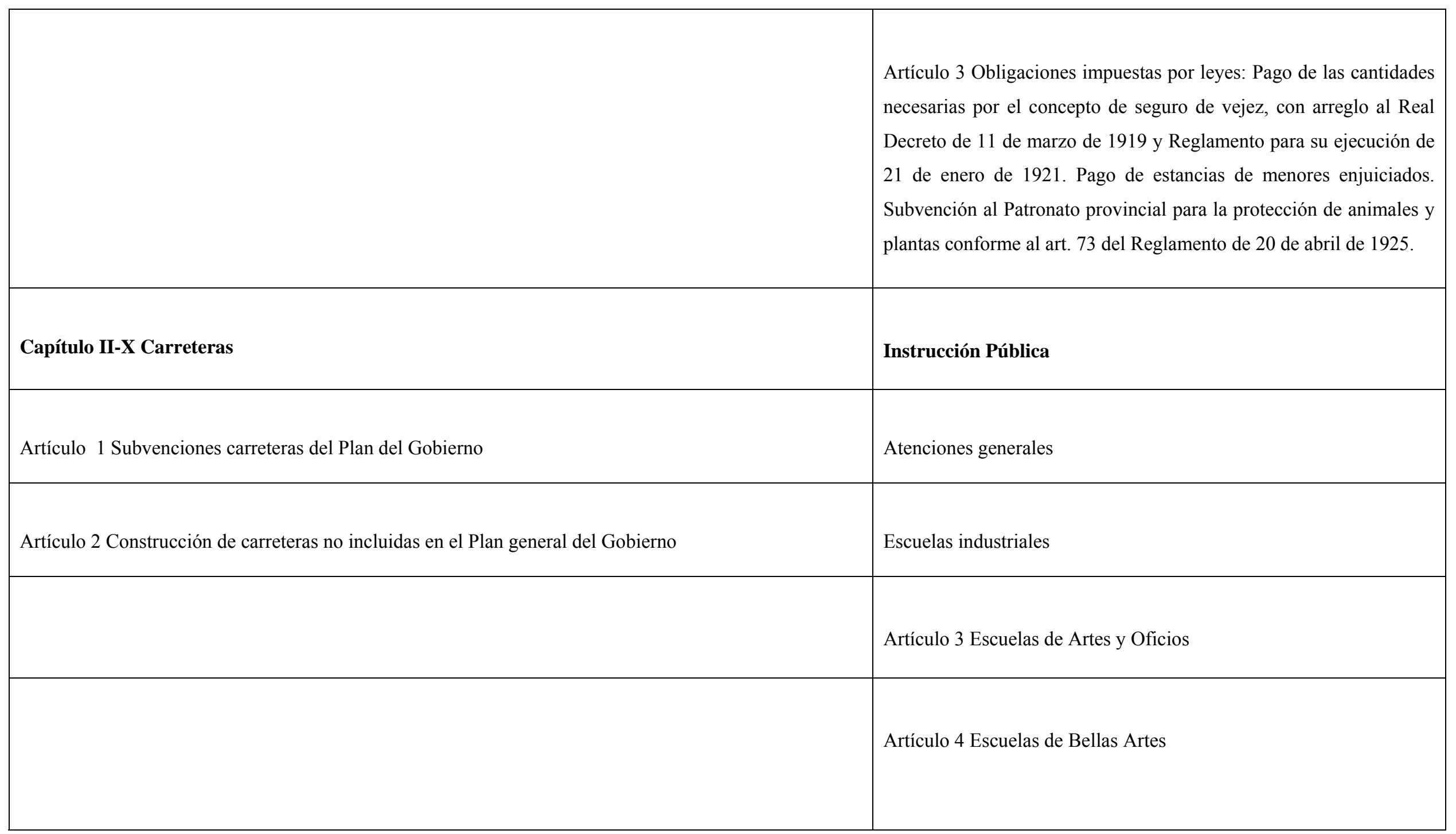




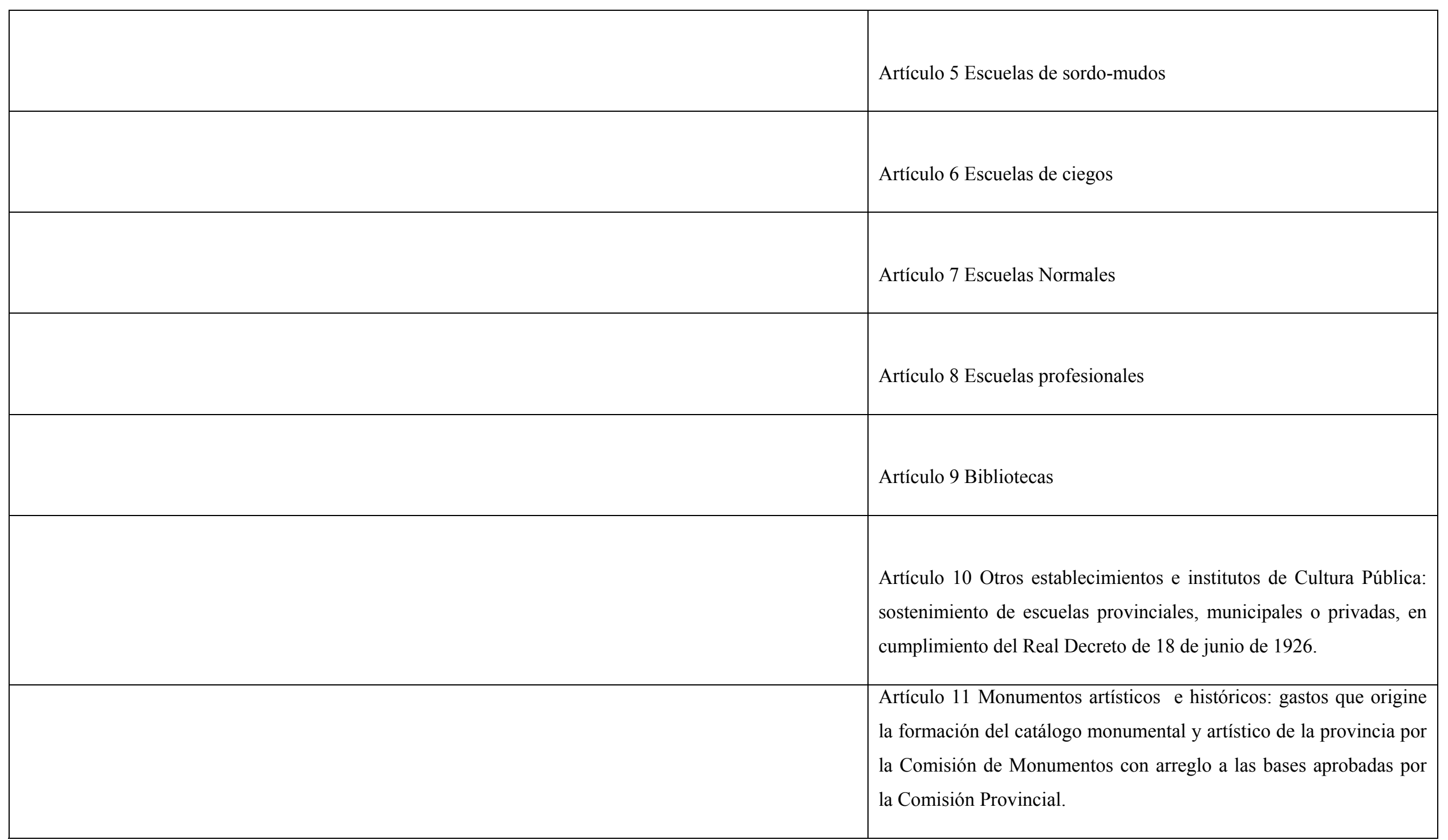




\begin{tabular}{|c|c|}
\hline & $\begin{array}{l}\text { Artículo } 12 \text { Subvenciones o becas: subvención al Patronato } \\
\text { Universitario de Valladolid. Subvención a las escuelas del Ave } \\
\text { María de la capital. }\end{array}$ \\
\hline Capítulo III-XI Obras diversas & XI Obras públicas y edificios provinciales \\
\hline \multirow[t]{5}{*}{ Artículo Único Subvenciones para obras a cargo del Estado o de los ayuntamientos } & Artículo 1 Atenciones generales \\
\hline & Artículo 2 Construcción caminos vecinales \\
\hline & Artículo 3 Reparación y conservación caminos vecinales \\
\hline & Artículo 4 Construcción de otros caminos y carreteras provinciales \\
\hline & $\begin{array}{l}\text { Artículo } 5 \text { Reparación y conservación de otros caminos y carreteras } \\
\text { provinciales }\end{array}$ \\
\hline
\end{tabular}




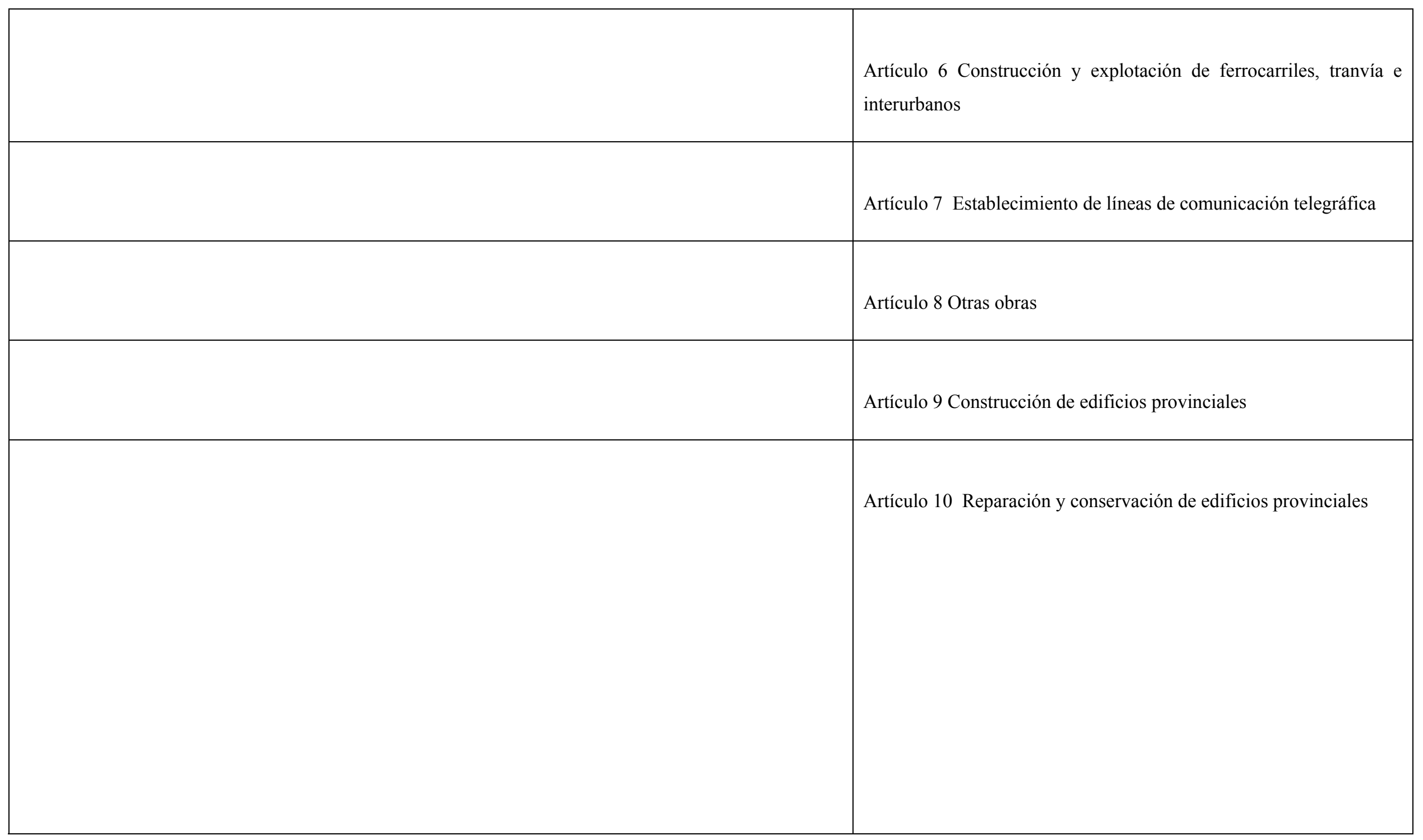




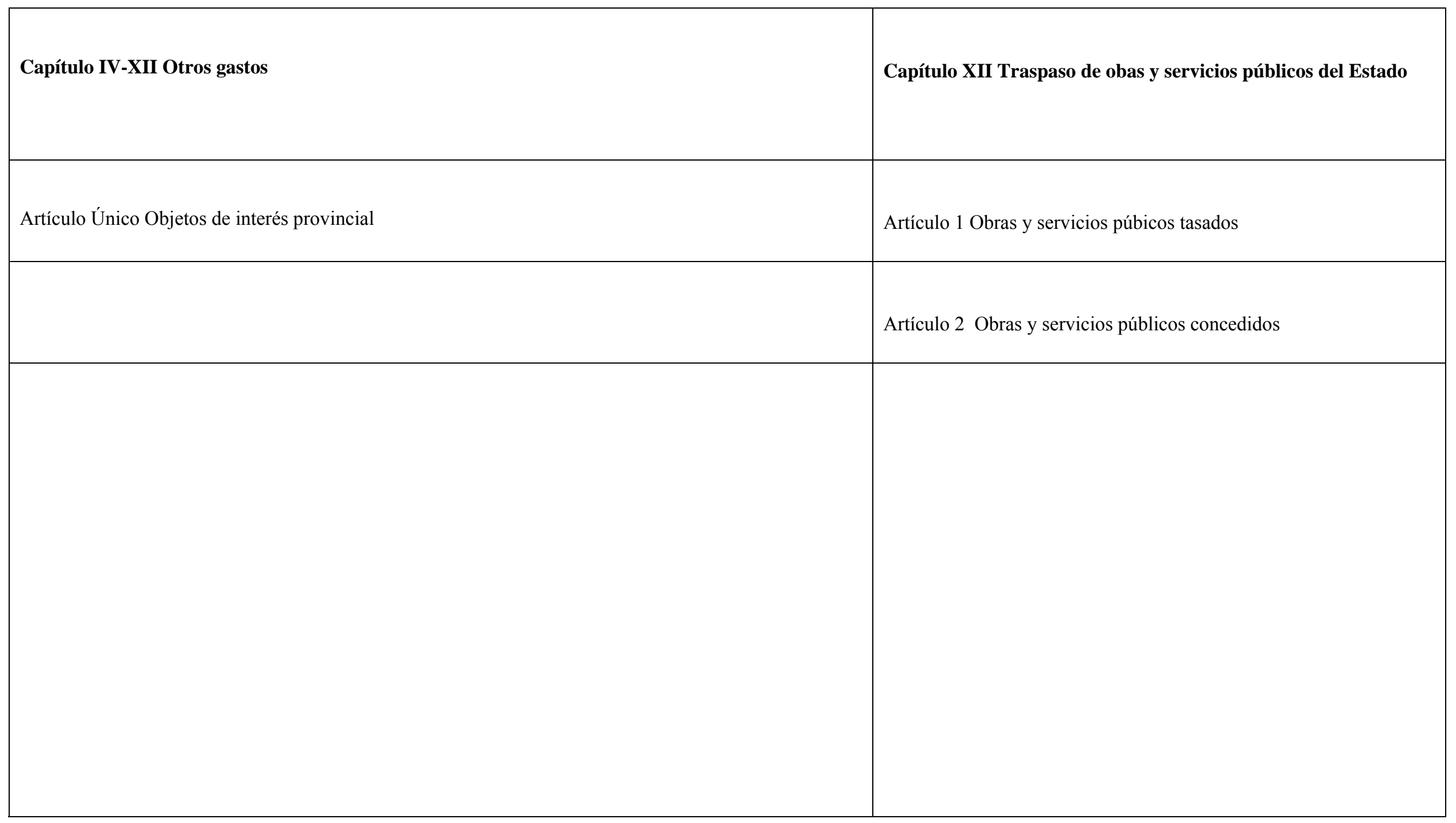




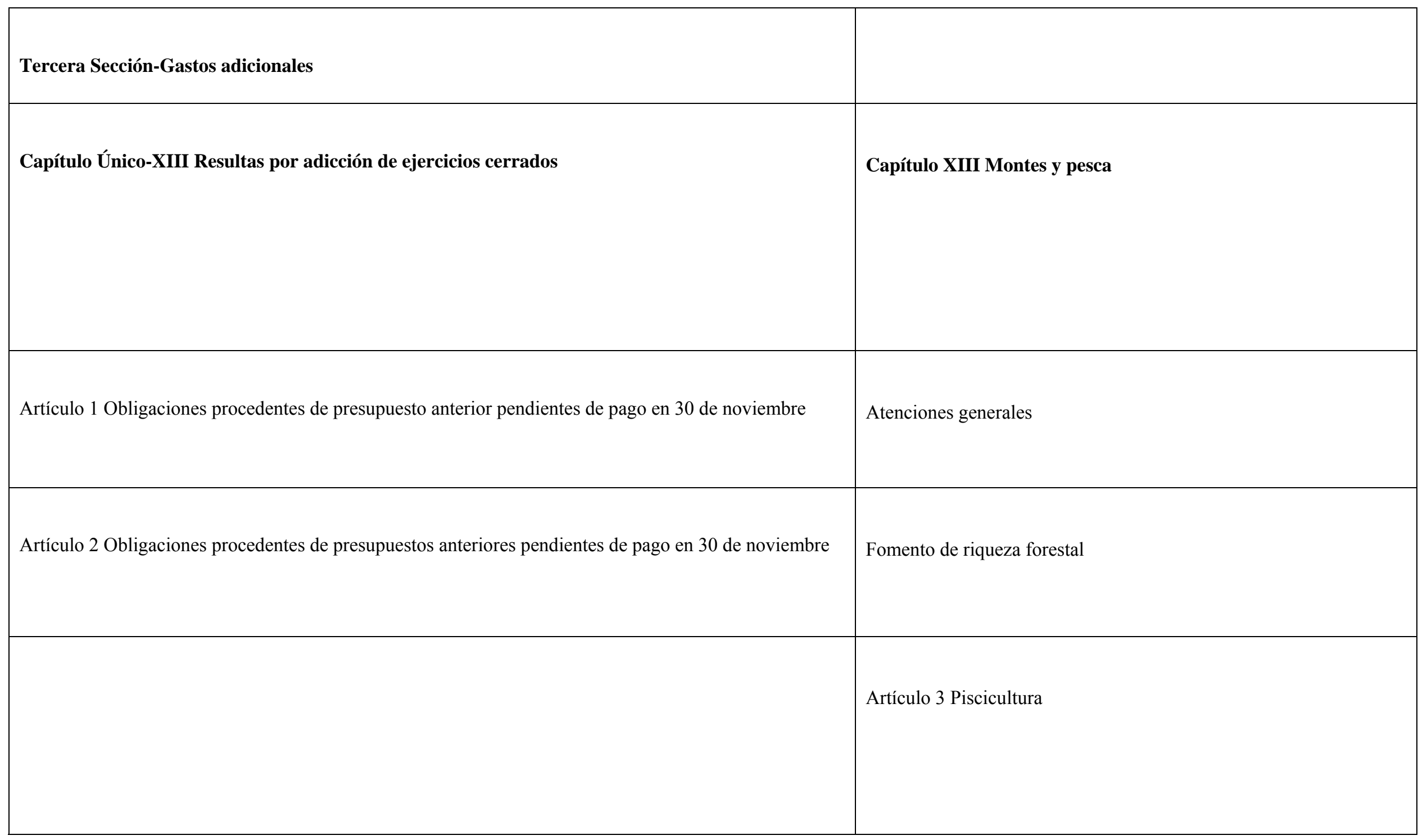




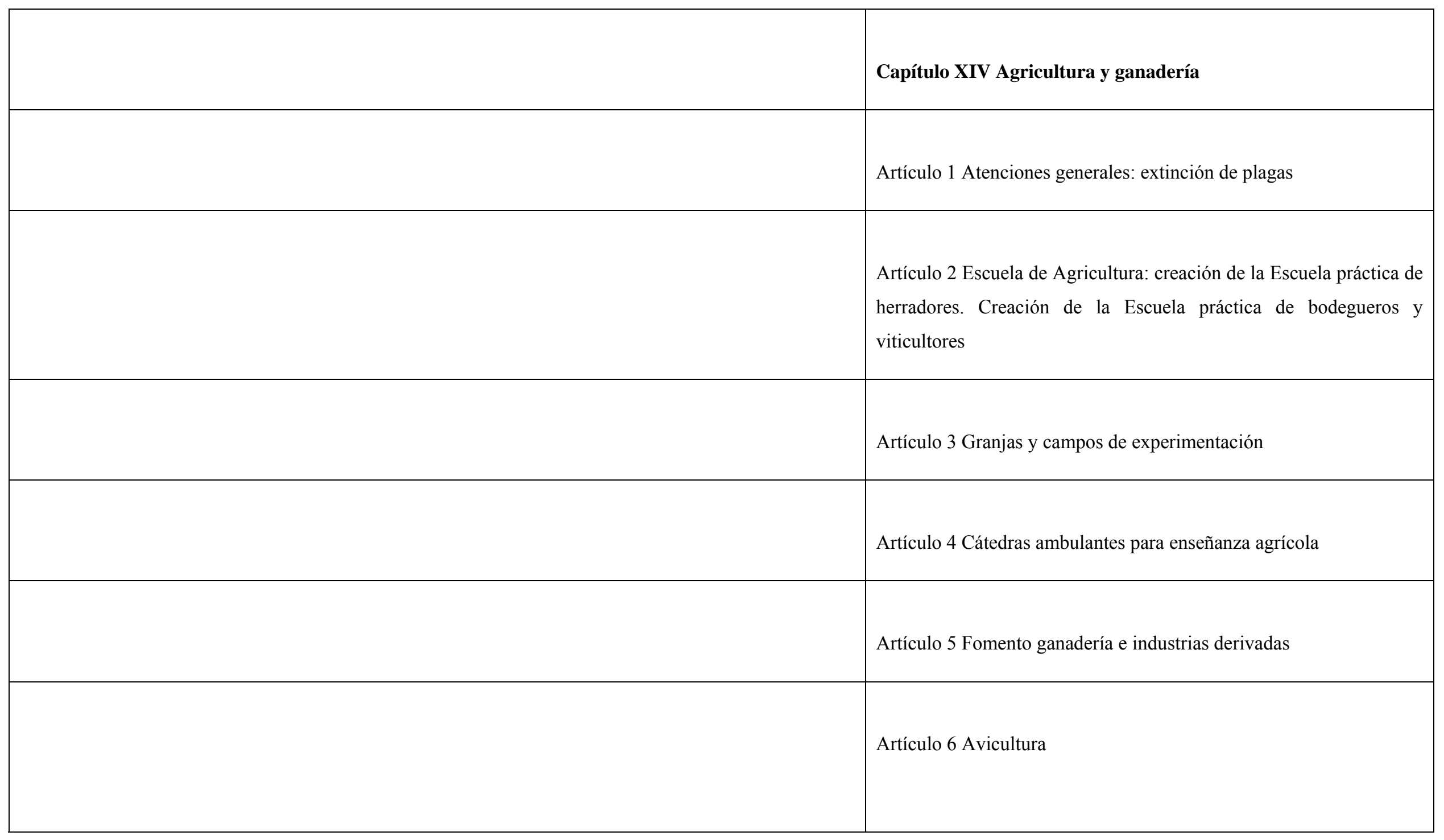




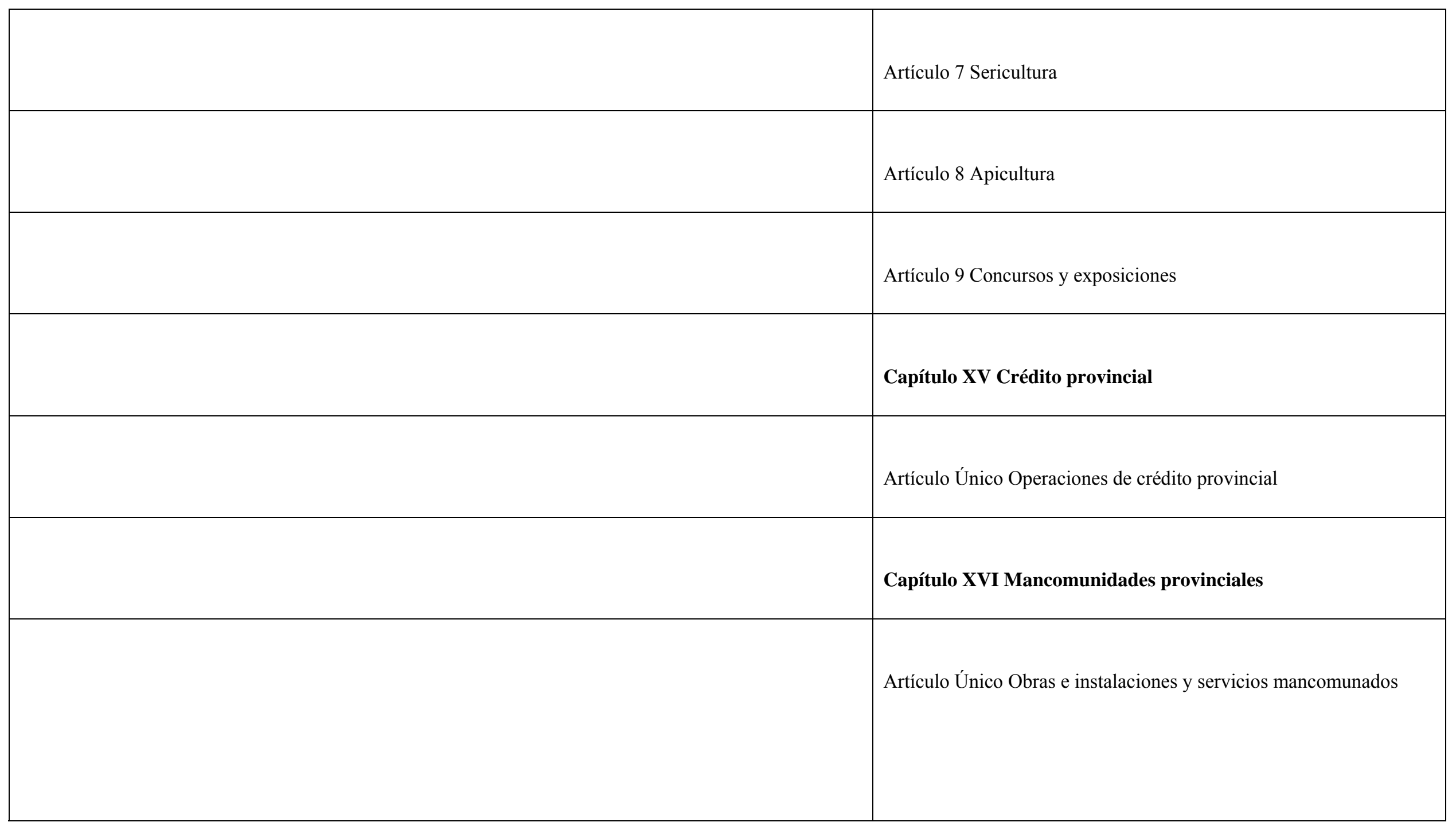




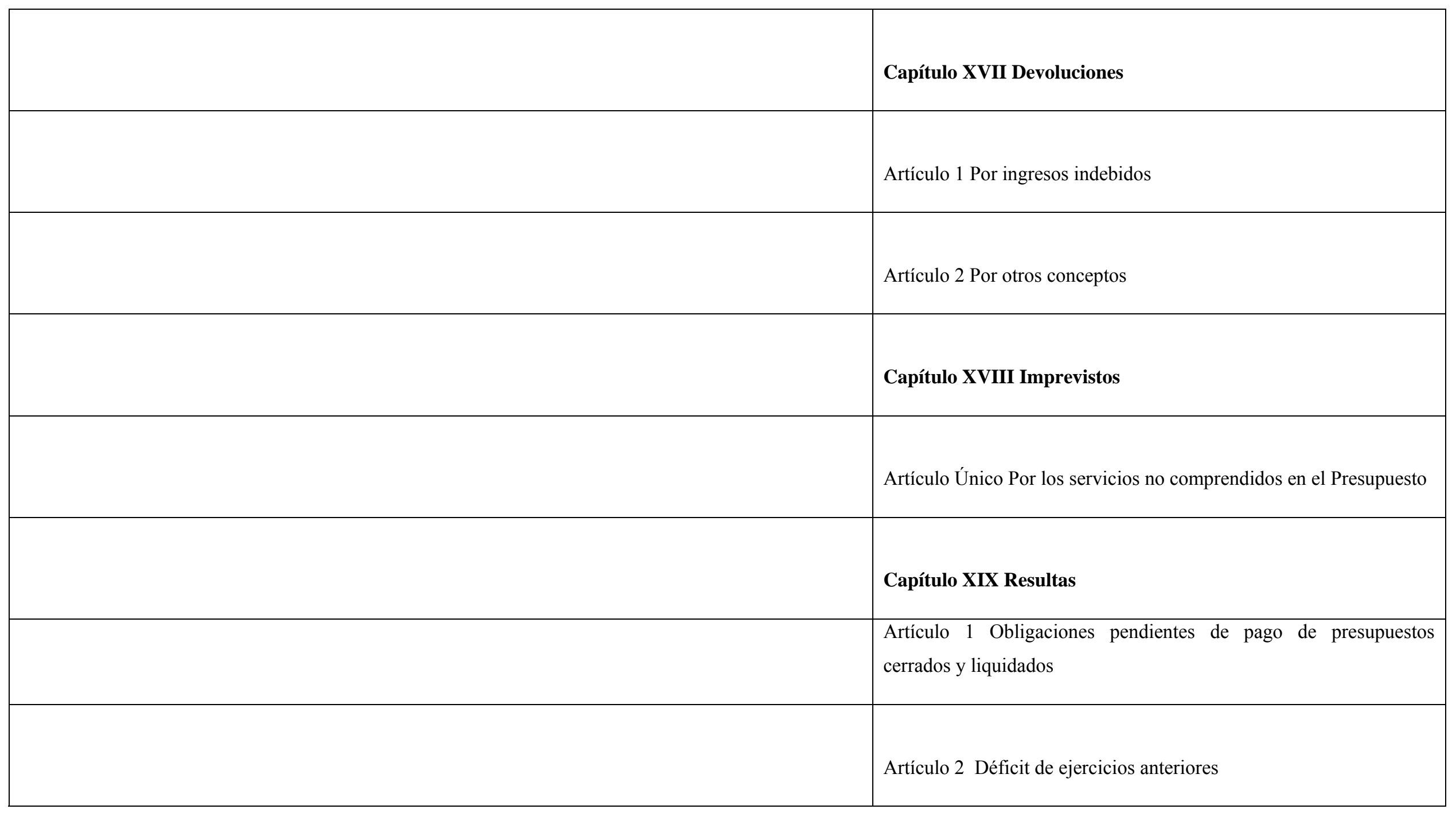




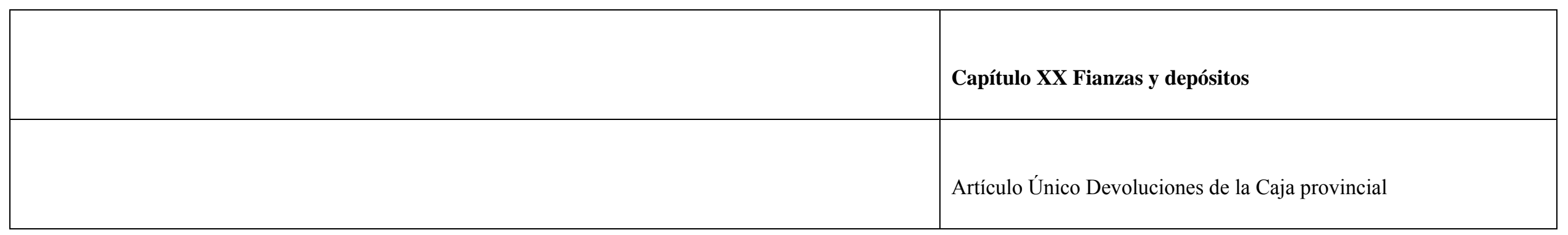




\begin{tabular}{|c|c|}
\hline \multicolumn{2}{|l|}{ Ingresos } \\
\hline \multicolumn{2}{|l|}{ Primera Sección-Ingresos ordinarios } \\
\hline Capítulo I Rentas y censos de la provincia & Rentas \\
\hline Artículo 1 Producto de censos y rentas de propiedades & Propiedades \\
\hline \multirow[t]{4}{*}{ Artículo 2 Intereses de los efectos públicos de la provincia } & Censos \\
\hline & Artículo 3 Intereses de los efectos públicos y demás valores \\
\hline & Artículo $4 B O P$ e Imprenta provincial \\
\hline & Artículo 5 Otros temas \\
\hline
\end{tabular}




\begin{tabular}{|c|c|}
\hline Capítulo II Derechos portazgos, pontazgos y barcajes & Bienes provinciales \\
\hline Artículo 1 Derechos portazgos & $\begin{array}{l}\text { Aprovechamientos especiales: parte proporcional que correspondía a la Diputación } \\
\text { Provincial por la tasa especial de rodaje }{ }^{1373} \text { con destino al Patronato Nacional de Firmes } \\
\text { Especiales }\end{array}$ \\
\hline Artículo 2 Derechos pontazgos & Enajenaciones \\
\hline Artículo 3 Derechos barcajes & \\
\hline Capítulo III Donativos, legados y mandas & Subvenciones y donativos \\
\hline Artículo Único Donativos, legados y mandas hechos en la provincia & Artículo 1 Del Estado \\
\hline & Artículo 2 De las corporaciones locales \\
\hline
\end{tabular}

${ }^{1373}$ Establecida por el Real Decreto de 26 de junio de 1926 conforme a la Instrucción de 8 de junio de 1927. 


\begin{tabular}{|c|c|}
\hline & Artículo 3 Donativos \\
\hline Capítulo IV Recargos sobre contribuciones ${ }^{1374}$ (Repartimiento) & Legados y mandas \\
\hline Artículo Único Recargos sobre las contribuciones directas y consumos & Artículo Único Legados y mandas \\
\hline Capítulo V Recargo sobre la sal, eliminado desde 1890 & Eventuales y extraordinarios e indemnizaciones \\
\hline Artículo Único Sobre la sal común & $\begin{array}{l}\text { Artículo } 1 \text { Eventuales: el } 25 \% \text { de las multas impuestas por el Gobierno de la provincia con } \\
\text { destino a la Beneficencia Provincial }\end{array}$ \\
\hline & Artículo 2 Extraordinarios \\
\hline & Artículo 3 Indemnizaciones \\
\hline
\end{tabular}

${ }^{1374}$ Territorial, Industrial y Consumos, además se añadía una cuota provincial, el Repartimiento. 


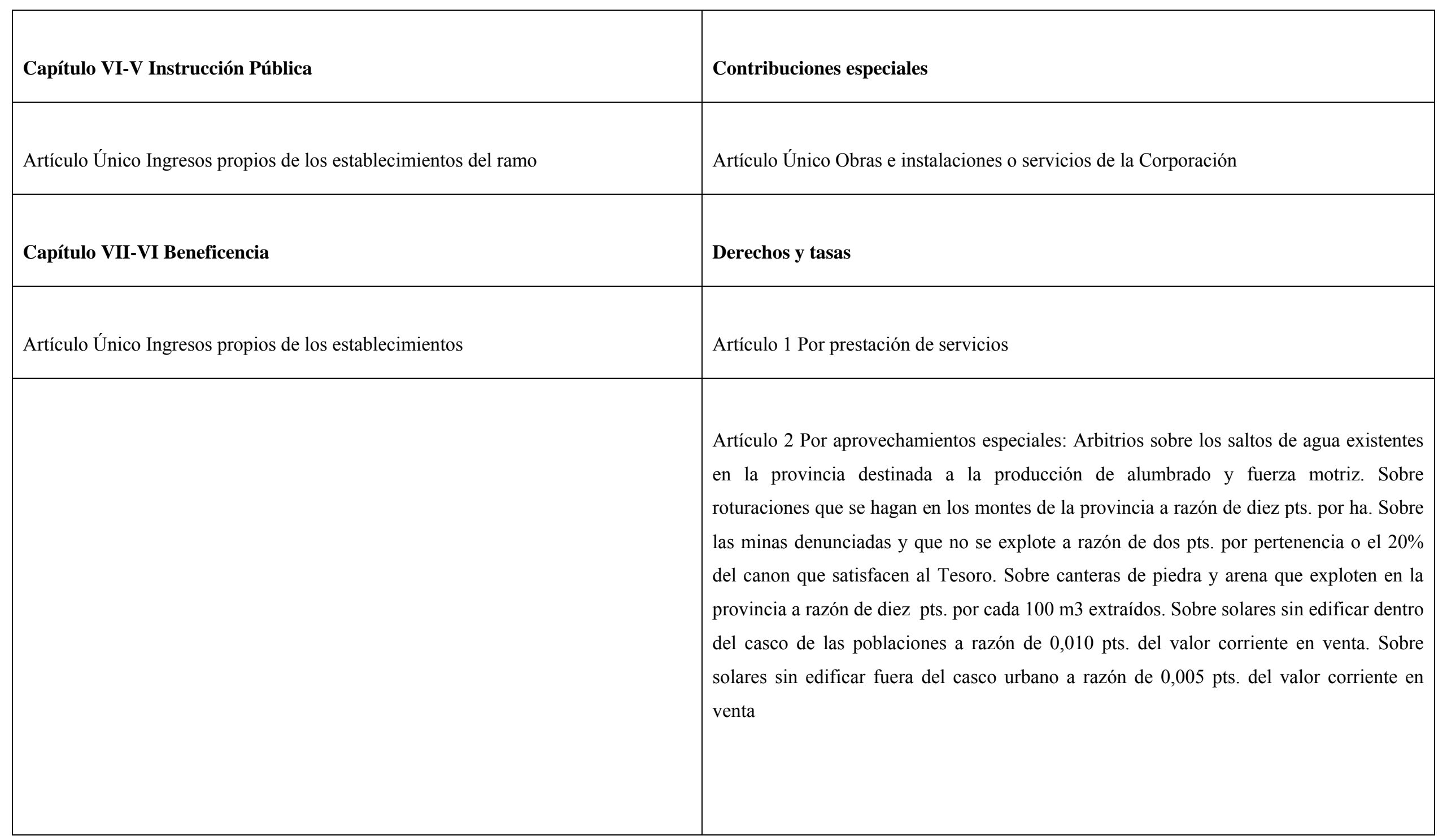




\begin{tabular}{|c|c|}
\hline Segunda Sección-Ingresos extraordinarios & \\
\hline Capítulo I-VII Aumento recargo sobre contribuciones & Capítulo IX Impuestos y recursos cedidos por el Estado \\
\hline Artículo Único Sobre contribuciones directas y consumos & $\begin{array}{l}\text { Artículo } 1 \text { Contribución territorial: Importe calculado del } 5 \% \text { sobre las cuotas de } \\
\text { contribución territorial sobre la riqueza rústica y pecuaria existente en la provincia de } \\
\text { conformidad con lo que determinan los arts. } 222 \text {, letra b y } 225 \text { del Estatuto Provincial }\end{array}$ \\
\hline & Artículo 2 Cédulas personales: Arts. 222, letra b y 226 y 2 \\
\hline Capítulo II-VIII Arbitrios especiales & Capítulo X Cesiones de recursos municipales \\
\hline $\begin{array}{l}\text { Artículo Único Sobre objetos no determinados en la Ley de Presupuestos y } \\
\text { contabilidad provincial }\end{array}$ & $\begin{array}{l}\text { Artículo } 1 \text { Aportación municipal: Importe de la aportación forzosa ordinaria con la que } \\
\text { han de contribuir los ayuntamientos de la provincia de conformidad con lo que determina } \\
\text { el art. } 231 \text { del Estatuto Provincial. }\end{array}$ \\
\hline
\end{tabular}




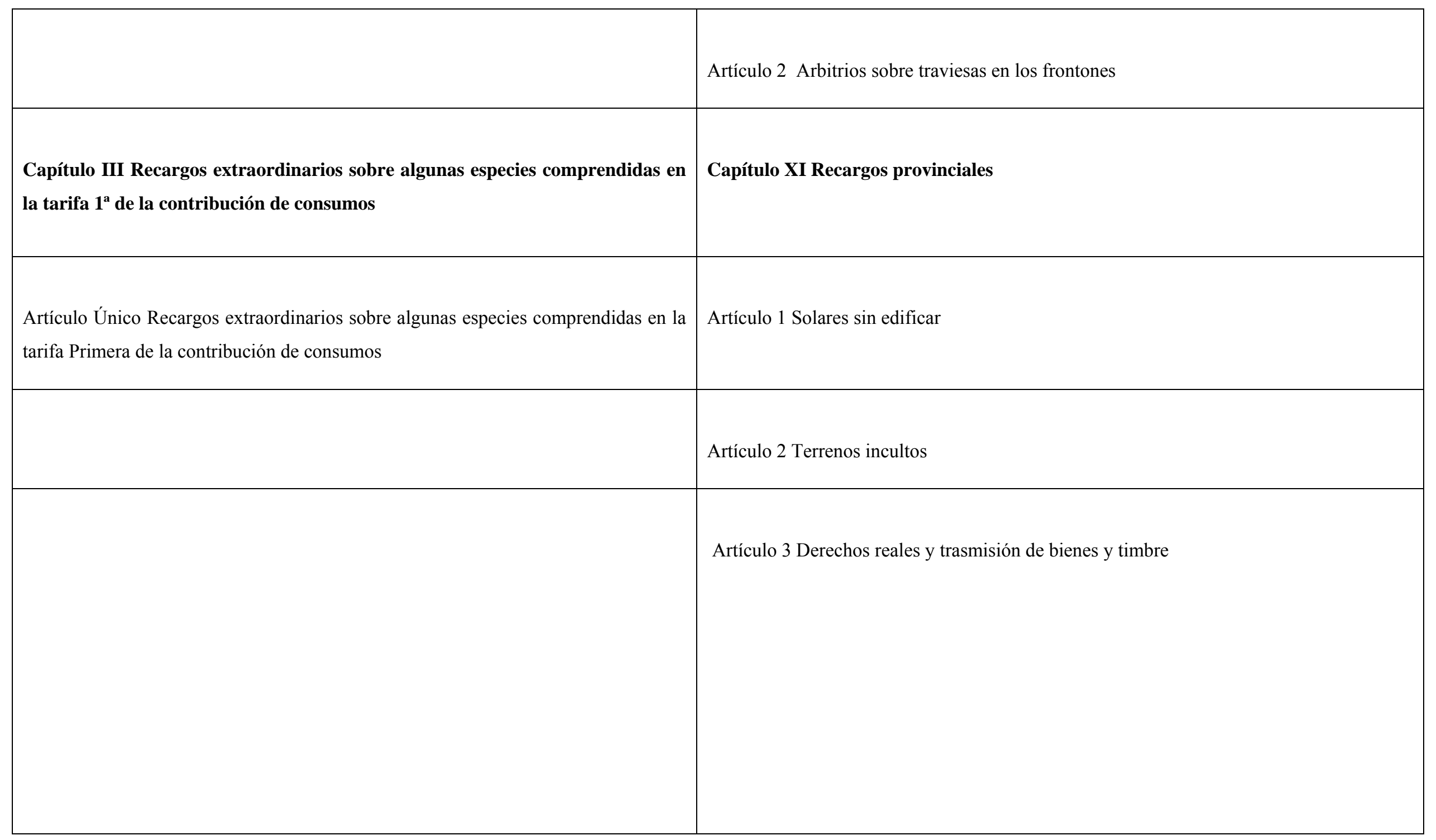




\begin{tabular}{|c|c|}
\hline Capítulo IV-IX Empréstitos & Capítulo XII Traspaso de obras y servicios públicos \\
\hline $\begin{array}{l}\text { Artículo Único Producto de los empréstitos controlados por la provincia con } \\
\text { autorización competente }\end{array}$ & Artículo 1 Recursos del Estado \\
\hline & Artículo 2 Otros ingresos \\
\hline Capítulo V-X Enajenaciones & Capítulo XIII Crédito provincial \\
\hline Artículo Único Producto de venta de propiedades provinciales & Artículo Único Operaciones de crédito provincial \\
\hline
\end{tabular}




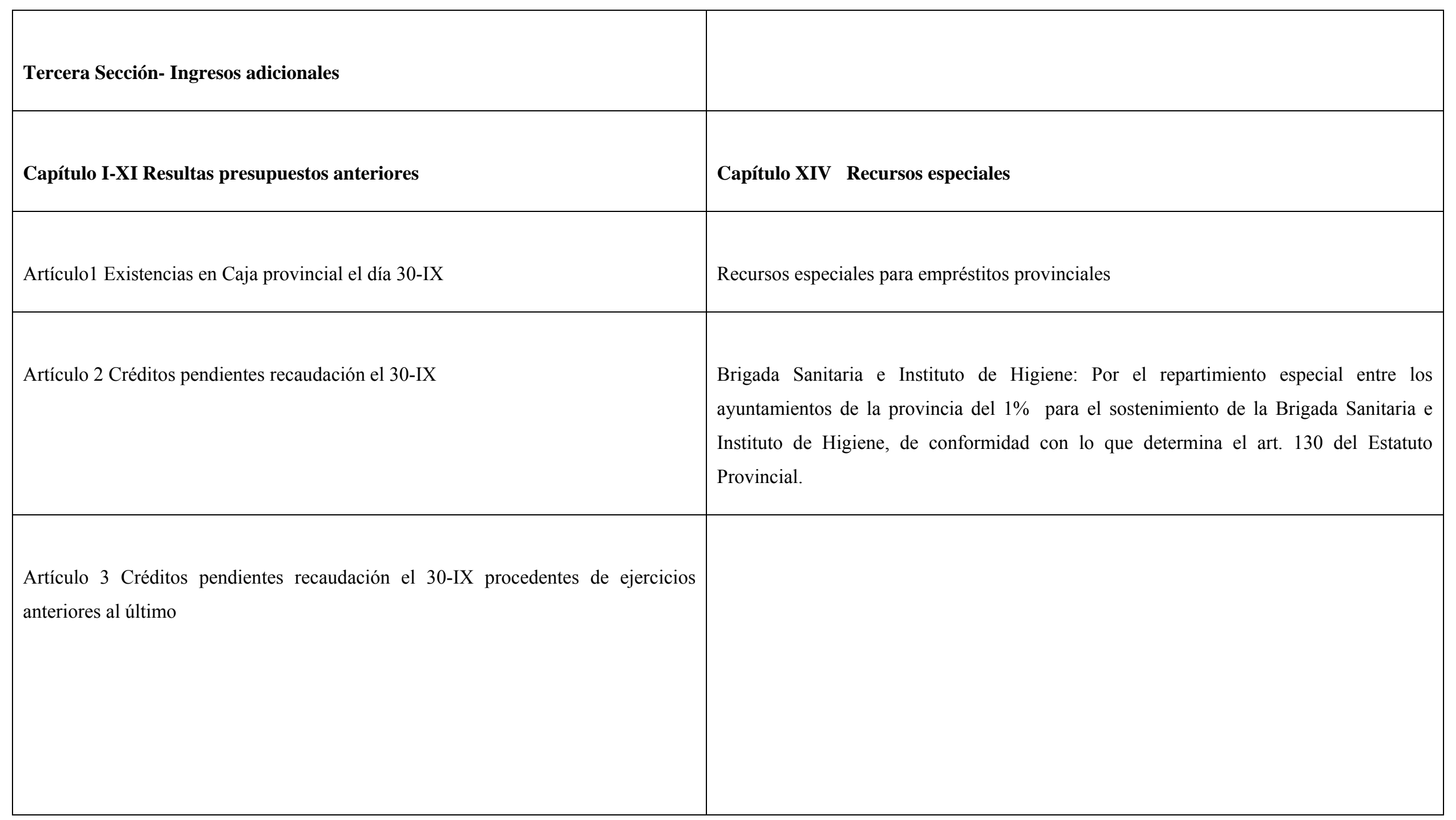




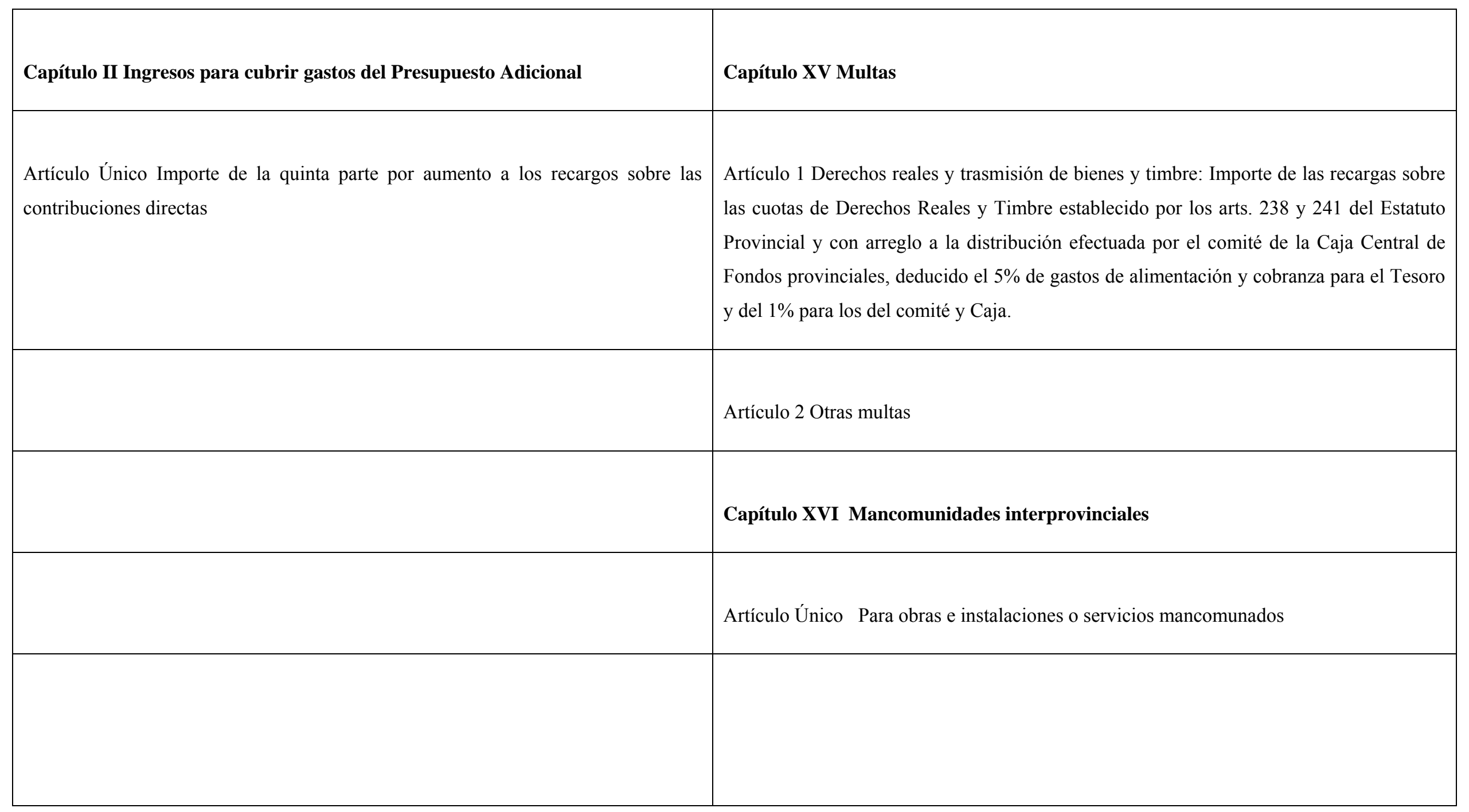




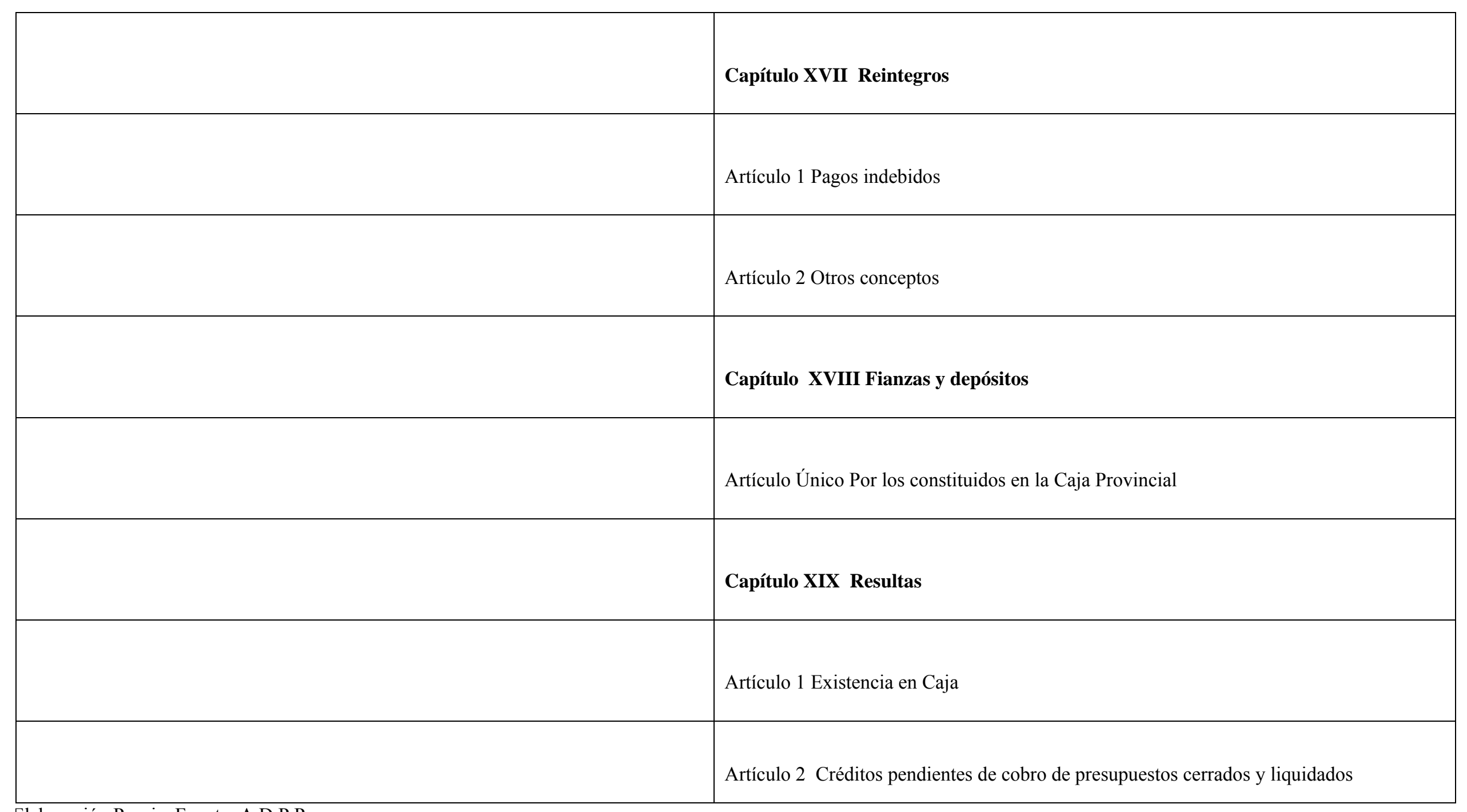

Elaboración Propia .Fuente: A.D.P.P. 


\section{Anexo II-Presupuesto provincial en pts. por capítulos 1878-1899}

Tabla I.

\begin{tabular}{|c|c|c|c|c|c|c|c|c|c|c|c|c|c|c|}
\hline $\begin{array}{c}\text { Año } \\
\text { económi } \\
\text { co }\end{array}$ & Cap.1 & Сар.2 & Сар.3 & Сар.4 & Сар.5 & Cap.6 & Сар.7 & Сар.8 & Сар.9 & Cap.10 & Cap.11 & Cap.12 & Cap.13 & Total \\
\hline $78-79$ & 54.350 & 43.250 & & 5.000 & $58.000,6$ & $173.253,76$ & & 39.000 & & 359.440 & 75.000 & & $8.183,25$ & $815.483,51$ \\
\hline $79-80$ & 64.631 & 41.250 & & $5 . .500$ & $63.888,93$ & $198.104,75$ & & 20.000 & & $65.139,10$ & 54.000 & & $185.389,99$ & $698.083,77$ \\
\hline $80-81$ & 58.281 & 33.000 & & 2.500 & $62.157,22$ & $260.984,63$ & & 10.000 & & $188.471,75$ & & & $64.602,67$ & $679.997,27$ \\
\hline $81-82$ & 63.031 & 48.000 & & $12.424,96$ & 67.324 & $259.512,75$ & & 10.000 & & 124.192 & & & $116.202,34$ & $760.687,05$ \\
\hline $82-83$ & 62.510 & 40.000 & & 14.683 & 76.849 & $271.740,13$ & & 10.000 & & 134.245 & & & $176.344,38$ & $786.371,51$ \\
\hline $83-84$ & 66.274 & 40.000 & & 16.500 & 72.294 & $263.882,11$ & & 10.000 & & 155.577 & $50.421,24$ & 40.000 & $108.058,56$ & $823.007,44$ \\
\hline $84-85$ & 72.974 & 41.000 & & 3.500 & 78.055 & $244.357,52$ & 4.000 & 10.000 & & 235.163 & & & $114.414,41$ & $803.463,93$ \\
\hline $85-86$ & 75.596 & 76.000 & & 5.500 & 76.854 & 224.967 & 2.700 & 11.500 & & $255.609,99$ & & & $110.040,24$ & $838.767,23$ \\
\hline $86-87$ & 76.096 & 56.500 & & 7.697 & 68.769 & $223.291,27$ & 104.100 & 13.000 & & 241.168 & & $58.927,18$ & 117.832 & $967.380,45$ \\
\hline $87-88$ & 75.703 & 25.000 & & 7.547 & 70.444 & $207.347,25$ & 12.000 & 10.000 & & $292.524,75$ & & 14.033 & 154.000 & 868.599 \\
\hline 88-89 & 72.002 & 24.230 & & 16.288 & 11.149 & $200.367,5$ & 22.625 & 10.000 & & $223.482,93$ & & 13.005 & $179.697,16$ & $772.866,59$ \\
\hline $89-90$ & $71.280,05$ & 22.000 & & 9.098 & 11.149 & $202.161,50$ & $19.083,50$ & 8.000 & & 168.668 & 48.000 & 13.133 & $146.227,39$ & $719.350,44$ \\
\hline $90-91$ & $69.280,05$ & 27.000 & & $6.406,75$ & 11.733 & $202.017,15$ & $18.800,05$ & 8.000 & & $246.317,64$ & 4.000 & 13.133 & 108.000 & $714.692,59$ \\
\hline $91-92$ & 68.030 & 24.000 & & $14.424,50$ & 13.223 & $210.431,90$ & 17.625 & 8.000 & & 169.172 & 25.000 & 13.498 & 113.000 & $676.404,4$ \\
\hline $92-93$ & 89.416 & 24.000 & 80.000 & $7.849,49$ & 12.874 & $221.369,5$ & 19.859 & 8.000 & & 163.818 & 20.000 & 11.833 & 7.000 & $666.098,99$ \\
\hline $93-94$ & 96.792 & 20.000 & 55.000 & $5.450,50$ & 12.874 & $207.400,5$ & 16.229 & 14.000 & & $199.515,02$ & 26.565 & 11.833 & $33.754,53$ & $699.413,55$ \\
\hline $94-95$ & 95.681 & 16.000 & 55.900 & 6.598 & 13.124 & 211.361 & 16.374 & 13.184 & 15.000 & $199.068,60$ & & 11.833 & $124.495,08$ & $778.618,88$ \\
\hline $95-96$ & 92.146 & 18.000 & $115.778,33$ & 6.898 & 13.124 & 213.916 & 16.374 & 15.500 & & 78.268 & & 12.052 & $15.600,5$ & $597.656,83$ \\
\hline $96-97$ & 72.988 & 58.000 & 500 & 17.403 & 25.065 & 212.285 & 20.374 & 18.537 & & 73.210 & & 11.787 & $75.280,83$ & $586.131,83$ \\
\hline $97-98$ & $99.274,57$ & 60.000 & & 9.340 & 13.142 & 215.462 & 21.217 & 15.000 & & 178.572 & & $13.820,75$ & $25.017,95$ & $651.116,71$ \\
\hline $98-99$ & $98.139,57$ & 29.000 & & 8.800 & 13.624 & $222.820,7$ & 21.217 & 15.000 & & 86.141 & & 12.052 & & $507.094,27$ \\
\hline
\end{tabular}

Elaboración propia. Fuente: C-R/ 1,15 Memoria Primer Semestre 1898-99. 


\section{Anexo III-Porcentaje del Contingente Provincial en la etapa 1875/1924/251375}

Tabla I.

\begin{tabular}{|c|c|}
\hline $\begin{array}{c}\text { Ejercicio } \\
\text { económico }\end{array}$ & Porcentaje \\
\hline $1875-76$ & $10 \%$ \\
\hline $1876-77$ & $12 \%$ \\
\hline $1877-78$ & $12 \%$ \\
\hline 1878-79 & $10 \%$ \\
\hline 1881-82 & $15,75 \%$ \\
\hline $1882-83$ & $25 \%$ \\
\hline $1883-84$ & $15 \%$ \\
\hline 1884-85 & $15 \%$ \\
\hline 1885-86 & $17 \%$ \\
\hline 1886-87 & $15 \%$ \\
\hline 1887-88 & $12 \%$ \\
\hline 1888-89 & $14 \%$ \\
\hline $1889-90$ & $14 \%$ \\
\hline $1890-91$ & $14 \%$ \\
\hline 1891-92 & $14 \%$ \\
\hline 1892-93 & $14 \%$ \\
\hline 1893-94 & $14 \%$ \\
\hline 1894-95 & $14 \%$ \\
\hline 1895-96 & $14 \%$ \\
\hline 1896-97 & $13,88 \%$ \\
\hline 1897-98 & $13,44 \%$ \\
\hline 1898-99 & $13,26 \%$ \\
\hline
\end{tabular}

${ }^{1375}$ Desde el ejercicio económico $1895 / 96$ ya no se tributa por Contribución Territorial, sino por Urbana, Rústica, Industrial, Consumos y la Cuota provincial. 


\begin{tabular}{|c|c|}
\hline 1907 & $15,37 \%$ \\
\hline 1908 & $14,19 \%$ \\
\hline 1909 & $17,61 \%$ \\
\hline 1910 & $17,61 \%$ \\
\hline 1911 & $17,61 \%$ \\
\hline 1912 & $16,91 \%$ \\
\hline 1913 & $17,31 \%$ \\
\hline 1914 & $17,64 \%$ \\
\hline 1915 & $18,70 \%$ \\
\hline 1916 & $19,03 \%$ \\
\hline 1917 & $19,29 \%$ \\
\hline 1918 & $19,70 \%$ \\
\hline 1919 & $20,04 \%$ \\
\hline $1920-21$ & $25 \%$ \\
\hline 1921-22 & $25 \%$ \\
\hline $1922-23$ & $25,43 \%$ \\
\hline 1923-24 & $25,43 \%$ \\
\hline 1924-25 & $20 \%$ \\
\hline
\end{tabular}

Elaboración propia. Fuente: A.D.P.P., C-L/ 7,2, C-L/ 7,4. 


\section{Anexo IV-Presupuesto Provincial en pts. 1875-1931}

Tabla I.

\begin{tabular}{|c|c|c|c|}
\hline 1875-76 & Presupuesto Ordinario & Presupuesto Adicional & Total \\
\hline Gastos & $437.186,76$ & $54.510,84$ & $491.697,60$ \\
\hline Ingresos & $374.820,07$ & $399.024,23$ & $774.288,62$ \\
\hline Déficit & $62.366,69$ & & \\
\hline Sobrante & & $345.513,39$ & $282.591,02$ \\
\hline
\end{tabular}

Elaboración propia. Fuente: A.D.P.P. C-L/ 4.1.

Tabla II.

\begin{tabular}{|c|c|c|c|}
\hline 1877-78 & Presupuesto Ordinario & Presupuesto Adicional & Total \\
\hline Gastos & $646.454,17$ & $84.991,08$ & $731.445,25$ \\
\hline Ingresos & $445.514,07$ & $468.911,92$ & $914.325,99$ \\
\hline Déficit & $200.940,10$ & & \\
\hline Sobrante & & $383.920,84$ & $182.880,74$ \\
\hline
\end{tabular}

Elaboración propia. Fuente: A.D.P.P. C-L/ 4,1.

Tabla III.

\begin{tabular}{|c|c|c|c|}
\hline 1878-79 & Presupuesto Ordinario & Presupuesto Adicional & Total \\
\hline Gastos & $760.911,54$ & $54.571,97$ & $815.483,51$ \\
\hline Ingresos & $389.400,00$ & $543.515,43$ & $932.915,43$ \\
\hline Déficit & $371.511,54$ & & \\
\hline Sobrante & & $488.943,46$ & $117.431,92$ \\
\hline
\end{tabular}

Elaboración propia. Fuente: A.D.P.P. C-L/ 4,1

Tabla IV.

\begin{tabular}{|c|c|c|c|}
\hline 1880-81 & Presupuesto Ordinario & Presupuesto Adicional & Total \\
\hline Gastos & $589.806,50$ & $90.190,77$ & $679.997,27$ \\
\hline Ingresos & $388.972,57$ & $424.809,13$ & $813.781,70$ \\
\hline Déficit & $200.833,93$ & & \\
\hline Sobrante & & $334.618,36$ & $133.784,43$ \\
\hline
\end{tabular}

Elaboración propia. Fuente: A.D.P.P. C-L/ 4,2. 
Tabla V.

\begin{tabular}{|c|c|c|c|}
\hline 1881-82 & Presupuesto Ordinario & Presupuesto Adicional & Total \\
\hline Gastos & $543.316,75$ & $217.370,30$ & $760.687,05$ \\
\hline Ingresos & $389.972,57$ & $370.763,98$ & $760.736,55$ \\
\hline Déficit & $153.344,18$ & & \\
\hline Sobrante & & $153.393,68$ & 49,50 \\
\hline
\end{tabular}

Elaboración propia. Fuente: A.D.P.P. C-L/ 5.

Tabla VI.

\begin{tabular}{|c|c|c|c|}
\hline 1882-83 & Presupuesto Ordinario & Presupuesto Adicional & Total \\
\hline Gastos & $574.387,34$ & $211.984,17$ & $786.371,51$ \\
\hline Ingresos & $618.027,82$ & $263.678,98$ & $881.706,80$ \\
\hline Déficit & & & \\
\hline Sobrante & $43.640,48$ & $51.694,98$ & $95.335,29$ \\
\hline
\end{tabular}

Elaboración propia. Fuente: A.D.P.P. C-L/ 5,1.

Tabla VII.

\begin{tabular}{|c|c|c|c|}
\hline $\mathbf{1 8 8 3 - 8 4}$ & Presupuesto Ordinario & Presupuesto Adicional & Total \\
\hline Gastos & $605.795,25$ & $217.212,19$ & $823.007,44$ \\
\hline Ingresos & $510.531,57$ & $312.475,87$ & $823.007,44$ \\
\hline Déficit & $95.263,68$ & & \\
\hline Sobrante & & $95.263,68$ & $95.263,68$ \\
\hline
\end{tabular}

Elaboración propia. Fuente: A.D.P.P. C-L/ 5,1.

Tabla VIII.

\begin{tabular}{|c|c|c|c|}
\hline 1884-85 & Presupuesto Ordinario & Presupuesto Adicional & Total \\
\hline Gastos & $580.105,52$ & $223.358,41$ & $803.463,93$ \\
\hline Ingresos & $516.730,57$ & $286.908,09$ & $803.638,66$ \\
\hline Déficit & $63.374,95$ & & \\
\hline Sobrante & & & 174,73 \\
\hline
\end{tabular}

Elaboración propia. Fuente: A.D.P.P. C-L/ 5,2. 
Tabla IX.

\begin{tabular}{|c|c|c|c|}
\hline 1885-86 & Presupuesto Ordinario & Presupuesto Adicional & Total \\
\hline Gastos & 625.364 & 213.402 & $838.767,23$ \\
\hline Ingresos & 580.632 & 258.163 & $838.795,79$ \\
\hline Déficit & $44.732,99$ & & \\
\hline Sobrante & & 44.761 & 28,56 \\
\hline
\end{tabular}

Elaboración propia. Fuente: A.D.P.P. C-L/ 5,2.

Tabla X.

\begin{tabular}{|c|c|c|c|}
\hline 1886-87 & Presupuesto Ordinario & Presupuesto Adicional & Total \\
\hline Gastos & 640.804 & $326.576,45$ & $967.380,45$ \\
\hline Ingresos & $585.521,57$ & $382.218,34$ & $967.739,91$ \\
\hline Déficit & $55.282,43$ & & \\
\hline Sobrante & & $55.641,89$ & 358,46 \\
\hline
\end{tabular}

Elaboración propia. Fuente: A.D.P.P. C-L/ 5,2.

Tabla XI.

\begin{tabular}{|c|c|c|c|}
\hline 1887-88 & Presupuesto Ordinario & Presupuesto Adicional & Total \\
\hline Gastos & $584.086,25$ & $284.512,75$ & 868.599 \\
\hline Ingresos & $584.036,57$ & $325.033,08$ & $909.119,65$ \\
\hline Déficit & & & \\
\hline Sobrante & & & $40.520,65$ \\
\hline
\end{tabular}

Elaboración propia. Fuente: A.D.P.P. C-L/ 5,2.

Tabla XII.

\begin{tabular}{|c|c|c|c|}
\hline 1888-89 & Presupuesto Ordinario & Presupuesto Adicional & Total \\
\hline Gastos & $505.344,25$ & $323.522,34$ & $830.523,97$ \\
\hline Ingresos & 466.463 & $364.060,97$ & $828.866,59$ \\
\hline Déficit & $38.881,25$ & & \\
\hline Sobrante & & $40.538,63$ & $4.657,38$ \\
\hline
\end{tabular}

Elaboración propia. Fuente: A.D.P.P. C-L/ 6,1. 
Tabla XIII.

\begin{tabular}{|c|c|c|c|}
\hline 1889-90 & Presupuesto Ordinario & Presupuesto Adicional & Total \\
\hline Gastos & $557.994,55$ & $161.355,89$ & $719.350,44$ \\
\hline Ingresos & 494.365 & $325.676,07$ & $820.041,07$ \\
\hline Déficit & $63.629,55$ & & \\
\hline Sobrante & & $164.320,18$ & $100.690,63$ \\
\hline
\end{tabular}

Elaboración propia. Fuente: A.D.P.P. C-L/ 6,1.

Tabla XIV.

\begin{tabular}{|c|c|c|c|}
\hline 1890-91 & Presupuesto Ordinario & Presupuesto Adicional & Total \\
\hline Gastos & $600.367,94$ & $114.324,65$ & $714.692,59$ \\
\hline Ingresos & 476.871 & $274.338,19$ & $751.209,19$ \\
\hline Déficit & $123.496,94$ & & \\
\hline Sobrante & & $160.013,54$ & $36.516,60$ \\
\hline
\end{tabular}

Elaboración propia. Fuente: A.D.P.P. C-L/ 6,2.

Tabla XV.

\begin{tabular}{|c|c|c|c|}
\hline 1891-92 & Presupuesto Ordinario & Presupuesto Adicional & Total \\
\hline Gastos & 529.916 & $146.488,40$ & $676.404,40$ \\
\hline Ingresos & 469.970 & $245.516,10$ & $715.486,10$ \\
\hline Déficit & 59.946 & & \\
\hline Sobrante & & $99.027,70$ & $39.081,7$ \\
\hline
\end{tabular}

Elaboración propia. Fuente: A.D.P.P. C-L/ 6,2.

Tabla XVI.

\begin{tabular}{|c|c|c|c|}
\hline 1892-93 & Presupuesto Ordinario & Presupuesto Adicional & Total \\
\hline Gastos & $636.124,49$ & $29.924,50$ & $666,048,99$ \\
\hline Ingresos & $486.218,25$ & $285.172,08$ & $771.390,33$ \\
\hline Déficit & $149.906,24$ & & \\
\hline Sobrante & & $255.247,58$ & $105.341,34$ \\
\hline
\end{tabular}

Elaboración propia. Fuente: A.D.P.P. C-L/ 6,2. 
Tabla XVII.

\begin{tabular}{|c|c|c|c|}
\hline 1895-96 & Presupuesto Ordinario & Presupuesto Adicional & Total \\
\hline Gastos & $498.065,50$ & $99.591,33$ & $597.653,83$ \\
\hline Ingresos & $496.167,27$ & $171.521,93$ & $667.689,20$ \\
\hline Déficit & $1.898,23$ & & \\
\hline Sobrante & & $71.930,60$ & $70.032,37$ \\
\hline
\end{tabular}

Elaboración propia. Fuente: A.D.P.P. C-L/ 7,1.

Tabla XVIII.

\begin{tabular}{|c|c|c|c|}
\hline 1896-97 & Presupuesto Ordinario & Presupuesto Adicional & Total \\
\hline Gastos & 469.740 & $116.391,83$ & $586.131,83$ \\
\hline Ingresos & 469.740 & $235.972,5$ & $705.712,50$ \\
\hline Déficit & & & \\
\hline Sobrante & & $119.380,67$ & $119.380,67$ \\
\hline
\end{tabular}

Elaboración propia. Fuente: A.D.P.P. C-L/ 7,2

Tabla XIX.

\begin{tabular}{|c|c|c|c|}
\hline 1897-98 & Presupuesto Ordinario & Presupuesto Adicional & Total \\
\hline Gastos & $556.005,32$ & $95.111,39$ & $651.116,71$ \\
\hline Ingresos & $492.715,54$ & $256.245,46$ & $748.961,03$ \\
\hline Déficit & $63.289,75$ & & \\
\hline Sobrante & & $161.134,07$ & $97.844,32$ \\
\hline
\end{tabular}

Elaboración propia. Fuente: A.D.P.P. C-L/ 7,3.

Tabla XX.

\begin{tabular}{|c|c|c|c|}
\hline 1898-99 & Presupuesto Ordinario & Presupuesto Adicional & Total \\
\hline Gastos & $507.094,27$ & $160.248,01$ & $667.342,28$ \\
\hline Ingresos & $491.205,57$ & $287.345,76$ & $778.551,33$ \\
\hline Déficit & $15.888,7$ & & \\
\hline Sobrante & & $111.209,05$ & $95.320,35$ \\
\hline
\end{tabular}

Elaboración propia. Fuente: A.D.P.P. C-L/ 7,4. 
Tabla XXI.

\begin{tabular}{|c|c|}
\hline 1903 & Presupuesto Ordinario \\
\hline Gastos & $487.721,02$ \\
\hline Ingresos & $489.721,02$ \\
\hline Déficit & 2.000 \\
\hline Sobrante & \\
\hline
\end{tabular}

Elaboración propia. Fuente: A.D.P.P. C-L/ 8,3.

Tabla XII.

\begin{tabular}{|c|c|}
\hline 1904 & Presupuesto \\
\hline Gastos & $593.105,18$ \\
\hline Ingresos & $594.179,18$ \\
\hline Déficit & 1.074 \\
\hline Sobrante & \\
\hline
\end{tabular}

Elaboración propia. Fuente: A.D.P.P. C-L/ 8.

Tabla XXIII.

\begin{tabular}{|c|c|}
\hline 1907 & Presupuesto \\
\hline Gastos & $663.434,18$ \\
\hline Ingresos & $663.434,18$ \\
\hline Déficit & \\
\hline Sobrante & \\
\hline
\end{tabular}

Elaboración propia. Fuente: A.D.P.P. C-L/ 9,1.

Tabla XXIV.

\begin{tabular}{|c|c|}
\hline 1908 & Presupuesto \\
\hline Gastos & $659.490,86$ \\
\hline Ingresos & $659.490,86$ \\
\hline Déficit & \\
\hline Sobrante & \\
\hline
\end{tabular}

Elaboración propia. Fuente: A.D.P.P. C-L/ 9,2. 
Tabla XXV.

\begin{tabular}{|c|c|}
\hline 1909 & Presupuesto \\
\hline Gastos & $672.748,41$ \\
\hline Ingresos & $672.748,41$ \\
\hline Déficit & \\
\hline Sobrante & \\
\hline
\end{tabular}

Elaboración propia. Fuente: A.D.P.P. C-L/ 9,3.

Tabla XXVI.

\begin{tabular}{|c|c|}
\hline 1910 & Presupuesto \\
\hline Gastos & $686.968,85$ \\
\hline Ingresos & $686.968,85$ \\
\hline Déficit & \\
\hline Sobrante & \\
\hline
\end{tabular}

Elaboración propia. Fuente: A.D.P.P. C-L/ 9,4.

Tabla XXVI.

\begin{tabular}{|c|c|}
\hline 1911 & Presupuesto \\
\hline Gastos & $730.484,20$ \\
\hline Ingresos & $730.584,20$ \\
\hline Déficit & 100 \\
\hline Sobrante & \\
\hline
\end{tabular}

Elaboración propia. Fuente: A.D.P.P. C-L/ 9,5

Tabla XXVII. Presupuesto ejercicio 1912.

\begin{tabular}{|c|c|}
\hline 1912 & Presupuesto \\
\hline Gastos & $701.013,98$ \\
\hline Ingresos & $701.013,98$ \\
\hline Déficit & \\
\hline Sobrante & \\
\hline
\end{tabular}

Elaboración propia. Fuente: A.D.P.P. C-L/ 10,1. 
Tabla XXVIII.

\begin{tabular}{|c|c|}
\hline 1913 & Presupuesto \\
\hline Gastos & $724.296,86$ \\
\hline Ingresos & $724.296,86$ \\
\hline Déficit & \\
\hline Sobrante & \\
\hline
\end{tabular}

Elaboración propia. Fuente: A.D.P.P. C-L/ 10,2.

Tabla XXIX.

\begin{tabular}{|c|c|}
\hline 1914 & Presupuesto \\
\hline Gastos & $703.413,29$ \\
\hline Ingresos & $703.413,29$ \\
\hline Déficit & \\
\hline Sobrante & \\
\hline
\end{tabular}

Elaboración propia. Fuente: A.D.P.P. C-L/ 10,3

Tabla XXX.

\begin{tabular}{|c|c|}
\hline 1915 & Presupuesto \\
\hline Gastos & $703.345,01$ \\
\hline Ingresos & $703.345,01$ \\
\hline Déficit & \\
\hline Sobrante & \\
\hline
\end{tabular}

Elaboración propia. Fuente: A.D.P.P. C-L/ 10,4.

Tabla XXXI.

\begin{tabular}{|c|c|}
\hline 1916 & Presupuesto \\
\hline Gastos & $719.025,40$ \\
\hline Ingresos & $719.025,40$ \\
\hline Déficit & \\
\hline Sobrante & \\
\hline
\end{tabular}

Elaboración propia. Fuente: A.D.P.P. C-L/ 10,5. 
Tabla XXXII.

\begin{tabular}{|c|c|}
\hline 1917 & Presupuesto \\
\hline Gastos & $695.923,13$ \\
\hline Ingresos & $695.923,13$ \\
\hline Déficit & \\
\hline Sobrante & \\
\hline
\end{tabular}

Elaboración propia. Fuente: A.D.P.P. C-L/ 11,1.

Tabla XXXIII.

\begin{tabular}{|c|c|}
\hline 1918 & Presupuesto \\
\hline Gastos & $699.944,85$ \\
\hline Ingresos & $699.944,85$ \\
\hline Déficit & \\
\hline Sobrante & \\
\hline
\end{tabular}

Elaboración propia. Fuente: A.D.P.P. C-L/ 11,2.

Tabla XXXIV.

\begin{tabular}{|c|c|}
\hline 1919 & Presupuesto \\
\hline Gastos & $704.658,53$ \\
\hline Ingresos & $704.658,53$ \\
\hline Déficit & \\
\hline Sobrante & \\
\hline
\end{tabular}

Elaboración propia. Fuente: A.D.P.P. C-L/ 11,3.

Tabla XXXV.

\begin{tabular}{|c|c|}
\hline $1920-21$ & Presupuesto \\
\hline Gastos & $860.366,65$ \\
\hline Ingresos & $860.366,65$ \\
\hline Déficit & \\
\hline Sobrante & \\
\hline
\end{tabular}

Elaboración propia. Fuente: A.D.P.P. C-L /11,4. 
Tabla XXXVI.

\begin{tabular}{|c|c|}
\hline 1921-22 & Presupuesto \\
\hline Gastos & $902.149,68$ \\
\hline Ingresos & $902.149,68$ \\
\hline Déficit & \\
\hline Sobrante & \\
\hline
\end{tabular}

Elaboración propia. Fuente: A.D.P.P. C-L/ 12,1

Tabla XXXVII.

\begin{tabular}{|c|c|}
\hline 1922-23 & Presupuesto \\
\hline Gastos & $880.579,49$ \\
\hline Ingresos & $880.579,49$ \\
\hline Déficit & \\
\hline Sobrante & \\
\hline
\end{tabular}

Elaboración propia. Fuente: A.D.P.P. C-L /12,2.

Tabla XXXVIII.

\begin{tabular}{|c|c|}
\hline 1923-24 & Presupuesto \\
\hline Gastos & $879.286,33$ \\
\hline Ingresos & $879.286,33$ \\
\hline Déficit & \\
\hline Sobrante & \\
\hline
\end{tabular}

Elaboración propia. Fuente: A.D.P.P. C-L/ 12,3.

Tabla XXXIX. Presupuesto ejercicio 1924-25.

\begin{tabular}{|c|c|}
\hline 1924-25 & Presupuesto \\
\hline Gastos & $899.815,65$ \\
\hline Ingresos & $899.815,65$ \\
\hline Déficit & \\
\hline Sobrante & \\
\hline
\end{tabular}

Elaboración propia. Fuente: A.D.P.P. C-L/ 12,5. 
Tabla XL.

\begin{tabular}{|c|c|}
\hline 1925-26 & Presupuesto \\
\hline Gastos & $1.575 .975,14$ \\
\hline Ingresos & $1.652 .546,90$ \\
\hline Déficit & $74.571,76$ \\
\hline Sobrante & \\
\hline
\end{tabular}

Elaboración propia. Fuente: A.D.P.P. C-L/ 13,1.

Tabla XLI. Presupuesto ejercicio 1927.

\begin{tabular}{|c|c|}
\hline 1927 & Presupuesto \\
\hline Gastos & $1.688 .440,58$ \\
\hline Ingresos & $1.688 .440,58$ \\
\hline Déficit & \\
\hline Sobrante & \\
\hline
\end{tabular}

Elaboración propia. Fuente: A.D.P.P. C-L/ 13,3.

Tabla XLII.

\begin{tabular}{|c|c|}
\hline 1928 & Presupuesto \\
\hline Gastos & $2.301 .402,60$ \\
\hline Ingresos & $2.301 .402,60$ \\
\hline Déficit & \\
\hline Sobrante & \\
\hline
\end{tabular}

Elaboración propia. Fuente: A.D.P.P. C-L/ 13,4.

Tabla XLIII.

\begin{tabular}{|c|c|}
\hline 1929 & Presupuesto \\
\hline Gastos & $2.102 .392,99$ \\
\hline Ingresos & $2.102 .392,99$ \\
\hline Déficit & \\
\hline Sobrante & \\
\hline
\end{tabular}

Elaboración propia. Fuente: A.D.P.P. C-L/ 14,1. 
Tabla XLIV.

\begin{tabular}{|c|c|}
\hline 1930 & Presupuesto \\
\hline Gastos & $1.986 .254,27$ \\
\hline Ingresos & $1.986 .254,27$ \\
\hline Déficit & \\
\hline Sobrante & \\
\hline
\end{tabular}

Elaboración propia. Fuente: A.D.P.P. C-L/ 14,2

Tabla XLV.

\begin{tabular}{|c|c|}
\hline 1931 & Presupuesto \\
\hline Gastos & $2.057 .124,97$ \\
\hline Ingresos & $2.057 .124,97$ \\
\hline Déficit & \\
\hline Sobrante & \\
\hline
\end{tabular}

Elaboración propia. Fuente: A.D.P.P. C-L/ 14,3. 


\section{Anexo V-Presupuesto Provincial en pts. Beneficencia, Instrucción Pública, Corrección Pública y carreteras 1875-1931}

Tabla I.

\begin{tabular}{|c|c|c|}
\hline Año económico 1875-76 & Ingresos & Gastos \\
\hline Beneficencia & $10.164,25$ & $138.613,89$ \\
\hline Instrucción Pública & & $49.361,29$ \\
\hline
\end{tabular}

Elaboración propia. Fuente: A.D.P.P. C-L/ 4,1.

Tabla II.

\begin{tabular}{|c|c|c|}
\hline Año económico 1877-78 & Ingresos & Gastos \\
\hline Beneficencia & $10.827,77$ & $148.851,17$ \\
\hline Instrucción Pública & & 57.152 \\
\hline
\end{tabular}

Elaboración propia. Fuente: A.D.P.P. C-L/ 4,1.

Tabla III.

\begin{tabular}{|c|c|c|}
\hline Año económico 1878-79 & Ingresos & Gastos \\
\hline Beneficencia & $11.603,63$ & $173.253,76$ \\
\hline Instrucción Pública & & $58.006,05$ \\
\hline
\end{tabular}

Elaboración propia. Fuente: A.D.P.P. C-L/ 4,2.

Tabla IV.

\begin{tabular}{|c|c|c|}
\hline Año económico 1879-80 & Ingresos & Gastos \\
\hline Beneficencia & $10.551,99$ & $198.104,75$ \\
\hline Instrucción Pública & & $63.888,93$ \\
\hline
\end{tabular}

Elaboración propia. Fuente: A.D.P.P. C-L/ 4,2.

Tabla V.

\begin{tabular}{|c|c|c|}
\hline Año económico 1880-81 & Ingresos & Gastos \\
\hline Beneficencia & $8.513,15$ & $260.984,63$ \\
\hline Instrucción Pública & & $62.157,22$ \\
\hline
\end{tabular}

Elaboración propia. Fuente: A.D.P.P. C-L/ 4,2. 
Tabla VI.

\begin{tabular}{|c|c|c|}
\hline Año económico 1881-82 & Ingresos & Gastos \\
\hline Beneficencia & $11.428,9$ & $259.512,75$ \\
\hline Instrucción Pública & & 67.324 \\
\hline
\end{tabular}

Elaboración propia. Fuente: A.D.P.P. C-L/ 5,1.

Tabla VII.

\begin{tabular}{|c|c|c|}
\hline Año económico 1882-83 & Ingresos & Gastos \\
\hline Beneficencia & $12.313,26$ & $271.740,13$ \\
\hline Instrucción Pública & & 76.849 \\
\hline
\end{tabular}

Elaboración propia. Fuente: A.D.P.P. C-L/ 5,1.

Tabla VIII.

\begin{tabular}{|c|c|c|}
\hline Año económico 1883-84 & Ingresos & Gastos \\
\hline Beneficencia & $13.001,14$ & $263.882,15$ \\
\hline Instrucción Pública & & $72.294,53$ \\
\hline
\end{tabular}

Elaboración propia. Fuente: A.D.P.P. C-L /5,1.

Tabla IX.

\begin{tabular}{|c|c|c|}
\hline Año económico 1884-85 & Ingresos & Gastos \\
\hline Beneficencia & $11.043,01$ & 244.357 \\
\hline Instrucción Pública & 4.000 & 78.055 \\
\hline
\end{tabular}

Elaboración propia. Fuente: A.D.P.P. C-L/ 5,2.

Tabla X.

\begin{tabular}{|c|c|c|}
\hline Año económico 1885-86 & Ingresos & Gastos \\
\hline Beneficencia & $15.644,73$ & 224.967 \\
\hline Instrucción Pública & 750 & 76.854 \\
\hline
\end{tabular}

Elaboración propia. Fuente: A.D.P.P. C-L/ 5,2. 
Tabla XI.

\begin{tabular}{|c|c|c|}
\hline Año económico 1886-87 & Ingresos & Gastos \\
\hline Beneficencia & $13.564,61$ & $223.291,27$ \\
\hline Instrucción Pública & 1.000 & 68.769 \\
\hline Corrección Pública & & 104.100 \\
\hline
\end{tabular}

Fuente: Elaboración propia. A.D.P.P. C-L 5/2.

Tabla XII.

\begin{tabular}{|c|c|c|}
\hline Año económico 1887-88 & Ingresos & Gastos \\
\hline Beneficencia & 3.685 & $207.347,25$ \\
\hline Instrucción Pública & $9.277,57$ & 70.444 \\
\hline Corrección Pública & & 12.000 \\
\hline Carreteras & & $292.524,75$ \\
\hline
\end{tabular}

Elaboración propia. Fuente: A.D.P.P. C-L/ 6,1.

Tabla XIII.

\begin{tabular}{|c|c|c|}
\hline Año económico 1888-89 & Ingresos & Gastos \\
\hline Beneficencia & 7.685 & $200.367,50$ \\
\hline Instrucción Pública & & 11.149 \\
\hline Corrección Pública & & 22.625 \\
\hline Carreteras & & $227.482,93$ \\
\hline
\end{tabular}

Elaboración propia. Fuente: A.D.P.P. C-L/ 6,1.

Tabla XIV.

\begin{tabular}{|c|c|c|}
\hline Año económico 1889-90 & Ingresos & Gastos \\
\hline Beneficencia & 7.685 & $202.161,50$ \\
\hline Instrucción Pública & & 11.149 \\
\hline Corrección Pública & & $19.083,50$ \\
\hline Carreteras & & 168.668 \\
\hline
\end{tabular}

Elaboración propia. Fuente: A.D.P.P. C-L/ 6,2. 
Tabla XV.

\begin{tabular}{|c|c|c|}
\hline Año económico 1890-91 & Ingresos & Gastos \\
\hline Beneficencia & 7.320 & $202.017,15$ \\
\hline Instrucción Pública & & 11.733 \\
\hline Corrección Pública & & 18.805 \\
\hline Carreteras & & $246.317,64$ \\
\hline
\end{tabular}

Elaboración propia. Fuente: A.D.P.P. C-L/ 6,2.

Tabla XVI.

\begin{tabular}{|c|c|c|}
\hline Año económico 1891-92 & Ingresos & Gastos \\
\hline Beneficencia & 9.549 & $210.481,90$ \\
\hline Instrucción Pública & & 13.223 \\
\hline Corrección Pública & & 17.625 \\
\hline Carreteras & & 169.172 \\
\hline
\end{tabular}

Elaboración propia. Fuente: A.D.P.P. C-L/ 6,2.

Tabla XVII.

\begin{tabular}{|c|c|c|}
\hline Año económico 1892-93 & Ingresos & Gastos \\
\hline Beneficencia & 9.549 .75 & 221.369 .5 \\
\hline Instrucción Pública & & 12.874 \\
\hline Corrección Pública & & 19.889 \\
\hline Carreteras & & 163.818 \\
\hline
\end{tabular}

Elaboración propia. Fuente: A.D.P.P. C-L/ 6,2.

Tabla XVIII.

\begin{tabular}{|c|c|c|}
\hline Año económico 1894-95 & Ingresos & Gastos \\
\hline Beneficencia & $10.879,27$ & 206.039 \\
\hline Instrucción Pública & & 13.124 \\
\hline Corrección Pública & & 16.374 \\
\hline Carreteras & & $126.068,60$ \\
\hline
\end{tabular}

Elaboración propia. Fuente: A.D.P.P. C-L 6/3. 
Tabla XIX

\begin{tabular}{|c|c|c|}
\hline Año económico 1895-96 & Ingresos & Gastos \\
\hline Beneficencia & $10.879,27$ & 213.916 \\
\hline Instrucción Pública & & 13.124 \\
\hline Corrección Pública & & 16.374 \\
\hline Carreteras & & 78.268 \\
\hline
\end{tabular}

Elaboración propia. Fuente: A.D.P.P. C-L/ 7,1.

Tabla XX.

\begin{tabular}{|c|c|c|}
\hline Año económico 1896-97 & Ingresos & Gastos \\
\hline Beneficencia & 7.420 & 212.285 \\
\hline Instrucción Pública & & 25.065 \\
\hline Corrección Pública & & 20.374 \\
\hline Carreteras & & 73.210 \\
\hline
\end{tabular}

Elaboración propia. Fuente: A.D.P.P. C-L/ 7,2.

Tabla XXI.

\begin{tabular}{|c|c|c|}
\hline Año económico 1897-98 & Ingresos & Gastos \\
\hline Beneficencia & 7.420 & 215.462 \\
\hline Instrucción Pública & & 13.412 \\
\hline Corrección Pública & & 21.217 \\
\hline Carreteras & & 178.572 \\
\hline
\end{tabular}

Elaboración propia. Fuente: A.D.P.P. C-L/ 7,3.

Tabla XXII.

\begin{tabular}{|c|c|c|}
\hline Año económico 1898-99 & Ingresos & Gastos \\
\hline Beneficencia & 5.872 & $246.628,10$ \\
\hline Instrucción Pública & & 13.624 \\
\hline Corrección Pública & & 21.400 \\
\hline Carreteras & & 86.141 \\
\hline
\end{tabular}

Elaboración propia. A.D.P.P. Fuente: C-L/ 7,4. 
Tabla XXIII.

\begin{tabular}{|c|c|c|}
\hline Año económico 1899-1900 & Ingresos & Gastos \\
\hline Beneficencia & $5.872,5$ & $245.225,77$ \\
\hline Instrucción Pública & & 13.874 \\
\hline Corrección Pública & & 23.601 \\
\hline Carreteras & & 59.615 \\
\hline
\end{tabular}

Elaboración propia. Fuente: A.D.P.P. C-L/ 8,1.

Tabla XXIV.

\begin{tabular}{|c|c|c|}
\hline Año económico 1901 & Ingresos & Gastos \\
\hline Beneficencia & $8.284,5$ & $241.494,87$ \\
\hline Instrucción Pública & & 2.999 \\
\hline Corrección Pública & & $27.773,5$ \\
\hline Carreteras & & $60.427,13$ \\
\hline
\end{tabular}

Elaboración propia. Fuente: A.D.P.P. C-L/ 8,2.

Tabla XXV.

\begin{tabular}{|c|c|c|}
\hline Año económicom1903 & Ingresos & Gastos \\
\hline Beneficencia & $12.867,50$ & $219.584,37$ \\
\hline Instrucción Pública & & 15.999 \\
\hline Corrección Pública & & $27.199,5$ \\
\hline Carreteras & & $57.431,15$ \\
\hline
\end{tabular}

Elaboración propia. Fuente: A.D.P.P. C-L/ 8,3.

Tabla XXVI.

\begin{tabular}{|c|c|c|}
\hline Año económico 1904 & Ingresos & Gastos \\
\hline Beneficencia & $16.825,66$ & $226.298,26$ \\
\hline Instrucción Pública & & 20.250 \\
\hline Corrección Pública & & $27.199,5$ \\
\hline Carreteras & & $170.228,74$ \\
\hline
\end{tabular}

Elaboración propia. Fuente: A.D.P.P. C-L/ 8,4. 
Tabla XXVII.

\begin{tabular}{|c|c|c|}
\hline Año económico 1905 & Ingresos & Gastos \\
\hline Beneficencia & $10.993,2$ & $267.583,51$ \\
\hline Instrucción Pública & & 20.250 \\
\hline Corrección Pública & & $26.015,5$ \\
\hline Carreteras & & $170.516,75$ \\
\hline
\end{tabular}

Elaboración propia. Fuente: A.D.P.P. C-L/ 8,5.

Tabla XXVIII.

\begin{tabular}{|c|c|c|}
\hline Año económico 1906 & Ingresos & Gastos \\
\hline Beneficencia & 8.250 & $284.933,12$ \\
\hline Instrucción Pública & & 75.106 \\
\hline Corrección Pública & & 32.066 \\
\hline Carreteras & & $60.871,51$ \\
\hline
\end{tabular}

Elaboración propia. Fuente: A.D.P.P. C-L/ 8,6.

Tabla XXIX.

\begin{tabular}{|c|c|c|}
\hline Año económico 1907 & Ingresos & Gastos \\
\hline Beneficencia & 15.010 & $282.411,66$ \\
\hline Instrucción Pública & 60.256 & 77.556 \\
\hline Corrección Pública & & 37.018 \\
\hline Carreteras & & $70.921,35$ \\
\hline
\end{tabular}

Elaboración propia. Fuente: A.D.P.P. C-L/ 9,1

Tabla XXX.

\begin{tabular}{|c|c|c|}
\hline Año económico 1908 & Ingresos & Gastos \\
\hline Beneficencia & 15.710 & $267.171,77$ \\
\hline Instrucción Pública & 60.256 & 77.256 \\
\hline Corrección Pública & & 26.250 \\
\hline Carreteras & & $92.582,50$ \\
\hline
\end{tabular}

Elaboración propia. Fuente: A.D.P.P. C-L/ 9,2. 
Tabla XXXI.

\begin{tabular}{|c|c|c|}
\hline Año económico 1909 & Ingresos & Gastos \\
\hline Beneficencia & 16.210 & $264.086,02$ \\
\hline Instrucción Pública & 60.256 & 77.756 \\
\hline Corrección Pública & & 37.000 \\
\hline Carreteras & & $88.016,98$ \\
\hline
\end{tabular}

Elaboración propia. Fuente: A.D.P.P. C-L/ 9,3.

Tabla XXXII.

\begin{tabular}{|c|c|c|}
\hline Año económico 1910 & Ingresos & Gastos \\
\hline Beneficencia & $18.438,5$ & $275.778,77$ \\
\hline Instrucción Pública & 60.256 & 67.981 \\
\hline Corrección Pública & & $42.587,42$ \\
\hline Carreteras & & $67.929,78$ \\
\hline
\end{tabular}

Elaboración propia. Fuente: A.D.P.P. C-L/ 9,4.

Tabla XXXIII.

\begin{tabular}{|c|c|c|}
\hline Año económico 1911 & Ingresos & Gastos \\
\hline Beneficencia & $16.833,75$ & $282.346,52$ \\
\hline Instrucción Pública & 60.256 & 38.981 \\
\hline Corrección Pública & & $33.872,08$ \\
\hline Carreteras & & $68.931,53$ \\
\hline
\end{tabular}

Elaboración propia. Fuente. A.D.P.P. C-L/ 9,5.

Tabla XXXIV.

\begin{tabular}{|c|c|c|}
\hline Año económico 1912 & Ingresos & Gastos \\
\hline Beneficencia & 18.500 & $274.357,52$ \\
\hline Instrucción Pública & 60.256 & 68.231 \\
\hline Corrección Pública & & $34.145,38$ \\
\hline Carreteras & & $68.569,75$ \\
\hline
\end{tabular}

Elaboración propia. Fuente: A.D.P.P. C-L/ 10,1. 
Tabla XXXV.

\begin{tabular}{|c|c|c|}
\hline Año económico 1913 & Ingresos & Gastos \\
\hline Beneficencia & 13.000 & $276.760,12$ \\
\hline Instrucción Pública & 60.256 & 68.231 \\
\hline Corrección Pública & & 30.765 \\
\hline Carreteras & & $61.069,75$ \\
\hline
\end{tabular}

Elaboración propia. Fuente: A.D.P.P. C-L/ 10,2.

Tabla XXXVI.

\begin{tabular}{|c|c|c|}
\hline Año económico 1914 & Ingresos & Gastos \\
\hline Beneficencia & $14.575,20$ & $272.934,25$ \\
\hline Instrucción Pública & 61.683 & 67.181 \\
\hline Corrección Pública & & 30.795 \\
\hline Carreteras & & $59.878,75$ \\
\hline
\end{tabular}

Elaboración propia. Fuente: A.D.P.P. C-L/ 10,3.

Tabla XXXVII.

\begin{tabular}{|c|c|c|}
\hline Año económico 1915 & Ingresos & Gastos \\
\hline Beneficencia & 16.470 & $276.701,40$ \\
\hline Instrucción Pública & 67.972 & 66.931 \\
\hline Corrección Pública & & 30.965 \\
\hline Carreteras & & $47.219,75$ \\
\hline
\end{tabular}

Elaboración propia. Fuente: A.D.P.P. C-L/ 10,4.

Tabla XXXVIII.

\begin{tabular}{|c|c|c|}
\hline Año económico 1916 & Ingresos & Gastos \\
\hline Beneficencia & 16.450 & $285.629,21$ \\
\hline Instrucción Pública & 66.931 & 66.431 \\
\hline Carreteras & & $40.301,50$ \\
\hline
\end{tabular}

Elaboración propia. Fuente: A.D.P.P. C-L/ 10,5.

Tabla XXXIX.

\begin{tabular}{|c|c|c|}
\hline Año económico 1917 & Ingresos & Gastos \\
\hline Beneficencia & 16.000 & $299.466,87$ \\
\hline Instrucción Pública & 66.931 & 65.681 \\
\hline Corrección Pública & & $36.732,92$ \\
\hline Carreteras & & $42.601,50$ \\
\hline
\end{tabular}

Elaboración propia. Fuente: A.D.P.P. C-L/ 11,1. 
Tabla XL.

\begin{tabular}{|c|c|c|}
\hline Año económico 1918 & Ingresos & Gastos \\
\hline Beneficencia & $15.126,33$ & $302.254,12$ \\
\hline Instrucción Pública & 66.931 & 65.681 \\
\hline Corrección Pública & & $36.716,92$ \\
\hline Carreteras & & $43.333,25$ \\
\hline
\end{tabular}

Elaboración propia. Fuente: A.D.P.P. C-L/ 11,2.

Tabla XLI.

\begin{tabular}{|c|c|c|}
\hline Año económico 1919 & Ingresos & Gastos \\
\hline Beneficencia & $17.257,43$ & $340.997,37$ \\
\hline Instrucción Pública & 66.931 & 56.706 \\
\hline Corrección Pública & & $36.366,92$ \\
\hline Carreteras & & $43.333,25$ \\
\hline
\end{tabular}

Elaboración propia. Fuente. A.D.P.P. C-L/ 11,3.

Tabla XLII.

\begin{tabular}{|c|c|c|}
\hline Año económico 1920-21 & Ingresos & Gastos \\
\hline Beneficencia & 16.299 & $393.767,19$ \\
\hline Instrucción Pública & 66.931 & 66.095 \\
\hline Corrección Pública & & $43.516,92$ \\
\hline Carreteras & & 51.540 \\
\hline
\end{tabular}

Elaboración propia. Fuente: A.D.P.P. C-L/ 11,4.

Tabla XLIII.

\begin{tabular}{|c|c|c|}
\hline Año económico 1921-22 & Ingresos & Gastos \\
\hline Beneficencia & 15.041 & $439.205,75$ \\
\hline Instrucción Pública & 68.368 & 66.195 \\
\hline Corrección Pública & & $42.114,72$ \\
\hline Carreteras & & 55.810 \\
\hline
\end{tabular}

Elaboración propia. Fuente: A.D.P.P. C-L/ 12,1. 
Tabla XLIV.

\begin{tabular}{|c|c|c|}
\hline Año económico 1922-23 & Ingresos & Gastos \\
\hline Beneficencia & 14.600 & $437.465,75$ \\
\hline Instrucción Pública & 68.368 & 66.195 \\
\hline Corrección Pública & & $38.364,92$ \\
\hline Carreteras & & 58.540 \\
\hline
\end{tabular}

Elaboración propia. Fuente: A.D.P.P. C-L /12,2.

Tabla XIV.

\begin{tabular}{|c|c|c|}
\hline Año económico 1923-24 & Ingresos & Gastos \\
\hline Beneficencia & 15.300 & $444.903,75$ \\
\hline Instrucción Pública & 68.819 & 66.675 \\
\hline Corrección Pública & & 25.000 \\
\hline Carreteras & & 54.565 \\
\hline
\end{tabular}

Elaboración propia. Fuente: A.D.P.P. C-L/ 12,3.

Tabla XLVI.

\begin{tabular}{|c|c|c|}
\hline Año económico 1924-25 & Ingresos & Gastos \\
\hline Beneficencia & 17.800 & $436.789,37$ \\
\hline Instrucción Pública & 64.811 & 66.175 \\
\hline Corrección Pública & & 66.930 \\
\hline Carreteras & & \\
\hline
\end{tabular}

Elaboración propia. Fuente: A.D.P.P. C-L/ 12,5.

Tabla XLVII.

\begin{tabular}{|c|c|c|}
\hline Año económico 1925-26 & Ingresos & Gastos \\
\hline Beneficencia & & $627.480,95$ \\
\hline Instrucción Pública & & 19.500 \\
\hline
\end{tabular}

Elaboración propia. Fuente: A.D.P.P. C-L/ 13,1.

Tabla XLVIII.

\begin{tabular}{|c|c|c|}
\hline Año económico 1926 & Ingresos & Gastos \\
\hline Beneficencia & & $272.470,54$ \\
\hline Instrucción Pública & & 18.500 \\
\hline
\end{tabular}

Elaboración propia. Fuente: A.D.P.P. C-L/ 13,2. 
Tabla XLIX.

\begin{tabular}{|c|c|c|}
\hline Año económico 1927 & Ingresos & Gastos \\
\hline Beneficencia & & $616.631,25$ \\
\hline Instrucción Pública & & 38.500 \\
\hline
\end{tabular}

Elaboración propia. Fuente: A.D.P.P. C-L/ 13,3.

Tabla L.

\begin{tabular}{|c|c|c|}
\hline Año económico 1928 & Ingresos & Gastos \\
\hline Beneficencia & & $577.323,75$ \\
\hline Instrucción Pública & & 48.000 \\
\hline
\end{tabular}

Elaboración propia. Fuente: A.D.P.P. C-L/ 13,4.

Tabla LI.

\begin{tabular}{|c|c|c|}
\hline Año económico 1929 & Ingresos & Gastos \\
\hline Beneficencia & & 599.042 \\
\hline Instrucción Pública & & 74.300 \\
\hline
\end{tabular}

Elaboración propia. Fuente: A.D.P.P. C-L/ 13,4.

Tabla LII.

\begin{tabular}{|c|c|c|}
\hline Año económico 1930 & Ingresos & Gastos \\
\hline Beneficencia & & $639.221,47$ \\
\hline Instrucción Pública & & 84.300 \\
\hline
\end{tabular}

Elaboración propia. Fuente: A.D.P.P. C-L/ 14,2.

Tabla LIII.

\begin{tabular}{|c|c|c|}
\hline Año económico 1931 & Ingresos & Gastos \\
\hline Beneficencia & & $681.285,09$ \\
\hline Instrucción Pública & & 40.300 \\
\hline
\end{tabular}

Elaboración propia. Fuente: A.D.P.P. C-L/ 14,3. 


\section{Anexo VI-Tarifas Impuesto Cédulas Personales}

Tabla I. Tarifa primera: por rentas de trabajo

\begin{tabular}{|c|c|c|c|}
\hline Base & Clase & Importe pts. & Recargo de soltería \\
\hline Rentas de trabajo de más de 60.000 pts. anuales & $1^{\mathrm{a}}$ & 1.000 & 60 \\
\hline Ídem de 50.001 a 60.000 pts. anuales & $2^{\mathrm{a}}$ & 750 & 60 \\
\hline Ídem de 40.001 a 50.000 pts. anuales & $3^{\mathrm{a}}$ & 500 & 55 \\
\hline Ídem de 30.001 a 40.000 pts. anuales & $4^{\mathrm{a}}$ & 350 & 50 \\
\hline Ídem de 20.001 a 30.000 pts. anuales & $5^{\mathrm{a}}$ & 250 & 45 \\
\hline Ídem de 15.001 a 20.000 pts. anuales & $6^{\mathrm{a}}$ & 210 & 45 \\
\hline Ídem de 12.501 a 15.000 pts. anuales & $7^{\mathrm{a}}$ & 190 & 40 \\
\hline Ídem 10.001 a 12.500 pts. anuales & $8^{\mathrm{a}}$ & 120 & 40 \\
\hline Ídem 6.501 a 10.000 pts. anuales & $9^{\mathrm{a}}$ & 63 & 35 \\
\hline Ídem 5.001 a 6.500 pts. anuales & $10^{\mathrm{a}}$ & 50 & 35 \\
\hline Ídem 3.501 a 5.000 pts. anuales & $11^{\mathrm{a}}$ & 40 & 30 \\
\hline Ídem 2.501 a 3.500 pts. anuales & $12^{\mathrm{a}}$ & 25 & 30 \\
\hline Ídem 2.001 a 2.500 pts. anuales & $13^{\mathrm{a}}$ & 15 & 25 \\
\hline Ídem 1.501 a 2.000 pts. anuales & $14^{\mathrm{a}}$ & 11 & 25 \\
\hline Ídem 751 a 1.500 pts. anuales & $15^{\mathrm{a}}$ & 7,5 & 20 \\
\hline Ídem 1 a 750 pts. anuales & $16^{\mathrm{a}}$ & 3 & 20 \\
\hline
\end{tabular}

Fuente: Gaceta de Madrid núm. 90, del 31 de marzo de 1925. 
Tabla II. Tarifa segunda: por contribuciones directas

\begin{tabular}{|c|c|c|c|}
\hline $\begin{array}{l}\text { Contribuyentes por Contribución Territorial, Industrial o } \\
\text { Minera, que paguen más de } 15.000 \text { pts. anuales }\end{array}$ & $1^{\mathrm{a}}$ & 1.000 & 60 \\
\hline Ídem de 10.001 a 15.000 pts. anuales & $2^{\mathrm{a}}$ & 860 & 60 \\
\hline Ídem de 5.001 a 7.500 pts. anuales & $4^{\mathrm{a}}$ & 398 & 50 \\
\hline Ídem de 3.001 a 5.000 pts. anuales & $5^{\mathrm{a}}$ & 280 & 45 \\
\hline Ídem de 2.501 a 3.000 pts. anuales & $6^{\mathrm{a}}$ & 175 & 40 \\
\hline Ídem 501 a 1.000 pts. anuales & $9^{\mathrm{a}}$ & 55 & 35 \\
\hline Ídem 5.001 a 6.500 pts. anuales & $10^{\mathrm{a}}$ & 35 & 30 \\
\hline Ídem 301 a 500 pts. anuales & $11^{\mathrm{a}}$ & 17 & 25 \\
\hline Ídem 26 a 300 pts. anuales & $12^{\mathrm{a}}$ & 8 & 20 \\
\hline Ídem 1 a 25 pts. anuales & $13^{\mathrm{a}}$ & 3 & 20 \\
\hline
\end{tabular}

Fuente: Estatuto Provincial de 1925, p. 195. 
Tabla III. Tarifa tercera: pago anual por alquileres que no se destinen a Industria fabril o comercial

\begin{tabular}{|c|c|c|c|c|c|c|c|}
\hline $\begin{array}{c}\text { Poblaciones de } \\
\quad+300.00 \\
\text { habitantes }\end{array}$ & $\begin{array}{l}\text { Poblaciones de } \\
+50.000 \text { y - de } \\
300.000 \\
\text { habitantes }\end{array}$ & $\begin{array}{c}\text { Poblaciones de } \\
20.001 \text { a } 50.000 \\
\text { habitantes }\end{array}$ & $\begin{array}{c}\text { Poblaciones de } \\
12.001 \text { a } 20.000 \\
\text { habitantes }\end{array}$ & $\begin{array}{l}\text { Poblaciones de } \\
5.000 \text { a } 12.000 \\
\text { habitantes }\end{array}$ & $\begin{array}{c}\text { Poblaciones - } \\
\text { 5.000 habitantes }\end{array}$ & Clases/pts. & $\begin{array}{l}\text { Recargo } \\
\text { soltería }\end{array}$ \\
\hline + de 20.000 pts. & + de 18.000 pts. & + de 16.000 pts. & + de 15.000 pts. & + de 15.000 pts. & + de 15.000 pts. & $1^{\mathrm{a}} / 1.000 \mathrm{pts}$ & $60 \%$ \\
\hline 10.001 a 20.000 pts. & $\begin{array}{c}8.001 \text { a } 18.000 \\
\text { pts. }\end{array}$ & $\begin{array}{c}8.001 \text { a } 16.000 \\
\text { pts. }\end{array}$ & $\begin{array}{c}8.001 \text { a } 15.000 \\
\text { pts. }\end{array}$ & $\begin{array}{l}8.001 \text { a } 15.000 \\
\text { pts. }\end{array}$ & $\begin{array}{c}8.001 \text { a } 15.000 \\
\text { pts. }\end{array}$ & $2^{\mathrm{a}} / 750$ pts. & $60 \%$ \\
\hline 7.501 a 10.000 pts. & 5.001 a 8.000 pts. & 4.501 a 8.000 pts. & 4.001 a 8.000 pts. & 3.501 a 8.000 pts. & 3.001 a 8.000 pts. & $3^{\mathrm{a}} / 400 \mathrm{pts}$ & $55 \%$ \\
\hline 5.001 a 7.500 pts. & 4.001 a 5.000 pts. & 3.001 a 4.500 pts. & 2.501 a 4.000 pts. & 2.501 a 3.500 pts. & 2.001 a 3.000 pts. & $4^{\mathrm{a}} / 300 \mathrm{pts}$ & $50 \%$ \\
\hline 3.501 a 5.000 pts. & $3.001 \mathrm{a} 4.000$ pts. & 2.001 a 3.000 pts. & 1.501 a 2.500 pts. & 1.501 a 2.500 pts. & $1.001 \mathrm{a} 2.000 \mathrm{pts}$ & $5^{\mathrm{a}} / 200$ pts. & $45 \%$ \\
\hline 2.501 a 3.500 pts. & 2.001 a 3.000 pts. & 1.501 a 2.000 pts. & $1.251 \mathrm{a} 1.500 \mathrm{pts}$ & $1.001 \mathrm{a} 1.500$ pts. & 751 a 1.000 pts. & $6^{\mathrm{a}} / 100 \mathrm{pts}$ & $40 \%$ \\
\hline 2.001 a 2.500 pts. & $1.501 \mathrm{a} 2.000 \mathrm{pts}$ & 1.001 a 1.500 pts. & 1.001 a 1.250 pts. & 751 a 1.000 pts. & 501 a 750 pts. & $7^{\mathrm{a}} / 70$ pts. & $35 \%$ \\
\hline 1.501 a 2.000 pts. & $1.001 \mathrm{a} 1.500 \mathrm{pts}$ & 751 a 1.000 pts. & 751 a 1.000 pts. & 501 a 750 pts. & 301 a 500 pts. & $8^{\mathrm{a} / 50}$ pts. & $35 \%$ \\
\hline 1.001 a 1.500 pts. & 501 a 1.000 pts. & 251 a 750 pts. & 251 a 750 pts. & 251 a 500 pts. & 251 a 300 pts. & $9^{\mathrm{a} / 30}$ pts. & $30 \%$ \\
\hline 751 a 1.000 pts. & 301 a 500 pts. & 201 a 250 pts. & 151 a 250 pts. & 126 a 250 pts. & 126 a 250 pts. & $10^{\mathrm{a}} / 15$ pts. & $25 \%$ \\
\hline 501 a 750 pts. & 251 a 300 pts. & 151 a 200 pts. & 101 a 150 pts. & 101 a 125 pts. & 76 a 125 pts. & $11^{\mathrm{a} / 7} \mathrm{pts}$. & $20 \%$ \\
\hline 251 a 500 pts. & 126 a 250 pts. & 101 a 150 pts. & 76 a 100 pts. & 76 a 100 pts. & 51 a 75 pts. & $12^{\mathrm{a} / 3}$ pts. & $20 \%$ \\
\hline 250 pts. o menos & 125 pts. o menos & 100 pts. o menos & 75 pts. o menos & 75 pts. o menos & 50 pts. o menos & $13^{\mathrm{a} / 1,50}$ pts. & $20 \%$ \\
\hline
\end{tabular}

Fuente: Estatuto Provincial de 1925, p. 196. 


\section{Anexo Normativo}

- Constitución de 30 de junio de 1876, (Gaceta de Madrid núm. 184, de 2 de julio de 1876).

- Ley Provisional de Instrucción Primaria de 21 de julio de 1838, (Gaceta de Madrid núm. 1381, de 28 de agosto de 1838).

- Ley de 8 de enero de 1845, sobre Organización y Atribuciones de las Diputaciones Provinciales, (Gaceta de Madrid núm. 3776, de 15 de enero de $1845)$.

- Ley sancionada sobre establecimientos de Beneficencia de 20 de junio de 1849 , (Gaceta de Madrid, núm. 5398, de 24 de junio de 1849).

- Ley General de Instrucción Pública de 9 de septiembre de 1857, (Gaceta de Madrid núm. 1710, de 10 de septiembre de 1857).

- Ley de Presupuestos y Contabilidad Provincial de 20 de septiembre de 1865, (Gaceta de Madrid núm. 274, de 1 de agosto de 1865).

- Ley de Instrucción Primaria de 2 de junio de 1868, (Gaceta de Madrid núm. 156, de 4 de junio de 1868).

- Ley Electoral de 20 de agosto de 1870. Suplemento, (Gaceta de Madrid núm. 233, de 21 de agosto de 1870).

- Ley Provincial de las Provincias, su Territorio y Habitantes de 20 de agosto de 1870. Suplemento, (Gaceta de Madrid núm. 233, de 21 de agosto de 1870).

- Ley Benot de 24 de julio de 1873, excluyendo a los niños y niñas menores de 10 años del trabajo en fábricas, talleres, fundiciones o minas, y fijando las horas de trabajo en las mismas, (Gaceta de Madrid núm. 209, de 28 de julio de 1873).

- Ley Provincial de Bases de 16 de diciembre de 1876, reformando las leyes municipal y provincial de 20 de agosto de 1870, (Gaceta de Madrid núm. 352, de 17 de diciembre de 1876).

- Ley Electoral de Senadores de 8 de febrero de 1877, (Gaceta de Madrid núm. 41 , de 10 de febrero de 1877).

- Ley de 20 de julio de 1877 , reformando la electoral de Diputados á Cortes, y restableciendo la penal para los delitos electorales de 22 de Junio de 1864, (Gaceta de Madrid núm. 217 de 5 de octubre de 1877). 
- Ley Orgánica Provincial de 2 de octubre de 1877, (Gaceta de Madrid núm. 244, de 1 de septiembre de 1877).

- Ley General de Ferrocarriles de 23 de noviembre de 1877, dictando disposiciones referentes a la clasificación general de los ferrocarriles, (Gaceta de Madrid núm. 328, de 24 de noviembre de 1877).

- Ley Electoral de Diputados a Cortes de 28 de diciembre de 1878, (Gaceta de Madrid núm. 364, de 30 de diciembre de 1878).

- Ley de Aguas de 13 de junio de 1879, dictando disposiciones que se han de tener presentes respecto a la propiedad, uso y aprovechamiento de aguas, (Gaceta de Madrid núm. 170, de 19 de junio de 1879).

- Ley Orgánica Provincial de 29 de agosto de 1882, (Gaceta de Madrid núm. 244 de 1 de septiembre de 1882).

- Ley española de Policía de imprenta de 26 de julio de 1883, (Gaceta de Madrid núm. 211, de 30 de julio de 1883).

- Ley creando en Madrid una Comisión central de defensa contra la filoxera de 18 de junio de 1885, (Gaceta de Madrid núm. 183, de 2 de julio de 1885).

- Ley General de Presupuestos de gastos e ingresos del Estado para el año económico de 1887-88 de 29 de junio de 1887, (Gaceta de Madrid núm. 181, de 30 de junio de 1887).

- Ley Electoral para Diputados a Cortes de 26 de junio de 1890, (Gaceta de Madrid núm. 180 de 29 de junio de 1890)

- Ley de Presupuestos de 5 de agosto de 1893, Ley de Presupuestos para el año económico de 1893-94. (Gaceta de Madrid núm. 218, de 6 de agosto de 1893).

- Ley de Accidentes de Trabajo de 30 de enero de 1900, (Gaceta de Madrid núm.119, de 29 de abril de 1900).

- Ley de Protección a la infancia de 12 de agosto de 1904, (Gaceta de Madrid núm. 230, de 17 de agosto de 1904).

- Ley Electoral de 8 de agosto de 1907, reformando la Electoral vigente, (Gaceta de Madrid núm. 222, de 10 de agosto de 1907).

- Ley de Ordenación de las Telecomunicaciones de 26 de octubre de 1907, autorizando al Gobierno para que proceda a plantear o desarrollar los servicios de radiotelegrafía, cables y teléfonos, (Gaceta de Madrid núm. 301, de 28 de octubre de 1907). 
- Ley de 27 de febrero de 1908, de organización por el Estado de un Instituto Nacional de Previsión (I.N.P.), (Gaceta de Madrid núm. 60, de 29 de febrero de 1908).

- Ley de Asociaciones Religiosas de 27 de diciembre de 1910, prohibiendo el establecimiento de nuevas Asociaciones pertenecientes a Ordenes o Congregaciones religiosas, canónicamente reconocidas, sin la autorización del Ministerio de Gracia y Justicia, (Gaceta de Madrid núm. 362, de 28 de diciembre de 1910).

- Ley dictando Bases para la Ley de Reclutamiento y Reemplazo del Ejército, estableciendo el servicio militar obligatorio, (Gaceta de Madrid núm. 181, de 30 de junio de 1911).

- Ley de 26 de julio de 1922, de suspensión de pagos, disponiendo que los expedientes de suspensión de pagos de los comerciantes y de las Sociedades mercantiles que no estén comprendidas en el artículo 930 del Código de Comercio se tramiten con arreglo a los que se establece, (Gaceta de Madrid núm. 257, de 14 de septiembre de 1922).

- Proyecto de Ley aprobando el Plan General de Carreteras de 4 de mayo de 1877, (Gaceta de Madrid núm. 130, de 10 de mayo de 1877).

- Real Decreto de 4 de agosto de 1836, aprobando el Plan General de Instrucción Pública, (Gaceta de Madrid núm. 600, de 9 de agosto de 1836).

- Real Decreto de 17 de septiembre de 1845, aprobando el Plan General de Estudios, para la instrucción pública del reino en la parte relativa a las enseñanzas secundaria y superior, (Gaceta de Madrid núm. 4029, de 25 de septiembre de 1845).

- Real Decreto de 15 de mayo de 1849, sobre Instrucción Pública, aprobando el adjunto Reglamento para el régimen de las Escuelas normales superiores y elementales de instrucción primaria, (Gaceta de Madrid núm. 5366, de 23 de mayo de 1849).

- Real Decreto de 14 de mayo de 1852, mandando se observe el Reglamento de la Ley de Beneficencia de 20 de Junio de 1849, (Gaceta de Madrid núm. 6537, de 16 de mayo de 1852).

- Real Decreto de 15 de julio de 1867, aprobando el Reglamento de Segunda Enseñanza, (Gaceta de Madrid núm. 199, de 18 de julio de 1867). 
- Real Decreto de 4 de noviembre de 1868, suprimiendo la Junta general de Beneficencia y derogando varios artículos del Reglamento, (Gaceta de Madrid núm. 310, de 5 de noviembre de 1868).

- Real Decreto de 17 de diciembre de 1868, suprimiendo las Juntas provinciales y municipales de Beneficencia y derogando las leyes y reglamentos referentes a dichas Juntas, cuyas funciones se refunden en las que competen a las diputaciones provinciales y ayuntamientos, (Gaceta de Madrid núm. 353, de 18 de diciembre de 1868).

- Real Decreto de 27 de abril 1875, disponiendo que los servicios de la Administración central conocidos con las denominaciones de Beneficencia general y particular constituyan uno solo bajo el nombre genérico de Beneficencia, encomendado a la iniciativa y administración particular bajo la inspección y protectorado del Gobierno, (Gaceta de Madrid núm. 118, de 28 de abril de 1875).

- Real Decreto de 31 de agosto de 1875, autorizando al Ministro de la Gobernación para que acuerde el nombramiento de Subgobernadores en las poblaciones que lo estime necesario, (Gaceta de Madrid núm. 244, de 1 de septiembre de 1875).

- Real Decreto de 10 de agosto de 1877, por el que se aprueba el Reglamento para la ejecución de la Ley de Carreteras, de 4 de mayo de 1877, (Gaceta de Madrid núm. 226, de 14 de agosto de 1877).

- Real Decreto de 31 de agosto de 1882, aprobando la división de las provincias en distritos para las elecciones de Diputados provinciales, (Gaceta de Madrid núm. 244, de 1 de septiembre de 1882).

- Real Decreto de 4 de enero de 1883, sobre contratación de las Entidades Locales, disponiendo que los contratos que celebren las diputaciones provinciales o los ayuntamientos para toda clase de servicios, obras, compras, ventas y arrendamiento, $\mathrm{y}$ en general todos aquellos que hayan de producir gastos $\mathrm{o}$ ingresos en los fondos provinciales o municipales se celebren por remate, previa subasta pública, (Gaceta de Madrid núm.5, de enero de 1883).

- Real Decreto de 5 de diciembre de 1883, creando una Comisión para el estudio de las cuestiones que directamente interesen al bienestar de las clases obreras y que afecten a las relaciones entre el capital y el trabajo, (Gaceta de Madrid núm. 344, de 10 de diciembre de 1883). 
- Real Decreto de 6 de enero de 1884, sobre la elaboración de un Proyecto de Ley sobre la reforma de la Ley provincial, autorizando la presentación a los Cuerpos Colegisladores de un Proyecto de Ley sobre reforma de la provincial vigente, (Gaceta de Madrid núm. 8, de 8 de enero de 1884).

- Real Decreto de 27 de enero de 1885, aprobando la instrucción para la administración y gobierno de los establecimientos de Beneficencia general, (Gaceta de Madrid núm. 36, de 5 de febrero de 1885).

- Real Decreto de 19 de mayo de 1885, dictando reglas para la admisión de dementes en los establecimientos de beneficencia, (Gaceta de Madrid núm. 141, de 21 de mayo de 1885).

- Real Decreto de11 de marzo de 1886, en materia correccional, dictando disposiciones acerca del sostenimiento de los depósitos municipales y cárceles de las cabezas de partido y de Audiencias, (Gaceta de Madrid núm. 72, de 13 de marzo de 1886).

- Real Decreto de 15 de abril de 1886, disponiendo que todos los reos condenados a la pena de prisión correccional la sufran en las cárceles de la Audiencia del territorio que la hubiere impuesto, (Gaceta de Madrid núm. 107, de 17 de abril de 1886).

- Real Decreto de 21 de agosto de 1888, dictando disposiciones para impedir y combatir la invasión y propagación de la filoxera, (Gaceta de Madrid núm. 240, de 27 de agosto de 1888).

- Real Decreto de 24 de marzo de 1891, dictando disposiciones aclaratorias para completar los preceptos de la ley Electoral con relación al empadronamiento y listas de elegibles y actos posteriores a la proclamación de los Concejales hasta la constitución de los nuevos ayuntamientos, (Gaceta de Madrid núm. 84, de 25 de marzo de 1891).

- Real Decreto de 14 de junio de 1891, por el que se aprueba el Reglamento para el servicio benéfico sanitario de los pueblos, (Gaceta de Madrid núm. 167, de 16 de junio de 1891).

- Real Decreto de 3 de mayo de 1892, dictando disposiciones relativas a la formación de los presupuestos provinciales, (Gaceta de Madrid núm. 128, de 7 de mayo de 1892). 
- Real Decreto de 23 de septiembre de 1898, reformando las Escuelas Normales en la forma que se expresa, (Gaceta de Madrid núm. 268, de 25 de septiembre de 1898).

- Real Decreto e Instrucción de 14 de marzo de 1899, dictando reglas relativas a la Beneficencia en general, (Gaceta de Madrid núm. 74, de 15 de marzo de 1899).

- Real Decreto de 29 de marzo de 1899, declarando Escuelas Normales todas las que se citan en el art. 1 de este Real decreto, y elementales las normales a que se refiere el art. 2 del mismo, (Gaceta de Madrid núm. 92, de 2 de abril de 1899).

- Real Decreto de 17 de agosto de 1901, reformando los estudios de Segunda Enseñanza y las enseñanzas técnicas del Magisterio, Agricultura, Industria, Comercio, Bellas Artes y Artes industriales, (Gaceta de Madrid núm. 231, de 19 de agosto de 1901).

- Real Decreto de 23 de diciembre de 1902, referente a los gastos provinciales y municipales, (Gaceta de Madrid núm. 358, de 24 de diciembre de 1902).

- Real Decreto de 12 de julio de 1904, resolviendo la forma en que se han de sufragar los gastos que ocasionen los adecuados en los manicomios, (Gaceta de Madrid núm. 195, de 13 de julio de 1904).

- Real Decreto de 16 de junio de 1905, elevando a Superiores las Escuelas Normales de Maestros de Cáceres, Ciudad Real, Guadalajara, Palencia y Teruel, y restableciendo con el carácter de Superior la de Toledo, (Gaceta de Madrid núm. 172, de 21 de junio de 1905).

- Real Decreto de 26 de octubre de 1907, declarando de interés nacional la construcción de las cuatro redes telefónicas que se especifican, (Gaceta de Madrid núm. 301, de 28 de octubre de 1907).

- Real Decreto de 24 de febrero de 1908, ampliando las atribuciones que competen al Consejo Superior y a las Juntas provinciales y locales de Protección a la Infancia, en cuanto se refiere a la mendicidad, (Gaceta de Madrid núm. 56, de 25 de febrero de 1908).

- Real Decreto de 24 de diciembre de 1908, sobre adopción de los Estatutos del I.N.P., (Gaceta de Madrid núm. 361, de 26 de diciembre de 1908).

- Real Decreto de 27 de febrero de 1912, aprobando el Reglamento para la aplicación de la Ley de Reclutamiento y Reemplazo del Ejército de 29 de junio de 1911, (Gaceta de Madrid núm. 181, de 30 de junio de 1911) 
- Real Decreto de 5 de mayo de 1913, sobre Juntas Provinciales y Municipales de Primera Enseñanza, (Gaceta de Madrid núm. 133, de 13 de mayo de 1913).

- Real Decreto de 18 de diciembre de 1913, sobre Mancomunidades, (Gaceta de Madrid núm. 86, de 27 de marzo de 1914).

- Real Decreto de 30 de agosto de 1914, sobre reorganización de Escuelas Normales de Primera Enseñanza, (Gaceta de Madrid núm. 245, de 02 de septiembre de 1914).

- Real Decreto de 21 de enero de 1921, aprobando el Reglamento general que se inserta, para la aplicación del Real decreto de 11 de Marzo de 1919 sobre intensificación del régimen de retiros obreros, (Gaceta de Madrid núm. 23, de 23 de enero de 1921).

- Real Decreto de 18 de octubre de 1922, encomendando la administración económica de las prisiones provinciales y de Partido al Ministerio de Gracia y Justicia, (Gaceta de Madrid núm. 293, de 20 de octubre de 1922).

- Real Decreto 15 de septiembre de 1923, confiriendo a Miguel Primo de Rivera la Presidencia del Directorio Militar, y suprimiendo el Consejo de Ministros, (Gaceta de Madrid núm. 259, de 16 de septiembre de 1923).

- Real Decreto de 12 de enero de 1924, declarando disueltas las actuales Diputaciones provinciales de toda España; con la única excepción de las de Álava, Guipúzcoa, Navarra y Vizcaya, (Gaceta de Madrid núm. 13, de 13 de enero de 1924).

- Real Decreto Ley de 8 de marzo de 1924, aprobando el Estatuto Municipal, (Gaceta de Madrid núm. 69, de 9 de marzo de 1924).

- Real Decreto de 19 de junio de 1924, por el que se constituye el Tribunal Supremo de la Hacienda Pública, (Gaceta de Madrid núm. 172, de 20 de junio de 1924).

- Real Decreto de 20 de junio de 1924, aprobando la organización de los servicios nacionales agropecuarios, (Gaceta de Madrid núm. 174, de 22 de junio de 1924).

- Real Decreto de 23 de agosto de 1924, aprobando el Reglamento de Hacienda municipal, (Gaceta de Madrid núm. 243, de 30 de agosto de 1924).

- Real Decreto de 27 de febrero de 1925, aprobando el Reglamento desarrollando las bases del Decreto-ley de 29 de Marzo de 1924 para el reclutamiento y reemplazo del Ejército, (Gaceta de Madrid núm. 65, de 6 de marzo de 1925). 
- Real Decreto de 20 de marzo de 1925, aprobando el Estatuto Provincial, sobre organización y hacienda de las entidades provinciales y constitución de las regiones, (Gaceta de Madrid núm. 80, de 21 de marzo de 1925).

- Real Decreto de 20 de octubre de 1925, por el que se aprueba el Reglamento de Sanidad Provincial, (Gaceta de Madrid núm. 297, de 24 de octubre de 1925).

- Real Decreto de 2 de noviembre de 1925, aprobando el Reglamento, que se inserta, de funcionarios y subalternos provinciales, (Gaceta de Madrid núm. 311, de 7 de noviembre de 1925).

- Real Decreto de 5 de septiembre de 1928, en materia recaudatoria disponiendo que desde el día $1^{\text {o }}$ de Enero de 1929 correrá a cargo de la Diputación provincial de Palencia la recaudación en dicha provincia de las contribuciones e impuestos del Estado, y prorrogando el actual contrato de arriendo del servicio recaudatorio en la misma hasta el 31 de Diciembre del corriente año, en las mismas condiciones a que se halla sujeto, (Gaceta de Madrid núm. 253, de 9 de septiembre de 1928).

- Real Decreto Ley de 11 de abril de 1928, autorizando a las Diputaciones de Régimen común para que, mancomunada o separadamente, puedan emitir empréstitos o contratar créditos para la construcción de caminos vecinales, (Gaceta de Madrid núm. 106, de 15 de abril de 1928).

- Real Decreto Ley de 25 de abril de 1928, creando el Patronato Nacional de Turismo, (Gaceta de Madrid núm. 117, de 26 de abril de 1928).

- Real Orden de 10 de julio de 1872 , resolviendo que la renovación de las Diputaciones provinciales debe hacerse con relación a la mitad del número total de Vocales que deben componerlas aun cuando haya vacantes, (Gaceta de Madrid núm. 210, de 28 de julio de 1872).

- Real Orden de15 de marzo de 1876, dictando disposiciones sobre el nombramiento y separación de los Maestros de primera enseñanza de los establecimientos de Beneficencia, (Gaceta de Madrid núm. 85, de 25 de marzo de 1876). 
- Real Orden de 19 de marzo de 1879, dictando las disposiciones que deben tenerse presentes y el procedimiento que ha de seguirse cuando haya que hacer efectivos los débitos de los Municipios a favor de la provincia, y excitando el celo de las Diputaciones provinciales para que conectan plazos a las Corporaciones municipales para el pago de los débitos por el repartimiento hecho a los pueblos, (Gaceta de Madrid núm. 94, de 4 de abril de 1879).

- Real Orden de 30 de abril de 1880, resolviendo que, si una vez concedido por la Diputación el aplazamiento de pago del contingente provincial, los Ayuntamientos en ejercicio no satisfacen la parte corriente y la que corresponda por atrasos, podrá aquella disponer que por conducto del Gobernador se expidan los apremios que procedan, (Gaceta de Madrid núm. 160, de 8 de junio de 1880).

- Real Orden de 31 de mayo de 1886, dictando disposiciones para unificar el sistema de contabilidad de las corporaciones provinciales y municipales, (Gaceta de Madrid núm. 154, de 3 de junio de 1886).

- Real Orden de 8 de febrero de 1889 , sobre abono de estancias de presos pobres en las cárceles de partido o de Audiencia, (Gaceta de Madrid núm. 48, de 17 de febrero de 1889).

- Real orden de 14 de mayo de 1889, declarando válida la elección de Presidente de la Diputación provincial de Palencia hecha en sesión del 10 de Noviembre último, (Gaceta de Madrid núm. 140, de 20 de mayo de 1889).

- Real Orden de 28 de diciembre de 1892, declarando nula la constitución de la Diputación provincial de Palencia, y que se preceda de nuevo a la elección de Presidente y demás cargos de la misma, (Gaceta de Madrid núm. 2, de 2 enero de 1893).

- Real Orden de 18 de octubre de 1893, resolutoria de una alzada de ocho Diputados provinciales de Palencia contra validez de las sesiones celebradas en 7 y 9 de Enero último, (Gaceta de Madrid núm. 296, de 23 de octubre de 1893).

- Real Orden circular de 16 de octubre de 1894, disponiendo que los Presidentes de las Diputaciones provinciales y los Alcaldes cuidarán respectivamente del exacto cumplimiento de los artículos de la ley Provincial y Municipal que se citan, (Gaceta de Madrid núm. 290, de 17 de octubre de 1894). 
- Real Orden de 15 de octubre de 1898, aprobando la plantilla de la Escuela Elemental de Maestros, Real orden circular disponiendo que las Diputaciones provinciales resuelvan lo relativo a la constitución de Escuelas Normales en sus respectivas provincias, (Gaceta de Madrid núm. 289, de 16 de octubre de 1898).

- Real Orden de 25 de abril de 1902, disponiendo que por la Dirección general de Obras públicas se publique el plan de obras hidráulicas, (Gaceta de Madrid núm. 119, de 29 de abril de 1902.

- Real Orden de 3 de febrero de 1906, disponiendo se ejecuten por administración las obras de carreteras que se expresan, (Gaceta de Madrid núm.50, de 19 de febrero de 1906).

- Real Orden de 5 de febrero de 1909, aprobando la instrucción para abono de indemnizaciones en la ejecución de los planes provisionales de aprovechamiento de los montes, a cargo de los distritos forestales, (Gaceta de Madrid núm. 38, de 7 de febrero de 1909).

- Real Orden de 2 de septiembre de 1926, dirigida a los Gobernadores civiles, dictando los acuerdos que se expresan para el cumplimiento y vigilancia de la lucha contra la tuberculosis., (Gaceta de Madrid núm. 247, de 4 de septiembre de 1926).

- Real Orden de 30 de marzo de 1927, sobre la plantación de viveros de moreras, (Gaceta de Madrid núm. 90, de 31 de marzo de 1927). 
